\title{
VINNANDE BILDER: TECKNINGSTÄVLINGAR FÖR BARN 1938-2000
}

\author{
Elin Låby
}

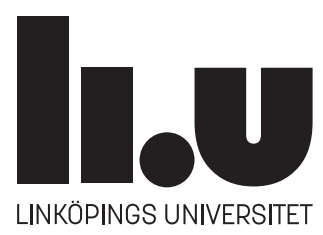

Linköping Studies in Arts and Sciences, No. 739 Linköpings Universitet, Institutionen för Tema - Tema Barn Linköping 2018 
Linköping Studies in Arts and Sciences, No. 739

Vid filosofiska fakulteten vid Linköpings universitet bedrivs forskning och ges forskarutbildning med utgångspunkt från breda problemområden. Forskningen är organiserad i mångvetenskapliga forskningsmiljöer, och forskarutbildningen huvudsakligen i forskarskolor. Gemensamt ger de ut serien Linköping Studies in Arts and Science. Den här doktorsavhandlingen kommer från Tema Barn vid Institutionen för Tema.

Distribueras av:

Institutionen för Tema, Tema Barn

Linköpings universitet

58183 Linköping

Elin Låby

Vinnande bilder:

Teckningstävlingar för barn 1938-2000

Upplaga 1:2

ISBN 978-91-7685-298-9

ISSN 0282-9800

(C) Elin Låby, Institutionen för Tema 2018

Omslagsbild av Britt Pettersson, (1938). Baksidans bild av Jesper Törjas, (1977). Bilderna är redigerade.

Tryck: LiU-Tryck, Linköping 2018 


\section{FÖRORD}

I mitt arbete som bildlärare på grundskolans mellan- och högstadium under tidigt 2000-tal blev det tydligt för mig hur bildämnet kommit att omfatta vitt skilda pedagogiska diskurser, liksom hur förställningar om och traditioner inom bildämnet levde kvar. Inte bara hos elever och föräldrar, utan också hos mig själv och mina kollegor. Möjligheten att inom ramen för Tema Barns doktorandutbildning kunna utforska barnteckningstävlingar och sätta tävlingarna i relation till samhällets förändrade syn på barn och barndom har varit ett oerhört givande arbete.

En nödvändig förutsättning för detta arbete har varit mina handledare Bengt Sandin och Anette Göthlund. Ett varmt tack till er båda! Bengt, som med stor entusiasm och ett oändligt tålamod hjälpt mig strukturera, sortera och tydliggöra analyser av texter och bilder. Anette, för diskussioner om bildanalysens begrepp och en textnära läsning. Andra som varit viktiga i processen med att läsa och kommentera texten är Ulla Lind, som var opponent på $60 \%$ seminariet, och Ingrid Söderling som var opponent på mitt $90 \%$ seminarium. Tack till er. Här vill jag även tacka läsgruppen vid 90 \% seminariet, Johanna Sköld, Joakim Landahl och Cathrine Björk.

Den kreativa och tvärvetenskapliga miljön på Tema barn har varit berikande och en förutsättning för min arbetsprocess. Tack alla på Tema Barn som deltagit på textseminarier, i den historiska seminarieserien "barnets århundrade" och i samtal vid fikat. Doktorandkollegorna har varit ett stort stöd under arbetes gång, tack Mathilda Hallberg, Joel Löw, Peter Skagius, David Cardell, Johanna Sjöberg, Åsa Pettersson, Zulmir Becevic, Mehek Muftee, Layal Wiltgren, Madelene Wirtzén, Emilia Strid, Malva Holm, Sofia Kvist- Lindholm, Sarah Mitchell, Emilia Zotevska, Daniel Gustavsson, Alex Orrmalm Auran. Speciellt tack till doktoranderna i D-11 gruppen Sofia Littmark, Jonathan Josefsson, Mina Kheirkhah och Mirjam Hagström. Mirjam, du har varit ett särskilt stöd i att dela skrivandets vedermödor. Tack för alla mysiga "take away "middagar och diskussioner på regionaltågen som gjorde pendlandet uthärdligt!

Karin Isaksson och Ulla Martola på svenskt barnbildsarkiv har visat stort intresse och engagemang för avhandlingen. Karin Isaksson har bistått med att ta fram arkivmaterial både vid besök och per mejl. Tack till er! Tack även till personal på Riksarkivet, Nationalmuseum, Kungliga biblioteket, Centrum för näringslivshistoria och Linköpings Universitetsbibliotek. Tack till Eva Danielsson som bistått med administrativ hjälp, Marie Clark Nelson som översatt slutkapitlet till engelska, och Tomas Hägg som har gjort layout.

Tack också till vänner och familj som stöttat mig helhjärtat, ert stöd har varit ovärderligt. Några av er har även läst och kommenterat delar av arbetet under processens gång. Tack till Christer Samuelsson, Christina Sundberg, Rudolf Painitz och Maria Eriksson för allt engagemang och uppmuntran! Ett särskilt tack till Per Blomkvist som bidragit med kommentarer både i början, i mitten och i 
slutet av avhandlingen, din entusiasm och konstruktiva kritik har varit betydelsefull.

Mitt varmaste tack går till dig, Ingvar. Utan dig, din humor, omsorg och förmåga att ordna vardagens tjatgnat hade jag aldrig blivit klar. Tack för din kärlek och ditt stöd.

Leopold, Agnes och Lydia - ni ger ständigt inspiration och kraft, denna bok tillägnar jag er..

Stockholm i mars 2018

Elin Låby 


\section{INNEHÅLL}

Kapitel 1.

Vinnande bilder! $\quad 1$

Bakgrund 4

Tidigare forskning 9

Barndomens förändring, barns kulturella världar 9

Barns bildskapande $\quad 12$

Barn och täulingar 16

Teoretiska och metodologiska utgångspunkter 19

Visuell kulturteori 19

Diskursanalys 21

Den semiotiska analysen och dess grundläggande begrepp 23

Avhandlingens syfte och frågeställningar 25

Material och Urval 26

Barns bilder i arkiv 26

Avgränsning av material: FIB, Televerket och Arla/Posten 28

Avhandlingens disposition $\quad 33$

Kapitel 2.

Teckningstävlingar - ett ambivalent fenomen 35

Barnkonstbilden i samhällsdebatt och samhället minne 41

Spara för framtiden - täulingssamlingar och temasamlingar $\quad 42$

Konstdiskursen och barnbilden - barnbilden som
ett nyskapande uttryck

Teckningstäuling, utvecklingspsykologi och pedagogik 50

Arrangörer av teckningstävlingar $\quad 57$

Arrangörerna över tid $\quad 59$

Vilka var arrangörerna 61

$\begin{array}{ll}\text { Skolan och tävlingar } & 78\end{array}$

Tävlingen i praktiken $\quad 80$

Tävlingar i läroplaner och pedagogisk debatt $\quad 82$

$\begin{array}{ll}\text { Uppdragen och barnen } & 88\end{array}$

Tävlingarnas utformning, anvisningar och priser $\quad 89$

Förändringar av material och teknik 94

Ålder och plats $\quad 97$

Täulingarnas teman 100

Bilderna möter publiken $\quad 117$

Sammanfattande diskussion 126 
Kapitel 3.

Bilder av Hembygden

Sverige och hembygden i FIB:s tävling och i folkskolans arbetsböcker 136

Televerkets hembygdstema - landsbygd och historia 142

Vad var" fel" hembygd 1977? 147

Flaggor och kungar $\quad 149$

Flaggan som symbol för gamla och nya traditioner 149

Kungen som både nationell och regional symbol 157

Folket i bild och Nationalmuseum - Sverige genom barnaögon $\quad 165$

Omslagsbilden Sverige genom barnaögon 167

Nationalmuseums hembygdsbilder

- barnbilden som uttryck för modernitet 171

FIB:s hembygdsbilder - från norr till söder, stad och land 177

Arla- detta vill jag värna om- barnen som politiska subjekt 182

Sammanfattande diskussion $\quad 186$

Kapitel 4.

Barns plats 189

Skolan 192

Skolan som ordnande av tid och rum 193

Bilder av skolans normer för barns kroppar 197

Relationer mellan lärare och elever $\quad 201$

Relationer mellan barn 204

Förändrad bild av barndomens villkor $\quad 208$

Relationer mellan barn och vuxna 208

Platser för vardag och fritid - var kan och bör barn vara 212

Platser i rörelse? 218

Sammanfattande diskussion $\quad 223$

Kapitel 5.

Bilder av flickor och pojkar, kvinnor och män 225

Genusdiskurser i skolan och på fritiden 228

Barns lekar och saker 238

Vuxna män och kvinnor representerade i barnens bilder 245

Barn skildrar framtida yrken $\quad 255$

Sammanfattande diskussion 264 
Kapitel 6.

Vinnande bilder - teckningstävlingar som arena för en förhandling av barndomens innebörder

Teckningstävlingar för barn - bra eller dåligt?

Vad har tävlingarna använts till

Förändring och kontinuitet

\section{Summary}

Bilder, tabeller \& diagram

Litteratur \& källmaterial

Bilaga 1 



\section{Kapitel 1. \\ VINNANDE BILDER!}

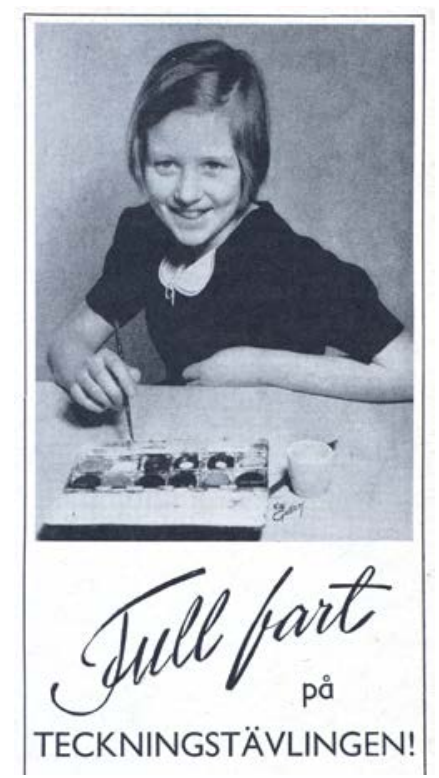

Bild 1:1. Folket $i$ bild nr 111940 sid. 29 detalj.

Veckotidningen Folket i Bild (FIB) arrangerade 1938 en teckningstävling, som sedan kom att pågå under ett par decennier. Bild 1:1 visar hur tävlingen presenterades 1940 på tidningens ungdomssidor. Tidningen skrev att det nu är "full fart på pennor och färglådor från Ystad till Haparanda" och uppmanade alla att sända in klassens bidrag före den 15e april, då det fanns 5000 kronor att vinna till skolresor, 150 skolklasser kunde vinna antingen 50 eller 25 kronor. ${ }^{1}$ Bredvid bilden ovan fanns även en teckning av en pojke med dragspel och en palett framför sig och överskriften "Tecknargossens sång”, en sång som handlar om att han ska skynda sig att göra en fin bild som blir tryckt i tidningen och får pris.

Att tävlingar var vanliga och uppskattade moment i skolan framgår även av insändare till FIB:

Då för skolungdomen i våra dagar som propaganda för respektive grenar tävlingar anordnas i idrott, gymnastik och sång, tor-

\footnotetext{
${ }^{1}$ FIB nr. 111940 sid. 29. Folket i bild har under denna tid ett par sidor i varje nummer som man kallar för "Ungdomsspalterna". Mellan 1938-1947 är foton av ett barn som deltar i tävlingen på tidningens omslag tre gånger; en gång en flicka $1942 \mathrm{nr}$ 23, och två gånger pojkar, i nr. 9 1945 och nr. 13 1946. Vid dessa tillfällen är det längre reportage om tävlingen i tidningen, utöver det som skrivs i ungdomsspalterna.
} 
de FIB:s teckningstävlan kunna bli av samma betydelse inom sitt område. Att som pris utge bidrag till skolresor är en god och välkommen belöning för ett väl utfört arbete.

Götha Skjöld lärarinna, Tureberg ${ }^{2}$

Det finns brev från 1938 och efterföljande år från lärare som berättar om hur omtyckta tävlingarna var både hos lärare och elever. 1940 skrev FIB:

Lärarna är förtjusta över dessa tävlingar, därom vittna de hundratals brev som kommit oss tillhanda. Man skriver och berättar om vilket intresse barnen fått för teckning och vilka goda resultat som uppnåtts tack vare att tävlingsmomentet utnyttjas i undervisningen. Och för övrigt är ju inte heller ett pris på 50 eller 25 kronor att förakta i skolkassan, eller hur? ${ }^{33}$

FiB kunde på det här sättet framställa tävlingar som något positivt, naturligt och bra.

När Riksförbundet för bildande konst 1945 organiserade en vandringsutställning med ett urval bilder från FIB:s teckningstävling, utkom katalogen Sverige genom barnaögon. ${ }^{4}$ Katalogen inleddes med kapitlet "Barnteckningar på vandringsutställning” av Sixten Strömbom. Han hade varit initiativtagaren till Riksförbundet för bildande konst 1930 och 1945 var han intendent på Nationalmuseum. ${ }^{5}$ Strömbom menar att den nya fria teckningsundervisningen väcker barnens "lust att i tävlan med kamraterna forma intryck/..../och utveckla sitt känsloliv.” Det fanns således ingen motsättning för Strömbom mellan att tävla och att utveckla sitt känsloliv. Han beskriver också att Riksförbundet för bildande konst kommer att turnera med en "elitsamling av tävlingarnas prisbelönta teckningar." 6 Tävlingar hade länge varit vanligt bland konstnärer, arkitekter och inom andra estetiska områden. Exempelvis tävlades både i konst, musik, litteratur och arkitektur under olympiaden i Stockholm 1912. ${ }^{7}$ Dessa tävlingsgrenar var etablerade i de internationella olympiska spelen fram till $1948 .^{8}$

2 FIB 1938 nr 27 sid. 27.

${ }^{3}$ FIB 1940 nr 8 sid. 29. (kursiv i original).

${ }^{4}$ Sverige genom barnaögon: Katalog. (1945). Stockholm: Riksförbundet för bildande konst Folket i Bild vandringsutställning 36 .

${ }^{5}$ Riksförbundet för bildande konst var en sammanslutning av konstföreningar som bildades 1930 av bland annat Sixten Strömbom (1888-1983), som också var intendent vid Nationalmuseum (1919-1949). De anordnade många vandringsutställningar, bland annat denna med barnteckningar.

${ }^{6}$ Sverige genom barnaögon: Katalog. (1945). Stockholm: Riksförbundet för bildande konst Folket i Bild vandringsutställning 36, sid. 5 .

7 Patrik Steorn 2012: http://www.idrottsforskning.se/da-konsten-blev-olympisk-os-1912-fick-aven-kulturen-medalj/ (20170615) Att tävla i konst var vanligt bland konstnärer under slutet av 1800-talet. Men under början av 1900-talet började kritiska röster höras mot Konstakademin och deras pristävlingar; där skolans elever skulle skildra ett historiskt ämne. Tävlingarna ansågs hämma konstnärernas egen personliga skaparkraft.

${ }^{8}$ Sandblad, Henrik (1985). Olympia och Valhalla: idéhistoriska aspekter av den moderna idrottsrörelsens framväxt $=$ Sport and ideas: aspects of the rise of the modern sport movement. Grillby: Lärdomshistoriska samf. sid. 235. 
Vi ser hur skilda intressegrupper som arbetarrörelsens tidning FIB, folkskollärare, Nationalmuseum och Riksförbundet för bildande konst betraktade tävlingsmomentet som något som sporrade barnen till goda resultat. Denna positiva inställning till barn och tävlingar blev ett antal decennier senare kontroversiell. I samband med att Televerket 1977 organiserar sin andra teckningstävling för omslagen till telefonkatalogerna, noteras av en televerkstjänsteman följande anteckning i ett protokoll, vid möte med Skolöverstyrelsen (SÖ) kring det kommande årets tävling. Representanten för SÖ framförde:
/.../ önskemålet att ordet "pristävling" byts ut mot något annat mindre "laddat" ord, då SÖ strävar mot att få bort tävlingar av alla slag i skolan. Samtidigt bör man understryka att "täv- lingen" skall vara ett kollektivt arbete (Dvs man planerar och jobbar tillsammans och man belönas kollektivt) [sic]. ${ }^{9}$

Enligt anteckningen var det problematiskt att tävlingen annonserats som "pristävling”. Att det faktiskt var en tävling med prispengar, borde inför nästkommande år därför inte framgå av tävlingens informationsmaterial. Istället för " $\mathrm{Ni}$ är inbjudna till en pristävling" var annonstexten följande år omformulerad till: "Vi på Televerket behöver glada framsidor igen. Nu till nästa års telefonkataloger. Vill ni hjälpa oss? Vi vänder oss till alla treor i hela landet." ${ }^{10}$

Det har uppenbart skett en förändring över tid kring skolans förhållande till tävlande och synen på tävlingarnas lämplighet för barn. Företrädare för nya pedagogiska idéer kom efterhand att uppfatta att tävlan stod i konflikt med det fria skapandet. ${ }^{11}$ Men samtidigt har teckningstävlingar varit ett återkommande inslag i svensk skola under perioden. Uppenbarligen har barn fortsatt att engageras i tävlingar även när dessa blev kontroversiella i takt med att såväl skolväsendet som synen på barn förändrades.

Med detta i åtanke är det intressant att reflektera över hur och med vilka syften teckningstävlingarna genomfördes, vilka som arrangerade tävlingar, vilka barn man vänt sig till och vilka bilder barn ombetts att teckna. Avhandlingens övergripande syfte är att studera barnteckningstävlingarna som ett historiskt och föränderligt fenomen. Tävlingarna kan både problematisera barns kulturella uttryck och vara utgångspunkt för att diskutera barndomens villkor under olika tidsepoker.

I Svenskt barnbildarkiv (SBBA) finns ett åttiotal tävlingssamlingar. Den tidigaste tävlingen som finns bevarad är FIB:s tävling som börjar 1938, och arrangerades som en skoltävling. Denna tävling utgör studiens startpunkt. Från perioden

\footnotetext{
9 Protokollanteckning Svenska telegrambyrån (STB) möte med SÖ angående tema för nästa års kataloger. 18/11 1976 Riksarkivet Televerket Telemedia Omslag till rikstelefonkataloger 1977 F2A:1

${ }^{10}$ Televerkets tävlingsbilder, SBBA:s arkiv.

${ }^{11}$ Se tex: Read, Herbert (1943). Education through art, översatt till svenska (1956). Uppfostran genom konsten. Stockholm: Natur och Kultur Lowenfeld, Viktor (1947). Creative and mental growth: a textbook on art education. New York: Macmillan Lowenfeld, Viktor (1954). Your child and his art: a guide for parents. New York: Macmillan överstt till svenska (1957). Alla barn kan måla. Stockholm: Rabén \& Sjögren.
} 
kring sekelskiftet 2000 minskar antalet bevarade nationella tävlingssamlingar, vilket gör att sekelskiftet framstår som en naturlig slutpunkt för en undersökning av tävlingarna.

Inledningskapitlet är disponerat på följande sätt: I bakgrunden kommer jag att presentera diskurser kring barns bildskapande praktiker i ljuset av barndomens förändrade innebörder från 1700-tal till början av 1900-talet för att skapa en kontext kring barnbildstävlingar. Därefter redovisas hur tidigare forskning problematiserat kultur för och av barn och barns bildskapande, samt förhållandet mellan barn och tävling. Avhandlingens teoretiska ramverk tar avstamp i visuell kulturteori i kombination med kritisk diskursanalys. Här presenteras också en förenklad semiotisk modell som används för näranalys av bilderna. Därefter preciseras syfte och forskningsfrågor. I avsnittet material och urval presenterar jag de olika arkivmaterial och tävlingssamlingar jag studerat, hur jag gjort mitt urval av de tävlingar jag näranalyserat och vilka tävlingar och bilder som valts ut för närmare granskning. Slutligen presenteras studiens disposition.

\section{Bakgrund}

Genom historien har det funnits olika sätt att betrakta barn, barndomens innebörd och utsträckning. Även om barndom preciseras som ett visst intervall av ålder i en människas liv, är det högst olika vad denna tid fylls med, både idag och historiskt. ${ }^{12}$ Den förändrade synen på barn och barndom har också konsekvenser för synen på barns bildskapande och i vilka sammanhang barns bilder ansågs höra hemma.

Många barndomsforskare hänvisar till den franske filosofen Jean-Jacques Rousseau (1712-1778) som den förste som lyfte fram vikten av en fri uppfostran för barn, där barnet skulle få utvecklas i enlighet med sin natur. Detta innebar enligt Rousseau att barn skulle teckna av så naturtroget som möjligt. ${ }^{13}$ Barnet borde enligt Rousseau teckna direkt efter naturen, inte efter avbildningar eller ur minnet, för att inte "förlora kännedomen om förhållandena och smaken förnaturens skönhet." I likhet med senare utvecklingspsykologiska teorier såg han hur barnen med stigande ålder gjorde framsteg mot ett mer korrekt tecknande. ${ }^{14}$ Det var också det Rousseau uppfattade som barnens eget mål: "Barnen, som har en stark efterhärmningsdrift, försöker att rita av allt." skriver han i Emile eller om uppfostran 1762. ${ }^{15}$ Johann Heinrich Pestalozzi (1746-1827) en schweizisk pedagog och författare med romantiska ideal, försökte omsätta Rousseaus

12 Se tex: Ariès, Philippe (1982) Barndomens historia. Stockholm: Gidlund; James, Allison, Jenks, Chris \& Prout, Alan (1998) Theorizing childhood. Cambridge: Polity; "Sandin, Bengt (2003) Skolan, barnen och samhället i ett historiskt perspektiv" I Selander, Staffan (red) Kobran, nallen och majjen: tradition och förnyelse i svensk skola och skolforskning.

${ }_{13}$ Rousseau, Jean-Jacques (1762) (1977-1978) Emile eller Om uppfostran. D. 1. Göteborg: Stegeland sid. 158. "Jag ska också akta mig för att ge honom en teckningslärare, som endast lät honom efterbilda efterbildningar och avteckna teckningar. Jag vill inte, att han ska ha någon annan lärare än naturen och inga andra modeller än föremålen själva."

${ }^{14}$ Ibid. sid. 158-159.

${ }^{15}$ Ibid. sid. $157 f$. 
teorier om barnens inneboende godhet i praktiken och drev skolor för fattiga barn. ${ }^{16}$ Barnets tidiga undervisning borde enligt Pestalozzi vara "en sinnenas, en hjärtats och en moderns sak." ${ }^{17}$ I en romantikens naturliga värld uppstod också gudskärleken hos barnet genom moderskärleken. Först senare kom mannen och förnuftets inflytande. Men till skillnad från Rousseau menade Pestalozzi att tecknandet av räta vinklar, kvadrater och cirkelbågar var nödvändiga för att höja människoanden från "dunkla åskådningar till tydliga begrepp". ${ }^{18}$

På samma sätt menade den tyske pedagogen Friedrich Fröbel (1782-1852), inspirerad av Pestalozzi, att barnen i teckningsundervisningen borde börja med enkla övningar. Genom att mäta och teckna räta linjer med rätlinjiga vinklar, skulle barnet få en "riktighet i åskådningen" och en konstbildning. ${ }^{19}$ I Människans fostran skrev Fröbel 1826 att det är genom matematiken, språket och konsten som människan ska fostras. Liksom både Rousseau och Pestalozzi före honom, såg Fröbel avbildningen av naturen som uttryck för det gudomliga. ${ }^{20}$ Fröbel, initiativtagare till de första förskolorna (Kindergarten) menade även att "förmågan att teckna är lika naturlig hos människan som förmågan att tala och fordrar lika mycket som denna att bli utvecklad." Han ansåg att tecknandet utvecklar minnet, liksom handens och armens rörelser. Alla barn borde lära sig teckna eftersom "en ny värld öppnas för barnet då det lär sig att teckna." ${ }^{11}$ Dessa teorier lägger grunden för den romantiska konstruktionen om att barn och bildskapande hänger samman. ${ }^{22}$

Den tyske pedagogen Adolph Stuhlmann (1838-1921) byggde också vidare på Pestalozzis idéer om geometriska figurer som grund för undervisningen. Folkskolan etablerades i Sverige under 1800-talets mitt, och bildundervisningen ansågs vara en hjälp för att skapa självdisciplinering hos barnen. Detta åstadkoms genom tecknande i räta linjer och gärna med linjal, lika för alla, vilket Stuhlmanns geometriska modeller gjorde möjligt. ${ }^{23}$ Hans Lärobok i frihandsteckning för Elementarläroverk, seminarier och folkskolor översattes 1878 till svenska och fick stort genomslag i den svenska teckningsundervisningen. I läroboken skriver han:

\footnotetext{
${ }^{16}$ Salomon, Otto (1904) Johan Henrik Pestalozzi: ett blad ur människokärlekens historia. Stockholm: Folkskolans vän, sid. 48.

${ }^{17}$ Pestalozzi, Johann Heinrich (1801/1896) Huru Gertrud undervisar sina barn: ett försök att gifva mödrarna ledning att själfva undervisa sina barn. Göteborg: Wettergren \& Kerber sid. 131.

${ }^{18}$ Ibid. sid. 42.

19 Fröbel, Friedrich (1826/1995) Människans fostran. Lund: Studentlitteratur.

${ }^{20}$ Fröbel, Friedrich sid. 193 ”I allt, i religion, och konst är det högsta målet för all framställning att finna uttryck för det rent mänskliga. Den kristna konsten strävar att framställa det evigt bestående, det gudomliga, i synnerhet i och genom människan, som är den mänskliga konstens främsta mål."

${ }^{21}$ Fröbel, Friedrich (1826/1995) sid. 67.

22 Änggård, Eva (2005) Bildskapande: en del av förskolebarns kamratkulturer. Diss. Linköping: Linköpings universitet, 2005.

${ }^{23}$ Hasse Hansson "När varje lärare kunde teckna" i Lind, Ulla, Hasselberg, Kersti \& Kühlhorn, Britt-Marie (red). (1992) Tidsbilder, Perspektiv på skola och bildskapande under 150 år. Utbildningsradion och Skolverket. sid. 26-40.
} 
De första modellerna bör så litet som möjligt egga fantasin, eftersom det hindrar nybörjaren från ett skarpt iakttagande och förleder honom att teckna efter godtycke. Men det är även viktigt att fantasin hålls vid liv och eggas till vidare verksamhet, men detta kan inte göras genom elementarteckning efter föremål, så det måste därför till särskilda övningar. Härtill egnar sig på de högre stadierna på ett alldeles utmärkt sätt kompositionen av växtarabesker. ${ }^{24}$

Här är det intressant att notera att det Stuhlmann menar med "fantasin" bör undvikas bland de yngre eleverna eftersom det gör att eleverna skapar godtyckligt. Först efter ett ingående studium av olika geometriska former med hjälp av rutnät, konturteckning och skuggning, kommer fantasin in. Att utveckla fantasi innebar för Stuhlmann att elever efter ingående studier kunde komponera egna bilder utan att teckna av, men fortfarande med naturen som förlaga. ${ }^{25}$

Barns tecknande var alltså strikt kontrollerat enligt de metoder Pestalozzi och Stuhlmann utverkade. Metoderna var geometriska till sin utformning och möjliggjorde undervisning i stora grupper. ${ }^{26}$ Undervisningen var också funktionell eftersom industrialismen medförde att kunskap i teknisk ritning efterfrågades, och teckning sågs i första hand som ett tekniskt ämne, avsett för till exempel blivande ingenjörer. ${ }^{27}$ Den svenska granskningskommittén för läroverken skrev redan 1858 att teckningsämnet borde ha fyra timmar per vecka på reallinjen men endast två på den humanistiska linjen. Det som skulle läras ut var konstruktionsritning, projektionsritning och slutligen ornamentsritning, efter mönster eller modeller. ${ }^{28}$

Under 1900-talets början uppträder en förändring, inte minst genom den amerikanske pedagogen John Deweys progressiva idéer som betonade elevers eget aktiva deltagande i undervisningen. ${ }^{29}$ Dewey menade att det var nödvändigt att reformera skolan för att skapa bättre förutsättningar för eleverna, och detta innebar bland annat att använda sig av elevernas egna erfarenheter i större utsträckning. I Sverige fick dessa reformpedagogiska idéer genomslag i 1919 års undervisningsplan för folkskolan, främst i det nya ämnet hembygdskunskap. ${ }^{30}$ Teckningsämnet var en del av hembygdskunskapsämnet och genom läroböcker och lärarhandledningar i hembygdskunskap kunde reformpedagogikens idéer

\footnotetext{
24 Stuhlmann, A. (1878) Lärobok i frihandsteckning. 2. Stockholm: Beijer sid. 29.

25 För flickskolans del bör detta ske i samband med sömnadsmönster. Ibid. sid. 33.

${ }^{26}$ Frost, Ulla (1988) Förlagor och teckningsläror: ett bidrag till den svenska teckningsundervisningens historia särskilt avseende 1800-talet. Diss. Stockholms Univ. sid. 122.

27 Pettersson, Sten \& Åsén, Gunnar (1989) Bildundervisningen och det pedagogiska rummet: traditioner, föreställningar och undervisningsprocess inom skolämnet teckning/bild i grundskolan. Diss. av båda förf. Stockholm : Univ.

28 Nordström, Gert Z. \& Romilson, Christer (1970) Bilden, skolan och sambället. Orig. utg. Stockholm: Aldus/Bonnier sid. 30.

29 Zilversmit, Arthur (2004) John Dewey, I Encyclopedia of Children and Childhood: In History and Society.. Ed. Paula S.Fass.Vol.1. New York: Macmillan Reference USA, sid. 267-269.

30 Pettersson, Sten \& Åsén, Gunnar (1989) sid. 86.
} 
omsättas i praktiken. ${ }^{31}$ Tanken var att barnen genom att använda alla sinnen, bland annat genom att teckna det som fanns omkring dem i närmiljön, skulle förbättra sin kognitiva förmåga..$^{32}$

I boken Barnets århundrade från 1901 formulerade Ellen Key många idéer om barns friare utbildning och uppfostran. Av samtiden uppfattades dessa som progressiva, men fortfarande är avbildningsdiskursen tydlig. Key skriver:

"Ty vad varje människa behöver kunna för att reda sig i livet, är mycket litet. Detta lilla är att läsa väl innantill och rätt stava;[skriva] att avrita enkla föremål, så att man sålunda erhåller en bildskrift likväl som en bokstavsskrift - en färdighet som är alldeles oberoende av konstnärlig begåvning;" ${ }^{33}$ (min kursiv)

Ellen Key var inte företrädare för att se barnens bilder som konst, istället betonade hon vikten av att visa fram god konst för barn, och god konst menade Key var konst som barnen ansågs kunna relatera till. Key avfärdade renässanskonstnärer som Botticelli och Rafael, och förordade istället till exempel den samtida Carl Larsson som ofta avporträtterade mera "vardagliga" scener och hade barn med i många av sina bilder. Samtidigt var Key förespråkare för en ny typ av pedagogik som tog hänsyn till barns egna intressen, vilket uppmärksammades som positivt bland annat av konstpedagoger. ${ }^{34}$ Teckningsämnet kom senare också att anses fylla behovet av att lära ut "den goda smaken", både för att få medborgare att vilja konsumera olika föremål med modern design och för att skapa teckningskunnig arbetskraft. ${ }^{35}$ Skönhetssinnet behövde utvecklas både för producenter och konsumenter. ${ }^{36}$

De internationella världsutställningar som arrangerats sedan 1851 gav tillfälle för de industrialiserade länderna att mäta sig och tävla med varandra, bland annat vad gällde estetik och utbildning. ${ }^{37}$ Vid världsutställningen i Paris 1900 uppmärksammade den svenske pedagogen Hjalmar Berg framförallt den amerikanska utställningen i teckningsutbildning, och inspireras av hur de visar fram

${ }^{31}$ Hasse Hansson "När varje lärare kunde teckna” I Lind, Ulla, Hasselberg, Kersti \& Kühlhorn, Britt-Marie (red). (1992) Tidsbilder, Perspektiv på skola och bildskapande under 150 år. Utbildningsradion och Skolverket. sid. 26-40; Exempel på dessa läroböcker är Sjöholm \& Göes anvisningar för hembygdskunskap i årskurs 1-3.

32 I en tysk kontext har diskuterats hur reformpedagogiken användes inom teckningsämnet för att framhäva nationalsocialismens vurm för tradition, hembygdskonst och nationsgemenskap, vilken ansågs gestalta ett motstånd mot den industrialiserade masskonsten, se Kerbs, Diethart \& Siepmann, Eckhard (red). (1976) Kind und Kunst: eine Ausstellung zur Geschichte des Zeichenund Kunstunterrichts. 2. verb. Aufl. Berlin: BDK sid. 67.

${ }^{33}$ Key, Ellen (1900/1996) Barnets århundrade. [Nyutg.] Stockholm: Informationsförl. sid. 158.

${ }^{34}$ Viola, Wilhelm (1936) Child art and Franz Cizek. Vienna: Austrian Junior Red Cross sid. 33.

${ }^{35}$ Nordström, Gert Z. \& Romilson, Christer (1970) Bilden, skolan och sambället. Orig. utg. Stockholm: Aldus/Bonnier sid. 29f.

${ }^{36}$ Lindberg, Anna Lena (1991) Konstpedagogikens dilemma: historiska rötter och moderna strategier. [Ny utg.] Lund: Studentlitteratur sid. 178f.

37 Se tex: Christian Lundahl and Martin Lawn, 'The Swedish Schoolhouse: a Case study in Transnational influences in Education at the 1870s World's fairs', Paedagogica historica, 51 (2014), 319-334. 
barnets olika utvecklingssteg. ${ }^{38}$ Den strikta Stuhlmanska metoden hade börjat anses omodern och otidsenlig. Anna Maria Roos, som också skev flera läseböcker för folkskolan, menade i en artikel i tidskriften Ord och Bild 1908 att den "tekniska ritningen" är hämmande för barnens både kognitiva och estetiska utveckling. ${ }^{39}$ Roos skriver att "hos de konstnärligt begåfvade barnen kan olusten för en själlös och tråkig linearritning bli ännu starkare än hos de alldeles obegåvade." 40 I artikeln med titeln "Barnet som konstnär", lyfter Roos samtida internationella idéer som diskuterar barns bilder som en egen konstform, jämförbar med äldre tiders konst eller så kallad primitiv konst. Dessa idéer byggde vidare på Darwins utvecklingslära och knöts tydligt till utvecklingspsykologiska föreställningar om barns bildutveckling. ${ }^{41}$

Det är tydligt hur flera olika diskurser om barns utveckling brottas med varandra, men Roos förhåller sig kritisk till idén om barns universella teckningsutveckling, liksom diskussionen kring att pojkar skulle ha större begåvning för teckning än flickor. ${ }^{42}$ Samtidigt som de begåvade barnen enligt Roos behövde en mer spännande teckningsutbildning så var det ändå iakttagelseförmågan som Roos, liksom Key, framhöll som den väsentligaste färdigheten för det stora flertalet barn att lära sig genom teckning. I praktiken tog det tid för nya pedagogiska idéer att få fäste, både på grund av brist på teckningsmateriel och brist på utbildande lärare. I skolorna höll man gärna fast vid de förhållandevis enkla geometriska metoderna från Stuhlmanns Lärobok i frihandsteckning. ${ }^{43}$ Med viss fördröjning vinner ändå nya pedagogiska idéer så småningom kraft. ${ }^{44}$

$$
* * *
$$

Förväntningar på barns bildskapande har således förändrats över tid. 1700- och 1800-talets romantiska barndomsdiskurs innebar att barnen borde övas i att teckna räta linjer, för att så småningom kunna teckna av naturen. Barnens tecknande skulle styras enligt fastlagda scheman med början i räta vinklar. Naturalistiskt tecknande var målet med barns skapande. Att teckna "efter fantasin" innebar att man efter övning kunde teckna naturen på fri hand. Fram till 1900-talets början var det en bildpedagogik med rutnät och naturalistiskt avbildande som var den helt dominerande diskursen både i folkskolan, realskolan och på läro-

${ }^{38}$ Landahl, Joakim "Aesthetic Modernisation and International Comparisons: Learning About Drawing Instruction at the Paris Exposition Universelle of 1900" in History of Education (forthcoming).

39 Roos, Anna Maria "Barnet som konstnär" i Ord och Bild (1908) sjuttonde årgången, sjunde häftet.

${ }^{40}$ Ibid. sid. 350.

${ }^{41}$ Ibid. sid. 337 f. Roos nämner Ricci L’arte dei Bambini som den tidigaste, och Levensteins Kinderzeichnungen samt Kerschensteiners Die entwicklung der zeichnerichen Begabung.

42 Ibid. sid. 348. Även Kerschensteiner själv menar att pojkarnas bättre bilder också är tydligast bland stadsbarn "låter det ju tänka sig att stadsgossarnas öferlägsenhet öfver stadsflickorna delvis kan bero därpå att de har flera tillfällen till växlande företeelser, eftersom de i regel vistas mera utomhus än flickor.

43 Stuhlmann, A. (1878).

${ }^{44}$ Pettersson, Sten \& Åsén, Gunnar (1989) sid. 87. 
verket. Men så småningom kommer nya strömningar att göra sig gällande, både vad gäller hur barn bör lära sig teckna och syftet med teckningsundervisningen.

Det fanns således en lång tradition av naturalistiskt och strikt ordnat tecknande i skolan som hade börjat ifrågasättas när teckningstävlingar för barn vinner popularitet under tidigt 1930-tal. Detta innebar att tävlingarna etablerades under en period när uppfattningen om hur barns bilder skulle värderas kunde förankras i diametral skilda uppfattningar om vad som kännetecknade en bra barnbild. De naturalistiska idealen kunde underlätta för att bedöma vad som uppfattades som en vinnande tävlingsbild, samtidigt som tävlingarna kunde användas som ett sätt att få gehör för nya och moderna konstnärliga och pedagogiska idéer.

\section{Tidigare forskning}

Teckningstävlingar för barn har inte tidigare varit föremål för vetenskapligt avhandlingsarbete, däremot finns relativt omfattande tidigare forskning om barns bildskapande. Barnteckningstävlingarna ger möjlighet att studera barns bildskapande och barnkultur i en historisk kontext. I det tvärvetenskapliga fält som denna studie är en del av, är tidigare forskning inom bland annat visuell kultur, barnkultur och bildpedagogik relevant att förhålla sig till. Tävlingarna diskuteras i avhandlingen som ett samhällsfenomen, där jag både undersöker tävlingarnas struktur och organisation liksom de barnbilder som vunnit och visats fram och hur de kan förstås i sin samhälleliga kontext. Detta motiverar en presentation av tidigare forskning om barnkultur, barndomens historiska förändring samt av etnografiska studier om hur barn gör bilder. Avslutningsvis diskuterar jag också hur tidigare forskning relaterat till barn och tävlingar.

\section{Barndomens förändring, barns kulturella världar}

Bilden av barnet både som arvtagare av en befintlig samhällskultur och deltagande i en ständigt pågående process av kulturskapande, är väsentlig i min studie. Sharon Stephens argumenterar för att kulturen, liksom den moderna idén om barndomen är "ett historiskt situerat diskursivt objekt" med ett europeiskt ursprung och en europeisk historia ${ }^{45}$ Hon visar även hur "görandet av kultur" producerar och reproducerar av kollektiva förståelser. Det blir därför viktigt att diskutera forskningsmaterial och kontext utifrån vad kulturproduktion uppnår socialt, politiskt och diskursivt för olika grupper i samhället.

Därutöver lyfter Stephens fram hur olika kulturbegrepp har funnits sida vid sida, dels ett brett antropologiskt kulturbegrepp, som beskrivits i termer av organiskt integrerad kultur, samtidigt som ett smalt estetiskt kulturbegrepp, i motsats till politik eller ekonomi, associerats med högre estetiska eller intellektuella sysselsättningar, som litteratur, teater eller konst. Bland andra Johan Fornäs har

\footnotetext{
45 Stephens, Sharon (1995) Introduction: Children and the politics of culture in "late capitalism", In Sharon Stephens (ed)., Children and the politics of culture, pp. 3-48. Princeton; Princeton University Press.
} 
diskuterat hur det estetiska kulturbegreppet ligger nära Bourdieus begrepp "kulturellt kapital”, där vissa grupper i samhället haft tillgång till etablerade normer kring vad som betraktades som god konst, bland annat genom etablerandet av specifika institutioner, som museer och gallerier. ${ }^{46}$

Med en antropologisk blick på barndomens specifika kulturella uttryck sätter historikern Steven Mintz i The changing Face of Childrens culture fokus på synen på barn som oskyldiga. Barnkulturen kunde användas för att förhandla barndomens innebörder, maktrelationer och samhällsrelationer. ${ }^{47}$

Tidigare forskning visar också att barnkulturens uttryck och synen på barn förändrats. Vivianne Zelitzer har i ett inflytelserikt arbete beskrivit hur synen på barn förändrats under 1900-talet. Då barn alltmer kom att betraktas som emotionellt värdefulla värderades de inte i samma utsträckning för att de i framtiden skulle kunna arbeta och bidra med ett ekonomiskt värde. Barns deltagande både i betalt arbete och obetalt arbete i hemmet ersattes efterhand av en förlängd skoltid med ökad fritid. ${ }^{48}$ På denna ökade fritid förväntades barn exempelvis teckna och måla. Även barns bilder gavs ett emotionellt värde, som uttryck för barnens inre liv och barns fria skapande uppvärderades både i hemmet, förskolan och skolan. $^{49}$

Ett framträdande drag i barnkulturforskningen är intresset för barns egna röster. Detta syns i Chatarina Hällströms studie av barns insändare till tidskriften Kamratposten. ${ }^{50}$ Hon diskuterar vilka centrala fenomen barn har skrivit om i sina insändare och hur har de skrivit om dessa fenomen. Hällström gör nedslag 1977, 1987, 1997 och 2007. Hon visar bland annat att engagemang för fattiga barn i tredje världen ökar i Kamratposten under 1970-talet, liksom insändare som rör klimathot och miljöfrågor ökar från 1980-talet. Hällström lyfter här barnens insändare som del av en pågående global och kollektiv berättelse. ${ }^{51}$ Hon diskuterar hur tillhörighet och plats har upplevts av barn som både berikande och inskränkande.

Barns röster får en annan innebörd i Ingegerd Rydins studier Barnens röster: program för barn i Sveriges radio och television 1925-1999 Rydin visar hur SVT producerar både tradition och förnyelse, och hon diskuterar hur synen på vad som ansågs vara god barnkultur förändrats över tid. ${ }^{52}$ Även om programmen

${ }^{46}$ Fornäs, Johan (2012) Kultur. 1. uppl. Malmö: Liber sid. 24- 28.

${ }^{47}$ Mintz, Steven The changing Face of Childrens culture in Fass, Paula S \& Grossberg, Michael (red). (2012) Reinventing childhood after World War II. Philadelphia: University of Pennsylvania Press.

${ }^{48}$ Zelizer, Viviana A. Rotman (1994) Pricing the priceless child: the changing social value of children. Princeton, N.J.: Princeton University Press; Bendroth Karlsson, Marie (1996). Bildprojekt $i$ förskola och skola: estetisk verksambet och pedagogiska dilemman. Diss. Linköping: Univ. sid. 20ff.

49 Pettersson, Sten \& Åsén, Gunnar (1989); Änggård, Eva (2005); Halldén, Gunilla (red). (2007) Den moderna barndomen och barns vardagsliv. Stockholm: Carlsson.

${ }^{50}$ Hällström, Catharina (2011) Insändare $i$ Kamratposten: uttryck för villkor i barns kulturella sammanhang. Diss. Stockholm: Stockholms universitet, 2011.

${ }^{51}$ Ibid. sid. 252.

52 Rydin, Ingegerd (2000) Barnens röster: program för barn i Sveriges radio och television 1925 1999. Stockholm: Stift. Etermedierna i Sverige sid. $312 \mathrm{ff}$. 
skulle vara underhållande snarare än undervisande, hade tidiga Radio och Tv program en paternalistisk hållning och ville, i ett folkbildande syfte, uppfostra barn till god smak. ${ }^{53}$ Under 1960-1970-talet lyfter barnprogram fram mer av barns inre, emotionella utveckling, och på 1980 - 90-talet lyfts barn fram som självständiga aktörer, bland annat som programledare. ${ }^{54}$

Duktiga, aktiva och deltagande barn var också en del i det moderna samhällsbygget. Barns deltagande i bygget av nationella gemenskaper diskuteras av Anneli Lindgren i "Att ha barn med är en god sak": barn, medier och medborgarskap under 1930-talet". Lindgren beskriver bland annat barns deltagande i skolradion; och vilken bild av barn och barndom de vuxna konstruerat genom vad de låtit barn säga." 55 Lindgrens resultat visar hur barn görs delaktiga i en kulturgemenskap med gemensamt språk, gemensamma seder och historiska traditioner, sammanvävt med tankar om modernitet och teknisk utveckling.

Barndomsidealet förändrades gradvis från sextiotalet mot ett mera vuxet, självständigt och autonomt barn. Det kompetenta barnet konstruerades och romantiserades, som en partner för vuxna att arbeta tillsammans med. ${ }^{56}$ Likhet med vuxna snarare än olikhet blev den dominerande idén om barn. Detta nya kompetenta barn hade också en kommersiell roll att spela eftersom det kunde efterfråga varor och vara intressanta som konsumenter. Barns perspektiv skulle tas tillvara, och barns röster fick betydelse i kultur och politik. Barn uppfattades ha förmåga att avgöra vad som är bra för barn, och de borde därför delta i samhälleliga beslut. ${ }^{57}$ En liknande syn på barn diskuterar Söderlind och Engwall då de visar hur olika offentliga utredningar under 1990-talet lyft fram vikten av att stärka ungdomars inflytande över politiska beslut, exempelvis vad gäller fritid och skola..$^{58}$ Även arbetet mot en hållbar utveckling tas upp i utredningarna som en specifik barn- och ungdomsfråga, där barn i ett romantiserat ideal kan uppfattas som att de representerar framtiden och står närmare naturen. Söderlind och Engwall menar att detta också kan ses som att vuxna undandrar sig ansvar för miljöfrågorna och överför ansvaret på barn. ${ }^{59}$

Samtidigt aktualiserar detta frågan om vilka som är intresserade av lyfta fram barns röst och inflytande. Lindgren och Halldén problematiserar i artikeln "Individuella rättigheter; autonomi och beroende. Olika synsätt på barn i relation till FN: s barnkonvention" hur samhällsaktörer använder barns röster för olika syften. De frågar sig vem det är som vinner på att det skapas en föreställning

\footnotetext{
${ }_{53}$ Ibid. sid. 340 .

${ }^{54}$ Ibid sid. 347.

${ }^{55}$ Lindgren, Anne-Li (1999) "Att ha barn med är en god sak": barn, medier och medborgarskap under 1930-talet. Diss. Linköping : Univ. sid. 26.

${ }^{56}$ Sandin, Bengt (2012) sid. 128f.

57 Ibid sid. 131.

${ }^{58}$ Söderlind, Ingrid \& Engwall, Kristina (2005) Var kommer barnen in?: barn i politik, vetenskap och dagspress. Stockholm: Institutet för framtidsstudier sid.56ff. (tex utredningarna Ungdom och makt och Politik för unga).

${ }^{59}$ Ibid. sid. $56 \mathrm{ff}$.
} 
om att barnen bestämmer den politiska dagordningen. ${ }^{60} \mathrm{I}$ detta sammanhang blir också Halldéns definition av begreppet "barnperspektiv" relevant för min studie, eftersom bilderna kan betraktas som uttryck för barns erfarenheter, samtidigt som teckningstävlingarna är samhälleligt styrda och reglerade. Halldén menar att genom att ha ett barnperspektiv på forskning uppmärksammar man barns röster, samtidigt som man ser dem som inskrivna i ett diskursivt sammanhang. Forskning som utgår från ett barnperspektiv vill visa vilken plats barn ges i samhället, vilka erfarenheter barn generellt får i det samhälle de växer upp i och hur barnen kan uttrycka dessa erfarenheter. ${ }^{61}$ Barnbildstävlingarna kan ses som kultur för barn, skapad av vuxna i vilken vissa barns röst och vissa handlanden ges utrymme. ${ }^{62}$ Kultur för och av barn kan uppenbarligen, som i de här studierna, användas för att avtäcka nya synsätt på barn och barndom. Även om barnkulturen i första hand ansågs vara till för att roa snarare än lära ut så var den ändå full av normativa budskap, något som även teckningstävlingar kan tänkas aktualisera. ${ }^{63}$

\section{Barns bildskapande}

Som tidigare nämnts saknas forskning om teckningstävlingar för barn, men tidigare forskning om barns bildskapande och bildpedagogik kan ge vissa redskap. Jag kommer nu att redogöra för forskning om barns bildskapande i ett historiskt perspektiv och därutöver i samtida pedagogisk praktik.

Barns bilduttryck i ett historiskt perspektiv har studerats av Karin Aronsson. Utifrån en studie av barnteckningar från en familj i tre generationer under 1900-talet, konstaterar hon att de olika generationernas bilduttryck karaktäriseras av realistiska, modernistiska och postmoderna ansatser ${ }^{64}$ Aronsson tar i avhandlingen Barns världar - Barns bilder upp det som hon menar är två olika huvudtyper av teorier kring barns skapande, dels konventionsteorin, dels universalteorin. ${ }^{65}$ Till universalteorin hör utvecklingspsykologisk forskning som letat efter generella likheter i barns bildproduktion, på liknande sätt som modernistiska konstpedagoger som Herbert Read. Till konventionsteoretikerna räknar Aronsson de som menar att bilder till största del påverkas av samhälleliga bild-

\footnotetext{
${ }^{60}$ Lindgren, Anne-Li och Halldén, Gunilla (2001), Individuella rättigheter; autonomi och beroende. Olika synsätt på barn i relation till FN: s barnkonvention, Utbildning och Demokrati, (2), 65-79.

${ }^{61}$ Halldén, Gunilla Barnperspektiv som ideologiskt eller metodologiskt begrepp i Pedagogisk Forskning $i$ Sverige 2003 årg. $8 \mathrm{nr}$ 1-2 sid. 12-23 issn 1401-6788.

62 SOU 2006:45, Tänk framåt, men gör nu: Så stärker vi barnkulturen, sid. 33.

${ }^{63}$ Sandin, Bengt (2012) Children and the swedish welfare state: from different to similar In Fass, Paula S \& Grossberg, Michael (red). Reinventing childhood after World War II. Sid. 129ff.

${ }^{64}$ Aronsson, Karin (1997) Barns världar - barns bilder. Stockholm: Natur och kultur. Sid. $98 \mathrm{ff}$. Bilderna är från mellan 1920-1996.

${ }_{65}$ Aronsson, Karin (1997) sid. 148.
} 
konventioner. ${ }^{66}$ Aronsson menar att barns bilder kan stärka och lyfta fram barnets egen röst, att barn "ritar vad de vill berätta" ${ }^{67}$

I Barnbilder som försvann visar Aronsson hur bildkonventioner även bland små barn är historiskt och kulturellt bundna.$^{68}$ Hon lyfter fram utvecklingspsykologen Luqets betydelse för senare forskning, eftersom han tidigt betraktade barns tecknande som en möjlighet att lyfta fram det som barn själva ansåg vara det väsentliga i bilderna.

1900-talets förändrade samhällsideal angående barns "naturliga" bildskapande diskuterar Helene Illeris i Billede, Pedagogik og Makt: postmoderne optikker $i$ det billedpcedagogiske felt. Hon visar hur bildämnet i Danmark från 1940-talet fick terapeutiska inslag, där barnen genom bildarbete förväntades uttrycka sina idéer och känslor. ${ }^{69}$ Pedagogerna hoppades att konsten skulle befria barnen i skolan liksom modernismen befriat konstnärerna: "Där teckningsundervisningen tidigare skulle göra barn till duktiga människor skulle den nu göra dem till lyckliga människor.” skriver Illeris. ${ }^{70}$

Till följd av dessa nya pedagogiska idéer blev alla bilder, konstbilder såväl som barnbilder, vilka kunde uppfattas som resultat av onaturlig disciplinering och teknifiering, sedda som konstiga eller manierade. Bildproduktion i undervisningen skulle stimulera "återväckandet av de slumrande konstanlagen" hos eleverna. Man borde arbeta med konsten "inifrån och ut" och se vardagsmänniskan, inte de stora mästarna. De antika idealen förkastades. ${ }^{71}$

Bildarbetet likställdes med en form av terapi, där barnen kunde avreagera sina instängda känslor genom att teckna och måla, vilket antogs ha en positiv inverkan på deras socialitet. Den så kallade formningsundervisningen, som motsvarade den svenska teckningsundervisningen, skulle också förhindra dåliga vanor efter skolan och göra att eleverna fick en bra fritidssysselsättning. ${ }^{72}$

Illeris polemiserar också med tidigare bildpedagoger och menar att både Gert Z Nordströms Skolan, bilden och sambället och Christian Pedersens Børns billeder $i$ en billedkultur främst bör läsas som motböcker mot en under 1950-60-talet rådande diskurs "vars primära syfte var att dekonstruera föreställningen om barnet som ett marginaliserat naturväsen, som existerade i sitt eget universum."73 Men det fanns ändå tydliga idéer om hur en "god barnbild" borde se ut, enligt Illeris. Det fanns kvar föreställningar om det "mest" verkliga, något som uttryck-

\footnotetext{
${ }^{66}$ Aronsson nämner Gombrich, E. H (1977) Art and illusion: a study in the psychology of pictorial representation. 5. ed. London: Phaidon men det gäller även tex Köhler, Rolf \& Pedersen, Kristian (1978). Børns billedproduktion i en billedkultur. Bredsten: Ulrika eller Gert Z Nordström som var aktiv i tekcningslärarförbundet i Sverige från mitten av 1960-talet.

${ }^{67}$ Ibid. sid. 228.

${ }^{68}$ Aronsson, Karin "Barnbilder som försvann" i Lind, Judith et.al.(red). (2009) Historien, barnen och barndomarna: vad är problemet? : en vänbok till Bengt Sandin. [Linköping: Linköpings universitet] sid. 17.

${ }^{69}$ Illeris, Helene (2002) Billede, pedagogik og magt: postmoderne optikker i det billedpcedagogiske felt. 1. uppl. Frederiksberg: Samfundslitteratur sid. 213f.

${ }^{70}$ Ibid. sid. 155f. (min övers).

${ }^{71}$ Ibid. sid. 119.

72 Ibid. sid. 147.

${ }^{73}$ Ibid. sid. 190 (min översättning).
} 
tes till exempel i begrepp som myt och verklighet, eller sanna bilder och kliché$e r$, liksom psykologiska föreställningar om allmänmänskliga existentiella teman som människor i alla tider överallt använt i sin bild och formproduktion. ${ }^{74}$

Marie Bendroth Karlsson har studerat estetiska lärprocesser i förskola och grundskolans lägre år ur ett sociokulturellt perspektiv, där hon bland annat undersöker pedagogiska dilemman mellan bildverksamheten och idéer kring barns utveckling. ${ }^{75}$ Bendroth Karlsson lyfter fram bildpedagogen Jan Tomeaus, som hon kallar Herbert Reads "främste profet" i Sverige. Han var verksam på förskoleseminariet i Stockholm och var från 1945 även bildlärare, och var en flitig debattör för att utveckla skolan till ett mera personligt och mindre finkulturellt bildskapande. Bendroth Karlsson skriver: "I debatten kring det "fria skapandet" fanns ämnesföreträdare som såg professionaliseringen och försvaret för den egna yrkeskåren som det viktigaste, medan Thomaeus tog barnets perspektiv." 76 Diskussionen kring vad som har betraktats som barnets perspektiv vad gäller skapande aktivitet och hur "barns perspektiv" efterfrågats av olika aktörer under olika tider, är relevant för min undersökning.

I sin avhandling Bildundervisningen och det pedagogiska rummet: traditioner, föreställningar och undervisningsprocess inom skolämnet teckning/bild i grundskolan belyser Sten Petterson och Gunnar Åsén bland annat den svenska teckningslärarutbildningens förändring under 1940-talet. När utbildningen förlades till den nystartade Konstfackskolan istället för som tidigare till tekniska skolan, knöts teckningsämnet till konstnärlig utbildning snarare än teknik och linjarritning. ${ }^{77}$ Vidare beskriver de hur 1940-talets skolkommissioner gav ett ökat stöd till "det fria skapandet" och hur modernismens konstideal också förändrade normerna för hur pedagoger bedömde barns bilder. Herbert Reads argument om "uppfostran genom konsten" fick gehör i efterkrigstidens förhoppning om fostran till demokratiska individer och kunde användas för att stärka bildämnets ställning i skolan, menar Åsén och Petterson..$^{78}$ I sin studie uppmärksammar de hur det fria skapandets ideal bygger på att eleverna skulle förstå det outsagda, även då syftet med bilduppgifterna ofta var otydligt. En av de få uppgifter i skolan som Petterson Åsén i sin klassrumsetnografi definierar som att det hade ett tydligt syfte, var däremot teckningstävlingar. ${ }^{79}$ Deras undersökning påvisar att den "fria bildpedagogiken" stämmer överens med de normer som barn från en akademisk medelklass möter i sin hemmiljö. De barnen har därför haft lättare att anpassa sig till de uppgifter som bygger på det fria skapandets metodik, än barn från arbetarklasshem. Den förhoppning som funnits bland pedagoger att det fria skapandet skulle "utgöra ett utrymme i skolan där 'vanliga' sociala och sorterande krafter skulle ha mindre utrymme", hade därför inte fått något genomslag. ${ }^{80}$

\footnotetext{
74 Illeris, Helene (2002) sid. $204 \mathrm{ff}$.

75 Bendroth Karlsson, Marie (1996) Bildprojekt i förskola och skola: estetisk verksamhet och pedagogiska dilemman. Diss. Linköping : Univ.

76 Ibid. sid. (1996) sid. 20.

77 Ibid. sid. 89.

78 Pettersson, Sten \& Åsén, Gunnar (1989) sid. 95 f.

79 Ibid. sid. 270.

80 Pettersson, Sten \& Åsén, Gunnar (1989) sid. 275.
} 
Läroplanen 1980 betonade bilden som språk, liksom hur budskap kommuniceras i bilder av olika slag. När Åséns och Pettersson genomför sin undersökning 1989 i grundskolans årskurs tre, sex och nio visar de hur tidigare läroplaner lever kvar i den faktiska klassrumspraktiken, där avbildning och bilden som inre uttryck fortfarande var dominerande. ${ }^{81}$ Undersökningen visar hur den nya läroplanens bildpedagogiska diskurser hade svårt att få genomslag.

I och med utbyggnaden av den svenska förskolan under 1970-80-talet, har också förskolans bildskapande praktiker blivit ett aktuellt forskningsområde. Eva Änggårds avhandling Barns skapande i förskolan visar hur barns bildskapande blivit central i konstruktionen av vad som kännetecknar den samtida barndomen. Änggård använder Vygotskijs teori om tolkande reproduktion. Hon beskriver detta som en kreativ process där barn både omtolkar och använder den omgivande kulturen för egna syften, samtidigt som de på så vis aktivt reproducerar samhällets kultur. ${ }^{82}$ Barnbilderna kan betraktas som uttryck för ett växelspel som både innefattar historisk och kulturell reproduktion och omtolkning av denna reproduktion. Både att få och vilja göra bilder är något som förknippas med barndom, menar Änggård..$^{83}$

I sin etnografiska studie av barns bildskapande på fritidshem belyser Anna Sparrman vikten av att se bildproduktionen i en samhällelig kontext. ${ }^{84}$ Hon visar hur barn på sin fritid använder sig av olika populärkulturella medieförebilder i sitt eget bildskapande, liksom hur de i interaktion och diskussion förhåller sig till exempelvis sexualitet och genus. ${ }^{85}$

Flera studier undersöker hur bildskapande praktiker använts för att förhandla vad som betraktas som "pojkigt och flickigt" och som del i ett identitetsskapande. Det kan vara vilka olika sagofigurer flickor och pojkar tecknar på förskolan, vilka favoritleksaker pojkar och flickor tecknar, eller hur ungdomar förhandlar identitet inom medieundervisningens ram. ${ }^{86}$

Stina Wikberg visar i Bland självporträtt och parafraser: om kön och skolans bildundervisning hur eleverna i bilder framställer sig själva som feminina eller maskulina, delvis utifrån de bildreferenser som används i undervisningen. ${ }^{87}$ Det framkommer också tydligt att det är olika diskurser som bryts mot varandra kring vad som är bildämnets huvudsakliga innehåll. Bland eleverna dominerar idén om ämnet som självbespeglande, individorienterat och kopplat till det fria

${ }^{81}$ Ibid. sid. $192 \mathrm{ff}$.

82 Änggård, Eva (2005) sid. 5ff.

83 Änggård, Eva (2005) sid. 28.

${ }^{84}$ Sparrman, Anna (2006) Barns visuella kulturer: skolplanscher och idolbilder. Lund: Studentlitteratur sid. $26 \mathrm{ff}$.

85 Ibid. sid. $98 \mathrm{f}$.

${ }^{86}$ Heikkilä, Mia "Genusperspektiv på teckningar av favoritleksaker" I Eriksson, Yvonne (red). (2014) Barn tecknar världen: att förstå och tolka barns bilder sid.153; Änggård, Eva (2005), sid. 193ff.; Öhman-Gullberg, Lisa (2008). Laddade bilder: representation och meningsskapande i unga tjejers filmberättande. Diss. Stockholm: Stockholms universitet; Hellman, Annika (2017) Visuella möjlighetsrum: gymnasieelevers subjektsskapande i bild och medieundervisning. Diss. Göteborg : Göteborgs universitet.

${ }^{87}$ Wikberg, Stina (2014). Bland självporträtt och parafraser: om kön och skolans bildundervisning. Diss. Umeå. 
skapandet medan lärarna, åtminstone i teorin, företräder den mera kommunikationsorienterande diskursen..$^{88}$ Den tidigare forskningen har i de presenterade studierna visat inte bara bildämnets förändring och nära knytning till barndomens innebörder utan också den potential som ligger i att förstå barnbilden som ett samspel mellan barn och vuxna inom givna kulturella ramar.

\section{Barn och tävlingar}

Som jag visade inledningsvis har barns deltagande i teckningstävlingar betraktats som mer eller mindre problematiskt över tid, vilket framstår som en konsekvens av konflikterna mellan olika synsätt på barns bildskapande. Även avseende barnidrotten har tävlingsmomentet problematiserats. Krister Hertting undersöker i sin fenomenologiska studie om ledarskap och lärprocesser i barnfotboll, bland annat tävlingen som kulturellt fenomen. ${ }^{89}$ Glädje och tillfredsställelse framställs som viktigare inom barnfotbollen än att vinna, men det är ändå tävlingen som är drivkraften i verksamheten..$^{90}$ Att uppnå rättvisa förutsättningar var viktigt, exempelvis genom att barnen delas in efter ålder, vilket också förekom i vissa av teckningstävlingarna. ${ }^{91}$ Fotbollens bestämda regelsystem gör att vare sig barn eller vuxna har något större utrymme att påverka. Hertting menar att barnens möjlighet att påverka träningen är en skendemokrati som påminner om livet i vardagen. ${ }^{92}$

Fotbollen som fenomen i ett historiskt perspektiv har studerats av Torbjörn Andersson. ${ }^{93}$ Han visar hur ungdomar (pojkar) ur arbetarklassen under början av 1900-talet alltmer kom att engageras i och intressera sig för fotbollen, som tidigare varit en mer medelklassbetonad sport. ${ }^{94}$ Tävlandet kunde ses som en kombination av rivalitet och lek, samtidigt som spelet krävde disciplin och ordning. ${ }^{95}$

Pia Lundquist Wannberg visar i Kroppens medborgarfostran: kropp, klass och genus i skolans fysiska fostran 1919-1962 hur tävlan i lag ansågs vara att föredra, framför personlig prestation av Skolidrottsförbundet på 1920-talet. ${ }^{96}$ När Skolöverstyrelsen 1936 uttalade sig om tävlingar i folkskolan, var man oroliga att idrottstävlande kunde orsaka fysiska eller psykiska men. Samtidigt menade man att tävlingar var "idrottens tjusning och alla barn äro roade av att tävla". ${ }^{77}$ Lagidrotten framställdes som bättre för medborgarfostran för att inte "fostra till att de känna sig alltför märkvärdiga".$^{98}$ På läroverken däremot uppskattades

\footnotetext{
${ }^{88}$ Ibid. sid. 214.

${ }^{89}$ Hertting, Krister (2007) Den sköra föreningen mellan tävling och medmänsklighet: om ledarskap och lärprocesser i barnfotbollen. Diss. Luleå: Luleå tekniska universitet, 2007.

${ }^{90}$ Ibid. sid. 123.

${ }^{91}$ Hertting, Krister (2007) sid.100. I idrottssammanhang även efter vikt och kön.

92 Ibid. sid. 86f.

${ }_{93}$ Andersson, Torbjörn (2002) Kung fotboll: den svenska fotbollens kulturhistoria från 1800-talets slut till 1950. Diss. Lund : Univ.

${ }^{94}$ Ibid. sid. $164 \mathrm{ff}$.

${ }^{95}$ Ibid. sid. 73.

${ }^{96}$ Lundquist Wanneberg, Pia (2004) Kroppens medborgarfostran: kropp, klass och genus i skolans fysiska fostran 1919-1962. Diss. Stockholm.

${ }_{97}$ Wanneberg, Pia (2004) sid. 164.

${ }^{98}$ Ibid. sid. 101.
} 
emellertid den individuella tävlingsidrotten, som en fungerande del av läroverkens elitistiska prägel. Att värderande av individuella prestationer var en del av skolkulturen, understryker Ulla Johansson i Normalitet, kön och klass, liv och lärande i svenska läroverk 1927-1960. Studenterna värderade sig själva utifrån individuella prestationer, med ständig offentlig bedömning och kontroll. ${ }^{99} \mathrm{I}$ detta perspektiv kan man se tävlingsformen och teckningstävlingarna som en del av en samtida skolkultur. I vår samtid finns det exempel på att detta löses genom den inkluderade idén om att alla barn ska ges tillträde både till deltagande och att vinna priser. David Cardell visar hur idrottstävlingar där alla deltagare får pris används av organisationer och företag för att visa fram specifika symboler och varumärken. ${ }^{100}$

En av Televerkets teckningstävlingar har studerats av Yvonne Eriksson. Kapitlet presenteras i antologin Barn tecknar världen att förstå och tolka barns bilder. ${ }^{101}$ Studiens empiri bygger på inskickade förslag för 1982 års omslag till telefonkatalogen, med temat "Handikappad i samhället - Lika men ändå olika" som finns samlade i SBBA:s arkiv. ${ }^{102}$ Temat för tävlingen valdes då FN proklamerat det internationella handikappåret 1981. Det fanns också under denna tid en ambition att barn med funktionsnedsättning inte skulle gå i särskilda klasser utan delta i vanlig skolundervisning. ${ }^{103}$ Eriksson menar att det är ofrånkomligt att barnen genom tävlingsbilderna medverkar till att förstärka synen på individer med funktionsnedsättning som de andra, som objekt som de skapar berättelser kring i sina bilder. ${ }^{104}$ Samtidigt lär de sig och visar i bilderna den moraliska koden att man bör bete sig på ett schysst sätt mot alla och inkludera funktionsnedsatta i olika aktiviteter. Eriksson visar hur tävlingsbilderna interagerar med samtida diskurser och hur tävlingsbilder genom att de är utvalda, antingen av klassen eller av en jury, kan ses som karaktäristiska bilder för sin tid. De visar samtida normer för hur en bra barnbild bör se ut.

En möjlig plats för barns bildaktivitet och tävlande har också varit genom TV-mediet. Exempelvis har barn kunnat delta aktivt i TV genom att skicka in teckningar där några väljs ut och visas upp i barnprogram. ${ }^{105}$ Åsa Pettersson diskuterar i sin avhandling TV for children: how Swedish public service television imagines a child audience SVTs föreställningar om vad barnpubliken behöver och vill ha. Hon beskriver även hur tävlingar för barn i TV gav barn möjlighet

99 Johansson, Ulla (2008) Normalitet, kön och klass liv och lärande i svenska läroverk 1927 1960. Enskede: TPB.

100 Cardell, David "Barnidrottens spridning, kulturindustrin och kulturstudiernas möjligheter" I Tolvhed, Helena \& Cardell, David (red). (2011). Kulturstudier, kropp och idrott: perspektiv på fenomen i gränslandet mellan natur och kultur. Malmö: idrottsforum.org sid. sid. 90.

101 Eriksson Yvonne (2014) "Handikappad- lika men ändå olika” I Barn tecknar världen att förstå och tolka barns bilder (red). Studentlitteratur.

${ }^{102}$ De bilder som Eriksson studerat är inte de bilder som vann, men de fem som skickades in från varje skola.

103 Sandin, Bengt \& Sundkvist, Maria (2014) Barn, barndom och sambälle: svensk utbildningshistoria. 1. uppl. Malmö: Gleerup sid. $96 f$.

${ }^{104}$ Eriksson Yvonne (2014) (red) sid. 45.

${ }^{105}$ Pettersson, Åsa (2013) TV for children: how Swedish public service television imagines a child audience. Diss. Linköping : Linköpings universitet, 2013 sid. $191 \mathrm{ff}$. 
till deltagande, men att tävlandet samtidigt förutsatte kunskap och en inordning i det regelsystem som skapats av vuxna. ${ }^{106}$

Hur vuxnas fotografier av barn har använts i tävlingssammanhang visar Mathilda Hallberg i sin studie där hon bland annat analyserar Aftonbladets så kalllade A-barnstävlingar. ${ }^{107}$ Hon argumenterar där för att tävlingsbilder använts som del av en politisk retorik under 1930 och 40-talet. Tävlingsfoton av barn är med och förhandlar normer och ideal kring exempelvis föräldraskap, barns hygien och fostran, liksom barnet som symbol för nationen. ${ }^{108}$ Där foton och kommentarer i Aftonbladets A-barnstävling valde att lyfta fram familjen och den goda modern, betonade den statligt initierade Svenska barn i bild den framväxande välfärdsstatens omsorger om nationens barn. Genom analys av foton av barn i åskådningskulturen visar Hallberg hur tävlingarna och fotoböckerna kunnat användas för olika syften; och därmed delta i förhandlingen av det nationella projektet. ${ }^{109}$ Söderlind och Engwall diskuterar barns plats i vetenskapen och lyfter särskilt fram att det är förhållandevis få historiska avhandlingar som belyser barnfrågor. Ännu färre är det inom (bild)konstvetenskap, och de menar att "avsaknaden av konstvetenskapliga studier är förvånande, med tanke på bildens starka roll i vår tids samhälle." ${ }^{110}$ Här kan denna avhandling ge ett bidrag.

$$
* * *
$$

Sammanfattningsvis finns således historisk forskning som har lyft barndomens förändring och visar hur barn på olika sätt varit delaktiga på en samhällelig arena. Den betoning tidigare forskning haft på barns egna uttryck genom skapande har visat att det funnits ett intresse att synliggöra barns aktörskap och barns skapande. Liksom tidigare forskning visat kan barns bilder analyseras, för att lyfta hur barn gestaltat sig själva och världen. Tävlingar för barn är ett relativt outforskat område, och genom att studera barnteckningstävlingar är det möjligt att diskutera barndomens förändrade innebörder, både genom tävlingarnas organisering och genom bildernas innehåll och estetiska uttryck. Dessutom finns det anledning att förhålla analysen till diskussionen om barnperspektiv och barnkultur i brytningen mellan vuxnas inflytande och barns egna röster. Tävlingsbilder är intressanta att studera eftersom de antas tala med barns röst, men med en röst som är mer eller mindre kontrollerad av vuxenvärlden.

Den tidigare forskningen om barn visar också att kontexten för barns kulturella handlande och uttryck förändrats över tid. Då tävlingsbilderna kan studeras inte enbart som "barnbild" utan snarast som producenter av samtidsdis-

\footnotetext{
${ }^{106}$ Ibid. sid. 201ff.

107 Hallberg, Mathilda (2017) Barn till beskådan: familj, välfärdsstat och nation i fototävlingar och fotoböcker 1930-1944. Diss. Linköping: Linköpings universitet, 2017. I denna tävling skickade föräldrar in bilder av sina barn (2-4 år), det kunde vara både bilder de tagit själva eller hos en fotograf. Tävlingens syfte var att förbättra barnhälsovården, där idén var att kora "A-barnet" vilket innebar att föräldrarna, speciellt mamman hade skött sina uppgifter väl för att få barnet friskt och hälsosamt. sid. $61 \mathrm{ff}$.

${ }^{108}$ Ibid. sid. $217 f$.

${ }^{109}$ Hallberg, Mathilda (2017) sid. 261f.

110 Söderlind, Ingrid \& Engwall, Kristina (2005) sid. 85.
} 
kurser är en viktig utgångspunkt att undersöka inom vilka sociala, ekonomiska och politiska arenor som tävlingarna verkar. I bakgrund och tidigare forskning har jag också visat hur barns bilder under 1940-talet kom att betraktas utifrån pedagogiska teorier om bilder som personliga uttryck för barns inre känsloliv. Detta kom i konflikt med tävlingsmomentet, där bilderna rangordnades efter arrangörernas omdömen.

Konflikterna som kom till uttryck i ställningstagandet till barns fria skapande och barns medverkan i tävlingar där bilderna värderades och bedömdes motiverar studiens diskursteoretiska perspektiv.

\section{Teoretiska och metodologiska utgångspunkter}

Jag kommer i det följande att redogöra för de teoretiska utgångspunkter som varit vägledande i arbetet med att analysera, bearbeta och tolka materialet. För att undersöka hur olika aktörer använt sig av bilderna, liksom för att analysera bilderna i sig, använder jag visuell kulturteori som en överordnad ram för min studie. Inom denna ram har jag sedan använt diskursanalys och semiotisk analys som lämpliga redskap. Jag har inspirerats av Gillian Roses metod för analys av visuellt material där diskursanalys som metod kombineras med semiotisk analysmetod. Rose visar hur man kan använda visuellt material både för att visa hur diskurser kan artikuleras genom bilder och hur institutionella praktiker, som exempelvis arkiv eller museum, är del av de diskursiva praktikerna. ${ }^{111} \mathrm{I}$ det här arbetet betraktar jag teckningstävlingar som en sådan praktik.

\section{Visuell kulturteori}

En utgångspunkt $\mathrm{i}$ avhandlingen är att bilder har stort inflytande över människans sätt att tänka om och förstå världen. En förutsättning för kommunikation och meningsskapande genom bilder är att de, som i all kommunikation, ingår i ett kulturellt kretslopp med en gemensam kod och ett gemensamt teckensystem i en kultur eller ett samhälle. Att använda visuell kulturteori innebär att lyfta fram hur både de bilder vi möter och de vi själva producerar inte bara visar en specifik förståelse för eller tolkning av världen, utan också interagerar med och inverkar på betraktaren. Bilderna är bärare av sociala, kulturella och politiska betydelser. Därför behövs ett kritiskt förhållningssätt som tar hänsyn till de specifika praktiker, tekniker och kunskaper som omger bilderna. Visuella representationer är aldrig oskyldiga; de såväl reproducerar som producerar sin tids normer och ideologier. ${ }^{112}$

${ }^{111}$ Rose, Gillian (2007) Visual methodologies: an introduction to the interpretation of visual materials. 2. ed. London: Sage sid. 143f, 173.

${ }_{112}$ Rose, Gillian (2016). Visual methodologies: an introduction to researching with visual materials. 4th edition London: Sage; Eriksson, Yvonne \& Göthlund, Anette (2012). Möten med bilder: att tolka visuella uttryck. 2. [rev.] uppl. Lund: Studentlitteratur sid. 18.; Sturken, Marita \& Cartwright, Lisa (2009). Practices of looking: an introduction to visual culture. 2. ed. New York: Oxford University Press sid. 5.; Lindstrand, Fredrik \& Selander, Staffan (red). (2009) Estetiska lärprocesser: upplevelser, praktiker och kunskapsformer. 1. uppl. Lund: Studentlitteratur sid. $211 \mathrm{ff}$. 
Att studera visuell kultur ur ett historiskt perspektiv ger möjlighet att synliggöra tillfällen då det visuella debatterats, transformerats och ifrågasatts. Det visuella kan ses som en ständigt utmanande plats för social interaktion och definitioner av exempelvis barn, kön, klass eller nationstillhörighet. ${ }^{113}$ Att bilder kan ha övertygande funktioner har diskuterats länge vad gäller både reklam och konstbilder, medan barnbilder oftare ansetts vara spontana uttryck för inneboende kreativitet. Det kan därför vara intressant att granska bildskapande just i sammanhang som tydligt regisserats av vuxna. Hur föreställningar om barns naturliga kreativitet och fantasi historiskt konstruerades i samband med tävlingarna är relevant både avseende tävlingarna och bilderna i sig. Det blir i detta sammanhang intressant att studera på vilket sätt tävlingarna och bilderna är aktiva i att producera ideal och sociala och samhälleliga normer. ${ }^{114}$ För att göra detta används såväl semiotisk närläsning av bilderna som en analys av den samhälleliga kontexten och diskursiva praktiker.

Tävlingarna skapas i ett socialt och historiskt sammanhang och kan liksom bilderna förstås i förhållande till de maktförhållanden inom vilka de har tillkommit, det vill säga i egenskap av tävlingar initierade av vuxenvärdens olika politiska, sociala och ekonomiska arenor. Som Rolf Köhler skriver angående barns bilder som historiska artefakter i boken Børns billedproduktion i en billedkultur:

Deres (börns) billeder er selv historiske billeder, fordi de bestemmes af kulturen og representerer den. De er altså reproduktion av kultur. Men de er også produktion av kultur, fordi deres billeder produceres ind i en social sammenhang, hvor de existerer. ${ }^{115}$

Barnens tävlingsbilder kan alltså inte enbart förmedla kulturella betydelser, utan producerar också betydelser, speciellt de offentligt publicerade bilder jag studerat. Bilderna är komplexa och mångfacetterade och producerar dessutom oftast fler än en betydelse. Här kan en semiotikens redskap vara till hjälp. I en given barnbild finns alltså en mängd betydelser möjliga att förmedla, bland annat beroende av i vilken kontext bilden befinner sig, vem som möter bilden och var. ${ }^{116}$ Genom att studera teckningstävlingarna går det att uppmärksamma vilka olika synsätt som dominerat synen på barns bilder och barns bildskapande över tid, samt om det funnits mot varandra stridande synsätt. Studiet av hur tävlingarna konstruerats blir ett särskilt viktigt område för granskning. I denna kontext kan vi avteckna bildproduktionens diskursiva praktiker. ${ }^{117}$ Genom att se teckningstävlingarna som producenter av förväntade normer inom ett samhälle, kan vi även se när dessa normer omförhandlas. ${ }^{118}$

${ }_{113}$ Mirzoeff, Nicholas (red). (1998) The visual culture reader. London: Routledge sid. 5 f.

114 Van Leeuwen, Jewitt, Carey (2001) Handbook of visual Analysis sid. 85f.

${ }^{115}$ Köhler, Rolf \& Pedersen, Kristian (1978) sid. 78.

116 Lindgren, Simon (2009) sid. 64.

117 Jean Carabine "Unmarried Motherhood 1830-1990: A genealogical Analysis" I Wetherell, Margaret, Taylor, Stephanie \& Yates, Simeon J. Eds. (2001) Discourse as Data. A Guide for Analysis London: Sage sid. 267.

${ }^{118}$ Barker, Chris (2012) Cultural studies: theory and practice. 4. ed. London: SAGE sid. $66 f$. 


\section{Diskursanalys}

Jag har framför allt använt mig av Norman Fairclough, vars tolkning av Michel Foucaults diskursbegrepp betonar att diskurser är aktiva inte enbart för att skapa kontinuitet utan även i att skapa förändring. Kritisk diskursanalys frågar efter vilka sanningar som skapas genom olika diskursiva praktiker, i det här sammanhanget hur tävlingar organiserats och utformats och innehållet i de bilder och texter som tävlingarna genererat. Barnens bilder i tävlingarna har historiskt specifika gränser för vilka bilder som är möjliga att producera, både vad gäller teknik och innehåll. Bildpraktiker var formade av sina specifika historiska och sociala sammanhang och är därmed intressanta att studera och jämföra mellan olika historiska perioder. I det här sammanhanget blir det intressant att följa de diskursiva bestämningar, värden och normer, som knyts till barns tävlingar och bildproduktion. Tävlingsformen kan te sig likartad men laddas med olika innebörder under olika perioder. Med diskurs avses därmed olika sätt att tala om, representera och organisera världen, som skapar normer och föreställningar och definierar vad som betraktas som sant och viktigt, i en specifik tid. ${ }^{119}$ "Diskurser inkluderar representationer av hur saker är och har varit likväl som imaginära föreställningar om hur något skulle kunna, eller borde vara." ${ }^{120}$ Det är dessa normer och föreställningar som står i centrum för min analys.

Denna metod för diskursanalys innebär att intresset riktas mot hur diskurser produceras på olika nivåer och hur sociala förändringsprocesser förhandlas mellan enskilda aktörer och större strukturer. Genom att studera relationer mellan olika aktörer går det att undersöka vad diskurserna gör, hur de konstrueras som sanna och formuleras som giltig kunskap om världen. ${ }^{121}$ Metoden avser även att visa på en ständig växelverkan mellan olika samhälleliga nivåer och hur diskurser därigenom reproduceras eller förändras. Sådan förändring innebär också en förskjutning mellan olika diskurser med förankring i professionella och institutionella praktiker. Denna diskursordning kan användas för att förstå de diskursiva praktikernas relation till en bredare process av social och kulturell förändring. ${ }^{122}$ Detta innebär att jag vill kombinera näranalyser av bilder/bildtexter på textuell nivå, samtidigt som jag studerar olika diskursiva praktiker som tävlingarna verkat inom och hur tävlingarna relaterar till en bredare historisk kontext. ${ }^{123}$ Den diskursiva praktiken studerar bilden i sitt sammanhang, vilka praktiker den skapats igenom. Det vill säga, det handlar om var den producerats, inom vilka organisationer, var den är placerad, vem som ser/läser den, vem som "beställt" den, inom vilka sammanhang tävlingarna och bilderna kommit till.

\footnotetext{
119 Winther Jørgensen, Marianne \& Phillips, Louise (2002) Discourse analysis as theory and method. London: Sage sid. 153.

${ }^{120}$ Fairclough, Norman (2003). Analysing discourse: textual analysis for social research. New York: Routledge sid. 207.

121 Rose, Gillian (2007) sid. 147.

${ }_{122}$ Fairclough, Norman (1992). Discourse and social change. Cambridge: Polity sid. 54.

123 Modellen är först utvecklad av i Fairclough, Norman (1992) i Discourse and social change, och används på bildmaterial exempelvis i Lindgren, Simon (2009) sid. 101-108. Med "text" menas här det som kallas det "utvidgade textbegreppet" som innefattar även bilder som text.
} 
Det innebär att det både är viktigt att sätta tävlingarna i fokus för analysen och att granska bilderna.

I ett socialkonstruktivistiskt perspektiv blir subjektet definierat genom de olika kulturella och sociala praktiker det ingår i, där olika diskurser erbjuder olika positioner eller platser som subjektet kan befinna sig i och tala utifrån. Dessa subjektspositioner är inte fasta och därmed möjliggörs skiftande subjektspositioner. ${ }^{124}$ Exempelvis finns tydliga subjektspositioner för att vara skolelev, att vara pojke eller flicka eller att vara familjemedlem. Analysen handlar delvis om att undersöka förändringar över tid av hur dessa positioner gestaltats. Både tävlingarnas praktik och bildernas innehåll har därmed någonting att förmedla då det gäller skilda diskurser om barn och barndom. Barn och barndom ser olika ut utifrån olika subjektspositioner. Diskursen erbjuder specifika positioner som barn vill, tillåts inneha, eller kan identifiera sig med, eller som andra identifierar dem med. Att bli till genom att synliggöras är väsentligt för att förstå det moderna subjektet, subjektet blir till och blir synligt genom att vara betraktat av sig själv och andra. ${ }^{125}$

Den diskursiva praktiken kan därför också förhållas till den historiska kontexten. Det blir möjligt att kritisk värdera vilka maktordningar och subjektspositioner som görs möjliga genom tävlingarna och bilderna. Tävlingarna förhåller sig därmed också till diskurser inom olika institutionella fält, som exempelvis utbildningsväsendet, museivärlden eller offentliga myndigheter. ${ }^{126}$ Detta gör det också meningsfullt att förstå barns bilder i relation till andra bilder från andra fält. Det kan till exempel vara veckotidningen som bilden publiceras i och andra samtida bilder; populärkulturella bilder, konstbilder eller skolbilder. ${ }^{127}$ Den intertextuella kontexten är viktig för att förstå diskursen, då diskurser kan artikuleras på flertal olika sätt och inom olika områden. ${ }^{128}$ Intertextuella referenser har således också en historia. Bilder föreställande barn eller gjorda av barn, skapar förväntningar av hur barn och barndom ska visualiseras i en specifik historisk och kulturell kontext. ${ }^{129}$ Som framgick av bakgrunden finns det olika förväntningar i olika tider av hur en barnbild bör se ut, och tävlingsbildernas historiska och sociala kontext är därför betydelsefull för hur sådana föreställningar traderas.

En utgångspunkt för studien blir med detta teoretiska ramverk att betrakta tävlingsbilderna som utryck för en barnkultur som efterfrågades av vuxenvärlden, men producerades av barn. Diskursteorin hjälper till att belysa hur människors/barns aktörskap kan ses från två håll: som ett subjekt som agerar utifrån

${ }^{124}$ Lind, Ulla (2010) Blickens ordning: bildspråk och estetiska lärprocesser som kulturform och kunskapsform. Stockholm: Institutionen för didaktik och pedagogiskt arbete, Stockholms universitet sid. 29.

${ }^{125}$ Ibid. sid. 101.

${ }^{126}$ Rose, Gillian (2016) kap. 8 och 9.

${ }^{127}$ Winther Jørgensen, Marianne \& Phillips, Louise (2000) sid. 132.

${ }^{128}$ Rose, Gillian (2016) sid. 187.

${ }^{129}$ Higonnet, Anne (1998) Pictures of innocence: the history and crisis of ideal childhood. London: Thames \& Hudson.; Banér, Anne (1994) Bilden av barnet: från antiken till 1900. Stockholm: Bergh,; Sjöberg, Johanna (2013) I marknadens öga: barn och visuell konsumtion, 1. uppl., Tema barn, Institutionen för Tema, Linköpings universitet, Diss, sid. 52. 
det som är kontextuellt möjligt, samtidigt som subjektet blir delvis förutbestämt av dessa kontextuella förutsättningar. ${ }^{130}$ Bilderna är producerade i skilda praktiker och historiska kontexter, och genom att studera bilderna noggrant är det möjligt att analysera hur barns röster görs aktiva i diskurser om barn och barndom. Här erbjuder den semiotiska teorin och analysen värdefulla verktyg.

\section{Den semiotiska analysen och dess grundläggande begrepp}

Semiotik, ursprungligen utvecklad som en lingvistisk teori, intresserar sig för hur människor kommunicerar via tecken. ${ }^{131}$ Bildsemiotiken innebär att studera de olika tecken som bygger upp en bild, det vill säga hur bilden är komponerad, och genom en social och kulturell kontextualisering erbjuds troliga tolkningar av bilden. ${ }^{132}$ Analysen av "text" innebär sålunda i den visuella semiotiken både text och bild. ${ }^{133}$ Den ideologi som är dominerande i ett samhälle syns bland annat genom de olika tecken som finns i samhället och de myter och föreställningar som finns i samhället uttrycks genom bland annat dess bilder och bildernas innehåll. ${ }^{134}$ Bilden är ett meddelande till åhöraren, den som ser bilden. Varje bild är mångtydig och det är möjligt med olika läsningar av samma bild, beroende på vilka betydelsessystem som ges företräde. ${ }^{135}$

I varje kultur finns centrala berättelser och kulturella myter. En central del i analysen är att se vilka underliggande mönster och regler som skapas eller upprätthålls genom bildernas användning. Det är också väsentligt att synliggöra det sätt som bilder byggs upp på och som reglerar hur myter kan bli meningsfulla. Hur komponeras bilder för att skapa kulturell mening?

I mina näranalyser av bilderna används alltså en semiotisk analys, där jag tolkar de tecken som är framträdande i bilden. Roland Barthes använder en analys som betraktar bilden utifrån tre olika utgångspunkter. ${ }^{136}$ Det är språkliga meddelanden, det vill säga skriven text om det finns någon sådan på bilden. Därutöver bildens denotationer, genom en deskriptiv beskrivning av det som syns i bilden. Slutligen undersöks bildens konnotationer, som synliggör bilders ideologiska och betydelsebärande nivå. Konnotationerna är kontext- och kulturberoende och bygger på denotationerna och språkliga meddelanden.

${ }^{130}$ Foucault, Michel (2002) Sexualitetens historia. Bd 1, Viljan att veta. [Ny utg.] Göteborg: Daidalos.

${ }^{131}$ Lindgren, Simon (2009) Lindgren hänvisar till Saussures semiotiska teorier; "En text är ett begrepp som syftar på alla slags meningsfulla kulturella uttryck. En text är uppbyggd av tecken.” sid. 73.

132 Eriksson, Yvonne \& Göthlund, Anette (2012) Möten med bilder: att tolka visuella uttryck sid. 53.

${ }^{133}$ Rose (2007) sid. 78. I den semiotiska analysen är inte i första hand antalet bilder eller förekomster som är intressant, oftast används istället ett fåtal bilder som får representera det som uppfattas som väsentligt i materialet.

${ }^{134}$ Lindgren, Simon (2009) Myter upprätthåller bland annat idéer om hur en kultur ska förstå binära motsatspar som till exempel manligt/kvinnligt, barn/vuxen sid. $73 \mathrm{ff}$.

135 Barthes, Roland (2007) Mytologier. Lund: Arkiv.

${ }^{136}$ Barthes, Roland (2016). Bildens retorik. Stockholm: b Faethon: sid. 36. 
Den semiotiska analysmetoden gör det också möjligt att noggrannare och närmare studera bildens olika tecken och dess funktioner. ${ }^{137}$ Tecken har olika betydelsefunktioner, där den referentiella funktionen innebär att tecknet har en förmåga att referera till något och därigenom hänvisa till specifika betydelser. Det finns ofta en given referentiell funktion i bilden. I den här studien handlar det om att alla arrangörerna haft givna teman för teckningstävlingarna och att temat, i text, ofta presenteras ihop med bilden. Exempelvis har tävlingsbilderna skapats för att referera till "Vad jag vill bli när jag blir stor" eller "Mitt bästa skolminne" eller "Min hembygd". Bildernas referentiella funktioner påvisar hur ett tecken har förmåga att åberopa ett visst kulturellt innehåll och laddning. Det kan exempelvis vara hur symboler har förmåga att referera till olika saker beroende på sin kontext. Symboler är inlärda, konventionella tecken som bygger på historiskt utvecklade kulturella överenskommelser som kan röra till exempel, flaggor, minnesmärken, etc. En semiotisk analys kan synliggöra symboler som finns i bilderna och hur de relaterar till ett historiskt sammanhang. ${ }^{138}$

Bilderna har samtidigt en tilltalsfunktion. Den som är talande genom bilderna är dels barnet, dels arrangörerna. Arrangörerna vill säga eller förmedla något genom användandet av barns bilder och barnen kan förhålla sig till och förhandla de uppdrag de ges. I vissa tävlingar är tilltalet tydligare än $i$ andra, exempelvis i Arla/Postens tävling genom att de använder interpellerande texter, ofta med utropstecken, som säger "Sluta förorena luften! Kör bil på bananer!" eller "Lär er simma!", "Sluta mobbas!"

Samtidigt innebär detta att bilderna konstruerar ett förhållande mellan de talande och de tilltalade, hur somliga innesluts och andra utesluts genom texten och bilden. Detta brukar benämnas som bildens kontaktfunktion. Bilderna kan ses skapa kontakt både mellan barn och barn och mellan barn och vuxna. Bilder har även olika formella funktioner som att de betecknas efter det sammanhang de anses höra hemma i, det vill säga om det är en så kallad konstbild eller barnbild eller som i detta sammanhang, en barntävlingsbild. Formen kodas olika beroende på olika sammanhang, tid och plats. Funktionerna som de presenteras ovan är inte oberoende av varandra utan samverkar. De semiotiska begreppen används i olika omfattning i analyserna, och alla begrepp kommer inte att användas i varje näranalys av bilderna.

$$
* * *
$$

Diskursanalys och semiotisk analys kan alltså samverka på ett fruktbart sätt. I den semiotiska analysen synliggörs tecken som är betydelsebärande i bilden och näranalys av bilder blir ett hjälpmedel för att identifiera hur olika tecken och bilder arbetar diskursivt. ${ }^{139}$ Den diskursanalytiska metoden söker efter återkommande, eller avvikande, teman i bilderna. Den kan peka på hur bilder och texter producerar specifika idéer om världen och hur tävlingsbilderna och tävlingarnas

\footnotetext{
${ }_{137}$ Lindgren, Simon (2009) sid. 66. (ref. till Jakobsson1956/1990: 73ff /Hymes/Twaites et.al).

${ }_{138}$ Eriksson, Yvonne \& Göthlund, Anette (2012) sid. 40f.

${ }^{139}$ Rose (2016) sid. 107f.
} 
utformning därigenom är delaktiga i att producera kunskap och utöva makt. Bildernas sammanhang och analysen av bildernas tecken ger en möjlig förståelse av hur bilderna skapar kulturell mening. Tävlingarna och bilderna kan ingå i olika diskursiva formationer. På detta sätt kan teckningstävlingarna studeras för att se hur de uttrycker maktordningar i den kontext där de förekommer, liksom vilka myter och föreställningar, identiteter, som upprätthålls eller skapas genom tävlingarna och tävlingsbilderna.

\section{Avhandlingens syfte och frågeställningar}

Den inledande bakgrundsteckningen och genomgången av den tidigare forskningen antyder att barns bildskapande och engagemang i barnbildtävlingar svarar mot såväl en förändring av diskurser om barn såväl som om barns bildskapande. Det är slående att fenomenet teckningstävlingar förekommer under en lång period. Samtidigt var de också föränderliga och har laddats med skilda kulturella innebörder. Innebörder som i vissa fall även har speglat samhälleliga konflikter. Detta innebär som inledningsvis påpekades, att barnteckningstävlingarna måste studeras som historiskt föränderliga fenomen. Hur kan vi förstå tävlingarnas och bildernas sociala, kulturella och politiska sammanhang? Tävlingarna kan både problematisera barns kulturella uttryck och vara utgångspunkt för att diskutera barndomens föränderliga villkor under perioden 1938-2000. Den övergripande frågeställningen blir därmed: Hur kan tävlingarna och tävlingsbilderna synliggöra förändrade synsätt på barn och barndom under 1900-talet?

Avhandlingen har därmed två fokus: Det första är att studera kontexten kring bilderna, det innebär tävlingarnas organisation, vilka aktörer som var drivande, var bilderna producerats och visats, och vilka argument som angavs för teckningstävlingarna. Mitt andra fokus är att analysera bildernas innehåll. Bildernas innehåll och utförande berättar om på vilka sätt barn varit med och gestaltat sin samtid. Båda dessa fokus kan berätta om förändrade ideal om barns bildskapande, liksom om barndomens förändring och om samhällsförändring i stort. Annorlunda uttryckt: Vad ville vuxenvärldens aktörer uppnå med teckningstävlingarna och vad kunde barnen uppnå genom att delta i tävlingarna?

Avhandlingens empiriska frågeställningar blir därför:

1. Vad kan teckningstävlingarna visa om hur arrangörer av olika slag ser på barns bilder och deras användning i samhället och hur detta förändras över tid?

2. Vilka kulturella innebörder och uttryck gestaltas i tävlingar och bilder?

Detta innebär att avhandlingens inledande del lägger tonvikten vid hur och med vilka syften vuxna arrangörer utformade tävlingarna och uppdragen till barnen. Granskningen av bilderna förhåller sig däremot mera explicit till frågan om hur barnen löste de föreskrivna uppdragen. På detta sätt studeras vilka olika syften arrangörerna anger och vilka olika teman barnen anvisas att teckna, samt hur olika arrangörer och samhällsdebattörer under olika tider talade om tävlingarna och bilderna. I inledningarna till de olika delkapitlen utvecklas de empiriska frå- 
gorna närmare. I det följande avsnittet kommer jag att också närmare precisera urval och avgränsningar av material men också vilka teman som är i fokus för kapitel 3-5.

\section{Material och Urval}

Avhandlingens har sin teoretiska ram i den visuella kulturteorin vilket innebär att bilder är utgångspunkten för materialinsamlingen. Barnbilder behöver inte bara produceras utan också sparas för att vi ska kunna berätta något om dem i efterhand. Hur bilder arkiverats och kategoriserats, har betydelse för betraktarens blick men också för vad som överhuvudtaget är bevarat och därmed forskningsbart. Jag har anledning att återkomma till hur kategorisering av bilderna i arkiven och samlingarna påverkat vad som betraktats som tävlingsbilder. I detta avsnitt skall jag presentera mina källor till undersökningen och mina urval och avgränsningar.

\section{Barns bilder i arkiv}

På Svenskt barnbildarkiv (SBBA) finns över 650000 barnbilder, vilket gör det till den mest omfattande arkivsamlingen av barnbilder i Norden. ${ }^{140}$ SBBA:s verksamhet grundades 1977 med utgångspunkt från en privat samling av historiska och samtida nationella och internationella barnbilder. ${ }^{141}$ Arkivets äldsta bilder är från 1700-talet, och insamlingar av nytt material pågår kontinuerligt. ${ }^{142}$ Att ett arkiv med barnbilder har kunnat byggas upp både med regionalt och nationellt stöd innebär att barnbilder uppfattas som värdefulla och som del av ett gemensamt nationellt kulturarv. Detta innebär att arkivet i sig är betydelsefullt för vad som har bedömts vara viktigt och relevant att arkivera, men att det också gjorts val av vad som hör hemma i arkivet eller i andra samlingar. Eric Keteelar har problematiserat arkivens tysta och dolda berättelser, och hur arkivskapande och arkivering definierar vad som ses som värdefullt och sant, genom att ange vad som är värt att bevara för framtiden. ${ }^{143}$ Anna Sparrman diskuterar i kapitlet "Barn tecknar nakenhet - och sexualitet?" hur samhälleliga förväntningar på vad barn förväntas teckna avspeglar sig i hur man i arkivet benämner sökord för barns bilder. Hon uppmärksammar hur ordet "sexualitet" inte finns som sökord

140 Martola, Ulla, "Barns bilder - bevarade och tillgängliga” I Eriksson, Yvonne (red). (2014) Barn tolkar världen att förstå och tolka barns bilder.

141 Andersson, Margareta, Flood, Ann-Katrin \& Königsson, Eva (1990). Bevara, registrera, upplev!: handbok $i$ hanteringen av barnteckningar vid Svenskt barnbildarkiv. Eskilstuna: Barnkulturcentrum.

${ }^{142}$ Från 1977 erhålls även statligt bidrag, och Eskilstuna Stadsarkiv hjälper till med exempelvis registreringssystemet. SBBA:s samling har endast använts i en doktorsavhandling tidigare, av bildläraren och konstvetaren Ulla Frost, som också var delaktig i arkivets uppbyggnad. Frost använde sig inte av barnbilderna, utan av de förlagor man använt sig av för teckningsundervisning under 1800- talet i sin studie. Frost, U. (1988) Förlagor och teckningsläror. Ett bidrag till den svenska teckningsundervisningens historia särskilt avseende 1800-talet. Akademitryck AB, Edsbruk och Täby.

${ }^{143}$ Eric Ketelaar (2001) Archival Science 1 sid. 31-41 Tacit Narratives - The meanings of Archives. 
på Svenskt barnbildarkiv. Detta, menar Sparrman, handlar inte nödvändigtvis om att det inte finns denna typ av bilder, utan till stor del om att barn inte ses som sexuella aktörer. ${ }^{144}$

Av arkivets 650000 bilder är ca 130000 scannade och möjliga att söka med sökord i arkivets databas. I min studie har jag inte använt mig av sökorden eller de digitaliserade bilderna, utan istället studerat specifika samlingar i SBBA och Nationalmuseums samling. Från SBBA handlar det i första hand om alla de som kategoriserats som tävlingssamlingar.

I SBBA finns cirka åttio tävlingssamlingar från åren 1938-2000. Antalet varierar lite beroende på hur man definierar tävlings- och temasamling, vilket jag återkommer till i diskussionen om fenomenet teckningstävlingar. Dessa samlingar innehåller de inskickade tävlingsbilderna som arkiverats, men oftast inte de vinnande bilderna. ${ }^{145} \mathrm{I}$ en första bearbetning av materialet har jag gått igenom tävlingssamlingarna 1938-2000 i SBBA, där jag studerat ett urval av bilderna från flertalet av de åttio tävlingssamlingarna för att få en uppfattning om vilka teman som efterfrågats och hur olika teman gestaltats, liksom hur lärarutskick eller annat material som har funnits i anslutning till tävlingarna varit utformade. Att det till vissa samlingar även bevarats utskick till skolor eller annonser från tidskrifter och tidningar gjorde det möjligt att kontextualisera tävlingarna och bilderna.

Jag har kategoriserat tävlingarna både utifrån vilka som arrangerat dem, vilka syften som angavs, samt vilka teman tävlingarna hade. ${ }^{146}$ För att få en fördjupad bild av förekomsten av teckningstävlingar har jag även översiktligt gått igenom de teckningstävlingar som omnämnts i Tecknings/bildlärarförbundets olika tidskrifter mellan 1931-2000. ${ }^{147}$ Det övergripande resultatet av studiet av alla tävlingar presenteras i kapitel två, Fenomenet teckningstävlingar. Utöver detta material har jag även sökt i arkivdatabaser, för att få en utökad kontext och förståelse kring vilka röster som talade för eller emot en förändrad teckningsundervisning, teckningstävlingar och barnbildens offentlighet. ${ }^{148}$ Detta fenomen diskuteras bland annat i tidskriften Ord och Bild (1908), tidskriften Idun (1923), och tidskriften Folkskolläraren (1945), tidskriften Teckning: tidning för svensk teckningsundervisning 1939-1980, samt konsttidskriften "Paletten”(1989). För en fördjupad kontext används även undervisnings- och läroplaner från 1919 till 1980, som källmaterial, liksom läroböcker i hembygdskunskap under 1930-talet, samt andra illustrationer från FIB, som inte är bilder från teckningstävlingar.

\footnotetext{
${ }^{144}$ Sparrman, Anna "Barn tecknar nakenhet- och sexualitet?” I Eriksson, Yvonne (red). (2014) Barn tolkar världen att förstå och tolka barns bilder.

${ }^{145}$ Många gånger behöll arrangören de vinnande bilderna, och arkivet var främst intresserade av att samla in "alla" barnbilder.

146 Se bilaga ett och två, detta diskuteras också i kapitlet Fenomenet teckningstävlingar.

147 Teckningslärarnas tidskrift benämns Tidning för Sveriges teckningslärare 1931-1938, Teckning 1939-1979, och 1979 byts namnet till Bild i Skolan 1979-2000.

148 Sökord: teckningstävling, teckningsundervisning och barnbild http://libris.kb.se, samt https:// sok.riksarkivet.se/nad.
} 


\section{Avgränsning av material: FIB, Televerket och Arla/Posten}

Utifrån SBBA:s tävlingssamlingar mellan 1938-2000 har jag valt ut tre för näranalys, där jag fördjupat både bild- och kontextanalysen. ${ }^{149}$ Det är FIB:s tävling (1938-1947), Televerkets tävling för omslag till telefonkatalogen (1977-1985) och Posten/Arlas tävling (1976). De sträcker sig över närmare femtio år, 19381985, vilket gör det möjligt att följa både teman och teknikers utveckling över tid under en period när synen på barn förändrades genomgripande. De har även tryckts och distribuerats på olika sätt, i böcker, som affischer, i tidningar, som omslag på telefonkataloger etc.

Den tidigaste tävlingen i SBBA s samling är FIB:s teckningstävling för skolungdom, som också utgör studiens startpunkt 1938. I arkivet finns de bilder som skickats in till tävlingen från Sörmland, samt jubileumsalbumet Sverige genom barnaögon. ${ }^{150}$

Nationalmuseum och tidningen FIB gav 1947 ut det man kallade ett jubileumsalbum: "Sverige genom barnaögon - FIB:s teckningstävling för skolungdom" där man presenterade teckningstävlingen och flera av de vinnande bidragen genom åren. ${ }^{151} \mathrm{I}$ albumet finns förutom bilderna ett förord skrivet av Erik Wettergren som var överintendent vid Nationalmuseum, ett kapitel "Sverige genom barnaögon" författat av fil.dr. Ragnar Hoppe som var förste intendent vid Nationalmuseum, och ett kapitel om "Teckningsundervisningen förr och nu", författat av teckningsläraren Gustav. A Nordlander. Slutligen finns en sammanställning med information om FIB:s teckningstävling, vilka teman man haft och vilka priser som utdelats. I albumet finns 16 helsidor färgreproduktioner och 36 svartvita reproduktioner fyra per sida, alla bilderna är utvalda från FIB:s teckningstävling mellan 1938-1946.

Redan 1945 publicerades en katalog med likande namn, Sverige genom barnaögon av Riksförbundet för bildande konst, i samband med att ett urval av bilderna visades på museer runt om i landet. ${ }^{152}$ Denna inleds med kapitlet "Barnteckningar på vandringsutställning" av Sixten Strömbom, som var grundaren av Riksförbundet för bildande konst, och intendent på Nationalmuseum. ${ }^{153}$ Följande kapitel heter "Barnet som Konstnär" av psykologiprofessor Helga Eng, Oslo. Slutligen finns en förteckning över de bilder som var med på vandringsutställningen. De är indelade dels i teckningar från förskoleåldern (20 bilder), ${ }^{154}$ dels i de olika teman som FIB:s tävling haft mellan 1939-1944. ${ }^{155}$

Jag har granskat veckotidningen FIB:s ungdomssidor mellan 1938-1946 och de övriga sidor där tävlingen diskuterats, för att få en kontext till hur tävlingen

${ }_{149}$ I Arlas fall publicerade bilder i boken, eftersom de inte valde några officiella vinnare.

150 Jungmarker, Gunnar \& Hoppe, Ragnar (red). (1947). Sverige genom barnaögon: Folket $i$ bilds teckningstäuling för skolungdom. Stockholm: Nationalmuseum.

${ }_{151}$ Albumet annonseras och presenteras i FIB 1947 nr 10 sid. 32.

152 Sverige genom barnaögon: Katalog. [Ny tr.] (1945). Stockholm: Förb.

153 Strömbom var intendent vid Nationalmuseum 1919-1949 och 1930 initiativtagare till Riksförbundet för bildande konst.

${ }^{154}$ Dessa har troligtvis tillkommit utanför teckningstävlingens ram, då de inte är gjorda i skolan.

155 Där hembygdsbilderna från 1939 är representerade med störst antal bilder, 42 bilder, mer än dubbelt så många bilder jämfört med något annat tema. 
presenterats liksom vilka av vinnarbilderna tidningen valt att publicera. Varje år publiceras lite olika antal (mellan sex och fjorton) svartvita reproduktioner av årets vinnarbilder i FIB.

Eftersom FIB: s tävling kom att sträcka sig över flera år, har denna tävlings teman varit vägledande för att göra jämförelser med Televerkets och Arlas tävling. Publikationerna med bilder och texter betraktar jag som värdemätare på hur barn och barnbilder betraktades inom den samtida konst- och bildpedagogiska diskursen, och texterna har till stor del varit vägledande för indelningen i de empiriska kapitlen. FIB:s och Televerkets tävlingar är intressanta att studera då de har haft liknande teman kring hembygden.

Televerkets teckningstävlingssamlingar är de mest omfattande på SBBA, med totalt över 200000 bilder. Varje klass i årskurs 3 fick skicka in fem bilder för att delta i tävlingen om omslag till Telefonkatalogen mellan 1977-1984. ${ }^{156} \mathrm{Av}$ de ca trehundra bilder som kom in till varje distrikt valdes en vinnande bild som blev omslag för katalogen, fem bilder som kom på andra plats och fick också pris. SBBA har alltså alla de bilder som skickats in till Televerket från hela landet, men inte fick pris.

I Televerkets arkiv som förvaras på Riksarkivet, finns handlingar angående "omslag till rikstelefonkataloger" som har gett en fördjupad förståelse för hur tävlingen initierats och presenterats. Bland annat genom Televerkets interna material rörande tävlingarna och genom pressklipp från lokalpressen där tävlingarna presenterats. ${ }^{157}$ Denna arkivsamling aktualiserar också både förespråkare och motståndare till tävlingen. SBBA:s arkiv innehåller delar av det informationsmaterial som Televerket skickat ut till klassföreståndare i årskurs tre inför teckningstävlingen till telefonkatalogomslagen.

Att jag valt att ta med Arla/Postens samling är för att den delvis kan representera en syn på barns bildberättande som förekommer i flera andra samtida barnbildstävlingar och utställningar. Arlas och Postens tävling "Detta vill jag värna om" kan ses som representant för tävlingssamlingar på SBBA som behandlar både natur- miljö- och barnrättsfrågor. Arlas bok Varför får inte barn bestämma publicerades, likt telefonkatalogens första barnbilder, 1977. Boken innehåller förutom 133 bilder en introduktionstext från Arla/Posten, en text av Danny Kaye som företrädare för Unicefs barnfond och en text av Fil.dr. Kerstin Fällström, barnpsykolog. ${ }^{158}$ Material rörande Arlas teckningstävling har också till viss del arkiverats på Centrum för Näringslivshistoria. ${ }^{159}$

Material som berör Arlas och Televerkets tävlingar har jag alltså studerat på Riksarkivet och Centrum för Näringslivshistoria. Där finns bland annat hänvisningar till, eller kopior av, tidningsurklipp från tävlingarna. Exempelvis public-

\footnotetext{
156 I dessa 200000 ingår även bilder från Televerkets "stoppa sabbet” tävling 1980-1990 som var en nationell tävling för att minska vandaliseringen av telefonkiosker.

157 Omslag till rikstelefonkataloger 1977 F2A:1 Televerket, telemedia Katalogverksamheten (RA).

${ }^{158}$ Varför får inte barn bestämma: en bok av barn för vuxna!/ utg. av Arla/Posten med anledning av teckningstävlingen $1976-1977$.

159 Arla Foods AB arkiv, Centrum för Näringslivshistoria.
} 
erades ett urval av Arlas bilder i Expressen (1977) och samtliga vinnande bilder till Telefonkatalogernas omslag i Aftonbladet (1976).

Mitt urval för den semiotiska analysen bygger i huvudsak på bilder som är utvalda av olika aktörer som vinnande bilder, eftersom vinnarbilder kan ses som representativa, "ideala" bilder för sin tid. Därför har jag delvis sökt mig vidare till andra arkiv och källor, för att hitta de vinnande bilderna. ${ }^{160}$, I Nationalmuseums samling finns 546 vinnarbilder i original bevarade från FIB:s tävling1938-1946, där Nationalmuseum var medarrangör efter 1941. Vinnarbilderna från Televerkets tävling har jag studerat tryckta på Telefonkatalogen. ${ }^{161}$

Urvalet av tävlingssamlingar för närstudier av bilderna är således:

- Bilder publicerade i FIB (1938-1946) från den teckningstävling de arrangerade i samarbete med Teckningslärarnas riksförbund och från 1941 även tillsammans med Nationalmuseum; Nationalmuseums samling av barnbilder från denna teckningstävling 1938-46; bilderna i albumet Sverige genom Barnaögon. ${ }^{162}$

- Tävlingsbilderna publicerade på telefonkatalogomslagen 1977-78.

- Bilderna i Posten/Arlas tävling "Detta vill jag värna om" 1976 publicerade i boken Varför fär inte barn bestämma 1977.

Från FIB och Televerket har jag granskat samtliga vinnarbilder. Bildexemplen för den semiotiska analysen i kapitel 3-5 är i huvudsak hämtade från dessa tre tävlingar. Vinnarbilder från Televerket är bevarade tryckta på framsidan av telefonkatalogerna, och jag granskar katalogerna mellan 1977-1984. För den semiotiska analysen har jag begränsat urvalet av bilder till Televerkets hembygdstema 1977-1978. ${ }^{163}$ De bilder jag använt från Arla/Postens tävling är de 133 bilder som tryckts i boken Varför får inte barn bestämma, samt fyra fotografier av mjölkkartonger från tävlingen. Från både Televerkets och Arlas tävling har jag även studerat ett urval av de icke vinnande bilderna, i SBBA, och kunde konstatera att de inte på ett påtagligt sätt avvek från de vinnande bilderna med ett undantag som jag diskuterar i kapitel 3.

Genom kategorisering och sortering av vinnarbilderna från de tre utvalda tävlingarna, har olika teman och diskurser utkristalliserats. De samtida texterna i publikationerna med tävlingsbilderna har varit vägledande för vilka teman som kommit att utgöra avhandlingens kapitel 3-5. De inledningstexter till bildpublikationerna som arrangörerna publicerar, kan kontextualisera bilderna och synliggöra barnbilderna i ljuset av samtida diskurser som är intressanta att granska närmare. Det gäller synen på barn och nation, Sverigebilder, men också frågor om barns sociala och kulturella plats samt konstruktionen av genus, som även

${ }^{160}$ Bilder publicerade i tidskriften Folket i Bild 1938-1947, och Nationalmuseums samling av vinnande bilder 1938-1947 i original, samt Telefonkatalogerna 1977-78 med de tryckta vinnarbilderna.

161 Originalbilderna finns i Televerkets samlingar på riksarkivet.

162 Tävlingen höll på till 1957 men Nationalmuseum har bilder till 1946.

163 Telefonkatalogerna finns på Kungliga Biblioteket (KB), det är ca 23-26 kataloger varje år, beroende på hur Televerket valde att dela in de lokala katalogområdena. 
har varit framträdande i såväl barndomshistorisk som bildpedagogisk forskning. Dessa teman diskuteras närmare i inledningarna till de olika kapitlen.

De bilder som valts ut för semiotisk analys representerar dessa olika teman. Inom dessa teman har bilder valts ut som då innehåller både bild och text $\mathrm{i}$ själva bilden, där texterna bidrar till att sätta in bilderna i sammanhang och definiera bilderna. Texterna gör det möjligt att närmare kontextualisera bilderna. Den semiotiska analysen används även för de vinnande bilder som valts till omslagsbilder till bokpublikationer just för att bilderna utvalts att vara omslagsbilder och därmed kan antas ha varit betraktade som exemplariska bilder av sin samtid. Bilderna är mångsemantiska, och kan innehålla flera olika betydelser och tolkningar. Därigenom kan bilderna problematisera de teman och diskurser som presenteras.

Hur bilderna talar till andra bilder, bildernas intertextuella referenser, har i vissa fall använts för att fördjupa kontexten. Samtida bilder som jag diskuterar och som inte är en del av teckningstävlingarna har identifierats i FIB:s tidning och genom kommentarer i jubileumsalbumet Sverige genom barnaögon.

I följande tabell presenteras, för översiktlighetens skull, de tre arrangörerna, vilka teman de haft olika årtal, samt var tävlingarna visats. Samtliga tävlingar var nationella. 


\begin{tabular}{|c|c|c|c|}
\hline Årtal & Arrangör: & Teman: & Visad på: \\
\hline 1938-1948 & $\begin{array}{l}\text { Tidskriften FIB, Tecknings- } \\
\text { lärarförbundet och Natio- } \\
\text { nalmuseum } \\
546 \text { bilder i NM samling } \\
\text { (totalt ca } 400000 \text { inskick- } \\
\text { ade bilder under tävlings- } \\
\text { perioden) }\end{array}$ & $\begin{array}{l}1938 \text { Livet i vår skola } 135 \\
\text { bilder } \\
1939 \text { Livet i vår hembygd } \\
117 \text { bilder } \\
1940 \text { Min fritid } 53 \text { bilder } \\
\text { 1941 Mitt roligaste } \\
\text { skolminne } 65 \text { bilder } \\
1942 \text { Vad jag skall bli när } \\
\text { jag blir stor } 6 \text { bilder } \\
1943 \text { Svenskarna i allvars- } \\
\text { tider - beredskap förr och } \\
\text { nu } 61 \text { bilder } \\
1944 \text { Svenskt helgfirande } \\
52 \text { bilder } \\
1945 \text { Våra lekar } 48 \text { bilder } \\
1946 \text { När jag plockade... } \\
\text { bär, frukt mm } 53 \text { bilder } \\
\text { (Antalet bilder per år de } \\
\text { som idag finns i National- } \\
\text { museums samling). }\end{array}$ & $\begin{array}{l}\text { Utställd på: } \\
19381939 \text { PUB } \\
1940 \text { Skansen } \\
\text { Från } 1941 \text { på Nationalmu- } \\
\text { seum } \\
\text { Bilder visade i FIB, samt i } \\
\text { två bildhäften båda med } \\
\text { namnet: "Sverige genom } \\
\text { barnaögon” }\end{array}$ \\
\hline $1977-1985$ & $\begin{array}{l}\text { Televerket } \\
184 \text { bilder } \\
\text { (Totalt finns ca } 200000 \\
\text { icke vinnande bilder på } \\
\text { SBBA) }\end{array}$ & $\begin{array}{l}1977 \text { En händelse från vår } \\
\text { hembygd } \\
1978 \text { En historisk händelse } \\
\text { från vår hembygd } \\
1979 \text { Yrken och arbetsliv } \\
\text { från vår hembygd } \\
1980 \text { Sagor och sägner från } \\
\text { vår hembygd } \\
1981 \text { Djur och natur i vår } \\
\text { hembygd } \\
1982 \text { Handikappad i sam- } \\
\text { hället - Lika men ändå } \\
\text { olika } \\
1983 \text { Så vill vi ha det i } \\
\text { trafiken där vi bor } \\
\text { 1984 Så blir idrotten i } \\
\text { skolan roligare } \\
\text { 1985 En sevärdhet i vår } \\
\text { hembygd }\end{array}$ & $\begin{array}{l}\text { Omslagen till telefonkata- } \\
\text { logen } \\
1977-1985\end{array}$ \\
\hline 1976 & $\begin{array}{l}\text { Posten/Mejerierna } \\
\text { Totalt ca } 15000 \text { bilder i } \\
\text { SBBA:s samling) }\end{array}$ & "Detta vill jag värna om" & $\begin{array}{l}\text { Bok: Varför fär inte barn } \\
\text { bestämma, samt bilder } \\
\text { upptryckta på mjölkpaket } \\
\text { samt som vykort. } 133 \\
\text { bilder i boken. }\end{array}$ \\
\hline
\end{tabular}

Tabell 1. De tävlingar som varit föremål för näranalys och deras teman över tid. 


\section{Avhandlingens disposition}

Avhandlingen har två skilda delar med olika utgångspunkter, där den första delen, (kapitel 2) undersöker teckningstävlingarnas uppdrag och syften, och den andra delen, (kapitel 3-5) undersöker hur barnen löser uppdragen. I studiens första empiriska kapitel Fenomenet teckningstävlingar rör sig därför analysen främst kring samhällskontexten, för att försöka begripliggöra hur teckningstävlingar kommit till. Här diskuteras vilka olika institutioner, organisationer och aktörer som gör tävlingarna möjliga, och hur tävlingarna kan förstås, utifrån arrangörernas och aktörernas engagemang och intressen. Vidare analyseras hur fenomenet teckningstävlingar blev möjligt i den svenska 1930-talskontexten, och hur ideal kring teckning, barn och tävling har formulerats och förändrats över tid. Därutöver diskuteras vilka teman som barn har ombetts att teckna, under perioden 1938-2000, och hur dessa teman kan beskrivas som en del av den politiska och sociala kontexten kring barn och barndom.

Kapitlet Sverigebilder diskuterar hur hembygden har efterfrågats och reproducerats som ett återkommande tema över hela perioden, både i skolan generellt och i tävlingsbilder. Här analyseras hur hembygden visuellt har kopplats ihop med nationsskapande. Därutöver granskas hur symboler som flaggan och kungen, kunnat användas både för att förändra och reproducera diskurser, genom bildernas olika kontexter. Slutligen problematiseras hur bilderna gestaltar både barndomens och hembygdens radikalt förändrade innebörder mellan 1940-talet och 1970-talet.

I det följande kapitlet Barns platser diskuteras vilka platser som tävlingsarrangörerna efterfrågat bilder av, och hur barn gestaltat dessa platser. Den mest framträdande platsen är skolan, och i kontexten kring skolan syns även förändring i relationer mellan barn och vuxna över tid.

Kapitlet Bilder av flickor och pojkar, kvinnor och män undersöker hur genus görs genom texter och bilder i tävlingarna. Hur bilder av flickor och pojkar både reproduceras och förändras, och därigenom skapar likhet eller skillnad i innebörden av att vara barn, eller flicka eller pojke. Dessutom diskuteras hur tävlingsbilderna beskriver arbete och arbetets innebörd som genusskapande praktik i hembygden under både 1940-talet och 1970-talet, samt vilka olika framtidsdiskurser för pojkar och flickor som synliggörs i bilder och texter. 

Kapitel 2.

\section{TECKNINGSTÄVLINGAR - ETT AMBIVALENT FENOMEN}

I vårt dagliga liv och i samhället finns överallt en tendens att prestera mer och bättre, och detta resulterar i tävlan och konkurrens. En form därav är när vi tävlar med oss själva, /.../ När det gäller s.k. pristävlingar ligger det något annorlunda till. Då måste man följa vissa regler, och det delas ut priser som uppmuntran eller belöning. Denna form av tävling används ofta i skolorna. De flesta föräldrar har nog varit med om att deras barn kommit hem olustiga och modstulna efter att ha misslyckats i en sådan tävling. /.../ men inget pris i värden kan mäta sig med vad äkta skaparglädje betyder för barnen. ${ }^{164}$

Under rubriken "Bör barnen deltaga i tävlingar?” uttalade sig konstpedagogen Viktor Lowenfeld på detta sätt i den svenska översättningen 1957 av boken Alla barn kan måla. I Raben \& Sjögrens helsidesannonser för boken i Teckningslärarförbundets tidskrift Teckning skrev förlaget:

Grundtanken i Lowenfeldts arbeten är att alla barn kan rita och måla och att den skapande aktiviteten är av fundamental betydelse för utvecklingen. Att skapa är att vara lycklig! Författarens avsikt med boken är att vägleda föräldrar och lärare i konsten att fostra lyckliga människor. ${ }^{165}$

I citaten ovan synliggörs en pedagogisk och didaktisk konflikt kring teckningstävlingar i vilken tävlandet stod i motsättning till äkta skaparglädje. ${ }^{166}$ Lowenfeld menade dessutom att vid pristävlingar belönades det som av vuxna ansågs vackert och originellt. Många barn kunde skapa med stark inlevelse utan att lyckas framställa något vare sig vackert eller ovanligt enligt Lowenfeld, och de fick då aldrig pris i tävlingar. Istället kände de sig olustiga och modstulna, vilket motverkade syftet med "äkta skaparglädje": att fostra lyckliga människor.

Lowenfelds ställningstagande stod i stark kontrast till de folkskollärares röster som uttalade sig positivt om hur tävlingarna skänkte barnen glädje i arbetet. ${ }^{167}$ I boken Alla barn kan måla vände han sig både till föräldrar och lärare.

\footnotetext{
164 Lowenfeld, Viktor (1957) sid. 58.

165 Tidskriften Teckning $1957 \mathrm{nr}$ 3, 4, 7 (fetstil i original).

166 Viktor Lowenfeld utbildande sig, och arbetade med konstpedagogik i Österrike, men flydde 1938 till England och flyttade senare till USA. Han var där verksam som professor i konstpedagogik i Pennsylvania, och hans bok Creative and Mental Growth : a textbook on art education (1947), användes som lärobok vid många olika universitet.

167 I FIB under 1940-talet, se citat i avhandlingens inledning sid. 7.
} 
Flera svenska inflytelserika pedagoger omfamnade hans idéer. ${ }^{168}$ Det fanns av allt att döma en ambivalens inom den pedagogiska diskursen mellan att se teckningstävlingar som en lust- och glädjefylld aktivitet, och att se tävlingen som skapare av olust och som hämmande för barns skapande förmåga. Detta pekar både på skilda synsätt inom lärarkåren liksom på förändring över tid.

I detta kapitel kommer jag att analysera tävlingarna som samhällsfenomen; hur de uppfattades och presenterades av olika aktörer och arrangörer under perioden 1938-2000. Därutöver kommer jag att diskutera tävlingarnas olika utformning och förändringar över tid, men även skillnader mellan olika arrangörer under samma tidsepok.

Hur kan man då närma sig tävlandet som fenomen? Olika typer av tävlingar har gjorts möjliga genom specifika samhälleliga traditioner och institutioner. Roger Caillois beskriver tävlingar som en specifik kultur i vilken lekar och spel också ingår. ${ }^{169}$ Tävlingarna skiljer sig från lekar och spel genom betoningen av konkurrens och vinst. Tävlande förutsätter ofta träning och disciplin. Poängen med tävlingen, tydligare än vid andra former av lekar och spel, är enligt Caillios att den bygger på viljan att vinna. ${ }^{170}$ De flesta tävlingar innebär en kombination av kunskap och tur, men för att upplevas som rättvisa, bör jämlika förutsättningar ges. ${ }^{171}$

Tävlingarna kan under början av 1900-talet också ses som en del av en framväxande nöjes- konsumtions- och fritidsindustri. Något som också lockade till deltagande var att det ofta utdelades prispengar. Ilona Literat har visat hur tävlingar blandade inslag av underhållning och utbildning. Tävlingarna lanserades både som ett glädjefullt nöje och som ett sätt att skapa ny kunskap. ${ }^{172}$ I sin artikel om tävlingskulturen i tidskriften Popular Science Monthly 1918-1938, beskriver hon hur tidskrifter, genom bland annat tävlingar, konstruerade läsarna som aktiva och deltagande. Deltagandet i tävlingarna användes för att skapa en känsla av samhörighet mellan läsarna, och mellan tidningen och läsarna. Genom tidningarna kunde man nå ut till en nationell publik och genom tidningarnas ungdomssidor, kunde man identifiera och mobilisera en ny och aktiv läsekrets. Tävlingar kunde också vara ett instrument att åstadkomma förändring genom lanseringen av sociala och politiska budskap.

${ }^{168}$ Idéer om vikten av barns fria skapande syns bland annat i metodiklektorn Elis Hammarbergs avsnitt "Synpunkter på barns utveckling och teckningsundervisning" i Folkskolans metodik från 1954 och i boken Barnets bildvärld (1962) av Nils Breitholz, rektor vid teckningslärarinstitutet. (Breitholtz, Nils (1962). Barnens bildvärld: idéer och motiv. Stockholm: Svensk läraretidnings förlag) De skriver ingenting explicit om just tävlingar. Det gör däremot Arne Larsson i Det fria skapandet - en bok om teckningsundervisning 1956, som jag återkommer till i nästa kapitel. Nordström, Gert Z. \& Romilson, Christer (1970).sid.41, se även Pettersson/ Åhsen (1989) sid. 91.

169 Caillois, Roger (2001). Man, play and games. Urbana, Ill.: University of Illinois Press.

${ }^{170}$ Ibid. sid. 15.

${ }^{171}$ Ibid. sid. 14 Till exempel indelning i åldersgrupper, som fanns i FIB tävling. Caillois nämner även t.ex. handikapp i golf.

${ }^{172}$ Literat, I. (2013). Participatory Innovation: The Culture of Contests in Popular Science Monthly, 1918-1938. Journalism \& Mass Communication Quarterly, 90(4), 776-790. 
Matilda Hallberg har studerat tävlingsbilder av barn under 1930- 40-talet, som ett uttryck för den offentliga kulturen, där fotografier av barn publicerades i Aftonbladets A-barns tävlingar. Avhandlingen placerar in tävlingarna i den samtida politiska debatten om den låga nativiteten; det makarna Myrdal benämnde "Kris i befolkningsfrågan" under 1930-talet. ${ }^{173}$ Hallberg använder begreppet åskådningskultur och diskuterar hur fotografier av barn i tävlingar var en del av en kultur under tidigt 1900-tal, som alltmer betonade det visuella. Åskådningskulturen producerade diskurser kring normalitet. Hallberg diskuterar hur tävlingarna kunde användas i syfte att sprida politiska ideal. Bilderna skapade föreställningar om hur ett "A- barn" borde se ut. Tävlingarna ingick $i$ en modernitetsdiskurs där bilderna blev en del av ett förvetenskapligande, en professionalisering och ett bejakande av framtiden. ${ }^{174}$

Tiden uppmärksammade inte bara bilder på barn utan även bilder av barn. Petterson och Åsén visar att barnbilder generellt under 1940-50-talet åtnjöt ett medialt intresse som inte förekommit vare sig förr eller senare. Det var en del av utvecklingen av den nya grundskolan och stod i samklang med den progressiva skolpolitiken. ${ }^{175}$ Den tidigare forskningen visar att teckningstävlingar förhöll sig till såväl ett intresse för barnbilder som till en offentlighet i vilken tävlingar var en del av en åskådningskultur i vilken normer om samhället gestaltades. Den historiska bakgrunden i Sverige bekräftar detta i de teckningstävlingar som förekom innan min studieperiod.

Teckningstävlingar i dagstidningar riktade sig till en början till vuxna läsare. År 1916 och 1917 publicerade DN på sidan "Namn och Nytt” teckningstävlingar som en form av samtidskommentarer och skämtteckningar. Exempelvis skriver man i augusti 1916:

DN:s inbjudan till teckningstävlingen Kantiga gubbar, mottages på samma sätt som alla föregående inbjudningar till teckningstävlingar, Dvs brevlådan fylles av bidrag många och goda. Vi börja med att återge Kaiserns och Tsarens synnerligen lyckade porträtt. ${ }^{176}$

Bilden visar en svartvit teckning med två just "kantiga", lite kubistiska mansporträtt, Tsaren med stor mustasch och skägg, Kaisern med mustasch och hjälm. Humor, satir och skämtbilder med politiska och sexuella undertoner var teman som fanns i bilderna. ${ }^{177}$

Redan 1918 anordnade DN en teckningstävling för barn. Tävlingen riktade sig till deltagare från 3-14 år och tidningen skrev att man fått in ca 4000 bilder från 1000 deltagare. I tidningen skriver man att juryn prisbelönat de bilder som

\footnotetext{
${ }^{173}$ Myrdal, Alva \& Myrdal, Gunnar (1934). Kris i befolkningsfrägan. Stockholm: Bonnier, diskuteras även i Hallberg, Mathilda (2017) Barn till beskådan. Familj, välfärdsstat och nation $i$ fototäulingar och fotoböcker 1930-1944 .

${ }^{174}$ Hallberg (2017) sid. 35.

175 Pettersson, Sten \& Åsén, Gunnar (1989) sid. 101.

176 DN 1916-08-09 sökord teckningstävling.

177 Se t.ex. DN 1916-05-28, 1917-06-09, sista sidan "Namn och Nytt".
} 
"antagits vara ett självständigt arbete rakt igenom." ${ }^{178}$ Det betonades att det var viktigt att det var barnet själv, och inte en förälder som gjort bilden. I tidningen publicerades sjutton prisbelönta teckningar, oftast teckningar av människor eller djur. 1:a pris till de äldre barnen gick till Björn, 11 år, med teckningar av "Pan" och "Satyr". DN skrev: "Föreningen av den livligaste fantasi med manuell skicklighet är påtagligt stark." ${ }^{179}$ Livlig fantasi i kombination med ett tekniskt drivet tecknande var det som belönades.

DN beskrev även 4-årige Lars "Njutningsfulla bidrag" Häst med släde "vilkens omedelbara framställning med all naivitet och omedelbarhet äro ytterst intressanta." ${ }^{180} \mathrm{DN}$ framhöll släktskapet mellan barnbilder och folkkonst, när man skrev om Lars bild: "En etnograf borde inte ha svårt att i den finna jämförelser med urfolkens konst." 181 Som citaten visar uppskattades och belönades barns fantasi och omedelbarhet, för elvaåringen i kombination med manuell skicklighet. År 1919 rapporterade DN om teckningstävlingen "Den vackraste flickan”. Det var en tävling för vuxna, men Elsa Berg som vann var bara 16 år, varpå DN skrev: "Teckningstävlingar äro kanske inte bra muntra förströelser utan en slagruta för upptäckandet av slumrade konstnärsbegåvningar. Vem vet?" 182 I dessa kommentarer kan vi notera uppskattning av barns teckningsförmåga kan röra både det naiva och det skolade bildskapandet. Vi kan emellertid bland dessa tävlingar också iaktta ett folkuppfostrande och pedagogiskt anslag av det slag som Ilona Literat och även Mathilda Hallberg visat, vilket nästa tävling är ett exempel på.

Den 1:a november 1932 hade DN ett reportage med bild och text om en teckningstävling på både första och sista sidan. Tävlingen var arrangerad av Olof Sandberg, chef för Stockholms stads skolkliniker, i samråd med rektor och överlärare på Högalids folkskola. Temat var: "Varför skall man sköta sina tänder i tid" Bildtexterna lyder: "Skolbarnen har tecknat och tävlat. Tandvården blir populär. Tandatletens liv hänger på att ha friska och starka tänder" Teckningen som är återgiven i färg i tidningen föreställer en man som häger i en lina från ett flygplan och håller sig fast med tänderna. Dessutom fanns i reportaget svartvita fotografier ett av barn som borstar tänderna och ett barn i en tandläkarstol, med två tandläkare bredvid. Teckningstävlingen användes som ett sätt att förmedla önskvärda medicinska kunskaper till skolbarn och deras föräldrar, och för att göra "tandvården populär", som det stod i bildtexten. ${ }^{183}$ Tävlingen omnämndes både med text och med färgbild i dagspressen, vilket ökade budskapets spridning. ${ }^{184}$

178 DN 1918-02-17 sid. 6.

179 Ibid. sid. 6.

${ }^{180}$ Ibid. sid. 6.

181 Jämförelser mellan barnkonst och folkkonst är vanlig under en lång period, både Anna-Maria Roos 1908, och Helga Eng i kommande kapitel 1945, gör denna jämförelse med hänvisning till barnbildsforskning.

182 DN 1919-11-16 1a sida. Nästa teckningstävling i DN har temat "Det manliga idealet”

${ }_{183}$ Hallberg, Mathilda, (2017).

${ }^{184} \mathrm{DN}$ 1a november 1932 första samt sista sidan, bild och text. 
I FIB anordnades också andra tävlingar för barn än teckningstävlingar. I den relativt nystartade tidskriften syftade tävlingarna till stor del om att knyta ungdomarna till tidskriften genom att ordna hobbyverksamheter och att skapa en kundkrets. Mellan 1937-1945 anordnades en modellflygstävling där olika regionala klubbar deltog och som varje år hade final i Stockholm. Denna tävling annonserades under flera år. ${ }^{185}$ Andra tävlingar var av mera tillfällig eller skiftande karaktär, som exempelvis novelltävlingar och slöjd- och fototävlingar i FIB, riktade både till barn och unga och även till vuxna.

Materialet i detta kapitel utgörs av samtliga så kallade tävlingssamlingar i Svenskt barnbildarkiv och de tävlingar som omnämnts i Tecknings/bildlärarförbundets tidskrift 1938-2000. ${ }^{186}$ I avsnittet om arrangörerna diskuterar jag både de tävlingsarrangörer som finns på SBBA, samt de som finns omnämnda i teckningslärarförbundets tidskrift. ${ }^{187}$ I avsnittet om barnens uppdrag där jag diskuterar vilka teman tävlingarna haft, används däremot enbart material från SBBA:s arkiv. Detta beror på att SBBA har de faktiska bilderna som skickades in till tävlingar och ofta lärarinformation. I teckningslärarförbundets tidskrift finns enbart artiklar och annonser, vilket inte alltid ger ett tillräckligt underlag för analys av hur uppdragen utförts eller formulerats. ${ }^{188}$ Information och tidningsklipp om tävlingarna för omslagen till telefonkatalogerna 1977-1984 finns i Televerkets arkiv som är deponerat på riksarkivet. Tidningsklipp kring Arlas och Postens tävling "Detta vill jag värna om" finns på Centrum för näringslivshistoria. Förutom tävlingarna används även undervisnings- och läroplaner från 1919 till 1980 liksom läromedel av olika slag.

Den tidigaste tävlingen i mitt undersökta material är FIB:s teckningstävling för skolungdom, som under hela tidsperioden engagerade över 800000 skolbarn och pågick mellan 1938-1957.189 Tidningen startar 1934 och teckningstävling-

${ }^{185}$ Se t.ex. FIB 1939 nr. 23 sid. 28, och FIB nr. 171940 sid. 29. I samarbete med LO och SAF utlystes också den uppskattade tävlingen "uppfinnare i blåställ", riktad till verkstadsarbetare. Det fanns flera teckningstävlingar riktade till vuxna arrangerade av NKI-skolan, 1939 med rubriken "Kan Ni rita av Signe Hasso?", med en total prissumma på 10. 000, och 1:a pris på 500 :- .1941 var rubriken ”NKI skolans stora teckningstävling Rita av dem!” och en bild av Sickan Karlsson och Georg Fant i militäruniform. NKI-skolan arrangerade även tävlingen "Kan Ni teckna en profil?”1946. Teckningstävlingarna för vuxna under 1940-talet handlade alltså om att kunna teckna av, ofta berömda personer, och arrangerades av Nordiska korrespondensinstitutet, som också därigenom även kunde öka efterfrågan på sina egna korrespondenskurser inriktade mot teckning och målning.

186 Teckningslärarnas tidskrift benämns Tidning för Sveriges teckningslärare 1931-1938, Teckning 1939-1979, och 1979 byts namnet till Bild i Skolan 1979-2000.

187 Det är både tävlingar från SBBA och de som omnämnts i teckningslärarförbundets tidskrift. Även om jag i detta kapitel vill visa på alla tävlingar, så har de tre tävlingar som jag kommer att använda i bildanalyserna, också här en mera omfattande bakgrundsteckning, det är alltså Folket i bilds tävling 1938-1946, Televerkets tävling 1976-84, samt Arlas och Postens tävling 1976.

${ }^{188}$ Det finns ibland bilder med i artiklar i Teckning, men materialet är inte tillräckligt omfattande för att kunna jämföras med SBBA:s arkiv, vad gäller tävlingsuppdragen. Även SBBA:s arkiv har inte lärarhandledningar till alla tävlingar, så analysen omfattar primärt de tävlingar där det finns riklig information.

189 Öhman, Ivar (red). (1984) Folket i bild: tidningen som var en folkrörelse. D. 1, 1934-1949. Stockholm: Tiden sid. 6. 
en arrangeras första gången 1938 i samarbete med teckningslärarförbundet. ${ }^{190}$ Bilder från tävlingen 1938-1946 publicerades i boken Sverige genom barnaögon 1947. Det är denna bok och de bilder som finns i Nationalmuseum samling från samma period som begränsat undersökningen av FIB:s tävling till 1938-1946. Av de senare samlingarna är det Televerket som arrangerar de mest omfattande tävlingarna 1976-1995.

Låt mig mot den här bakgrunden precisera forskningsuppgiften för det här kapitlet. Utifrån det mångfacetterade område tävlingarna utgör, kommer jag att närma mig avhandlingens övergripande syften genom att analysera barnteckningstävlingars skiftande uttryck, organisation och initiativtagare. Min undersökning identifierar vilka som varit initiativtagare, förespråkare och motståndare, liksom hur tävlingarna ifrågasattes och förändrades över tid. Därutöver diskuteras hur tävlingarnas förutsättningar var olika beroende på var tävlingarna genomfördes, vilka barn som tillfrågades, material- och teknikförändringar samt hur bilderna nådde ut och publiceras på olika sätt.

Kapitlet har disponerats på följande sätt: Först kommer jag i avsnittet Barnkonstbilden $i$ sambällsdebatt och sambället minne att diskutera den historiska kontexten för tävlingarna från 1930-talet, som visar på hur intresset för barnbilden kunde relateras till samtida diskurser inom konst, pedagogik och psykologi. Därefter diskuteras samhällets intresse av att bevara och arkivera barnbilder, både i museisamlingar och nationella arkiv. Här problematiseras även hur arkivens kategoriseringar och ordnande haft betydelse för hur barnbilder har uppfattats och tolkats, liksom komplexiteteten kring definierandet av en tävlingssamling.

Det andra avsnittet Arrangörer av teckningstävlingar tar upp frågan om vilka aktörer som arrangerar tävlingar och vad de explicit anger för syften med tävlingarna. Vilka som arrangerat barnteckningstävlingar och hur de definierat tävlingarnas syften visar hur idén om barndomens innebörder varit komplex och mångfacetterad och beroende av både tid, plats och barnens ålder. Eftersom skolan var den plats där tävlingarna ofta arrangerades diskuterar jag i ett särskilt avsnitt Skolan och tävlingarna även skolans ambivalenta förhållande till tävlingar över tid. Detta har synliggjorts både i läroplaner, i teckningslärarförbundets tidskrift och dagstidningar.

I avsnittet om Uppdragen och barnen, diskuteras både anvisningar till juryn, och uttalade anvisningar från arrangörerna till barnen om hur bilderna ska utföras. För att ytterligare kontextualisera uppdragen och tävlingarna diskuteras material och teknikförändringars betydelse för tävlingarnas utförande, liksom juryns sammansättning och tävlingarnas priser. Uppdragen som barnen har fått om vad de ska teckna har jag klassificerat i olika teman. Dessa olika tema har förts samman utifrån uppdragens centrala aspekter. Uppdrag som rör Nationoch Hembygd, Jul och högtider och Barnet som framtiden, är teman som återkommer under hela undersökningsperioden medan Internationell rättvisa och

190 Öhman, Ivar (red). (1984) sid. 6. 
barns rättigheter samt Natur, Miljö och Trafik, dyker upp från 1970-talet. ${ }^{191}$ I det avslutande avsnittet diskuterar jag var bilderna visats, hur detta förändrats över tid och hur platserna påverkar hur och till vilka bilderna nått ut och kommunicerats.

\section{Barnkonstbilden i samhällsdebatt och samhället minne}

De tävlingar jag intresserar mig för omfattar en period under vilken barnteckningstävlingar beskrivits både i positiva och negativa ordalag. Både tävlingsformen och barnbilden har uppfattats och beskrivits på olika sätt och även kategoriserats på olika sätt och med olika begrepp.

Utställningar med barnteckningar entusiasmerade tidigt modernistiska konstnärer. Utvecklingspsykologer studerade barnbilder för att de ansågs spegla barns utveckling. 1939 skrev Gustav Nordlander, som var med och arrangerade FIB:s tävling, hur insikt i teckningsämnet kunde bibringas "genom segrar och nederlag i tävlingar". ${ }^{192}$ Samtidigt sker en tydlig förskjutning under perioden där tävlingsformen stod i konflikt mot ett mer fritt skapande inom teckningsämnet.

Tävlingarna framställdes i teckningslärarförbundets tidskrift även som positiva då de gav teckningslärare en framträdande roll som jurymedlemmar. ${ }^{193}$ Tio år efter FIB första tävling kommer Lowenfelts bok Alla barn kan måla på svenska, med kapitlet "Bör barnen deltaga i tävlingar?". Här kritiseras barns deltagande i tävlingar, som vi såg i citatet i början av detta kapitel. Dessa idéer fick gehör i den svenska pedagogiska debatten, där man menade att fanns en tydlig motsättning mellan vad de vuxna ansåg vara vackert eller originellt, och det karaktäristiska och unika bilduttryck som varje barn bar inom sig. ${ }^{194}$

Här ser vi således hur både bilder i sig och tävlingsfenomenet uppfattades, beskrevs och betecknades på olika sätt. Dessa kontroverser påverkar också hur vi bevarar och sparar barns bilder. Det gäller till exempel hur barns bilder och tävlingar arkiverats, med vilka begrepp och under vilka rubriker. Sättet som barnbilder bevarats säger oss något om synen på barns bildskapande och tävlingar som fenomen, exempelvis om bilderna bevarats under beteckningen tävlingar, samlingar eller temabilder.

Vissa tävlingsbilder har sparats för att de är bilder som vunnit tävlingar, medan andra tävlingsbilder har sparats för att de inte har vunnit. Synen på vilka barnbilder som har ansetts viktiga att bevara har alltså skiftat över tid. Min övergripande fråga för detta delkapitel rör således hur tävlingsbegreppet etableras och omdefinieras över tid i olika kontexter och hur tävlingarnas utformning har anpassats till samtiden. I det andra avsnittet ska jag granska hur barns bilder och

\footnotetext{
191 Dessa uppdrag gäller SBBA:s samling: Se tabell 1 SBBA teckningstävlingar.

192 I teckningslärarnas tidskrift Teckning 1939 nr. 2, 15:e mars sid. 89.

193 Det förs en återkommande diskussion om varför teckningslärarnas specifika sakkunskap kring barns bildutveckling och konst, gör att de bör anlitas som jurymedlemmar. Teckning 1939 nr. 1 sid. 2 samt Teckning 1940 nr. 1 sid. $25 \mathrm{f}$.

194 Lowenfeld, Viktor (1957) Stockholm: Rabén \& Sjögren sid. 58. Originalets titel: Lowenfeld, Viktor (1954). Your child and his art: a guide for parents. New York: Macmillan.
} 
barnbildstävlingar beskrevs inom den expressionistiska konstdiskursen under tidigt 1900-tal, vilket satte agendan för hur den tidigaste tävlingen arrangerad av FIB och Nationalmuseum under 1930 och 40-talet diskuterades. Mot den här bakgrunden kommer jag att diskutera hur de utvecklingspsykologiska och pedagogiska diskurserna beskrev barnbilder och tävlingar under undersökningsperioden. I det första avsnittet diskuterar jag hur bilderna och tävlingarna har bevarats i arkiv och samlingar.

\section{Spara för framtiden - tävlingssamlingar och temasamlingar}

För att förstå tävlingarna är det nödvändigt att också titta närmare på hur tävlingsbilderna har sparats och bevarats. Hur de vinnande bilderna sorterats och katalogiserats spelar roll för hur bilderna uppfattas och vilka bilder sedan kan återfinnas i arkivet. Eric Keetelar beskriver i The meaning of Archives vikten av att uppmärksamma att arkiven konstruerar flera olika sanningar och verkligheter. För att undersöka hur dessa multipla meningar konstruerats är det viktigt att studera relationerna mellan arkivet och den sociala, kulturella, politiska eller religiösa kontexten kring samlingarnas skapande, upprätthållande och användning. Arkivens ordnande och begrepp är en kvarleva i sig, menar Keetelar. ${ }^{195}$ Originalbilderna från FIB:s tävling finns inte i SBBA utan är till största delen bevarade därför att Nationalmuseum införlivade dem i sina samlingar, som vi såg tidigare. Barnbildens konstnärliga kvalitéer var ett kriterium för dess bevarande, där de som utvalts som bäst i nationell konkurrens sparades. ${ }^{196}$

FIB:s teckningstävling startar alltså 1938. 1939 presenteras tävlingens affisch i FIB:s ungdomsspalter (bild 2:1). Affischen visar en palett med penslar, och i paletten ett foto av barn i skolbänkar, med texten "Unga Konstnärer", och "Utställning”. Även i förgrunden syns foton av barn i skolbänkar som tecknar. Tävlingen anordnades i samarbete mellan FIB och Teckningslärarnas riksförbund. ${ }^{197}$ Arrangörerna menade att barnen kunde ses som unga konstnärer, vilket underströks av texten till höger; "Våra tecknare till NATIONALMUSEUM". I texten berättas att bilderna skulle få möjlighet att ingå i Nationalmuseums samling och FIB skrev; "Hur stolta kan ni inte alla känna er, som deltagit i denna tävling? Att få in sina saker på Nationalmuseum är minsann inte vem som helst förunnat.”198 Två år senare, 1941, håller överintendenten på Nationalmuseum, Axel Gauffin ett tal vid öppnandet av den stora skolteckningsutställningen på museet. Talet publiceras på FIB:s ledarsida:

Vid öppnandet av årets stora skolteckningsutställning på Nationalmuseum, anordnad av FIB i samarbete med Gustav

\footnotetext{
${ }^{195}$ Eric Ketelaar (2001) Archival Science 1 Tacit Narratives - The meanings of Archives sid. 3141, se även Sparrman, Anna I Eriksson, Yvonne (red). (2014) Barn tolkar världen att förstå och tolka barns bilder.

196 Nationalmuseums samlingar är inte ett arkiv, och har därför inte samma krav på sökbarhet och offentlighet.

197 FIB nr. 81939 sid. 28.

198 Tävlingsbilderna på denna sida analyserades i föregående kapitel; Hembygden och hembygdens folk.
} 
Adolfakademin och PA Nordsteds förlag höll överintendenten vid museet, Axel Gauffin, ett av den talrika vernissagepubliken livligt uppmärksammat anförande om skolteckningarnas plats och betydelse i museets konstsamlingar. ${ }^{199}$

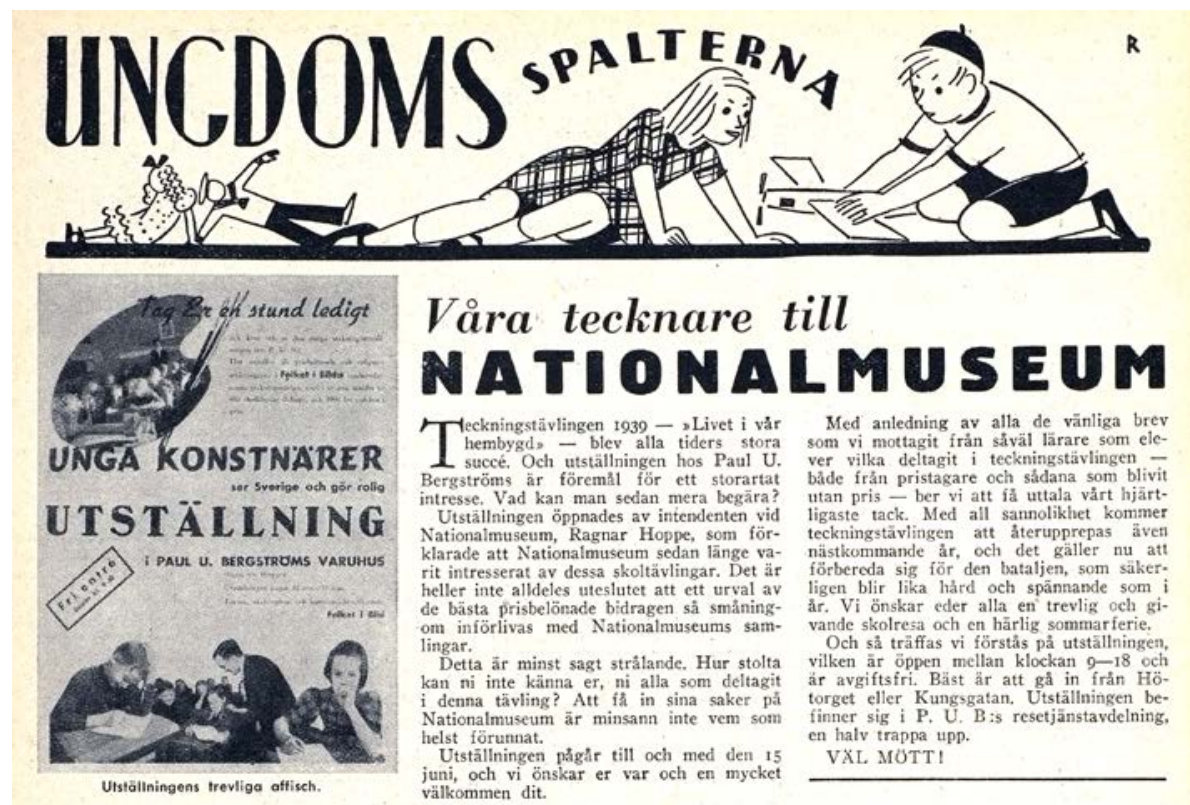

Bild 2:1. Folket i bild nr 211939 sid. 28 detalj.

Att bilderna fick vara del av museets konstsamlingar, användes som argument för att gestalta barnbildens ökade status som just konstbild. Men, Gauffin menar samtidigt att det inte handlar om att jämföra barnteckningarna med vuxna mästerverk: "allt ska bedömas efter sin art och barnet själv är den första att erkänna att det ser på allting på ett annat sätt än de stora."200

När SBBA bildades 1977 påbörjades ett aktivt insamlande av bilder. ${ }^{201}$ SBBA vände sig redan samma år till Televerket och ber att få ta del av de bilder som skickades in till Televerkets tävlingar för telefonkatalogomslag. ${ }^{202}$ I brev från Jan Brandt till Tony Olofsson på Televerket 1977 menade Brandt att i och med den vidgning av kulturbegreppet som skett under senare år behövdes en intensifierad samverkan mellan kulturpolitiska, socialpolitiska och utbildningspolitiska insatser. Barn hade här rätt till speciella kulturpolitiska insatser, som alternativ till

199 Fönstret (ledaren) FIB 1941 nr. 27 6:e juli sid. 2.

200 Ibid sid. 2.

201 Martola, Ulla I Eriksson, Yvonne (red.) (2014).

202 Vilka idag är den till antalet bilder största samlingen på SBBA, med över 200000 bilder, och alltså en betydande del av arkivet. 
det "kommersiella spekulationsutbud av kultur som idag erbjuds barn" ${ }^{203}$ Här skulle arkivet och dess verksamhet, som även innefattade skapande verksamhet för barn, vara till gagn för barnen, och tävlingsbilderna skulle vara till gagn för arkivet, som även skulle kunna var en "unik källa för forskning" menade Brandt. Vid arkivets 30-årsjubileum presenteras arkivet på följande sätt:

Varje teckning av ett barn, oavsett ålder eller talang är lika viktig. Därför samlar arkivet in barns bilder, allt från småbarnsklotter till ungdomarnas mer avancerade konstverk utan att låta vuxnas uppfattning om bra eller dålig konst avgöra. ${ }^{204}$

Arkivet innehåller en blandning av privata bildsamlingar och pedagogers samlingar, vilket påverkar bildurvalet. Många tävlingssamlingar saknar dock information om urvalsförfarande. Arkivets fokus på barnbilder gör således att information om tävlingarnas/bildernas kontext saknas eller är bristfällig. Några är utvalda, och representerar då det som en enskild person velat spara eller det en skola velat spara, andra bilder är sparade utan urval.

I arkivets första registrering var tävlingsbilder inte någon egen kategori. De tävlingsbilder som fanns i det första registret, katalogiseras under temabundna kollektioner. Utöver temabundna kollektioner fanns pedagogiska kollektioner, specialkollektioner, internationella kollektioner och personliga kollektioner. Sedan 1993 har man delat in samlingarna i Pedagogiska samlingar, Privata samlingar, Tävlingssamlingar och Temasamlingar. ${ }^{205} \mathrm{I}$ det nya registret finns alltså både temasamlingar och tävlingssamlingar, samt Televerkets täulingsbilder som en egen samling. ${ }^{206}$ I tävlingssamlingarna ingår bilder som skickats in till tävlingar, men i de flesta fall inte de vinnande bilderna, vilket jag återkommer till. ${ }^{207}$

Hur vet man då vad som ska räknas som en tävlingssamling i SBBA? Det är inte självklart eftersom i arkivförteckningarna är det ibland oklart vad som kan betraktas som en tävlingssamling och vad som betraktats som en temasamling. Exempelvis har samlingen "Vårt gröna arv" som arrangerades av Världsnaturfonden och Ica- kuriren, katalogiseras av SBBA både under tävlingssamling och under temasamling, då det fanns flera olika samlingar för de olika regioner som deltog. Eftersom Ica- kuriren och Världsnaturfonden själva i sin affisch benämnde det "teckningstävling för ungdom" och då det fanns tydliga vinnare som presenteras med namn i tidningen har jag valt att betrakta det som en tävlingssamling.

${ }^{203}$ Brev till Torsten Olofsson från Jan Brandt, SBBA 1977-09-02 Televerket, Telemedia Omslag för telefonkataloger; Riksarkivet.

204 Martola, Ulla (red.) (2008). Folk och färd: Svenskt barnbildarkiv: 30 år jubileumsutställning. Eskilstuna: Svenskt barnbildarkiv i Eskilstuna.

${ }^{205}$ Svenskt Barnbildarkiv i Eskilstuna (SBBA) har sedan 1977 samlat in barnbilder från främst Sverige, men även andra delar av världen. Arkivet hör idag till Eskilstuna konstmuseum och drivs samordnat med statliga och kommunala medel, För att bilderna ska räknas som barnteckning får bildskaparen inte vara äldre än 18 år. I barnbildssamlingen finns bilder från 1790-talet fram till idag.

${ }^{206}$ Kopia av SBBA:s registerförteckning 12 mars 2009.

207 De finns inte i någon av Televerkets tävlingar, inte heller i Arla /Postens 1977, vilka jag båda kommer att presentera närmare. 
Konsumentverkets tävling "Konsument 2000" annonserades i bildlärarförbundets tidning Bild i Skolan 1984. Genom annonsen hittade jag samlingen i arkivet, där den var den katalogiserad som temasamling, och inte tävlingssamling. "Europeiska skoldagen" finns katalogiserade både under internationell samling och under tävlingssamling. Även dessa hade ordet tävling tydligt i instruktionerna till lärarna. En temasamling däremot innebar oftast att barnen tecknade ett specifikt tema, men det har inte varit för att välja ut någon/några specifika vinnare och det har inte heller funnits någon tydlig jury, även om bilderna ibland visats offentligt och därmed valts ut. I den översiktliga analysen av samtliga tävlingar har jag har tagit med några av arkivets temasamlingar från 1990-talet som jag diskuterar längre fram $\mathrm{i}$ avsnittet om internationella och frivillig organisationer som arrangörer, de var utställda på barnkonstmuseet i Vårby gård, arrangerade av Rädda barnen. Dessa temasamlingar har då varit utställda och utvalda, men saknat pris och jury och de teman de haft speglar till viss del ratificerandet av barnkonventionen, 1989.

Som en blandform av tävling och temasamling kan även Arla/Postens Teckningstäuling för alla tjejer och killar! från 1976/77 betraktas. Den har katalogiserats som tävlingssamling, och Arla kallade fenomenet för tävling, men de delade inte ut några priser. Vinsten var istället att få sin bild upptryckt på mjölkpaketen eller på ett vykort. Då Arla/Posten inte hade pengar som pris, behövde de heller inte ha någon uttalad jury, även om någon hade valt vilka bilder som publicerades. Tävlingen presenterades i oktober 1976 i en artikel i Expressen med rubriken "Det här vill jag värna om - Över 10000 barn har visat vad de tycker". Där publiceras namnen på de som gjort vad Expressen benämnde "vinnande" bidrag, även om det inte fanns några vinster förutom att bli publicerad. Arla erhöll även ett tackbrev från en deltagare som bland annat skrev: Det är "en fördel att ni inte utlovar några löjliga priser för det är ju inte det som är det viktiga”. ${ }^{208}$ Om detta tackbrev är representativt för deltagarna i tävlingen går inte att avgöra. Det säger dock något om vad Arla vill framhäva, att Arla allierade sig med barnen för att nå ut med sitt budskap.

När SBBA startade sin verksamhet 1977 fanns alltså inte någon ambition eller något intresse av att betona eller skilja ut tävlingsbilder. SBBA har heller aldrig aktivt samla in, eller skiljt ut vinnarbilder. Det problematiska med tävlingsformen som jag hänvisade till $\mathrm{i}$ inledningen att Skolöverstyrelsen påpekade och som, återspeglades även i arkiveringen av bilderna. I den första katalogiseringen arkiverades inte tävlingsbilder som en egen kategori. Från 1993 finns tävlingssamlingar som kategori, men ibland kategoriserades tävlingssamlingar under begreppen temasamlingar eller internationella samlingar.

Att tävlingarna som kontext varit mindre betydelsefull för insamlingen än barnbilden i sig framgår också av initiativtagaren till SBBA Jan Brandt, som 1977 kontaktade Torsten Olofsson på Televerket och berättade om det nya barnbildsarkivet. Han presenterar det som en "nationell kulturpolitisk angelägenhet" att de bilder som inte belönades skulle skickas till svenskt barnbildarkiv från

${ }^{208}$ Brev SBBA diarienr: 1991:016. 
samtliga olika telekontor när urvalsprocessen var över. Torsten Olofsson skickade förfrågan vidare ut $\mathrm{i}$ organisationen, varefter de flesta telekontor skänkte de bidrag som inte vann tävlingen till SBBA. ${ }^{209}$ Jan Brandt kontaktade återigen Televerket 1980, och angav då ett ytterligare skäl för Televerket att tävlingsbilderna borde bevaras, då det var angeläget för "bevakning av barnens bildutveckling." ${ }^{210}$ Citaten visar ett samband mellan den utvecklingspsykologiska diskursen och barnkonstdiskursen, liksom den utvecklingspsykologiska diskursens betydelse för att vilja samla och bevara barns bilder. Tävlandet har ironiskt nog skapat förutsättningar för bevarande samtidigt som tävlingsfenomenet ibland inte synliggjorts $i$ arkivet.

\section{Konstdiskursen och barnbilden - barnbilden som ett nyskapande uttryck}

Redan under tidigt 1900-tal ägnade de relativt nya vetenskaperna psykologi och pedagogik liksom konstvetenskap, stor uppmärksamhet åt barns bildskapande och barns bildutveckling. ${ }^{211}$ Corrado Ricci menade bland annat i "Barns konst" att barnet i första hand tecknar vad det vet och inte vad det ser, vilket stod i motsats till tidigare idéer om barns skapande. Relationen mellan barnkonst, förhistorisk konst och så kallad primitiv konst aktualiserades på dessa sätt också för modernisterna. ${ }^{212}$ I det här avsnittet kommer jag uppehålla mig vid den moderna expressionistiska konsten, inledningsvis med betoning på den diskussion som fördes internationellt och som påverkade den svenska konstdiskursen.

Konstvetaren Max Vervorn kritiserade den utvecklingspsykologiska idén att förhistorisk konst var likställd med barns konst. Han menade att man bör skilja på konst som representerar objekten så som de ser ut för ögat, och konst som representerar idén om objekten, skapade i den individuella hjärnan. Förhistorisk konst försökte efterlikna objektet, barnbilder försökte skapa en idé om objektet, enligt Vervorn. ${ }^{213}$ Detta var en tydlig förändring jämfört med Rousseaus och utvecklingspsykologins idéer om att barnet alltid ville teckna av verkligheten. Enligt Vervorn så vill barnet genom bilden skapa en "idé om" det avbildade.

Den abstrakta expressionismen omfattade idén om barnbildens konstnärliga kvalitéer, där det naiva och oskyldiga barnet hade inneboende kunskaper om ett

209 Brev från Jan Brandt till Torsten Olofsson 1977-09-02 Televerket telemedia, Riksarkivet, (Olofsson var den som höll i att organisera tävlingen, han var den som lärare ombads kontakta om de hade några frågor, i den information som skickades till skolorna).

${ }^{210}$ Brev från Jan Brandt ankom 1980-10-17, Televerket, Telemedia Omslag för telefonkataloger, Riksarkivet.

${ }^{211}$ Ricci, Corrado (1887/1906). Lárte dei Bambini Översatt: Kinderkunst: Ber.Ubers.aus dem Ital. von E.Roncali. Leipzig: Se Även Levinstein, Siegfried (1905). Kinderzeichnungen bis zum 14. Lebensjahr.: Mit Parallelen aus der Urgeschichte, Kulturgeschichte und Völkerkunde. Mit einem Anhang von Karl Lamprecht.. Leipzig:; Kerschensteiner, Georg (1905). Die Entwickelung der zeichnerischen Begabung: neue Ergebnisse auf Grund neuer Untersuchungen. München: Carl Gerber.

${ }^{212}$ Lasko, Peter (2003) The expressionist roots of modernism. Manchester: Manchester University Press.

${ }^{213}$ Ibid. sid. 121. Där physioplastisk konst är den avbildande, och ideoplastisk konst, den idébaserade. 
abstrakt, känslomässigt måleri, som kunde avslöja tingens äkta essens. ${ }^{214}$ Konstnären Kandinsky resonerade på följande sätt om barn och konst $1912 \mathrm{i}$ konsttidskriften der Blaue Reiter Almanac:

"Så, utan undantag framträder i varje barns teckning automatiskt själva objektets inre klang. Vuxna, speciellt lärare, försöker påföra barnet tingens praktiska betydelser och påpekar exempelvis att mannen inte kan gå, när han bara har ett ben...". 215

Barnet hade en inneboende förmåga att komponera, visa formers olika sidor och hitta en schematisk samverkan mellan delarna och helheten, menade Kandinsky. Det fanns en omedveten enorm kraft i barnet, som gjorde att barnens verk var jämförbara, eller till och med stod högre än, vuxnas konst. ${ }^{216}$ Kandinsky menade vidare att konstnärens liv på många sätt liknar barnets, då den moderna konstnären liksom det oförstörda och ofördärvade barnet ville avslöja det outsagda i människans inre. ${ }^{217}$ Akademisk skolning gjorde att konstnärerna förlorade förmågan att erfara de inre klangerna, bilderna blev korrekta men med ett dött innehåll. ${ }^{218}$

Konstnären Paul Klee menade att barnsligt beteende borde tas seriöst och inte ignoreras. Istället borde det barnsliga vara det som togs på allvar, och det var det som kunde reformera dagens konst, mer än den konst som visades på officiella gallerier. ${ }^{219}$ Kandinsky, liksom Paul Klee och Frans Marc var med i den expressionistiska grupp av konstnärer som kallade sig "Der blaue Reiter". 220

Expressionisterna och kubisterna ifrågasatte alltså de naturalistiska idealen inom akademin. De ville komma åt och analysera det som fanns under den synliga ytan. Konsten ville se det som fanns under ytan, påverkade av de nya psykologiska strömningarna, och av ny teknik som kameran, röntgen och mikroskop. ${ }^{221}$ Barn och konstnärer betraktades som att de kunde avslöja något som andra inte såg. Dessa kvalitéer möjliggjorde för barnkonsten och den barnlika konsten att betraktas som förnyande och progressiv. Många kända konstnärer i början av 1900-talet, som till exempel Picasso, Klee eller Kandinsky, hade egna samlingar

\footnotetext{
214 Ibid. sid. 121.

215 Kandinsky, Marc, Frans (1912/2016) Der Blaue Reiter München Piper \&co. Verlag. Sid. 168. (min översättning) Text i original: So entblösst sich in jeder Kinderzeichniúng ohne ausnahme der inneren Klang des Gegenstandes von Selbst. Die ervachsenen, besonders die Lehrer, bemühen sichdem Kinde das Praktisch- Zweckmässige aufzudrängen, und kritisieren dem Kinde seine Zeichnung gerade von diesem flachen Standpunkte aus "dein mench kann nicht gehen, weil er nur ein Bein hat...”.

216 Översatt från original: Es ist ein unbewusste, enorme Kraft im Kinde, die sich hier äussert und di edas Kindwerk dem weke des Erwaschsenen gleich hoch (und oft viel höher!) stellt. Sid. 169.

217 Lasko, Peter (2003) sid. 120.

218 Kandinsky, Marc, Frans (1912/2016) sid. 169.

219 Lasko, Peter (2003) Sid. 121.

220 Der Blaue Reiter ("Den blå ryttaren”) är en beteckning på de expressionistiska konstnärerna i kretsen runt den München-baserade utgivnings- och utställningsredaktionen med samma namn under åren 1911-1914. I Blaue Reiter Almanack som gavs ut 1912 fanns flera barnbilder.

221 Klee, Paul Pedagogical sketchbook (1953) Introduction by Sibyl Maholy-Nago sid. 7.
} 
av barnbilder som de använde sig av för att inspireras i sitt konstnärliga skapande. 222

I denna utveckling av konstscenen tog således barns bilder plats. Bilderna kunde både i sig själva betraktas som att de innehöll konstnärliga kvalitéer, samt att de betraktades som inspiration för en ny generation konstnärer som vill komma åt nya naiva och moderna konstuttryck.

Bourdieu menar i Rules of Art, att konstnären Rousseaus oskolade och naiva måleri aldrig blivit erkänt om han levt i en annan tid. "Om han hade levt tjugofem år tidigare, om han alltså dött 1884 istället för 1910, före grundandet av den oberoende konstsalongen i Paris, hade vi aldrig hör talas om honom". ${ }^{223}$ Av diskussionen framgår att den moderna konstens upphöjande av barnbilden, föregick intresset för barnteckningstävlingarna.

När tidningen IDUN 1923 ställer ut barnteckningar i Gummesons konsthandel på Strandvägen i Stockholm, så blir det succé. Engagerade teckningslärare, som Charlotte Mannerheim från Samskolan i Göteborg, var pådrivande. ${ }^{224} \mathrm{I} \mathrm{nr}$ 37 från 1923 visar IDUN bilderna på ett mittuppslag och i nr 38 finns på ledarplats en artikel om "Iduns utställning av barnkonst. Värdesatt av modernistiska konstnärer." 225 Idun lät flera samtida konstnärer kommentera barnbildsutställningen och Einar Jolin menade att: "Vad barn har målat har alltid intresserat mig, liksom allt som är äkta och ursprungligt." och han menade vidare att "Barnteckningar äro alltid bra därför att barnet som regel är opåverkat av dålig kultur."226

Även konstnären Arvid Fougstedt var delvis positiv, men påpekade:

...för 100 år sedan skulle en sådan här utställning vara otänkbar, den är först nu aktuell, trots att barnmålningar nog alltid varit sig lika i alla tider. Det är den moderna konsten som väckt intresset för barnmålningar, släktskapen är uppenbar. ${ }^{227}$

Barnkonstbilden var alltså ett etablerat fenomen när FIB startar sin tävling1938, liksom den naiva och expressionistiska konsten. Tävlingarna byggde på konstens idealiserande av den naiva barnbilden. Synen på barnbild som konstbild var alltså en viktig förutsättning för teckningstävlingarna på 1930 och 40-talet. Uppvärderingen av det naiva måleriet gjorde också att tävlingarna kunde motiveras och stödjas av Nationalmuseum. Nationalmuseums intendent Gauffins beskrev i sitt tal vid öppnandet av utställningen 1941 att barnbilden uppvisade kvalitéer som vuxna konstnärers verk saknade:

222 Sievert-Staudte, Adelheid, Kind und Kunst In: Schreiner-Maierhofer, Marie (Ed.).: Kinder kennen/ können Kunst (1998) Johannes Hey verlag: Wien sid. 33ff.

${ }^{223}$ Bourdieu, Pierre (1996). The rules of art: genesis and structure of the literary field. Cambridge: Polity press Henri Rousseau (1844 -1910) räknas som den förste naivistiska målaren, även om han blev erkänd först efter sin död.

${ }^{224}$ Idun 1923 nr 37 sid. 895f.

225 Idun 1923 nr 38 sid. 895.

226 Idun 1923 nr. 38 sid. 895 .

${ }^{227}$ Idun 1923 nr. 38 sid. 895. 
Om du skulle tala med den lille mästaren om konstnärens martyrskap, skulle han inte förstå dig. Men just därför kunna barnteckningarna, när de äro som bäst, äga en egendomlig ömtålig charm, som den vuxnes verk, trots all deras fulländning - inte besitta. De äro spontana och oförfalskade uttryck för ett själsliv, lika märkligt värdefullt som den vuxnes, men oändligt mycket mera ömtåligt. De äro omedvetna som skogens blomster och liksom de formade efter lagar om vilka de själva inte ha någon aning/.../Nationalmuseum mottager med tacksamhet den bukett av årets vackraste barnteckningar, som den i år liksom de senaste åren fått införliva med sina samlingar. ${ }^{228}$

Talet är intressant på flera sätt. Det visar hur Gauffin framställde konstnären som en martyr, som måste kämpa för att uppnå det barnen lyckades med bara genom sin oförfalskade spontanitet. Denna syn på barnens omedvetna förmåga att gestalta det oförfalskade känns igen från Klee och Kandinsky. Gauffin beskrev även hur barn hade mycket lättare att måla än vuxna. Bilderna beskrevs som oförfalskade själsliga uttryck med en ömtålig charm, och barnen liknades vid skogens blomster. Barnen stod utan att veta om det i en direktkontakt med naturen, med ett själsliv mycket mera ömtåligt än den vuxnes. ${ }^{229}$

I Gauffins tal som publicerades i FIB 1941 menade han även att barnen genom skapandet av bilderna skulle "bevara minnet av dessa lyckliga barndomsdagar och att det minnet ska hjälpa dem att förstå livets outtömliga rikedom och den konstnärliga egenartens berättigande och värde." 230 Teckningstävlingen innefattar även en kulturdiskurs där barnen genom deltagandet ska lära sig förstå konstens värden. Gauffin reproducerar en romantisk barndomsdiskurs där barndomen är lycklig och omedveten och där barnen just genom sin omedvetenhet kan skapa mera oförfalskade och ömtåliga verk. Många andra tidningar uppmärksammar FIB:s utställning på Nationalmuseum, bland annat Aftonbladet som skriver: "En konstnär måste bli ganska fundersam när han studerar den utställning av barnteckningar med mottot "våra lekar" som pågår på Nationalmuseum. Där finns en blick för färger och en känsla för komposition som gör att man skulle kunna tro att det döljer sig en konstnär i varje barn." ${ }^{231}$ FIB publicerar även utdrag ur DN:s recension av tävlingsutställningarna:

Man vågar tro att tävlingar som dessa, som nog uppfostrar en hel del lärare såväl som barnen, kan göra sitt för att skänka ett visst anseende till det som är äkta och roligt på en gång och därigenom motarbeta den ytliga kulturens nivelleringstendenser. $^{232}$

\footnotetext{
228 FIB 1941 6:e juli nr. 27 sid. 2.

229 Denna romantiska barndomssyn där barnet placeras i ett naturligt oförstört idealtillstånd diskuteras bland annat av Halldén, Gunilla (2011). Barndomens skogar: om barn i natur och barns natur. Stockholm: Carlsson sid. $54 \mathrm{ff}$.

230 FIB 1941 6:e juli nr. 27 sid. 2.

231 Citaterat i FIB 1945 nr28 sid. 33.

232 FIB 1945 nr. 28 sid. 33.
} 
Barnbildens konstnärliga kvalitéer, konsten som god kultur, liksom tävlingens förmåga att på ett roande sätt både uppfostra och lära ut det som representerade det äkta och goda, i motsats till den ytliga kulturen är tydliga diskurser i dessa uttalanden.

FIB:s teckningstävling startar 1938, och bilderna blev så småningom en del av Nationalmuseums samlingar. Bilderna åtnjöt också anseende genom att de blev en del av Nationalmuseums samlingar, och barnen presenterades på utställningsaffischen som unga konstnärer(bild 2:1). ${ }^{233}$

Tävlandet kunde alltså även vara en möjlighet att upptäcka unga begåvningar. Nationalmuseum arrangerar också mellan 1937-1975 tävlingen "Unga tecknare", öppen för alla mellan 16-35 år. ${ }^{234}$ Det är värt att notera att först efter att FIB:s tävlingsbilder visats på varuhuset PUB och därefter på Skansen blev Nationalmuseum intresserade av barnbildstävlingarna. Från 1941 var tävlingen ett samarrangemang även med Nationalmuseum, där bilderna också ställdes ut varje vår under hela 1940-talet. Ett flertal av vinnarbilderna finns idag som en del av deras samling. ${ }^{235}$

\section{Teckningstävling, utvecklingspsykologi och pedagogik}

Intresset för barnbilden påverkades även av den utvecklingspsykologiska forskningen. Som en del av en naturlig mognadsprocess ansågs barn göra liknande bilder vid samma ålder. Utvecklingspsykologen Luquet menar på 1920-talet att barn alltid försöker efterlikna verkligheten, men för att nå det realistiska målet finns olika faser som barn måste passera. ${ }^{236}$ Diskursen tog avstamp i Darwins utvecklingsteori där både barn och mänskligheten är i olika stadier av utveckling. ${ }^{237}$ Barnet eftersträvar enligt Luquet efter ca 8-9 år den "visuella realismen" och då förlorar många barn också intresset för teckning, eftersom de kunde bli besvikna och desillusionerade när de upptäcker sin oförmåga. ${ }^{238}$ Luquet menar alltså likt Rousseau under 1700-talet att barn självmant eftersträvar perspektivteckning och ett realistiskt avbildande av naturen. Luquets Artikel "Psykologiskt studium över teckningen som barnets uttrycksmedel" i Teckningslärarförbundets tidskrift visar att hans idéer fortfarande 1952 även rönte intresse hos svenska

233 Se bild (2:1). FIB nr 211939 sid. 28.

${ }^{234}$ Nationalmuseum (1956) Unga tecknare : tävlingen om stipendiet "Maria Leander-Engströms minne" Stockholm : Nationalmuseum.

2351941 ställde Nationalmuseum samtidigt ut ett urval teckningar från tävlingen Svenska folksagor enl. FIB 1941nr 22 sid. 28.

${ }^{236}$ Luquet, Georges Henri (1927/2001) Luquet inleder kapitlet The development of childrens drawings på följande sätt:"Nothing describes children drawing in general better than the term realism".

237 Detta sätt att betrakta barns bilder syns även ex i Anna Maria Roos artikel i Ord och bild 1908 "Kerschensteiner anmärkte, att liksom barnet i fysiskt hänseende, innan det möter dagens ljus, såsom embryo genomlöper naturens långa utvecklingskedja, så tyckas också barnen till sin intellektuella utveckling ha att genomgå de stadier mänskligheten långsamt kämpat sig igenom." sid. 343.

238 "Children become disenchated with drawing around the time they acquire the concept of visual realism and it's fundamental commitment to perspective." Luquet, Georges Henri (1927/2001) sid. 52. 
teckningspedagoger. ${ }^{239}$ Olika teoretiker har haft delvis skilda uppfattningar om barns olika bildstadier och även samtida forskning visar hur olika bildformer ses som representativa just för de yngre barnens (0-5 år) utvecklingsstadier. Den utvecklingspsykologiska diskursens barnsyn är fortfarande idag tydlig i samhälleliga praktiker. ${ }^{240}$

Att Luquet benämner den intellektuella realismen som "höjdpunkten av barns skapande", visar hur de bilduttryck som uppskattades av den abstrakta moderna konstens representanter, blivit normen även inom utvecklingspsykologin, för vad som kunde benämnas som "höjdpunkt av barns skapande". Även om perspektivteckningen var målet menade Luquet att höjdpunkten av barns bildproduktion var under den fas han benämner "Intellektuell realism". ${ }^{241} \mathrm{Lu}-$ quet gav olika exempel på hur barn tecknar under denna fas. Det kunde vara det han benämnde röntgenbilder, där man till exempel kunde se in i ett hus trots att det finns väggar, eller utvikta perspektiv. Det kunde även vara att ett och samma motiv skildrades från flera olika blickpunkter. Detta sätt att förvrida perspektiv och blickpunkter uppskattades inom det moderna abstrakta måleriet, som jag visade tidigare.

Utvecklingspsykologin påverkade också pedagoger. Richard Rothke var liksom Cizek från Wien, men till skillnad från Cizek utvecklade han en teckningsundervisning för hela folkskolan. Boken Kindertümlisches Zeichnen (1929) översattes till svenska 1937, och Den fria barnteckningen hade stor spridning bland tidens svenska bildpedagoger. ${ }^{242}$ Rothe delade Cizeks idé om att den goda bilden är den som skapas av barnet, utan påverkan av vuxenvärlden, och att den tidigare "illustreringen" i skolan till stor del borde ersättas med "skapande ur förställning (egen idé)" ${ }^{243}$ I Den fria barnteckningen betonade Rothe att han ville främja den psykologiskt orienterade teckningsundervisningen, och barnkonst borde ses som ett eget konstområde, med kvalitéer utanför det föreställande.

Barnkonsten är ett område för sig, närmast besläktat med allmogekonst, (bondekonst, herdekonst,) med den primitiva konsten, ett förstadium till den äldsta konsten. Den vill mätas med en egen måttstock, vilken dock ej har något som helst att göra med bildens riktighet. ${ }^{244}$

239 Tidskriften Teckning $1952 \mathrm{Nr} 1$ sid. 29.

240 Rhoda Kellog studerar på 1970-talet stora mängder barnbilder och menar att utveckling karaktäriseras av att barn utvecklar likadana universella symboler. Read, Herbert in Kellog, Rhoda, (1963) Analyzing children's art sid.4.; Machón, Antonio (2013).Children's drawings: the genesis and nature of graphic representation: a developmental study.; Hörnfeldt, Helena (2009) Prima barn, helt u.a.: normalisering och utvecklingstänkande i svensk barnhälsovård 1923-2007. Diss. Stockholm: Stockholms universitet.

${ }^{241}$ Luquet, Georges Henri (1927/2001) Children's drawings: (le dessin enfantin). London: Free Association Books sid. 141.

${ }^{242}$ Nordström, Gert Z. \& Romilson, Christer (1970). Bilden, skolan och sambället. Orig. utg. Stockholm: Aldus/Bonnier sid.41. Även teckningslärarförbundets tidskrift skriver redan 1931 nr 1 sid. 17 om Cicek, och hur han var motståndare till undervisning i allmänhet och teckningsundervisning i synnerhet, lkiksom Rothes idé att barnbilden aldrig borde rättas till.

${ }^{243}$ Rothe, Richard (1937) Den fria barnteckningen. Stockholm: Sveriges lärarförbund sid. 12.

${ }^{244}$ Rothe, Richard (1937) sid. 24. (kursiv i original) 
Rothe ansåg alltså att barnkonsten hade ett eget konstnärligt värde, liksom primitiv konst och äldre konst, som inte har något att göra med bildens riktighet. Barnkonsten är ett eget område, och då det kan betraktas som konst kan det också ställas ut.

Utifrån den abstrakta konstens ideal och utvecklingspsykologins idéer förändras och förskjuts de pedagogiska idealen om barns bildskapande. Rothe är tydlig påverkad utvecklingspsykologin där han ser att "utvecklingen av bilduttrycket är ett naturligt växande, inom vilket bestämda utvecklingsstadier kunna urskiljas.” ${ }^{245}$ (kursiv i original). Därför var det enligt Rothe viktigt för läraren och föräldern att ha kännedom om utvecklingsstadiernas lagar. Och "I teckningsundervisningen bör det barnsliga uttrycket, det rena gestaltandet, odlas.” menar Rothe. ${ }^{246}$

Dessa idéer om barnkonst fanns även i den svenska och nordiska kontexten av FIB:s teckningstävlingar. Psykologiprofessor Helga Eng, från Oslo beskrev 1945 "Barnet som Konstnär", i ett av förorden till katalogen till vandringsutställningen Sverige genom barnaögon. Även hon likställde barnkonsten med "konst i fjärran tider och hos primitiva folk" och menade därför att barnteckningen var "konstens ursprung". ${ }^{247}$ Sedan gick hon igenom alla barnets olika stadier från klotter, schemabilder (som var det samma som Luquet det benämnt "intellektuell realism") när barn tecknar vad de vet, snarare än vad som syns, och slutligen perspektivbilder. ${ }^{248}$ Så liksom Henri Luquet på 1920-talet uppfattar Helga Eng perspektivbilden som slutfasen för barnets utveckling. Det är också från den utvecklingspsykologiska diskursen som Televerket hämtar idén om att barn som är i nioårsåldern har kvar sitt spontana uttryckssätt, som vi kommer att se längre fram.

Parallellt med utvecklingspsykologin utformas alltså pedagogiska idéer som inte alls menar att naturalistisk avbildning är det som är målet för barns skapande. I linje med Rothe på 1930-talet menade även Viktor Lowenfeld att barns bilder inte behövde ha avbildandet som norm. Förutom kritiken mot tävlingar som vi såg i det inledande citatet skriver han $i$ Alla barn kan måla:

"Man bör inte utan vidare acceptera att barn vill måla "likt verkligheten". Det är inte säkert att denna önskan att måla "likt" kommer från barnen själva; det är troligare att den har uppkommit av felaktig kritik från de vuxna.". ${ }^{249}$ I jämförelse med tidigare bildpedagoger så talar Lowenfeld på ett helt annat sätt om barn tecknande. Så här beskriver han "Vad ska vi göra när barnen säger att de inte kan rita?":

För det mesta tror man att ett sådant påstående betyder att barnen inte har några anlag för teckning, det vill säga att de inte kan exakt avbilda vad de ser. Men det förhåller sig inte alls så, ty barn känner inte till några regler för exakt återgivande av

245 Rothe, Richard (1937) sid. 30.

246 Ibid. sid. 24.

247 Ibid. sid. 9.

248 Sverige genom barnaögon: Katalog. [Ny tr.] (1945).

${ }^{249}$ Lowenfeld, Viktor (1957) Stockholm: Rabén \& Sjögren sid. 111. 
verkligheten. Istället uttrycker sig varje barn efter sin egenart, och för barn existerar inte något $\mathrm{i}$ vanlig mening riktigt eller oriktigt. Om barn inte kan rita beror det helt enkelt på att de har mist sitt självförtroende. ${ }^{250}$

Citatet visar en diskursiv förskjutning i synen på barn och barns bildskapande: varje barn har ett unikt bildspråk och bryr sig inte om regler om att teckna likt verkligheten, om det inte blir felaktigt bemött av vuxna som hämmar deras inneboende kreativitet. Utvecklingspsykologin och den pedagogiska psykologin går här delvis olika väg. Barn utvecklades genom att teckna, men att "varje barn uttrycker sig efter sin egenart" ${ }^{251}$ var skilt från utvecklingspsykologins idé om barns universella teckningsmönster, där den abstrakta barnbilden kunde uppskattas, men utvecklingsmålet ändå var perspektivbilden. Lowenfeld följer här idéströmningen som beskrevs inledningsvis från konstvetenskapen och Der blaue reiter gruppen, om att barnbilden, till skillnad från förhistorisk konst, inte försöker teckna objekten som de ser ut för ögat, utan försöker göra sig en egen "idé om" och därigenom visa på ett inre budskap.

Som jag visade i kapitlets inledning kunde det finnas ett motstånd från många lärares sida då de anammat tanken om det fria skapandet, mot att tävla i teckning. Lowenfelt skriver vidare i Alla barn kan måla, som översattes till svenska 1957: "När man börjar tala om vad som är 'bra' eller 'mindre bra' föregriper man det individuella och särpräglade hos barnen. Barn är alltid tekniskt omedvetna och bör inte undervisas att följa ett visst manér." 252 Att alla barn ville göra bilder ansågs fortfarande lika naturligt som att barn lärde sig tala. Vad som betraktades som naturligt bildskapande förändrades dock, konsten skulle befria barnen i skolan liksom modernismen hade befriat konstnärerna. Bildämnet fick terapeutiska inslag, där barnen genom bildarbete förväntades uttrycka sina idéer och känslor. ${ }^{253}$ Barns individuella förmåga till bildskapande borde bevaras utan att behöva anpassas efter omvärldens förväntningar. Som vi ska se längre fram kommer detta att debatteras i i lärarpressen under 1940 och 50-talet.

Nationalmuseum och tidningen FIB gav, som tidigare nämnts, 1947 ut skriften: "Sverige genom barnaögon - FIB:s teckningstävling för skolungdom" där man presenterade teckningstävlingen och flera av de vinnande bidragen genom åren. En generation efter Kandinsky skrev Nationalmuseums överintendent Wettergren följande i förordet till denna, som han själv benämnde, "kulturhistoriska bilderbok":

Man hoppas också, att den ska ge stimulerande impulser åt de vuxna konstnärerna, som i själva verket brottas med samma uttrycksproblem som för barnen är en allvarlig lek. För de flesta barnen hejdas denna lek så fort kraven på en efterbildande naturalism binder deras fantasi och kommer dem att skämmas

\footnotetext{
250 Ibid. sid. 38.

251 Lowenfeld, Viktor (1957) sid. 56.

252 Lowenfeld, Viktor (1957) sid. 59.

253 Pettersson, Sten \& Åsén, Gunnar (1989). Sid. 93 ff. ; Illeris, Helene (2002).
} 
för "barnsligheten" i sina tidigare ritningar och målningar.

Samtidigt går konstnären, den moderna konstnären, den andra vägen och söker till varje pris rädda något av den omedelbara naivitet som för honom betyder mera än handens skicklighet och teknisk flyhänthet. Kanske dessa målningar, tillkomna utan grubbel, kan göra det lättare för honom att komma i den impulsiva kontakt med verkligheten och med färg och form som är hans mål..$^{254}$

Intendent Wettergrens kombinerade här uttryck för både konstens och utvecklingspsykologins syn på barn, och barns bildskapande. Det gick inte att komma undan barnens inneboende krav på utveckling mot en efterbildande naturalism, men samtidigt var det den "omedelbara naiviteten" i barnmålningarna som konstnären längtade efter. I barndomen låg en förmåga till skapande lek som sedan ohjälpligt var förlorad i och med vuxenblivandet. Där Kandinsky likställde konstnären med barnet, så var barnen och de vuxna konstnärerna för Wettergren tydligt skilda åt. Barndomens skapande förmåga skulle förloras, men barnbilder kunde stimulera de vuxna konstnärerna och vara en inspirationskälla för dem.

I Arla/Postens tävling "Detta vill jag värna om” 1976 syntes återigen en förskjutning i diskursen om barns bildskapande. I boken Varför fär inte barn bestämma? (1977), med bilder från tävlingen skriver Fil.dr, Kerstin Fällström, barnpsykolog, i förordet:

Vi psykologer har länge använt oss av teckningar i vårt arbete.

Dels för att studera barns utvecklingsstadier, dels i samband med vissa former av psykiska störningar. På senare tid har emellertid barns sätt att uttrycka sig börjat intressera allt fler samhällsvetenskapliga forskare. Både psykologer, pedagoger, och sociologer. ${ }^{255}$

Från att barnbilden omtalades som konstens ursprung eller som intressant för att studera barns utveckling, blev bilderna nu istället ett sätt att kommunicera och ett medel för att visa hur barns åsikter borde tas på större allvar. Nu skulle barnbilderna vara ett sätt för barn att få påverka och uttrycka sina åsikter.

De vänsterradikala strömningarna på 1970-talet innebar även en förändring av kulturlivet. Konstscenen på 1970 talet blev mer inriktad på politiska budskap, och kultur sågs som en rättighet för alla. ${ }^{256}$ Samtidigt gick KRO, Konstnärernas riksorganisation, till storms mot både Arlas och Televerkets teckningstävlingar för barn, som de uppfattade som ett hot mot den egna verksamheten. Göran Eriksson på Arlas marknadsavdelning blev intervjuad angående KROs kritik i DN 27 juli 1976, och försvarade sig med:

\footnotetext{
254 "Sverige genom barnaögon" Folket i bilds teckningstävling för skolungdom (1947) Nationalmuseum - Folket i bild. Stockholm: Esselte sid. 3.

255 Varför fär inte barn bestämma: en bok av barn för vuxna! (1977) Stockholm: Utg. sid. 6.

256 Prop. 1974:28. Den enskildes kreativitet skulle tas till vara alla skulle vara delaktiga och inte bara passiva konsumenter. 1974 års kulturpolitiska mål betonade detta, liksom att kulturen skulle nå ut till alla och att kommersialismens negativa verkningar skulle bekämpas.
} 
Man måste skilja på två saker. När det gäller att ändra förpackningsdekoren då kopplas konstnärer in. I det här fallet handlar det om en budskapsruta där man får ge uttryck för sina känslor. Det handlar inte om att byta ut dekoren. Tävlingsbidragen kommer att bytas ut varje vecka. ${ }^{257}$

Enligt Arlas undersökningar lästes baksidestexterna på mjölkpaketen av ca 70 procent av användarna. Därför hade Arla under en period haft något man kalllade för Arla-forum, dit människor kunde skicka in det man kallade för "opinionsyttringar" som i urval trycktes på mjölkpaketen. Det var ett slags medborgaryttranden. Barnbilderna, menade Arla, var en del av dessa opinionsyttringar, som innebar att man gav barn en röst. Bilderna uppfattades däremot av KRO som hot mot arbetstillfällen som annars konstnärer skulle haft.

Arlas och Televerkets barnteckningstävlingar på 1970-talet kritiserades av konstnärernas riksorganisation, KRO, då man menade att barnen gjorde "konst" nästan helt gratis. Under rubriken "Konstnärerna rasar - igen - Vår situation än värre!" beskrev KRO i Göteborgsposten att teckningstävlingsbilderna som skulle pryda mjölkförpackningarna var "Ett billigt sätt för företagen att göra vår situation allt värre", och Bengt Blomkvist från KRO menade att "konstnärer fråntas sina arbetsuppgifter genom tävlingar av det här slaget." Blomkvist kommenterade Televerkets tävling för omslagen till telefonkataloger: "man frågar sig varför t.o.m. statliga verk gör så, när det är kärva tider för utbildade konstnärer”258

I tidskriften Konstperspektiv skrev konstrescencenten J-O Brunnström 1985 en artikel som heter "Ersätt inte konstnären med barn" där han menade att det var en "kulturfientlig handling" från samhället att inte använda konstnärers bilder till telefonkatalogen, och han uttryckte även: "Att utnyttja skolungarna till minsta möjliga kostnad är omoral från de ansvarigas sida." 259

Dessa konstnärer betraktade nu inte barntävlingarna som ett sätt att ge barn röst i offentligheten. Barnen ansågs vara utnyttjade i de statliga företagens tjänst. Det hävdades att Televerket som statligt organ snarare borde värna de nationella konstnärernas överlevnad framför egen PR genom användandet av naivistiska barnbilder. Värderingen av tävlingarna hade alltså delvis förändrats sedan modernismens uppskattande uttalanden om barnbilder. Nu blev konstnärer inte inspirerade som under tidigt 1900-tal utan såg barnens bilder som ett hot mot sin egen verksamhet. Teckningstävlingar uppfattas efter hand som ett hot mot konstnärerna, och barnen blev då också betraktade som utnyttjade för att ge företag ekonomisk vinning. Konflikterna ledde dock inte till att barnteckningstävlingarna försvann. År 1985 var visserligen sista året med barnteckningar på framsidan av telefonkatalogerna men Televerket fortsatte att ordna tävlingar. De tävlingar Televerket och senare Telia anordnade med början 1980 gjordes i opinionsbildande syfte kring frågor om vandalisering och framtida teknik och

\footnotetext{
257 Arla aktuellt - intern information från mjölkcentralen Arla nr. 8 12:e aug. 1977. Klipp från DN, 27 juli 1977. Centrum för näringslivshistoria.

258 GP 760708 Arlas arkiv, pressklipp, Centrum för näringslivshistoria.

259 Konstperspektiv 1985; 2 sid. 44-45.
} 
miljö. I dessa tävlingar underordnades det konstnärliga syftet de pedagogiska och uppfostrande ambitionerna.

På 1940-talet ansåg Nationalmuseum att de vinnande barnbildernas specifika kvalitéer gav anledning att bevara bilderna i museets samlingar. 1977 startat svensk barnbildarkiv, som en del av Barnkulturcentrum, där barnbilden som en specifik del av barnkulturen värdesattes och sparades.

$$
* * *
$$

Studien visar hur fenomenet teckningstävlingar under undersökningsperioden både uppskattats och kritiseras. Både konstscenen och psykologin uppvärderade och värdesatte under början av 1900-talet barns icke figurativa avbildningar. Barns bilder betraktades också som att de kunde fånga idén eller essensen av det som de avbildade, och att de i detta avseende hade förmågor som liknade konstnärens.

Liksom den moderna konstnären, ansågs barnen berätta om sina inre liv genom sina bilder. Moderna pedagoger använde utvecklingspsykologins teorier för att betona det yngre barnets olika stadier, och att den vuxne inte borde störa barnet i sitt skapande, eftersom det i så fall skulle bli hämmat i sin utveckling. Bilderna sågs som uttryck för barnets utveckling där barn ansågs ha förmåga till ett unikt skapande som både jämfördes med allmogekonst eller "primitiv" konst. FIB:s tävling från 1938 och framåt propagerade för denna nya och friare bildundervisning som betonade barns fria fantasi. Samtidigt ledde denna nya undervisning - som etablerades med hjälp av tävlingen - till att tävlingsformen blev mera omdiskuterad.

När tävlingsbilderna under 1970-talet användes i massproducerade sammanhang kom tävlingsformen emellertid att uppfattas som problematisk. Konflikter och motsättningar uppstod från flera håll. Dels eftersom tävlingen i skolan uppfattades stå i konflikt med det fria skapandet och tanken om att moderna barn skulle samarbeta och inte tävla. Dels menade KRO att barntävlingarna tog arbetstillfällen från yrkesverksamma konstnärer, och argumenterade för att barnbilder inte borde användas i marknadsföringssyfte. Användandet krockade med idén om de oskuldsfulla barnen, som inte borde utnyttjas i profitsyfte.

Den nya tiden skapade även nya kulturpolitiska normer, där sparande och samlandet av både bilder och tävlingar blev intressant, som utryck för att uppvärdera barnkultur och barnbilder som uttryck för barns berättelser. De olika bildsamlingarna på Svenskt barnbildarkiv visar hur barns skapande kategoriserats och ordats. Till skillnad från Nationalmuseum betonar barnbildarkivet att man vill samla alla bilder, inte bara de som valts ut som vinnarbilder av vuxna bedömare. Barns bilder var intressanta i sig, och inte utifrån konstnärlig eller utvecklingspsykologisk synpunkt. Ambivalensen mellan det fria skapandet och tävlandet, syns också i arkivets ordnande, där teckningstävlingar inte var något som påtalades eller värderades när arkivet grundades. Bilder från tävlingar återfinns även arkiverade som temasamlingar eller internationella samlingar, och tävlingssamlingar möjliggjorde efterhand insamlandet av stora mängder bilder till SBBA. 
Barns bildskapande uppvärderades således under min undersökningsperiod, delvis knutet till tävlingar med barnbilder, som ofta utfördes i skolan. Diskursen om barnets konstnärliga förmåga som samtidigt skulle stå utanför konkurrens och kompetenssamhället skapade en konflikt som tävlingsformen aktualiserade, vilket ledde till att tävlingen efterhand tonades ner alltmer. Samtidigt låg denna barnsyn till grund för insamlandet av både barns bilder och barnteckningstävlingar. Mot denna bakgrund blir det intressant att undersöka de olika aktörer som valde att arrangera teckningstävlingar och använda barns bilder, och för vilka syften.

\section{Arrangörer av teckningstävlingar}

För att få en uppfattning om hur vanligt förekommande tävlingar var under olika perioder har jag både utgått ifrån tävlingssamlingarna i SBBA s arkiv, och de tävlingar som omnämns i teckningslärarförbundets tidskrift 1931-2000. ${ }^{260}$ Tävlingssamlingarna på SBBA utgör den huvudsakliga empirin i detta kapitel, men då arkivet har flest samlingar från tiden efter 1977 då arkivet startar, har jag även undersökt Teckningslärarförbundets tidskrift under perioden, vilka arrangörer av teckningstävlingar som blev synliga i den, och under vilka tidsperioder. Jag är således också intresserad av vem som arrangerade tävlingarna och hur dessa motiverades med tanke på trenderna i den offentliga diskussion som jag tecknat bilden av ovan. Ibland framgår det vad organisationen själva skrev fram som mål och syfte tydligt i arkivmaterial, ibland inte. Det var dessutom vanligt att olika arrangörer kunde samarbeta i arrangerandet av en tävling, vilket gör att det därför inte är helt enkelt att definiera arrangörerna i olika kategorier och inte heller självklart att avgöra motiven bakom tävlingsarrangemangen. Det förhållandet, att tävlingar kopplades till lek eller nöjen, gör också att explicita syften och olika motiv var del av en allmän nöjeskultur kring barns kulturella uttrycksformer.

Som jag visade inledningsvis hade FIB, Teckningslärarförbundet och så småningom även Nationalmuseum ett samarbete runt sin teckningstävling. Tävlingen kunde därigenom få stort genomslag både publikmässigt och medialt. Veckotidningen FIB kunde nå ut med information till många, Teckningslärarförbundet underlättade för att få tillgång till skolan som produktionsplats, och Nationalmuseum gav tyngd och intresse åt utställningarna med vinnarbilder. Tävlingen annonserades och rapporterades även i teckningslärarnas tidskrift Teckning och genom att bilderna ställdes ut på Nationalmuseum, recenserades tävlingsbilderna även i andra dagstidningar. Att samarbeta med en tidning var bra för att nå en stor läsekrets och tidningar kunde också själva se arrangerandet av tävlingar som ett sätt att visa tidningens engagemang i specifika frågor.

Exempelvis arrangerar tidningen ICA-kuriren 1985 tillsammans med Världsnaturfonden en riksomfattande teckningstävling för att uppmärksamma utrotningshotade svenska växter, inom ramen för WWFs kampanj Vårt Gröna Arv.

260 Jag kallar tidningen för tekningslärarförbundets tidskrift då den bytte namn övertid. De hette först Tidning för Sveriges teckningslärare 1931-1938, därefter Teckningslärarnas tidskrift Teckning 1939-1979, och den byter därefter 1979 namn till Bild i Skolan 1979-2000. 
Tidigare har WWF arrangerat tävlingen med tema "Tigern i Indien" i samarbete med DN, och tävlingen "Levande hav" också i samarbete med ICA-kuriren. ${ }^{261}$ Ett annat samarrangemang var SAS/Linjeflyg som i samarbete med Sunne hembygdsförening och tidskriften Hemmets journal 1989 anordnade tävlingen "I Nils Holgerssons spår", för elever i årskurs fyra. Första priset var en flygresa med SAS/Linjeflyg "I Nils Holgerssons spår". Man kan förmoda att flera aktörer i dessa fall gynnas av publicitet genom tävlingen. Genom veckotidningen når man ut till många, nya läsare lockas till tidningen, SAS och Linjeflyg får positiv förstärkning av sitt varumärke, och hembygdsföreningen kan ökas ungas intresse för hembygden. 1996 har Sveriges hembygdsförbund och Utbildningsradion också ett samarrangemang med hembygdstema: "Nils Holgerssons resa i nutid". Ett uttalat syfte i denna tävling var att samla in bilderna till SBBA för att i framtiden "kunna se tillbaka på hur barn såg på sin hembygd."262 Statliga Utbildningsradion såg alltså ett gemensamt intresse med Svenskt barnbildarkiv med en nationell insamling av barnbilder som gestaltade Nils Holgerssons resa genom Sverige. Den vikt som läggs vid barns upplevelse av hembygden under hela undersökningsperioden är något som jag återkommer till i kommande kapitel.

Så, vi kan konstatera att det faktum att flera arrangörer samarbetade är en del av tävlingarnas komplexitet. Jag har ändå för att kunna diskutera fenomenet valt att dela in arrangörerna i olika huvudkategorier: Tidningar som huvudarrangör, Internationella och frivillig-organisationer som arrangörer, Privata/Kooperativa arrangörer samt Offentliga arrangörer. Inledningsvis skall jag granska vilka tävlingar som registrerats i SBBA:s arkiv och vilka tävlingar som nämns i teckningslärarförbundets tidskrift. Det innebär att jag först undersöker under vilka tidersperioder tävlingar nämns i tidningen eller förekommer ibland arkivets handlingar. De olika arrangörernas karaktäristik kommer därefter att analyseras var och en för sig i separata avsnitt.

261 1985-08-28 Skrivelse till barnbibliotekskonsulenten, Eskilstuna, från Sven Wahlberg, f.d. generalsekreterare WWF (Tävlingen var del av en internationell kampanj kallad Plants Campaign).

${ }^{262}$ Från Lärarhandledning "Rita och måla bilden av din hembygd" UR och Svenskt papper 1996. 
Antal tävlingar per år i Teckningslärarförbundets tidning och SBBA

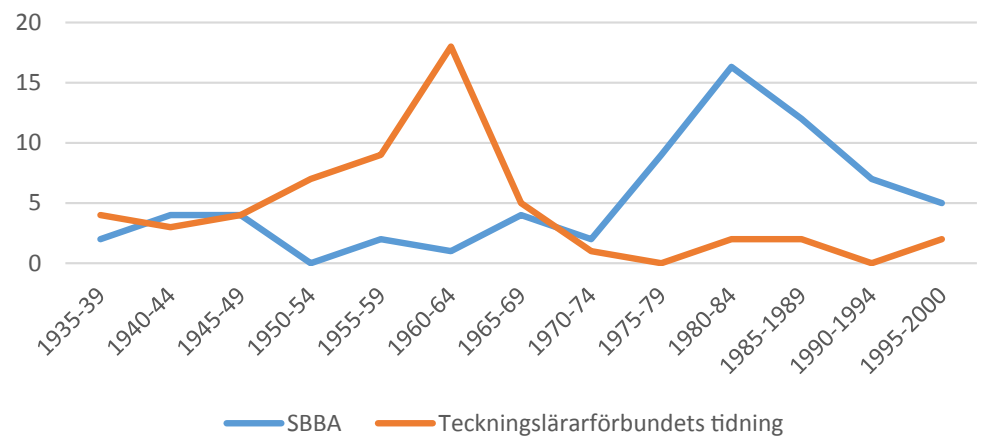

Diagram 1. Antalet tävlingar i SBBA:s samling och i teckningslärarförbundets tidskrift mellan 1935-2000 fördelat på femårsperioder. Källa. SBBA arkiv och tekningslärarförbundets tidskrift.

\section{Arrangörerna över tid}

När arrangerades då tävlingar? Diagram 1 visar antal tävlingar per femårsperiod i teckningslärarförbundets tidskrift och i SBBA:s arkiv mellan 1935-2000. Den röda linjen representerar antalet tävlingar som nämns i teckningslärarförbundets tidskrift. ${ }^{263}$ Den blå linjen visar antal tävlingssamlingar i SBBA:s arkiv. ${ }^{264}$ SBBA:s arkiv har flest antal tävlingar under senare delen av perioden, tekningslärarförbundets tidskrift hade störst mängd annonser och reportage om tävlingar under början av perioden, med en topp vid 1960-talets mitt. Tabellen tydliggör hur antalet tävlingar förändrats över tid i teckningslärarnas tidskrifter och i SBBA:s arkiv. Tabellen ger även en bild av under vilken tid teckningslärarförbundet haft intresse av teckningstävlingar, eller blivit engagerad av olika intressenter i dessa, och av hur SBBA samling byggts upp genom ett aktivt bildinsamlande från 1970-talet. Det kan således finnas tävlingar som inte intresserat teckningslärarförbundet och tävlingar som inte uppmärksammats av SBBA eller gjorts tillgänglig för arkivet. Denna registrering är således inte fullständig men bör kunna ge en representativ bild över tävlingarnas förändring över tid.

Som vi ser hade teckningslärarförbundet flest annonser och artiklar för tävlingar under perioden 1955-1969, och i SBBA:s arkiv finns flest tävlingar under perioden 1975-1990. Teckningslärarförbundet var medarrangör i FIB:s tävling 1938-1957, och det rapporterades flitigt från den tävlingen i tidningen Teckning, men det stora antalet annonser för teckningstävlingar generellt visar tydligt

${ }^{263}$ Om en tävling omnämns flera gånger är den räknad endast en gång per år. Detta gäller ofta FIB:s tävling, där teckningslärarförbundet är medarrangör.

${ }^{264}$ Tabellen stämmer inte helt med bilaga 1, där jag också tagit med Rädda barnens samlingar som kommit från Barnkonstmuseet, dessa finns inte med här, dels då de inte är uttalade tävlingar, dels då de inte har årtal, endast 1990-tal, men man kan alltså lägga till ytterligare sex samlingar på 1990-talet i SBBA:s samling. 
att teckningstävlingar uppfattades som populärt inom lärarförbundet fram till 1960-talets slut. I samband med de tidigast rapporterade tävlingarna på 1930-talet lyfte teckningslärarförbundet framförallt fram det positiva med att teckningslärare anlitades $i$ juryarbetet, vilket också kan ha bidragit till intresset för tävlingarna från lärarförbundets sida. ${ }^{265}$ Diskrepansen beror även på att SBBA började sitt aktiva insamlande 1977, även om de har fått tillgång till vissa tävlingssamlingar från tiden före arkivet startar. Arkivet har alltså haft större möjlighet att få tillgång till bilder från tävlingar som arrangeras efter 1977. Den slutsats vi kan dra från diagrammet är framförallt att fenomenet teckningstävlingar var vanligt även under 1940-60-talet, trots att detta inte syns i SBBA:s arkiv. ${ }^{266}$

Samtidigt ger bilden möjlighet att reflektera över utvecklingens innebörder i förhållande till mina övergripande frågeställningar. Antalet omnämnda tävlingar i Teckning sjönk dramatiskt under 1970 talet efter en topp tidigt 1960-tal. Teckningslärarförbundet slutade då att annonsera om tävlingar, trots att exempelvis Televerket hade årliga tävlingar från 1977-1995, som dokumenterats i SBBA:s arkiv. Att många tävlingar arrangerades även under 1970- 90-talet syns tydligt i SBBA:s samling. ${ }^{267}$ Att färre tävlingar annonserades i Teckning under undersökningens senare del kan förstås både i ljuset av bildämnets förändrade plats i skolan och i synen på tävlingarnas lämplighet i skolan. Folkskolan blev grundskola 1962 och både lärar- och elevgrupper förändrades jämfört med de tidigare folkskolorna, realskolorna och läroverken.

I tidningen Teckning problematiserades och debatterades syftet med teckningsämnet under 1960 och 70-talet. ${ }^{268}$ Under denna tid ifrågasattes också tävlingarna som form i bildämnet, vilket i tidningen syns genom frånvaron av annonser och artiklar om tävlingar. Förändringen $\mathrm{i}$ ämnets innehåll utrycks även genom att skolämnet Teckning bytte namn till Bild i den nya läroplanen 1980. Teckningslärarförbundet blir bildlärarförbundet och förbundets tidskrift ändrade 1979 namn från Teckning till Bild i Skolan. Även detta namnbyte speglar bildämnets förändrade innehåll. Samtidigt kan SBBA:s intresse för barns bilder också förstås som en del av politiken om barn och barndom under 1970-talet. Den kritiska diskussionen kring den kommersiella barnkulturen ställdes där i kontrast till barns rätt till eget skapande, en politik som vi sett även innefattade en kritik av tävlingar. Insamlandet av barnbilder ledde ironisk nog därmed inte bara till insamlandet av barnbilder utan också till insamlandet av barnteckningstävlingar. Detta engagemang i barns villkor och visuella uttryck som låg till

\footnotetext{
265 Teckning 1939 nr. 1 sid. 2. (se även sid. 75) Tidning för Sveriges teckningslärare Ragnar Brandelius skriver redan 1936 nr. 4 sid. 1, om Svenska skolläkarföreningens teckningstävling bland gossar och flickor inom småskolor och folkskolor som prisbedömdes av professorerna Albert Engström, Isaac Grünewald och konstnären Egil Schwab; och hur dessa saknade den sakkunskap som teckningslärare eller barnpsykologer kunnat bistå med. 1937 i nr. 1-2 sid. 35 skriver tidningen om en ny tävling av skolläkarföreningen och då är både Ragnar Brandelius själv som företrädare för teckningslärarna och en barnpsykolog med i juryn.

${ }^{266}$ En trolig förklaring är att SBBA inte haft så lätt att få tillgång till tävlingar i efterhand, och att arkivet startade 1977.

${ }^{267}$ De kunde ändå göras i skolan, även om de inte annonserades i fackpressen.

${ }^{268}$ Bland annat av Gert Z Nordström i Teckning årgång 1964-67.
} 
grund för inrättandet av SBBA 1977, svarade sannolikt också mot en förändrad syn på barn och barndom. Tvehågsenheten kring tävlingarnas lämplighet har som jag visat i avsnittet om teckningstävling, utvecklingspsykologi och pedagogik fått konsekvenser för hur tävlingarna och andra samlingar har arkiverats.

\section{Vilka var arrangörerna}

Vilka var då de aktörer som arrangerade teckningstävlingar? Som vi såg inledningsvis var det vanligt att olika arrangörer kunde samarbeta runt en tävling, och det är därför inte helt enkelt att definiera arrangörerna i olika kategorier. Vissa arrangörer har varit svåra att klassificera. Exempelvis har jag satt fackföreningar under privat/kooperativ arrangör, liksom idrottsutbildarna som driver en stiftelseägd folkhögskola. ${ }^{269} \mathrm{Som}$ jag nämnde har jag ändå definierat fyra huvudkategorier: Tidningar som huvudarrangör, Internationella och frivilliga organisationer som arrangörer, Privata/Kooperativa arrangörer samt Offentliga arrangörer.

Bland de offentliga arrangörerna finns Televerket, museer, kommunala bostadsbolag, fritidsverksamheter eller statliga organisationer som konsumentverket och utbildningsradion.

Privata företag fanns i tidskriften Teckning under början av perioden. Ibland hade de tävlingar där bilderna skulle anknyta till verksamheten, som Automobilhandlarförbundet där man skulle teckna en bil, medan däremot Fröjds Herrekipering hade en tävling med temat "Svenska flaggans dag". I SBBA:s samling kan privata företag ibland samarbeta med andra aktörer, men jag har i denna kategori även räknat in kooperativa arrangörer som Konsum, Mjölkpropagandan och Arla, då de i likhet med privata företag delvis använder tävlingarna för att marknadsföra sina produkter.

Som introduktionen visar har definierandet av de olika grupperna av arrangörer inte alltid varit självklar, vilket också kompliceras av att tävlingarna kan vara ett samarbete mellan olika aktörer.

I gruppen "Tidning” är det olika tidningar eller tidskrifter som är huvudarrangörer. Här återfinns tidskriften FIB:s tävling i både SBBA:s samling och i artiklar i teckningslärarförbundets tidskrift Teckning. Även dagstidningar som DN och SVD och barn och ungdomstidningen Kamratposten arrangerade teckningstävlingar.

I gruppen "internationella - frivilligorganisationer" är det både internationella tävlingar och tävlingar anordnade av frivilligorganisationer, som också kan vara internationella. Annonser för internationella tävlingar i Teckning, kunde ibland vara utan en tydlig avsändare, som den internationella teckningstävlingen med tema "Maskinen" 1962. ${ }^{270}$ En annan internationell tävling är "Shankars weekly" som var återkommande över flera år, med början efter Indiens självständighet 1947, och som arrangerades av den indiske tidskriften och redaktören

\footnotetext{
269 För fullständig tabell se bilaga 1.

270 Teckning 1962 nr. 6 sid. 5.
} 
Shankar. ${ }^{271}$ Här har jag ansett att det faktum att tävlingen riktades mot en internationell målgrupp, var viktigare för kategoriseringen än att det var en tidskrift som arrangerade. I tre andra internationella tävlingar var Unesco en av arrangörerna. ${ }^{272}$ I SBBA:s arkiv finns det fem olika arrangörer i gruppen internationella-frivilligorganisationer. De är de internationella tävlingarna "Milk for vitality" arrangerat av mjölkpropagandan, och "Europeiska skoldagen" arrangerat av EU-rådet, samt frivilligorganisationerna Rädda barnen, Världsnaturfonden och Lutherhjälpen, alltså två internationella och en svensk organisation.

I tabell 2 jämförs arrangörerna i SBBA:s tävlingssamlingar med de arrangörer som omnämns i teckningslärarförbundets tidskrift. ${ }^{273}$ Tabellen visar antal tävlingar inom respektive kategori. Det speglar således vilka tävlingar som teckningslärarförbundet velat uppmärksamma, och vilka tävlingar som SBBA sett möjlighet att samla in och betecknat som tävlingar.

\section{Tävlingsarrangörer}

1938-2000

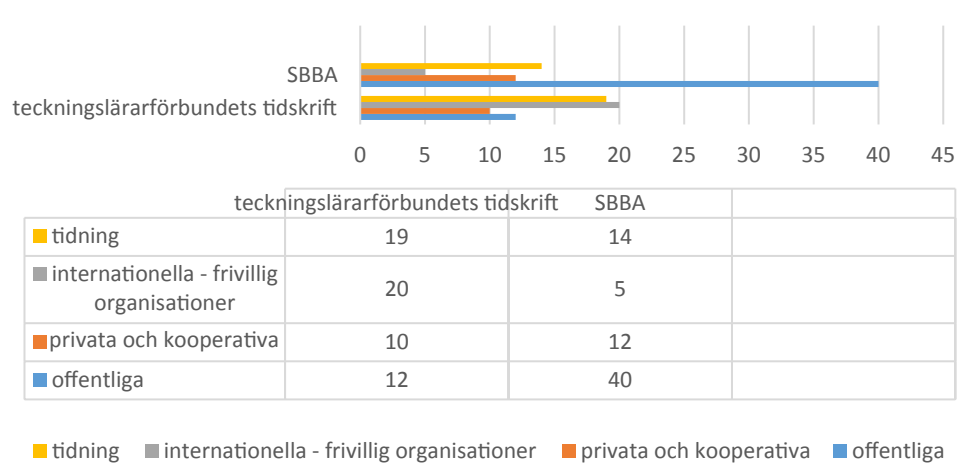

Tabell 2. Olika arrangörer i SBBA respektive Teckningslärarförbundets tidskrift

Tabell 2 visar att det är flest antal offentliga arrangörer i SBBA:s arkiv, vilket främst beror på att statliga Televerket arrangerar tävlingar under en lång följd av år, och ibland flera per år. Det är alltså en och samma aktör som drar upp stapeln

271 Den är arrangerad av en indisk tidskrift, men den är alltså inräknad som internationell, inte under tidskrift.

272 Förenta nationernas organisation för utbildning, vetenskap och kultur, brukar förkortas Unesco (av det engelska namnet United Nations Educational, Scientific and Cultural Organization) bildades 1945. Ungerska unescorådet 1959, Polska unescorådet i samarbete med polska radion, samt Koreanska unescorådet 1966 arrangerar internationella tävlingar som annonseras i Teckning.

273 Tidning för Sveriges teckningslärare 1931-1938, Teckningslärarnas tidskrift Teckning 19391979, Bild i Skolan 1979-2000. 
för de "offentliga" tävlingarna. ${ }^{274}$ En viktig skillnad mellan SBBA:s tävlingar och de tävlingar som nämns i teckningslärarförbundets tidning är att de som finns på SBBA vet vi att de verkligen genomfördes, då arkivet har de faktiska bilder som producerats. I Teckning presenterades ibland bara en annons, och vi vet då inte alltid hur annonsen sen emottogs i skolorna. I vissa fall publicerades även $\mathrm{i}$ senare nummer några utvalda vinnarbilder, men frånvaron av bilder behöver inte betyda att tävlingarna inte genomförts. När tidningen rapporterade från FIB:s tävlingar publicerades också vinnarbilder, troligen därför att teckningslärarförbundet var en av tävlingens arrangörer. Fram till 1960-talet annonserades många teckningstävlingar för barn i teckningslärarnas tidskrift, trots att tävlingsformen, alltmer av den fria pedagogikens förespråkare, kom att ses som problematisk. Tävlingar efter 1950 var främst internationella tävlingar, där tanken om internationellt samarbete av allt att döma kunde väga upp den brist på samarbete som tävlingsformen kunde anses medföra. Jag återkommer till frågan om vilka arrangörer som är mest aktiva under olika tidsperioder.

Men, genom att gruppera arrangörerna kan jag nu undersöka om dessa olika grupper har haft gemensamma eller skilda intressen i att arrangera tävlingarna. Vad karaktäriserade de olika arrangörerna och vad har de angett för syfte? Ibland framgår det av vad organisationen själva skrev fram som mål och syfte tydligt i arkivmaterial, ibland inte. Det innebär att jag i det följande lagt betoningen på de tre arrangörer jag har valt att studera närmare, nämligen FIB, Arla och Televerket. I avsnittet om internationella arrangörer tecknas en allmänna bild av ett antal olika teckningstävlingsarragörer.

\section{Tidningar som arrangörer, fallstudie, FIB}

Både dags-och veckotidningar har arrangerat tävlingar, ibland även gemensamt med andra aktörer. Som jag visat var Dagens Nyheter en tidig arrangör av barnteckningstävlingar redan 1918. Tidningarna nådde ut till många och de kunde genom tävlingarna också nå en ny läsekrets, de unga läsarna. Vissa var lokala tidningar, som Eskilstunakurrirern och Stockholmstidningen, och det finns troligen mängder av tävlingar som arrangerats av lokalpressen som inte finns bevarade i några arkiv. Flera tidningar var specifika branschtidningar, som tidningen "Flyg”, där uppgiften var att teckna flygplan, eller tidskriften Råd och Rön, som är konsumentverkets tidskrift. Barn och ungdomstidningen Kamratposten arrangerade många teckningstävlingar, och några av dessa tävlingsbilder återkommer jag till i senare bildanalyser. ${ }^{275}$ Den tidigaste tävlingen i SBBA:s samling initierades 1938 av veckotidningen FIB tillsammans med Teckningslärarnas riksförbund. Det var en omfattande tävling som kom att pågå under tjugo år. Denna

\footnotetext{
${ }^{274}$ Det är viktigt att inte se tabellerna som några exakta mått av tävlingarnas spridning eller genomslag. Vissa tävlingar har färre deltagare, andra fler, som jag nämnde tidigare. Jag har valt att räkna en tävling per år, och inte räkna antal samlingar i SBBA:s arkiv, då många tävlingar har flera samlingar, beroende på hur omfattande de är. T.ex. har Televerket en för varje region/ år.

275 Tidningen ICA-kuriren samarbetade med världsnaturfonden angående tävlingen "Vårt gröna arv" 1987, men där har jag istället räknat in denna tävling i kategorin internationella/frivillig organisationer.
} 
tävling anger avhandlingens startpunkt, och är en av de tre tävlingar jag valt att granska närmare. Jag kommer därför att fördjupa mig något i tidningens och tävlingens historik.

FIB startade 1934 som protest mot den så kallade "kolorerade veckopressen". ${ }^{276}$ I första numret i september skrev man: "Finns det endast kungligheter, film-och teaterstjärnor samt societet i detta land? Finns det inte andra människor i olika samhällsställningar, som genom sina insatser och sitt arbete, äro värda att skildras i ord och bild?" ${ }^{277}$ Man skrev även att tidningen skulle försöka tillgodose hela familjens intressen "de äldres likväl som ungdomens och barnens". ${ }^{278}$ Omslaget till den första tidningen 1934 visade en bild av en skolpojke som sitter med huvudet lutat i händerna och läser i en uppslagen bok på skolbänken. Bildtitel är "Plugget har börjat". 279

Socialisten Karl Kilbom var ursprungligen initiativtagare till tidningen, och tanken var att "åstadkomma en tidning som skulle ge en bild av det arbetande folket och därmed uppfattas som dess eget organ." ${ }^{280}$ I styrelsen satt företrädare för hyresgästföreningen, flera olika fackförbund, nykterhetsrörelsen och bondeorganisationer. Ägande övergick efter några år till Esselte. ${ }^{281}$ Upplagan ökade kraftigt, bland annat genom ombudsförsäljning på arbetsplatser. 1942 var upplagan på ca 170000 och tidningen var landets femte största veckotidning. ${ }^{282}$ Teckningstävlingen hade flera syften, ett av dem, speciellt i den första tävlingen från 1938, var att sprida kunskap om tidningen, något man uppnådde genom att man uppmanande de barn som läst om tävlingen i tidningen att ta med den till skolan och berätta för kamraterna och lärarna om att de önskade delta i tävlingen. ${ }^{283}$

Genom att den första tävlingens tema var "Livet i vår skola" kunde även folkskollärarna engageras så att tävlingen kunde utföras i skolan. ${ }^{284}$ Teckningslärarförbundet, som var medarrangör, ville genom tävlingen modernisera och stimulera intresset för teckningsundervisning i skolorna. Redan efter den första tävlingen 1938 skrev FIB att man fått in hundratals brev från "överförtjusta lärare och lärjungar” och man har sedan med flera citat där lärare berättar hur

${ }^{276}$ Ur Öhman, Ivar (red). (1984). Folket i bild: tidningen som var en folkrörelse. D. 1, 1934-1949. Stockholm: Tiden sid.12.

277 Ibid.sid.12.

${ }^{278}$ Ibid.sid.12.

279 FIB $1934 \mathrm{nr} 1$.

${ }^{280}$ Lundström, Gunilla, Rydén, Per \& Sandlund, Elisabeth (red). (2001). Den svenska pressens historia. 3, Det moderna Sveriges spegel (1897-1945). Stockholm: Ekerlid sid. 243. Tidningen fick problem då Kilbom uppfattades som att han stödde en viss kommunistisk falang, men efter 1935 gick Esseltegruppen in som majoritetsägare. Tidningen blev då partipolitiskt obunden och representerade folkrörelserna i stort.

281 Öhman, Ivar (red) (1984) sid.5. Ekonomen Gustaf Lindgren fick Esselte att satsa på Kilboms tidning, och Esselte gick in som $90 \%$ aktieägare, men det var minoriteten med $10 \%$ från olika folkrörelser som satt i styrelsen. Lindgren var bolagets VD till 1954. Einar Ebe var den som arrangerade både modellflygklubben, teckningstävlingen och frimärksklubben.

${ }^{282}$ Lundström, Gunilla, Rydén, Per \& Sandlund, Elisabeth (red). (2001) sid. 244.

${ }^{283}$ Folket i bild nr 61938 sid. 28.

${ }^{284}$ FIB nr. 191938 sid. 28. "Den stora teckningstävlingen som folket i bild utlyste för en tid sedan har mottagits med verklig förtjusning inte bara av alla skolbarn, utan också lärarna, som anser att det är den mest lyckade tävling som någonsin utlysts.” 
entusiastiskt barnen deltagit i denna tävling. FIB hade längre bildreportage med bilder av barn som tecknar och på tidningens ungdomssidor beskrevs varje år årets tema och regler för tävlingen. Efter sommaren visades exempel på vinnarbilder, där man även publicerade namnen på de som gjort de vinnande bilderna, vilken skola de gick i och ibland även lärarens namn. ${ }^{285}$

Från 1941 var även Nationalmuseum medarrangörer för tävlingen. Denna tävling var således ett exempel på hur flera olika aktörer och intressen samverkade, även om tävlingen omtalades som "FIB:s teckningstävling”. Skolan var en viktig faktor för produktionen av bilderna. Att tävla i teckning kunde vara ett sätt att skapa engagemang bland eleverna, lärare skrev i insändare till FIB: "Med tack för allt nöje barnen beretts genom denna tävling" eller "Det har ökat elevernas intresse för teckning, de har haft roligt och skrattat hjärtligt". ${ }^{286}$

Totalt kom ca 800000 barn att delta i FIB:s tävling. ${ }^{287}$ I beskrivningen av tävlingen i albumet Sverige genom barnaögon omtalade man också hur intresset för tävlingen stadigt ökat, "inte minst beroende på både dags- och lärarpressens uppskattning av denna tävling." 288 Tidningar och tidskrifter generellt var alltså viktiga inte bara för att annonsera om tävlingar utan även rapportera om dem för att väcka allmänhetens intresse och uppskattning. Ett motiv för deltagande som man lyfte fram för tidningens läsare var just att tävlingen skulle hjälpa till att bidra till kassan för skolresor, och många tackbrev för prispengarna förekom i tidningen. 1947 beskrevs i albumet Sverige genom barnaögon, syftet med tävlingen på följande sätt:

I syfte att stimulera intresset för modern teckningsundervisning i våra folkskolor och därmed söka ge ungdomen en hobby, startades 1938 FIB:s teckningstävling för skolungdom. Tävlingen genomfördes i samarbete med Teckningslärarnas riksförbund och en representant för Nationalmusei handteckningsoch gravyravdelning. ${ }^{289}$

Här var det uttalade syftet alltså flerfaldigt; teckningslärarna drev på för att skapa intresse för den moderna bildundervisningen, och man såg även ett folkbildande intresse av att ungdomen i folkskolan skaffade sig en "hobby". Barn och unga ansågs i den nya moderna tiden ha behov av en hobby. Förutom teckningstävlingen visades andra fritidsverksamheter som frimärkssamlande och modellflygande, på FIB:s ungdomssidor. ${ }^{290}$ Det är också tydligt hur arrangörerna ville nå även folkskolorna på landsbygden, för att få upp intresset för en modernare teckningsundervisning, som betonade just alla människors behov av och lust till

\footnotetext{
${ }^{285}$ De vinnande bidragen publiceras på skiftande sätt, ibland är det skolans och lärarens namn, ibland är det skolan och elevens namn, ibland både skolan, elevens och lärarens namn, som anges i FIB.

${ }^{286}$ FIB nr. 241940 sid. 29.

287 Öhman, Ivar (red). (1984) sid. 6. (Öhman var mellan 1946-1962 chefredaktör på FIB)

288 Sverige genom barnaögon - Folket $i$ bilds teckningstävling för skolungdom (1947) Ivar Öhman sid. 5. I albumet står även att tävlingen nått ut till ca 200000 barn 1938-1947.

289 Sverige genom barnaögon - Folket i bilds teckningstävling för skolungdom (1947) sid. 12.

${ }^{290}$ Se t.ex. FIB nr 1939 nr. 19 sid. 28. FIB nr. 171940 sid. 29.
} 
att uttrycka sig via bilder. ${ }^{291}$ Tidningen lyfter även fram att det syns vilket stort intresse det finns för teckning, och "att den svenska skolungdomen kan teckna". ${ }^{292}$ Ett ytterligare syfte var att inspirera verksamma konstnärer samt hitta den nya generationens konstnärer. ${ }^{293}$ Tecknandet som hobby var också en förutsättning för senare tävlingar som arrangerades av tidningar, där barn skickade in bilder hemifrån. ${ }^{294}$ Även DN hade återkommande teckningstävlingar vid jul under hela 1950-talet, vilket syns i artiklar, även om det enbart finns bevarade bilder i SBBA från 1955. ${ }^{295}$ Även SVD och Eskilstuna-Kuriren finns med som arrangörer i SBBA:s samlingar. Tävlingarna användes alltså under hela perioden 1938-2000 som del av en nöjes- och fritidskultur, likt korsord eller pysselsidor, och tidningarna kunde genom dem knyta till sig nya unga läsargrupper.

FIB:s tävlingar pågick under 20 år och är den utan jämförelse mest omfattande tävling arrangerad av en tidning som finns i materialet. Tidningen lyckades sammanföra sitt eget folkbildande intresse av att nå barn och unga, med teckningslärarförbundets förhoppning om nya grepp i undervisningen och $\mathrm{Na}$ tionalmuseums barnkonstintresse. Denna trio innebar ett samarbete mellan ett nationellt konstetablissemang, folkrörelserna och pedagogerna. Barns tecknande var på detta sätt en del av den politiska satsningen på en tidning för folket, utan celebriteter och kungligheter, som hade ambitionen att spegla ett folkligt vardagsliv. Både FIB och ett flertal andra tidningar har kunnat använda tävlingarna för att skapa intresse för tidningen hos barn och unga och öka upplagan. FIB:s teckningstävling skapade också den gemenskap mellan läsarna och tidningsutgivarna som Ioana Literat har diskuterat. Både förekomsten av ungdomssidor, där tävlingen och bilderna publicerades, och tävlingen i sig var del av att lyfta fram barn och ungas egna röster och samtidigt göra barn och unga till aktiva och framtida läsare av tidningen. Detta gällde även i högsta grad för Kamratposten som också arrangerade många teckningstävlingar, men de hade inte samma omfattande utställningsverksamhet som FIB, och nådde då heller inte ut i media på samma sätt. ${ }^{296}$

Att arrangörerna för FIB:s tävling poängterade att "den svenska skolungdomen kunde teckna", kunde även vara viktigt för att hävda sig vid internationella jämförelser. ${ }^{297}$ De internationella tävlingarna och tävlingar arrangerade av frivilligorganisationer diskuteras i nästa avsnitt.

\section{Internationella arrangörer och frivilligorganisationer}

En anledning att jag har sammanfört internationella arrangörer och frivilligorganisationer under samma rubrik är att frivilligorganisationerna oftast är internationella, eller att de berör internationella frågor. Överstatliga arrangörer, som

\footnotetext{
291 Detta diskuteras utförligare i barns alder och plats i avsnittet om Uppdragen och barnen.

292 FIB 1938 nr. 24 sid. 27.

293 FIB 1939 nr. 24 sid 28.

294 Se vidare i avsnittet Uppdragen och barnen; tex tävlingarna "Min Stenmark" eller "Idolen”, eller olika julteckningstävlingar.

295 Se exempelvis Eskilstunakurirens och DN:s jultävling

296 Bilderna publicerades oftast bara reproducerade i tidningen.

297 FIB 1938 nr. 24 sid. 27.
} 
UNESCO, EU eller FN, skulle även kunna ingå som del av gruppen offentliga arrangörer, men jag har här räknat dem bland de internationella. Som jag visat i tabell 3, var de internationella tävlingarna i majoritet i teckningslärarnas tidskrift efter 1950. Det var ibland otydligt vilka som var arrangörer i tidskriftens annonser, men ett uttalat syfte var i många fall ett ökat internationellt konstnärligt utbyte och samarbete.

I Teckning nr 71962 var rubriken på tidningens omslag "Barnteckningar ger internationella kontakter". ${ }^{298}$ Tidningen skrev om den från 1949 återkommande indiska teckningstävling "Chankars Weekly" i New Delhi som inbjudit barn upp till 16 års ålder, från hela världen till en tecknings- och skrivtävling. 1956 fick man in 33.000 bilder och 2000 texter från 57 länder. ${ }^{299}$ Man menade att tävlingarna visade fördelarna med ökade internationella relationer samt hur bildkommunikation gynnade fredsarbete. ${ }^{300}$ Över 300 priser delades ut och de bästa bidragen belönades med guldmedalj som donerats av Indiens president och vice president. Tidningen Teckning rapporterade att över 33000 bilder mottagits 1955, två barn från Sverige fick medalj, ett från Danmark och åtta från Finland, samt att en finsk flicka vann guldmedaljen 1952. ${ }^{301}$ Motivet var valfritt i denna tävling. Att tidningen tydligt rapporterade vilka som vunnit visar att tävlingsformen var en viktig komponent i det internationella utbytet. Tävlandet förväntades öka samarbetet mellan länder, och dessutom har tävlandet mellan nationer haft en lång tradition, både inom idrott eller vid exempelvis världsutställningar.

Två internationella teckningstävlingar för barn annonserades redan 1950 och 1951 i tidningen Teckning. Temat för den egyptiska tävlingen 1950 var "Ditt land, dess karaktäristiska drag, innevånare, landskap m.m." och anordnades av Le societé des Amis de l'Art. De bästa bidragen skulle senare ställas ut i Kairo. Tidningen skriver "Teckningslärarnas riksförbund har åtagit sig att utforma den svenska representationen", och att tävlingsbestämmelser tillsänts alla förbundets medlemmar. ${ }^{302} 1951$ meddelar man att 1200 bidragit inkommit och att alla landskap var representerade. Juryn hade valt ut 130 bidrag, där många föreställde midsommar, julfirande eller bröllop. ${ }^{303}$ Även den tävling som La societé de lárt á Ecole i Luxemburg annonserar i tidningen Teckning 1951 har temat "Vårt land". ${ }^{304}$ Ungerska Unescorådet ordnade 1959 en internationell tävling, och polska radion ordande i samarbete med Unesco tävlingen "Mitt fosterland". 305 1960 annonserades en internationell tävling med temat "olympiska spelen". ${ }^{306}$ Den konflikt som skulle kunna uppstå mellan att motivet ofta är kopplat till "vårt land" och att tävlingarna antogs främja fredsutbyte, verkar aldrig ha varit

\footnotetext{
298 Teckning $1962 \mathrm{nr} 7$, omslag.

299 Teckning 1956 nr 5 sid.112.

300 I Teckning nr 71962 sid. 126, beskrivs att tävlingen grundats efter Indiens självständighet 1947.

301 Teckning 1956 sid.112.

302 Teckning 1950 sid 130.

303 Teckning 1951 nr2 sid.36.

304 Teckning 1951 nr 3 sid. 48.

305 Teckning 1962 Nr.3 sid.45.

306 Teckning 1960 nr 4 sid. 65.
} 
aktuell under 1950 -60-talet. Genom deltagandet i tävlingarna blev barnen istället inkluderade i ett större nordiskt/europeiskt/östeuropeiskt/asiatiskt samarbete. Det kalla kriget kan ha medverkat till att samarbete och samförstånd österut var viktigt under 1950- 60-talet. Att bilderna och utställningarna ansågs främja fred är något jag återkommer till under avsnittet uppdragen och barnen.

Europarådet, EG och Europeiska kulturstiftelsen, samt Mjölkpropagandan, är de två tävlingsarrangörer som finns i SBBA från 1950 -60-talet, och båda dessa är internationella tävlingssamlingar riktade mot skolan. Om Europarådet liksom Unesco var överstatliga organisationer, var mjölkpropagandan del av en federation av Europeiska mjölkproducenter, alltså snarast en privat/kooperativ arrangör, men med ibland de internationella då de arrangerade en tecknings- och uppsatstävling 1967 med namnet "Milk for Vitality". ${ }^{307}$ Tävlingen var både en klasstävling, en rikstävling och en internationell tävling, där de tre bästa Svenska bidragen gick till den internationella finalen, som ordnades av internationella mejerifederationen IDF. ${ }^{308}$ Priserna var både resor och pengar. Denna tävling hade alltså individuella priser och priserna gick inte till hela klassen, som i de nationella tävlingarna. I materialet som sändes till skolorna ingick även filmen Den vita drycken från de gröna ängarna. I tävlingsinbjudan skrev man "Tävlingen avser givetvis att aktualisera den undervisning i kost och näringslära, som föreningen Mjölkpropanandan har till uppgift att hjälpa till med i skolorna." ${ }^{309}$ Håkan Jönsson har beskrivit hur föreningen Mjölkpropagandan hade stort inflytande både i skolor och bland politiker, och hur den bidrog till att mjölken redan under 1930-talet blev en del av det moderna projektet, där gratis skolmjölk sågs som en del av en progressiv skolpolitik. ${ }^{310}$

Europeiska kulturstiftelsens tävling finns i SBBA:s arkiv, och är också annonserad flera gånger i tidskriften Teckning /Bild i skolan. Tävlingen är årligt återkommande från 1952 och i Teckning skrev man 1960 en utförlig artikel om tävlingen, där syftet beskrevs vara "att fästa skolans och skolungdomens uppmärksamhet på de Europeiska nationernas gemensamma kulturarv, det europeiska samarbetes olika former och betydelsen av en vidgad förståelse och samhörighet mellan Europas folk.” Tidningen anmärkte även att tävlingen var politiskt och religiöst neutral, och att Europarådet ämnade utge en kalender med teckningsbidragen. ${ }^{311}$

307 Mjölkpropagandan byter 1971 namn till "Vår näring".

308 SBBA 1990:13 Milk for Vitality information om teckningstävlingen Milk for Vitality.

309 SBBA 1990:13 Milk for Vitality.

${ }^{310}$ Håkan Jönsson: http://fof.se/tidning/2006/3/den-svenska-mjolkpropagandan (2018-03-07) "I föreningen Mjölkpropagandan förenades jordbrukare och mejeriföretag med politiker, läkare, lärare och forskare. Verksamheten finansierades till största delen med avgifter från jordbrukare och mejerier, men även riksdagen och länens hushållningssällskap bidrog med anslag. Att myndigheter på detta sätt gynnade en särskild bransch framstod inte som anmärkningsvärt, eftersom alla delade den positiva inställningen till mejerivaror."; Gullberg, Eva (2004). Det välnärda barnet: föreställningar och politik $i$ skolmåltidens historia. Diss. Linköping: Univ., 2004 sid. 65.

311 Teckning $1960 \mathrm{Nr} 2$ sid. 26. 
I SBBA:s arkiv finns bilder från 1959, 1966 och 1987, i informationsfoldern till skolorna 1987 uttalades följande syfte för tävlingen: "Europeiska skoldagen är en årlig bild och uppsatstävling inom Europarådets verksamhet som syftar till att skapa en större medvetenhet om Europa bland ungdom och lärare" ${ }^{312}$ Tävlingen hade olika teman olika år, och annonserades 1984 och 1985 i teckningslärarnas tidskrift Bild $i$ skolan vilket jag återkommer till i avsnittet om tävlingar i skolan.

Den enda teckningstävling som annonserades i bildlärarförbundets tidning Teckning under 1970-talet hade rubriken "Regler för 9:e internationella utställningen Barnteckningar från Östersjöstaterna i Rostock 1974" och det var först i sista meningen som arrangemanget presenteras som en tävling:

I Tyska demokratiska Republikens kustdistrikt pågår årligen Östersjöveckan under parollen "Östersjön måste vara ett fredens hav" Till detta mål tjänar också den internationella utställningen "barnteckningar från östersjöstaterna" som arrangeras för IX gången under östersjöveckan 1974 under mottot "Fred- vänskap- solidaritet" Alla barn och ungdomar upp till 19 år från östersjöstaterna, Norge och Island kan delta i tävlingen. ${ }^{313}$

Barnen ombads att i sina skapande arbeten berätta om sitt liv, om sin hembygd, arbetet i staden och på landet, om sina lekar, önskningar och drömmar.

Att den enda tävling som nämndes under 1970-talet arrangerades av det dåvarande DDR, visar också vilka samarbetspartners som redaktionen för tidningen Teckning ansåg lämpliga 1974. Den politiska diskursen under 1970-talet är tydlig även i vad som annonseras och diskuteras i tidskiften.

En frivilligorganisation som kommit att uppmärksammas för att använda barns bilder var Världsnaturfonden (WWF), som arrangerade den internationella tävlingen "Vårt gröna Arv" (Plants Campaign) i samarbete med ICA-kuriren, 1985/86. Tidigare hade WWF haft tävlingar med temat "Levande Hav" och "Operation Tiger". Generalsekreteraren för WWF beskrev att syftet med projektet varit att uppmärksamma "omsorgen om de hotade växtarterna, i vårt land och världen". 314

Störst bland temasamlingarna på SBBA är Rädda barnens "Livets träd" som startade 1970 och som innehåller över 4000 bilder, både svenska och internationella. Bilderna visar ett gemensamt tema, och vissa bilder blev sedan utvalda för att vara med i en internationell vandringsutställning. De har tryckts på affischer, och fått stor mediauppmärksamhet. ${ }^{315}$ Rädda Barnen valde att inte kalla det för tävling, de delade inte ut några priser, och de hade inte någon officiell jury, så

\footnotetext{
312 SBBA s samling 2005:011, 2005:018. 2005:19 "Europeiska skoldagen" utskick till skolorna finns för 1984, 1986 och 1987, med samma formulering.

313 Teckning nr 11974 sid. 33.

314 SBBA samling 1990-032 WWF Vårt gröna arv 1985-08-28 Skrivelse till barnbibliotekskonsulenten, Eskilstuna, från Sven Wahlberg, f.d. generalsekreterare WWF (Tävlingen var del av en internationell kampanj kallad Plants Campaign).

315 Se samling 1992:053 "Livets träd" SBBA.
} 
hur urvalet av bilder gick till blir därför dolt. En förklaring till att man valde bort priser kan vara en föreställning om att man når barns egna uttryck om de tecknar och målar utan tanke på vinning utan bara för att de känner lust och engagemang.

Insamlingen startade i Sverige, av Sylvia Lindström, som var ordförande i Rädda barnens lokalförening i Danderyd, och "meningen var att så småningom visa det insamlade materialet på en utställning till förmån för Rädda barnen." ${ }^{316}$ Tanken var att barn på så sätt genom intäkter från försäljning av bilderna kunde hjälpa andra barn, samtidigt som bilderna skapade uppmärksamhet åt Rädda barnen.

De samlingar som finns på SBBA från 1990-talet där Rädda barnen initierat utställningar kring barnkonventionen, är skänkta från barnkonstmuseet i Vårby Gård. ${ }^{317}$ Även dessa temasamlingar hade ett givet tema, där några bilder blev utvalda och utställda, men de är inte betecknade som tävlingar i arkivet, även om de har en form som delvis påminner om tävlingssamlingarnas.

Utställningar av barns bilder hade en lång tradition i Rädda barnen/Save the Children. ${ }^{318}$ Redan under 1920-talet var Rädda barnen med och arrangerade barnkonstutställningar från Franz Cizeks konstskola i Wien, som sedan även fortsatte som vandringsutställningar i både Europa och USA. ${ }^{319}$ Internationella Röda korset tryckte också upp vykort och affischer som såldes till publiken på utställningarna under 1920-30-talet och som också blev ett verksamt propagandamedel för Rädda barnen. ${ }^{320}$

Som vi har sett har de svenska och internationella arrangörerna som här diskuterats, omfattat både frivilligorganisationer, kooperativa företag och överstatliga organisationer. Teckningstävlingarna i Sverige är en del av en internationell företeelse där barn i olika länder engagerades. Barnens tecknande blir redskap i propaganda för skilda ting, som kunde omfatta nationsbygget i enskilda länder och samtidigt ansågs leda till en internationell gemenskap. Barnen positioneras som aktörer för fredsarbete genom deltagandet i tävlingarna tillsammans med barn från andra länder. Rädda barnen har under hela perioden varit en viktig aktör för att ställa ut och visa barnbilder som symbol för barnkonst och fred, även om de inte arrangerat tävlingar. Teckningstävlingar har även används för att uppmärksamma internationella miljöfrågor.

${ }^{316}$ Lindström, Sylvia, Berefelt, Gunnar \& Wik-Thorsell, Anna Lena (1978). Livets träd: världen genom barnets ögon. Stockholm: Rabén \& Sjögren i samarbete med Rädda barnen sid. 10.

$317 \mathrm{http}: / /$ kulturfritid.huddinge.se/sv/IBKM/Om-oss/ (2017-06-07).

${ }^{318}$ Viola, Wilhelm (1936) Child art and Franz Cizek. Vienna: Austrian Junior Red Cross.

319 Efter 1:a världskriget kunde konstskolan fortsätta tack vare finansiell hjälp från frivilligorganisationer i England och USA, speciellt från ungdomssektionen i amerikanska röda korset. Viola, Wilhelm (1936) sid. 24.

${ }^{320}$ Ibid. sid. 25. Även teckningslärarförbundets tidskrift skriver redan $1931 \mathrm{nr} 1$ sid. 17, om Cicek, och hur han var motståndare till undervisning i allmänhet och teckningsundervisning i synnerhet. 


\section{Privata och kooperativa arrangörer, fallstudie Arla}

Tävlingen som en trevlig aktivitet för barn och barnteckningen antingen som konst, eller som ett viktigt sätt för barn att kommunicera, är tydliga argument för teckningstävlingarna även bland de privata och kooperativa arrangörerna som också kunnat använda teckningstävlingen som propaganda för sitt företag.

I jämförelse med de internationella tävlingarna i teckningslärarförbundets tidning eller övervikten av offentliga arrangörer i SBBA:s arkiv, var de privata och kooperativa arrangörerna inte någon stor grupp. Däremot var de viktiga initiativtagare för de tidiga tävlingarna. Bland de privata och kooperativa arrangörerna har jag även räknat in olika fackförbund och yrkesorganisationer. Skolläkarförbundet var, förövrigt, den första arrangör av teckningstävlingar som nämns redan 1936 i teckningslärarförbundets tidskrift, alltså före min undersökningsperiod. ${ }^{321}$ En annan tidig tävling som rapporterades om i Teckning var "Svenska flaggans dag" som arrangerades av Fröjds herrekipering 1938. Den annonserades som en teckningstävling för läroverken och vinnarbilder presenterades i Teckning. ${ }^{322}$ Tidningen omtalade hur positivt det var att Fröjds, till skillnad från vissa tidigare tävlingsarrangörer, lämnat teckningslärarna stort utrymme i juryarbetet. De var till och med i majoritet. ${ }^{323}$

I Teckningslärarförbundets tidskrift var annonser och artiklar om teckningstävlingar i skolan vanligt förekommande mellan 1940-1960, som jag har visat i diagram 2. Men det fanns även tävlingar som riktades till "skolungdom", men inte genomfördes i skolan. HSB och Socialdemokraterna anordnade en tävling under påsklovet 1941, för elever från Stockholms folkskolor, där flera teckningslärare var med i juryn. De fyra vinnande bilderna från årskurs 4-7 publicerades i Teckning. ICAs tävling 1942 i DN omtalades som att bilderna gjordes på elevernas fritid, men även den annonserades med en helsida i Teckning. ${ }^{324}$ Underlaget är förvisso litet, men det förefaller som om de privata arrangörernas tillträde till skolan som plats för att göra tävlingar begränsades.

Detta syns även i de tävlingar som bevarats i SBBA:s arkiv. Exempelvis arrangerade Konsum, Arla, Svenska turistföreningen liksom olika tidningar tävlingar där bilderna oftast skickades hemifrån. Däremot kunde SAS, Linjeflyg och Hembygdsföreningen använda skolan för sin tävling, något som kan förklaras med att temat var Selma Lagerlöfs geografibok Nils Holgerssons underbara resa, och att hembygdsbilderna hade en lång tradition inom skolan. ${ }^{325}$ Även tävlingen "Pappas jobb" som arrangerades av Metallarbetareförbundet 1963, gjordes i

\footnotetext{
${ }^{321}$ Den tidigaste tävling man rapporterar om arrangerad av Svenska skolläkareföreningen. Tidning för Sveriges teckningslärare 1936, Nr 4, "Barn och bild, några intryck från en utställning", sid 1 (55). Resultatet av denna "teckningstävlan bland gossar och flickor inom småskolor och folkskolor från sydligaste Skåne till Norrbottensgränsen" visades i NKs utställningshall i Stockholm 1936. Det utdelades vinst till utvalda bilder, men det framhölls även att "Entréavgift och överskott av reproduktionsförsäljning komma att av skolläkareföreningen användas till främjande av våra skolbarns kroppsliga och själsliga hälsa.”

322 Teckning 1940 sid. 107.

${ }^{323}$ Teckning $1939 \mathrm{nr} 1$, sid. 2.

324 DN 1942 10-14 sid. 8.

${ }^{325}$ Hembygdsföreningen är en intresseförening och inte en privat eller kooperativ arrangör.
} 
skolan. Tidskiften Teckning skriver: "Vi teckningslärare rikta tack till "metall" som satt fart och krydda på vår undervisning." 326 Bilder från tävlingen var också på tidskriftens omslag. Denna tävling var också ett samarrangemang med Nationalmuseum, vilket påminner om FIB:s tävling. Att samarbeta med Nationalmuseum kan ha underlättat för möjligheten att göra tävlingen i skolan.

Teckningstävlingar som huvudsakligen arrangerades av privata eller kooperativa aktörer var dock oftare gjorda utanför skolan. Detta gäller exempelvis Arlas och Postens tävling 1976, som är en av de tre tävlingar jag har studerat i detalj, och som jag därför presenterar lite närmare här. ${ }^{327}$

Som nämnts ligger tyngdpunkten av SBBA:s tävlingsbilder på 1970- till 80-talet, vilket också var en tid när barnrättsfrågor diskuteras. ${ }^{328}$ I tävlingen Detta vill jag värna om 1976 har Arla/Posten anammat idén om barns röst. ${ }^{329}$ Men man gick inte ut med tävlingen till skolan, utan satte istället upp information på postkontor. Vinnarna publicerades senare i tidningen Expressen. Utöver temat "det här vill jag värna om" angav Arla vikten av att barnen i tävlingen berättade om vad de tyckte var fel, och vad de ville ändra på:

Tala om vad du tycker! Speciellt om saker som borde rättas till, som du tycker är fel. Det kan handla om precis vad som helst. Om djur, om miljöförstöring, om mobbingen på skolgården, om orättvisor. Ja, sådant du lägger märke till och vill göra något åt. Det är viktigt att de vuxna får veta vad du tycker, vad du vill värna om, vad du vill ändra på!330

Här var det i första hand barns röst som skrevs fram som det viktiga, inte hur det var utfört, som i FIB:s eller Televerkets tävlingar. Arla/Postens väljer i "Detta vill jag värna om" tävlingen att lyfta upp "miljöförstöring" och "orättvisor" eller "mobbning", som exempel på vad barnen kunde ta upp i sina bilder. ${ }^{331}$

Arla menade att "Ett eget vykort eller mjölkpaket, det är vinsterna i tävlingen". Vinsten blev därmed att barn genom att synas gavs möjligheten att påverka. Framsidan av boken som publicerades 1977 visade ett barn som ropar: "Varför får inte barn bestämma". ${ }^{332}$ Men, på bokens baksida syns en bild av en ko och en kalv, där kon säger i en pratbubbla: "Mmmm....mjölk är GOTT och NYTTIGT!" Och kalven svarar: "Jút dä!” Framför dem står" Slurp! Slurp!” På marken står dels en hink, dels ett paket som det står MJÖLK ARLA på. Ytterligare fem (av 135) bilder i boken relaterades till mjölk. Arla lyckades att både göra

\footnotetext{
326 Teckning Nr 11963 sid12, samt omslag.

327 Min granskning bygger på det material som jag identifierat i SBBA:s arkiv och Centrum för näringslivshistoria.

328 Sandin, Bengt (2012).

329 Arla är en kooperation av mjölkföretag, i SBBA arkiv finns även tävlingar arrangerade av Arla från 1987 och 2000. 1987 "Rita en Mellankossa” och 2000 ”det bästa jag vet”, enbart Arla, inte i samarbete med Posten.

330 Infoblad SBBA Diarienr 1991:016.

331 Jag återkommer till flera av bilderna i analyser i kapitel 3-6.

332 Se bild 4:13.
} 
reklam för barns röst och för mjölk på samma gång. ${ }^{333}$ Medan mjölkpropagandans tävling på 1960-talet gjordes i skolan, var Arlas tävlingar från 70-80 och 2000-tal gjorda på fritiden. Detta kan bero både på att Arla inte ville förknippa tävlingen med skolan, eller att skolan under 1970-talet inte ville förknippas med ett vinstdrivande företag som Arla.

När barnteckningstävlingar blev populärt under 1930-talet, påtalade teckningslärarna att de var bäst lämpade att vara med $i$ juryarbetet för att bedöma just barns konst. Teckningslärare användes som jurymedlemmar även vid tävlingar utanför skoltid, och av privata arrangörer. Privata företag har huvudsakligen arrangerat tävlingar utanför skolan. Ibland har de kunnat vara i skolan, genom samarbete med andra aktörer eller genom specifika uppdrag som passade skolans arbete.

Arla riktade sin tävling till barn utanför skolan. Arlas uttalade syfte att ge barnen en röst och den retoriska frågan om varför barn inte fick bestämma innebar att man kunde knyta an till tidsandan under 1970-talet och den förändrade synen på barn. Teckningstävlingen innebar på detta sätt att barns aktörskap mobiliserades för att stärka det egna varumärket. Barns bilduttryck gav uttryck för barns åsikter och uppfattningar, om än starkt redigerade och regisserade av Arla. Genom att poängtera att barn och mjölk hörde ihop kunde Arla stärka sitt varumärke och öka försäljningen. Tävlingarna under 1970-talet kunde användas för att positionera företagen som progressiva och framtidsinriktade genom att visa att man ville lyssna på barns åsikter.

Om de privata arrangörerna var förhållandevis få, så var det offentliga arrangörerna däremot den största gruppen i SBBA:s arkiv.

\section{Offentliga arrangörer, fallstudie Televerket}

I SBBA s arkiv är majoriteten av arrangörerna offentliga institutioner, dels Televerket och Posten, men även statliga museer, kommuner, bibliotek, SVT och UR, eller Barnkulturcentrum själv som Svenskt barnbildarkiv var en del av till 2007. Nationalmuseum arrangerar tävlingar tillsammans med FIB 1941-1957, Metallarbetarförbundet 1963 och från 1999 finns även Nationalmuseums egen tävlingssamling Barns självporträtt i SBBA:s arkiv. ${ }^{334}$ Att det är förhållandevis många offentliga tävlingssamlingar som bevarats kan hänga ihop med att det varit lättare för SBBA att få tillgång till dessa än till dem som arrangerats av privata aktörer. Däremot kan tävlingar ibland ha blivit arkiverade som temasamlingar, som exempelvis Konsumentverkets "Konsument 2000" för mellanstadiebarn 1984, trots den mycket tydliga annonsen: "Hallå alla barn på Mellanstadiet. Var med i vår framtidstävling!" 335 Även tävlingsregler och priser var tydligt framskrivna. Förutom bilderna från tävlingen finns i arkivet ett kompendium

333 Varför fär inte barn bestämma: en bok av barn för vuxna! .... (1977). Stockholm: Utg.

334 Se bilaga 1.

${ }_{335}$ Barns framtidssyn: [en analys av mellanstadiebarns bidrag till tävlingen "Konsument 2000"]. (1985). Vällingby: Konsumentverket. 
med analys av tävlingen med namnet Barns framtidssyn, utgivet av barnkulturcentrum i Eskilstuna, SBBA och Konsumentverket i samarbete. ${ }^{336}$ Konsumentverkets tidskrift Råd och rön arrangerade även 1990 tävlingen "Motbilder till reklamen". Den utlystes för mellan- och högstadieklasser i hela landet och man skriver i instruktionerna att den "går ut på att skapa motbilder till reklamens glättade produktbilder. Motbilderna ska ha en anknytning till miljön." ${ }^{337}$ Det var viktigt när tävlingar skulle göras i skolan att det som arrangörerna ville förmedla var något som de deltagande skolorna såg som angeläget för skolans arbete. Teckningstävlingar i skolan av offentliga arrangörer kunde accepteras utifrån det som av samtiden sågs som skolans kunskapsförmedling.

Televerket hade under perioden 1976-1995 tre olika typer av rikstäckande tävlingar. ${ }^{338}$ De ligger delvis under olika tidsperioder och riktar sig delvis till olika åldrar och Televerket uttalar olika syften med tävlingarna. Den första tävlingen arrangerades mellan 1976-1984 för alla tredjeklassare och handlade alltså om att Televerket ville ha barnbilder som omslag till telefonkatalogerna. Televerkets tävling för telefonkatalogernas omslag är en av de tre tävlingar jag valt att studera mera ingående, både genom text och bildmaterial. Tonvikten ligger vid den första och andra tävlingen 1977/78, men jag diskuterar också de andra översiktligt.

1976 ville Televerket förändra sin byråkratiska framtoning och undersökte "förutsättningar att bjuda in olika grupper till en pristävling, nämligen konstnärer, yrkesdesigners eller skolbarn." 339 Televerkets marknadsavdelning lämnar in förslag om att förändra katalogens framsida genom en teckningstävling för skolbarn vilket tillstyrktes bland annat med motiveringen: "Uppsåtet att få skolungdomen att intressera sig för telefonkatalogen och dess användning och att $\mathrm{i}$ gemen bibringa en positiv inställning till Televerket är gott.” ${ }^{340}$ När förslaget presenterades för de olika regionkontoren föreslog Televerket, att tävlingens tema skulle anknyta till ämnet hembygdskunskap. Hembygdskunskap ingick i skolans kursinnehåll för årskurs tre och detta tema borde dessutom ge dekorativa bilder. ${ }^{341}$ Televerket lät Svenska Telegrambyrån sondera förutsättningarna med personer inom SÖ (skolöverstyrelsen), länsskolenämnder och lokala skolstyrelser. De ställde sig positiva och menade att främsta värdet för skolan låg $i$ att det blev en bra telefonkatalog. SÖ beskrev det som positivt att klasser blev belönade för att de "gjort en värdefull insats". ${ }^{342}$ Man uppskattade att Televerket vände sig till

${ }^{336}$ Barns framtidssyn: [en analys av mellanstadiebarns bidrag till tävlingen "Konsument 2000"]. (1985). Vällingby: Konsumentverket; jag återkommer till tävlingen under Barnens uppdrag.

337 SBBA Infoblad diarienr 1994:00.

338 Televerket arrangerade tävling för omslagen till telefonkatalogerna 1976-1984, Stoppa sabbet 1980-1900, samt fyra tävlingar 1991-1994 som belyser positiva effekter av framtida telekommunikation.

339 Motiven till varför man förordar barnteckningstävling presenteras utförligare i avsnittet Bilderna möter Publiken. Riksarkivet Televerket, telemedia Katalogverksamheten Omslag till rikstelefonkataloger 1977 F2A:1 Skrivelse från STB AB svenska Telegrambyrån Stockholm 19:e januari 1976 Pristävling om utformning av telefonkatalogdelarnas framsida. Sid. 2.

340 Ibid. sid. 1

${ }^{341}$ Ibid. sid 1.ff.

${ }^{342}$ Ibid. sid. 3. 
skolbarn med detta viktiga uppdrag och menade att tävlingen kunde vara en del av skolans aktuella arbete. ${ }^{343}$

Innan tävlingen drog igång skickades förfrågan ut till telefonkonsulenterna i alla de 24 distrikten, men inte riktigt alla var positivt inställda. Konsulenten från Kristianstad skrev:

\begin{abstract}
Vid närmare eftertanke kan man dock allvarligt ifrågasätta om det icke innebär att man slår över från den ena ytterligheten till den andra. Det gäller att skapa goodwill inte enbart hos tioåringarna utan också hos alla andra som använder telefonkatalogen. Barnteckningar på telefonkatalogen kan ge upphov till funderingar och frågor om vad Televerket egentligen sysslar med. Det administrativa arbetet vid de årligen återkommande teckningstävlingarna skulle kunna bli avsevärt. ${ }^{344}$
\end{abstract}

Uttalandet visar att om Televerket tidigare uppfattades som byråkratiskt skulle barnteckningar på omslaget kunna få Televerket att framstå som oseriösa och inkompetenta. Även konsulenten från Malmö var tveksam, då han befarade att bilderna skulle bli för likartade i sin utformning. Även andra intressegrupper, äldre elever, fotoklubbar etc. borde tillfrågas, menade han. Men överlag var de 24 konsulenterna positiva, och Televerket beslutade 1976 att gå ut med förfrågan till skolorna, och även annonsera i lärartidningar. I en skrivelse från tryckeriet, Wezäta Melins $\mathrm{AB}$, föreslås alternativa användningsområden för bilderna, för att öka både sin egen och Televerkets profit, t.ex. genom broschyrer, mappar, vykort, planscher eller tärningsspel. "Försäljning till allmänheten bör kopplas till något allmännyttigt eller "välgörande" ändamål såsom Nationalföreningen mot hjärtoch lungsjukdomar, cancerforskning eller liknande." menade tryckeriet. ${ }^{345}$ Detta förslag verkar aldrig ha kommit längre än till planeringsstadiet, men det säger något om vilka ändamål som barnbilder ansågs kunna användas till. Televerkets tävlingar annonserades eller omtalades inte alls i teckningslärarnas tidskrift. Televerket valde istället att annonsera 1977 i Svensk skoltidning, lärarförbundets tidning. Det var också klasslärare i årskurs tre som förväntades administrera tävlingarna. ${ }^{346}$

Televerket beräknade efter den första tävlingen 1977 att man nått ut till ca $75 \%$ av landets tredjeklassare. Televerket genomförde också i juli 1977 en undersökning i anslutning till Sifos så kallade veckobussar, där man genomförde

${ }^{343}$ SÖ var alltså positiva till att barn var delaktiga i att utforma telefonkatalogerna, men efter första året bad SÖ Televerket tona ned att det rörde sig om en tävling som jag visade i inledningen till kapitel 1, även om tävlingen fortsatte åtta år till.

${ }^{344}$ Sammanställning av yttranden Televerket 1976-04-20, Televerket, Telemedia, Katalogverksamheten 1977 F2A:1 Riksarkivet.

345 Skrivelse till Televerket från Wezäta Melins AB i Göteborg, skickad i samband med offert 1977-03-12 Televerket telemedia, Omslag till rikstelefonkataloger 1977 F2A:1 Riksarkivet.

346 Skrivelse från T Olofson Byrådirektör , Marknadsavdelningen; pris för annons i lärar-tidningen 150000 prispengar till tävlingen 108 000. Samt Kkopior av annonser i lärarförbundets tidning införda 20/2 1978 samt 22/2 1979. Omslag till rikstelefonkataloger, F2A:1 1977. Riksarkivet 
500 personliga intervjuer med ett riksrepresentativt urval i åldern 18-70 år. ${ }^{347} 77$ procent av dessa kände till att det var barnteckningar på omslagen, och av dem ansåg 79 procent att barnteckningar var bättre än den tidigare utformningen. ${ }^{348}$ Vid frågan om framtida omslag tyckte 39 procent att barnteckningar var bästa alternativ. 22 procent förordade Sverigekarta och 20 procent foto av landskap, endast 8 procent en bild gjord av konstnärer. Det framgår inte varför man beslöt att göra undersökningen, men en anledning kan ha varit att konstnärernas riksorganisation uttryckt att de var missnöjda med att uppdraget inte gått till dem. ${ }^{349}$

Den andra tävlingen som Televerket arrangerade var mellan 1980 och1990 för alla sjätteklassare, om att "Stoppa sabbet" av telefonkiosker. Televerkets primära syfte var att minska vandaliseringen av telefonkiosker. I Televerkets utskick till Svenskt barnbildarkiv 1989, skrev man uttryckligen att "Stoppa sabbet kampanjen är ett försök att förändra attityder", och att målet var att "utforma affischer som ska få människor att bry sig om och vara rädda om telefonkioskerna." ${ }^{350}$ I skolmaterial som skickades ut, fanns företrädare för olika ungdomskulturgrupper som skulle leda de blivande ungdomarna rätt. Musikern Tommy Nilsson, hockeyspelaren Håkan Södergren, liksom Martin Timell som var programledare i ungdomsprogrammet "Bullen". Även fotbollslag berättade hur man var "faddrar" åt telefonkiosker och såg efter att ingen sabbade dem. I ett reportage från Fryshuset i Stockholm med rubriken "Från värsting till kamratstödjare" beskrev Jesper sig själv: "Jag var en värsting för några år sedan. Jag klottrade jättemycket i tunnelbanan." ${ }^{351}$ Televerket kunde genom att använda lite äldre ungdomars röster skapa ett tilltal som skulle uppfattas som att det kom från andra ungdomar, och från dem som ungdomar själva hade som förebild, snarare än från myndigheter som Televerket eller skolan. Ungdomsdiskursen relaterades i utskicken till skadegörelse, videovåld och mobbing, men före detta "värstingar", och Televerkets tävling, skulle inspirera de blivande ungdomarna till ett annat beteende. ${ }^{352}$

Här syns att Televerket uppfattade att man hade ett tydligt kunskapsuppdrag. Man diskuterade även skadegörelsens kostnader och följder, i en tydligt samhällsuppfostrande diskurs, där Televerkets vinst var att barnen slutligen blivit så upplysta att de till och med "kan mer än vuxna". I 1984/85 års utskick till lärare skrev man: "En tävling som ger resultat." Ordet tävling var i detta sammanhang inte problematiskt. Detta kunde bero på att tävlingen riktade sig till äldre barn än telefonkatalogtävlingen för årskurs tre, eller på en förändrad tidsanda där både

\footnotetext{
${ }^{347}$ Rapport 1978-01-10Undersökning ang telefonkatalogens första omslagssida december 1977. F2A:3 1978. Televerket, Telemedia, Riksarkivet.

${ }^{348}$ Vid en veckobuss kunde Sifo samla ihop olika frågor från olika intressenter i ett frågeformulär för att hålla nere kostnaderna.

349 skrivelse från KRO till Televerket 1976-11-15, samt tidningsartiklar 1977 F2A:1 Televerket telemedia, Katalogverksamheten Omslag till rikstelefonkataloger

350 Brev från Televerket till SBBA1989-0307 SBBA.

351 Stoppa Sabbet lärarhandledning 1990 sid. 7 .SBBA.

352 Stoppa Sabbet Lärarhandledning 1984/85 SBBA.
} 
"tävling" och "resultat" var mer accepterat 1984 än 1977.353 I tävlingen "Ord och Bild" året därpå, tackar Televerket i lärarutskicket "alla Sveriges mellanstadielärare för att ni hjälpt till att stoppa sabbet" och beskrev att kostnaderna för förstörda telefonkiosker minskat med $62 \%$ under den tid tävlingen pågått. Med 1991 års tävling "Ord och Bild" ville Televerket istället ta fasta på "det positiva med framtidens telekommunikation". ${ }^{354}$ Detta gäller även den kommande tävlingen "Tittofonresan" 1992. När de två sista tävlingarna arrangerades hade Televerket ombildats till bolaget Telia $\mathrm{AB}$. Även dessa var riktade mot årskurs sex, och ville också ta upp hur telekommunikation kunde ge positiva framtidsutsikter i ”Den gränslösa världen” 1993 och ”Miljö i skolan” från 1995.

Det är tydligt att Televerket hade olika syften med sina olika tävlingar, och att ålder spelade roll när de vände sig till skolbarn. De är en av få arrangörer i mitt material som varit så åldersspecifika, att de enbart vände sig till en årskurs. Televerket hade på 1970-talet kontakt med Skolöverstyrelsen för att undersöka hur de kunde anpassa tävlingen för att passa i skolans arbete, för att därigenom kunna få tillgång till skolelevers bilder. Företaget Televerket, och senare Telia, kunde genom dessa tävlingar göra sig kända för ett stort antal skolelever, och skapa positiva associationer runt sitt varumärke, då tävlingarna höll på från 1976-1995.355 I Televerkets första tävling för Telefonkatalogernas omslag ville man använda barnbilden som färgglad estetiskt tilltalande konstbild. Att tävlingen var framgångsrik, mätte de själva genom en mindre sifo undersökning 1977. Televerkets andra tävling "Stoppa Sabbet" handlade t ex om att förändra attityder. Där är det uppenbart att Televerket deltog i och formulerade sig kring en samhälleliga diskurs kring aktuella problem kring barn och ungas uppväxtvillkor. De utnyttjade också barns röst genom att mobilisera ungdomars egna röster i tilltalet av yngre. Den moderna tekniken, telefonen, kommunikationen, blir ett instrument både att nå barn och förändra världen.

Som jag visat har teckningstävlingarna varit del av en komplex väv av olika intressen och maktrelationer som både barn, olika arrangörer och i många fall även skolan som institution varit en del av. Studiet av diskursiva praktiker innebär att undersöka hur olika aktörer och institutioner samverkat historiskt, för att belysa hur specifika diskurser eller sanningsregimer skapas. Undersökningen så här långt visar hur arrangörernas uttalade syfte i flera fall både handlade om att lyfta barns röster och barns rättigheter, samtidigt som barnbilder kunde användas för att gynna specifika institutioner, företag eller organisationer.

Att flera olika intressen kunde sammanfalla i arrangerandet av tävlingar, var tydligt då de ofta samarrangerades exempelvis med en tidning eller tidskrift som

\footnotetext{
${ }^{353}$ Det är tydligt i flera utskick till skolorna att ordet tävling inte är problematiskt i "Stoppa sabbet" tävlingen. Ny läroplan 1980 kan också vara en orsak.

354 Citat från informationsfolder för "Ord och bild” tävlingen från 1991.SBBA; Från 1993 ombildas Televerket till Telia AB.

${ }^{355}$ Tävlingarnas teman återkommer i analyser i kommande avsnitt.
} 
en arrangör. Flertalet tävlingar arrangerades i ett uttalat syfte att propagera eller göra reklam för något, exempelvis ny teckningsundervisning, mjölk, barns rättigheter, eller för att påtala behovet av omsorg om växter och djur. De internationella tävlingar som var i majoritet i tidskriften Teckning från 1950-talet och framåt omfattade tanken om att tävlingarna främjade internationellt samarbete.

Henrik Sandblad beskriver på liknande sätt hur de tidiga OS-tävlingarna ledde till ökade internationella kontakter och ökat idrottsutbyte. ${ }^{356}$ Barnbildstävlingarna och utställningarna antogs inte bara öka utbytet mellan barn från olika nationer, utan dessutom stärka internationell solidaritet och internationellt fredsarbete. Barn betraktades från 1970-talet som specifikt kompetenta att förhålla sig till vissa frågor i bild, som fredsfrågor eller värnade om utsatta grupper.

Televerkets tävlingar hade både syften som uttalades offentligt till elever och skolor, och delvis andra syften som uttalades inåt i den egna organisationen. Exempelvis menade Televerkets i sin interna dokumentation att barnbildens positiva naivistiska konnotationer lämpade sig för kampanjer i marknadsföringssyfte - ett argument som för övrigt även kan ses som giltigt för de bilder som användes av frivilliga organisationer som exempelvis Rädda Barnen. Barnbilder och tävlingarna ingick i en reklam- och marknadsdiskurs, där mindre explicita syften var att tävlingarna kunde ge ekonomiska fördelar, där arrangörer kunde få uppmärksamhet för sitt varumärke genom barnens bilder, både bland barn själva och bland en bredare allmänhet, genom medias rapportering. Barnbilder skapade goodwill.

Vi kan också se hur arrangörerna under 1970-talet och framåt använde sig av barns röst och krav på inflytande och delaktighet som ett sätt att stärka sina egna varumärken eller åstadkomma en av arrangörerna definierad och önskad samhällsförändring. Budskapen blir på det här sättet komplexa, det handlar såväl om att barn behöver lära sig normer och värderingar som om att vuxna skall lyssna och lära av barn. Denna bild förmedlar positiva associationer av barn som kan stärka kommersiella eller uppfostrande budskap. Även statliga organisationer, som konsumentverket, har kunnat samarbeta med skolan kring gemensamma folkbildande målsättningar.

Att teckningslärarförbundets tidskrift i princip helt slutar annonsera för tävlingar efter 1969 visar även det på en diskursiv förskjutning där god pedagogik och tävlande uppfattades stå var i konflikt eller var oförenliga. Vi ska därför nu titta närmare på hur skolan förhållit sig både till tävlingen som sådan och till teckningstävlande specifikt.

\section{Skolan och tävlingar}

Internationella jämförelser och tävlingar mellan olika skolsystem och olika skolämnen förekom på flera av världsutställningarna i början av förra seklet. De skolämnen som lyftes fram vid dessa jämförelser, visar vad som ansågs vara vär-

356 Sandblad, Henrik (1985) Olympia och Valhalla: idéhistoriska aspekter av den moderna idrottsrörelsens framväxt $=$ Sport and ideas : aspects of the rise of the modern sport movement . Grillby: Lärdomshistoriska samf. sid. 238. 
defull kunskap. ${ }^{357}$ Redan på världsutställningen i Paris 1900 visade bland annat USAs, Frankrikes och Englands utställningar instruktioner för en moderniserad teckningsundervisning, som delvis utgick från hur barns sätt att teckna följde liknande utvecklingssteg. ${ }^{358}$ Joakim Landahl menar att estetiken spelade en viktig roll på världsutställningarna. En annan viktig faktor var idén om modernitet - den estetiska moderniteten. Båda dessa idéer kunde teckningsämnet omfatta. ${ }^{359}$ Vid en utställning 1907 i Stockholm belönades Sverige med guldmedalj just för sin utställning om teckningsämnet, vilket Landahl menar visar hur snabbt internationella influenser kunde spridas och få inflytande genom världsutställningarna. ${ }^{360}$ Barns bildskapande kunde används i många olika skolämnen, och det blev därför viktigt att betona teckningsämnets roll i skolan. ${ }^{361}$ Kunskap om utvecklingspsykologi och barns bildutveckling blev ett tecken på modernitet. Ämnet hade även på läroverken breddats till att inte enbart omfatta teknisk ritning, utan hade även som mål att utveckla elevernas smak och skönhetssinne. ${ }^{362}$

Flera olika aktörer påverkade barns arbete i skolan. Staten genom läroplaner, läromedelsförfattare och andra som sågs som experter inom olika områden, liksom lärares tolkningar av läroplaner och undervisningsmål. Även om skolan inte själv tog initiativ till någon av de tävlingar jag studerat, var skolan oftast den plats där bilderna producerades. Att skolan var den tänkta platsen för produktion, är tydligt när det finns lärarhandledningar, eller när annonserna anger att vinsterna går till "klassen". ${ }^{363}$ Teckningstävlingarna har relaterats till olika skolämnen och både folkskollärare, läroverkslärare liksom låg- och mellanstadielärare och tecknings-och bildlärare har varit de som administrerat tävlingarna i skolan. Arrangörer har använt skolan, som ett sätt att nå ut till många barn. För både FIB:s tävling på 1940-talet och Televerkets tävlingar på 1970 till 1990-talet var skolan som plats en förutsättning för att nå ut nationellt, och till ett stort antal skolor. Jag kommer i följande avsnitt att diskutera hur olika skolaktörer uttryckligt förhållit sig till tävlingarna.

Jag har fokuserat på läroplansförändringar över tid främst i hembygdskunskaps- och teckningsämnet, där det nya ämnet hembygdskunskap som infördes från 1919 års läroplan kunde utöka teckningsundervisningen i skolan. Debatten i Teckningslärarförbundets tidning under 1940-50 talet och nya läroböcker från

${ }^{357}$ Landahl, Joakim "Aesthetic Modernisation and International Comparisons: Learning About Drawing Instruction at the Paris Exposition Universelle of 1900" in History of Education (forthcoming).

358 Ibid. sid. 8.

359 Ibid. sid. 14.

${ }^{360}$ Ibid. sid. 12.

${ }^{361}$ Detta fick genomslag i 1919 års skolplan, bland annat i ämnet hembygdskunskap.

${ }^{362}$ Nordström, Gert Z. \& Romilson, Christer (1973). Bilden, skolan och sambället. 2., utök. uppl. Stockholm: Aldus/Bonnier sid. 38 nämner hur dessa mål skrevs in i 1905 års Läroverksstadga, även Pettersson, Sten \& Åsén, Gunnar (1989) tar upp hur smak och konstfostran var viktiga inslag i 1933 års nya undervisningsplan för läroverken.

${ }^{363}$ Det gäller exempelvis Televerkets teckningstävlingar eller tävlingen ”Trafiken och miljön” från 1989, som arrangerades av Länstrafiken. I flera av SBBA:s samlingar finns även lärarhandledningar, men då det i första hand var bilderna och inte materialet omkring som man samlat in, kan det finnas än fler lärarhandledningar än vad som finns i arkivet. 
denna tid presenteras för att visa hur teckningsämnet och därmed förutsättningarna för tävlandet förändras. Slutligen visar jag hur diskursen om tävlan i skolan återigen förändras under 1970-80-talet. Eftersom diskussionen om tävlingar förhåller sig till de tävlingar som arrangerades bland annat av FIB skall jag dock först presentera hur FIB:s tävling introducerades i tidningen och av företrädare för Nationalmuseet.

En övergripande fråga för det följande avsnittet är hur teckningstävlingar både kunde betraktas som ett sätt att förnya undervisningen och samtidigt betraktas som djupt problematisk, och hämmande för barns utveckling.

\section{Tävlingen i praktiken}

I tidningen FIB:s första tävling 1938 ber man eleverna att ta med tidningen till skolan. Genom att visa annonsen om tävlingen för läraren, kunde FIB och Teckningslärarförbundet få hela klassen att delta, då det också var teckningsundervisningen man ville modernisera. ${ }^{364}$ Sixten Strömholm, som var initiativtagare till riksförbundet för bildande konst, skriver i förordet till vandringsutställningens katalog 1945 hur "framsynta teckningslärare med stöd av barnpsykologer länge verkat för användandet av friare uttryckssätt" och att "Först efter en sådan frigörelse skapas den lust för skolarbetet, som ger liv och mening åt kunskapsinhämtandet." ${ }^{65}$ Strömholm menar vidare att den nya fria teckningsundervisningen väcker barnens "lust att i tävlan med kamraterna forma intryck....och utveckla sitt känsloliv.” ${ }^{366}$ Strömholm såg alltså ingen motsättning mellan att tävla och att utveckla sitt känsloliv. Här är det tydligt hur bildskapande anses ge mening åt skolarbetet som helhet, om man anammar de nya bildpedagogiska idéerna, som enligt Strömholm även kan innebära tävlan.

FIB:s reportage efter den första tävlingen 1938 har som rubrik: "Tusen tack! Hela Sverige tackar för den strålande teckningstävlingen och de fina priserna." ${ }^{367}$ Flera vinnarbilder publicerades i tidningen och veckan dessförinnan berättades att utställningen av bilderna i PUB-varuhuset invigts av undervisningsrådet Ruben Wagnsson och fått mycket positiv uppmärksamhet från press och allmänhet. $^{368}$ Så redan från den första tävlingen visade skolans representanter uppskattning för tävlingen.

I FIB:s reportage 1941 med rubriken Slutspurt i teckningstävlingen från Adolf Fredriks skola, syns flickor i årskurs sju sysselsatta med FIB tävling. Reportaget visar hur lärarnas skicklighet i perspektiv och figurteckning sågs som självklara fördelar att kunna för att vinna tävlingen (bild 2:2). Ur bildtexten: Till vänster

\footnotetext{
${ }^{364}$ Att teckningslärarförbundet är medarrangör innebär att teckningslärarna troligen vill ha tävlingen i skolan, och i introduktion till boken Sverige genom barnaögon skriver teckningsläraren Nordlander kapitlet "Den moderna teckningsundervisningen".

365 Sverige genom barnaögon: Katalog. (1945). Stockholm: Riksförbundet för bildande konst Folket i Bild vandringsutställning 36. sid. 5.

366 Ibid. sid. 5.

367 FIB 1938 nr 29 sid. 31.

${ }^{368}$ FIB 1938 nr.28 sid.27.
} 
ser vi "fröken" förklara perspektivets finesser. Och på bilden till höger undervisar hon Margareta Törne i konsten att teckna figurer."

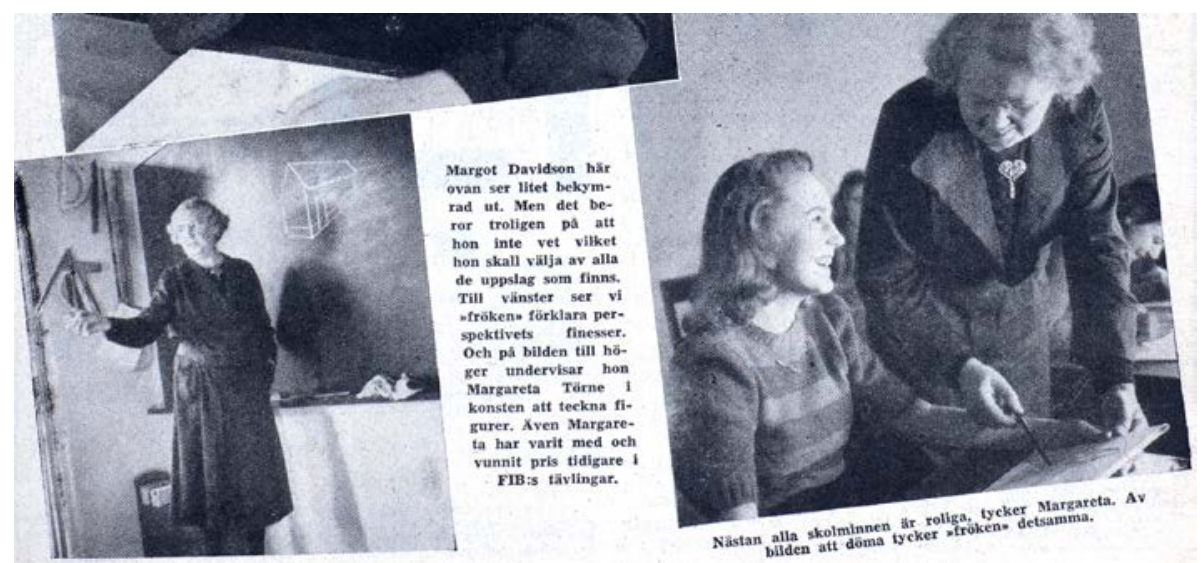

Bild 2:2. Från FIB 1941 nr 16 sid. 29. detalj.

Varje år publicerade FIB flera citat av brev de fått in från, som de skriver "belåtna lärare"; det kunde exempelvis vara att: "deltagandet i teckningstävlingen har skänkt barnen stor fröjd". eller "I likhet med föregående år har ungarna med samma glada förväntan absolut velat vara med och tävla... för oss lärare finns ju inget roligare än förberedelserna till dylika tävlingar." ${ }^{369}$ eller "Både lärare och elever ha uttryckt sin glädje och tacksamhet över denna tävling som komma som ett roligt avbrott i det vanliga skolarbetet." ${ }^{370}$ Dessa citat visar att tidningen och lärarna ville framställa tävlingarna som något glädjande för barnen, och ett välkommet och uppskattat avbrott från den ordinarie undervisningen.

Bilden med bildtexten "Vem blir först och vem har rätt?" är från FIB:s teckningstävling 1938 med temat "Livet i vår skola" (bild 2:3). I bilden syns två flickor med liknande klänningar i olika färg, stå framme vid svarta tavlan, de syns bakifrån och de har båda ljust kort hår och högerarmen höjd för att skriva siffror på tavlan. Bilden visar hur tävlingar i skolan har varit en del av skolans "dolda läroplan": tävlandet var inte öppet framskrivet i läroplanen men fanns ändå. I denna bild blir det tydligt hur skolan handlar om tävlan, både $\mathrm{i}$ att göra rätt och att göra fort. Tävling fungerade som en del av skolans praktik och jag återkommer i nästa avsnitt till hur tävling-

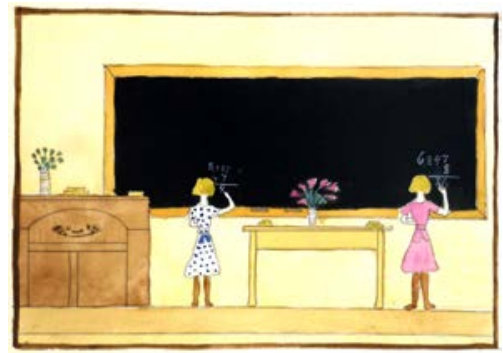

Tem bir foint, och wom haw wh?

Bild 2:3. Livet i vår skola FIB:s tävling 1938.

\footnotetext{
369 FIB 1940 nr 8 sid. 29.

${ }^{370}$ FIB 1941nr 24 15e juni sid. 29-30.
} 
arnas anvisningar formulerades i FIB. Att tävlingsformen var ett medel för att åstadkomma en förändrad undervisning uttrycks i följande citat:

Tävlingen ger en klar bild av att teckningsundervisningen i Sveriges skolor moderniserats och lagts på en förnuftigare basis än den gamla stränga avritningsmetoden. Man har låtit teckningen bli ett naturligt uttrycksmedel för barnens fantasi. ${ }^{371}$

Citatet visar hur barnens möjlighet att uttrycka sin fantasi i teckningsundervisningen presenterades som en del av en modern och förnuftsbaserad skola år 1939. Så legitimerade alltså FIB teckningstävlingar i skolan. Men vad framgår då av läroplanerna för skolan?

\section{Tävlingar i läroplaner och pedagogisk debatt}

I 1919 års undervisningsplan och 1954 års kursplaner nämndes "tävling” enbart i ämnet gymnastik. ${ }^{372}$ I 1969, 1980 och 1994 års läroplaner fanns ordet tävling inte alls med. Tävlingen som form syntes alltså inte i läroplanernas texter, förutom 1919 och 1954 och då främst i lagsporter i gymnastikämnet. Lundquist Wannberg som studerat skolidrott i Sverige mellan 1919-1962 har visat att idrottspedagoger lyfte två problem med tävlingar. Det ansågs fysiskt olämpligt med den tuffa tävlingsidrotten för barn och unga. Dessutom var det ideologiskt olämpligt med tävlingar, då tävlingarna kunde utveckla ett omoraliskt kortsiktigt prestationstänkande, individualism, äregirighet och självhävdelse. ${ }^{373}$ Detta representerade ett brott mot Linggymnastikens ledord: lydnad, självdisciplin och kollektivet.

I folkskolans och grundskolans undervisnings- och läroplaner är det också tydligt att samarbete, snarare än tävlan, poängterats under hela 1900-talet.. ${ }^{374}$ Men att ordet tävling inte funnits med i läroplaner betyder inte att det inte förekommit tävlingar i skolan. Skolan kan sägas vara en del av ett tävlingssystem enbart genom betygssystemet och skolans praktiker som vi såg exempel på i bild 2:3. De samhällsideal som uttrycks i läroplaner avspeglar inte självklart skolans praktiker. ${ }^{375}$

371 FIB nr. 221939 27:e maj sid. 28.

372 Undervisningsplan för rikets folkskolor den 31 oktober 1919. (1920). Stockholm: Norstedt sid. 134. och då inte under mål men som en delaktivitet under "anvisningar"; i skidlöpning och skridskoåkning”, tävlingar mellan olika lag”. Även i 1954 års kursplan i gymnastik finns ordet tävling; "På mellan- och högstadierna tillkommer inslag av tävlingar, speciellt lagtävlingar, men den kontinuerliga övningen bör hela tiden vara det viktigaste.” Sverige. Skolöverstyrelsen. (1955). Timplaner och huvudmoment vid försöksverksambet med nioårig enhetsskola: fastställda av Kungl. Skolöverstyrelsen för läsåren 1955/1958. Sid. 90.

373 Lundquist Wanneberg, Pia (2004) sid. 106.

3741919 års undervisningsplan för folkskolor handlar till största delen om skolans organisation, då det fanns många olika varianter av samläsning för $\mathrm{B}, \mathrm{C}$ och D-klasser i små skolor på landsbygden. Undervisningsplan för rikets folkskolor den 31 oktober 1919.. (1924). Stockholm: Norstedt.

${ }^{375}$ Se t.ex. Linde, Göran, Det ska ni veta! En introduktion till läroplansteori, 3:dje uppl., Lund: Studentlitteratur 2000, 2012 sid. 11ff. 
Efter första världskriget kom en ny undervisningsplan1919, som hade för sin tid mycket progressiva idéer som man bland annat hämtade från Dewey och den nya progressivismen som växt fram i USA. ${ }^{376}$ När FIB:s tävling pågick, var det 1919 års undervisningsplan som gällde, fram till 1954. Även om undervisningsplanen var densamma under denna tid, utvecklades läromedlen och undervisningssätt i teckning i många skolor. Teckning ingick som ett viktigt moment i det nya ämnet hembygdskunskap som infördes $\mathrm{i}$ och med den nya undervisningsplanen. ${ }^{377}$ Under hela perioden fram till LGR 80 när hembygdskunskap tas bort som eget ämne, är teckningsämnet i årskurs 1-3 kopplat till hembygdsundervisningen. Både i FIB:s och framför allt Televerkets teckningstävlingar kan man se att hembygdskunskapsämnet varit en förutsättning för tävlingens genomförande och delvis även för utformandet av tävlingens teman. Precis som teckningsundervisningen, som började först i årskurs fyra, hade Hembygdsundervisningen till syfte att "...utveckla deras iakttagelseförmåga" och arbetsövningar i hembygds-undervisningen skulle också "utgöra förberedande undervisning i teckning och slöjd." ${ }^{378}$ Eleverna förväntades även teckna på krittavla och:
De arbetsövningar, som lämpligen förbindes med hem-
bygds-undervisningen böra vara ägnade såväl att fullständiga och skärpa barnens iakttagelser som att bereda dem tillfälle att med händerna utföra något, varmed de kunna giva yttre ut- tryck åt sin uppfattning av det som genom iakttagelserna in- hämtas. Bland de arbetsarter som härvid kunna ifrågakomma, är teckningen att anse som den viktigaste. ${ }^{379}$

I anvisningarna till 1:a årets övningar i hembygdskunskap från 1919 står att "Arbetsövningarna göra det lättare att få omväxling i arbetet. De hjälpa fram ett arbetssätt som står i överenstämmelse med barnens natur, som särskilt tar hänsyn till deras verksamhetsdrift." 380

Från årskurs fyra fanns teckning som eget ämne på schemat, oftast i två eller tre år i folkskolan. Det fanns i 1919 års läroplan fortfarande samma syn på målet för teckningsundervisningen som hos Rousseau på 1700-talet, eller hos Ellen Key i början av 1900-talet: teckningskunskap handlade om att teckna av och öva upp iakttagelse, samt utveckla barnens skönhetssinne. ${ }^{381}$

FIB:s teckningstävling hade en uttalad ambition att förändra undervisningen mot friare arbetsformer, exempelvis genom sina anvisningar om att teckna ur

376 Se inledningskapitel, bakgrund, samt Pettersson, Sten \& Åsén, Gunnar (1989) sid. 85ff.

377 Pettersson, Sten, Åsén Gunnar (1989) sid. 101. Nya läromedel var exempelvis Sjöholm \& Goes arbetsböcker i hembygdskunskap.

378 Undervisningsplan för rikets folkskolor den 31 oktober 1919.. (1920). Stockholm: Norstedt Ett annat nytt ämne som infördes var medborgarkunskap, som fanns kvar till 1955.

${ }^{379}$ Ibid. sid 77.

380 Sjöholm, L. Gottfrid (1919). Handledning vid undervisningen i hembygdskunskap. 1, Första skolåret. 3. uppl. Stockholm: Sv. bokförl. (Norstedt) inledande kapitel.

${ }^{381}$ Ur läroplan 1919 sid. 229 ”Teckningsundervisningen i folkskolan har till uppgift att, på samma gång den övar lärjungarnas iakttagelseförmåga och utvecklar deras skönhetssinne, bibringa dem färdighet att i bild återgiva enkla föremål på fri hand i profil eller perspektiv eller ock meddelst geometrisk ritning." 
fantasin, som jag återkommer till. Tävlingen kunde alltså förespråka ett friare skapande, trots att det var en tävling, och som tävling styrd av både tema och jury. ${ }^{382}$ Det fördes under 40 -talet en livlig debatt om bildämnet och dess behov av friare arbetsformer som jag nämnde tidigare. ${ }^{383}$ Detta leder till ett efterhand alltmer ambivalent förhållande till huruvida tävlande i teckning kunde överensstämma med skolans uppfostrande roll. Teckningsläraren Olle Strandman skriver 1947 under rubriken Teckningsundervisning och uppfostran:

Bland de stora kulturfrågor som efter det andra världskriget tilldragit sig uppmärksamhet, intar problem rörande uppfostran en särställning... Det är först den psykologiska forskningen under 1800-talets sista årtionden och under 1900-talet som påvisat den betydelse som det självständiga skapandet av bilder äger för personlighetens harmoniska växt under barn och ungdomsåren. Att få alla elever i en klass att uttrycka sig är idag det eftersträvansvärda, odlandet av den konstnärliga specialbegåvningen är för undervisningen tämligen likgiltigt. ${ }^{384}$

Strandman betonade alltså självständigt bildskapande som en nödvändighet för en harmonisk uppfostran, men också hur det därför idag - till skillnad från förr - utifrån ny psykologisk forskning, ansågs viktigare att alla skapade, än att träna specialbegåvade, exempelvis för att vinna teckningstävlingar. Liksom Ulla Johansson skrivit om hur begreppet begåvning mellan 1927-1960 var det viktigaste instrumentet för flickor och pojkar ur arbetarklassen för att legitimera sin plats på läroverket, betraktades begåvning i att teckna avbildande i de tidiga tävlingarna som positivt. ${ }^{385}$ Teckningskunskap var något som gick att värdera och därmed kunde det bedömas och legitimera tävlingarna.

Målet för teckningsämnet i läroplanerna förändras under 1950-talet, från att tidigare varit inriktat på teknisk ritning, avbildning och konstforstran. Teckningsundervisningen i 1954 års kursplan för sjuårig folkskola hade till uppgift: " att bibringa eleverna färdighet att i fritt skapande giva uttryck à sina erfarenheter och sin fantasi samt att i form och färg återgiva sina förställningar och iakttagelser." ${ }^{386}$ Förutom att alla elevers möjlighet till självständigt, fritt och fantasifullt skapande var i konflikt med tidigare idéer om att i en tävling kunna välja ut en vinnare som tecknade "bäst", var dessutom tävlingen som form ställd i motsatsförhållande till samarbetet. Den engelske konstpedagogen Herbert Read fick stort inflytande för de nya pedagogiska mål- och metodikförändringarna i

${ }^{382}$ Se vidare avsnitt Hur ska bilderna göras sid. 29.

383 Se t.ex. Pettersson, Sten \& Åsén, Gunnar (1989) sid. 95f. till exempel i facktidningarna Teckning och Folkskolan i samband med 1946 års skolkommission. Folkskolan var en tidskrift för Federationen Sveriges allmänna folkskollärarförening.

384 Barn och Bild Teckning och uppfostran Ett program vid teckningskongressen i Malmö 1947.

385 Johansson, Ulla (2008). Normalitet, kön och klass liv och lärande i svenska läroverk 1927 1960. Enskede: TPB.

${ }^{386}$ Tim- och kursplaner för sjuårig folkskola (klasserna 1-6 i folkskola med flera än sju årsklasser): fastställda av Kungl. Maj:t den 4 juni 1954. 2. uppl. (1954). Lund: H. Ohlsson (min kursivering) 
Sverige. ${ }^{387}$ Read skrev i Uppfostran genom konsten: "Om vi ska hålla undervisningens sociala betydelse i tankarna, så måste samarbete, inte tävlan, vara vår ledande princip." ${ }^{388}$ När Skolöverstyrelsen 1955 formulerade sig inför försöket med nioårig grundskola är det barns och ungas rätt till likvärdig skola som lyfts fram, och de betonar: "att man nå längre och uträtta mer med samarbete, än om var och en begränsar sig till sina egna möjligheter," vilket kan tolkas som att individuell tävlan mellan elever inte ansågs vara lämplig. ${ }^{389}$

Skolans allt mer negativa inställning till tävlingar syns även i läroböcker i teckningsundervisningen. Arne Larsson skriver i Det fria skapandet - en bok om teckningsundervisning 1956:
Teckningstävlingar är i regel av ondo, liksom all sådan tävlan inom klassen. Jag vet ingen situation där inte samarbete skulle ge bättre resultat än tävling. Kommersiella teckningstävlingar borde vara helt bannlysta. Den enda form av teckningstävling som förefaller acceptabel, är den som utgår från lagtävlingens principer - och - i den mån belöningar utdelas - betraktar klassen som ett lag, utan hänsyn till vilka individuella presta- tioner som kan ha fört klassen fram till belöningen..$^{390}$

Även Larsson ser samarbetet som en motsättning till tävlandet. Endast om det är laget och inte individen som premieras, kan tävlingen fungera. Det är också just genom att betrakta klassen som ett lag, där fem väljs som gemensamt ska tävla för hela klassen, som både FIB:s och Televerkets mångåriga tävlingar kan legitimeras. De kommersiella aktörerna som Larsson vände sig emot, syntes bara tidigt under perioden i skolan, under den senare perioden riktade sig privata och kommersiella aktörer främst till barn utanför skolan. ${ }^{391}$

1948 nämndes i teckningslärarnas tidskrift Teckning att facket fått igenom kravet på en teckningskonsulent, som bland annat samordnade olika teckningstävlingar. ${ }^{392}$ Fortfarande en bit in på 1960-talet fanns många annonser för främst internationella teckningstävlingar, som jag visade i föregående avsnitt. Men från mitten av 1960-talet förändrades innehållet i Teckning. Under 1960- och 70-talet uppmärksammades att barns bilder färgades av det växande massmedieutbudet. Detta är också framträdande i den syn på barnbilder som växer fram på teckningslärarutbildningarna i de nordiska länderna under 1970-talet. ${ }^{393}$ Gert Z Nordström blev en flitig skribent i Teckning, och i ett önskemanifest 1964, men-

\footnotetext{
387 Nordström, Gert Z. \& Romilson, Christer (1970). sid. 42f. Pettersson, Sten \& Åsén, Gunnar (1989) sid. 94f.

${ }^{388}$ Read, Herbert (1956) sid. 268. (Utgiven på engelska 1943: Read, Herbert Education through art. London: Faber and Faber.)

389 Sverige. Skolöverstyrelsen. (1955). Timplaner och huvudmoment vid försöksverksamhet med nioårig enhetsskola: fastställda av Kungl. Skolöverstyrelsen för läsåren 1955/1958, sid. 8.

${ }^{390}$ Larsson, Arne (1956). Det fria skapandet: en bok om teckningsundervisning. Stockholm: Almqvist \& Wiksell/Geber sid. $124 f$.

${ }^{391}$ Se vidare resonemang tabell 2 arrangörer över i Teckning och i SBBA:s samling.

392 Konsulenten är teckningslärare Ragnar Brandelius. Att man fått igenom kravet på en teckningskonsulent sågs som en facklig framgång.

${ }^{393}$ Illeris (2002) sid. 164. Pettersson, Sten \& Åsén, Gunnar (1989) sid. $109 f$.
} 
ade Gert $\mathrm{Z}$ att skolan borde betygsätta idérikedom och engagemang, och inte estetiken i elevernas bilder. ${ }^{394} 1967$ skriver Gert Z Nordström att det nu behövs en ny form av pedagogik, inte den bundna perspektivteckningen och inte den fria som urartar i effektsökeri och teknikjakt, utan "den alternativa med målet en medveten elev" ${ }^{395}$ Teckningslärarförbundets tidning Teckning fokuserade därefter i sina artiklar på förändringen av bildämnet mot kommunikation, som till viss del handlar om att genomskåda kapitalistiska budskap i reklambilder. Annonser eller reportage om tävlingar försvinner nästintill helt under 1970-talet. ${ }^{396}$ FIB:s tävling som startade 1938 arrangerades då gemensamt med teckningslärarförbundet, som ville förändra undervisningen. Trettio år senare ansågs inte tävlingar kunna förändra undervisningen till det bättre. Tvärtom sågs tävlingar som problematiska bland lärare, både för att de ställdes i motsatsförhållande till "det fria skapandet", och för att tävlingen kunde ses som del av en kapitalistisk, konkurrensinriktad diskurs, i konflikt med skolans ideal om samarbete. Barnteckningstävlingar var inte längre användbara instrument för teckningslärarna för att öka professionens eller ämnets status. Men barnteckningstävlingar fanns kvar även efter 1970, som syns i diagram 1, även om de alltmer sällan annonseras i Teckning.

Teckningstävlingen "Liv i rymden" från 1977 riktade sig till alla skolbarn från grundskola till gymnasium. DN skrev under rubriken "Rita din egen Rymdvarelse - 10 barn får resa till Rymdveckan i Stockholm":

Barnens Nyheter och arrangörerna av rymdveckan inbjuder dig härmed att vara med i en stor teckningstävling. Ja, egentligen är det ingen "tävling", för vi kommer inte att avgöra vem som är "bäst”. Det är både omöjligt och ointressant. Men en jury kommer att bland de insända teckningarna göra ett urval att visa på Rymdveckan i Stockholm. ${ }^{397}$

Denna "tävling" hade alltså både jury och priser (bland annat att resa till Stockholm), men arrangörerna var ändå noga med att poängtera att det inte var en "tävling", då det inom barnbildsdiskursen under 1970-talet var både "omöjligt och ointressant" att tala om de "bästa barnbilderna".

Som jag nämnde annonserade tidskiften Teckning enbart för en tävling under 1970-talet och det var tävlingen "Östersjön måste vara ett fredens hav"1974. ${ }^{398}$ Det dröjde sedan till 1985 innan en tävlingsannons återigen publicerades i bild-

394 Teckning nr 21964.

395 Teckning 1967 nr 8. 1968 blev Gert Z föreståndare för teckningslärarutbildningen i Stockholm, och 1990 blev han professor i Bildpedagogik.

396 Teckning Nr 11971 sid. 28. En tävling, men inte teckningstävling, men som också speglar ämnets förändring är en internationell smalfilmstävling Decima Musa annonserades 1971, där Barnfilmskommittén och Sveriges radio utlyste den svenska delen av tävlingen. Föreslaget tema; vänskap.

397 DN 1977-08-28 sid. 40.

398 Teckning nr 11974 sid. 33. Begreppet "Östersjön fredens hav” användes av Sovjet under kalla kriget med intentionen att knyta samma Östersjöstaterna och förbjuda fartyg från utomstående stater. https://www.ne.se/uppslagsverk/encyklopedi/l\%C3\%A5ng/fredens-hav (2018-03-09) 
lärarförbundets tidning, som då bytt namn till Bild $i$ skolan. Utbildningsminister Lena Hjelm Wallén meddelade i ett särskilt uttalande i tidningen en rekommendation till ett utvidgat deltagande i tävlingen "Europeiska skoldagen":
att SÖ vill understryka betydelsen av att svenska ungdomar deltar i internationella aktiviteter, och önskar därför att den Europeiska skoldagen (bild- och uppsatstävling) genom lokala åtgärder på lämpligt sätt uppmärksammas som ett led i under- visningens internationalisering. ${ }^{399}$

Skolöverstyrelsen menade alltså 1985 att tävlingen som form lämpade sig bra då det handlade om att öka Europeiskt samarbete. Tävlingsformen blev därmed inte längre problematisk om tävlingarna var internationella och i likhet med 1950-och 60-talets tävlingar antogs leda till fördjupat internationellt samarbete.

$* * *$

I avhandlingens inledande kapitel påpekade jag hur Skolöverstyrelsen i samtal med Televerket 1977 uttryckte att de ville ha bort alla former av tävling i skolan, varpå Televerket följande år inte hade med ordet "pristävling" i sin annons. Genom att ta bort ordet tävling, kunde tävlingen i skolan fortsätta som förut. Men den styrda tävlingen som byggde på enskilda prestationer hade börjat rimma illa både med skolans ideal om samarbete och pedagogiska diskurser om det fria skapandet, och tävlandet för skolbarn blev något som skolan och samhället ville tona ned. En förutsättning som gällde för både FIB och Televerket var att alla i klassen deltog som ett lag, där läraren eller klassen valde ut fem bilder, och klassen delade sedan på vinsten, som gick till en gemensam skolresa. Endast när tävlingen framställdes som ett lagarbete kunde den fungera i skolans kontext.

Att tävla och jämföra kunde också öka både den regionala och den nationella prestigen, där tävlingsbilderna 1945 kunde omtalas som "elitbilder" av Nationalmuseums chef, Sixten Strömholm. Men skolan och Nationalmuseum uttalade inte självklart samma intressen, även om tävlingen Nationalmuseum är med och arrangerar görs i skolan. Samverkan och samarbete var det som betonas i skolans styrdokument, framför allt efter andra världskriget, och en tävlingsdiskurs ställs då i tydligt i motsatsförhållande till en samarbetsdiskurs.

När teckningslärare Strandman 1947 diskuterade teckningsundervisning och uppfostran lyfte han fram hur psykologisk forskning visade att det fria personliga skapandet var nödvändigt för att barnen skulle utvecklas till harmoniska människor, vilket kom i konflikt med odlandet av specialbegåvningar och med tävlingen som förutsatte vinnare.

Med ett ökat massmedie- och reklamutbud under 1960- 70-talet uppstod även en motreaktion där det viktiga nu inte var att barn producerar egna inre bilder, utan att de kunde läsa av och kommentera media-, propaganda- och reklambilder. I DN beskrevs 1977 att det de själva benämnde som "teckningstävling" inte handlade om att välja ut vem som var "bäst". Det hade i 1970-talets

399 Teckning 1985 nr1 sid. 5. 
kontext blivit omöjligt att definiera barnbilder som bättre eller sämre, samtidigt som tävlingsmomentet kunde locka till engagemang och deltagande. Den nya tiden behövde nya medborgare/barn som både kunde se igenom, tolka och producera masskommunicerade bilder, och barnens skapande borde bedömas utifrån sin idérikedom, kreativitet och förmåga till kritiskt tänkande snarare än utifrån estetiska normer. Tävlingarna var då inte heller en självklar form men accepterades således i samband med vissa förtecken.

Skolan har över tid förhållit sig till flera skilda diskurser om barnet. Dels det utvecklingspsykologiska barnet som når allt större korrekthet i sitt bildskapande med stigande ålder, dels barnet som konstnär och förmedlare av inre tankar, och slutligen det kompetenta barnet och som producent av politiska åsikter. Utifrån dessa diskurser ska teckningstävlingarna förstås. När bildämnet förändrades från det fria inre skapandet till ett mer kommunikationsorienterat ämne, kunde tävlingar betraktas som en möjlighet för elever att producera bilder för att uttrycka åsikter. Samtidigt blev tävlingar under 1980-talet mindre kontroversiella och kunde återigen fungera som del av undervisningens verksamhet för att överföra önskvärda normer och ideal. När Tävlingen Europeiska skoldagen, som första tävling efter ett uppehåll på tio år, annonserades i teckningslärarförbundets tidning Bild $i$ skolan 1984, var det betydelsen av internationella aktiviteter, som underströks i annonsen. Tävlingen borde uppmärksammas menade utbildningsminister Lena Hjelm Wallén, för att förmedla de svenska elevernas tillhörighet till en europeisk gemenskap. ${ }^{400}$ Både vad som betraktats som god pedagogik och vad som betraktats som vinnande barnbilder har förändrats över tid, vilket kommer till uttryck i de uppdrag barnen gavs. Barnens uppdrag står i fokus för nästa avsnitt.

\section{Uppdragen och barnen}

Vi kan således konstatera att teckningstävlingar inte var helt okontroversiella under vissa perioder men uppenbarligen ansågs de samtidigt lämpliga och användbara för en rad aktörer, då tävlingarna har kunnat anpassas efter en förändrad syn på barn och barns skapande. Det finns därför skäl att närmare granska hur de olika tävlingarna har organiserats och genomförts. Genom ordnandet och strukturerandet av tävlingarna skapades tydliga ramar som barnen hade att förhålla sig till. Dessa olika och föränderliga riktlinjer aktualiserar den ambivalens som funnits kring barns bildskapande, och tävlingar, liksom förändring över tid. Hur ville arrangörerna att bilderna skulle göras, vilka barn skulle bjudas in att delta, och hur påverkade förändrade material och tekniker tävlingarnas och tävlingsbildernas uttryck? Kort sagt; vilka uppdrag har då barn fått och vilka förutsättningar har funnits för de olika tävlingarna?

För att undersöka detta diskuterar jag FIB:s anvisningar till barnen om hur de ville att bilderna skulle göras som publicerades på tidningens ungdomssidor. I

400 Jfr kapitlet Folket i bilds hembygdstema, där de olika landskapen bildar en nationell helhet. I denna tävling användes liknande retorik för att beskriva hur olika nationer bildar en europeisk helhet. 
senare tävlingar som gjordes i skolan har jag granskat de regler och anvisningar för tävlingarna som skickades direkt till skolorna som finns i SBBA:s arkiv. Anvisningar riktades från arrangörerna till barnen, och till lärarna.

Även juryns sammansättning och vilka priser som delats ut diskuteras, i de tävlingar som haft jury och priser. Förhållningssätt för juryn i FIB:s tävling lyfts fram i facktidskriften Teckning, liksom en diskussion kring vad som är lämpliga vinnarbilder. I Televerkets arkiv finns tydliga anvisningar riktade till juryn.

Förutom hur bilderna skulle göras och bedömas kommer jag också att diskutera hur tävlingsanvisningarna förhöll sig till barnens åldrar och var tävlingarna skulle äga rum, var bilderna skulle göras. För att undersöka vilka uppdrag barn har fått av olika arrangörer över tid presenterar jag också hur arrangörerna formulerade sina uppdrag till barnen, vilka motiv och teman de ombads att teckna, och vilka förändringar som syns över tid.

\section{Tävlingarnas utformning, anvisningar och priser}

Förutsättningarna för tävlingarna har förändrats över tid, både då det gäller barnens och juryns arbete. Arrangörerna gav instruktioner om hur bilderna skulle göras och anvisningar kring exempelvis vilket format bilderna skulle ha, eller vilket material som borde användas men också hur bilderna bedömdes, genom anvisningar som gavs åt juryn eller eleverna. Det var både direkta anvisningar som skickades till lärare och elever, men även anvisningar i Teckning eller FIB som visade hur jury gjorde sitt urval.

I Televerkets tävlingar 1977-1990 och FIB:s tävlingar mellan 1938 och1957 som gjordes i skolan, hade arrangörerna instruktioner för hur bilderna ska skickas in, fem bilder från varje klass, som skulle väljas ut av klassen gemensamt eller av läraren. 1938 skriver man i FIB: "Teckningarna skola utföras på vitt olinjerat ritpapper minsta format omkring 20X15 ca samt målas med vattenfärg." ${ }^{401} 1939$ har man ändrat till "Minimimått 18X25 Maxmått 28X36. Helst bör olinjerat ritpapper användas. Teckningarna bör insändas i kuvert och ej rullas". ${ }^{402}$ I nedre hörnet på teckningens framsida "antecknas tecknarens namn och ålder. På baksidan skall läraren teckna sin egenhändiga namnteckning och sin adress, skolans namn och adress, samt skolans beteckning. (A, B1, B2 eller C)" ${ }^{403}$ Anvisningarna i FIB har en rubrik ur tävlingsreglerna med titeln "Självständigt arbete" och inleds med "Att deltagarnas bidrag skall vara resultat av fullkomligt självständigt arbete är en given sak." Sedan är dock nästa rubrik ur tävlingsreglerna "Lagtävling" där det framhålls att "tävlingen inte är individuell på något sätt, utan varje avdelning (klass eller skola) tävlar gemensamt." ${ }^{404}$ Det är med andra ord precis som när man lyfte fram tävling som del av skidlöpning och skridskoåkning, för laget man tävlar, men individuellt, alla gör sitt eget bästa för allas bästa, individen arbetar för det kollektiva.

\footnotetext{
401 FIB nr 81938 19:e febr. sid. 28.

402 FIB nr 91939.

403 FIB nr 81938 19:e febr. sid. 28.

${ }^{404}$ FIB 1945 nr 8 sid. 33.
} 
Men FIB betonade samtidigt idén om det enskilda konstnärskapet, då eleverna skulle signera de bilder de målat. Även läraren skulle skriva sin egenhändiga namnteckning, och när vinnarna sedan presenterades i FIB, var det förutom skolans namn, ibland elevens namn, och ibland lärarens, som angavs. I Televerket nationella tävling för årskurs tre för telefonkatalogomslag, hade distributionen av bilderna underlättats för lärarna. Televerket skickade med speciella kuvert ut till skolorna som de sedan skulle använda för att återsända bilderna. Bilderna skulle ha formatet $32 \mathrm{~cm}$ på bredden och $25 \mathrm{~cm}$ på höjden, alltså ett liggande format. Som nämnts tidigare skriver man "Måla med oljekritor. Då blir det lättare för oss att trycka din bild". ${ }^{405}$ Televerket skickade även fem lappar som skulle fästas bak på de av klassen utvalda bilderna med den information man behövde. Här finns uppgifter om skolans namn, vilken telefonkatalogdel skolan tillhör, vilken klass som gjort bilden och vad bilden föreställer. Däremot finns inte uppgift om vilken enskild person som gjort bilden ${ }^{406}$ (bild 2:4).

Dalatrafik, som 1989 var med i länstrafikens tävlingen Trafiken och miljön "Var bussig mot miljön" ville ha både de enskilda

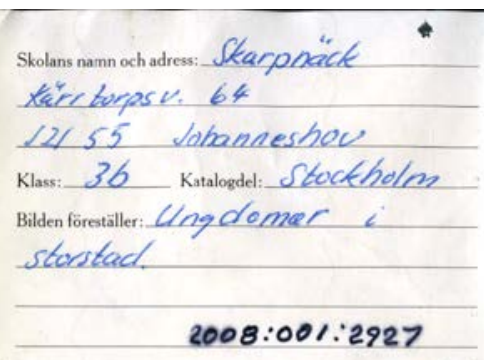

Bild 2:4. Exempel på adressetikett använd vid Televerkets tävling 1977. elevernas och skolans namn på de inskickade bidragen. Genom att skicka ut ett speciellt papper att använda i tävlingen, med sin egen logga på, kunde man dessutom uppmärksamma både elever och lärare på sitt varumärke, och det användes också av flera elever i de bilder de tecknade. ${ }^{407}$ Posten och Svenska turistföreningen (1979) ville ha sina bilder i vykortsformat, troligen för att lätt kunna göra vykortsreproduktioner. Arla/Posten skriver 1976 i informationsmaterialet om tävlingen "Det här vill jag värna om": "Rita en teckning, en eller flera färger spelar ingen roll. Eller skriv kortfattat, varför inte en dikt, som handlar om just det du går och funderar på." ${ }^{408}$ De flesta teckningar i samlingen är gjorda i tuschpennor eller blyerts, i olika format, oftast på vitt papper, men ibland randigt kollegieblockspapper. ${ }^{409}$ Eftersom Arla/Posten riktade sig till barn i hemmiljö fanns mindre krav på specifika mått eller materiel och både texter och bilder går bra att skicka in.

Reklamens och marknadsföringens förändrade logik under 1900-talet, påverkade också bildernas uttryck. I Televerkets "Stoppa sabbet" tävling 19801990 för årskurs sex, uppmuntras i anvisningarna eleverna att samarbeta och göra bilderna i grupp. I Lasse Åbergs affischskola, framhölls, förutom att arbeta med collageteknik som jag nämnde tidigare, även vikten av att eleverna arbetade

\footnotetext{
405 Informationsutskick till skolor inför tävlingen 1976. Televerket Telemedia Omslag för rikstelefonkatalogen 1977 F2A:1 Riksarkivet.

406 Siffrorna längst ned är från SBBA:s katalogisering av bilderna.

407 Se SBBA samling Trafiken och miljön 1989 nr 1990:022.0001-0077.

408 Infoblad SBBA Diarienr. 1991:016.

409 SBBA samling 1987:024 Arla-Tävlingsbilder.
} 
i grupp, precis som på en annonsbyrå, och bilderna anpassades härmed efter en reklambildsdiskurs snarare än en konstdiskurs, samtidigt som grupparbetet fungerade väl ihop med skolans ambitioner att undvika individuell tävlan. Här syns en ytterligare utveckling över tid då idealet om barns "egna individuella bilduttryck" förändrades mot att bildskapandet betraktades som ett kollektivt konstnärligt arbete. ${ }^{410}$

Teckningstävlingar förutsatte en bedömning av vad som var god barnkonst, liksom vilket som var rätt sätt att skildra det angivna temat. Under rubriken "5000 kr i kontantpris i FIB:s sjätte teckningstävlan" skrev FIB:

$\mathrm{Nu}$ är det av synnerligen stor vikt att de tävlande absolut undvika varje slag av plagiat. Det är icke tillåtet att rita av bilder, att "låna" eller "stjäla" idéer, placering av personer eller föremål eller överhuvudtaget ha någon bild såsom mönster och förebild vid ritandet. ${ }^{411}$

Anledningen var att barnets egna, inre bilder skulle vara framträdande. Det var viktigt att barnen använde sin fantasi och inte tecknade av. Man ville komma åt det som betraktades som barnens egna unika uttryck, och komma ifrån den tidigare traditionen att teckna av föremål. Efter den första tävlingen $1938 \mathrm{skrev}$ FIB att de tävlingsbidrag som var mindre lyckade var de som hade lämnat ämnet "Livet i vår skola" eller där hela klassen ritat samma sak. Det var viktigt att hålla sig till ämnet men ändå vara individuell. ${ }^{412}$

Av de tävlingar som ingår i mitt undersökta material, har flera haft prispengar till klassresor, bland annat de två mest omfattande tävlingarna, FIB och Televerket. Det var tydligt i artiklar och arkivmaterial vilka som satt i juryn och vad de delade ut för priser. Däremot saknar många andra tävlingssamlingar i Svenskt barnbildarkiv uppgifter kring urvalsförfarandet. Det kan bero på att informationen inte arkiverats, då det är bilderna man haft intresse av och inte kontexten kring bilderna.

I de flesta fall behövs för en tävling en jury och ett pris. I tävlingar med tydlig jury finns också tydliga vinnare - de som enligt juryn tecknat de vinnande bilderna. Det var en omfattande procedur att sortera och bedöma alla bilderna. FIB visade under åren bilder av juryn då de arbetade med att välja ut vinnare bland stora mängder bilder. I nr 24 från den 19 juni 1938 är rubriken för ungdomsspalterna: "Den stora teckningstävlingen "VÅR SKOLA" blev en FULLTRÄFF med underrubriken "De bästa bidragen utställes hos Paul U. Bergström" ${ }^{413}$ Tidningsbilden visade fyra män runt ett bord med stora högar av papper framför sig med bildtexten: "Tävlingsnämnden $i$ arbete med att sortera de många tusen bidragen." Juryn hade lite olika sammansättning över åren, men bland annat satt Nationalmuseums dåvarande överintendent Erik Wettergren, dåvarande chefen

\footnotetext{
410 Jfr tex "the factory", Andy Warhols namn på ateljén där han och hans medarbetare skapade massproducerad, reklaminspirerarad konst.

411 FIB nr 111943 sid. 33.

412 FIB 1938 nr 24 sid. 27.

413 FIB 1938 nr 24 sid. 27.
} 
för Nationalmuseums grafikavdelning Ragnar Hoppe, samt två teckningslärare och två folkskollärare i juryn.

I FIB:s ungdomsspalter 1940 visades juryn i en palett och alla ivriga deltagare därunder (bild 2:5). Överst talade man om att "MIN FRITID" ger 5000 kronor. ${ }^{414}$ Juryn presenterades med fotografier av de som satt $\mathrm{i}$ juryn, vilket kunde ge en tyngd och ett allvar åt tävlingen, att det var något seriöst som juryn avsatte tid för. Tidningssidan kan tolkas som att deltagarna i juryn ifrån sin upphöjda position och placering betraktade och valde ut de mest talangfulla av barnen nedanför.

Det var sex herrar, och en dam, som var satta att rättvist bedöma bilderna. I juryn representerades tidningen, Nationalmuseum, teckningslärarna och folkskollärarna.

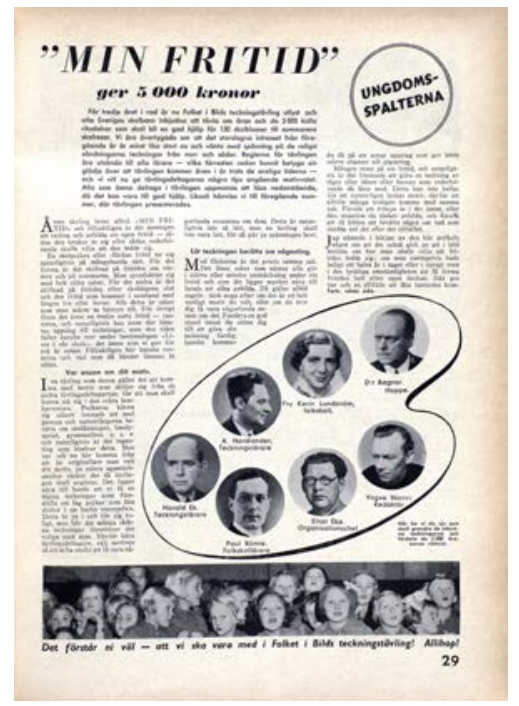

Bild 2:5. Folket $i$ bild $1940 \mathrm{nr} 9$ sid.29.

Paletten i denna form var ingenting eleverna använde då de målade med vattenfärg, men den var en symbol för att det var konst juryn skulle bedöma. Att juryns ansikten visades i en palett gjorde att tävlingen associerades till konst. Televerkets jury för telefonkatalogernas omslag 1976-1984 bestod av två fortbildningskonsulenter eller bildlärare och en representant från Televerket. I Televerkets arkiv finns tydlig information om vilka som var med och vilken ersättning som utgick till televerkstävlingens jurymedlemmar. ${ }^{415}$ Televerkets jurymedlem var ordförande och de av länsskolnämnderna utsedda jurymedlemmarna gjorde en första grovsortering av bilderna. ${ }^{416}$ Arrangerandet av jury och utdelandet av priser innebar att det avsattes tid och engagemang för administration och juryarbete. En tävling som Arlas, som saknade prispengar, behövde inte heller sortera och värdera bilder eller administrera vinstutdelningar.

Vad juryn ville ha för sorts bilder kunde även tydliggöras genom att tala om vad man inte vill ha. En av initiativtagarna till FIB:s tävling, teckningslärare Gustav Nordlander, beskrev i teckningslärarnas tidskrift vilka bilder som valdes bort: "Juryn tycker inte om form och färgdiktatur och än mindre teckningsdisciplin. Skvallra de fem teckningarna om slaveri under en förkvävande diktator

\footnotetext{
${ }^{414}$ Inte ett pris utan uppdelat på 50 och 25 kronors priser. Bilden visar att arrangörerna efterfrågar bilder av barns fritid, vilket speglar ett samhälleligt intresse för "barns världar". FIB:s tävling frågar också efter barns bilder av sin skola och sin hembygd. Detta återkommer jag till $i$ analys av teman.

${ }^{415}$ Televerket, Telemedia Omslag till risktelefonkataloger 1977 F2A:1 och ev. F2A:2 Riksarkivet.

${ }^{416}$ Exempelvis var för Ystadsdelen Tvt s jurymedlem Helge Lindh, de av länsskolnämnderna utsedda jurymedlemmarna var fortbildningskonsulent Bo Ahlner och teckningslärare Göran Holmberg.
} 
blir det inte tal om pris." ${ }^{417}$ Av att Nordlander ansåg det fanns anledning för att påpeka vad juryn valde bort genom att använda ord som diktator, slaveri och disciplin, kan vi förstå att det fanns normer kring teckningsundervisningen som Norlander ville förändra. Det är tydligt att det pågick förhandlingar inom teckningslärarförbundet om vad som betecknar en god och bra barnbild. Detta var uppenbarligen en anledning att Nordlander var med som initiativtagare till FIB:s tävling. Tävlingen var ett sätt att nå ut till både folkskollärare och teckningslärare, liksom till barnen och andra läsare av tidningen.

Följande citat visar emellertid på hur motsättningsfulla föreställningar om den bra barnbilden kunde vara. Samme teckningslärare Nordlander som tidigare uttalat sig emot ett diktatoriskt förhållningssätt i teckningssalen skriver på ledarplats i tidskriften Teckning 1941:

Men då man finner en utställning med barnteckningar, där
det efterblivna barnets teckningar belönats med första pris,
blir man ledsen. Det förefaller som arbetsprinciperna har
varit, slarv är bättre än ordning, tillfälligt krafs är bättre än
genomtänkt arbete, okunnighet bättre än kunskaper. Ett vaket
och tidigt utvecklat barn, som besitter en för sin ålder mindre
vanlig iakttagelseförmåga och kännedom om sitt motiv (tex ett
tröskverk) blir kallt refuserad i en sådan salong. ${ }^{418}$

Nordlander var engagerad i FIB:s tävling och en flitig skribent i teckningslärarförbundets tidskrift. ${ }^{419}$ Han förordade en förändrad, friare, teckningsundervisning, men samtidigt ansåg han i detta citat att han är noga med att barnen skulle besitta kunskaper och göra ett genomtänkt arbete. Det framgår inte vilken tävling eller bild Nordlander syftar på som belönats med 1a pris, men troligen en abstrakt bild, vilket var den typ av bilduttryck konsten sökte i barnbilden vid denna tid som jag diskuterat tidigare. Citatet kan möjligen också förstås i ljuset av samtida diskussioner om ärftlighetsbiologi och normalitet, där teckningar av "ett vaket och tidigt utvecklat barn" är vad Nordlander menar borde premieras i tävlingen framför "det efterblivna barnets teckningar." ${ }^{20}$

Även om det moderna barnet i FIB och Teckningslärarförbundet 1939-41 definierades genom sin fantasi och förmåga att teckna utan avbildande, var barnet samtidigt inskrivet $i$ en utvecklingspsykologisk diskurs, där den tidiga utvecklingen, som innefattade god iakttagelseförmåga premierades. Citatet visar tydligt konflikten mellan barnkonstdiskursen och den utvecklingspsykologiska diskursen, och hur barns kompetenser i teckning förhandlades.

Tony Olofson som var chef för Televerkets marknadsavdelning, meddelade 1976 Televerkets jurymedlemmar från marknadsavdelningen hur bilderna skulle

\footnotetext{
${ }^{417}$ G. Nordlander artikel "FIB:s teckningstävlan" i Teckning: tidning för svensk teckningsundervisning. (1939-1979) 1941-42: 12-13 Stockholm: Teckningslärarnas riksförbund sid. 49.

${ }^{418}$ G Nordlander teckningslärare i ledare i Teckning $1941 \mathrm{nr} 4$ sid. 65.

${ }^{419}$ Han skrev bland annat förordet om ”Teckningsundervisning förr och nu I Sverige genom barnaögon" 1947.

${ }^{420}$ Lind, Judith (2000). Det sinnesslöa skolbarnet: undervisning, tvång och medborgarskap 19251954. Diss. Linköping : Univ.
} 
bedömas. Vid bedömningen skulle hänsyn tas till bland annat följande fyra faktorer:

1. Tävlingsförutsättningarna skall vara uppfyllda, det vill säga bilden ska ha anknytning till ämnet hembygdskunskap.

2. Bilden får inte ha omotiverad politisk anknytning.

3. Bilden får inte innehålla omotiverad reklam.

4. Samma klass kan tilldelas flera priser. ${ }^{421}$

Intressant att notera är att Televerket poängterade att bilderna inte skulle göra reklam eller ha "omotiverad politisk anknytning", vilket jag diskuterar vidare i kapitlet Sverigebilder.

Det var 24 olika jurys, en för varje katalogområde, som valde ut vinnarbilderna. I arkivet finns namnen på de bidrag som vann och ibland även juryns motivering till de vinnande bilderna. Några av dessa motiveringar återkommer i avsnittet "Flaggor och kungar".

Sammanfattningsvis visar min analys att distributionen av bilder förenklades mellan 1940-tal och 1970-tal, genom att Televerket skickade ut färdiga kuvert för bilderna att återsändas i. Genom att underlätta för skolorna att delta kunde man också få med fler skolor. Konflikten mellan det skolade och inlärda och den känslomässiga egna kreativiteten, som Anna-Lena Lindberg problematiserat som ett konstpedagogiskt dilemma, är påtaglig i 1940-talets diskussion om teckningstävlingarna. ${ }^{422}$ Detta gäller såväl vid juryns arbete som vid instruktioner till eleverna. Televerket försäkrade sig om tillgång till barns fantasi och kreativitet genom att låta endast 9-åringar delta, vilket jag diskuterar vidare i barns ålder och plats. Televerket har på 1970-talet tydliga anvisningar till juryn, där reklam och politisk propaganda har blivit aktuella ämnen för juryn att förhålla sig till, till skillnad från FIB:s jury på 1940-talet.

\section{Förändringar av material och teknik}

Som vi såg var kamera och röntgenteknik del i att utveckla de moderna expressionistiska konstnärliga uttrycken. Ny teknik var således en förutsättning såväl för konsten som för att arbeta med teckning och målning i skolan. Även nya och billigare trycktekniker för reproduktion skapade möjligheter för konstnärer, liksom de var en förutsättning för barnteckningstävlingarna. En viktig faktor för att överhuvudtaget genomföra teckningstävlingar var barnens tillgång till material. I takt med att skolväsendet byggdes ut och där man så småningom övergick från griffeltavlor till papper och pennor och sedan även till färgkritor, vattenfärger och så småningom tuschpennor och oljepastellkritor, gavs utökade

\footnotetext{
${ }^{421}$ Skrivelse Till Televerkets jurymedlemmar från T Olofson 1976 05-14 Telemedia Omslag till rikstelefonkataloger F2A:1 Riksarkivet.

${ }^{422}$ Lindberg, Anna Lena (1991) sid15f.
} 
möjlighet för barn att göra bilder, och delta i tävlingar. ${ }^{423}$ Skolan gav tidigt denna möjlighet åt alla, men under senare delen av 1900-talet finns papper, pennor och färger även i de flesta hem.

Materialet bilderna gjordes i påverkar också hur de betraktas. Redan 1923 uttalade konstnärinnan Mollie Faustman när hon blev intervjuad i tidskriften Idun angående den pågående barnbildsutställningen på Gummessons konsthandel:

De utställda alstren äro i många avseenden förbluffande. Vackra och eleganta i en grad, som vi gångna tiders barn, aldrig skulle drömt om där vi slet med våra hårda färgkritor, som trots ideligt bestickande, nekade att gifva ifrån sig något alls av den färgglädje som brände inom oss. Materialet är nu ett annat, tekniken likaså. ${ }^{424}$

Landahl beskriver hur pedagogen Hjalmar Berg i sitt tal på nationella folkskolemötet med rubriken Den reformerade teckningsundervisningen 1903 menar att det blir problematiskt att införa en förändrad teckningsundervisning i något annat än Stockholms skolor, vilket berodde dels på brist på materiel, dels på brist på utbildade lärare. ${ }^{425}$ Fortfarande 1939 beskrevs i FIB att skolor frågade hur de skulle förhålla sig om de inte har haft möjlighet att skaffa de material som behövdes för teckningstävlingarna:

Dessutom har från vissa håll frågats hur man ska bete sig på sådana platser där det är svårt att få fatt i vattenfärger, exempelvis i mycket isolerade trakter, där sådana får rekvireras mycket långt ifrån. Är så fallet tar vi naturligtvis även emot bidrag utförda med vanliga färgkritor, men då bör vederbörande lärare påpeka varför sådana använts. ${ }^{426}$

Självklart påverkade tillgången på materiel möjligheten att delta i tävlingen. Flera gånger under de år tävlingen pågår påpekade FIB, som nämndes tidigare, att även landsortsskolorna klarade sig bra i konkurrensen. Eventuellt kunde sämre förhållanden vad gäller materialtillgång vara ett argument för en fortsatt uppdelning. ${ }^{427} 1944$ delade FIB ut flera hundra vattenfärgslådor till just landsortsskolor, vilket man rapporterar om på ungdomssidorna. ${ }^{428}$ Med vattenfärgen gavs möjlighet både att lägga ganska flödigt med färg, och att göra små detaljer.

${ }^{423}$ Se även Ulla Frosts resonemang kring hur bruket av blyertspenna formade 1800-talets linjära teckningsundervisning. Frost, Ulla (1988). Förlagor och teckningsläror: ett bidrag till den svenska teckningsundervisningens historia särskilt avseende 1800-talet. Diss. Stockholm: Univ. Sid. 156.

${ }^{424}$ IDUN 1923 nr. 38 sid. 895.

${ }^{425}$ Detta efter att Hjalmar Berg varit på världsutställningen i Paris och inspirerats till en förändrad undervisning. Landdahl (2017) Aesthetical modernization and international comparisons: drawing instruction at the Exhibition Universelle in Paris 1900.

${ }^{426}$ FIB 1938 nr 19 sid. 28.

${ }^{427}$ B-och C-skolor var när två eller tre klasser läste ihop, vilket var vanligt på landsbygden om det var litet elevunderlag.

${ }^{428}$ FIB 1945 nr14, sid. 32 
Möjligheten till mer betoning av färg och form framför avbildande måleri, som gavs med hjälp av vattenfärgsmåleri, användes dock inte i särskilt stor utsträckning i de vinnande tävlingsbilderna från FIB. ${ }^{429}$ Det var överlag mycket föreställande och mycket noggrant målade bilder, ofta med många detaljer och ett korrekt perspektiv, som fanns bland de vinnande bilderna. Både bland barnen själva, deras lärare och även juryn, var det tydligt att den avbildande naturalistiska diskursen var dominerande, trots att FIB uppmanat barnen i tävlingarnas anvisningar att använda sin "fantasi" och inte teckna av. Utvecklingspsykologins idéer om att realismen var målet för barns bildskapande var fortfarande dominerande. ${ }^{430}$

Förutom nya material som användes för bildernas tillverkning spelade förändrade trycktekniker roll för bildernas spridning och reproduktion, och vilka bilder som valdes ut. FIB poängterade att vissa bilder inte kunnat tryckas i tidningen, då tidningen trycktes i svartvitt. Färgbilder med lite konstraster fungerade därför dåligt att reproducera, därför valdes kontrastrika bilder som exempel på vinnarbilder.

När Televerkets marknadsavdelning 1976 presenterar förslaget att använda barnbilder på telefonkatalogernas omslag för de olika regioncheferna, poängterar man att det nu gick att göra 4-färgstryck, "utan nämnvärd merkostnad". Det var inte bara det att det fanns önskemål om ett "mera färgglatt yttre" på katalogen, man hade nu också med den nya tekniken möjlighet att genomföra det utan att det blev för dyrt. ${ }^{431}$

För att få de "levande och färgglada" omslag till telefonkatalogerna som Televerket önskade, skrev man tydligt i information till skolorna om tävlingen, att man vill att materialet barnen i trean skulle använda var oljepastellkritor. ${ }^{432}$ Det blev bra tryck om det var kraftiga färger, men det gjorde också att det var svårare att göra mindre detaljer, då kritorna var ganska trubbiga. Materialvalet underlättade för att åstadkomma naiva och enkla barnkonstbilder. Dessa kritor var också billiga och fanns i de flesta skolor, och det var möjligt att få fram måleriska effekter då färgerna kunde blandas med varandra. På bilderna som skickades in tävlingen, ser man att barnen ibland valde att trots förskrifter använda blyertspennor, tuschpennor, eller kritor, för att kunna göra mindre detaljer, i ansikten, kläder eller liknande. ${ }^{433}$ Likaså syns att juryn ofta, men inte alltid, valt bilder med mycket detaljer som vinnarbilder, trots anvisningar om att använda trubbiga kritor.

På "stoppa sabbet" tävlingen mellan 1980 och 1990 för årskurs sex efterfrågade Televerket nya arbetsformer, i sina instruktioner till skolorna. 1984/85

${ }^{429}$ Den färgbild i albumet Sverige genom barnaögon som tydligt använder teknik där färgerna flyter in i varandra, är inte ifrån Folket i bilds tävling utan kommer från Sacha och Siri Faith Els skolklasser.

${ }^{430}$ Med att teckna ur sin fantasi uppfattades som jag tidigare diskuterat angående Stuhlman, att inte teckna efter en exakt förlaga.

${ }^{431}$ Ibid.

432 Marknadsavdelningen; Televerket telemedia Omslag till rikstelefonkataloger 1977 F2A:1 Riksarkivet.

${ }^{433}$ SBBA Televerket samling Telefonkataloger Se tex Malmö 2003:009, Gävle 2003:002 
skriver man "Om du och dina kamrater vill måla, fotografera eller använda någon annan teknik är helt upp till er. När tävlingsjuryn bedömer bidragen är det idén som är viktigast" ${ }^{434}$ I arbetsmaterialet som skickas ut till skolorna 1988 fanns för eleverna en genomgång av skådespelaren Lasse Åbergs "affischskola", där han beskriver att han även arbetar som grafisk formgivare och därför kunde ge tips om hur man gjorde en bra affisch. ${ }^{435}$ Affischerna i A3 format skulle väcka intresse "genom en kul eller annorlunda" bild eller text. Nu önskade Televerket att eleverna skulle arbeta i grupp, och att det var idén som var det viktiga inte vilket material den var utförd $i$. Varje år framhöll man också vikten av att det gick bra att använda foton eller collage av olika material, men bilderna som skickas in var trots detta ofta traditionellt framställda med blyertspenna, kritor eller tuschpennor. ${ }^{436}$

Det är tydligt att arbetet med färg var viktigt för teckningstävlingarna, i FIB:s tävling handlade det om vattenfärg och i Televerkets oljepastellkritor. Barnens "färgglädje" ansågs viktig att uppmärksamma, både under 1940-talet och 1970-talet. Här var också de nya möjligheterna med trycktekniker i färg viktiga för telefonkatalogens tävling. Under 1980-talets "Stoppa Sabbet" tävling efterfrågade Televerket större affischer som skulle synas bra på långt håll. Här var det inte utförandet utan idén som juryn sa sig bedöma. Eleverna uppmanades att använda nya tekniker som foto och collage, att det inte fick genomslag kan bero både på elevernas eller lärarnas brisande intressen eller skolans bristande tillgång till material. Trögheten vad gäller förändringar i skolans praktiker kan bero på flera saker, bland annat bristande tillgång till och kunskap om ny teknik. Andra faktorer som kunde ha betydelse för de olika tävlingarnas materialval vara barnens olika åldrar, och var bilderna gjordes, något jag diskuterar i nästa avsnitt.

\section{Ålder och plats}

Var tävlingarna gjordes och vilka barn arrangörerna vände sig till såg olika ut i olika tävlingar. Vad var anledningen att dela in i ålderskategorier och varför vill arrangörerna ha bilder gjorda i skolan, eller bilder gjorda hemma?

FIB menade att för att priserna ska upplevas som rättvisa delade de in skolbarnen i olika tävlingsgrupper; A-skolor under 11 år, A-skolor över $11 \mathrm{ar}$, och B- och C skolor. ${ }^{437}$ Barnen delades alltså både upp efter ålder, och efter typ av skola, som visade om flera klasser läste tillsammans eller inte. FIB använde sig som jag tidigare nämnt av skolan som ett sätt att nå ut till många barn. Barnens kreativitet ansågs inte hämmas, utan snarare främjas av skolans tillgång till material och lärarkunskap, vilket exempelvis åskådliggörs av bilden på lärarinnan

\footnotetext{
434 SBBA Arkiv Televerkets informationsfolder Stoppa Sabbet 1984/85.

435 SBBA Arkiv Televerkets tävling stoppa Sabbet, informationsfolder 1988.

436 SBBA arkiv Televerkets tävling Stoppa sabbet, informationsfolder, se även bild 2:15.

437 Se tex $1941 \mathrm{nr} 9$ sid. 29: "För att alla skolor kunna deltaga och ha samma utsikter till pris uppdelas de deltagande skolorna i grupper, varför exempelvis en C-skola har lika stor chans till pris som en A-skola.”(A-skolor är där alla i en årskurs läser gemensamt, B-skolor där det är samläsning med två klasser, och c -skolor där det är samläsning med tre klasser. B- och C-skolor förkom främst på landet där det var lite barn/långt till skolan).
} 
som visar hur man tecknar perspektiv i avsnittet Tävlingen i praktiken. ${ }^{438}$ Tävlingen riktade sig till alla skolbarn mellan sex och femton år. ${ }^{439}$ Yngre och äldre barn delades upp, "varför de yngre ha samma chanser som de äldre". ${ }^{440}$ FIB:s tävlingskommitté skriver 1939: "Konkurrensen har givetvis varit störst i de äldre grupperna, och bedömningsgrunderna har varit hårdare och strängare just där, som sig bör." ${ }^{411}$ Med stigande ålder blev alltså konkurrensen svårare och bedömningen hårdare, och att de äldre barnens bilder uppskattades syns även genom att vinnarbilderna från FIB:s tävling som sparats i Nationalmuseums samling, oftast är gjorda av äldre barn.

FIB formulerade sig på följande sätt angående B-och C-skolor inför tävlingen "Min Fritid" 1940, under rubriken Alla kunna deltaga:

Tyvärr händer det då och då att vi få höra sådana uttryck som: 'Vi kan inte vara med, vi är för dåliga. Vår skola är bara C-skola. Inte kan vi konkurrera med stadsskolorna!'. Alltihop det där är nonsens. För det första framgår det av tävlingsbestämmelserna att de tävlande uppdelas i olika klasser, både beträffande skolform och ålder. Och för det andra så visa resultaten i de föregående två tävlingarna, att barnen på landsbygden teckna minst lika bra som de i städerna. Och kan någon förresten säga varför de inte skulle göra det? Nåja, de flesta vet ju det där men vi vill $i$ alla fall ha det sagt, för att förebygga att någon mer ska gå omkring och känna sig underlägsen. ${ }^{42}$

Citatet visar hur relationen mellan stads- och landsbygdsskolor inte självklart var likvärdiga, där landsbygdens barn positionerades i en självpåtagen underlägsenhet. Uppdelningen mellan A-skolor och B- och C-skolor bibehölls, trots att tidningen menade att "de på landsbygden teckna minst lika bra som de i städerna”. Att det hos juryn fanns en oro att B-och C-skolor inte skulle prestera, eller tro sig om att prestera, lika bra som städernas A-skolor, var en farhåga som man också kunde se gällde generellt för skolprestationer, då skolöverstyrelsen i 1955 års presentation av försöksverksamheten för nioårig grundskola under rubriken "Om skolpliktstidens längd och enhetsskole-principen" skrev att förlängning av skolpliktstiden tillkommer för att nå ett medborgerligt likvärdigt utbildningsmål och "... att möjligheter borde skapas för att bringa upp den egentliga landsbygdens system till en nivå, som bättre tålde jämförelse med tätorternas." ${ }^{443}$

Här uttalades att landsbygdsskolornas utbildningsnivå var sämre än stadsbarnens, och ansågs öka likvärdigheten då hemmets stöd visade sig vara otillräckligt. Genom den nioåriga grundskolan hoppades Skolöverstyrelsen uppnå

${ }^{438}$ Liksom diskussionen i teckningslärarnas tidskrift Teckning, som jag diskuterade i avsnittet Tävlingarnas utformning, anvisningar och priser.

${ }^{439}$ Priserna är indelade i under 11 år och över elva år; i Sverige genom barnaögon skriver man i förordet att tävlingen varit för barn mellan sex och femton.

${ }^{440}$ FIB 1940 nr 8 sid. 29.

${ }^{441}$ FIB 1940 nr 8 sid. 29.

${ }_{442}$ FIB 1949 nr 8 sid. 28.

${ }^{443}$ Timplaner och huvudmoment vid försöksverksambet med nioårig enhetsskola. 2. tr. (1956) Stockholm: Sv. bokförl. (Norstedt) sid. 10. 
större likvärdighet mellan stad och landsbygd. FIB poängterade att det var en delvis självpåtagen myt hos barn i b- och c-skolor att de inte kunde teckna. Tävlingen var ett sätt att visa alla svenska elevers kunskaper och förmågor och därigenom utjämna konflikten mellan stad och landsbygd och undvika "att någon mer ska gå omkring och känna sig underlägsen”.

I Posten/Arlas tävling 1976 "Detta vill jag värna om" skrevs i instruktionerna att det var en "teckningstävling för alla killar och tjejer", utöver det var inget angivet om ålder eller plats. ${ }^{444}$ Där deltagares ålder angavs på inskickade bidrag är det alltifrån fyra till femton år. ${ }^{445}$ Bidragen var främst inskickade hemifrån men några även från förskolor och skolor. Att bilden skickades hemifrån syns på att det inte står på avsändaren vilken klass hen går i, och att den som skickade in angav sin hemadress, och inte skolans adress. De tävlingar som hade personliga, kommersiella priser gjordes hemma, som exempelvis "Min önskejulklapp", från 1961, där man kunde vinna det man ritade. Konsums tävling "Rita konsum-tomten" från 1988 är "för alla som har barnasinnet kvar" vilket såklart kunde vara fler än barn. Även i Svenska Turistföreningens (STFs) tävlingar "Sverige är fantastiskt" 1978 och 1979 skickades bilderna oftast från hemadresser. Turistföreningen hade olika priser för olika åldrar 0-6, 7-10, 11-13 samt 14-16, alla priser var en vecka i en STF stuga i Sverige, och resebidrag. Priserna var anpassade efter barnen ålder, så priset kunde här vara en anledning till åldersindelning, utöver barns teckningsförmåga i olika åldrar. Priserna riktades till familjen. När priser gick till familjen och inte till skolklasser är även det ett tecken på att bilderna gjordes utanför skolan.

Televerkets marknadsavdelning menar inför den första tävlingen till telefonkatalogens omslag att årskurs tre är lämpligt eftersom:

Vi har också via egna iakttagelser och samtal med teckningslärare förvissat oss om att vi kan förvänta oss bra alster ur dekorativ synpunkt från 9-10-åringar. Den allmänna bedömningen är att 9-10-åringen ofta har kvar sin skapande spontanitet. ${ }^{446}$

Här har tanken om att den skapande spontaniteten försvinner med åldern fått genomslag på ett helt annat sätt än under 1940-talet, och för att få de spontana bilder man önskar valde Televerket att rikta tävlingen mot just årskurs tre.

Europarådets tävlingar liksom Televerkets "Stoppa sabbet" tävlingar var riktade mot skolan, men mot äldre barn, 12-16 åringar respektive 12-åringar. ${ }^{447}$ Med stigande ålder förväntades andra bilder, men kanske var det framförallt tävlingens möjlighet till kunskapsförmedling, snarare än barnkonstbilder, som var det arrangörerna hoppades att uppnå.

Uppdragen påverkades alltså både av vad barn förväntades kunna bidra med och vad de förväntades ha behov av att lära sig, både i olika åldrar och på olika

\footnotetext{
${ }_{444}$ Det finns inte någon tävling där pojkar och flickor skulle tävla separat.

445 Skolbilderna är ofta i enhetligt material, t.ex. akvarellfärg eller pastellkritor, där bilder gjorda hemma ofta använder enklare teknik och material.

${ }_{446}$ Riksarkivet Arninge Televerkets Skrivelse från Marknadsavdelningen 1976-01-22.

${ }^{447}$ Europarådet arrangerar även uppsatstävlingar för 12-16 och 16-19 år.
} 
platser. Därutöver kunde de påverkas av vad arrangörerna uppfattade kunde intressera barn, speciellt de tävlingar som riktade sig till barn i hemmet. Jag har även visat att önskvärt och förväntat kunnande, liksom lämpliga priser kunde spela roll för åldersindelning av barnen. I FIB:s tävling delades barnen in både efter ålder, och efter om det är en stad- eller landsbygdsskola. I FIB ansågs högre ålder och därmed ökad kunskap i teckning öka möjligheterna att vinna, och stadsskolor kunde eventuellt ha bättre möjlighet att förmedla kunskap än landsbygdsskolor. FIB:s jury ansåg inte att de yngre barnen kunde tävla med de skickligare äldre barnen, vilket var en helt motsatt syn mot Televerkets på 1970-talet. Televerket förväntade sig 1976 specifikt dekorativa bilder av yngre barn, som hade kvar sin "skapande spontanitet". Skolan har även varit en plats för arrangörer att nå ut med moraliska budskap, och överföra lämpliga normer och värden, mot slutet av perioden uttalat när tävlingarna vände sig till äldre barn.

Vi ska nu titta närmare på vilka olika teman och motiv barnen har fått i uppdrag att teckna, och hur dessa teman kan förstås både utifrån arrangörernas syn på barn, och förändrade samhällsstrukturer över tid.

\section{Tävlingarnas teman}

Som jag visat var en grundförutsättning för tävlingarna att barns bilder av arrangörerna har antagits kunna intressera och inspirera både vuxenvärlden och andra barn. Barnbilden i sig var intressant, men vad sa arrangörerna att de ville att barnen skulle måla och varför? Hur formulerade arrangörerna de motiv och teman barnen ombads att teckna, och vilka förändringar syns över tid? Uppdragens innehåll har delvis förändrats över tid i de fall det handlar om samma arrangörer, med det har också sett olika ut beroende på vem som varit arrangör. Som en del av analysen har jag efter genomgång av samtliga tävlingar i SBBA:s samlingar identifierat fem centrala teman. Hembygds- och Nationstema, Jul- och högtidstema, Framtiden, Internationell rättvisa och barns rättigheter, samt Natur, Miljö och Trafik. ${ }^{448}$ Ibland kan temana vara överlappande vilket jag återkommer till. Uppdragen till barnen har ibland varit komplexa och svåra att enkelt definiera men ändå kunnat rymmas inom ramen för dessa övergripande teman. Hembygds, Jul-och Framtidstema finns representerade under hela undersökningsperioden 1938-2000. Internationell rättvisa och barns rättigheter och Natur, Miliö och Trafik kommer först under 1970- 80-talet, vilket redan detta indikerar en förändrad syn på barn och barndom. Förutom de tävlingsuppdrag som jag tematiserat som grundläggande och framträdande i materialet, finns andra uppdrag som enbart förekom i en eller ett par tävlingar, och som inte ingår i de teman som nämns ovan. Min Stenmark arrangerad av DN 1978, liksom Idolen arrangerad av SVT 1978 är exempel på tävlingar där det man tänkte sig var barns intressen lyftes fram, och barn ombads teckna sina idoler. Likaså fanns tävlingar som refererade till den etablerade bildkonsten. Redan 1949 har Jämt-

${ }^{448}$ Se bilaga 1 tävlingarnas teman. Observera att det enbart är tävlingarna i SBBA:S samling som ligger till grund för dessa kategorier, och inte tävlingar i tidskriften Teckning i föregående redovisning, då dessa ofta har väldig knapphändig information. 
lands länsmuseum en tävling med namnet konstens vecka, KP har 1988 tävlingen Mitt självporträtt, och Nationalmuseum slutligen 1999 Barns självporträtt. Självporträttet kan ses som ett etablerat konstnärligt motiv, och som, även om underlaget endast är tre tävlingarna ändå kan sägas ha varit återkommande över tid mellan 1949 och 1999. Även Bokförlaget Natur \& Kulturs Skattkammartävling 1988 ett exempel på när barn ombads teckna sagoillustrationer, vilket även förekommer i vissa temasamlingar i SBBA, som inte ingår i min studie. ${ }^{449} \mathrm{I}$ den följande analysen kommer jag att diskutera de olika temana, och även visa något bildexempel som får representera temat.

\section{Nations- och hembygdsbilder}

Nations och hembygdstema har, som påpekats ovan funnits med under hela perioden och väcker frågor om hur tävlingar förehållit sig både till hembygd och övernationella enheter som EU. Här ligger fokus på vilka arrangörer som har velat visa upp barnbilder av hembygden eller nationen.

FIB:s första tävling hade temat "Livet i vår skola", och den andra tävlingen hade temat "Livet $i$ vår hembygd". Skolan och Hembygden ansågs således vara relevanta platser och teman för barnen att gestalta. Genom skolan och tävlingen iscensattes bilden av barnen som del av den gemensamma skolan, skolan som en del av hembygden, och hembygden som en del i ett gemensamt nationsbygge. Televerket hade olika former av hembygdstema mellan 1977 och 1981, samt 1985. Televerket kom i samråd med SÖ överens om att deras tävling var lämplig att genomföra inom ämnet hembygdskunskap, och hembygdsbilder fungerade även bra som omslag för telefonkatalogerna då de var indelade i olika regionala delar. Genom bilderna på telefonkatalogernas omslag betonades regionerna som del av en nationella gemenskap. ${ }^{450}$

Men även andra arrangörer såg nation och hembygd som relevanta teman. Europarådet, EG, och Europeiska kulturstiftelsen hade som jag nämnt, från 1953 en återkommande tecknings- och uppsatstävling, som genomfördes i flera Europeiska länder. ${ }^{451}$ Från 1959 års tävling finns bilder bevarade på SBBA; ett tema eleverna kunde välja var då: "Rita eller måla något, som du tycker är typiskt svenskt" (bild 2:6). Bildexemplet visar ett bidrag till Europeiska kulturstiftelsens tävling 1959 "måla något som du tycker är typiskt svenskt" Syftet som uttalas är att visa upp Sverige i Europa. Exempelbilden visar ett collage av motiv som var vanligt även på flera andra bilder i tävlingssamlingen: Kyrkan, barn i skolan, tre kronor, midsommarstång, man som borrar, man med samisk mössa och kåta i bakgrunden, man som fiskar, man som hugger träd och man som gräver.

Enligt tävlingsinstruktionerna var tanken att de olika ländernas bidrag (1959) sedan skulle bli väggmålningar i en samlingssal i en skola i Luxemburg där det gick barn från hela Europa. Några av utskicken till skolorna finns bevarade men det är oklart hur många skolor som deltagit och samlingen från 1959 är inte

\footnotetext{
449 Alla samlingarna syns i tabell 1

${ }^{450}$ För vidare analys se kapitlet Sverigebilder.

451 Tidskriften Bild i Skolan Nr 11983 sid. 4.
} 
större än 57 bilder. ${ }^{452}$ Det man kan se på dessa bilder är mycket folkdräkter, samer i traditionella kläder, midsommarfirande, kyrkor, svenska flaggor, och Nils Holgersson som flyger på gåsens rygg över Sverige. Även sådant som är svenska exportvaror, som timmer eller järnmalmsbrytning, finns representerat i flera bildexempel. Sveriges turistråd och Svenska turistföreningen arrangerade 1978 och 1979 tävlingen "Sverige är fantastiskt" för barn mellan 6 och 16 år. Uppdraget var att teckna eller måla någon fin sommarupplevelse i Sverige. Bild 2:7 visar ett av bidragen; ett rött hus, sol, midsommarstång, och en svensk flagga. I denna samling finns många bilder av röda stugor, midsommarstänger, sol och bad, olika naturbilder, att rida på häst, simma eller tälta. Ytterligare hembygds- och landsbygdstema syns i Nils Holgersson samlingarna från 1987-89, och 1996. Teckningstävlingen "I Nils Holgerssons spår" arrangerades av Sunne Hembygdsförening, Tidningen VI, Sas och Linjeflyg 1987-89, under parollen "Fyran får Flyga!" då den riktade sig till årskurs fyra ${ }^{453}$ (bild 2:8). Uppdraget var att illustrera en scen ur åttonde eller nionde kapitlet ur Selma Lagerlöfs berättelse, där Nils Holgersson efter att ha blivit förvandlad till en pyssling kunde han höra djuren tala, och han hör att gässen vill skydda honom mot räven. Nils, som tidigare var elak mot djuren på gården där han bodde, lär sig genom gässens omsorg att tycka om andra och att vara vänlig mot både djur och människor.

Selma Lagerlöfs berättelse om Nils Holgersson från 1906, som länge användes som lärobok i geografi i svenska skolor, var dels en sedelärande berättelse om tonårstiden och om vikten av att lära sig att vara hjälpsam och att inte vara lat, men handlade också om att uppmärksamma skolbarn kring det gemensamma nationella projektet, där Nils på gåsens rygg flyger över alla svenska landskap. ${ }^{454}$ Bilderna från samlingen I Nils Holgerssons spår visar motiv från berättelsen, ofta även med andra djur, eller landskapsmotiv sett uppifrån med Nils Holgersson på gåsen. Uppdraget från 1996, "Nils Holgerssons resa i nutid" arrangerades i ett samarbete mellan Utbildningsradion och Sveriges hembygdsförbund. Här ville man kombinera Nils Holgersson berättelsen med kunskap om och bilder av den samtida hembygden 1996. I informationsfoldern om tävlingen omtalas att det 1996 var 90 år sedan Selma Lagerlöfs bok om Nils Holgersson kom ut. Utbildningsradion visade då också på TV korta program från Sveriges 27 landskap, där barn varit delaktiga i att göra filmerna, och där några av teckningarna barnen gjort visades upp. ${ }^{455}$ Troligt är att både hembygdsföreningen, som var medarrangör i båda dessa tävlingar, och Utbildningsradion, såg som syfte både att generera barns delaktighet och kunskap om hembygden. Förutom kännedom om hembygden hos barn, kunde arrangörerna även skapa intresse för Selma Lagerlöfs berättelse hos en ny generation.

452 SBBA samling 2005:019 Europeiska skoldagen 1959.

${ }_{453}$ SBBA samling 1989:040.

454 "Swedish childhoods from the Era of Great Power to the Welfare State" I Ogata, Amy Fumiko \& Weber, Susan (red). (2014). Swedish wooden toys. New Haven: Yale University Press sid. 37-38.

${ }^{455}$ Tidskriften Abrakadabra nr 21996 sid. 30, samt Infoblad SBBA till samling nr 1996:008 samlingen är ett uppdrag till utvalda skolklasser, och inte i uppropet definierad som tävling, även om den är arkiverad som tävlingssamling. 


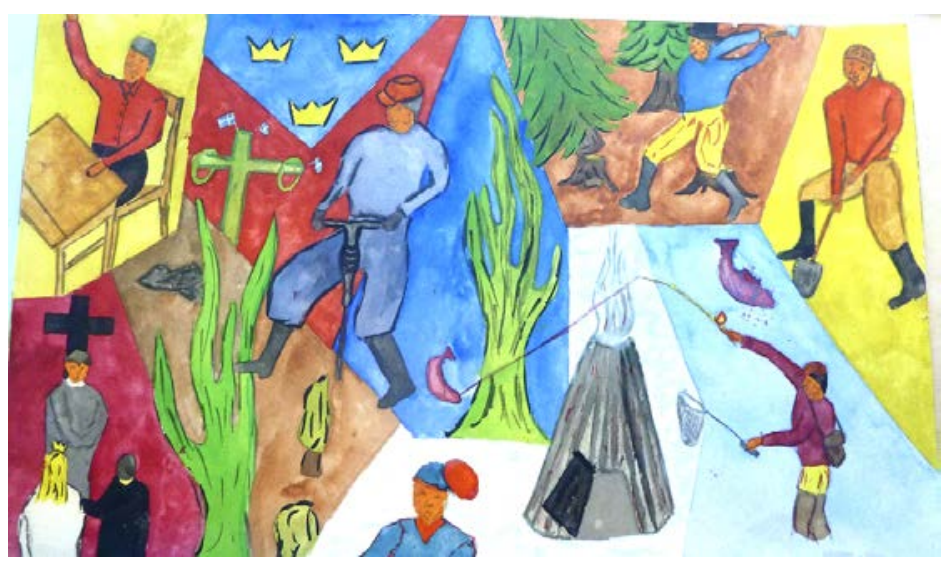

Bild 2:6. Europeiska skoldagen Måla något typiskt svenskt, arrangerad av Europarådet, EG, och Europeiska kulturstiftelsen 1959.

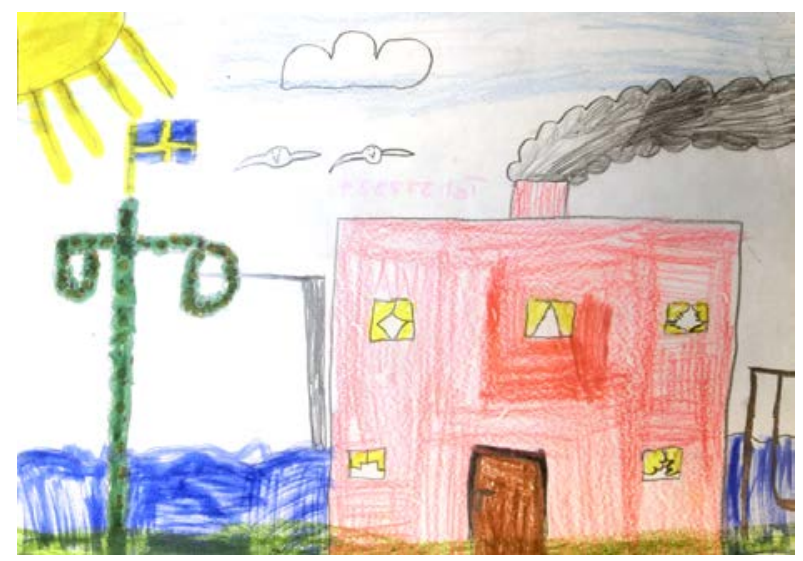

Bild 2:7. Sverige är fantastiskt, arrangerad av Sveriges turistråd och STF 1978.

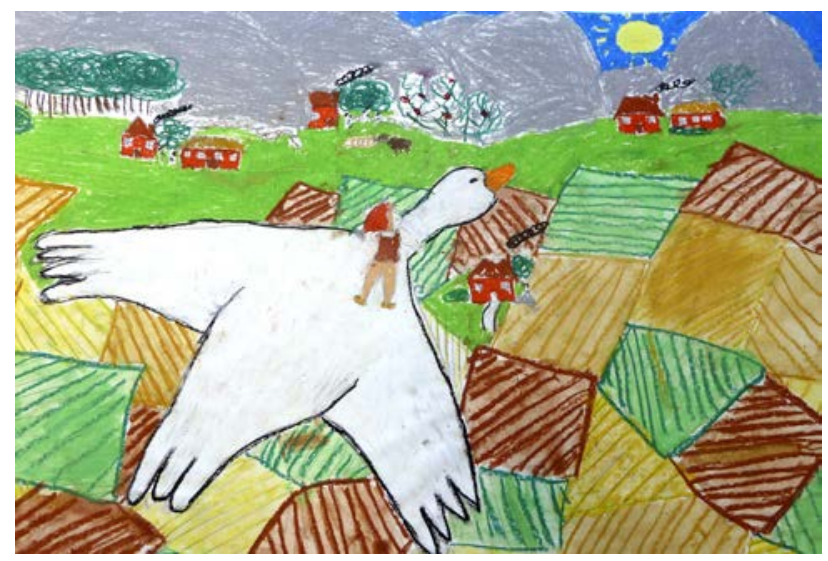

Bild 2:8. I Nils Holgersons spår, arrangerad av Hemmets Journal, Sas/Linjeflyg och Sunne hembygdsförening 1989. 
Som vi kan se har Hembygden varit ett frekvent tema, något som delvis kan förstås genom att hembygdskunskap var ett skolämne mellan 1919 och 1980.456 Aktiva hembygdsföreningar liksom inrikesflyget kunde se fördelarna av att öka intresset för Sveriges olika regioner, och därigenom en ökning av inhemskt resande och turism. Barns Sverigebilder kan under slutet av undersökningsperioden även användas i syfte att skapa intresse för Sverige som turistland. I STF:s tävlingar "Sverige är fantastiskt" är syftet just att öka intresset för turism inom Sverige. I de tidigare internationella EU-tävlingarna med nationella teman frågar Europeiska kulturrådet efter det specifikt svenska, men då som en del av en Europeisk gemenskap. Tävlingarna visar hur den nationella och regionala hembygden förstärks genom att ingå i ett större globalt sammanhang.

Ett annat tävlingstema som återkommer under hela undersökningsperioden är firandet och tecknandet av julen.

\section{Jul och högtider}

Teckningstävlingar med julen som tema har arrangerats under hela perioden, ofta av tidningar. Som jag diskuterade i föregående avsnitt var firandet av midsommar också ett vanligt bildmotiv i hembygds- eller Sverigeteman. Det förekommer dock inte som ett avgränsat eget uppdrag till barnen. Således innebar detta att tävlingarnas uppdrag och barnens val av motiv kan vara helt olika saker. FIB har 1944 temat "Svenskt helgfirande", här är jul- och midsommarbilder i majoritet av de vinnande bilderna, men de bilder från detta tema som valdes ut för publikation i färg i tidskriften "Sverige genom barnaögon" visar Valborgseld, kräftkalas, och Svenska flaggans dag. Kanske valde man medvetet andra högtider än de två vanligast förekommande. Förutom FIB:s tema Svenskt helgfirande har alla de andra tävlingarna under denna rubrik julen som tema. Den tidigaste tävlingen i SBBA:s samling där julen var med i tävlingens namn var "Min roligaste jul" arrangerad av DN $1955 .{ }^{457}$ I DN skrev man 1959 att det var DNs 9:e julteckningstävling, så tävlingarna pågick alltså mellan 1950 och 1959, och eventuellt längre fram i tiden, även om SBBA bara har bilder från 1955. ${ }^{458}$ Bilderna från "Min roligaste jul" visar exempelvis när det avslöjas vem som är tomten bakom masken, eller när barnen var med i julspel i kyrkan.

Ingegerd Rydin diskuterar att specifika barnprogram som har sänts vid jul i Sveriges radio och TV, varit en återkommande tradition över hela den period hon undersöker mellan 1925 - 1999. Däremot var firandet för barn ganska stillsamt när det enbart var radio, men med TV ökade julprogram både generellt och specifikt för barn. Den första julkalendern i TV sändes 1960. De tidiga julkalendrarna innehöll sällan religiösa inslag, skriver Rydin, utan kunde snarare berätta om julpyssel, jullekar eller hur man firade jul på landet. ${ }^{459}$ Några av julkalendrarnas teman som Rydin benämner i sin analys är dels "Att drömma sig bort och bakåt i

456 Ämnet hembygdskunskap återkommer jag till i kapitel 3.

${ }^{457}$ Redan 1944 arrangerade FIB Svenskt helgfirande.

${ }^{458}$ DN 1959-12-24.

459 Rydin, Ingegerd (2000). Barnens röster: program för barn i Sveriges radio och television 19251999. Stockholm: Stift. Etermedierna i Sverige sid. 334. 
tiden" och dels "Jultradition". Dessa teman är synliga också i teckningstävlingar med julen som tema. Bilder av jul har traderats över generationer också genom Jenny Nyströms julkort, som skapat föreställningar om den svenska tomten. ${ }^{460}$ Från 1968 finns samlingen "Jul på landet" arrangerat av DN/Kamratposten. Här är motiven mestadels små tomtenissar vid julgrötsfat, olika julmat, interiörer från hus med juldekorationer eller vinterbilder.

Julteckningar, med temat "julkort" arrangerades av Eskilstuna-Kuriren 1978, och jul-vinterbildstävling arrangerades återigen av Kamratposten 1982. Tävlingarna som ett sätt att skapa konsumtion och efterfrågan, syns exempelvis i "Min önskejulklapp" från 1961. Det var en landsomfattande tävling och parollen var "Önska vad du vill... och du kan vinna vad du vill!" Rita hur du tänker använda din önskeklapp... OCH DU KAN FÅ DEN! Tävlingen var öppen för alla barn mellan 3 och 12 år, och skulle skickas in till "Tomten" i Sundbyberg. ${ }^{461}$ Barnen tecknade till exempel rullskridskor, skidor, skridskor, tågbanor eller dockor. Konsum Sörmland hade 1987 en tävling som man kallade "Rita Konsum-Tomten!” Vi ser här ett exempel av de bilder som finns i samlingen (bild 2:9). Enligt informationsmaterialet sattes bilderna upp i varuhusen runt om i Sörmland och det delades ut "roliga priser till de roligaste teckningarna". ${ }^{462}$ Tävlingen riktade sig enligt annonsen till alla som oavsett ålder "hade barnasinnet kvar". Majoriteten av deltagarna var barn, enligt de ålderbeteckningar som finns på bilderna. Att bilderna gjorde reklam för Konsum är givet i och med tävlingens namn, och den var inte

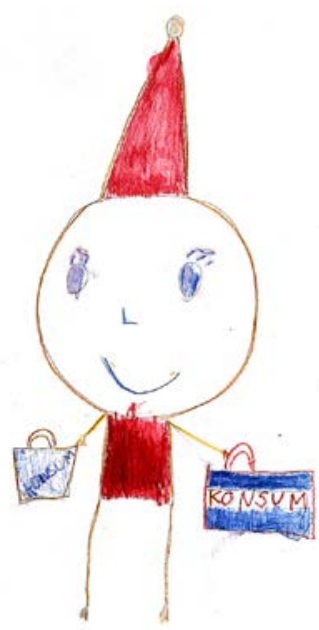

ANNA UTAS 5\%

Bild 2:9 Rita Konsumtomten, arrangerad av Konsum Sörmland 1988.

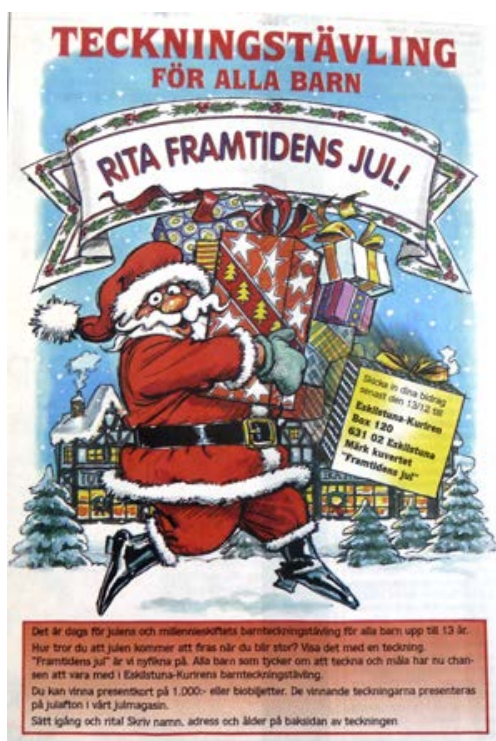

Bild 2:10. Eskilstunakuriren 24 dec.1999 sid.12-13.

\footnotetext{
${ }^{460}$ Se t.ex. Forsberg Warringer, Gunnel \& Nyström, Jenny (1999). God jul med Jenny Nyström. [Ny utg.] Stockholm: Forum.

461 Infoblad SBBA diarienr 2005:020.

462 SBBA arkiv 1988:010 Konsum-tomte.
} 
genomförd i skolan utan troligen hemma, vilket också syns då papper och pennor är av skiftande sorter.

Det finns ytterligare en jultävling från Eskilstuna-Kuriren i SBBA:s samling, denna från år 1999 hade temat "Framtidens jul”(bild 2:10). Barn upp till 13 år var inbjudna att delta med bilder av "Hur tror du att julen kommer att firas när du blir stor?" Vinnarbilden visade en tomte som delar ut presenter runt jordklotet med hjälp av en rymdsnowboard. ${ }^{463}$ Uppdraget "Framtidens jul" visar vad barn förväntades rita och vad barn förväntades fira, både nu och i framtiden. Den visar också att samlingar kan definieras och ordnas på flera olika sätt, i detta fall både som jul- och som framtidssamling. "Framtidens jul” visar alltså också framåt mot nästa tema, och att barn på många sätt förväntats ha åsikter och idéer om framtiden.

Att just tidskrifter och affärer ordnade tävlingar med jultema kan ha flera förklaringar. Julen har under perioden varit en inarbetad samhällelig tradition med tydliga figurer och artefakter som barn även lärde sig teckna i skolan. ${ }^{464}$ Det faktum att det var skollov vid jul och barn var lediga från skolan, kunde ge tidningar anledning att anordna teckningstävlingar som fritidssysselsättning, eller julpyssel. Företag eller tidningar kunde också just vid jul vilja ge "julklappar" eller vinster för att skapa positiva associationer hos sina kunder och läsare. Tävlingarna kunde användas i kommersiella syften för att skapa efterfrågan för företags produkter. De kunde även överföra traditioner och värderingar kring julen.

\section{Barnet som framtiden}

Framtiden var ett uppdrag som återkom i teckningstävlingar på olika sätt över åren. Temat för FIB:s teckningstävling 1942 var "Vad jag vill bli när jag blir stor" ${ }^{465}$ (bild 2:11). På bilden ser vi en telefonist som sitter med ryggen mot oss och arbetar med att koppla fram telefonsamtal. Bilder från denna tävling återkommer i analyser i kapitlet Bilder av flickor och pojkar. Denna bild aktualiserar också hur teknikförändringar innebär att framtider förändras, då det som en gång var ett tänkbart framtidsyrke inte längre finns kvar. Framtida teknik är också tydligt i bilderna från Konsumentverkets tävling 1984 "Konsument 2000". Eleverna i mellanstadiet ombads att i ord och bild tala om hur de trodde det skulle bli att vara konsument år 2000 eller hur de skulle önska att det blev. Förväntad teknikutveckling är tydlig i bilderna. Det kan skildras som positivt genom att man kan trycka på en knapp och maten kommer hem, rymdfärder och robotar kan ordna världen till det bättre, men även skräckskildringar av hur teknik används för att förstöra. ${ }^{466}$ Inom ramen för världsungdomsåret 1985 inbjöd fritidsdistrikt Stockholm tre högstadieskolor till en tävling kallad "Söder år 2001”. Det var elever i årskurs åtta och nio som deltog, och de skulle i ord och

${ }^{463}$ SBBA arkiv Eskilstunakuriren "Julextra” 24 dec.1999 sid. 12-13.

${ }^{464}$ T. ex. Sjöholm, L. Gottfrid, Handledning vid undervisningen i hembygdskunskap. 1, Första skolåret, 3. uppl., Sv. bokförl. (Norstedt), Stockholm, 1919 Färgplansch 13 och 14.

${ }^{465}$ Denna tävling återkommer i bildanalyser längre fram.

466 Bild i skolan $\mathrm{nr} 21985$ sid.37. Barns framtidssyn En analys av mellanstadiebarns bidrag till tävlingen konsument 2000 (1985) Konsumentverket/ SBBA. 
bild ge skildringar av sin stadsdel och sitt liv år 2001. Man beskrev att man vill få fram "ungdomars drömmar, visioner och farhågor". ${ }^{467}$ Uppsalahem AB firade 1986 40-årsjubileum och anordnade då en teckningstävling för elever i årskurs tre i Uppsala, med temat "Framtidens boende". I Televerkets affischtävlingar på 1990-talet var framtiden en del av temat, till exempel i "Tittofonresan" från 1992, där elever i årskurs sex ombads uppfinna och teckna en tittofon som man kunde resa med i tid och rum. Liknande tema fanns i "Den gränslösa världen" från 1993 där barn i bild skulle beskriva hur en framtida teleresa i en gränslös värld kunde se ut - eller hur "resemaskinen" skulle se ut. Sörmlands museum och Svenskt barnbildarkiv samarbetade under 1999 kring projektet "Framtidstro, när jag blir stor", där bilderna visades dels på konsthallen i Nyköping och i Eskilstuna konstmuseum. Tävlingen var både för förskola, samt låg- och mellanstadium. Att fråga barn om bilder av framtiden var också ett sätt att göra barnen delaktiga och engagerade i framtiden. De är de framtida konsumenterna, de framtida hyresgästerna, de framtida arbetarna och medborgarna, och kanske de som arrangörerna hoppades skulle ha smarta lösningar för framtiden.

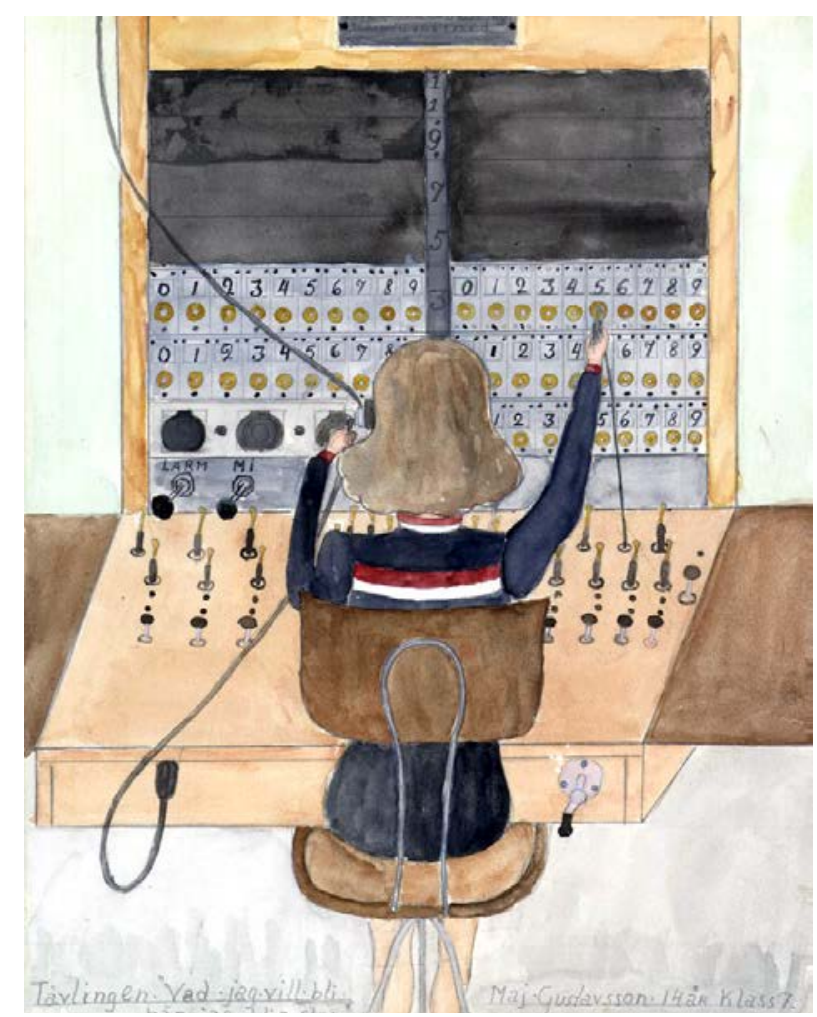

Bild 2:11. Vad jag vill bli när jag blir stor, FIB:s tävling 1942.

${ }^{467}$ Infoblad SBBA samling 1987:028 söder år 2001. 
Att tänka på framtiden kunde handla om hur olika arrangörer och organisationer ville påvisa vad de menade behövde förändras i framtiden. Att ordna en tävling för barn kunde då vara en möjlighet både att nå ut med ett budskap till den nya generationen, och att genom publikation av bilderna visa att barn och unga sympatiserade med arrangörens intressen. Arlas och postens tävling "detta vill jag värna om" är också relevant i förhållande till de olika uppdrag som rörde framtiden. När arrangörerna ger barnen uppdraget att tala om vad de vill värna om, frågar man samtidigt efter vad barn tycker är viktigt att bevara för framtiden. Tävlingen har dessutom en tydlig anknytning till följande tema om Internationell rättvisa och Barnens rättigheter, vilket syns genom boken som ges ut 1977 med titeln "Varför får inte barn bestämma?".

Sammanfattningsvis syns en förändring över tid där arrangörernas frågor runt framtiden efter hand blir mer komplexa. Uppdragen föreslår både positiva och negativa uppfattningar om framtiden och även teknikutveckling kan presenteras som både problematisk eller värdefull. I FIB:s tävling "Vad jag vill bli när jag blir stor" är premisserna självklara, barnen kommer att växa upp och "bli något" när de är vuxna. Tävlingsuppdrag under 1970-talet och framåt innehåller frågeställningar som öppnar upp för barns och ungdomars både förhoppningar och rädslor.

\section{Internationell rättvisa och barns rättigheter}

Teckningstävlingar som behandlar temat Internationell rättvisa innefattar till stor del även barns villkor, och barns rättigheter, vilket är anledningen att de presenteras under samma rubrik. Under detta tema finns dels tävlingar, men även några temasamlingar från Röda korset finns med, då de dels varit utvalda och utställda och även haft ett stort medialt genomslag.

I Tidningen Lutherhjälpen, som var en del av svenska kyrkans mission, presenterades organisationens teckningstävling "SHARE - dela med dig” 1971, genom att understryka hur viktigt det var att både barn och vuxna förstod vikten av att dela med sig till de som ber om hjälp. ${ }^{468}$ Bertil Dovelius från Lutherhjälpen skriver i ett brev 1986 till SBBA: "under ett antal år har vi i Lutherhjälpen bedrivit teckningstävlingar dels på skolor och dels bland konfirmander. 1a pris har varit en resa till något land med många biståndsprojekt. ${ }^{469} \mathrm{I}$ tidningen Lutherhjälpen finns från 1971, 1980 samt 1982, artiklar och bilder från tävlingen. ${ }^{470}$

I denna vinnande bild syns den svenska flaggan, formad av orden "dela med dig” överst i bild och de behövande barnen - till största delen färgade barn - som sträcker ut sina händer mot den svenska flaggan (bild 2:12). Denna bild finns

${ }^{468}$ Lutherhjälpen nr 11971 sid. 5. Lutherhjälpen var tidskriften till hjälporganisationen med samma namn, som var Svenska kyrkans organ för utvecklingssamarbete och humanitärt bistånd 1947-2008. De slogs 2008 samman med Svenska kyrkans mission (SKM), som idag bedriver verksamhet under namnet Svenska kyrkans internationella arbete.

469 SBBA Lutherhjälpens teckningstävlingar 2007:012 I brev till SBBA skriver Bertil Dovelius 1986-07-11 "Under ett antal år har vi i Lutherhjälpen bedrivit teckningstävlingar dels på skolor och dels bland konfirmander. 1a pris har varit en resa till något land med många biståndsprojekt”.

470 SBBA Lutherhjälpens teckningstävlingar 2007:012. 
med som exempel i Jörgen Lissners avhandling "The politics of altruism" från 1977, och i en sammanfattande analys på svenska menade forskarna att tävlingsbilder som dessa var bidragande till att måla upp en bild av att problemen finns "där ute", och att vi i de rika länderna har uppnått vår högre levnadsstandard genom hårt arbete, och det "enda eller viktigaste vi nu kan göra för att minska fattigdom och mänskligt lidande i den tredje världen är att ge mer hjälp." ${ }^{371}$ Lissners slutsats var att det var viktigare att arbeta för en långsiktigt rättvisare fördelning av resurser. ${ }^{472}$

I Lutherhjälpens teckningstävling finns också flera bilder där barn avbildat Lutherhjälpens arbete med att ge exempelvis sjukvård, mat eller kläder. I samtliga bilder är de som ger vita biståndsarbetare och de

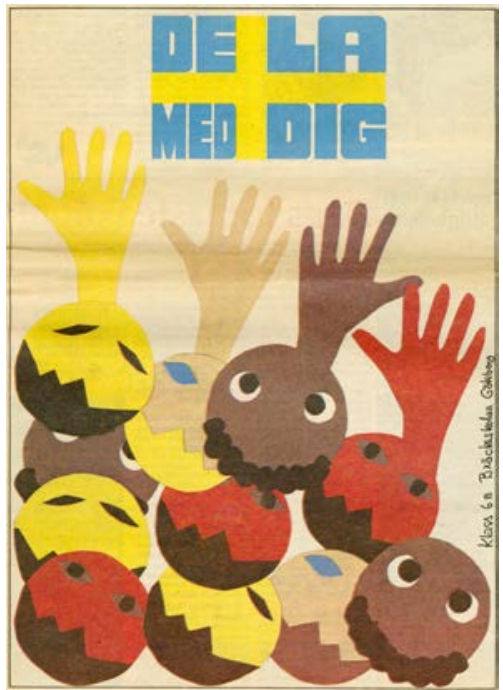

Bild 2:12. Lutherbjälpen nr 11971 sid. 5.

som tar emot färgade, afrikanska eller asiatiska barn. Bilderna bär spår av en kolonial diskurs där det är tydligt hur skillnad skapas mellan de med makt att ge och de $\mathrm{i}$ behov av att få. I tidningen beskrivs "att tävlingen varit ett viktigt inslag i Lutherhjälpens opinionsarbete för att öka förståelsen för u-ländernas situation". ${ }^{473}$ Att barns deltagande har kunnat användas i politisk propaganda diskuterar även Johanna Sköld och Ingrid Söderling i en artikel om hur mediala representationer av barn användes för att mobilisera den svenska allmänhetens stöd för Finladshjälpen under andra världskriget. ${ }^{474}$ De för även ett intressant resonemang kring svårigheten att definiera barns aktörskap. Barns egen hjälp till andra barn har ofta medialt betraktats som autentisk, även om insamlingar eller hjälp var arrangerad av vuxna. Å andra sidan är det inte självklart att barn själva saknar politiskt aktörskap och engagemang, även om aktiviteter, som exempelvis teckningstävlingarna, arrangerades av vuxna.

I tidningen Lutherbjälpen visades de vinnande bilderna, som även trycktes upp som affischer. Vinsten var som sagt att få följa med till "något land med många biståndsprojekt". ${ }^{475}$ Det land som omtalades i tidningen 1982 var

\footnotetext{
${ }^{471}$ Fröberg, Per (red). (1979). Oegennyttans politik. Stockholm: Frivilligorganisationernas informationscentral i samarbete med SIDA, Lutherhjälpen, Sv. Missionsrådet.

${ }^{472}$ Lissner, Jørgen (1977)The politics of altruism: a study of the political behaviour of voluntary development agencies. Geneva.

${ }^{473}$ SBBA:s arkiv 2007:012 Lutherhiälpen nr 11982.

474 Sköld, J., Söderlind, I., (2018), Agentic Subjects and Objects of Political Propaganda: Swedish Media Representations of Children in the Mobilization For Supporting Finland During World War II, Journal of the History of Childhood and Youth, 11(1), 27-46.

${ }^{475}$ Ur Brev från Lutherhjälpen (Bertil Dovelius) till Svenskt barnbildarkiv. Lutherhjälpen var sedan starten 1947 en del av svenska kyrkans mission, slogs 2008 ihop med svenska kyrkans mission till Svenska kyrkans internationella arbete.
} 
Tanzania, dit första- och andrapristagarna fick åka, tredje pris var en resa till Stockholm/Uppsala och 4-7:e pris var böcker och u-landshantverk, 8-10 pris var böcker. ${ }^{476}$ Temat med att rika i Sverige ger till fattiga barn i tredje världen är representerat i barns tolkningar även av andra teman, exempelvis i Televerkets "Den gränslösa världen" från 1993, med bilder av uppfinningar som gör att man kan förflytta sig snabbt och dela ut mat och kläder till fattiga barn i Somalia. Liksom i Lutherhjälpens tävling från 1970 var utgångspunkten även 1993 att de rika barnen gjorde "en god gärning" genom att dela ut presenter. ${ }^{477}$ Samma tema fanns också i bilder från tävlingen Milk for vitality 1967, där mjölk delas ut till undernärda färgade barn. Det är alltså tydligt visualiserat hur de barn, och vuxna, ser ut som behöver hjälp, och hur de ser ut som ger hjälp.

Även om det blir problematiskt att man i bilder åstadkommer stereotyper kring gestaltandet av givare och av behövande så kan man även se bilderna som del av diskursen om "det goda barnet", som vi bör lära oss något av. Inom denna diskurs blev barnet en kristuslik gestalt, som kunde rädda både andra barn, och vuxna, genom att de alltid har välvilliga och kärleksfulla intentioner. Sylvia Lindström skriver i kapitlet "Budskap från barnens värld" i boken Livets träd-Världen genom barnets ögon: "De höll upp plakat och sände ballonger mot himlen, på vilka det stod orden FRED och KÄRLEK i stora bokstäver. De skrev långa brev och berättade om sina liv och om hur de vill ha det på vår jord." 478 Rädda barnens utställning med barnbilder "Livets träd" (1977) visades i utställningslokaler runt om i världen, bland annat i FN-byggnaden i Geneve och New York. Nu var det inte bara konstnärer som hade något att lära av barnen, utan alla vuxna. Lindström menar att den succé som bildutställningen blev visar att världen behövde barnens budskap, och budskapen visades fram genom barnbildernas konstnärliga kvaliteter. ${ }^{49}$

Arlas och postens tävlingsinformation till tävlingen 1976 Detta vill jag värna om avslutades med "Kanske just det du tycker kan bli en tankeställare hos de som bestämmer". Budskapet, som delvis handlade om barns rätt att delta och höras i samhället, var det som betonades, inte bildernas konstnärliga värden. Arla angav att syftet var att barnen genom bild och text skulle tala om vad de tyckte och vad de ville ändra på. Det uttalade syftet var då att ge det enskilda barnet en röst, samtidigt som barnet kunde ses som representant för alla barn.

I och med FNs barnkonvention, som ratificerades av Sverige 1990, blev också barns rättigheter, ett angeläget tema för barnbildstävlingar eller temasamlingar. 1990 har Rädda barnen en temasamling med namnet "Alla barn är lika värda" och 1992 en med namnet "Konfliktlösning". 1997-98 finns ytterligare en temasamling från Rädda Barnen just med namnet "Barnkonventionen", där det är alla barnkonventionens olika artiklar som tas upp. ${ }^{480} 1996$ arrangerade Barn

\footnotetext{
476 SBBA:s Arkiv 2997:012 Lutherhiälpen nr 11982 sid. 10.

477 SBBA Televerkets samling Den gränslösa världen 1993 Citat från bildtext till bilden"starsprinter"2010:005:0022.

478 Lindström, Sylvia, Berefelt, Gunnar \& Wik-Thorsell, Anna Lena (1978). sid. 8.

479 SBBA:s arkiv 1992:053 Pressklipp Livets träd och öarnas barn.

480 Bilderna kommer från Stockholm, Uppsala och Norrtälje.
} 
och ungdomskulturgruppen i Uppsala kommun en dikt- och teckningstävling för tredjeklassare i Uppsala med anledning av FN-dagen 24 oktober 1996. Temat var att rita en teckning som tog upp barns rättigheter som det uttrycks i FN:s Barnkonvention artikel två, om icke diskriminering. ${ }^{481}$ Prisutdelning skedde i Domkyrkan, där bilderna sedan också först var utställda, därefter på Dag Hammarskölds bibliotek.

Vi kan alltså se hur arrangörer kunnat använda teckningstävlingar för att visualisera behövande barns behov av hjälp och stöd, både från vuxna och från andra barn. Genom tävlingarna har även kunskap om missionsarbete nått konfirmander och skolelever. Rädda barnen använde barnbilder för att påtala barns ansvar och generella inneboende givmildhet och skapande förmåga. Barnrättighetsdiskursen blir tydlig i Arlas tävling under slutet av 1970-talet för att åter aktualiseras efter ratificerandet av barnkonventionen på 1990-talet. Tävlingarna kan ses som del av ett utbildnings- och informationsarbete för att genom tävlingarna skapa kunskap om barnkonventionen och barns rättigheter både hos de som gör och de som ser bilderna och domineras av frivilligorganisationer som arrangörer. Förutom Rädda barnen har Svenska Kyrkan har haft en framträdande position i temat om internationell rättvisa och barns rättigheter, vilket i SBBA:s arkiv syns genom Lutherhjälpens tävling 1971-1982 och att prisutdelning och utställning av barnkonventionens bilder 1996 anordnades i domkyrkan i Uppsala.

Ett annat anknytande tema som aktualiseras under senare delen av min undersökningsperiod, är temat jag kallat Natur, Miljö, Trafik. Också här ser vi hur barns presenteras som ansvariga och centrala aktörer.

\section{Natur, Miljö och Trafik}

Att teckna och måla naturen på olika sätt har varit ett genomgående tema, över hela tidsperioden. Ett nytt tema som aktualiseras under 1970-talet är däremot att naturen och miljön är hotad och behöver värnas om, vilket uppmärksammas i Arla/Postens tävling "Detta vill jag värna om" från 1976. Av samlingens ca 15000 bilder handlar många om att värna om miljön på olika sätt. ${ }^{482}$ Att Arla/ Postens i sin information kring "Detta vill jag värna om" tävlingen nämner just "djur" "miljöförstöring" och "orättvisor" eller "mobbning", som exempel på vad barnen kan ta upp i sina bilder, är relevant att tänka på vid analysen av tävlingen. Arlas tävling adresserar både barnen som framtiden och barns rättigheter, som jag nämnt tidigare, där frågor kring miljö och natur kan betraktas som en del av barns framtida rättigheter.

Bildmotiven som valts för publicering i boken Varför fär inte barn bestämma (1977) efter uppdraget i Arla/Postens tävling ”Detta vill jag värna om” fördelar sig på följande sätt. Fördelningen är naturligtvis ett uttryck för arrangörernas val av lämpliga motiv för publicering, men speglar då också det förhållande att bar-

${ }^{481}$ https://www.raddabarnen.se/om-oss/barnkonventionen/barnkonventionen-lang-version/\#Art 2 (2018-03-10).

${ }^{482}$ Uppskattningen är gjord efter att ha studerat SBBA:s samling 1991:01: Det här vill jag värna om vol.1 1-800. 
nen valt att teckna sådana bilder. Jag återkommer till analyserna av bildmotiven i kommande kapitel.

\begin{tabular}{lr} 
Bildernas Tema i boken Varför får inte barn bestämma & Antal \\
\hline Natur/Nedskräpning/ Föroreningar & 24 \\
Utrotningshotade djur/djurrättsfrågor & 22 \\
Värna det gamla (hus/människor/skog) & 13 \\
Ta hand om/lyssna på (barn/sjuka/körsbär/handikappade) & 13 \\
Aktsamhet i trafiken/på sjön & 10 \\
Tobak/knark/Alkoholism & 10 \\
Konsumtion/Reklam/Ekonomi & 8 \\
Fred & 7 \\
Skola/skolgård & 6 \\
Mobbning & 5 \\
Mjölk & 5 \\
Inte Stjäla & 4 \\
Inte Elda & 4 \\
Atomkraft & 3 \\
Övrigt (dikt med flera olika teman) & 1 \\
Totalt: & 135
\end{tabular}

Djur och naturfrågor är, som syns i tabellen, vanligast förekommande i bilderna. I denna tävling från 1976 var tydligt att det ofta var den moderna människan och den moderna tekniken som framställs som hotfull. ${ }^{483}$ Det kan exempelvis gälla att gamla hus är hotade av höghus, djuren hotas av djurförsök och pälsindustrin, eller att växter hotas av bekämpningsmedel, som i bilden Làt alla växter leva! (bild 2:13). Även tävlingens tema, att teckna "Detta vill jag värna om" implicerar att det finns något som är hotat, och som behöver värnas.

Televerkets tävling för omslagen till telefonkatalogerna, har 1983 temat "Så vill vi ha det i trafiken där vi bor". Bilderna handlar mycket om säkerhet, övergångsställen, cykelbanor, cykelhjälmar och reflexer. ${ }^{484}$ En annan tävling med trafiktema var "Trafiken och miljön" från 1989 som arrangerades av Länstrafiken för landets fjärdeklasser, med devisen "Var bussig mot miljön”. I lärarhandledningen skrev man att: "Både samhället och den enskilde har mycket att vinna på ett ökat kollektivtrafikresande" och att "Kollektivtrafik är sedan 1979 års riksdagsbeslut en grundläggande samhällsservice". Att skapa kunskap hos barn om nya politiska riktlinjer kunde användas som argument för tävlingens genomförande. Temat var "Trafiken och miljön" med den valfria tolkningen "som det var", "som det är", "som det borde vara" eller "som det kan bli i framtiden". Länstrafiken menar vidare att tävlingen är mycket viktig just i skolan, "bland dem som ska överta dagens miljö”, och att man därför ägnar en del av kam-

${ }^{483}$ Ziehe, Thomas (1993) Kulturanalyser: ungdom, utbildning, modernitet: essäer. 3. uppl. Stockholm: B. Östlings bokförl. Symposion sid. 120f.

${ }^{484}$ Redan 1955 noteras i första numret av Tidskriften Teckning att FIB:s tävling har temat Vägtrafiken, denna tävling finns dock inte i SBBA:s arkiv. 


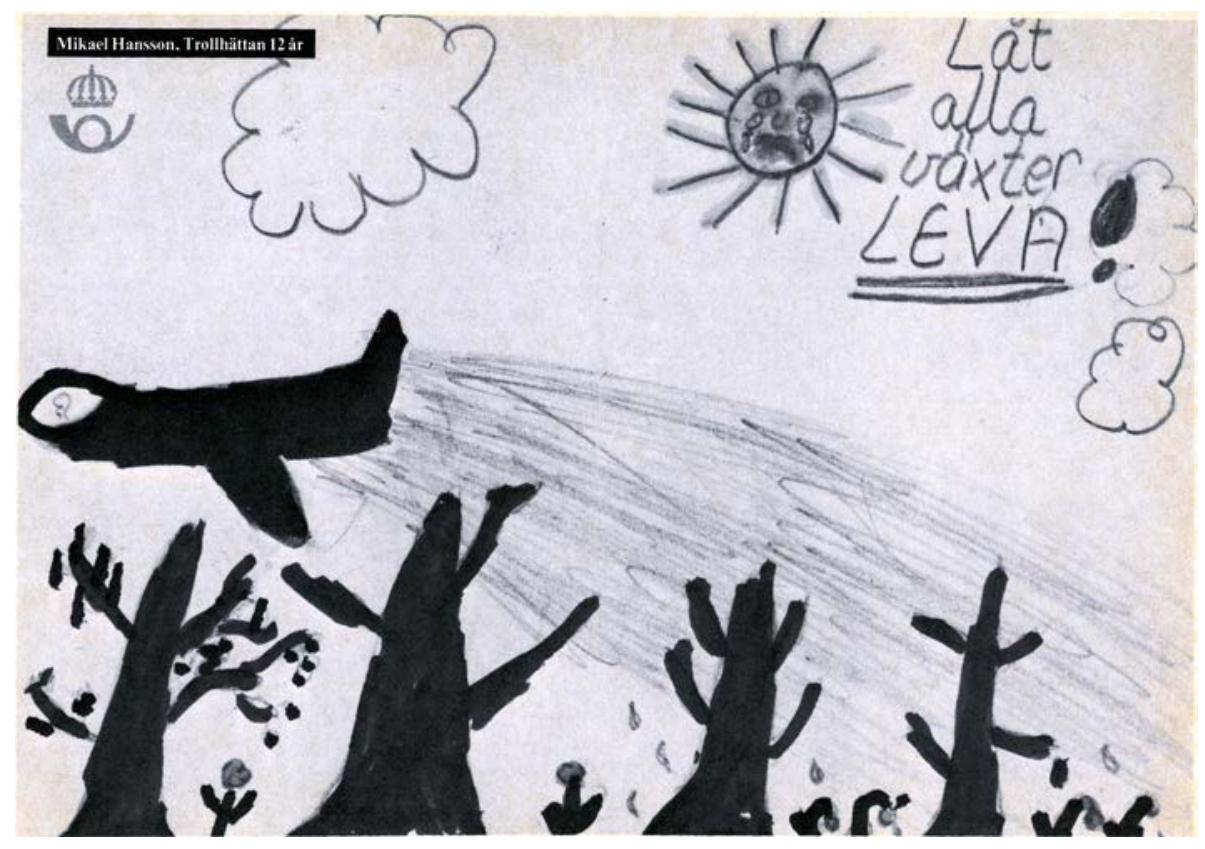

Bild 2:13. Mikael Hansson, i Varför får inte barn bestämma (1977).

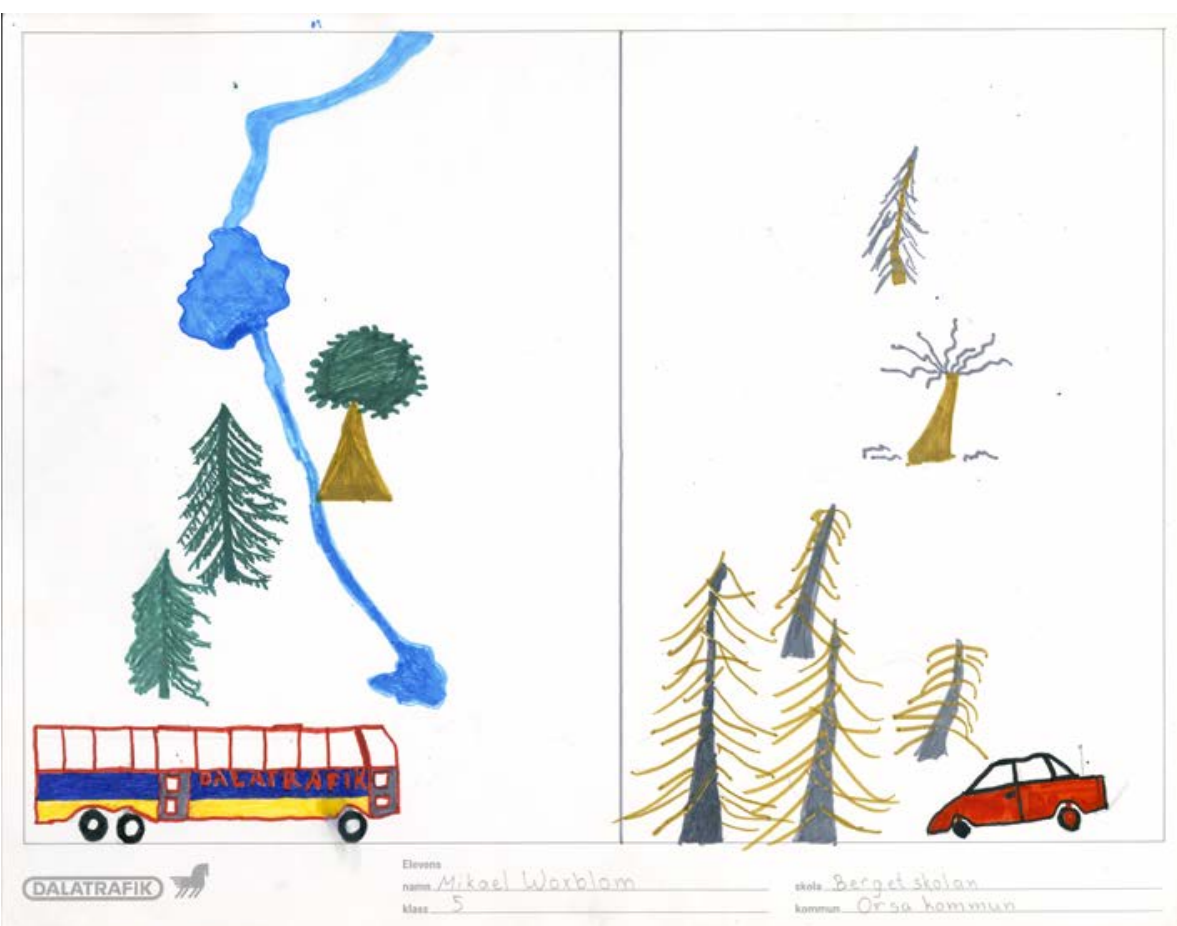

Bild 2:14. Trafiken och miljön, arrangerad av Länstrafikens 1989. 
panjen åt en teckningstävling. Tävlingar med Miljötema visar ofta bilder med framtiden visualiserad som antingen mörk eller ljus. Exempelvis en ljus bild med gröna träd om vi åker kollektivt och en mörk bild med döda träd om vi inte gör det (bild 2:14).

I informationsmaterialet till skolorna visade man också upp bilder av flera olika djur och växter, som hotades av utrotning genom ökade utsläpp, vilket ger en tydlig hänvisning till vad kollektivtrafiken kan hjälpa till att rädda. I denna samling (se bild) från Dalatrafik har man också noga tryckt upp sin egen logga på pappret. Troligen för att skapa en association mellan värnandet av miljön och det arrangerande företaget. Flera bilder i samlingen tar, liksom denna, upp både det negativa och det positiva scenariot, där bussen omges av grönska och bilen av vissnade träd. Telia arrangerar 1995 en tidningstävling: "Miljö i skolan" som tar upp hur klimatet i närmiljön påverkar globalt. "Tävlingen syftar till att engagera deltagarna i miljöfrågor och tävlingsbidragen ska lyfta fram telekommunikationernas möjlighet till förbättringar av skolmiljön" skrev man i anvisningarna. ${ }^{485}$ Som jag tidigare nämnt hade Televerket även mellan 1980-1990 en affischtävling under namnet "Stoppa sabbet", som främst inriktar sig på att man inte ska förstöra telefonkiosker, men den kan ingå under denna rubrik "natur, miljö och trafik" då temat kan inkluderas i att ta hand om en gemensam miljö.

1982 deltog, enligt Televerket, över 2500 av alla landets sjätteklasser. ${ }^{486}$ På omslaget med information till skolorna skriver man 1983: "STOPPA SABBET vinn 5000:- kronor", och att "Televerket utmanar alla landets sjätteklasser till en ny tävling i Stoppa sabbet. Hjälp till att minska förstörelsen av telefonkiosker." ${ }^{487}$ Vid tävlingens tioårsjubileum syns några av de tidigare vinnande bilderna publicerade i den informationsfolder som skickades ut till skolorna 1989 (bild 2:15).

Mycket av tilltalet i dessa bilder bygger på humor och satir och referenser till samtida populärkulturella fenomen. Bilden E.T. cant phone home - why? refererar till sciencefiction filmen E.T. från 1982, om en utomjording som kommer på besök till jorden. En viktig replik i filmen är "E.T. phone home”. Nu kan han inte ringa för telefonkiosken är trasig. I bilden från 1981 kommenteras den ryska u-båten U-137 som gick på grund i Blekinges skärgård med bild och text "Hela telefoner är bra överallt, även för ryska u-båtskaptener..." I bilden från 1986 liknas Telefonkiosken vid andra utrotningshotade arter som pandan och valen. Precis som i de tidigaste teckningstävlingarna från början av 1900-talet som publicerades i DN så är humor fortfarande något som kan användas för att fånga positiv uppmärksamhet. Att dessa bilder också vann visar att humorn kunde vara ett uppskattat sätt att svara på det som betraktades som problem kring ungdomars vilja att sabotera.

I lärarhandledningen 1989 skriver Televerket under rubriken "Varför förstör vi??"

${ }^{485}$ Ur Televerkets tävlingsregler Bedömningsgrunder med uppgift att göra en klasstidning; SBBA Arkiv.

486 SBBA Arkiv Televerkets tävlingssamlingar Stoppa sabbet informationsfolder till skolorna 1983.

487 SBBA Arkiv Stoppa sabbet informationsfolder till skolorna 1983 omslag. 
Var går gränsen mellan lek och sabb? Det är ju naturligt att man som barn vill undersöka och ha sönder saker. Man klättrar i träd, kastar stenar eller klottrar på en vägg. Men när övergår leken i allvar, att man medvetet förstör? Diskutera skillnaden med klassen. [...] Har dina elever sabbat någon gång? Försök få igång en diskussion om klassens egna erfarenheter. ${ }^{488}$

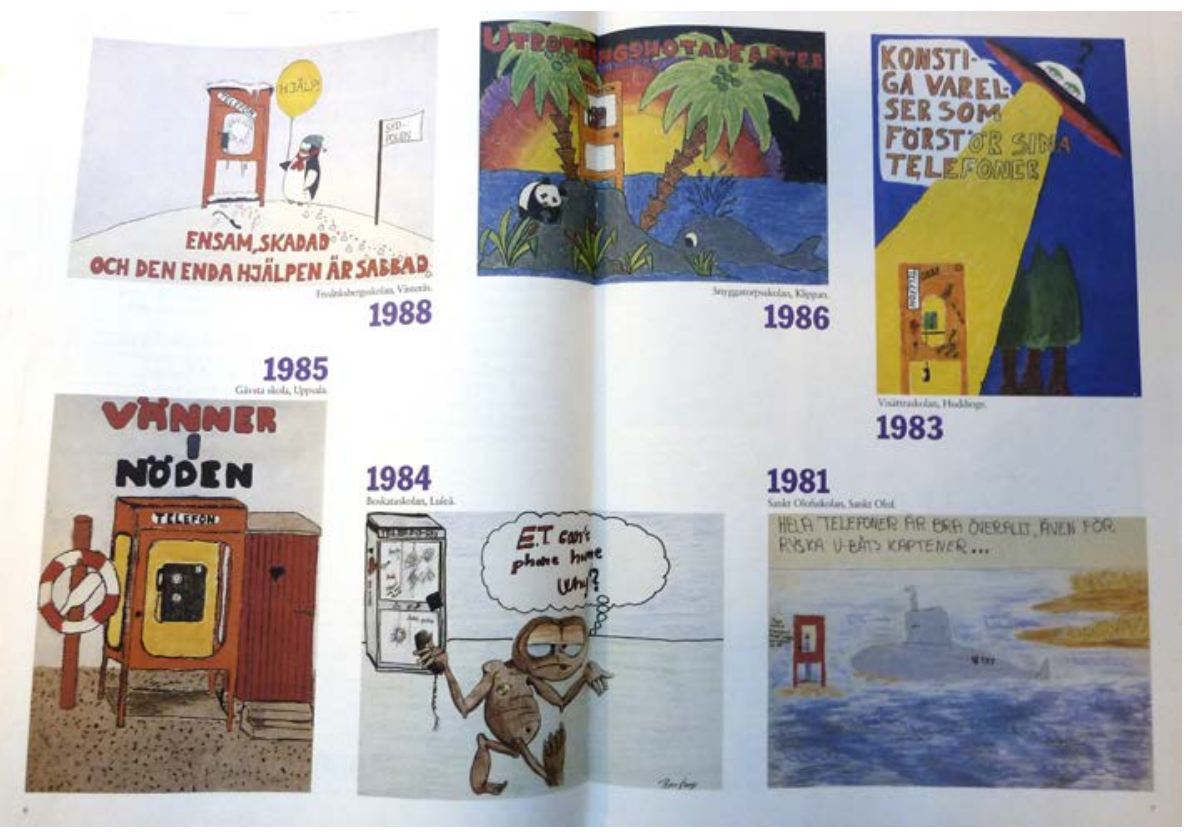

Bild 2:15. Del av Televerkets informationsfolder om tävlingen Stoppa sabbet 1989.

Att barn vill undersöka och ha sönder saker betraktades som något naturligt, där det viktiga var att uppmärksamma barnen på skillnaden mellan att leka och att förstöra. Det fanns också med ett förslag till en enkät för eleverna att svara på, där man bland annat frågade om, och i så fall hur ofta, de tittade på filmer som innehöll våld, om de någon gång "sabbat" en telefonkiosk eller något annat, liksom om de mobbat eller blivit mobbade. ${ }^{489}$ Det var tydligt att man menade att teckningstävlingen skulle initiera en diskussion kring dessa frågor. Här var uppdraget till lärarna och eleverna inte enbart att teckna och skicka in bilder, de förväntades även diskutera så kallat videovåld och mobbning, och därigenom förändra det Televerket uppfattade som problematiskt ungdomsbeteende. Televerket formulerade en problemdiskurs, som sedan både skolan och eleverna fick förhålla sig till.

\footnotetext{
${ }^{488}$ SBBA Arkiv Televerkets tävlingssamlingar Stoppa Sabbet informationsbroschyr om tävlingen som skickades till skolor 1989 sid. 2.

489 SBBA arkiv Televerkets tävlingssamlingar Stoppa Sabbet informationsbroschyr om tävlingen.
} 
Världsnaturfonden (WWF) hade som nämnts tidigare, 1985-86 en kampanj för "Våra växter", och arrangerar tillsammans med ICA-kuriren en barnbildstävling under namnet "Vårt gröna arv". De flesta av dessa bilder är ganska detaljerade studier av olika blommor, ofta utrotningshotade, som till exempel blåsippa eller vit näckros. Syftet med teckningstävlingen Vårt gröna arv var "omsorgen om de hotade växtarterna i vårt land och i världen" och generellt att väcka opinion för Världsnaturfondens frågor. ${ }^{490}$

Europarådets tävling från 1987 uppmärksammade det Europeiska miljövärnsåret. Uppgiften var "Rita ett eller flera vilda djur som finns i Europa och som hotas av utrotning” Även Råd och Röns och Konsumentverkets tävling 1990 "Gör en motbild" handlar om att uppmärksamma miljöproblem; "bilden ska visa vad produkten betyder för miljön, den ska avslöja det mindre vackra under den glättiga ytan." Och tidningen fortsatte: "Komplettera gärna bilden med en kort text." De gav följande exempel: "Till och med regnskogen faller för big Smack", apropå att de tropiska regnskogarna fälls för att bli betesmark åt kor, som ska bli hamburgare. ${ }^{491}$

Det är påtagligt att tävlingarna som berörde natur och miljöfrågor användes som ett sätt att lyfta samhällsfrågor och samtida diskussioner in i klassrummet, vilket också var förenligt med skolans intentioner som de kom till uttryck i läroplanen från 1980. I Tävlingen Stoppa sabbet (1980-1990) uppmanade Televerket till en bredare diskussion om relationen mellan sabotage, videovåld och mobbing. Riksdagens miljö- och konsumentpolitik kunde genom tävlingarna nå ut och uppmuntra till engagemang hos både lärare och elever. Det är också tydligt att miljöfrågor engagerar både offentliga organisationer och frivillig organisationer, liksom mjölkproducent kooperationen Arla.

Sammanfattningsvis kan vi konstatera att en mängd olika faktorer påverkade hur tävlingarna utformades och vad och hur barn ombads teckna.

Tillgång till färg- och pappersmaterial som inte självklart funnits tidigare $\mathrm{i}$ skolan var en förutsättning för tävlingarna, och nya trycktekniker var avgörande för tävlingsbildernas spridning och distribution. Skolan kunde vara med och fördela ut material och materialkunskap för att ge jämlika villkor över landet. Materialet kunde även bidra till att få fram det enkla, barnsliga uttryck som i vissa tävlingar eftersträvades. I FIB:s anvisningar poängterades att bilderna skulle göras självständigt och att barnen skulle använda sin fantasi. Att tävlingen bidrog till att göra undervisningen modern, kommenterades också i FIB.

Jag har visat att önskvärt eller förväntat kunnande kunde spela roll för åldersindelning av barnen. I FIB:s tävling delades barnen in både efter ålder, och efter om det var en stad- eller landsbygdsskola. I FIB ansågs högre ålder och därmed ökad kunskap i teckning öka möjligheterna att vinna, och stadsskolor kunde eventuellt ha bättre möjlighet att förmedla kunskap än landsbygdsskolor.

\footnotetext{
490 Citat från brev till barnbibliotekskonsulenten i Eskilstuna 1985.

491 Infoblad från Råd \& Rön 1/90 Diarienr: 1994:008 SBBA. Samlingen innehåller 2384 bilder.
} 
Televerket förväntade sig 1976 specifikt dekorativa bilder av yngre barn, som hade kvar sin "skapande spontanitet". Arrangörer har genom samarbete med skolan kunnat nå ut med moraliska budskap, och överföra lämpliga normer och värden, mest uttalat när tävlingarna vände sig till äldre barn. FIB:s jury ansåg inte att de yngre barnen kunde tävla med de skickligare äldre barnen, vilket var en delvis motsatt syn mot Televerkets på 1970-talet, då de yngre barnen var de som ansågs ha kvar sin skapande kreativitet. Diskursen om den äkta och naiva barnbilden är genomgående från 1940-tal till 1970-tal. Anledningen till att barns skapande förmåga ansågs försvinna relaterades ibland till att barnen blev äldre, ibland till att den förstördes av skola och omvärld. Då skolan av vissa arrangörer ansågs skapa "framtvingade" bilder, poängterades att arrangörerna ville ha bilder barnen tecknat på sin fritid.

I Stoppa sabbets bilder från 1980-talet efterfrågas inte naivistiska barnkonstbilder. Det är istället affischer med tydligt budskap, gärna med fotografer och i collageteknik som lyfts fram som föredömliga av arrangörerna. Vinnarbilderna skildrade ofta temat med humor och satir. Där tävlingsbilderna på 1940-talet skulle vara självständigt utförda borde de nu gärna vara gjorda i grupp. Reklambyrån snarare än konstnären är det som ska inspirera och locka ungdomarna till deltagande.

Det är tydligt att högtider, framförallt jul, varit ett återkommande tema för tävlingarna under hela perioden, liksom bilden av hembygden. Dessa kulturtraderande bildrepertoarer återfinns även på exempelvis konstmuseer eller i populärkultur. Bilder som belyser samhällsproblem som barnen förväntades påvisa att de borde rättas till, kommer från slutet av 1970-talet. Detta kunde gälla både nationella eller internationella rättvisefrågor eller miljö- och naturfrågor. Här användes bilderna mer för att skapa opinion kring en viss fråga, där barnen gavs en framträdande röst som framtida arvtagare av klimat och resurser.

Som vi sett har barnen fått olika uppdrag, som visar fram en komplex bild av barn och barndom, både över tid och beroende på vilka som arrangerat tävlingen och deras intentioner. Vinnarbilder har diskuterats på olika sätt och gjorts i olika material, men de har också presenterats och visats fram på olika sätt. På vilka sätt en bild möter sin publik spelar en väsentlig roll för hur de uppfattas, liksom hur publiken tolkar bilden. Om detta handlar nästa avsnitt.

\section{Bilderna möter publiken}

Tänk att som barn få möjlighet att se sina teckningar använda som brukskonst. Få klart för sig att teckning och målning inte bara är något övergående kludderi, som barn sysslar med, utan något som uppskattas och värderas i samhället. Det är viktigt 
att människor lär sig att delta i kulturlivet, inte bara blir passiva kulturkonsumenter. ${ }^{492}$

Citatet ovan betecknades som ett öppet brev till konstnärernas riksorganisation, efter att KRO uttalat sig om att barn inte borde anlitas i tävlingar för att göra omslag till Telefonkatalogerna. ${ }^{493}$ Artikelns rubrik var "Är ni rädda för konkurrens från barnen?” I talet om barnen och tävlingarna gjordes barnen i denna artikel till medskapare av kultur, där Konstnärernas riksförbund i brev till Televerket istället uttalade sig om hur barnen blev offer för det kommersiella konkurrenssamhället:

Tanken att barn i en tävling av det slag det här gäller skulle producera spontan, omedveten konst är helt verklighetsfrämmande. Barnen ställer självklart in sig på de förutsättningar som ges genom tävlingsformen. Tanken att barn skulle bevara någon oskuldsfull eller omedveten hållning till sina bilder under det starka uppbåd av marknadsföring i form av press och TV som omgett prisutdelningarna är kort sagt ovanligt enfaldig. Televerket har såldes inte brutit någon annan ny mark än att dra in teckningstävlingen och därmed eleverna i det kommersiella mönstret i konkurrenssamhället. ${ }^{494}$

KRO avslutade därefter brevet med att skriva att de har en egen tävlingsnämnd som gärna ställer sig till förfogande för att diskutera olika former av tävlingar. De lyfter även fråga om upphovsrätt, och att det bör ges ersättning för varje gång en bild används. ${ }^{495}$

Olika aktörer har haft skilda uppfattningar om barns deltagande i tävlingar, där KRO i den här dialogen värnar sina intressen. Tävlingen och barnbilderna blir ett hinder eller ett medel att nå organisationens eller myndighetens egna mål. Det som framförallt kommer att diskuteras i detta avsnitt är hur bilderna har visats och offentliggjorts. Utan den offentlighet som barnbilden gavs genom miljontals telefonkataloger, hade reaktionerna ovan inte kommit till stånd. Jag kommer att undersöka på vilka platser tävlingsbilder har visats av olika arrangörer och under olika tidsperioder och vad detta kan berätta om fenomenet teckningstävlingar och om en förändrad syn på barn. Var bilderna visats upp och publicerats, och vilka som betraktat bilderna, spelar som KRO:s brev visar en väsentlig roll för hur de uppfattas. ${ }^{496}$ När vinnarbilderna visades i tidningar, som vi såg

492 Artikel införd i GT kopierad i Televerkets arkiv, datum saknas. Artikelförfattaren Ingemar Eriksson är medlem av Göteborgs konstnämnd och suppleant i nämnden för Göteborgs stads kulturstipendier. Insändaren betecknades som ett "öppet brev till Konstnärernas Riksorganisation" med rubriken $\ddot{A} r$ ni rädda för konkurrens frän barnen? Omslag till rikstelefonkataloger 1977 F2A:1 Televerket, telemedia Katalogverksamheten. Riksarkivet.

493 Telekontoret, Tidningsklipp 1979-05-22 Omslag till rikstelefonkataloger 1977 F2A:1 Televerket, telemedia Katalogverksamheten; Aftonbladet 1976-07-04.

494 Skrivelse till Televerket från KRO 1976-11-15 Ang. omslag till Telefonkatalogerna, Omslag till rikstelefonkataloger 1977 F2A:1 Televerket, telemedia Katalogverksamheten. Riksarkivet.

495 Ibid.

496 Rose, Gillan (2016) sid. 36. 
redan vad gällde även det tidiga tiotalets tävlingar, ansågs det ge en känsla av gemenskap och inkludering att kunna uppleva att ens egen bild kanske skulle publiceras i en tidning, och kanske till och med vinna ett pris.

Inför FIB:s första tävling 1938 skrev man i februari att vinnarbilderna kommer att tryckas i tidningen, i svartvitt. Men redan första året ordnade tidningen även en utställning, vid entrén till varuhuset PUB i Stockholm, där originalmålningarna visades. Även 1939 visades bilderna på PUB varuhuset. 1940 visades bilderna $\mathrm{i}$ en utställningslokal på Skansen, under parollen "Ung färgglädje”.

1941 blev även Nationalmuseum

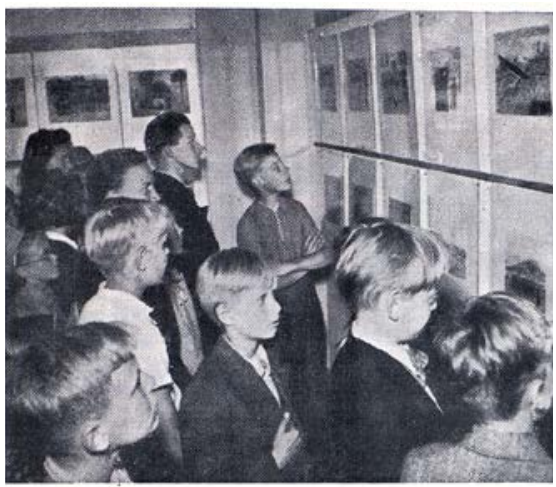

I fjol samlade tävlingen omkring 20000 deltagare frản alla delar av landet. Här se vi några intresserade tävlingsdeltagare studera de teckningar som voro ułställda pả Nationalmuseum. Fjolårets ämne var Svenskarna i allvarstider, beredskap förr och nu.

Bild 2:16. Folket $i$ bild 1944 nr.9 sid.33. detalj. medarrangör av tävlingen och bilderna visades därefter i maj varje år på Nationalmuseum, eftersom det möjliggjorde för skolklasser att komma och besöka utställningen innan skolterminen var slut (bild 2:16).

Tidningen FIB hade varje år fotoreportage från dessa utställningar, där man visade fram hur välbesökta de var. Nationalmuseum som plats gjorde att bilderna associeras till den etablerade smakens kultur, även om bilderna var utställda $\mathrm{i}$ bottenvåningen, och inte i de stora salarna. Genom att visa upp bilderna på museum, och bjuda in skolklasser, hoppades arrangörerna intressera den unga generationen för konst och för museet. Museet kunde med dessa utställningar ta in och erbjuda den yngre generationen (barnen) plats både i salarna och på väggarna. Uppenbarligen ville Nationalmuseum göra barnens konstnärliga uttryck acceptabla för en konstnärligt intresserad publik. ${ }^{497}$ Nationalmuseum ordnade också en vandringsutställning 1946 med ett urval av barnbilderna, i samarbete med Riksförbundet för bildande konst, som visades i tjugo svenska städer. ${ }^{498}$

En förteckning över bilderna som var med på vandringsutställningen, samt några svartvita reproduktioner, och omslagsbilden i färg finns med i katalogen "Sverige genom barnaögon" som Riksförbundet för bildande konst gav ut 1945. Även Nationalmuseum gav 1947 ut en katalog med samma namn, med 16 färgbilder och 36 svartvita tryck. Katalogen annonserades för 7:50 i FIB och där omtalades också att den distribuerats till alla svenska skolbibliotek. ${ }^{499}$

De vinnande EU-bilderna från 1959 skulle enligt anvisningarna som sändes till skolorna användas för att sättas upp i en Europaskola i Luxemburg, med bilder från olika länder, men om dessa bilder verkligen kom på plats där framgår inte av arkivmaterialet. Televerkets tävlingsbilder mellan 1977 och 1984 visades

\footnotetext{
497 Rose, Gillian (2016) sid. 38.

498 Sverige genom barnaögon: Katalog. [Ny tr.] (1945)

499 FIB 1947 nr 10 sid. 32.
} 
på telefonkatalogens omslag, som distribuerades till alla svenska hushåll. De 27 katalogerna hade alla olika vinnarbilder. ${ }^{500}$

Men hur kommer det sig att Televerket valde att ha barnbilder som omslag till Telefonkatalogen? 1976 efterlyser Televerkets marknadsavdelning att telefonkatalogens framsida behövde "Ett mera levande och färgglatt yttre", då den varit oförändrad sedan 1967..$^{501}$ Dessutom gick det nu att göra 4-färgstryck, "utan nämnvärd merkostnad". Det är inte bara det att det finns önskemål om ett mera färgglatt yttre, man har nu också med den nya tekniken möjlighet att genomföra det utan att det blir för dyrt. ${ }^{502}$ En reklambyrå gav fyra olika förslag: barnteckningar, konstnärstävling eller yrkesdesigners. De flesta distrikten förordade barnteckningar, och det var också Marknadsavdelningens förstahandsval.

Televerket skrev:

Skolbarn rekommenderas av STB (AB svenska telegrambyrån) av följande skäl:

1. Goodwill värdet av aktiviteten blir klart större bland en större allmänhet.

2. Televerket bereds unik möjlighet att få elever positiva till telefonerande.

3. Detta är det billigaste alternativet om man vill byta framsida ofta.

4. Barnteckningar har en obestridlig charm och det breda underlaget bör ge tillräckligt antal fräscha idéer och goda utformningar.

Både tävlingen som sådan och de framkomna - med all sannolikhet okonstlade och färgrika - nya omslagen på katalogerna kan i någon mån motverka det intryck av tvt (sic, Televerket) som en opersonlig och byråkratisk inrättning, vilket gett sig tillkänna i intervjuundersökningar. ${ }^{503}$

Att Televerket valde att publicera barnbilder, istället för bilder av konstnärer eller designers, på framsidan av katalogerna hade alltså flera skäl. ${ }^{504}$ Man hoppades barn skulle förändra Televerkets opersonliga och byråkratiska image, man antog att barnbilder gav positiva reaktioner hos "allmänheten", och man trodde att tävlingen skulle intressera barn och unga för telefonerande. Genom själva tävlingsformen nådde man ut både bland skolbarn och till allmänheten. Barnteckningar ansågs ha en obestridlig charm, vilket Televerket kunde ha nytta av i sin nya marknadsföring av sig själva som obyråkratiska, och barnbilder var dessutom billigast om man vill byta omslag ofta. ${ }^{505}$ Syftet för Televerket med att använda barnbilder beskrevs som en "ansiktslyftning" åt framsidan för att göra den mer dekorativ, så att den skulle få ligga framme tillgängligt och komma

${ }^{500}$ Det var 24 olika distrikt, men Stockholm hade tre katalogdelar och Göteborg två, så totalt 27 olika bilder varje år.

${ }^{501}$ I Skrivelse från Marknadsavdelningen, B Widenfors Sektionen för säljstöd 1976-01-22 Televerket Telemedia Omslag för rikstelefonkatalogen 1977 F2A: Riksarkivet.

502 Ibid.

503 Skrivelse från Marknadsavdelningen, Sektionen för säljstöd 1976-01-22 tvt-Televerket Telemedia Omslag för rikstelefonkatalogen 1977 F2A:1 Riksarkivet.

${ }^{504}$ För mer info se tidigare avsnitt Offentliga Arrangörer.

${ }^{505}$ Skrivelse från Marknadsavdelningen, Sektionen för säljstöd 1976-01-22 tvt-Televerket Telemedia Omslag för rikstelefonkatalogen 1977 F2A:1 Riksarkivet. 
till större användning. Genom tävlingen ville Televerket också engagera grupper som kunde ge Televerket goodwill och "aktivt bidra till ett bättre utnyttjande av telefonen". ${ }^{006}$

Inför den första tävlingen bad man de olika telekontoren inkomma med synpunkter. Telekontoret i Helsingborg tillstyrkte förslaget om barnteckningar på framsidan, och menade att man även kunde överväga att skriva katalogens riktnummerområden på katalogryggen. Därutöver anförde Telekontoret: "Betr teckningarna kan man befara att en alltför god konstnärlig kvalité kan bidra till ökad förstörelse av kataloger i och för prydande av fristående lantliga bekvämlighetsinrättningar." ${ }^{07}$ Vad Telekontoret hade i åtanke med bekvämlighetsinrättningar framkommer inte, men det är tydligt att man befarade att om telefonkatalogens omslag blev alltför estetiskt tilltalande så fanns risk att de skulle förstöras för att hänga upp omslagsbilden på andra platser. Redan före bilderna har tryckts på katalogerna, funderar Televerket alltså på hur de kan komma att spridas och cirkulera, och om en alltför god konstnärlig kvalité kan öka spridningen, inte enbart så att katalogerna får liga framme utan även så att de skulle komma att förstöras.

"Tävlingen kan också i övrigt ge gynnsam publicitet genom kommenterade inslag i massmedia." menade marknadsavdelningen. ${ }^{508}$ Detta var också något som man ansåg uppfylldes, då tävlingen ofta kommenterades i både bild och text både i lokalpressen och lokalradion..$^{509}$

Här ser vi ett exempel från Gotlands Allehanda 1979 (bild 2:17). Televerkets representant bjöd på saft och tårta och blev omkramad av flickan som gjort vinnarbilden. Bildtext: Nog syns det att Chatarina Grönstam blev glad över Televerkets pris. Arvo Keinonen fick stora famnen. ${ }^{510}$ På bilden i mitten håller vinnarna upp sina bilder, bildtext: De ordnade seger! Båda pristagarna $i$ Ronne skola med sina belönade verk, Chatarina Grönstam och Mona Melin.

Trots Skolverkets anmodan om ett kollektivt arbete och att undvika ordet tävling, blev vinnarna av tävlingen ändå tydliga i flera av lokaltidningarnas reportage som vi ser exempel på här.

1980-1990 arrangerade Televerket "Stoppa sabbet" kampanjen, för att minska skadegörelse på telefonkiosker, och dessa bilder blev affischer som sattes upp på skolorna och i telefonkiosker. Televerkets/Telias tävlingsbilder från 1991-95 ställdes ut på telemuseum, och blev även upptryckta på telefonkort (som hade samma storlek som ett betalkort) och på nästkommande års informationsfolder

\footnotetext{
${ }^{506}$ STB AB svenska Telegrambyrån Stockholm 19e januari 1976 Pristävling om utformning av telefonkatalogdelarnas framsida, sid. 1. Omslag till rikstelefonkataloger 1977 F2A:1 Televerket telemedia Riksarkivet.

507 Brev från Försäljningssektionen i Helsingborg Ink. 1976-02-24 Omslag till rikstelefonkataloger 1977 F2A:1 Televerket telemedia Riksarkivet.

508 Skrivelse från Marknadsavdelningen, B Widenfors Sektionen för säljstöd 1976-01-22 tvt-Televerket Telemedia Omslag för rikstelefonkatalogen 1977 F2A:1 Riksarkivet.

509 Pressklippen finns dokumenterade och bevarade i Televerkets arkiv löpande under åren.

${ }^{510}$ Gotlands allehanda lördag 19:e maj 1979. Televerket Telemedia omslag till rikstelefonkataloger 1979-1980 F2A:4. Riksarkivet.
} 
Vinnande bilder: Teckningstävlingar för barn 1938-2000

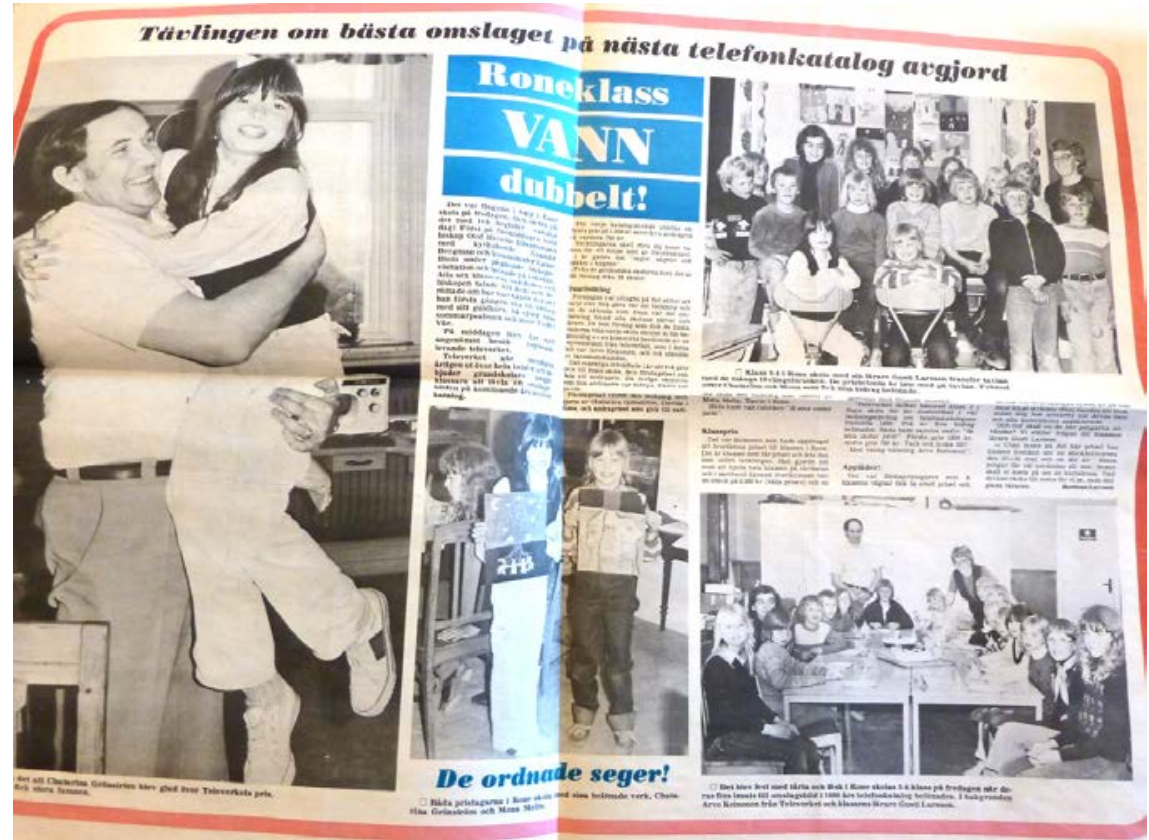

Bild 2:17. Gotlands Allehanda, 197919 maj.

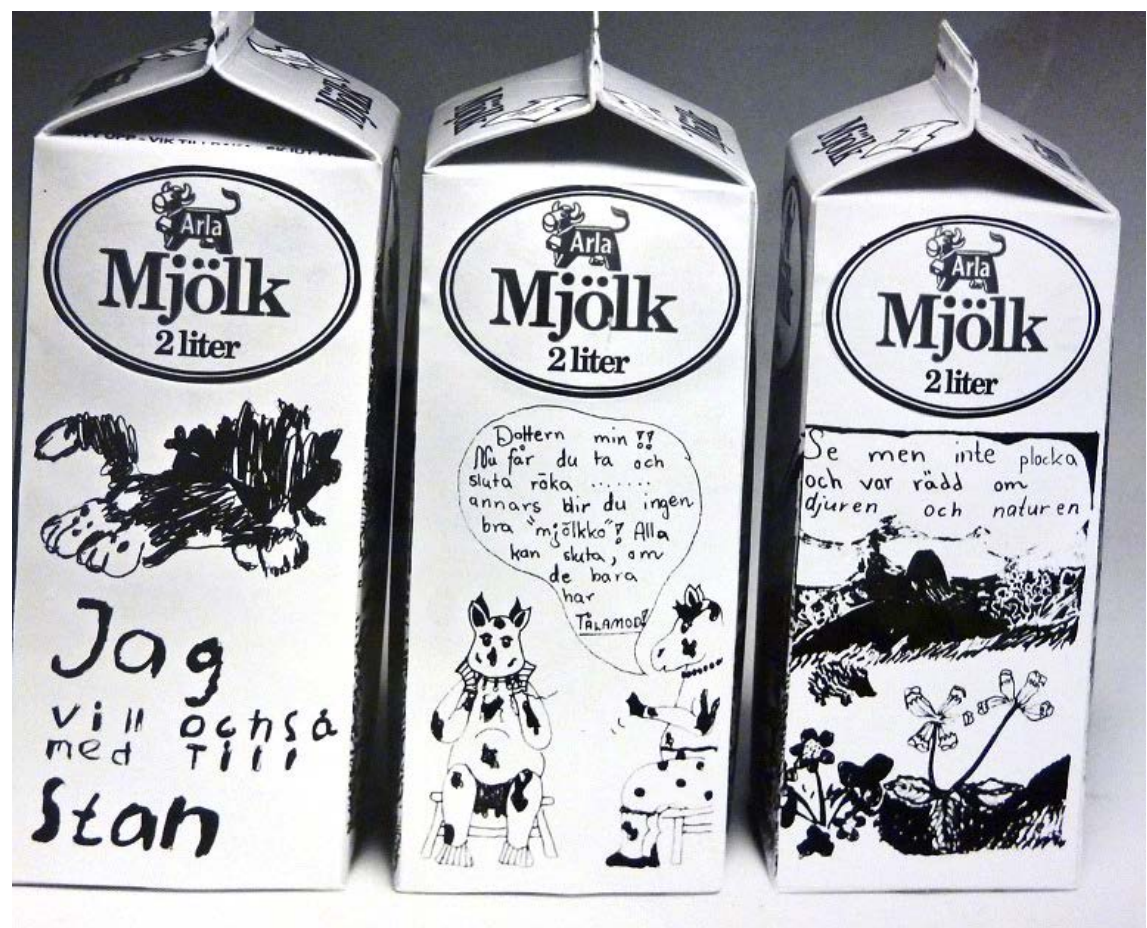

Bild 2:18. Mjölkpaket Arla/Postens tävling, 1976. 
för tävlingen. ${ }^{511}$ Efter Telias tävling Miliö $i$ skolan, arrangerar man inga fler tävlingar. Kanske hade det blivit svårare för Telia som privat aktör att få tillgång till skolan, samtidigt som tävlingsbilderna heller inte längre hade någon självklar plats, när bilderna enbart används för utställningar på Telemuseum.

När tävlingar arrangerades gemensamt av olika aktörer, kunde det få betydelse för bildernas spridning. Exempelvis i tävlingen från 1976 "Det här vill jag värna om", som arrangerades av Posten och Arla. Där blev de vinnande bilderna sedan dels tryckta på baksidan av mjölkpaket, dels trycktes de upp som vykort ${ }^{512}$ (bild 2:18). På mjölkpaketen på bilden ser vi en katt, med texten "jag vill också med till stan" En bild med två sittande kor där den ena säger "Dottern min! $\mathrm{Nu}$ får du ta och sluta röka, annars blir du ingen bra "mjölkko"! Alla kan sluta om de bara har tålamod!" Längst till höger en bild av gullvivor och blåsippor, med texten" Se men inte röra var rädd om djuren och naturen."

Posten och Arla gav också ut en bok 1977 med namnet "Varför får inte barn bestämma". ${ }^{513}$ Boken skickades till alla de 15000 som skickat in bidrag, och den kunde beställas mot enbart portokostnad från Posten och Arla. Bilder från boken visades också i artiklar i Expressen 1977. Expressen skrev om boken i sin Söndagsbilaga den 31a juli 1977 "15000 SVENSKA BARN FICK RITA ALLT DE VILL VÄRNA OM" ${ }^{514}$ Där visades fyra bilder med följande bildtexter; Hjälp alkoholisterna, Trampa inte på myrorna, Jag vill värna om min fantasi, och en bild med texten "syre" på en syrgastub på en fisk.

Expressen inledde artikeln:

Killen ligger utslagen på en parksoffa, ett par vinare ligger kullslagna bredvid. Polisbilen är på väg uppför parkgången. Då ryter Birgitta Gustavsson; Örebro, i med ett: Hjälp alkoholisterna!" Det är ett av de många fina tänkvärda bidragen till "varför får inte barn bestämma" - boken som presenterar ett urval av de 15000 barnteckningar som kom till Arlas och Postens pristävling "det vill jag värna om. ${ }^{515}$

Expressen skrev ett år tidigare om den första teckningen på mjölkpaketen, en teckning av en fågelmamma som grät över ett tomt rede och texten, TA INTE FÅGELÄGGEN vilket, enligt Expressen "satte igång en folkrörelse bland barn." ${ }^{16}$ Att Birgitta Gustavsson beskrivs som att hon "ryter" och att bidragen till tävlingen beskrivs som "fina" och "tänkvärda", visar också hur barn förväntades ha tänkvärda synpunkter och att barn gavs röstgenom tävlingen; de kan till och med ryta högt genom sina bilder. Genom att bilderna publicerades i dagspressen kunde de nå ut till många och budskapet kanske även sätta igång

\footnotetext{
511 Televerket ombildades 1993 till det privata bolaget Telia.

512 Fotot av mjölkpaket från K1da Produktbilder volym nr 11 1970-1999, Arlas arkiv Centrum för näringslivshistoria.

513 Bild av Omslaget finns i kapitel 4 Relationer mellan barn och vuxna.

514 Expressen 1977-07-31 sid. 18.

515 Ibid. sid.18.

516 Expressen 31 juli 1977 sid. 18.
} 
"en folkrörelse", kring något ämne som betraktades som viktigt av både barnen och tidningsredaktörerna.

Även Sveriges turistråds och Posten tävlingsbilder från tävlingen "Sverige är fantastiskt"1979, trycktes upp som vykort, och bilderna skulle då göras i vykortsformat. Listan över vilka som vann publicerades sedan i Dagens Nyheter, och vinnarbilderna från tävlingen 1978 ställdes ut i Sverigehuset bredvid Kungsträdgården i Stockholm. Världsnaturfonden (WWF) visade varje läns vinnarbilder från tävlingen Vårt gröna Arv 1985 på Läckö Slott under sommaren, och sedan trycktes affischer upp för vandringsutställning på bibliotek. ${ }^{517}$ Tidigare hade WWF 1974/75 arrangerat Operation Tiger och 1977/78 Levande hav, där vinnarbilderna tryckts upp som brevmärken för försäljning och där intäkterna gått till WWFs verksamhet (bild 2:19). De brevmärken som syns på bilden såldes till förmån för "Operation Tiger" Världsnaturfondens arbete för att skapa nationalparker i samarbetet med scoutrörelsen och Naturskyddsföreningen.
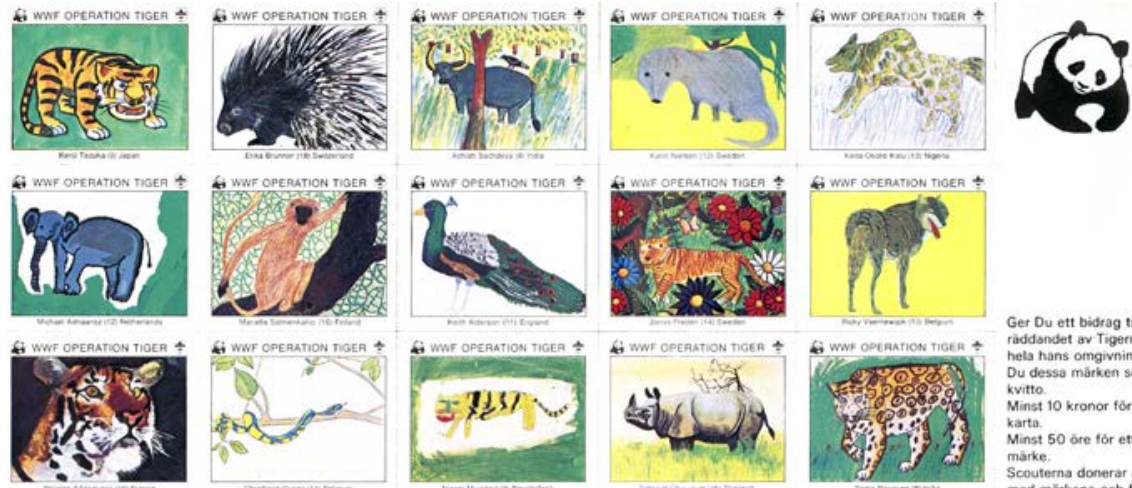

Ger Du ett bidrag till hiddondet av Tigern och Du dessa märken som. kvitto. Minst 50 öre fôr ett

màrke.
Scouterna donerar arbete Scouterna donerar arbetet
med märkena och far $1 / 3$ Ged märkena och tar $1 / 3$
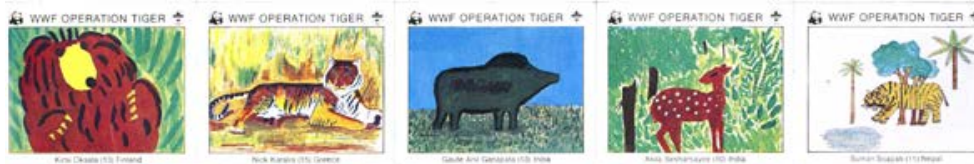
av intakterna till sitt natu.
valdsarbete, $2 / 3$ gatr till operation Tiger.

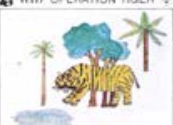
Faltbiologerna hialper ocksa till pá samma sătt. väridsnaturfonden WWF Fituna
14041 Sorunda

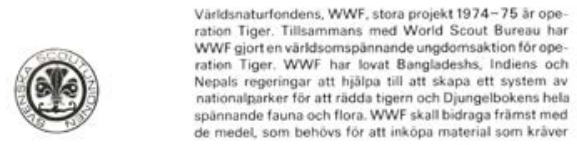

fràmmande valuta: jeepar, radioapparater och annan ut. rustning.

Ett led i denna har varit en văridsomspănnande tecknings täsling för barn, som i Sverige anordnades av Dagens Ny. heter och WWF. I Sverige deltog 15000 barn med 20000 teckningar. De tjugo bassta i väriden har tryckts som brev.

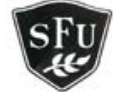

Bild 2:19. Brevmärken WWF, 1975

Bilderna från Rädda barnens "Livets träd" visades på olika, både nationella och internationella utställningar, bland annat på FN huset i New York och i Geneve. Bilderna efterfrågas fortfarande av olika barnrättsorganisationer, och flera är

517 SBBA arkiv samling 1990:032 WWF teckningstävling 1985-08-28 Skrivelse till barnbibliotekskonsulenten, Eskilstuna, från Sven Wahlberg, f.d. generalsekreterare WWF (Tävlingen var del av en internationell kampanj kallad Plants Campaign). 
också publicerade i boken Livets träd: världen genom barnets ögon. ${ }^{518}$ Lutherhjälpens tävling "Share" trycktes upp som affischer, och i Lutherhjälpens tidning.

De tidningar som var med och arrangerade tävlingar tryckte upp alla, eller några utvalda vinnarbilder $\mathrm{i}$ tidningen. Det har varit viktigt att nå ut och visa fram bilderna på olika sätt. Av denna anledning var det också en fördel att ha tävlingen i samarbete med en tidskrift.

$* * *$

Jag har i detta avsnitt diskuterat hur medias publiceringar om tävlingar och bilderna var viktig för att nå ut och marknadsföra sig som en part som engagerade sig i barn generellt och i barns skapande specifikt. Samtidigt är det uppenbart att det sätt som bilderna har visats upp har påverkats av olika faktorer. Det kan handla om olika förväntningar på barn från olika aktörer och under olika tid, liksom om hur material och teknikförändringar möjliggör olika former av bildproduktion.

Tävlingsbilderna har visats i traditionella former för konstbilder, som på galleri och vandringsutställningar. Barnkonstbilden, visad på galleri, var tydligast under den tidigaste tävlingen 1938-1945. Men även Temasamlingen Livets Träd 1977, visades på gallerier och i artiklar lyftes bildernas konstnärliga kvalitéer fram. Även tävlingen Sverige är fantastiskt 1978 ställdes ut i traditionellt konstnärlig kontext på ett galleri. Bilder reproducerades också i tidningar och tidskrifter. Under senare delen av perioden har ny teknik möjliggjort även andra former för att visa och sprida bilderna även i färg. Det kan vara att de tryckts på brevmärken, som vykort, på mjölkkartonger och telefonkataloger. Härigenom kunde bilderna få en ökad spridning, då de var reproduktioner och inte originalbilder.

Televerket menade att okonstlade barnbilder på telefonkatalogens omslag skapade goodwill för företaget, samtidigt som företaget kunde etablera sig hos barnen. Televerkets tävling synliggör en konflikt mellan hur teckningstävlingen å ena sidan positionerade barnen som offer för kommersialism och å andra sidan som aktiva deltagare i samhällets kulturliv. Tävlingsformen kunde användas för att få återkommande publicitet i dagspressen, och olika tävlingar kunde lyfta aktuella samhällsfrågor kring natur och miljö i media. Tävlingarna har under hela perioden visat fram barnbilden som ett uttryck för vuxnas uppskattning av barns deltagande på delvis olika arenor. Hur bildernas presenterats ger uttryck för samhällets förändrade syn på barn och barns skapande, och pendlar mellan att bilderna dels sågs som en del av den expressionistiska konstarenan och att de sågs som uttryck för barns åsikter om samhället och samhällets förändring.

\footnotetext{
518 Samtal med arkivarie 2015, Lindström, Sylvia, Berefelt, Gunnar \& Wik-Thorsell, Anna Lena (1978). Livets träd: världen genom barnets ögon. Stockholm: Rabén \& Sjögren i samarbete med Rädda barnen.
} 


\section{Sammanfattande diskussion}

I detta kapitel har jag undersökt fenomenet teckningstävlingar och hur de har beskrivits, organiserats och genomförts. Jag har även diskuterat hur tävlingarna och bilderna har använts för olika syften och i en rad skilda sammanhang. Det har påvisat att tävlingarna inte är något entydigt och homogent samhällsfenomen. Genom granskningen har jag också kunnat problematisera barndomens förändrade innebörder mellan 1938-2000. Analysen av barnteckningstävlingarna visar en tydlig komplexitet och ambivalens i förhållandet mellan barns skapande och barns tävlande under perioden, och rymmer tydliga konflikter mellan olika syn på barns bildskapande.

Under 1930 och 40-talet fanns ett intresse för de svenska barnens bilder som kan sägas spegla välfärdsstatens framväxt och uppbyggnad och ett bredare samhälleligt engagemang i barns villkor och uppväxt. När barnbilden blev en eftertraktad bildpreferens var teckningstävlingarna ett uttryck för barnets betydelse i samhällsbygget. Veckotidningen FIB som propagerade för arbetarklassens bildning kunde förenas med teckningslärarnas önskan om förnyad bildundervisning. Även Nationalmuseum, som hade tradition av tävlingar även för vuxna, intresserade sig för tävlingen. Tävlingen kunde vara del i att introducera barn i uppskattning av konstnärliga värden och vad som ansågs vara god smak.

Som jag har visat fanns en stark relation mellan de tidiga tävlingarna på 1930-talet och den moderna konsten. Barns bildskapande kunde representera det okonstlade och naiva som modernismen sökte. Barnbilder kunde användas för att ge Nationalmuseum uppmärksamhet, och samtidigt gav utställningarna och publiceringen av bilderna möjlighet att lyfta fram barnen och öka barns deltagande i samhälls- och kulturlivet. Att ge barn möjlighet att teckna utifrån sin fantasi var en del av den nya moderna pedagogiken. FIB:s teckningstävlingar för barn kan ses som del av denna modernitet, arrangörerna förenades i att vilja driva på för förändring mot en modern konstpedagogik.

Samtidigt visar analysen hur skolan haft ett ambivalent förhållande till barn och tävlande. FIB:s tävling på 1940-talet kan ses som del av en samtida samhällsdiskurs med ambitionen att skapa en mer jämställd skola, med samma förutsättningar för barn från alla klasser och platser att kunna delta. Tävlandet betraktades som positivt och lekfullt och det som bedömdes var barnens förmåga, oavsett socioekonomisk bakgrund. Teckningstävlingen lyftes fram som ett mått på att "svenska skolungdomen kan teckna" ${ }^{519}$ Detta kunde betraktas som ett mått på att den svenska skolan klarade sig bra i internationell konkurrens.

Barnkonst var således ett etablerat, om än komplext, begrepp. Men att tävla i teckning blev efterhand alltmer problematiskt. Konstdiskursen definieras av institutionella konstscener, av vad museer och gallerier värderat och definierat som konst, och vad som inte räkas som konst. ${ }^{520}$ När barnbilder under början av 1900-talet kommer in på gallerier och museer innebär det en diskursiv förskjutning, En förändring av hur konst kunde och borde se ut, innebar ett

519 FIB 1938 nr. 24 sid. 27.

${ }^{520}$ Rose, Gillian (2016) sid. 187. 
uppvärderande av barnbilden. Barnbilder kunde accepteras som ett konstnärligt uttryck, men främst som inspiration för konstnärer inom det tidiga 1900-talets expressionistiska måleri.

Teckningstävlingarna uppskattades sålunda av konstnärerna under 1940-talet, men 30 år senare kom tävlingarna istället i konflikt med vuxna konstnärer som såg barnen som konkurrenter om arbetstillfällen. Analysen av Arlas och Televerkets tävlingar 1976 visar att konstnärernas riksorganisation var kritiska till tävlingarna. KRO menade att barnen både tog konstnärers jobb, och barnen beskrevs samtidigt som utnyttjades i ett kommersiellt kapitalistiskt system. Barnen ansågs av konstnärerna inte längre som "oskuldsfulla blomster" som på 1940-talet, utan fullt medvetna om de kommersiella strukturer de ingick i. Andra kulturföreträdare menade att tävlingarna tvärtom var en möjlighet för barnen att delta i samhällets kulturliv. Samhällets förändring gjorde barndomen svårdefinierad. Barn borde inte utnyttjas i kommersiella syften, men samtidigt ansågs de vara kapabla att verka på lika villkor som vuxna och ha rätten att göra sin röst hörd.

En annan tydligt konflikt som funnits med under perioden var att tävlandet efterhand kom att betraktas som oförenligt med det fria skapandets ideal. Barn blev lyckliga av att skapa och måla, men olyckliga av att tävla, då inte alla kunde vinna. Den nya tidens ideal om uppfostran genom konsten, som etablerades i och med 1954 års läroplan, var oförenlig med tävlingen som form. Tävlingen gjordes i denna diskurs till samarbetets motsats.

Däremot uttalade sig flera teckningslärare under 1940-talet positivt till tävlingarna, då teckningslärarna genom sin specialkompetens att bedöma barnbilder, ansåg sig vara bäst lämpade för att vara jurymedlemmar i barnteckningstävlingar. De menade också att tävlingarna kunde bidra till samarbete då klasserna tävlade gemensamt. Bland lärarna fanns alltså inte någon enhetlig uppfattningar om tävlingarna.

På 1970-talet har diskursen om barns generella kreativitet och skapande förmåga etablerats. $\mathrm{Nu}$ höjdes igen röster för att spara barns bilder, men av andra skäl än att bevara de bästa konstverken. Den kulturpolitik som ligger bakom grundandet av SBBA:s arkiv 1977 handlade om att uppvärdera barnkultur och barns egna uttryck. Arkivet ville samla alla barns bilder oavsett vuxnas idéer om vad som var bra bilder. Bilderna ansågs framförallt kunna berätta om barns erfarenheter och perspektiv snarare än om inom vilka områden barnbilderna använts. Detta får till följd att det finns en otydlighet i arkiverandet av bilderna, där vilka samlingar som är resultat av tävlingar inte alltid syns. Vissa arrangörer från 1970-talet och framåt valde också bort jury och pris, även om man kallade evenemanget tävling. Därmed förändrades även tävlingens form delvis med tiden.

Den tekniska utvecklingen påverkade också tävlingarnas möjligheter att nå ut. Under 1970-talet blev det möjligt att trycka stora upplagor i färg utan alltför stora kostnader, vilket är en anledning att det blev möjligt för företag och organisationer att trycka upp och distribuera även barnbilder i massupplagor, som på telefonkataloger, vykort, mjölkpaket eller affischer. Just publicering på telefonkataloger och mjölkpaket gjorde barnbilden närvarande i de flesta hem. 
Samtidigt blev tävlingsbilderna del av ett ständigt pågående massmedialt bildflöde och med det kunde bilderna uppfattas på ett annat sätt av sin publik, än 40-talets bilder som ställdes ut på museum. Bilderna kunde till viss del bli mer osynliga när de fanns i vardagen, men barnbilden kunde också användas för att de syntes och uppmärksammades igenom medieflödet. ${ }^{521}$ Barnbilder kunde när de visades till exempel på mjölkpaket, ge företag en aura av att de värnade om barnen och att de ville visa fram barns skapande förmåga, vilket kunde locka vuxna konsumenter.

Tävlingen som fenomen förutsätter en förväntan på barns aktörskap, och barns kompetens under den undersökta perioden. Barn gjordes aktiva och synliga genom tävlingarna. Förutom att lyfta barn som aktörer, visade tävlingarna även samtida normer och värden kring barn och barndom. Tävlingarna kunde både handla om att uppmärksamma de värden som ansågs inneboende i barnen, eller vilka normer som borde överföras till barnen. Kontexten kring hur man definierar barndomen har haft betydelse och förändrats: i 40-talets tävlingar omtalades barnen av Nationalmuseums intendent som oskuldsfulla blomster, medan ungdomar i tävlingsutskick från Televerket på 1980-talet tilltalades som potentiella sabotörer. I Televerkets tävlingar under 1990-talet beskrevs och efterfrågades ungdomar istället som nyfikna uppfinnare. Under den senare perioden positioneras de också som framtida konsumenter.

Analysen av tävlingarnas syfte och teman visar en komplex bild av barn och barndom, där barn konstruerades både som potentiellt hotfulla och som dem som kunde ge lösningar och framtidsperspektiv. Tävlingarna framställer barnen både i positionen av att vara samhällsbevarare och samhällsförnyare.

I de följande fyra kapitlen kommer jag att analysera bildernas innehåll och hur bilderna omtalats i sin samtid, samt hur tävlingarnas teman skapade strukturer och gränser för vilka subjektspositioner barn kunde förväntas inta. Jag kommer bland annat att undersöka hur tävlingsbilderna definierar vad som är barns platser, och hur det återkommande temat hembygden har definierats både av barnen och hur olika arrangörer har kommenterat bilderna. Därutöver diskuteras hur barn har positionerats i bilder av skolan, i relationer med andra barn och med vuxna. Slutligen granskas hur genusdiskurser formulerades i bilderna och texter om bilderna.

${ }^{521}$ Rose, Gillian (2016) sid. 39. 


\section{Kapitel 3. SVERIGEBILDER}

Att avbilda hembygden var ett uttalat och återkommande syfte med teckningstävlingarna från arrangörers och skolans sida under perioden 1938-2000, vilket jag visade i föregående kapitel. Många skilda aktörer var involverade och hade påtagligt olika engagemang i bilder av Sverige och hembygden. Detta speglar hur kommersiella intressen kunde samverka med myndigheters intressen i tävlingar arrangerade av exempelvis Svenska turistföreningen eller Europeiska Unionen. ${ }^{522}$ FIB, Nationalmuseum och Televerket visade också att det fanns intresse av att upprätthålla och tradera nationella diskurser från både folkrörelseföreträdare och företrädare för offentliga institutioner.

Att bilder hade betydelse för "det nyvaknade sinnet för Sverige och det svenska", underströks redan 1911 av Carl G Laurin i boken Sverige genom konstnärsögon. Han skriver i förordet:

Meningen med utgifvandet af "Sverige genom konstnärsögon" har varit den att ge en föreställning om hvad de sista tiotalets målning betydt för det nyvaknande sinnet för Sverige och det svenska. Vi behöfva stanna ett ögonblick och glädjas åt hvad vi fått af våra konstnärer också på detta viktiga område, det nationella." 523

I den efterföljande texten menar Laurin att "vi längta efter en äkta, en varm men försynt fosterlandskänsla", och att vi behöver en ökad känsla för "den svenska egenartens värde" i en tid då många emigrerar och vi "fortplanta och gifta oss alldeles för litet." ${ }^{524}$ Laurin var en betydande konstskribent vid sekelskiftet och var också med och grundade föreningen för skolornas prydande med konstverk, från 1903 benämnd Konsten i skolan. ${ }^{525}$ I Sverige genom konstnärsögon beskriver Laurin även de specifikt svenska barnen. Efter en tågresa genom Skåne, ”som med sina vitrappade gårdar ge ett osvenskt intryck”, skrev Laurin:

Det är först då tåget susar igenom Smålands tallskogar, och då vid stationerna små lingula, blyga och blåögda flickor, stumma

522 Se kap. 2, Europeiska kulturstiftelsens tävling 1959 "Rita och måla något som du tycker är typiskt svenskt” Sveriges turistråds tävling "Sverige är fantastiskt” 1978 och 1979, Två Nils Holgersson tävlingar 1989 och 1996.

${ }^{523}$ Laurin, Carl G. (1911) sid. 5.

${ }^{524}$ Laurin, Carl G. (1911) sid. 10.

525 Werner, Jeff \& Björk, Tomas (2014) Blond och blåögd: vithet, svenskhet och visuell kultur = Blond and blue-eyed : whiteness, Swedishness, and visual culture. Göteborg: Göteborgs konstmuseum Laurin gav även ut boken Barnet i liv och konst (1938) och flera verk om svensk och nordisk konsthistoria. 
som fiskar, med bedjande blickar utbjuda hallon och blåbär i näferaskar, som man känner att man är hemma i Sverige. ${ }^{526}$

Citatet visar hur gemensamma idéer om vad som gav ett svenskt eller osvenskt intryck skapades genom beskrivning av specifik natur, arkitektur eller växter och människor i naturen. ${ }^{527}$ I det här kapitlet skall jag granska hur diskurser om Sverige visualiserats genom teckningstävlingar. Jag lägger särskilt fokus på två perioder 1938-1947 och 1976-1978. Genom att granska två skilda perioder kan jag visa på förändring och kontinuitet över tid.

Det finns anledning att inledningsvis precisera några centrala aspekter av vad som kännetecknat skapandet av nationella identiteter. En sådan aspekt innefattar en distinkt kulturell identitet, och även förmågan att producera kultur inom den estetiska och intellektuella bemärkelsen. Exempelvis skapades specifika nationella språk som nationalspråk genom skolan och andra institutioner under mitten av 1800-talet. Genom gemensamt språk och gemensam skola avgränsades det nationella både geografiskt och kulturellt. ${ }^{528}$ Nationell identitet är således en inlärd företeelse som stor till del bygger på visuell kultur, och nationella kulturella produkter, som exempelvis flaggor eller kungabilder. ${ }^{529}$

Identifikation med den nationella gemenskapen har historiskt definieras både genom beskrivningar av landskap och beskrivningar av de människor som fanns och bodde i landskapet. Detta innebar att platser, landskap eller utseende laddades med nationell innebörd. ${ }^{530}$ Tidigare forskning har problematiserat hur kulturmönster ofta uppfattas som naturgivna även om de styrs medvetet. ${ }^{531}$

När nationalstater växte fram i Västeuropa under 1800-talet, aktualiseras parallellt även barndom som en specifik period i en människas liv. Barn betraktas då också som del i den större nationella familjen. ${ }^{532}$ Barnen blir viktiga objekt i nationsbyggandet och barns hälsa och skolgång ses delvis som en angelägenhet för staten. ${ }^{533}$ Nationalismen kunde verka på samma gång sammanhållande som exkluderade; sammanhållande över exempelvis klassgränser, men exkluderande för dem som saknade medborgarskap. ${ }^{534}$ Under 1900-talets framväxande svenska välfärdsstat förändrades efterhand innebörder både av barndomsideal och

526 Laurin, Carl G. (1911) sid. 18.

527 Se även Werner, Jeff (2014) kap. blågula landskap.

${ }^{528}$ Hobsbawm, E. J. \& Ranger, T. O. (red). (1992). The invention of tradition. Canto ed. Cambridge: Cambridge University Press sid.13f. Stephens, Sharon (1995).

529 Billig, Michael (1995). Banal nationalism. London: Sage.

530 Smith, Anthony D. (1999). Myths and memories of the nation. Oxford: Oxford University Press.

531 Gellner, Ernest (1999).

532 Hendrick, Harry (1997) Children, childhood and English society, 1880-1990. Cambridge: Cambridge Univ. Press sid. 41. Sandin, Bengt "Education" in Heywood, Colin (red). (2010). A cultural history of childhood and family in the age of empire, Berg, Oxford, sid. 10.

533 Lee, Nick (2001). Childhood and society: growing up in an age of uncertainty. Maidenhead: Open University Hendrick, Harry (2003). Child welfare: historical dimensions, contemporary debates. Bristol: Policy Sandin, Bengt (1995). "The Century of the Child”: on the changed meaning of childhood in the twentieth century. Linköping: Univ. sid. 18.

534 Gellner, Ernest (1999) Sid 92. Hobsbawm, E. J. (1992). Nations and nationalism since 1780: programme, myth, reality. 2. ed. Cambridge: Cambridge Univ. Press sid. 39. 
föräldraroller. Skolan blev en viktig plats i dessa förändringar. ${ }^{535}$ Skolväsendet som etablerades och byggs ut efterhand under 1800- och 1900-talet etablerade inte enbart ett enhetligt skriftspråk utan också ett bildspråk, bland annat genom skolplanscher eller särskilda åskådningsböcker. ${ }^{536}$

Boken Nils Holgerssons underbara resa av Selma Lagerlöf var både en lärobok i Svensk geografi och en sedelärande berättelse som gavs ut för att väcka en nationell identitet. Den gavs ut i två band 1906/07. ${ }^{537}$ Boken användes under lång tid i svenska skolors geografiundervisning. Ämnen som litteratur, geografi och historia var del i att etablera en gemensam nationsidentitet. ${ }^{538}$ Den svenska, och nordiska nationella identiteten har i hög grad varit förankrad i det nationella landskapet, något som syns både i poesi och exempelvis nationalsången. Det uttrycks även av konstnärer och i fotografier eller vykort. ${ }^{539}$ De skolresor som prispengarna från FIB:s teckningstävlingar gick till var också del i att skapa en känsla för det gemensamma svenska kulturarvet, för den nya generationens medborgare. ${ }^{540}$ Skolresor är något som beskrivits av både Lindgren och Löfgren som ett sätt att förstärka en nationell identitetskänsla, och idén om nationell modernitet. ${ }^{541}$

Teoretiskt har denna studie som utgångspunkt att den visuella kulturen är delaktig i skapandet av bestämda uppfattningar om världen och därmed också om nation och hembygd, som är föremål för granskning i det här kapitlet. Nicholas Mirzoeff diskuterar den västerländska uppfattningen om att "kultur" skapas först genom människans påverkan på naturen. Landskapsmåleriet från 1600-talet och framåt åskådliggör människans erövring av naturen. Mirzoeff menar att detta synliggör hur västvärlden alltsedan 1600-talet, sett naturen som av gud given människorna att förbruka för mänsklig vinning. ${ }^{542}$ Människans erövring av naturområden, innefattade också specifika visualiseringar av vad som betraktades som nationellt, eller hur det nationella såg ut. Detta kunde skildras genom avbildningar av landskap, personer, platser, händelser eller monument.

Konsten var medskapare av vad som kommit att betraktas som svenskt, genom skapandet av nationella museer och ett nationalromantiskt måleri, och genom hur museer i sina samlingar skapat ideala bilder kring svenskhet och svensk natur. ${ }^{543}$. Även specifika kroppsliga drag kom att fästas vid nationaliteten svensk.

\footnotetext{
535 Sandin, Bengt \& Halldén, Gunilla (red). (2003). Barnets bästa: en antologi om barndomens innebörder och välfärdens organisering. Eslöv: B. Östlings bokförl. Symposion sid. $221 \mathrm{f}$.

${ }^{536}$ Jonsson, Olof G. (2006) Skolplanschen: argument $i$ spänning mellan bild och text, perspektiv och kontext. Licentiatavhandling Uppsala : Uppsala universitet, 2006 sid. 56.

537 Sandin, Bengt I Ogata, Amy Fumiko \& Weber, Susan (red). (2014). Swedish wooden toys. New Haven: Yale University Press sid. 38.

538 Tingsten, Herbert, Gud och fosterlandet: studier i hundra års skolpropaganda, Norstedt, Stockholm, 1969.

539 Ehn, Billy, Frykman, Jonas \& Löfgren, Orvar (1993). Försvenskningen av Sverige: det nationellas förvandlingar. Stockholm: Natur och kultur sid. $89 \mathrm{ff}$.

540 Ibid. Bild av barn på skolresa. sid.99 Bildtext: årskull efter årskull av barn har i skolresans form skapat sig bestämda bilder av Sverige och dess sevärdheter.

541 Lindgren, Anne-Li (1999) sid173. Ehn, Billy, Frykman, Jonas \& Löfgren, Orvar (1993) sid. 99.

${ }^{542}$ Mirzoeff, Nicholas (2015). How to see the world. 1. uppl. London: Pelican sid. $219 \mathrm{ff}$.

543 Smith, Anthony (1999); Gellner, Ernest (1999); Werner, Jeff \& Björk, Tomas (2014).
} 
Werner och Björk undersöker i Blond och blåögd: vithet, svenskhet och visuell kultur föreställningar om hur svensken blev blond och blåögd, liksom hur det nationella från 1800-talets slut knyts till kroppen och landskapet. ${ }^{544}$ De visar också hur de nationella museerna och konsten görs delaktiga i att skapa ideal och föreställningar kring etnicitet och nation. Exempel på detta är Carl Larssons ljusa barn och Zorns ljusa kvinnokroppar, eller barnlitteraturen som Elsa Beskows "Putte i blåbärsskogen" eller "Tomtebobarnen". ${ }^{545}$ Bilder av barn har också använts för att förmedla nationella ideal i fototävlingar och fotoböcker. Exempelvis genom fotografier av de svenska "A-barnen" i tidningen Aftonbladets tävlingar under 1930 och 40 -talet..$^{546}$

Nationella landskap har kunnat laddas med specifik symbolisk och mytisk mening. Anthony Smith använder för detta fenomen begreppet "ethnoscape"; landskap som genererade känslor av vördnad och tillhörighet för vissa specifika platser och grupper. ${ }^{547}$ Bilder av landskapet och människor i landskapet blir del i att definiera en delad ursprunglig och folklig kultur, och delade minnen. Begreppet ethnoscape är användbart för att diskutera både vad barn ombetts avbilda och hur specifika platser, personer och barndomar därigenom visualiserats, med anknytning till specifika landskapsbilder. Föreställningar om ursprungliga, etniska samhällen kunde spridas genom bilder, texter och specifika kulturella symboler. Smith menar vidare att en överklass, som ville skapa en stark stat och få med sig regioner i periferin eller underklassen, kunde göra detta genom att använda en "Folkkulturdiskurs" med ett gemensamt symbolskapande..$^{548}$

Upplevelsen av en gemensam visuell kultur har således varit viktig för att definiera det nationella. ${ }^{549}$ Även producerandet av kultur, genom exempelvis teckningsundervisningen och teckningstävlingarna, kan ses som del av denna gemensamma kultur.

Frågorna för detta kapitel blir mot denna bakgrund; På vilka sätt har barn i tävlingsbilderna visualiserat nationella diskurser, på uppdrag av olika arrangörer? För att besvara dessa frågor kommer jag också att utgå ifrån hur tävlingsbilderna beskrevs och introducerades av Nationalmuseum och tidningen FIB, samt den norm som etableras genom förebildliga gestaltningar i skolans arbetsböcker. Analysen av bilderna kommer granska vilka visuella tecken som har fästs vid bilder av Sverige. Hur har det Svenska associerats och gestaltats i vinnande bilder? Hur har detta förändrats över tid? Bilderna samt textkommentarer till bilderna kan användas för att beskriva vilka normer och identitetskonstruktioner som uppskattades av tävlingarnas arrangörer och jurys.

Genom en semiotisk näranalys av bilderna och genom att studera bildernas intertextuella referenser blir det möjligt att se hur bilderna ingår i en bredare

\footnotetext{
544 Werner, Jeff \& Björk, Tomas (2014).

545 Beskow, Elsa (1937) Tomtebobarnen: bilderbok.[5. uppl.] Stockholm: Åhlén \& Åkerlund; Werner, Jeff \& Björk, Tomas (2014), bilder sid. 11-15.

546 Hallberg, Mathilda (2107).

547 Smith, Anthony D. (1999) sid. 152.

548 Smith, Anthony D. (1999) sid. 18.

549 Gellner, Ernest (1999) Nationalism. Nora: Nya Doxa sid. 19-23.
} 
kontext och hur bilderna bidrar både till upprätthållande och omförhandling av rådande diskurser. Barnbildsdiskursens äkthetsanspråk som jag diskuterade i kapitel två, har generellt inneburit att bilderna definierats som okonstlade och sanna, även om bilderna har haft vitt skilda framträdandeformer. Som jag diskuterade i metodkapitlet innebär den analysmetod jag använder att jag studerar både bildens denotationer och konnotationer, och hur de refererar till i sin samtid. Genom näranalyserna går det att se hur symboler och andra tecken diskursivt producerar specifika idéer om världen. Den diskursanalytiska metoden söker efter återkommande teman i bilderna, och kan peka på hur bilder skapar representationer och kunskap om världen. Ernest Gellner menar att det som definierar en nation är "delad kultur" ${ }^{550}$ Detta kan vara att visa fram en specifik bilduppfattning om "vårt land och folk". Detta innebär att även själva "görandet", genom exempelvis teckningsundervisningen, blir del av skapandet av den gemensamma kulturen.

I detta kapitel analyserar jag flera tävlingar, dels FIB:s "teckningstävling för skolungdom" 1938-1947, främst tävlingen 1939 med temat Livet $i$ min hembygd, och tävlingen 1944 med temat Svenskt helgfirande. Därutöver analyseras Televerkets tävling 1977 med temat En händelse i vår hembygd, och 1978 med temat En historisk händelse i vår hembygd, och slutligen Arla/Postens teckningstävling med temat Detta vill jag värna om, publicerade i boken, Varför fär inte barn bestämma 1977. ${ }^{551}$ De bilder som har valts för näranalys i denna tävling är dels de som innehåller nationella symboler samt de som refererar till landsbygds-och hembygdstemat.

Delavsnitten i det här kapitlet är utformade på lite olika sätt beroende på bildmaterialets heterogena karaktär. Det första avsnittet är benämnt Bilder av hembygden. Hembygden har alltså varit flitigt förekommande teman i tävlingarna, och i det första underavsnittet diskuterar jag samtliga tävlingsbilder från FIB:s tävling 1939. Här hade barnen ett direkt uppdrag att rita sin hembygd. I det här avsnittet granskar jag vilka tecken som hembygden laddas med. Eftersom hembygd också var ett kunskapsområde med ett särskilt ämne i skolan granskar jag också närmare hur två tävlingsbilder förhåller sig intertextuellt till skolans arbetsböcker i hembygdskunskap och geografi.

I det följande underavsnittet, Televerkets hembygdstema -landsbygd och historia, granskar jag en senare tidsperiod genom Televerkets hembygdstävlingar från 1977-78. Även här ligger mitt intresse i att se vilka tecken hembygden laddas med och vilka innebörder hembygden ges, samt förändring och kontinuitet över tid mellan FIB:s vinnande hembygdsbilder 1939 och Televerkets hembygdsbilder 1977-78. I detta avsnitt problematiseras också innebörden i vad som betraktades som en olämplig hembygdsbild. I avsnitt två, Flaggor och kungar, granskas hur symboler som flaggor och kungar delvis fătt förändrade innebörder över tid.

\footnotetext{
550 Ibid. sid. 19-23.

551 FIB arrangerar tävlingen tillsammans med teckningslärarförbundet; Arla/Postens tävling är oftast inte gjord i skolan; Tävlingarnas organisation är i övrigt mer utförligare diskuterad i kapitel 2.
} 
I avsnittet Folket $i$ bild och Nationalmuseum - Sverige genom barnaögon diskuteras hur dessa tävlingsarrangörer kunnat förenas i ett gemensamt intresse för barnbilder och barns skapande men av delvis skilda orsaker. Avsnittet inleds med en analys av omslagsbilden till jubileumsalbumet Sverige genom barnaögon. Från FIB och Nationalmuseums tävling har jag därefter valt att granska de två arrangörerna var för sig. Jag analyserar dels de tävlingsbilder från hembygdstemat som publicerades i tidningen FIB 1939, och hur de beskrevs i tidningen, dels de hembygdsbilder som publicerades i Sverige genom barnaögon, och hur Nationalmuseums intendent valt att kommentera och beskriva bilderna.

Under den senare perioden använder jag Arlas/Postens tävling från 1976 som jämförelse. Den hade inte hembygden som ett specifikt uppdrag. Uppdraget var istället var att rita det barnen ville värna om, där de bilder som analyseras refererar till värnande av Sverige eller hembygden, och de analyseras i avsnittet Arladetta vill jag värna om - barnen som politiska subjekt. Analysen av dessa skilda tävlingsbilder gör det möjligt att visa hur tävlingarna agerat inom skilda diskurser; men där de har det gemensamt att de alla omfattar diskursen om barns bildspråkliga förmåga. I nästa avsnitt granskas således först hur hembygdsdiskursen förankrats och förändrats både över tid och mellan och inom olika tävlingar.

\section{Bilder av Hembygden}

1938 har FIB sin första teckningstävling för skolungdom, och 1947, strax efter kriget ges jubileumsalbumet Sverige genom barnaögon ut, med reproduktioner av utvalda bilder mellan 1938-1946. Titeln parafraserar troligen medvetet Laurins Sverige genom konstnärsögon. I förordet till boken beskriver nationalmuseums intendent Ragnar Hoppe tävlingarna på följande sätt:
Överhuvud voro som sagt prisämnena väl valda, och barnens reaktion riktig och sund. Den bild av det nutida Sverige de skänkt oss i sina teckningsförsök har också blivit både fängs- lande sann och märkligt rikt facetterad och inte minst i Natio- nalmusei av FIB skänkta samling får man en föreställning om hur viktig och värdefull teckningsundervisningen är för bar- nens syn på och uppfattning om vårt land och folk..$^{552}$

Citatet visar att bilderna betraktades av museichefen Hoppe som både sanna och rikt facetterade. Teckningsundervisningen och bildskapande i skolan betraktades som värdefullt och viktigt för att ge barn en uppfattning om Sverige och svenskarna. Vid teckningstävlingen Livet i vår hembygd 1939 uppmanar FIB barnen att teckna det som är specifikt för just deras hembygd, och skriver i anvisningarna: "Det är meningen att hela Sverige ska vara med i denna tävling." 553

Jag kommer nu först presentera en översikt av de 117 bilder med temat " $\mathrm{Li}$ vet i vår hembygd" som finns bevarade i Nationalmuseums samling. I komman-

\footnotetext{
552 Jungmarker, Gunnar \& Hoppe, Ragnar (red). (1947). Sid. 7.

553 FIB 1939 nr 8 sid. 28. (kursiv i original).
} 
de avsnitt kommer några av dessa bilder att väljas ut för en utförligare semiotisk analys. Hur dessa valts ut framgår av varje delkapitel.

Hembygden skildras i bilderna både genom motiv som refererar till stads- och landsbygdsmiljöer. Totalt är det något fler bilder (62) som visar landsbygdsmotiv, än som visar stads- eller fabriksmotiv (55). Hembygdsbilder med stadsmotiv beskrevs exempelvis av gatumusikanter i Gamla Stan i Stockholm, barn och vuxna som tittar i skyltfönster, eller kvinnor i vackra hattar och dräkter runt Poseidon på Götaplatsen i Göteborg. Sex hembygdsbilder skildrar byggarbetsplatser. Det finns även sex kyrkobilder, som jag definierat som stadsbilder, även om de kan vara kyrkor i mindre samhällen. Stadsmiljöer kunde även vara bilder av parker, hamnar, torg- eller marknadshandel, men även fabriks- eller gruvbilder ingår i denna kategori. Industriella hembygdsbilder avbildar exempelvis glödugn från Olofströms bruk, eller interiör med män i arbete på Gislaveds gummifabrik. En interiörbild återger hemindustriell stickning, en annan interiör är en bild från en restaurang, men majoriteten bilder skildrar hembygden i utomhusmiljö. En bild som visar en stadsskola med lekande barn på trottoaren framför skolan. Det finns bilar i nio bilder, ofta vid arbetsplatser, även människor som cyklar till jobbet, och i två bilder hästar i som drar vagnar eller kärror. En bild är en närbild av ett flygplan. ${ }^{554}$ Fem bilder gestaltar högtider, två bröllop, en visar midsommarfirande där människor med folkdräkt dansar runt en midsommarstång och två bilder visar 1a maj tåg. ${ }^{555}$

Av hembygdsbilder med landsbygdsmotiv är det flest (19 bilder) som är associerade till skogsarbete, exempelvis timmerkörning med häst i skogen eller flottning, två bilder visar kolarmilor. ${ }^{556}$ I princip lika många (18 bilder) visar arbete på åkern, det kan vara betesskörd, slătter, att plöja eller skörda hö. ${ }^{557}$ Åtta bilder är landskapsbilder utan människor, och tre bilder är interiörbilder, av att baka bröd, karda spinna, och väva. Bland landsbygdsbilderna avbildas djur i 27 bilder och av dem gestaltar fem bilder jakt och fiske. När hästar avbildas i landsbygdsbilderna är det nästan uteslutande som arbetshästar (16) i skogen eller på åkern, endast en bild visar en ridhäst, en bild visar hästar i en hage. Även kor är vanliga i hembygdsbilderna, avbildade i hagar i sex bilder, avbildade mjölkade för hand på två bilder. ${ }^{558}$ Renar förekommer i två bilder, tillsammans med män i traditionella samiska kläder i vinterlandskap. Det finns två bilder med traktorer och en bild av en snöplog. ${ }^{59}$ Femton av landsbygdsbilderna är vinterbilder, oftast skogsarbete eller pimpelfiske. Skogsbruk visar även fem bilder av flottning av timmer.

Genomgången av alla bilderna visar att deltagandet $i$ att arbetet är något som framställs som viktigt både i skogen, på åkern eller i industrin. Det arbetande fol-

\footnotetext{
${ }_{554}$ Flygplanet har tre kronor på sidan och röda kors på vingarna, alltså symboler för att det är ett svenskt sjukvårds- eller rödakorset plan. Det fanns även militära flygplan i flera bilder 1944: Svenskarna i allvarstider - beredskap förr och nu.

${ }^{555}$ En av bröllopsbilderna återkommer senare i detta kapitel, bild (3:33)och en av 1:a majbilderna (bild 3:16).

556 Se t.ex. bild 5:14 i kapitel Bilder av flickor och pojkar, kvinnor och män.

557 Se t.ex. bild 3:8.

${ }_{558}^{55}$ Det finns även på temat min fritid 1940 två bilder av barn som mjölkar kor.

559 Bild 3:30 är en av traktorbilderna.
} 
ket, och även det arbetande barnet, var viktigt att visa fram. Av 117 bilder är det bara åtta som inte har människor med i bild. Människor skildras i staden, och i arbete i fabriker och gruvor. Bildmaterialet visar även hur hembygden associerades med jordbruksarbete på landsbygden, hästar framställdes mer frekvent än traktorer, och kor mjölkades i bilderna för hand snarare än med maskiner. Hur hembygden associerats med både modernitet och tradition är en framträdande fråga som återkommer i den senare diskussionen.

\section{Sverige och hembygden i FIB:s tävling och i folkskolans arbetsböcker}

När FIB 1947 i samarbete med Nationalmuseum ger ut jubileumsalbumet Sverige genom barnaögon med bilder från tävlingarna 1938-1945, skriver intendent Edvard Hoppe i inledningen:

Att det är just Sverige och svenskarna vi möta i dessa bilder råder ingen tvekan om. Vi får här vara med om trädfällning i höstgyllene skogar, fiskafänge och jakt i ett snövitt Norrland, höskörd och potatisupptagning på skånska slätten, vi följa med in i ladugården och se på mjölkningen, och årets alla högtider och helger passera revy i de mest olika miljöer. ${ }^{560}$

Citatet visar hur Hoppe poängterar att det inte är någon tvekan om att bilderna visar Sverige och svenskarna. Landskapens olika karaktäristik definierar den svenska identiteten; alltifrån ett snövitt Norrland till den skånska slätten. Även arbetet i landskapet, årstiderna och specifika högtider definierar det svenska.

Han beskriver vidare barnens bilder på följande sätt: "man... häpnar över hur dessa "artister" med koncentration och slående expressivitet fixerat de väsentliga dragen i skilda landskapskaraktärer, hur de tagit folktypen på kornet..."

Citatet visar på en samtida föreställning där specifika folktyper och landskapskaraktärer sågs som relationella, vilket kan användas för att skapa en känsla av nationell enighet på liknande sätt som begreppet ethnoscape, som jag diskuterade tidigare.

Utseende och kläder visade hur olika grupper representerades, och skolplanschers och läroböckers visuella retorik hade en både övertalande och övertygande funktion, som förmedlare av korrekt kunskap. ${ }^{561}$ Anne-Li Lindgren problematiserar vilka tolkningar kring medborgarskapet som formulerades i skolradion under 1930-talet, samt hur skolradion framställde högre och lägre kulturer, och därigenom definierade ett "vi" och "de andra". ${ }^{562}$ Detta avsnitt diskuterar hur både bilder i läroböcker och barnens egna bilder skapade normer och ideal, och hur visuella diskurser kring "vi" och "de andra" kunde definieras i bilderna.

I en av Sjöholm och Goes läroböcker med tysta övningar i Geografi presenteras landskapet Sörmland med en bild av de sörmländska barnen. ”De sörmländska barnen" visualiseras som sammanhörande med landskapet Södermanland.

${ }_{560}$ Jungmarker, Gunnar \& Hoppe, Ragnar (red). (1947).

561 Jonsson, Olof G. (2006) sid. 57.

562 Lindgren, Anne-Li (1999). "Att ha barn med är en god sak": barn, medier och medborgarskap under 1930-talet. Diss. Linköping : Univ., 2000 sid. 17, $197 \mathrm{ff}$. 
Att de delar en gemensam historia och kultur beskrivs genom bilder av odlingslandskapet, kyrkan, och folkdräkterna. ${ }^{563}$ Enligt bokens anvisningar skulle landskapsdräkterna användas för att teckna av och använda för att "klä" barnen i landskapsdräkter. Dräkten och det lokala landskapet definierade barnen, både $i$ en regional och $i$ en nationell kontext. Hallberg har tidigare visat hur barn $\mathrm{i}$ folkdräkt i användes i fotoböcker under 1930 och1940-talet för att reproducera idéer om folket, nationen och svenskhet. ${ }^{564}$ Även Werner och Björk diskuterar hur kläder varit viktiga för att definiera svenskhet, där folkdräkterna konstruerades som symbol för både lokal och nationell identitet. ${ }^{565}$ Folkdräkterna syns även i flera av Televerkets hembygdsbilder 1976/77. ${ }^{566}$

Hembygdskunskapsämnet och skolböckerna byggde på arbetspedagogikens progressiva pedagogiska idéer om "learning by doing". Skolbarnen aktiverades, exempelvis genom teckning. Samtidigt kunde skolan genom teckningsövningar i hembygdskunskap och geografi, skapa en samförståndskänsla och en känsla av gemensam kulturell identitet hos skolbarn, där specifika typer av klädsel och utseende görs möjliga, för specifika grupper. John Deweys progressiva pedagogiska ideal, har problematiserats för att de inte enbart avsåg fostran till demokratiska medborgare, utan även till arbetskraftskvalificering och nationalisering. ${ }^{567}$ På liknande sätt kunde arbetspedagogikens progressiva ideal genom skolböckers och planschers visuella retorik skapa normativa bildideal där specifika markörer för svenskhet gjordes giltiga, vilket även etablerades i barnens egna bilder.

Idealbilder återfinns även i den visuella framställningen i förlagor för teckningsundervisningen. Teckningsförlagor i hembygdskunskap och geografi från 1930 och 40-talet, visar hur bildgenrer bygger på och refererar till varandra, där FIB:s tävlingsbilder ofta är tydligt inspirerade av arbetsböckernas förlagor. Ett par av de bilder som förekom i Sjöholm och Goes arbetsböcker i hembygdskunskap och geografi kan också sättas i relation till två barnbilder från FIB:s tävling Livet $i$ vår hembygd, för att belysa att skolans teckningsförlagor och texter var en viktig inspirationskälla för barnens bilder (bild 3:1-3:4).

\footnotetext{
563 Sjöholm, L. Gottfrid \& Goës, A. (1927-1928). Arbetsövningar (tysta övningar) i geografi.. Arlöv ...: Skriv- och ritboks a.-b. Häfte 2 Södermanland Uppland Västmanland Närke Värmland Dalsland Västergötland Bohuslän.

${ }^{564}$ Hallberg, Mathilda (2017) sid. 230-235.

${ }^{565}$ Werner, Jeff \& Björk, Tomas (2014) sid. 84.

566 Se till exempel bild 3:6.

567 Dewey, John (1999). Demokrati och utbildning. Göteborg: Daidalos (democracy and education 1916) Broady, Donald (2007). Den dolda läroplanen. Göteborg: Krut sid. $92 f$.
} 


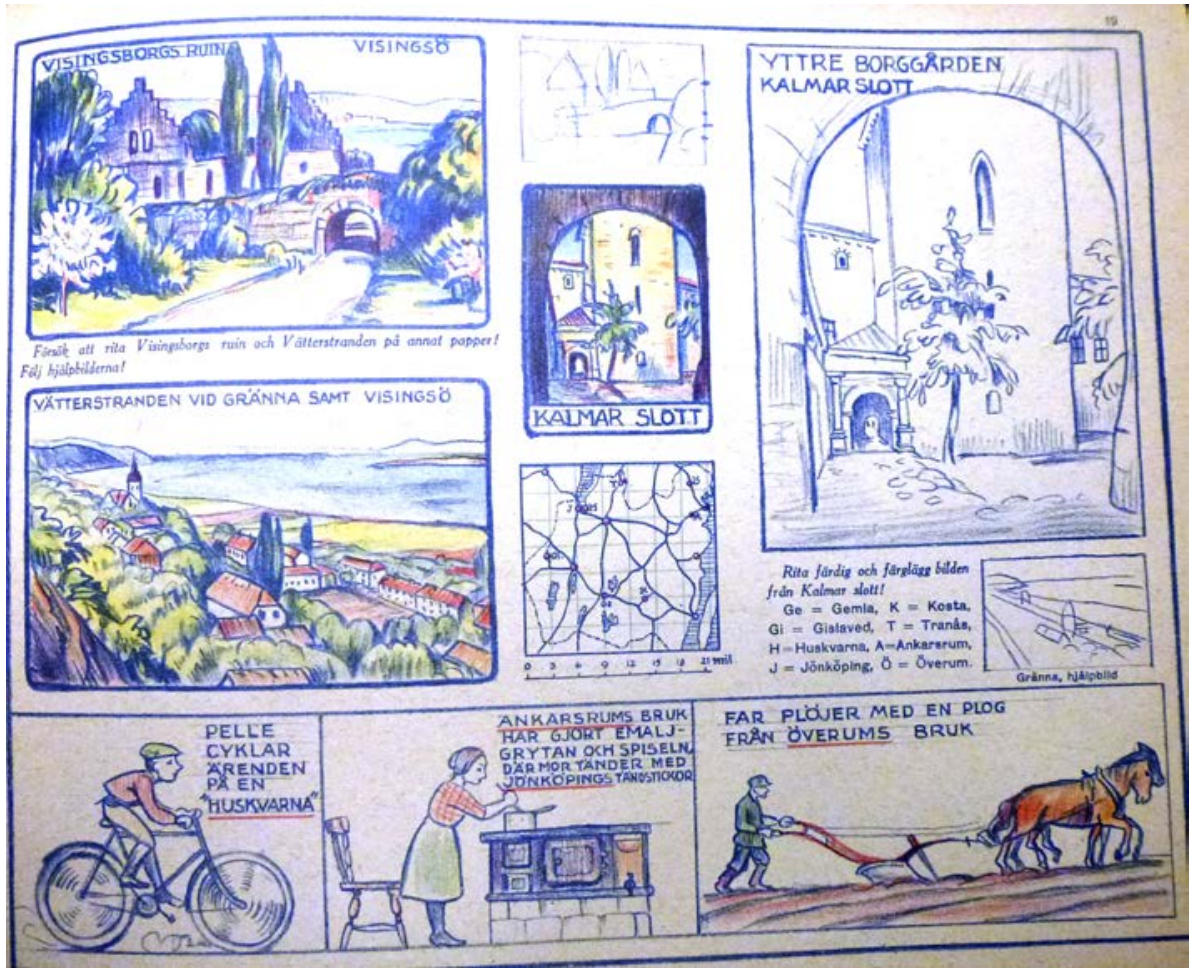

Bild 3:1. Sjöholm, L. Gottfrid \& Goës, Axel (1943) Arbetsöuningar (tysta övningar) i geografi sid. 19.

Bild 3:1 är från en av Sjöholm \& Goes arbetsböcker; "Tysta övningar i Geografi" för årskurs fyra. ${ }^{568}$ Bilder likt denna var en del av både geografi- och teckningsundervisningen i skolan. ${ }^{569}$ Texten under bilden högst upp till vänster lyder: "Försök att rita av Visingsborgs ruin på annat papper! Följ hjälplinjerna!" Och till höger: "rita färdig och färglägg bilden av Kalmar Slott". Liksom i exemplen ovan från Visingsö, är det vanligt att även barnens tävlingsbilder är bilder i fågelperspektiv, med hög horisontlinje. ${ }^{570}$ Genom övningarna tränades barn i en specifik bildkanon som vi kan se återkommer i flera av teckningstävlingarnas bilder. Mäns, kvinnors och även barns förväntade platser ser vi också i bildexemplet, vilket jag återkommer till i kommande kapitel. Det är också tydligt i Geografiboken hur gamla minnesmärken i landskapet lyfts fram, som ruinen och slottet, liksom att kartbilden befäster gränser och platser. I de fyra häftena i Geografi fanns också kartor för eleverna att fylla i med alla landskapens gränser. Vilka nationella orter som var producenter av varor är också tydligt framskrivet,

568 Sjöholm, L. Gottfrid \& Goës, A. (1927-1928) nytryck 1946. Arbetsövningar (tysta övningar) i geografi.. Arlöv ...: Skriv- och ritboks a.-b. sid. 19. Häfte 1.

569 Hasse Hansson "När varje lärare kunde teckna” i Lind, Ulla, Hasselberg, Kersti \& Kühlhorn, Britt-Marie (red). (1992) Tidsbilder, Perspektiv på skola och bildskapande under 150 arr. Utbildningsradion och Skolverket, sid. 26-40.

570 Se till exempel bild spela kula och skörd föregående kap. eller vårt fosterland detta kapitel. 
exempelvis som i bilden "Ankarsrums bruk har gjort emaljgrytan och spiseln, där mor tänder med Jönköpings tändstickor."

I Bild 3:2 ser vi en man som plöjer åkern, målad av Ingegerd Möller 11år. Det är mycket möjligt att bilden av "Far plöjer med en plog från Överums bruk" (föregående sida) eller liknande bild, är något som kan ha inspirerat och setts som förebildligt både i motivval och sätt att teckna. ${ }^{571}$ Även i lärobok i hembygdskunskap finns avritningsbild av en plog, liksom många andra jordbruksverktyg. 572 Här är intertextualiteten tydlig, det vill säga att bilden är skapad i relation till andra bilder i samtiden. Vi såg i föregående avsnitt om teckningstävlingarnas utformning och anvisningar, att tidningen FIB hade tydliga regler för teckningstävlingen, där de betonade att eleverna absolut inte fick plagiera, rita av, eller använda sig av några som helst förebilder vid sitt tecknande. ${ }^{573}$ Trots dessa anvisningar är det tydligt att barnen använde sig av den visuella miljö som fanns omkring dem, och som de sett och arbetat med i skolan.

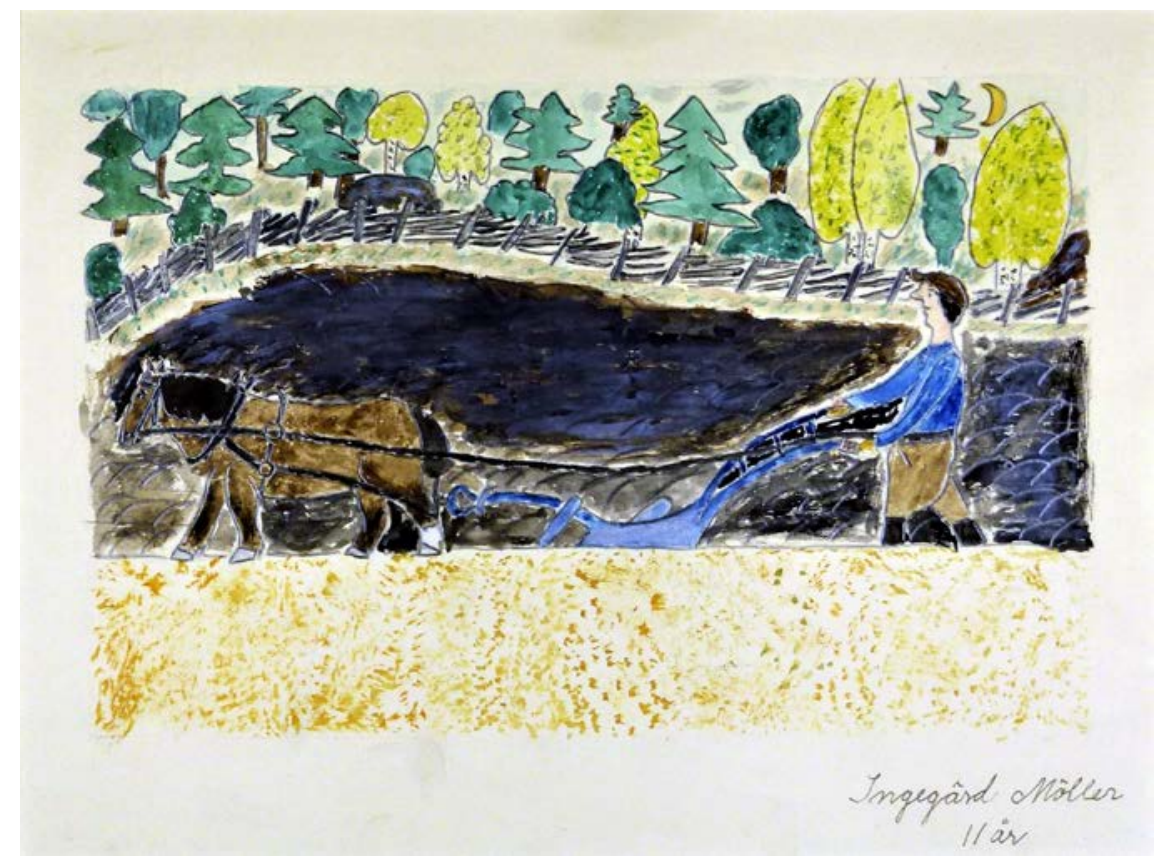

Bild 3:2. Livet i vår hembygd, FIB:s tävling 1939.

Att skolan gav liknande visuella erfarenheter över hela landet, kunde också skapa en gemensam förståelse kring vad som av samtiden betraktades som en bra barnbild.

\footnotetext{
${ }^{571}$ Ytterligare en bild i samlingen vår hembygd är väldigt likartad i sin utformning.

572 Sjöholm, L. Gottfrid, Handledning vid undervisningen i hembygdskunskap. 1, Andra skolåret, Sv. bokförl. (Norstedt), Stockholm, (1920) sid.3 samt färgplansch 15.

${ }^{573}$ FIB nr 111943 sid. 33.
} 
I handledning vid undervisningen i hembygdskunskap i årskurs två, är flaggorna angivna med exakta mått, för att eleverna skulle kunna göra egna flaggor för firandet av Svenska flaggans dag (bild 3:3). Olika månader/årstider presenteras bredvid flaggan, som beskrivningar av det svenska. Juni med dans runt midsommarstången. Augusti och september karaktäriseras av skördearbete, genom bilder av äppelplockning och höskörd. Vårbilder med fåglar och blommor, visar också barnets, specifikt flickans plats i blåsippsbacken. ${ }^{574}$ Texten som hör till bilden med månadsvinjetter beskriver hur barnen under en gemensam månadsbild i klassrummet varje dag bör föra in temperatur klockan nio och klockan tolv och att man sedan vid månadens slut gör ett diagram över temperaturen.

Att arbeta och skörda i kulturlandskapet är ett vanligt förekommande hembygdsmotiv i FIB:s tävlingar 1939. I Nationalmuseums samling på temat Livet i vår hembygd 1939 visar drygt hälften av bilderna landsbygd, jord- och skogsbruk. Bilderna visar människor som arbetar i skogen, med djurskötsel eller med arbete på åkern. Referenser till hembygdskunskapsböckernas bildnormer syns i denna bild med två hästar som drar en skrinda med hö eller halm (bild 3:4).

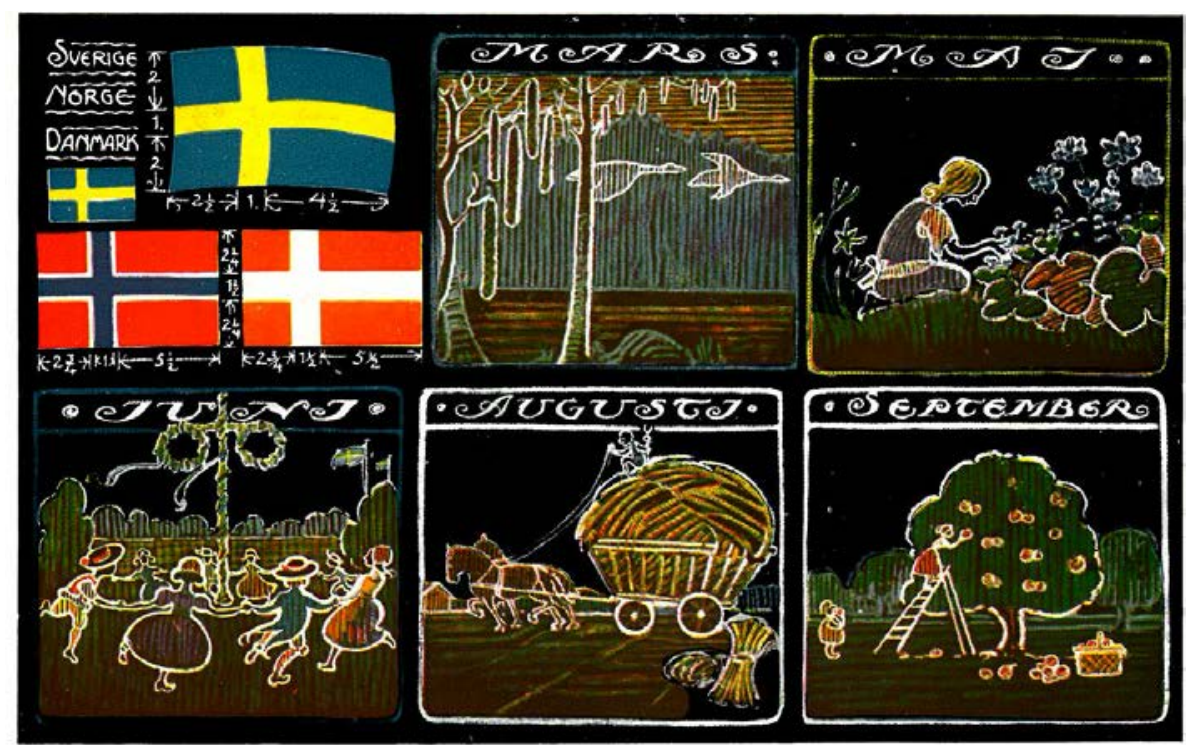

FARGPLANSCH 16. Klippning av svenska (samt norska och danska) flaggan till behandlingen av >En festdag >, s. 117. Månadsvinjetter - jämför text sid. 124 !

Bild 3:3. Sjöholm, L. Gottfrid \& Goës, Axel (1920) Handledning vid undervisningen $i$ hembygdskunskap. 2, Andra skolåret Färgplansch 16. 


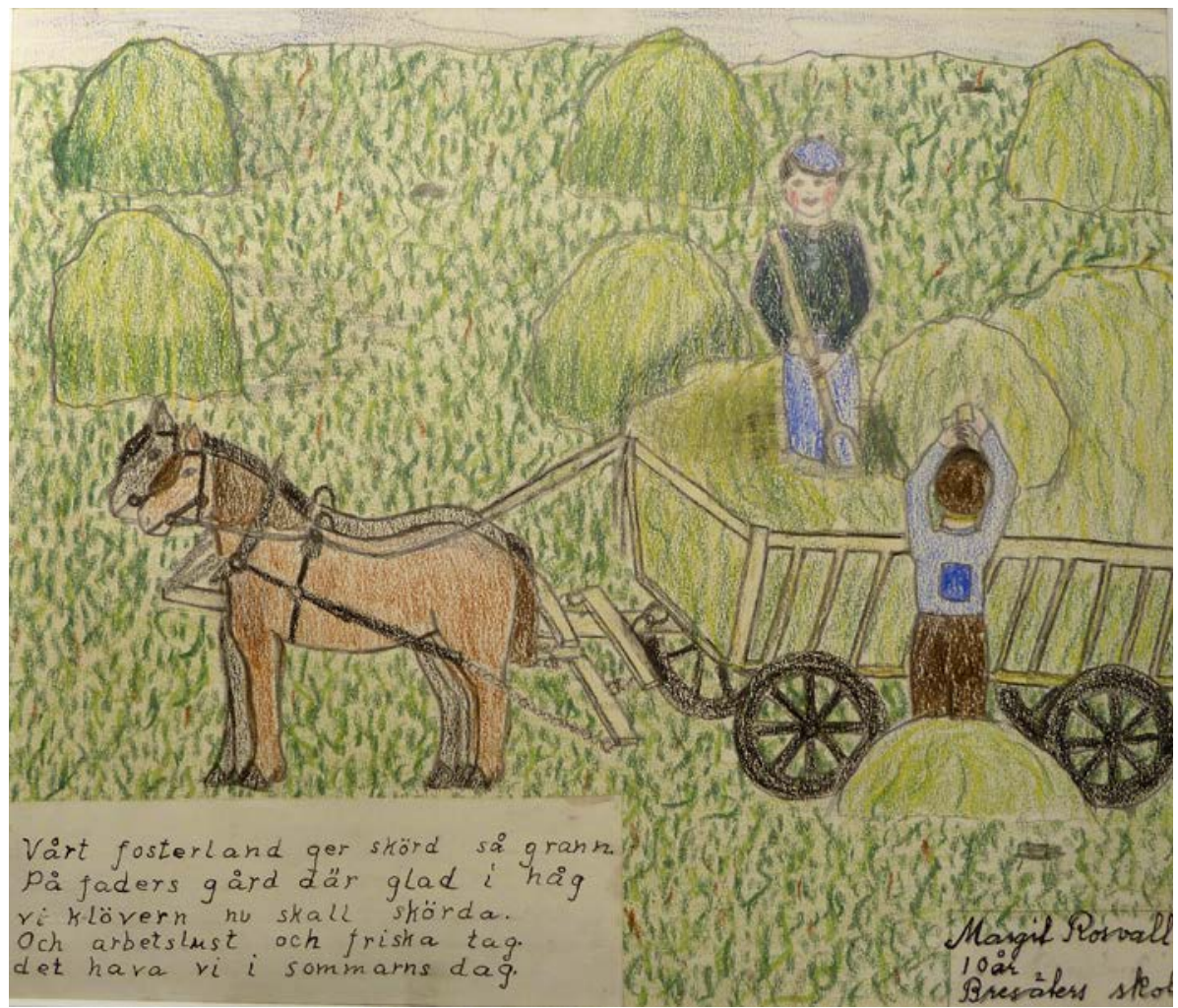

Bild 3:4. Livet i vår hembygd, FIB:s tävling1939.

Bilden visar en äng med höstackar på; vi ser fem höstackar i bakgrunden av bilden. I förgrunden syns två hästar som är spända för en höskrinda. I bildens mitt står en pojke i höskrindan, han har blå kläder och blå keps, och är vänd mot oss med en grep i handen. Han ler och är röd om kinderna. Framför skrindan står en pojke i en höstack och för upp hö i skrindan, han har ryggen mot oss, han har brunt hår, bruna byxor och blå tröja. Bilden innehåller även en bildtext, vilket är ovanligt. Bildtexten till teckningen lyder: Vårt fosterland ger skörd så grann På fäders gård där glad ihåg vi klövern nu ska skörda. Och arbetslust och friska tag det hava vi i sommarns dag. Genom att använda "Vårt och vi" inkluderade tecknaren sig själv, men även en större grupp i bilden, både det nationella "vi" i det gemensamma fosterlandet, och "vi" i familjen, som ska skörda klövern. De glada barnen i bild 3:4 blir genom texten inkluderade i fosterlandet och fädrens gård. Arbetets glädje och Fosterlandskärlek är tydliga diskurser i texten och bilden. Det är mycket arbete att skörda klövern, men fosterlandet ger denna skörd till oss, både barn, vuxna liksom den gjort till tidigare generationer. Begreppet "Fosterland" är med och skapar metaforen "nationen som en släkt", där de nationel- 
la banden blir till blodsband. ${ }^{575}$ Bild och text i denna teckning visar exempel på ethnoscape; föreställningen om ursprungliga landskap där etniska grupper kan se sig själva som relaterade och förbundna genom sina förfäder till en specifikt historisk hembygd..$^{576}$

$$
* * *
$$

Analysen har visat hur folkskolans arbetsböcker kunde definiera vad som var lämpligt och fördömligt bildspråk, både vad gällde innehåll och utformning, och att detta påverkade barnens teckningar och målningar. Bilderna visade också vikten av geografiska minnesmärken, geografiska gränser och geografiskt knutna producenter. Att bruka jorden var återkommande i både barnens och arbetsböckerna bilder. Även om "Hembygden" förekom i de mest skilda miljöer, eller kanske just därför, var det viktigt att samordna bilden av det svenska, som ett gemensamt "vi" från Norrlands snö till skånsk potatis, som Hoppe skrev i det inledande citatet. Hur Sverige och de svenska barnen såg ut visualiserades både i skolans arbetsböcker och i tävlingsbilderna. Genom bilderna av arbetet i landskapet, på åkern, i skogen och i fabriken skapas en identifikation mellan människan och landet, och även mellan människan och stads- och industrilandskapet.

\section{Televerkets hembygdstema - landsbygd och historia}

Som jag beskrev i föregående kapitel ville Televerket förändra sin byråkratiska image genom att använda sig av barnkonstbildens positiva associationer. Genom teckningstävlingar för årskurs tre kunde de få bilder som skulle pryda omslagen till de 24 olika telefonkatalogområdena. Från varje skola skickades fem bilder som klassen valt ut in till varje region. En jury bestående av två lärare och en representant för Televerket valde vinnarbilden som trycktes på telefonkatalogomslaget. Televerket hade 1976 haft samråd med SÖ (skolöverstyrelsen) som påpekade att det var viktigt att tävlingarna kunde vara en del av skolans fortlöpande arbete. ${ }^{577} \mathrm{I}$ ämnet hembygdskunskap ingick även "teckning, målning, modellering och annat skapande manuellt arbete". ${ }^{578}$ Att teckna och måla passade alltså bra in i skolans verksamhet, även om tävlingsformen blev problematisk och efterhand tonades ned. ${ }^{579}$ Ämnet hembygdskunskap kunde även av Televerket anses passande, då det kunde ge Telefonkatalogernas omslag en lokal prägel.

Tävlingarnas uppdrag anknöt till hembygdskunskapsämnet mellan 19771981. Även om hembygdskunskap upphör som eget ämne i och med Lgr 80,

\footnotetext{
575 Winther Jørgensen, Marianne \& Phillips, Louise (2000) sid. 164.

576 Smith, Anthony D. (1999) sid. 12f.

577 ”STB har efter samtal med SÖ fastnat för motiv som anknyter till ämnet hembygdskunskap som väl anpassat sig till kursinnehållet för årskurs 3. Detta bör vara bra ur dekorativ synpunkt och ge viss profil åt de olika katalogdelarna.” Skrivelse till Televerkets centralförvaltning, sektionen för säljstöd, handläggare Widfors, inkom 1976-01-23 sid. 3. Televerket telemedia arkiv, omslag till rikstelefonkataloger.

578 Lgr 69 sid. 178.

579 Se kapitel 2 avsnitt skolan och tävlingar.
} 
är temat 1985 då sista tävlingen för telefonkatalogomslag arrangerades "En sevärdhet i vår hembygd". ${ }^{580}$

Bild 3:5 visar den informationsfolder Televerket skickar till skolorna 1976, inför den första tävlingen med temat "En händelse $i$ vår hembygd”, Uppdraget formuleras på följande sätt: "Rita och måla bilder som berättar om den hembygd som er skola ligger i." Och man fortsätter:

Var och en av våra kataloger ska på sin framsida ha en bild med något från hembygden. Bilden kan vara byggnader, landskap, historiska händelser, fornminnen osv. I trean har ni börjat med hembygdskunskap. Rita och måla om sådant ni lärt er. ${ }^{581}$

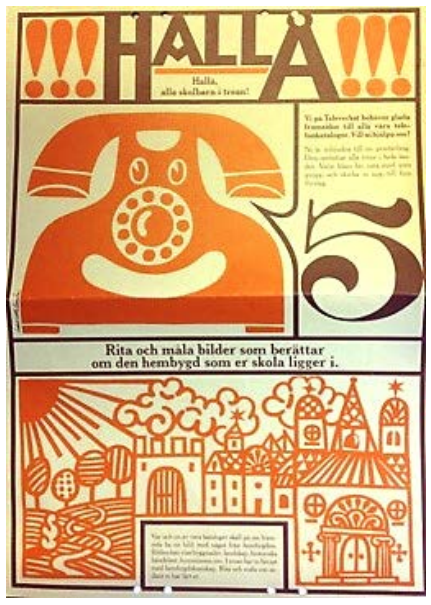

Bild 3:5. Livet i vår hembygd, FIB:s tävling1939.

Teckningarna på utskicket från Televerket visar en stor telefon; sol, träd, äng, en borg och en kyrka. Affischens bilder och texten ("historisk händelse, fornminnen, borg osv") kan ha bidragit till att många "händelser i hembygden" blev historiska snarare än samtida.

LGR 69 betonade under arbetssätt och mål i ämnet att "Undervisningen i hembygdskunskap bör i så stor utsträckning som möjligt grundas på elevernas egna iakttagelser av verkligheten." ${ }^{582}$ (kursiv i original) Trots Televerkets utskick är det förvånande att så få av bilderna visade samtida hembygdsbilder eller människor i hembygden. ${ }^{583}$ Jag kommer i detta avsnitt att göra en övergripande redovisning av de vinnarbilder som publicerades på Telefonkatalogerna 197778, med betoning på det första årets tävling 1976-77. Bilderna jämförs också med FIB:s tema "Livet i vår hembygd" 1939..$^{584}$

Dessa fyra bilder är ett urval som kan ses som representativa för Televerkets hembygdstävling "En händelse i vår hembygd" 1977 (bild 3:6-3:9).

I omslaget till Faluns telefonkatalog Kulla och Mas pratar i telefon, konnoteras hembygd både genom landskapsdräkten och genom den lokala benämningen "Kulla och Mas". (bild 3:6) Bilderna är mångbottnade och kan ses ur flera perspektiv. Bild 3:6 med "Kulla och Mas pratar i telefon" visar på hur blandningen

580 Tävlingarna genomfördes året före bilderna trycktes, tävlingen 1976 trycktes alltså som omslagsbild 1977.

581 SBBA arkiv Televerkets tävlingsbilder En händelse i vår hembygd 1977.

${ }_{582} \operatorname{Lgr} 69$ sid. 181.

${ }^{583}$ Lgr 69 sid. 178 under mål för hembygdskunskap: "I största möjliga utsträckning skall den [undervisningen] utgå från elevernas egna iakttagelser, upplevelser och problem samt tillvarata deras lust att upptäcka, fråga och undra. Det bör ge dem rika möjligheter att i egen skapande verksamhet finna uttryck för sina tankar och känslor och söka låta dem gestalta sina erfarenheter efter individuell förmåga."

${ }^{584}$ Telefonkatalogens omslagsbilder för teman 1979-85 som redovisas i Tabell 1 är alltså inte med i denna redovisning. 
Vinnande bilder: Teckningstävlingar för barn 1938-2000

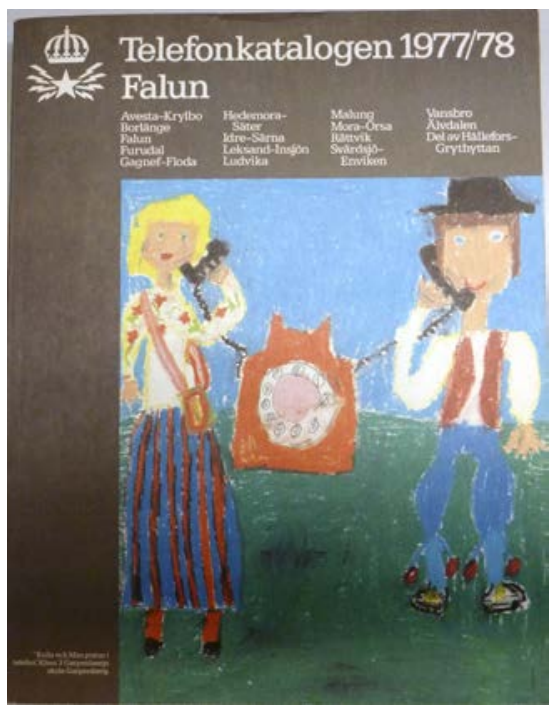

Bild 3:6 En händelse i vår hembygd, Telefonkatalogen Falun 1977/78.

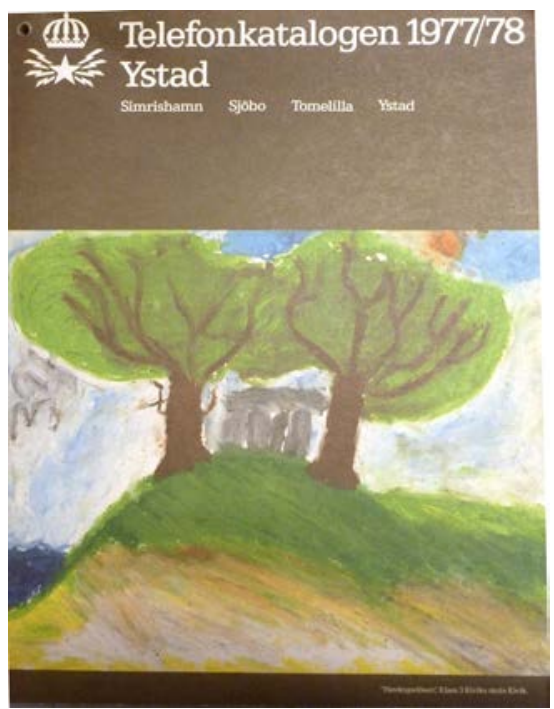

Bild 3:8 En händelse i vår hembygd, Telefonkatalogen Ystad 1977/78.

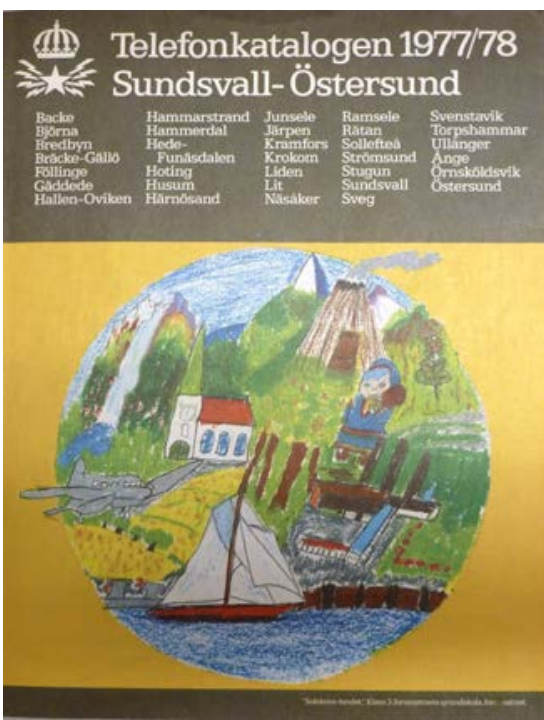

Bild 3:7 En händelse i vår hembygd, Telefonkatalogen Östersund 1977/78.

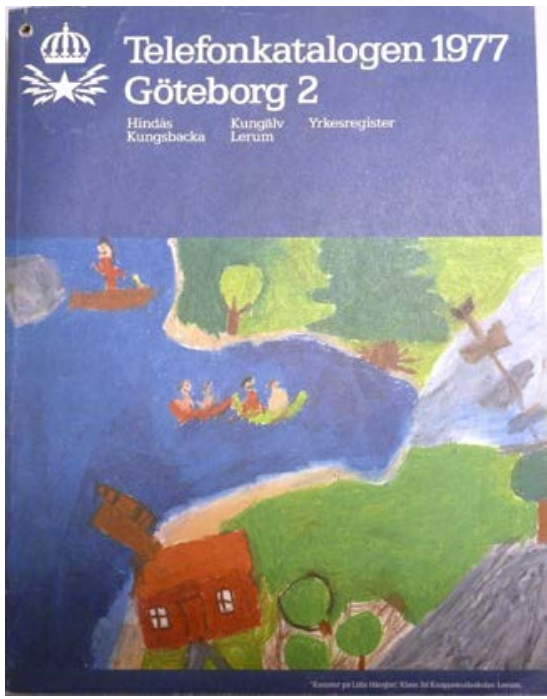

Bild 3:9 En händelse i vår hembygd, Telefonkatalogen Göteborg 1977. 
mellan det historiska och den moderna teknologin gör bilden överraskande och humoristisk. Den jättelika telefonen kunde referera intertextuellt till Televerkets utskick (bild 3:5) och Televerket lyckas genom barnbilderna göra "reklam" för sina egna produkter. Det finns ytterligare en vinnande bild med telefoner 1977 med titeln "Två vikingar som står på Uppsala högar och talar med varandra på telefon". I Bild 3:7 "solskenslandet" på Sundsvall- Östersunds Telefonkatalog syns en man i samedräkt, därutöver visualiseras ett collage av lokala sevärdheter. Bilden kan ses som del av en turismdiskurs som visar olika sevärdheter i hembygden.

1977 föreställer tre omslagsbilder statyer i hembygden, två katalogomslag visar bilder med människor i hembygdsdräkter, så det lokalhistoriska temat är tydligt. Det vi ser i bilden från Ystad benämnd "Havängsdösen" kan också representera "Minnesmärken" som Televerket frågar efter i sitt utskick (bild 3:8). Dessutom har pastellkritorna man uppmanat barnen att använda i denna bild gett en utsuddad, akvarellartad effekt som konnoterar konstbild och landskapsmåleri. I bilden "Kanoter på lilla Härsjön" syns bryggan och vattnet avbildat uppifrån men huset och kanoterna rakt framifrån (bild 3:9). ${ }^{585}$ Detta kan ses som exempel på det jag i kapitel två diskuterat angående vad som inom utvecklingspsykologin ansågs signifikativt och betecknande för just yngre barns bilder, med ett utvikt eller förskjutet perspektiv. ${ }^{586}$ Förändrade perspektiv i bilderna kunde representera det Televerket menade med att de hoppades få "okonstlade bilder" genom att vända sig till elever $\mathrm{i}$ just årskurs tre.

Flera av bilderna visar exempel på hur begreppet ethnoscape kunnat visualiseras, där specifika minnesmärken eller människor associerats till specifika landskap, som i sin tur kunnat associera till nationell enhet. ${ }^{587}$

Människor förekom endast i sex av tjugosju bilder 1977.588 Det var då oftast personer med historiska konnotationer. På Uppsalas katalog syntes vikingar, Falun och Helsingborg visade människor i folkdräkt, på Sundsvall-Östersunds katalog avbildades en person med samedräkt, se bild 3:7. Karlskronas katalog avbildande den danska och svenska kungen år 1671, se bild 3:19.589 Borås bild har bildtexten "En knalle kommer på besök". Göteborgs katalog, bild 3:9, "Kanoter på lilla Härsjön", är den enda bild där människor skildrats i en samtida miljö.

Endast två katalogområden har stadsmotiv med hus, det är Stockholm med "Punkthusen på Tullingeberg" och Gävle/Hudiksvall. Stadsbilden från Hudiksvall var historisk och visade "Strömmingssundet i Hudiksvall" vilket var gamla fiskarbostäder. ${ }^{590}$

\footnotetext{
585 Aronsson, Karin (1997) sid. 148.

${ }^{586}$ Se tex Luquets term "intellektuell realism" att barn tecknar vad de vet och inte vad de ser, kap. 2.

587 Alla vinnande omslag publicerades i Aftonbladet. På första sidan var rubriken Barn från hela Sverige, och på ett helsidesuppslag trycktes alla bilderna under rubriken "Från söderslätt till midnattsol".

588 Det fanns 24 katalogområden, men Stockholm hade tre och Göteborg två kataloger, så det fanns 27 kataloger varje år.

589 bilden analyseras i kapitel 6 .

590 Två har också statyer, Göteborg och Halmstad.
} 
Det vanligaste motivet var någon form av landskapsbild med lokal förankring, exempelvis "En gård utanför Stockaryd" i Växjödelens katalog, där vi ser en ko som betar framför ett rött hus på en kulle omgivet av träd och med en stålande sol, eller som bilden på Ystadskatalogen med titeln "Havängsdösen".

1978 var Televerkets tävlingstema "En historisk händelse i vår hembygd." Av de historiska händelserna i hembygden är fyra bilder av stadsbränder. På en telefonkatalog avbildas en valborgsmässoeld, ett bildtema som också återfinns i flera av FIB:s bilder på temat "Svenskt helgfirande". Televerkets historiska bilder innehåller delvis liknande motiv som FIB:s s tävling med hembygdsmotiv 1939, exempelvis bild av en mila, två bilder av hästar som drar släde/kärra, torghandel, gruvbrytning och därutöver två bilder av rallare. Däremot visar åtta bilder 197778 bilder av kungar eller andra historiska personer, vilket inte alls syns i FIB s tävling där hembygden gestaltades som samtida. ${ }^{591}$ I likhet med FIB:s tävling var "hela Sverige" representerat eftersom telefonkatalogerna var lokala, däremot var motivvalen olika då det 1977 enbart var stadsmiljö i två av 27 bilder, trots att det bodde betydligt fler i stadsmiljöer 1977 än 1939. ${ }^{592}$ Bilderna från FIB:s tävling 1939 visade fram den samtida hembygden med arbete och människor i bilderna, vilket inte var vanligt i Televerkets vinnande bilder.

$* * *$

Vi har alltså sett att de bilder som belönades av Televerket var de som uppfyllde kriterierna för det som både explicit och implicit frågades efter; det vill säga en kombination av naivistiska bilder men där materialet skulle användas på önskvärt sätt, vilket innebar att fylla hela pappret med färg. Därutöver borde motivet vara ett lokalt, gärna historiskt landsbygdsmotiv och gärna göra reklam både för Televerket och för hembygden. Jämfört med FIB:s tävling där hembygden var samtida, skildrade Televerkets bilder den historiska hembygden. Inte bara 1978 då temat faktiskt var "en historisk händelse i vår hembygd 1978, utan även bilderna från 1977 med temat "en händelse i vår hembygd" uppvisade övervägande historiska bilder. En sammanfattning av Telefonkatalogens omslagsbilder visar att de liksom FIB:s kodas som barnbild och barnkonstbild, men därutöver även till historisk bild, och reklambild. Som en del av reklamdiskursen kunde även humor vara ett sätt att väcka uppmärksamhet. Det är tydligt att förbudet i tävlingsreglerna mot "omotiverad reklam" inte gäller vid marknadsföring av Televerkets egna produkter. Idén om vad som betraktades som "Hembygden" har alltså förändrats över tid. Detta kan hänga samman med en förändrad samhällelig idé om hembygden som fenomen, där hembygden allt mer kommit att betraktas som förknippat med landsbygd och historisk tid i den senare tävlingen.

591 Detta kan självklart delvis förklaras av att temat 1978 var "En historisk händelse i vår hembygd", men även på temat "En händelse i vår hembygd" 1977 fanns kungabilder. Både av arrangörer lärare och elever uppfattades hembygden snarare som ett historiskt än som ett samtida fenomen $1977 / 78$.

592 Stockholm och Skövde hade stadsbilder. Detta trots att drygt 80 procent bodde i tätort 1977 jämfört med ca 50 \% 1939. https://www.scb.se/sv_/Hitta-statistik/Artiklar/Urbanisering--franland-till-stad/ (2017-06-10) 
Jag kommer nu att analysera en bild som inte betraktades som en vinnande hembygdsbild 1977, och som visar en samtida stadsmiljö.

\section{Vad var" fel” hembygd 1977?}

De bilder som skickades in till Televerket, men inte vann, finns bevarade på SBBA. Jag har gjort nedslag i fem olika katalogområden och studerat ca 250 av de bilder som skickades in men inte vann. I de allra flesta fall liknar de utvalda bilderna de vinnande bilderna både till utförande och innehåll. Denna bild är inskickad som bidrag för Stockholmsdelen av Telefonkatalogen (bild 3:10). Den avviker både från de vinnande bilderna, och från de icke vinnande inskickade bilderna. Den har en väldigt begränsad färgskala, och pappret är inte täckt. Detaljerna i blyertsteckningen är svår att uppfatta på håll.

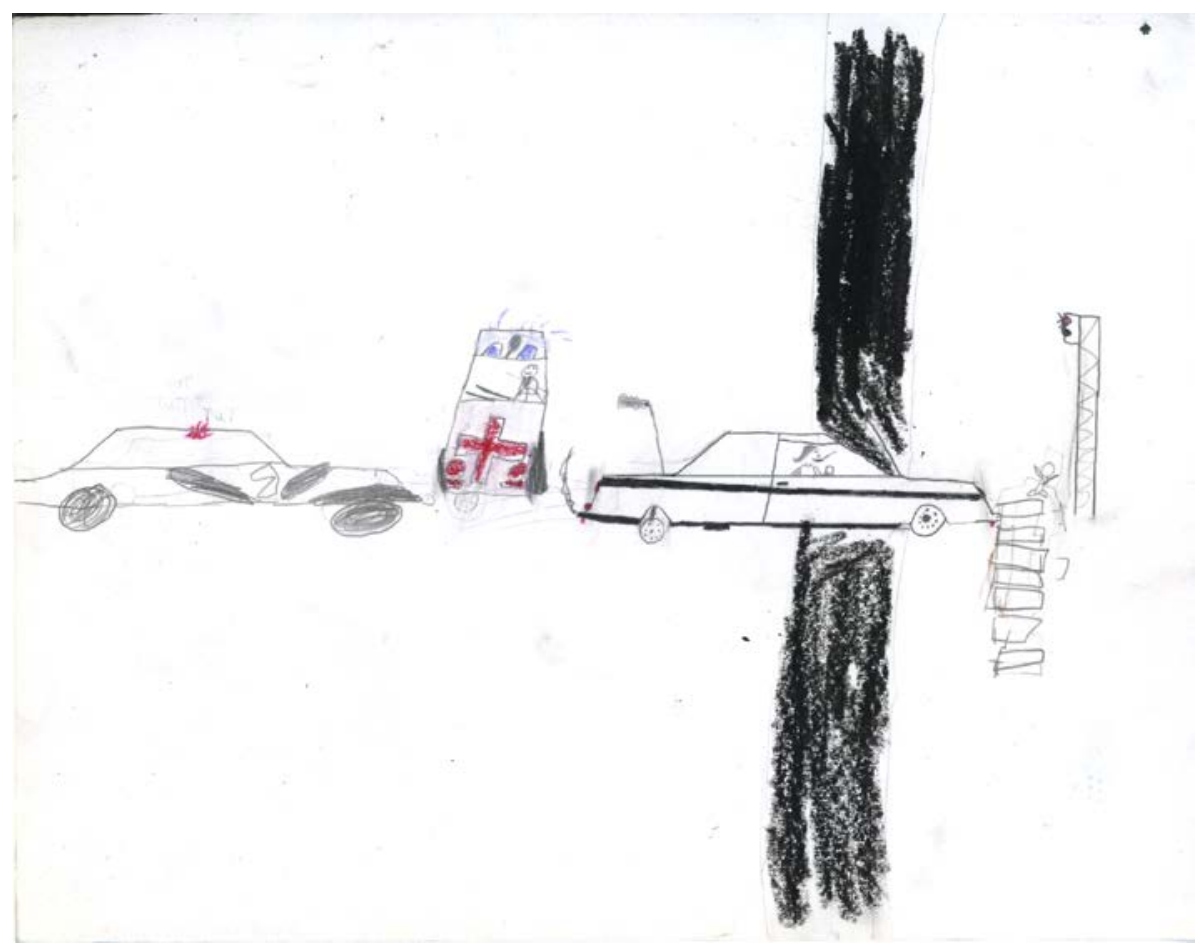

Bild 3:10. En händelse i vår hembygd, Televerkets tävling 1976.

Det var en av fem bilder som valdes av sin klass/lärare för att delta i Televerkets tävling. Bilden har namnet "Raggare". Vi ser en bil, som står rakt över ett svart rakt fält, som refererar till en asfalterad väg. Att det är en Raggarbil förstår vi dels genom bildens namn och dels genom vimpeln eller rävsvansen fastsatt på antennen längst bak på bilen. Bilen är tecknad rakt från sidan, den har ett svart streck längs hela sidan. På förarplatsen sitter en figur tecknad med blyerts, avbildad med en cigarett i munnen som ryker, och en rektangulär form i handen 
konnoterar en ölburk. Framför bilen syns vita rektangulära fält likt ett övergångsställe. En liten barnliknande figur är tecknad på övergångsstället.

Längst till höger syns en smal rektangulär form, troligen ett trafikljus. Bilden är tecknad i olika perspektiv, både från sidan, rakt ovanifrån och framifrån. Till vänster syns en bild av en svart och vit bil med en röd siren på taket vilket konnoterar polisbil, även den tecknad från sidan. Mellan raggarbilen och polisbilen står en bil avbildad framifrån, den tolkas som ambulans genom det röda korset på fören, och ett blått ljus på taket. Det är bara fyra färger i bilden, svart, vitt rött och blått, samt grå nyanser av blyerts. Det vita pappret och den svarta färgen är dominerande med några röda detaljer.

Det är en tydlig händelse i bilden då polisbilen och ambulansen refererar till olycka. Av bilens placering förstår vi att "raggaren" har kört över vägen, kanske var bilen på väg att köra över barnet vid övergångsstället? Eller har en olycka redan hänt som vi inte ser, eftersom ambulansen och polisen är på plats? Bilden visar en specifik händelse i hembygden, och hembygden innebär i denna bild en samtida stadsbild.

Innehållet i bilden "raggare" visar människor i en händelse i staden och kan på detta sätt liknas vid flera av FIB:s tävlingsbilder. Men "raggare" visar snarare upp problem och konflikt, än staden som modernitet och samförstånd. Både det konfliktfyllda innehållet i bilden "Raggare" och hur den är målad, påminner mer om bilderna från Arla/Posten tävling 1976 Detta vill jag värna om, som jag diskuterar i nästa avsnitt. Men i Televerkets tävling fungerade inte bildens vare sig i form eller innehåll, även om den valdes av klassen eller läraren att skickas in till tävlingen.

Det är också fel plats för det lilla barnet, att vara i en utsatt situation framför raggarbilen är inte en hembygd för barn som Televerket vill visa. När Televerket gestaltade trafik i tävlingen 1983 med temat "Så vill vi ha det i trafiken där vi bor" var det andra bilder som lyftes fram. Det handlade nu till stor del om vikten av att barn använder reflexer, och att bilförare uppmärksammar barnen.

$* * *$

Denna bild var som sagt en av de fem bilder från denna klass som skickades in till tävlingen. Det fanns troligen flera anledningar till att den sedan inte valts ut som vinnarbild. Hembygden visas inte på det sätt som förväntades av juryn. ${ }^{593}$ Televerket ville ha katalogomslag som var färgrika och glada. Denna bild var färglös och tog upp problem med poliser och raggare. Dessutom är bilden "fel" tecknad, med för lite färg, för otydliga figurer, och ett alltför naivt "slarvigt" bildspråk, om man jämför med de andra, vinnande bilderna, som också genomgånde visade landsbygdbilder eller historiska motiv.

Det förhållandevis enkla och snabba sätt att teckna som bilden "raggare" är exempel på, gillades inte av Televerkets jury, men när Arlas bok "Varför får

${ }^{593}$ Stockholmskatalogen har i och för sig stadsmiljö på en av sina kataloger, men då är det hus, och egentligen helt utan "händelse" som ju finns med i denna bild. Den andra bilden är av stadshuset som med de tre kronorna är en tydlig ikon för Stockholm, både idag och historiskt. 
inte barn bestämma" kommer ut samma år är detta bildspråk både vanligt och önskvärt. ${ }^{594}$ Detta har jag anledning att återkomma till.

Hur hembygden och det nationella definierats och visualiserats påverkas som jag visat av samtida ideal och samhälleliga föreställningar. Vissa tecken och symboler har tydliga nationella konnotationer. I nästa kapitel granskas hur bilder av flaggor och kungar gavs betydelse i olika tävlingsbilder.

\section{Flaggor och kungar}

Nationell identitet är inlärt och skapas på flera olika sätt. I föreställningen om en gemensam nation skapas en identifikation mellan stat, territorium och medborgare. Känslan av ett kollektivt hemmahörande i en nation blir något man föds in i, och som är svårare att träda ur och in i ${ }^{595} \mathrm{I}$ dessa föreställningar kring nation spelar olika symboler för, och bilder av, nationen en stor roll. ${ }^{596}$ För att skapa nationell identitet krävs bland annat ett skapande av en nationell visuell kultur, och nationella kulturella produkter, som exempelvis flaggor eller kungabilder. Bilderna är med och skapar och upprätthåller vissa ideal och myter, genom bildernas konnotationer. Samtidigt konnoteras tecken och symboler på olika sätt beroende på i vilka kontexter de befinner sig.

\section{Flaggan som symbol för gamla och nya traditioner}

I detta avsnitt analyserar jag flaggan som symbol i tävlingsbilderna, och hur flaggan kan representera skilda högtider och traditioner genom den kontext den placeras i. Vad är det för samhällsfenomen som associeras till flaggan? Bilderna i detta avsnitt är från FIB:s teman Mitt roligaste skolminne 1941, Svenska högtider 1944, och Våra lekar 1945, samt två tävlingsbilder från Arla/Postens tävling detta vill jag värna om $1976 .{ }^{597}$

Svenska flaggan som nationell symbol var också en del av undervisningen i hembygdskunskap. ${ }^{598}$ I Sjöholm och Goes handledning vid Hembygdskunskap årskurs två utgiven första gången 1916 och sedan 1946, finns en bild, text och noter till "vår flaggsång", bilden visar hur flaggan hissas och halas av två pojkar i sjömanskostym, rubriken är omgiven av tre kungakronor. ${ }^{599}$ De flaggor med måttangivelser som vi såg i föregående avsnitt (bild 3:3) är också ett föreslaget moment för barnen att tillverka i anslutning till flaggdagar. Handledningen till

594 Detta diskuteras i avsnittet Arla/Posten: Barnen som politiska subjekt. Arla/Posten som arrangerar har ingen offentlig jury, men de har heller inga kriterier som Televerket om att använda oljepastellkritor t.ex.

595 Winther Jørgensen, Marianne \& Phillips, Louise (2000) sid. $157 f$.

596 Lindgren, Anne-Li (1996). sid. 124.

597 En bild från SBBA:s samling, en tryckt i boken Varför får inte barn bestämma.

598 Under temat Livet i vår hembygd finns två bilder av svenska flaggan i offentliga stadsmiljöer, och en bild av flaggor i demonstrationståg på 1a maj, det finns inga kungabilder. (av totalt 117 bilder).

599 Sjöholm, L. Gottfrid (1946). Handledning vid undervisningen i hembygdskunskap. 2, Andra skolåret. Stockholm: Sv. bokförl. (Norstedt). 
sången tar upp Gustav Adolf dagen 6 november, och grundlagsdagen, Svenska flaggans dag, 6 juni som viktiga flaggdagar.

Flaggan som nationell symbol förekommer även i FIB:s tävlingar. Redan från första året, 1938, med temat "livet i vår skola" syns i några av bilderna från skolgården en svensk flagga hissad på skolgården. ${ }^{600} 1944$ var temat för FIB:s tävling "Svenskt helgfirande" Valet av temat kan ses som ett uttryck för det nationella, arrangörerna frågar inte efter det för barnen specifika, som i exempelvis temat "våra lekar" året därpå, utan efter bilder av hur svenska helger firas. Ämnet "Svenskt helgfirande" lockade till stort deltagande i tävlingen 1944 enligt FIB. ${ }^{601}$ Barnen förväntades skildra nationella högtider, men de gavs även möjlighet att definiera dem.

I bilden "Svenska flaggans dag i Stockholm, Kungen far i kortege." syns många människor med flaggor i händerna (bild 3:11). Kungen associeras med flaggan, och de associeras båda med nationen. Här gestaltas både flaggan och kungen som nationella symboler. Bilden är även publicerad i albumet Sverige genom barnaögon 1947.

Kungen, som far i kortege, föreställer den dåvarande kungen Gustav V. Han är avbildad med uniform och karaktäristiska runda glasögon, sittande i en vagn som dras av fyra vita hästar. En folkmassa står både framför och bakom ekipaget och vi ser sex svenska flaggor som människor bakom ekipaget håller i händerna. I bakgrunden syns ett stenhus och ett fönster där en man tittar ut och även han vinkar med en flagga. Förutom flaggan är kungen en av de tydligaste symbolerna för det nationella, där det nationella även associeras med huvudstaden Stockholm. Bilden refererar till nationell enighet och nationsidentitet genom uppskattning och uppvaktning av kungen. Bilden av firandet av svenska flaggans dag och kungen i kortege innesluter "oss svenskar", och utesluter samtidigt implicit det "icke svenska".

Bild 3:12 "Svenska flaggans dag" är målad på temat "mitt roligaste skolminne" $1941 .{ }^{602}$ Sex flickor och tre pojkar går på led med svenska flaggor i händerna. I bakgrunden ser vi en vit kyrka med ett vitt kors på sidan och ett gult kors på taket. Bakom kyrkogården syns björkar, berg, en blå himmel tre vita moln och en sol som strålar till vänster i bild. Färgen på himlen och solen och färgen på flaggan är densamma. Barnen har olika färg på kläder och hår, men framställs ända som lika, alla går i profil som en parad med ena benet framför det andra och alla är ungefär lika långa. Flaggorna refererar barnen till "Svenska barn”. Både flaggorna och barnen blir i bilden symboler för nationen. Att bära den svenska flaggan blir också i kontexten mitt roligaste skolminne något som barnen kunde uppleva som glädjande, och något som juryn uppskattade. Barnen blir bokstavligen bärare av nationen. Barnen i bilden upprätthåller den nationella myten av delaktighet, ett gemensamt flaggbärande "vi”. Även kyrkan i bakgrunden är

${ }^{600}$ I sex av totalt 26 bilder av skolgården.

${ }^{601}$ FIB 1944 nr 23 sid. 23.

${ }^{602}$ Svenska flaggans dag instiftades 1916 den 6:e juni då Gustav hade namnsdag, till minne av att Gustav Vasa valdes till kung och 1809 års regeringsform. Den blev nationaldag först 1983 och helgdag 2005. http://www.nordiskamuseet.se/aretsdagar/sveriges-nationaldag (2018-03-10) 


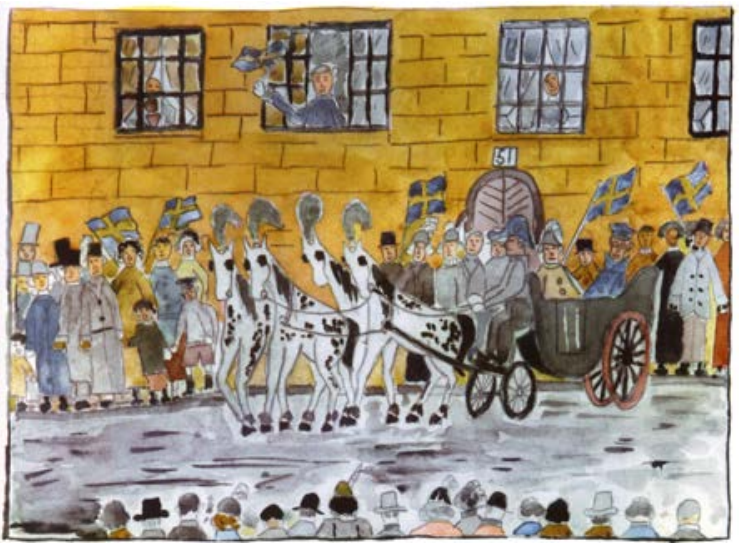

Bild 3:11. Svenskt helgfirande, FIB:s tävling 1944 i Sverige genom barnaögon 1947.

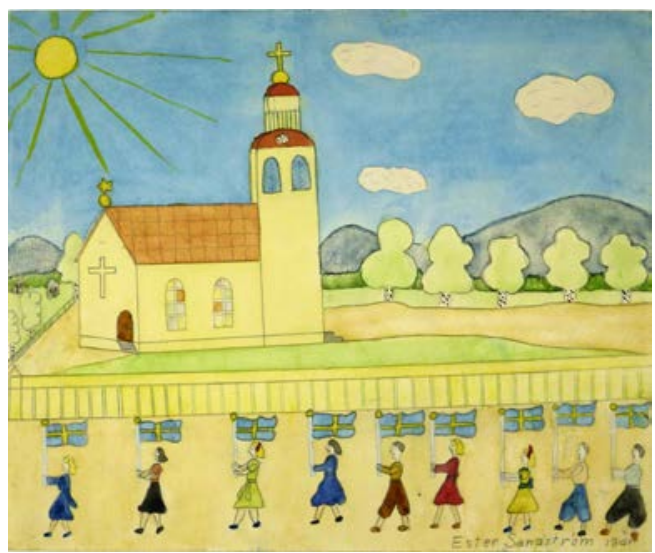

Bild 3:12. Mitt roligaste skolminne, FIB:s tävling 1941.

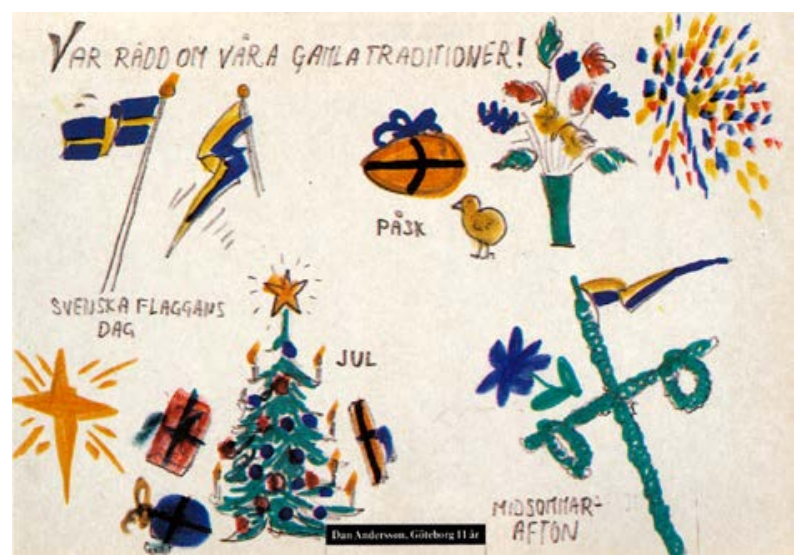

Bild 3:13. Dan Andersson 11 år Göteborg, i Varför får inte barn bestämma (1977). 
viktig för den nationella identifikationen. Kyrkor, och religiösa högtider, som refererar till kristendomen, finns med även i flera andra bilder och är tydliga ikoner för nationsskapande, exempelvis vid bröllop, julotta eller andra bilder från "vår hembygd" eller "Svenskt helgfirande" i FIB:s tävlingar. ${ }^{603}$

Flaggan som symbol för nationellt firande och nationella traditioner syns också i Boken Varför får inte barn bestämma 1977. Bild 3:13 är från Arlas tävling 1976 med temat "Det här vill jag värna om". Rubriken uppe till vänster i bild är "VAR RÄDD OM VÅRA GAMLA TRADITIONER!" ${ }^{604}$ Det finns likheter i motivval med bilder från temat "Svenskt helgfirande" från 1944. Vilka traditioner som är "våra gamla" framgår av bilderna och bildtexterna under rubriktexten. Det är Svenska flaggans dag, Jul, Påsk, och Midsommarafton. "Svenska Högtider" avbildades som samtida 1944 men har blivit "gamla traditioner" 1976.

Formuleringen "gamla traditioner" kan tolkas som att det också finns nya traditioner, eller att det är avsaknad av traditioner som gör att gamla traditioner behöver värnas. Svenskhet blir tydligt i begreppet VÅRA sammankopplat med bilden av svenska flaggan. Det är Våra Svenska traditioner som vi bör värna om och vara rädda om. Till vänster i bild syns en svensk flagga och en vimpel ovanför texten "SVENSKA FLAGGANS DAG". Till höger i bild syns ett gult och blått påskägg, en gul kyckling, ett påskris med fjädrar, samt streck i olika färger, gult blått och rött (kanske fyrverkeri) med texten "PÅSK" under ägget. I bildens nedre vänstra hörn syns en gul stjärna med strålar, tre inslagna paket, en klädd julgran med julgransljus och stjärna i toppen, med texten "JUL" och längst fram till höger texten "MIDSOMMARAFTON" vid en bild av en midsommarstång med en svensk vimpel i toppen, bredvid en blå blomma. Bilden är tecknad med blyerts och tuschpennor. Även bildens övervägande blå och gula färger ger nationella referenser.

De högtider som inte är beskrivna i denna bild, men finns 1944 är exempelvis valborg, kräftskiva och första maj. De religiösa högtiderna jul och påsk, samt nationaldagen och midsommar omtalas 1976. Det finns ytterligare en bild av en midsommarstång i Arla/Postens bok, med titeln "var rädd om sommaren". Midsommarstången kan ses som symbol både för Sverige och för den svenska sommaren. Även i FIB:s tävling 1944 frsmställs att "svenskt midsommarfirande" som" "tt motiv som många tecknare använt sig av". ${ }^{605}$ Midsommar är även skildrat i bilder i Europeiska skoltävlingen 1957 (se ex. bild 2:6).

I bild 3:14 syns också den svenska flaggan, på temat "Svenskt helgfirande", men här får flaggan en annan innebörd än i det mer traditionella Svenska helgfirandet, där människor hyllar kungen med viftande flaggor. Flaggan används här i bilden med namnet "taklagsfest". I FIB:s tävling görs den svenska flaggan också till det arbetande folkets symbol.

På bilden syns ett halvfärdigbyggt trähus. Den svenska flaggan vajar i varsitt hörn av takstolen, som även är ombunden med kransar. På bilden syns fyra män

\footnotetext{
${ }^{603}$ I samlingen Livet i vår hembygd finns sex kyrkobilder och endast två bilder av flaggor, av totalt 117 bilder.

${ }^{604}$ Ur boken "Varför får inte barn bestämma" sid. 13 bild av Dan Andersson 11 år i Göteborg.

${ }^{605}$ FIB 1944 nr 23 sid. 23.
} 
i blåkläder (arbetskläder) som vi konnoterar som byggnadsarbetare, eller de som byggt det halvfärdiga huset. Nu dricker de ur bruna pilsnerflaskor och har taklagsfest, alltså fest för att fira att takstolen och takstommen till det hus som håller på att byggas har kommit på plats. Att bygga nytt blir en symbol för ett svenskt högtidsfirande, liksom hantverkaren, snickaren, som dricker öl. Bilder av byggen är vanliga också i temat "Livet i vår hembygd" 1939.

Även på temat "Våra lekar" i FIB:s tävling 1945 förekommer svenska flaggan. Tre skidtävlingsbilder visar den svenska flaggan. Även här är det män som tävlar och presterar i bilden, sporten gav en möjlighet även för arbetarklassens barn att nå framgång, och skapade nya nationella hjältar. ${ }^{606}$ Den ena bilden föreställer backhoppning, Där syns ett högt torn till höger med svenska flaggan vajande i toppen. Från tornet går en backe ner och en backhoppare flyger genom luften, fyra män står och tittar nere på den snöklädda marken. I denna bild ser vi fyra skidåkare, där den första som just placerat målstolparna, har en krans runt huvudet (bild 3:15). Kransen, skidloppet och omgivningarna refererar till Siljansbygden och Vasaloppet. Målet består av en banderoll med titeln "Mål” och två kransar målade runtom. I toppen av målstolparna vajar svenska flaggor. Fullt med människor står längs med målgången och tittar på skidlöparna. I bakgrunden syns röda stugor med rök ur skorstenarna och ett gulrött sken på himlen som konnoterar skymning. Målet och kransen gör att vi förstår att det är vinnaren av tävlingen Vasaloppet vi ser.

Temat "Våra lekar" konoterar genom flaggorna och skidåkning i dessa fall snarast till "våra svenska tävlingar". Att barnen, FIB och Nationalmuseum genom dessa bilder för in nationell tävlingssport bland barns lek äger även idag sin giltighet. Billy Ehn menar i Försvenskningen av Sverige hur nationalkänslan inte någon annanstans har sådan genomslagskraft som inom sporten, och att man även hävdar sportsliga framgångar som ett led i den svenska modellen, en satsning både på bredd och elitidrott. ${ }^{607}$ Tidigare forskning har visat hur just vintersporten i media betraktats som svensk, maskulin och relaterad till naturen, vilket bilderna av skymningslandskapet med skidåkare och svenska flaggor kan visualisera. ${ }^{608}$ Genom barnens bilder 1944 uppmärksammas intresset för idrott och prestation som "Svenskt helgfirande" på liknande sätt som exempelvis jul, midsommar eller svenska flaggans dag. ${ }^{609}$

Ett annat helgfirande som gestaltades med flaggor var 1:a maj. 1:a maj har varit helgdag i Sverige sedan 1939. Det finns även i Nationalmuseums samling från 1939 med temat "vår hembygd" en bild av ett 1:a majtåg, där texten på en av de röda flaggorna i tåget är "Upp till Kamp emot kvalen" . ${ }^{610}$ Under världskriget 1939-1945 ersatte arbetarrörelsens 1:a majtåg 1940 och 1941 med Medborgartågen för Sveriges frihet och oberoende. Det var en manifestation som ett

\footnotetext{
${ }^{606}$ Ehn, Billy, Frykman, Jonas \& Löfgren, Orvar (1993) Försvenskningen av Sverige: det nationellas förvandlingar. Stockholm: Natur och kultur.

${ }^{607}$ Ehn, Billy, Frykman, Jonas \& Löfgren, Orvar (1993) sid. 226ff.

${ }^{608}$ Tolvhed, Helena (2008) sid 131.

609 Se även tävling SBBA:s arkiv 1992:020 1978"Min Stenmark".

${ }^{610}$ NM samling Livet i vår hembygd 1a maj demonstration av Vivan Andersson.
} 


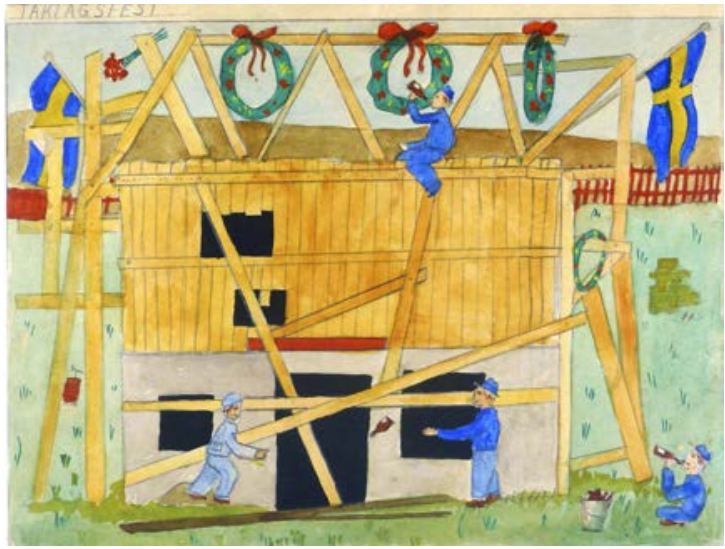

Bild 3:14. Svenskt helgfirande, FIB:s tävling 1944.

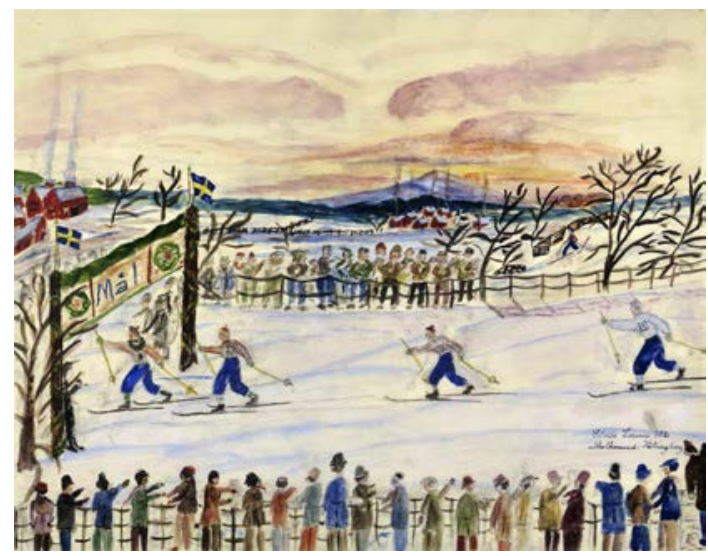

Bild 3:15. Våra lekar, FIB:s tävling 1942.

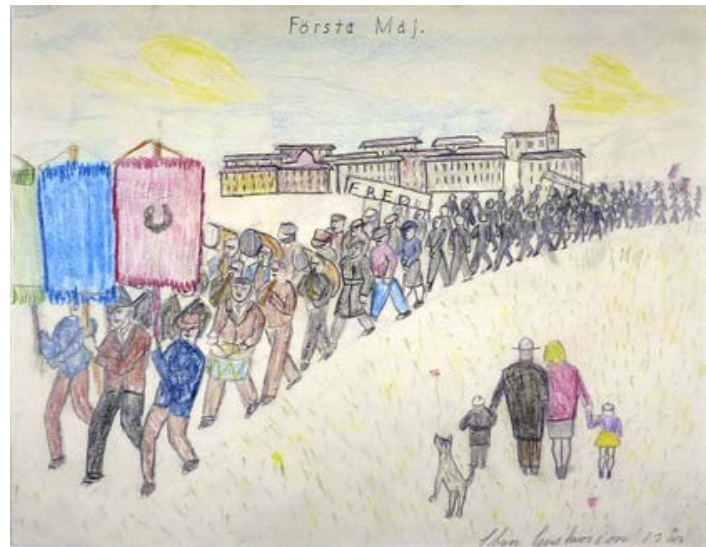

Bild 3:16. Svenskt helgfirande, FIB:s tävling 1944. 
resultat av ett beslut taget av samlingsregeringen. Medborgartåget, vars syfte var att visa upp ett nationellt politiskt samförstånd över klass- och partigränser, fick ett stort genomslag i media och 1940 uppskattades publiken till $150000 .{ }^{611}$

På temat Svenska högtider 1944 i FIB:s tävling finns två bilder av 1:a maj. ${ }^{612}$ På den ena syns människor som tågar i bakgrunden, i förgrunden syns studenter med mössor och blåsorkester, samt barn med ballonger och vuxna som betraktar tåget.

Bild 3:16 visar ett långt tåg med människor, i förgrunden tre män som bär flaggor i rött, blått och grönt. En man i tåget spelar trumma och några andra spelar på blåsinstrument. Längre bak i tåget ser vi en banderoll med texten "Fred". I bakgrunden ser vi en stadsbild med flerfamiljshus och en kyrka. I förgrunden ser vi en person i svart rock och hatt, och en person i röd rock och kjol, som konnoterar man och kvinna, på samma sätt som den små personerna konnoterar pojke och flicka. Till vänster om gruppen står en hund. Gruppen kan som helhet betraktas som symbol för familjen. Familjen står och betraktar tåget med massor av människor, som genom texten "FRED" refererar till en önskan att det pågående världskriget ska ta slut. Bilden av 1a majtåget konnoterar en positiv och hoppfull känsla.

Bilden är tecknad av Sten Gustavsson 13 år, och bilden upplevs som en ögonblicksbild, möjligen med ett foto som förlaga, eller att $1 \mathrm{a}$ majtåget är något tecknaren själv upplevt. Det är en frusen rörelse av människor på väg och människor som betraktar. Bilden refererar till 1:a maj, socialism, och en politisk vilja till förändring. Flaggorna konnoterar i den här kontexten dels socialism, och banderollen Fred ett internationellt engagemang, snarare än nationalism. Alla bilderna från FIB:s samling visar också att det är många människor som såväl deltar som betraktar, vilket konnoterar att flaggorna blir del av en gemenskap mellan många människor.

Detta uttrycks även i bild 3:17 av Bildtexten Alla länder hör ihop! Flaggorna konnoterar skillnad, även om länderna hör ihop är de ändå skilda stater. Flaggorna är placerade i en cirkelrund form som flaggorna sedan placerats ovanpå, där cirkeln refererar till jordklotet. Bilden förmedlar att det är enighet och likhet mellan länder som är viktigt.

Vid sökning i SBBA: digitaliserade arkiv på sökordet "flagga" var det inte svenska flaggor som var i majoritet, utan bilder av en mångfald flaggor som refererar till inter-

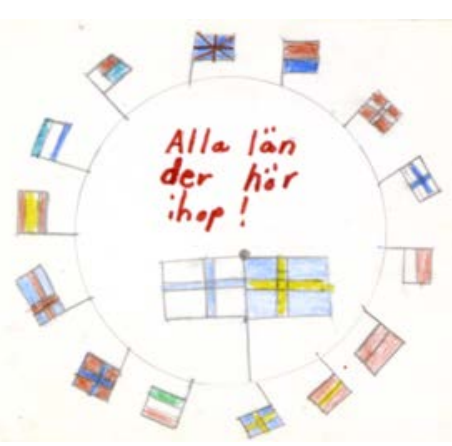

Bild 3:17. Detta vill jag värna om, Arla/ postens tävling 1976.

\footnotetext{
${ }^{611}$ Mats Jönsson "visuell fostran: Barnens dag i Sverige under andra världskriget” i Hedling, Erik \& Jönsson, Mats (red). (2008). Välfärdsbilder: svensk film utanför biografen. Stockholm: Statens ljud- och bildarkiv sid. 143.

${ }^{612}$ Totalt 52 bilder.
} 
nationalism snarare än nationalism. ${ }^{613}$ Bilden 3:17 av Juha Kuru i Eskilstuna skickades till Arla/Postens tävling, men är inte bland de utvalda i boken Varför fär inte barn bestämma. ${ }^{614}$ Genom att tecknaren sedan under texten tecknat den finska och svenska flaggans som om de sitter ihop på mitten, men vända åt varsitt håll, visualiseras hur Sverige och Finland på ett speciellt sätt hör ihop. Det kan både vara genom geografiskt läge, eller genom tecknarens egen upplevelse. Även i flera av SBBA:s samlingar från Rädda barnen finns till exempel barnbilder av fredsduvor med olika flaggor i näbben. ${ }^{615}$ Att Nationsstaterna är självklara beståndsdelar av jordklotet visualiseras, och nationsstaterna ingår som delar av en större, global helhet. På samma sätt som nationalismen kunde vara enande över klassgränser, kan internationalismen symbolisera enande över nationsgränser.

$* * *$

Flaggan som symbol för det Sverige finns med i både FIB:s, Televerkets och Arlas och Postens tävlingar. I avbildandet av svenskt helgfirande 1944 finns svenska flaggan även i andra sammanhang än på Svenska flaggans dag. Flaggan förekommer även i sporttävlingar av olika slag, vid bilder av skolor, eller som del av att fira arbete, som i bilden av taklagsfesten. Även 1:a maj har avbildats som en svensk högtid, och gestaltats med flaggor, men då med annan politisk innebörd. Både bilder av hur människor med flaggor hyllar kungen på svenska flaggans dag och bilder av att vara deltagare eller betraktare av 1:a majtåg, gestaltas som möjliga svenska högtidsdiskurser i FIB:s tävling 1944.

Det svenska helgfirande som visas i bilderna är både mer lokala som surströmmingsfirande eller mer nationella som julotta och midsommar. FIB och Nationalmuseum är delaktiga i att förmedla dessa bilder, där barnen genom definierandet av högtiderna också kan inkluderas i firandet av de svenska högtiderna. Bilderna både reproducerar och skapa nya arenor för känslor av nationell gemenskap. Midsommarafton har varit en återkommande högtid, där flaggan synts i toppen av midsommarstången. I Arlas och postens tävling 1976 "detta vill jag värna om" vill barn värna om det som då benämns "gamla" traditioner, och symboliseras genom bilder av flaggan, midsommarstången, påskris och julgran. Flaggan konnoterar att det är gamla svenska traditioner vi bör vara rädda om. Samtidigt gestaltar en annan av Arlas och postens bilder svenska flaggan tillsammans med andra flaggor runt jordklotet, där flaggorna konnoterar hur "alla länder hör ihop". Detta internationella tema återkommer i kapitel fyra, vi ska nu återknyta till början av detta avsnitt med kungabilder, men nu inte samtida kungar, utan i en historisk kontext.

\footnotetext{
${ }^{613}$ Arkivet startar 1977 och har sina största samlingar från 70 och 80-talet, se inledning.

${ }^{614}$ Arla Tävlingsbilder, samling 1987:024. SBBA.

${ }^{615}$ Se tex SBBA Rädda barnens samling "Livets träd och öarnas barn" (1992:053).
} 


\section{Kungen som både nationell och regional symbol}

Bilder av svenska kungar har vunnit uppskattning av tävlingars jurymedlemmar både på 1940 och 1970-talet. ${ }^{616}$ Vilka föreställningar om nationsskapande, och vilka maktordningar är det som synliggörs genom bilderna och texterna? Vilka nationella myter vill FIB, Nationalmuseum eller Televerket tradera genom barnbilderna? Avsnittet börjar i en analys av juryomdömen av två bilder, en bild av Gustav Vasa publicerad 1947 och en bild föreställande Gustav II Adolf publicerad på telefonkatalogen 1977. Jag kommer sedan att uppmärksamma ytterligare två bilder som refererar till Gustav II Adolf och avslutningsvis två bilder som refererar till Karl XII.

Om bilden Gustav Vasas äventyr i Dalarna skriver Ragnar Hoppe i Sverige genom barnaögon:

Både de agerande figurerna och den landskapliga omgivningen hade här fătt en prägel av svenskhet, som var omisskännlig, och den naivt folkliga stilen förde osökt tanken till äldre folkkonst. ${ }^{617}$

(Bild 3:18). Här kan man se att det är viktigt för FIB och Nationalmuseum att lyfta fram berättelsen om Gustav Vasas flykt i Dalarna som ett förebildligt exempel på temat "Svenskar i allvarstider- beredskap förr och nu" ${ }^{618}$ Hoppe beskriver i sin text hur både "figurerna" och "den landskapliga omgivningen" har fått en "omisskännlig prägel av svenskhet". Om vi betraktar bilden skulle den kunna vara från en mängd olika länder där det finns snö, hästar och slädar, möjligen kan stugans utformning ses som typisk för dalarna. Att skapa och minnas en gemensam historia är något som lyfts fram som en viktig nationell diskurs. Texten uttrycker det Anthony Smith beskriver som ethnoscapes, en specifik vördad för ett poetiskt förfaderslandskap, som ger en upplevelse av nationens historiska kontinuitet. ${ }^{619}$ Här är det främst bildens titel "Gustav Vasas äventyr i dalarna" som gör att bilden förstås som en historisk bild, genom kopplingen till kungen Gustav Vasa. Det är med berättelser som denna, där "folket" stöttar Gustav Vasa som också Dalarna senare kommit att ses som urtypen för svensk tradition, vilket också uttrycks i det sena 1800 -talets konst. ${ }^{620}$

På bilden ser vi en man vid en häst och släde och en man vid ett hus en bit bort som klättrar nedför väggen på ett lakan. Månen lyser så vi förstår att det är natt. De kala träden och snön refererar till vinter. Bilden skildrar en händelse

\footnotetext{
${ }^{616}$ I Sverige genom barnaögon finns flera liknande kommentarer till bilderna i boken, i Televerkets arkiv om tävlingen är det juryutlåtanade som diskuteras det enda som är lika omfattande.

${ }^{617}$ Jungmarker, Gunnar \& Hoppe, Ragnar (red). (1947) Förord av Nationalmuseums överintendent Ragnar Hoppe sid.7. Bild från 1943 års tävling Svenskarna i allvarstider, beredskap förr och nu. "Gustav Vasas äventyr i Dalarna" av Börje Carlestål 13 år, Publicerad i albumet Sverige genom barnögon 1947.

${ }^{618}$ Ta med de andra bilderna på detta tema i Sverige genom barnaögon? bilden "Erik Segersäll offrar till Oden", digerdöden och Stockholms blodbad. Obs, inga samtida bilder i boken, troligen då den gavs ut 1947 då kriget var slut.

619 Smith, Anthony D. (1999) Sid. 18.

${ }^{620}$ Se även Werner, Jeff (2014) sid. 91ff.
} 
från Gustav Vasas äventyr där den han trodde var hans vän visat sig istället vara allierad med den danske kungen Kristian. Frun och drängen på gården hjälper honom därför att fly under natten, då mannen är iväg och hämtar förstärkning mot Gustav Vasa. ${ }^{621}$

I nästa analys ser vi hur Televerkets jury motiverar valet av en annan kungabild, denna gång Gustav II Adolf.

Bild 3:19 av Gustav II Adolf, är intressant för att det finns tydliga uttalanden från juryn om varför den valdes ut. ${ }^{622}$ Det är den vinnande telefonkatalogbilden från Karlskrona- Kristianstad 1977. Även detta är en skildring av en historisk händelse, "Möte mellan den danske kungen Kristian den IV och den svenske

kungen Gustav II Adolf vid Ulfbäcks prästgård, Markaryd, år 1629.” I ett protokoll från sammanträde, 1976-05-26 med juryn för bedömning av teckningar till 1977 års telefonkatalog, beslutas att första pris (1000 kronor) går till Hagaskolan klass 3a i Markaryd.

I Juryn satt: Teledirektör John Jönsson, Kristianstad, Fortbildningsledare Carl Erik Nilsson, Kristianstad, Fortbildningskonsulent Leif Alftén, Kristianstad. Sekreterare var Sibylla Lindblad, Kristianstad.

Juryns formulerar följande motivering till den vinnande bilden:

Bilden erinrar om en händelse inom den aktuella telefonkatalogens spridningsområde samt om ett krig, som haft stor betydelse för oss och dessutom för hela svenska folket. Gustav II Adolf och Kristian IV överlade om ett gemensamt svensk-danskt agerande i det 30-åriga kriget, men förhandlingarna strandade. Valet av ett motiv från hembygden som väcker minnen till liv bland invånarna i hela telefonkatalogdelens spridningsområde och även utanför detta - är lovvärd. ${ }^{623}$

Att händelsen "väcker minnen till liv bland invånarna" gör att det uppfattas som att invånarna själva var med om denna händelse, vilket inte är möjligt då det utspelade sig 1629. Att temat "En händelse i vår hembygd" görs historisk ses som "lovvärt", och att det dessutom skildrar ett kungamöte, gör det till en bild av något som haft betydelse inte bara för Markarydsbor utan för "hela Svenska folket”.

Vi ser ett gult hus med rött tak, grönt gräs, kraftigt beskurna träd, blå himmel och en brun grusväg i förgrunden. Framför huset står två män, mellan männen en stor grå sten, den till höger med rött hår och skägg och blå kläder. Den till vänster med brunt hår, svart skägg och svarta kläder. Till vänster i bilden står fyra män klädda i svart och blått, liknande mannen till vänster. Alla jackor har gula detaljer, troligen knappar, vilket refererar till uniformer, liksom att alla har grå stövlar. Männen till vänster har grå detaljer i händerna, som kan tolkas som

${ }^{621}$ Roos, Anna Maria (1981). Gustav Vasas äventyr i Dalarne. [Ny utg.] Stockholm: Bonniers juniorförl.

${ }^{622}$ Några andra vinnarbilder hade korta kommentarer från juryn, de flesta saknar helt kommentar.

${ }^{623}$ Juryns val Protokoll från jurysammanträde Telekontoret i Kristianstad.Flik 3 F2A:1 1977 Omslag till rikstelefonkatalog Riksarkivet 


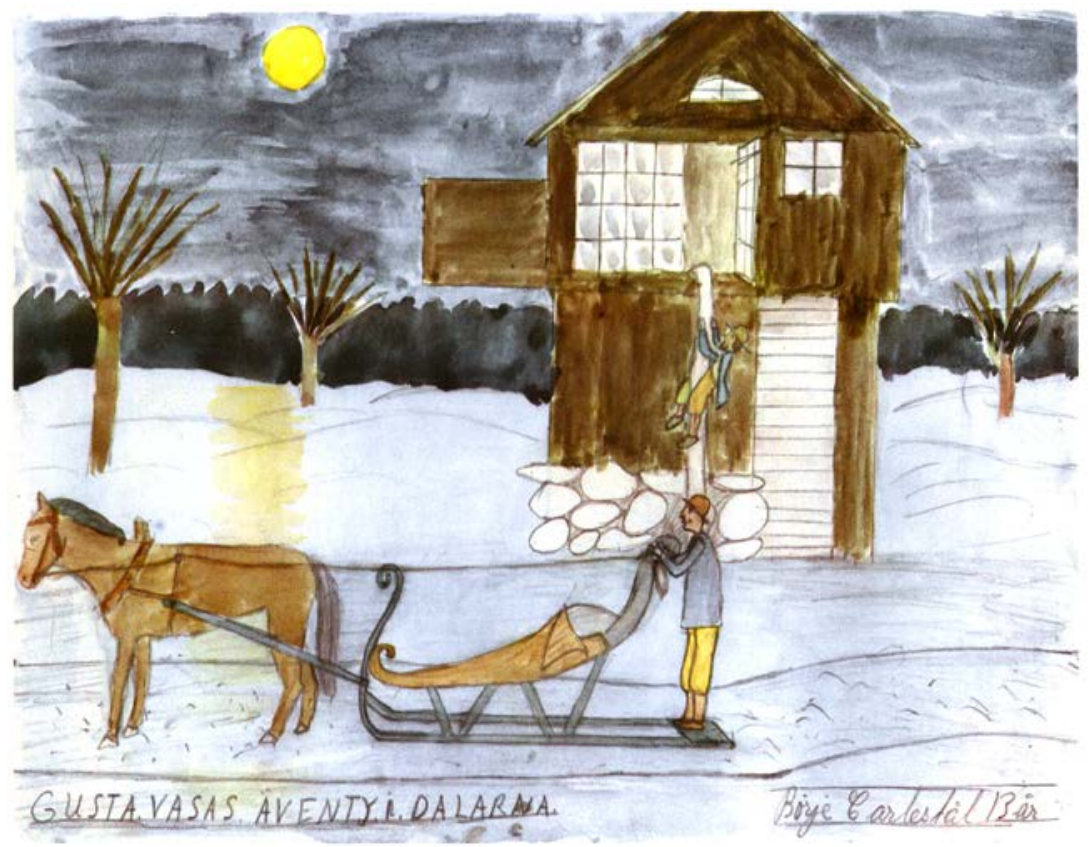

Bild 3:18. Svenskarna i allvarstider-beredskap då och nu, 1944, i Sverige genom barnaögon.

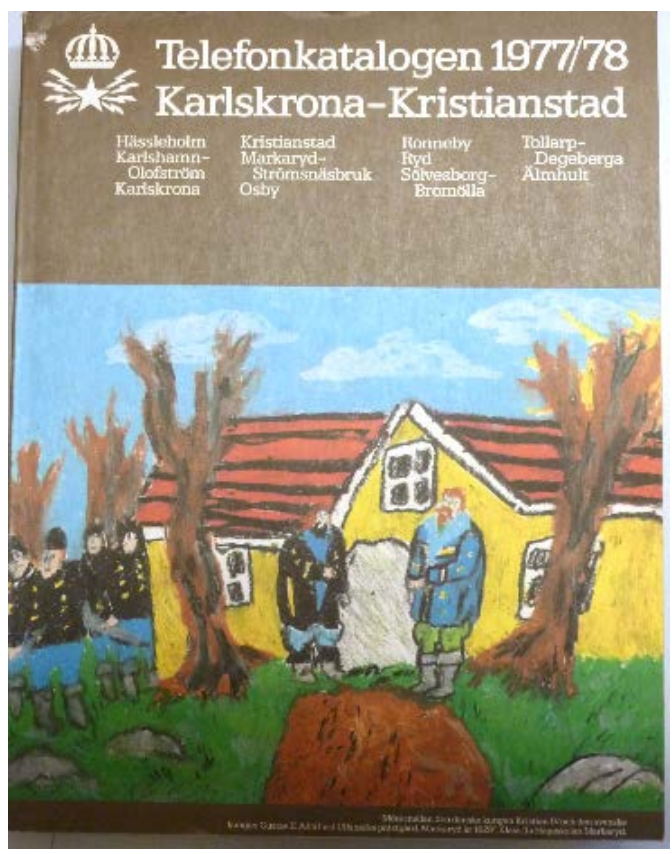

Bild 3:19. En händelse i vår hembygd, Telefonkatalogen Karlskrona 1977. 
gevär. De beskurna hamlade träden kan också möjligtvis referera till det sydsvenska landskapet. Av bildens titel förstår vi att det är Kristian IV och Gustav II Adolf. Här ser man hur tekniken som ses som av "ovanligt hög kvalitet" och med "detaljrikedom", det vill säga ganska naturalistisk och målad med många detaljer, görs till kriterium för att vara en "vinnande bild".

\begin{abstract}
"Tekniskt sett är bilden av ovanligt hög kvalitet och man har lyckats ge teckningen en historisk och ödesmättad stämning. Till detta bidrar inte minst placeringen av kungar och soldater samt sättet att beskriva träden vid kungsgården." ${ }^{24}$
\end{abstract}

Det blir här tydligt hur vissa platser och landskap kan ge en "historisk och ödesmättad stämning", det Smith beskriver som ethnoscapes. För att traderas behöver de återberättas, exempelvis som i denna bild och text. ${ }^{625}$ Juryn lägger in en idé om ödesmättad stämning, som snarare har att göra med bildens titel än med dess utformning. Bilden betraktas i juryns ögon snarare som historiserande måleri, än som en naivistisk barnbild.

Juryn i Kristianstad avslutar brevet med: "Enligt tävlingsbestämmelserna kan juryns beslut inte ändras." Inget annat distrikt kommenterade förhållandet att juryns beslut inte kan ändras, snarare skriver ett par att de kan tänka sig något av de sex, första, samt fem andrapriser, som omslag, beroende på vad man på huvudkontoret finner lämpligt. Televerket hade även i sina instruktioner skrivit att "Televerket förbehåller sig rätten att slutgiltigt avgöra vilket av de belönade förslagen som trycks på telefonkatalogerna." ${ }^{26}$ Men i Kristianstad vill juryn vara säker på att just denna bild ska bli telefonkatalogens omslag. John Jönsson från Televerket hade tidigare meddelat att han avstyrkte idén att använda barnbilder, med motiveringen att det kan väcka "funderingar och frågor om vad Televerket egentligen sysslar med." ${ }^{627}$

Det är troligt att just denna bild inte får någon att tvivla på vad Televerket sysslar med, enligt Jönsson som vill vara säker på att denna bild ska vinna. Juryn fortsätter: "Detaljrikedom i bilden gör den dessutom lämplig som katalogomslag, eftersom telefonerande människor efterhand kan upptäcka nya detaljer som sätter fantasin i rörelse.” ${ }^{628}$

Alla bilderna skulle, enligt instruktionen till skolorna, helst vara målade med pastellkritor (kladdkritor) vilket gav starka färger och en viss "utsuddande" effekt som gör att bilderna lätt blir både naivistiska och expressionistiska i sin estetiska utformning. Detta kunde göra det svårt att få med mindre detaljer, men

\footnotetext{
${ }^{624}$ Omslag till rikstelefonkatalog F2A:1 1977 Flik 3 Juryns val Protokoll från jurysammanträde Telekontoret i Kristianstad. Riksarkivet

${ }^{625}$ Smith, Anthony D. (1999). sid. 152.

${ }^{626}$ Televerkets tävlingssamling En händelse i vår hembygd 1977 Informationsutskick till skolorna SBBA

${ }^{627}$ Skrivelse till Televerket, Inställning av yttranden från HO 1976-01-22. Omslag till rikstelefonkatalog F2A:1 1977 Riksarkivet

${ }^{628}$ Juryns val Protokoll från jurysammanträde Telekontoret i Kristianstad. F2A:1 1977 Flik 3 Omslag till rikstelefonkatalog, Riksarkivet
} 
juryn beskriver att det är just detaljrikedomen som är en av orsakerna till att bilden betraktas som bra, snarare än ett barnsligt och naivistiskt bildspråk.

Kungabilder har en lång tradition, både i konsten och i skolan. I arbetsböcker i geografi och historia under första delen av 1900-talet fanns det studiebilder av historiska gestalter som alla barn i skolan förväntats teckna. ${ }^{629}$ Både skolan och Televerket uppfattade fortfarande 1976 denna kulturkanon av kungabilder som positiv när de valde kungabilder som vinnarbilder.

Telefonkatalogen hade alltså 1977 temat "En händelse i vår hembygd" och 1978 "En historisk händelse i vår hembygd". Trots uppmaningen att teckna "händelse" visar två tredjedelar av vinnarbilderna det första året enbart naturmotiv. Om det var människor i bild hade de folkdräkt eller var historiska personer.

Affischen som sänds från Televerket till skolorna för att uppmana till deltagande i tävlingen föreställer 1978 en man med vikingahjälm och skägg.

I en bild av klass 3b, Skolspåret, Angered ser vi en man på en kulle till vänster i bild med hatt, skägg och handskar (bild 3:20). Han pekar med ena handen ner mot hus till höger i bilden. Bildtexten är Gustav II Adolf "Här ska staden ligga" Centralt placerad i nedre delen av bilden är en svensk flagga. Ytterligare två gula kors med blå bakgrund syns i Gustav II Adolfs hatt och vid hans bröstficka. Bilden är i starka färger och med ett "naivt" bildspråk. Bilden refererar till Gustav II Adolf, som står staty i Göteborg, på Gustav Adolfs torg, och konnoterar både barnbild och historieundervisning. Den kan också ses som kodad till mängder av andra bilder av och berättelser om Gustav II Adolf. Den formella funktionen, att det är en barnbild, kan göra att bilden av kungen förändras. De tidigare historiserade och naturalistiskt avbildande idealbilderna av kungar, kan genom ett naivistiskt bildspråk bli mera sagolika eller overkliga. De vars röster framträder kan sägas vara barns röster men redigerade av Televerket och skolan.

Bilden är skapad i en skolkontext och katalogomslagen betraktades dels i hemmiljö, dels i offentliga lokaler med telefonkataloger 1978. Det konstrueras också ett gemensamt "vi i Göteborg", som en del av Sverige genom flaggan och Gustav II Adolf, och som del av staden Göteborg genom att bilden är placerad på telefonkatalogen för Göteborgsområdet.

${ }^{629}$ Se tex Sjöholm, L. Gottfrid \& Goës, Axel (1946). Arbetsövningar i historia. H. 2, Sveriges historia under reformationstiden och stormaktstiden. Arlöv ...: Skriv- \& ritboks-a.-b. 


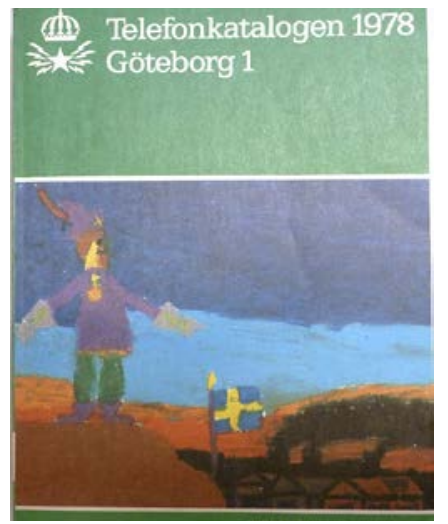

Bild 3:20. En historisk händelse i vår hembygd, Telefonkatalogen Göteborg 1978.

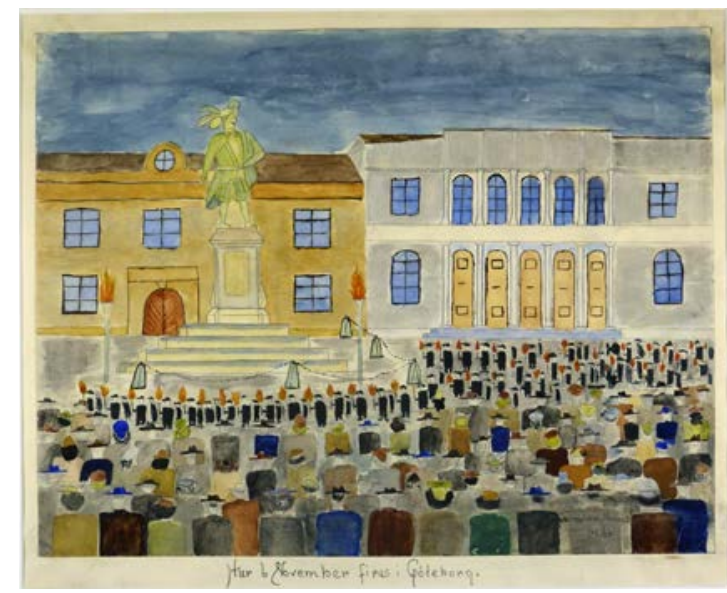

Bild 3:21. Svenskt helgfirande, FIB:s tävling 1944.

I bild 3:21 ser vi samma staty som 1978 kommer att pryda telefonkatalogen, men i denna bild från 1943 är statyn på Gustav Adolfs torg omringad av män i svarta rockar som bär facklor, och runt männen ser vi ryggar av människor, både män och kvinnor med olika sorters hattar. Bilden visar "Hur 6e november firas i Göteborg” av Mona-Lisa Nodvall 14 år, och är målad på temat Svenskt helgfirande. Bilden gestaltar hur stor folkmassa samlats för att fira Gustav den II Adolfs dödsdag den 6e november och konnoterar högtidlighållandet av ett offentligt kungafirande. ${ }^{630}$

Som jag nämnde inledningsvis är en gemensam och delad kultur en viktig maktfaktor vid etablerandet av den nationella idén. ${ }^{631}$

Cederströms målning "Karl den XII:s likfärd" på Nationalmuseum ingår i det sena 1800-talets kulturella nationsskapande. Originalmålningen av är en del av ett historiserande måleri som vill ge sken av att det är målat direkt på plats, nästan som en reportagebild. Målningen utfördes i själva verket i en ateljé 160 år efter Karl XII s död, men det naturalistiska bildberättandet ger en aura av "sanningsberättade" ${ }^{632}$ Målningen av Gustaf Cederström var utställd på vårutställningen i Paris 1878, och blev belönad med medalj. ${ }^{633}$ Nationalmuseet i Stockholm invigdes 1866, men redan Gustav Vasa och Gustav III hade börjat samla konst till Stockholms slott. Museet grundades alltså ungefär vid samma tid som

${ }^{630}$ Gustav II Adolfdagen firades till 2009 gemensamt av Göteborgs stad. http://spanaren. se/2015/05/15/inga-fler-hogtidstal-av-anneli-hulthen-pa-gustaf-adolfsdagen (2016-08-05).

631 Gellner, Ernest (1999) Nationalism. Nora: Nya Doxa sid.19-23.

632 Mirzoeff, Nicholas (1999). An introduction to visual culture. London: Routledge sid. 37.

633 http://www.nationalmuseum.se/sv/Om-samlingarna1/Hojdpunkter-maleri/Karl-XIIs-likfard/ (2018-03-10). ”Tavlans motiv är inte en realistisk skildring av händelsen, utan en diktad hyllning till den döde kungen. Karl XII blev aldrig buren på bår hem till Sverige den där kalla vintern 1718. Men Cederströms idé saknar inte helt verklighetsanknytning. Vid stora mäns och kvinnors begravningståg har ibland den döde burits öppet, klädd i sina bästa kläder, i procession till begravningsplatsen”. 
folkskolorna infördes. ${ }^{634} 1868$ invigdes Karl XII statyn i Kungsträdgården strax intill Nationalmuseum. Myten kring krigarkonungen backades upp av nationalromantisk litteratur som Esaias Tegners "Kung Karl den unge hjälte" eller Verner von Heidenstams romantiseringar av den svenska stormaktstiden. ${ }^{635} \mathrm{Re}-$ dan 1910 trycktes bilden av Karl XII:s likfärd i tionde upplagan av Läsebok för folkskolan och 1931 gavs den också ut som skolplansch och mötte därigenom många skolelever. ${ }^{636}$ I 1919 års undervisningsplan för rikets folkskolor står om historieundervisningen att den ska göra barnen förtrogna med "personligheter och händelser som bidragit till kulturens höjande" och som hos barnen lägger grund för en "sund fosterlandskänsla och god samförståndsanda". ${ }^{637}$

Skolradion som vann popularitet under 1930-talet kunde bland annat användas för att förmedla nationella ideal och skapa nationell medvetenhet. ${ }^{638} \mathrm{Ex}-$ empelvis fanns flera skolradioprogram om Karl XII, även om man i skolradion 1935 kritiserar att hans agerande inneburit lidande för befolkningen, och snarare hyllar hans soldater än honom själv. ${ }^{639}$ Bilden av "Krigarkungen" Karl XII har varit en del av den kulturkanon som funnits under tidigt 1900-tal, där både Nationalmuseum och skolan varit viktiga institutioner för att tradera bilden av ett gemensamt nationellt förflutet.

1941 tecknar Maj-Britt Jonsson 12 år "Mitt roligaste skolminne" (bild3:22). På bilden syns hur troligen en skolklass från en flickskola står samlade framför tavlan av Karl XII där en lärarinna eller museiguide står i profil med armen höjd mot tavlan av Karl XII. Bilden konnoterar en skolklass på besök på Nationalmuseum, där Lärarinnan berättar om bilden, och flickorna lyssnar. Att just kungen är viktig kan man förstå av det uppvikta perspektiv som används för att man ska se hela kungen där han ligger på båren. Det är betydligt fler soldater i originalbilden och flaggan är placerad i mitten av bilden, en flagga med tre kronor. I Maj-Britts skolminne är det en svensk flagga med gult kors längst till höger i bild. Både originalbilden och bilden från 1941visar det branta stupande berget som soldaterna går vid, och betraktaren bredvid följet. I Maj-Britts bild uppfattas bilden som stor i förhållande till barnen, de ser ut att få böja huvudet bakåt för att kunna se målningen ordentligt. Lärares förevisande av och barns betraktande av kungabilder på museum ges genom bilden positiva associationer, som ett det "roligaste skolminnet". Att Nationalmuseum gått med som arrangör

${ }^{634}$ Werner, Jeff \& Björk, Tomas (2014). Blond och blåögd: vithet, svenskhet och visuell kultur = Blond and blue-eyed : whiteness, Swedishness, and visual culture. Göteborg: Göteborgs konstmuseum sid. 34.

${ }^{635} \mathrm{http} / / /$ historiska.se/wp-content/uploads/2015/06/Karl-XII.pdf.(2018-03-07)

${ }^{636}$ Jonsson, Olof G (2006) Skolplanschen: argument $i$ spänning mellan bild och text, perspektiv och kontext, STEP, Department of Education, Uppsala University, Licentiatavhandling Uppsala : Uppsala universitet, sid. $144 \mathrm{ff}$.

637 Undervisningsplan för rikets folkskolor den 31 oktober 1919. (1924). Stockholm: Norstedt sid. 100. Denna undervisningsplan gällde fram till 1952.

${ }^{638}$ Lindgren, Anne-Li (1999) Att ha barn med är en god sak": skolradion och kampen om barn $i$ svensk rundradio under trettiotalet

${ }^{639}$ Lindgren, Anne-Li (1999) sid.125f. 
och jurydeltagare just 1941 kan möjligen spela roll för vilka bilder som valt ut som vinnande.

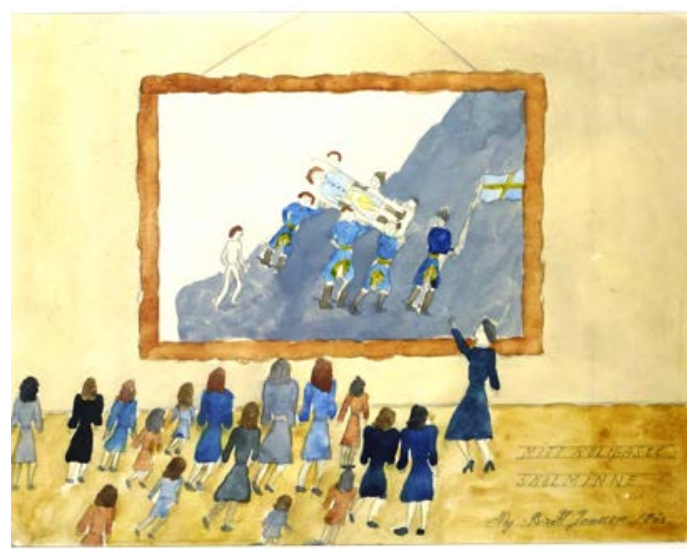

Bild 3:22. Mitt roligaste skolminne, FIB:s tävling 1941.

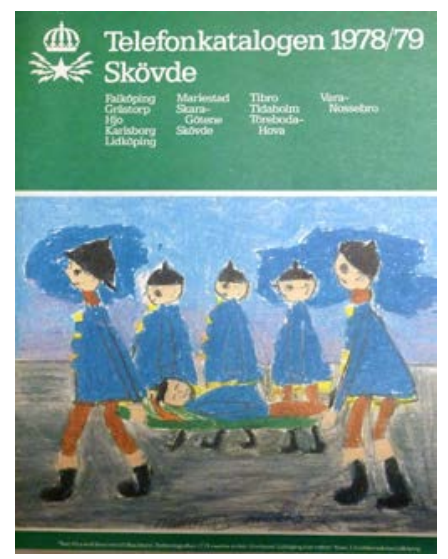

Bild 3:23. En historisk händelse i vår hembygd, Televerket 1978.

Bilden på Skövdes telefonkatalog med temat "En historisk händelse i vår hembygd" bär titeln: "Karl den XII:s stoft föres hem till Stockholm (bild3:23). Trettondagsafton 1719 insattes stoftet i Grevhuset i Lidköping över natten" Klass $3 d$ Lidåkersskolan Lidköping. Här ser vi hur även Karl XII är en del av en lokalt återberättad historiebeskrivningstradition, likt Gustav II Adolf, eller Gustav Vasa.

I bilden ser vi en man som bärs på bår, av bildtexten förstår vi att det är den döde Karl XII. Han bärs av karolinska soldater med spetsiga hattar, höga stövlar och blå uniformer med gula knappar. Personerna är här det viktigaste i bilden, och bakgrunden och miljön har ägnats mindre intresse. Det är betydligt färre personer som bär Karl XII än i originalbilden, bildtexten talar också om att bilden refererar till Lidköping, och vi ser också en helt annan miljö än originalbildens bergslandskap. Ändå kan bilden genom personen på båren och genom titeln Karl XII ses som en tydlig referens till Cederströms målning. Liksom i Karl XII:s likfärd är kungen placerad centralt i bilden.

$$
* * *
$$

De bilder som analyserats här visar att gestaltning av kungar både i text och bild har varit ett sätt att tradera bilden av den svenska historien, både på 40-talet och på 70-talet. Exempelvis är målningen av Karl den XII:s likfärd del av tävlingarnas visuella berättelse både på 1940- och 1970-talet. Att Televerkets hembygdsbilder knyter an till den lokala bygden, hembygden, behöver som vi sett inte stå i motsats till att de samtidigt visar symboler för det nationella, som kungen eller flaggan.

Kungarna är på olika sätt knutna till specifika hembygder likväl som till nationen, vilket syns exempelvis i bilderna av Gustav II Adolf. I juryns uttalande 
från 1977 om bilden av Gustav II Adolf, är ett gemensamt minnesskapande, ”om ett krig, som haft stor betydelse för oss [i denna hembygd] och dessutom för hela svenska folket" ett viktigt argument för att detta är en vinnarbild.

I Hoppes citat om bilden av Gustav Vasa konstrueras den "omisskännliga svenskheten" där den "naivt folkliga stilen" kopplar ihop det naiva barnet, som målat bilden, med den naiva folkkulturen. Barnen kunde under 1940-talet både ses som förbundna med en ålderdomlig folkkultur genom sin "naivt folkliga stil" som i bilden av Gustav Vasa, och den nya tidens expressionistiska moderna konst genom "barnkonstdiskursen". Tävlingsbilderna kan betraktas som traderande av heroiska kungaberättelser, men en möjlig läsning av materialet är att barnbildernas icke naturalistiska bildspråk också kan förskjuta kungabildernas innebörd så att de framstår som sagofigurer, snarare än nationalhjältar.

\section{Folket i bild och Nationalmuseum - Sverige genom barnaögon}

Överintendenten på Nationalmuseum Erik Wettergren, poängterar i Sverige genom barnaögon 1947 att boken berättar något om just svenska barn: "Man har rätt hoppas, att den både i Sverige och utlandet, skall berätta något om svenska barn och deras sätt att reagera och därigenom utgöra ett intressant jämförelseobjekt med liknande publikationer från andra länder." ${ }^{40}$ I detta kan man förstå att Wettergren anser att svenska barn förmodas reagera annorlunda än andra barn, och att barn från olika länder är intressanta att jämföra. Joakim Landahl har påpekat hur världsutställningarna från mitten av 1800-talet var ett vanligt sätt att jämföra och tävla mellan nationer. Utställningarna i sig skapar en idé om vikten av nationell identitet, där det nationella uttrycks bland annat i de pedagogiska paviljongerna. ${ }^{641}$

Detta kan vara en anledning till att Wettergren menar att boken är intressant att jämföra med liknande publikationer från andra länder, och att Sverige genom barnens tävlingsbilder kunde betraktas som ett pedagogiskt och konstnärligt föregångsland. I detta avsnitt kommer jag först att översiktligt och kortfattat redogöra för innehållet i jubileumsalbumet Sverige genom barnaögon. Därefter analyserar jag albumets omslag, för att därefter analysera och kontextualisera de vinnarbilder från temat Livet i vår hembygd som publicerats i albumet. Slutligen analyseras de vinnande bilder från samma tema som publicerades i tidskiften FIB 1939.

I albumet Sverige genom barnaögon återges sexton utvalda färgbilder och 36 svartvita bilder, samt en text av Edvard Hoppe, dåvarande intendent på Natio-

${ }^{640}$ Jungmarker, Gunnar \& Hoppe, Ragnar (red). (1947) Wettergren sid. 3. (min kursiv).

${ }^{641}$ Landahl, Joakim "Aesthetic Modernisation and International Comparisons: Learning About Drawing Instruction at the Paris Exposition Universelle of 1900" in History of Education (forthcoming). 
nalmuseum, och en text av Gustav A Nordlander, teckningslärare. ${ }^{642}$ De sexton bilderna som är utvalda för färgreproduktion i Sverige genom barnaögon, har följande titlar och är från olika teman:

\begin{tabular}{|c|c|c|}
\hline Årtal & Tävlingens tema & Bildens titel \\
\hline 1939 & Livet i vår hembygd & $\begin{array}{l}\text { Ånäsvägen strax före klockan 12, då } \\
\text { barnen börjar skolan. } \\
\text { Avesta järnverk } \\
\text { Bygget } \\
\text { Beteshage } \\
\text { Skörd } \\
\end{array}$ \\
\hline 1942 & Vad jag ska bli när jag blir stor & Skogshuggare \\
\hline 1943 & $\begin{array}{l}\text { Svenskarna i allvarstider - beredskap } \\
\text { förr och nu. }\end{array}$ & $\begin{array}{l}\text { Stockholms blodbad } \\
\text { Digerdöden } \\
\text { Gustav Vasas äventyr i Dalarna }\end{array}$ \\
\hline 1944 & Svenskt helgfirande & \begin{tabular}{|l|} 
Kräftkalas \\
Valborgsmässoeld \\
Svenska flaggans dag \\
\end{tabular} \\
\hline 1945 & Våra lekar & \begin{tabular}{|l|} 
Korgboll \\
Lek med docka
\end{tabular} \\
\hline 1933, 1938 & Två bilder utanför tävlingen & $\begin{array}{l}\text { I kyrkan } \\
\text { Erik Segersäll offrar till Oden. }\end{array}$ \\
\hline
\end{tabular}

Tabell 3. Bilderna i boken Sverige genom barnaögon

Bilder från 1938 och 1941 med uppdragen att teckna " Livet i min skola" och "Mitt roligaste skolminne" saknas. Temat "Min fritid" från 1940 är representerad genom omslagsbilden. De flesta teman är formulerade som "våra" eller "mitt", och frågar efter just barnens blick. Det specifikt svenska skrivs fram i två teman: "Svenskarna i allvarstider - beredskap då och nu". samt i temat "Svenska högtider". ${ }^{643}$

Temat Livet $i$ vår hembygd är representerat med fem bilder, fyra av dem analyseras i nästa avsnitt i det här kapitlet. I kapitel fem diskuterar jag bilden Lek med docka. Gustav Vasas äventyr i Dalarna och Svenska flaggans dag analyserades i avsnittet Nationella symboler. Hela albumet kan ses som en del av barnkonstdiskursen som jag diskuterat tidigare. Detta representeras kanske främst av bilden Erik Segersäll offrar till Oden, som inte varit del av FIB:s tävling men ändå är med i albumet. ${ }^{644}$ Bilden beskrevs i albumet som "en typisk exponent för den Faith-Ellska metoden" som ansågs karakteriseras av en flödande och skissartad teknik. ${ }^{645}$ Bilden är utförd i så kallad vått-i-vått teknik, en akvarell där färger flyter i varandra, vilket var en del av de nya moderna konstpedagogiska idealen. ${ }^{646}$

${ }^{642}$ De var båda redaktörer för boken och de satt också båda med i tävlingens jury, Ljungmarker från start och Hoppe efter 1941. I detta avsnitt är det främst bilderna i albumet som utgör analysmaterialet, men Hoppes text är del av kontexten och analysen i samtliga kapitel.

${ }^{643}$ Från temat "Svenskarna i allvarstider - beredskap då och nu" har man enbart valt historiska bilder, kanske för att kriget var slut när boken gavs ut 1947.

${ }^{644}$ Jungmarker, Gunnar \& Hoppe, Ragnar (red). (1947) sid.5.

${ }^{645}$ Siri och Sacha Faith-Ell var pionjärer inom en förändring av bildpedagogiken, de skrev återkommande artiklar i tidskriften Teckning och skrev även flera läroböcker.

${ }^{646}$ Se tex Faith-Ell, Zacha \& Faith-Ell, Siri (1955-1963). Färg och form. Stockholm: Ehlin. 
Bilden kan således ses som representant både för det moderna, genom de nya bildpedagogiska teknikerna, och det nationella med ett motiv som refererar till svensk historia och den fornnordiska mytologin.

Från tävlingen 1944 med temat Svenskt helgfirande, är de utvalda bilderna Kräftkalas, Svenska flaggans dag och Valborgsmässoeld. Även om det är till antalet fler bilder i samlingarna som avbildar jul eller påsk, så väljer man här en högtid som betonar ett nationellt, men även ett lokalt och mer sekulärt högtidsfirandet, som valborgseld och kräftkalas. Påskeld och kräftkalas är också konstreproduktioner i Laurins bok "Sverige genom konstnärsögon", av exempelvis Carl Larsson, vilket kan ge dessa högtider konsthistorisk referens. ${ }^{647}$

Från FIB:s tema "Livet i vår hembygd" 1939, publicerades förutom de fem färgbilderna, också fem bilder i svartvitt. ${ }^{648}$ De svartvita reproduktionerna föreställde "1a maj demonstration", "Timmerkörning", "Höbärgning i Skåne", "Arbetstidens slut" (bild av en fabrik där människor går från arbetet) samt "Borrning i gruvan". ${ }^{649}$

\section{Omslagsbilden Sverige genom barnaögon}

I samband med teckningstävlingarnas tioårsjubileum publiceras alltså albumet Sverige genom barnaögon; FIB:s teckningstävling för skolungdom 1947 (bild $3: 24) .{ }^{650}$

647 Laurin, Carl G. (1911). Sverige genom konstnärsögon. Stockholm: Norstedt.

648 Av totalt 36 mindre svartvita reproduktioner.

${ }^{649}$ Av både de svartvita och färgbilderna är det alltså sex som gestaltar stads- eller fabriksmotiv, och fyra mera lantliga motiv.

${ }^{650}$ På sid 2 står: Urvalet och redigeringen av bilderna har ombesörjts av tjänstemännen vid $\mathrm{Na-}$ tionalmusei Handtecknings- och gravyravdelning, förste intendenten Ragnar Hoppe och intendenten Gunnar Ljungmarker. Samtliga reproducerade teckningar med undantag för vinjetten sid 5 tillhör Nationalmusei barnteckningssamling, och med undantag för färgplanscherna nr 1 och nr 6 samt svartvita bilden $\mathrm{nr} 2$ ha de alla tillförts museisamlingen genom FIB:s teckningstävlingar. 


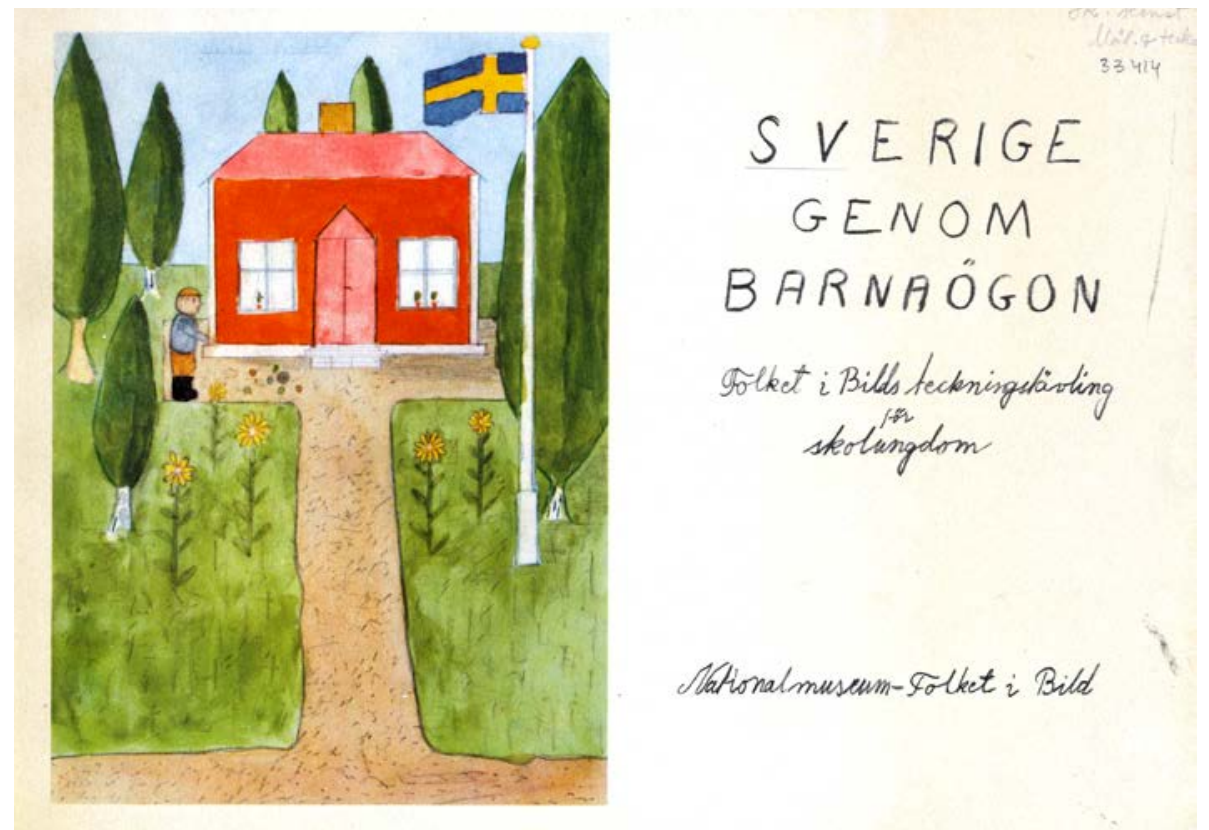

Bild 3:24. Omslag till katalogen Sverige genom barnaögon (1947).

Texten på framsidan är skriven med handstil, och "Sverige genom Barnaögon" med versaler, vilket ger intrycket att det inte bara är sett med barnögon, utan även skrivet av barn. Om det är det eller om det är skrivet av vuxna med "barnslig" stil är oklart. Bilden visar en av de deltagande vinnande bilderna i teckningstävlingen.

Bildens kontext är att det är en bild som gjorts i skolan, i en tävling för skolungdom, och på baksidan av bilden får vi veta att den är gjord av Sture 11 år, 1940 med temat "Min fritid". ${ }^{651}$ Bilden har sedan både ställts ut på Nationalmuseum, och används även för omslaget till detta album. Hela omslaget till albumet användes i en annons i FIB 1947 där det beskrivs som ett "jubileumsalbum" och där det omtalas att tidningen skänker ett exemplar till alla skolbibliotek, men att albumet även finns att köpa i bokhandeln för 7.50:- I annonsen skriver man även att förhoppningen från tidningens sida är att ytterligare stimulera intresset för teckningsundervisningen. ${ }^{652}$

På den denotativa nivån ser vi att bilden är tecknad snett uppifrån i fågelperspektiv. Till höger är en flaggstång, med en svensk flagga som blåser åt vänster. Ett rött hus är placerat mitt i bildens övre del, det har två fönster med små krukväxter, ljusröd dörr och tak med skorsten, samt vita knutar. Himlen är ljust blå. I förgrunden är en gräsmatta med en grusgång som leder fram till huset. På gräsmattan växer fem gula blommor. Sex träd, liknande stora enar står runtom

${ }^{651}$ Denna bild och två till i häftet saknar angivelse av skola och plats.

${ }^{652}$ FIB nr10 sid. 32. 
huset, de är skuggade till höger, vilket gör att vi föreställer oss en sol till vänster utanför bild. Till vänster om huset står en pojke i profil med keps, blå tröja, bruna byxor och svarta stövlar. Hans högra arm, som är vänd mot oss, är framsträckt. På marken är sju runda cirklar i olika färger; av titeln förstår vi att det är kulor. Blommorna, gräset och solljuset i bilden refererar till sommar, och ett bra väder för att spela kula.

På omslaget finns olika tecken som fungerar som referenser. Både texten och bilden refererar gemensamt till barn, dels textens innehåll "genom barnaögon", bokstävernas utformning, barnet som syns till vänster i bild, och slutligen själva det faktum att det är en barnbild, målad med en viss naiv stil. ${ }^{653}$ Den andra framträdande referensen i bilden är "Sverige" både genom albumets titel, och genom svenska flaggan och det röda huset med vita knutar som refererar till Sverige. ${ }^{654}$ Genom att Nationalmuseum gav ut albumet kodas bilden som barnkonstbild, men bilden kan även kodas som reklam- eller vykortsbild, genom de typiska attributen röd stuga och svensk flagga, och utgivarnas intention var att propagera för de svenska barnens kompetenser i teckning. ${ }^{655}$

På den konnotativa, tolkande nivån signalerar titeln "Sverige genom barnaögon" att Sverige är ett land som bryr sig om att lyssna till och betrakta både barn, och barns bilder, liksom bilden visar hur barn gestaltas i en solig trygg, miljö med (flaggstång), hus och växter. ${ }^{656}$ Bilden är målad på temat "min fritid" och bildens namn är "spela kula". I detta blir bilden även referent för "en svensk barndom där fritid innebär lek", men först genom titeln, eftersom kulorna knappt är synliga på bilden.

Att Sverige "ses genom barnaögon" indikerar också att det finns barn, på en bestämd plats, som ser den platsen, och att det de ser förmedlas till oss. Men det är en specifik bild av nationen som de ser, som kan vara dold för andra, för de ser denna bild i sin egenskap av att vara barn. Att det är genom barns ögon antyder att barn ser något annat: sitt eget rike, med sina egna regler, ritualer och normer. ${ }^{657}$

De som talar i denna text, ska förstås som barnen, då man använder uttrycket "genom" barnaögon. Men barnens röster är starkt redigerade av Nationalmuseum och FIB, och genom Teckningslärarförbundet, vilka är de tre institutioner som är representerade i juryn som väljer ut de vinnande bilderna. ${ }^{658}$ De som tilltalas är en konst- och barnintresserad allmänhet, samt skolorna som får detta

\footnotetext{
${ }^{653}$ Detta vet vi också då bilden är gjord i en skoltävling.

${ }^{654}$ Hur nationella symboler blev del av gemensamma erfarenheter diskuterar text Hobsbawm, E. J. (1992). Nations and nationalism since 1780: programme, myth, reality. 2. ed. Cambridge: Cambridge Univ. Press ch.5.

655 Se tillexempel bild sid. 68 från tävlingen "Sverige är fantastiskt".

${ }^{656}$ Hallberg, Mathilda, Sandin, Bengt; Pictured "Political Projects - the children in the welfare Story" opublicerat manuskript.

${ }^{657}$ se tex James, Allison, Jenks, Chris \& Prout, Alan (1998)"the tribal child" in Theorizing childhood. Cambridge: Polity Press sid. 28ff.

658 Jungmarker, Gunnar \& Hoppe, Ragnar (red). (1947) Sid 2. "Urvalet och redigeringen av bilderna har ombesörjts av tjänstemännen vid Nationalmusei Handtecknings och gravyravdelning, förste intendent Ragnar Hoppe och intendenten Gunnar Ljungmarker.”
} 
häfte till sina bibliotek, liksom FIB:s och DNs läsare, då de berättar om katalogen i sina tidningar. I det som i en semiotisk analys benämns den kontaktskapande funktionen, där man pekar på vilka som innesluts eller utesluts genom bilden, kan man säga att "svenska barn" är inneslutna, katalogen handlar om dem.

Vuxna, eller de som inte är svenska, utesluts inte som betraktare, men som medverkande i bildhäftet; här handlar det om en gestaltning av "det svenska" genom barn. ${ }^{659}$ Barns bilder skapar "bilden av" Sverige, barn blir värda att betraktas och synliggöras som de blivande svenska medborgarna.

Tävlingarna och utställningarna kunde etablera barnen som betydelsefulla i att avbilda hemlandet. ${ }^{660}$ Genom kulturella produkter som albumet Sverige genom barnaögon, skapades det nationella som något barn hade att förhålla sig till. Billig menar att nationalismen ständigt återskapas genom att betraktas som vardaglig och naturlig. Barnens oskyldiga blick kunde ses som det mest naturliga där "det svenska" genom barnens ögon, då också framstod som vardagligt och självklart. ${ }^{661}$

På liknande sätt som Hobsbawn menar att medborgare i nationalstater förväntas skapa sina egna subjekt som del i ett nationellt projekt, kan FIB s teckningstävling och albumet Sverige genom barnaögon förstås. Bilderna, utställningarna och jubileumsalbumet identifierade barns uppfattningar om Sverige. Genom att tydligt uttala att man ville ha bilder från hela Sverige kunde därigenom förena olika hembygder till en nationell identitet och därigenom få den nationella idén att överensstämma med människors (barns) självidentifikation. ${ }^{662}$

$* * *$

Utgivningen av albumet visar ett samhälleligt intresse både för barn, barnbilder och barns betraktelser av Sverige. De olika teman barnen gavs har av arrangörerna definierats som barns bilder av "Sverige", och det är i albumet flest bilder från temat Livet $i$ vår hembygd. Sammanfattningsvis visar denna korta redovisning att Nationalmuseum och FIB kunde förenas i intresset för det moderna och det nationella. Både företrädare för den moderna konsten och företrädare för det moderna politiska samhällsbygget såg barnen som förgrundsgestalter i omformandet av den moderna nationen. FIB och Nationalmuseum hade i samarbete med skolan intresse av att visa fram en modern teckningsundervisning för att också visa upp en bild av Sverige som ett föregångsland i pedagogik.

Nästa avsnitt diskuterar hur Nationalmuseum förhöll sig till och kommenterade barnbilderna. Förutom fyra färgbilder från temat Livet $i$ vår hembygd som publiceras i Sverige genom barnaögon 1947, presenteras även två bilder av samtida konstnärer som barnbilderna i samtida kommentarer ansågs referera till.

659 Jfr Hallberg, Mathilda (2017).

660 Sandin, Bengt, Aronsson, Karin "The sun match boy and Plant Metaphors: Swedish Image of a 20th-century childlhood" (2012) I The Global History of Chidlhood Reader / [ed] Heidi Morrison, London and New York: Routledge, 2012, sid. 60-72.

661 Billig, Michael (1995) sid. 10.

${ }^{662}$ Hobsbawm, E. J. (1992). Kapitel 5. 


\section{Nationalmuseums hembygdsbilder - barnbilden som uttryck för modernitet}

Att visa bilder av nationen var relevant både vid publikationen av boken Sverige genom konstnärsögon från 1911 och i Sverige genom barnaögon 1947.

Om det nationalromantiska måleriet från sekelskiftet användes för att visa de nationella landskapen och nationell tradition, användes barnens bilder även för att visa upp modernitet och förändring. Detta framgår bland annat av att Nationalmuseum i Sverige genom barnaögon uppmärksammar likheter med samtida konstnärer, både vad gäller bildernas form och motivval. Dessutom påtalas $\mathrm{i}$ albumet behovet av en progressiv bildpedagogik, framskrivet i kapitlet Teckningsundervisningen förr och $n u .^{663}$

I Sverige genom barnaögon refereras specifikt till Albin Amelin, Sven Eriksson, Einar Jolin och Otte Sköld som exempel på konstnärer som barnens bilder erinrar om:

Arbetet i fabriker och verkstäder, husbygge och lantbrukssysslor, målas intimt och lustigt, men ibland också med ett patos, som ger de små scenerna ett dokumentariskt värde. Det är inte utan att man inför dessa samtidsskildringar utav sotiga fabriker och mörka storstadsgator kommer att tänka på målare som Sven Eriksson och Albin Amelin, medan de mera idylliskt betonade bilderna med deras ljusa färghållning och sobra detaljerade teckning erinra om Otte Skölds och Einar Jolins ungdomsverk i naivistisk anda. ${ }^{664}$

I texten jämförs alltså barnens bilder med flera samtida svenska konstnärer, och hur de i likhet med dessa både kunde skildra arbete, sotiga fabriker och mörka storstadsgator, och även mera idylliska motiv. ${ }^{665}$ Två av färgbilderna från temat Livet $i$ vår hembygd i boken Sverige genom barnaögon, visas här i relation till två av de konstnärer som omnämns i citatet från Sverige genom barnaögon.

Albin Amelin var en politisk konstnär som ofta visade arbetarklasskildringar, Han var uttalad kommunist och ville använda måleriet för att förändra samhället. ${ }^{666}$ Bild 3:25 visar Albin Amelins målning Norrbottens järnverk. Den visar fyra arbetare med hjälm i förgrunden. I bakgrunden ser vi järnverkets höga skorstenar torna upp sig, och grå rök mot den gulröda himlen.

Bilden Avesta Järnverk av Arne Kvarnström 13 år, avbildar liksom Amelins bild ett järnverk. Vi se fyra grå fabriksbyggnader i bakgrunden och grå och svarta skorstenar med grå rök (bild 3:26). På avstånd syns en man köra en skottkärra, ytterligare tre män syns i bild. Liksom i Amelins bild syns också räls och/eller vägspår i bildens förgrund. Två skorstenar och tre byggnader är tegelröda eller

\footnotetext{
${ }^{663}$ Gustav A Nordlander i Jungmarker, Gunnar \& Hoppe, Ragnar (red). (1947) sid. 10-13. teckningslärare Gustav A Nordlander.

664 Jungmarker, Gunnar \& Hoppe, Ragnar (red). (1947) sid. 7.

665 Barnkonstbegreppet har diskuterats i föregående kapitel.

${ }^{666}$ Edwards, Folke (2000) Från modernism till postmodernism: svensk konst 1900-2000. Lund: Signum sid. $95 \mathrm{f}$.
} 
Vinnande bilder: Teckningstävlingar för barn 1938-2000

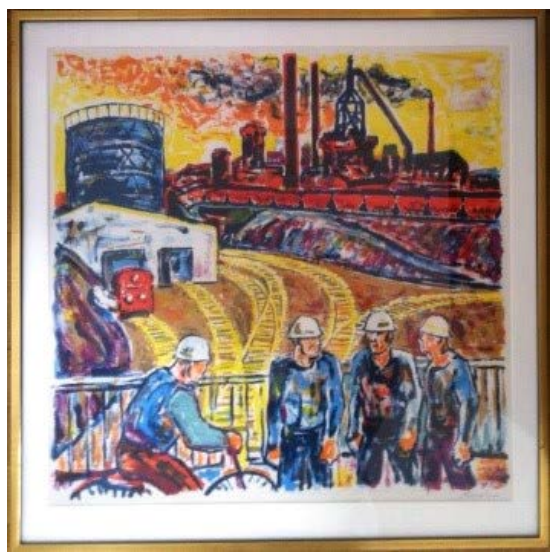

Bild 3:25. Albin Amelin (1902-1975) Norrbottens järnverk.

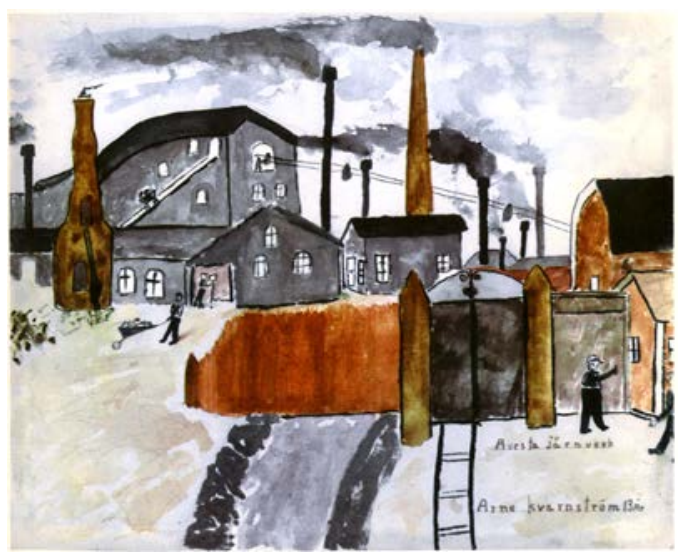

Bild 3:26. Livet i vår hembygd, FIB:s tävling 1939, $\mathrm{i}$ Sverige genom barnaögon.

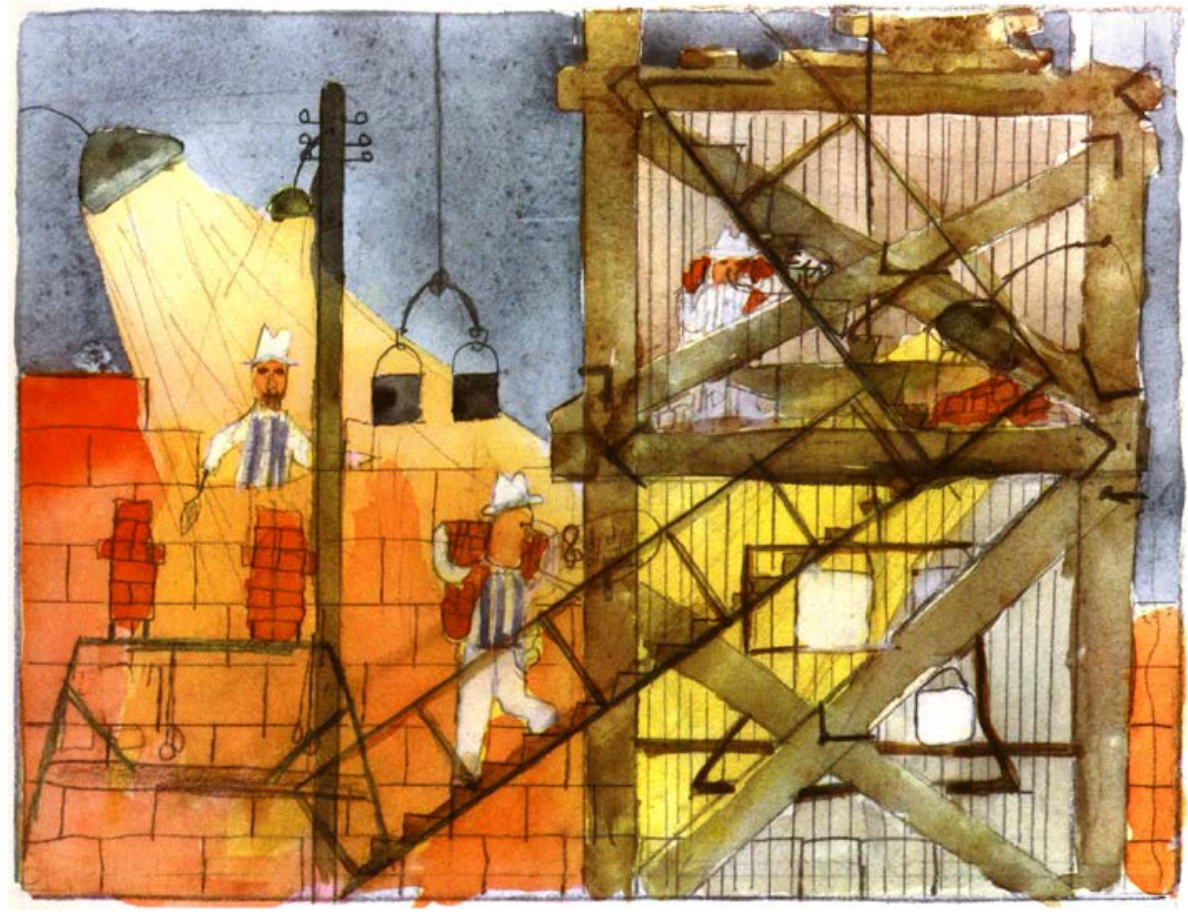

Bild 3:27. Livet i vår hembygd, FIB:s tävling 1939, i Sverige genom barnaögon. 


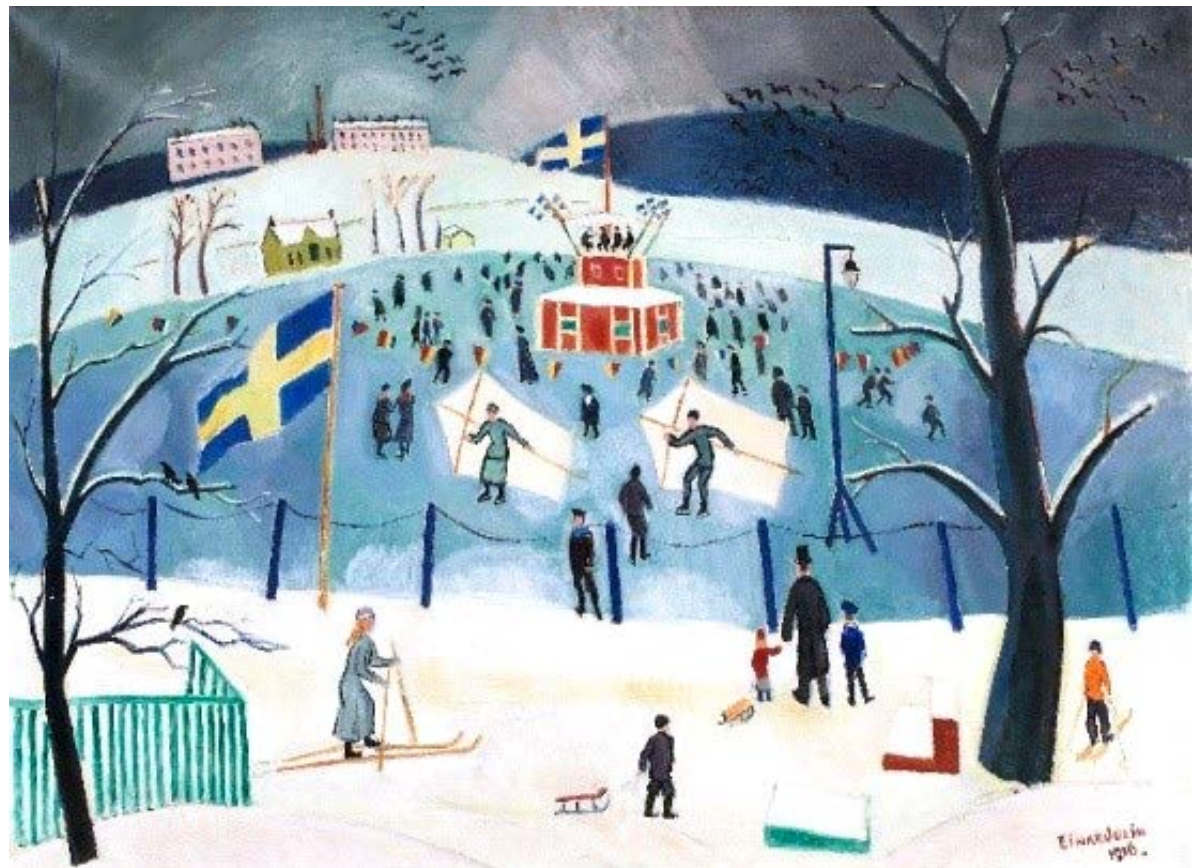

Bild 3:28. Einar Jolin (1890-1976) Skridskobanan vid Stallmästargården 1919

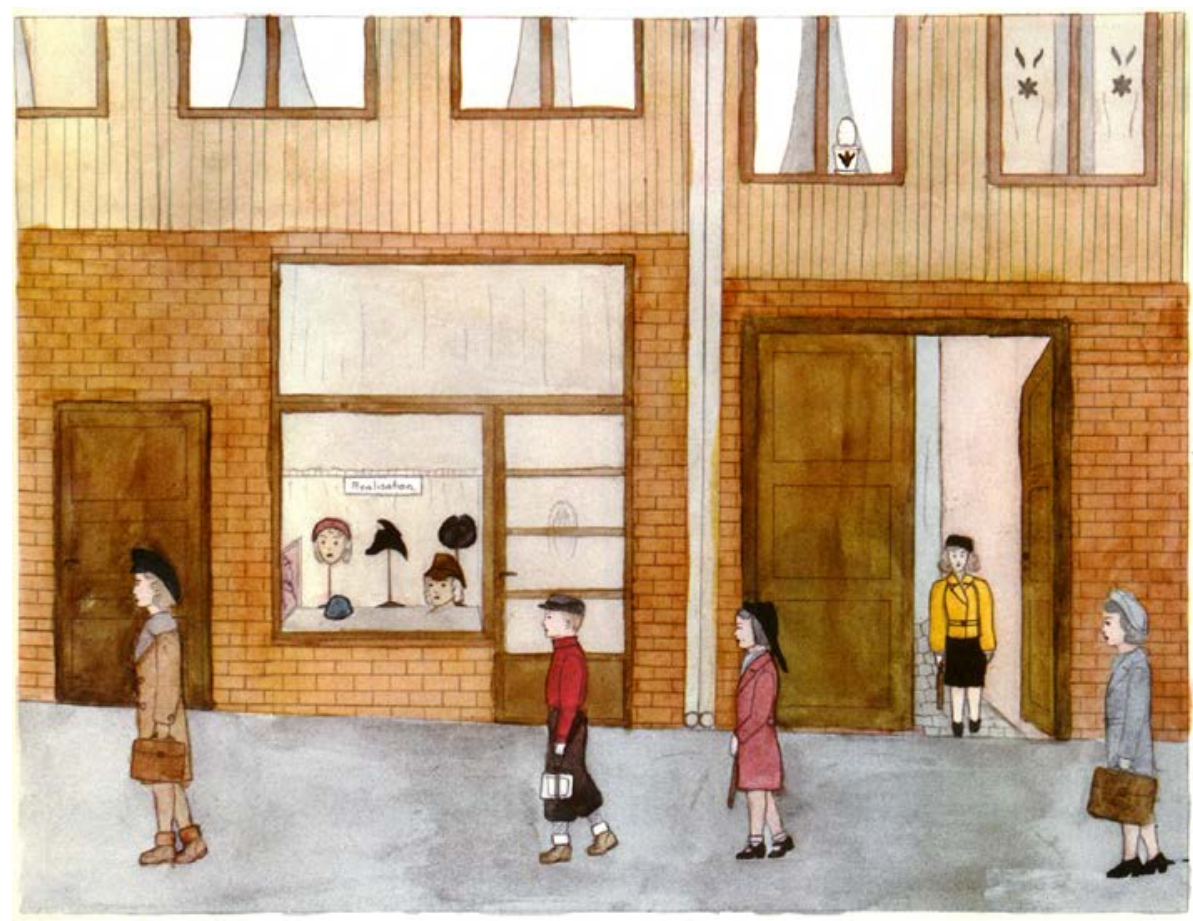

Bild 3:29. Livet i vår hembygd, FIB:s tävling 1939, i Sverige genom barnaögon. 
bruna i färgen. Den grå färgen är dock dominant både i byggnaden och i röken från de stora skorstenarna, och kan vara en del av de "sotiga fabriker" Hoppe refererar till. ${ }^{667}$

Staden och bygget som framtonar som en skildring av Livet i vår hembygd, genom avbildandet av ljussatta tegelstenar mot en mörkblå himmel i bakgrunden, skulle kunna referera till det Hoppe benämner "mörka storstadsgator"(bild 3:27). Färgsättningen i bilden Bygget, i kadmium, umbra och indigoblått påminner om Amelins målning. Mörkret gör att arbetsplatsen behöver lysas upp av en stor lampa som vi ser till vänster i bild. Vi ser tre män i bilden, de har vita kläder och vita hattar och de arbetar på en byggarbetsplats. En elledningsstolpe står också till vänster i bild. Det elektriska ljuset är nödvändigt för arbetet. Mannen till vänster står bakom en mur, framför honom ligger tegelstenar och han håller en murslev $i$ handen. Till höger i bild är en stor byggställning, en man bär tegelstenar uppför en trappa i byggställningen, han visslar troligen, eller sjunger (symboliserat av en G-klav och noter i en pratbubbla), på den övre delen av ställningen står ytterligare en man med tegelstenar.

Bilden konnoterar arbetsglädje; mannen till höger har ett svagt leende och en man sjunger samtidigt som de arbetar idogt. De slutar inte arbeta för att det är mörkt utan fortsätter ändå därför att det är viktigt att få det nya bygget på plats. Bilden kan också referera till spänning och fara, det händer något rafflande och spännande här, i den upplysta ljuskäglan och bland stegar och stativ som man kan falla ner ifrån om man inte är försiktig.

Både Avesta järnverk och Bygget visar upp bilden av "hembygden" som framväxten av det nya industrialiserade välfärdssverige, som bygger för framtiden. Även naivisten Sven Erixsons måleri beskrivits som skildrande av verklighetetens framväxande socialdemokratiska Sverige, i snabb förvandling från bondeland till industrination. ${ }^{668}$

I Einar Jolins Skridskobanan vid Stallmästaregården ser vi en vinterbild med snö och is i Hagaparken i Solna (bild 3:28). Människor, både barn och vuxna som åker skridsko, skidor, pulka och även segelflyger, med svenska flaggor som vajar. Jolin var också en av de konstnärer som tävlingsbilderna ansågs erinra om, enligt Hoppe i citatet tidigare. Det naivistiska måleriet eftersträvade att skildra det enkla folkets verklighet med en nativ uppriktighet, och med målningar som kunde ha motiv som föreställde vardagliga scener, med både barn och vuxna ${ }^{669}$ Jolin räknades liksom Amelin och Sköld till expressionisterna under tidigt 1900tal, även om Jolin hade en mera naivistisk stil och en ljusare färgsättning. ${ }^{670}$

Sverige var enligt Folke Edwards tämligen ensamt om att värdesätta den folkliga naivismen, och ser i det naivistiska en reaktion mot det moderna. "Naivismen innebar allt det som modernismen hade vänt ryggen åt, en återgång till det genuina, det troskyldiga det småskaliga och det i folksjälen ursprungliga, till

\footnotetext{
667 Jungmarker, Gunnar \& Hoppe, Ragnar (red). (1947) sid. 7.

668 Edwards, Folke (2000). sid. $92 \mathrm{f}$.

669 Edwards, Folke (2000). sid. 60.

${ }^{670}$ Jolin, Einar (1990). Einar Jolin: 1890-1976 : [Moderna museet, Stockholm 17 mars-13 maj 1990]. Stockholm: Moderna museet.
} 
bonden, landet, den förindustriella småstaden och koloniträdgården". ${ }^{671} \mathrm{Med}$ denna utgångspunkt kan man tolka att konstscenen värdesatte barnbilden som symbol för det naiva och oskolade, samtidigt som barnen kunde symbolisera den moderna framtiden. Det moderna framgår också som inslag i dessa följande bilder.

I bilden från temat "Livet i vår hembygd" med namnet "Ånäsvägen strax före klockan 12, då barnen börjar skolan" av Elsa 13 år Ånässkolan i Göteborg avbildas fyra skolbarn promenerande på en stadsgata framför ett skyltfönster som visar olika moderna hattmodeller (bild 3:29). I bakgrunden syns förutom skyltfönstret ett lägenhetshus i tegel och trä, i fönstren syns gardiner och blommor. En flicka i gul kavaj och hatt är på väg genom en stor port. Likt samtida konst som Jolin eller Amelin visar bilden en vardaglig scen. Det är ungdomar på väg till skolan, men barnbildens naiva uttryck anknyter i denna bild också till det moderna. Alla fyra flickor och en pojke är porträtterade med moderna kläder, hattar och väskor, ungdomliga eller vuxna snarare än barnsliga, i sin framtoning. ${ }^{672}$

Ytterligare en bild som publicerades i albumet Sverige genom barnaögon från temat Livet i vår hembygd, var bilden "Skörd" (bild 3:30). I bilden ser vi ett gult fält och en strålande sol uppe till höger, i förgrunden en man i blå kläder som kör en grön traktor med en röd skördetröska, i bakgrunden anas två personer som bär halmbalar, runda gröna bollar som refererar till träd och en blå himmel. Bilden är målad Ina Sjöberg 11 år, Hammars folkskola, Kristianstad. Förgrunden utgörs av en traktor och skördetröska vilket i samtiden konnoterar modernt lantbruksarbete. ${ }^{673}$ Det moderna jordbrukets krav på välutbildad arbetskraft och moderna maskiner var del i att formulera idén om den moderna nationen har beskrivits även i Lindgrens studie av skolradion under 1930-talet. ${ }^{674}$ Dessa ideal om ett modernt jordbruk kan bilden skörd ses beskriva. Albumet innehåller slutligen en hembygdbild med titeln "hästhage". Fyra av de fem hembygdsbilderna som valts ut för att tryckas i färg i Sverige genom barnaögon är alltså bilder som skildrar, teknik, stad eller fabrik.

\footnotetext{
671 Edwards, Folke (2000). sid. 57.

${ }^{672}$ Att avbilda barn och unga och vardagliga bildmotiv snarare än historiserande motiv var utmärkande för de moderna konstnärerna, framförallt många kvinnliga konstnärer. Bilden kan också referera till modeteckning.

${ }^{673}$ Också utifrån att det i hela bildmaterialet fanns betydligt fler hästar avbildade i arbete på åkern, se avsnitt Bilder av hembygden.

${ }^{674}$ Lindgren, Anne-Li (1999). sid 118f.
} 


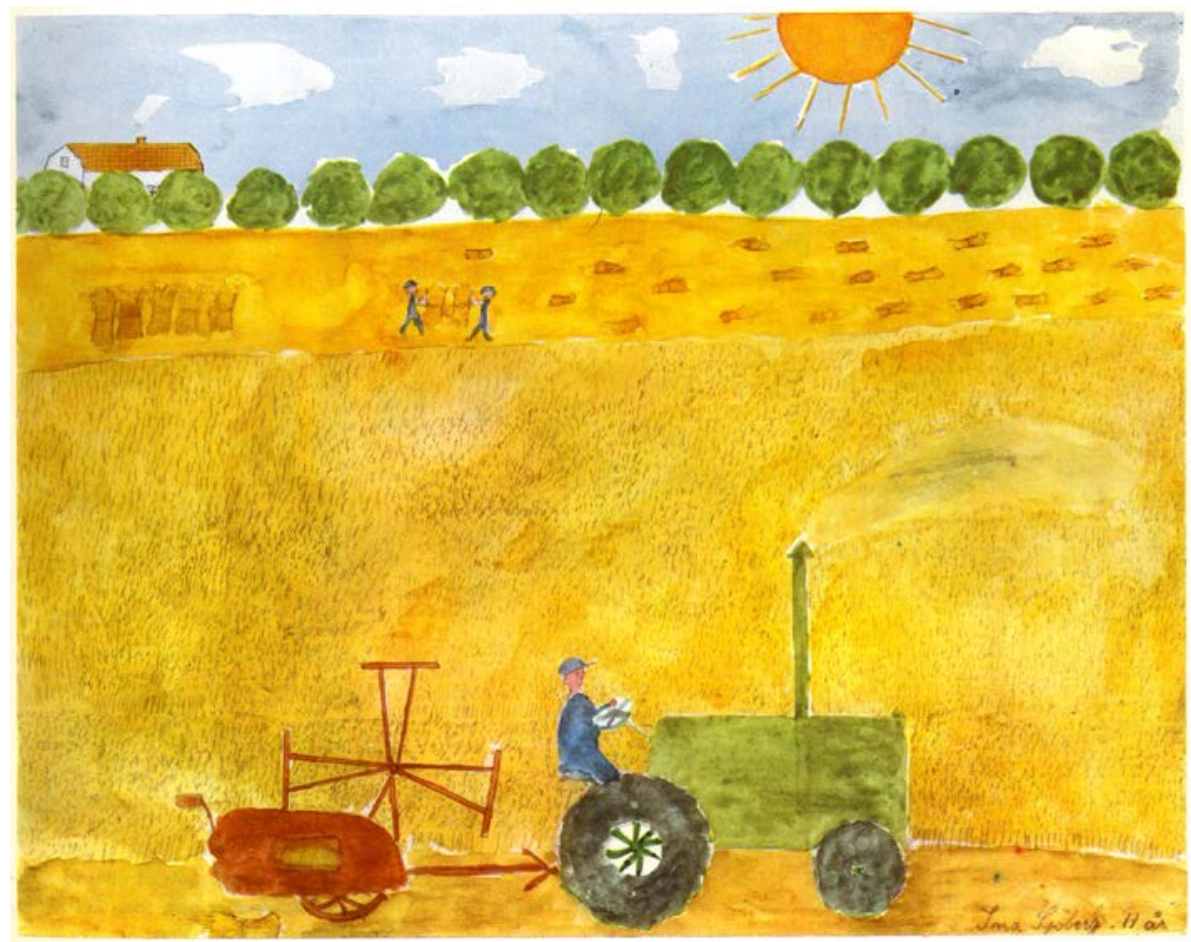

Bild 3:30. Livet i vår hembygd, FIB:s tävling 1939, i Sverige genom barnaögon

Staden, fabriken, arbete och den moderna tekniken är något som visas upp i albumet. Ungdomen på väg till skolan och de manliga arbetarna är de personer som visualiserar framtiden. ${ }^{675}$ Det finns som bland annat Löfgren påpekat, en idé i 30-talets folkhemska identitetsbygge som kunde uttryckas genom att positionera sig som modern och framåtskridande, vilket också syns i dessa bilder. ${ }^{676}$ Barnen, liksom den samtida konsten, skildrade det moderna livet, med moderna maskiner, moderna kläder och där man bygger nytt och arbetar både i fabriker och på landsbygden. Genom detta urval av bilder i jubileumsalbumet visualiserade Nationalmuseum idén om det moderna resursrika Sverige, med naturresurser, människor i arbete, unga människor på väg till skolan och modern teknik. Bildernas värde som konstbilder höjdes genom att de av Nationalmuseum associerades till samtida svenska konstnärer. De kompetenta barnen som målat bilderna kunde både värderas som källa till inspiration för samtida konstnärer, och som presumtiva framtida svenska konstnärer.

${ }^{675}$ Kopplingen mellan hembygden som en utpräglat manlig arbetsplats diskuteras vidare i kapitel 5 , Bilder av flickor och pojkar, kvinnor och män.

${ }^{676}$ Ehn, Billy, Frykman, Jonas \& Löfgren, Orvar (1993). Försvenskningen av Sverige: det nationellas förvandlingar. Stockholm: Natur och kultur sid. 54. 


\section{FIB:s hembygdsbilder - från norr till söder, stad och land}

Av alla de vinnande bilderna i 1939 års tävling ska vi nu titta närmare på vilka FIB:s redaktion tryckte i den egna tidningen. Det publiceras 1939 fjorton svartvita reproduktioner av tävlingsbilderna i tidningen. Även en bild från 1941 års tävling Mitt roligaste skolminne finns med för att visa hur samiska motiv använts både för att gestalta inkludering och exkludering.

Bilderna som trycktes i tidningen visar hur FIB:s bildurval representerar olika delar av Sverige (bild 3:31). Tävlingsbilden högst upp till höger visar män i samedräkt och renar, Bildtexten lyder: "Lappmotivet från andra sidan polcirkeln är utfört av Kurt Hellberg 11 år, folkskolan i Abisko”. Bilden gestaltar tillsammans med de övriga tre bilderna, väldigt olika landskap från norr till söder, skog slätt och fjällandskap, men alla definierade som svenska. Bilden nederst till höger presenteras som en: "typisk skånebild, tecknad av en skåning. Det är Gösta Persson, 12 år, Slottsvångsskolan, Hälsingsborg som ritat alla dessa välfödda nassar och den trygge skånske Odalmannen". FIB publicerar även en bild av "Marknad i Vimmerby" som visar två män i samspråk, där den ena mannen håller i ett grimskaft och en ko. Kanske är det en försäljning som pågår? Mannen med kon sträcker fram armen som för att skaka hand. I bakgrunden syns en kvinna i ett marknadsstånd, en man sitter på en pall framför ståndet. Bilden "Far har tänt milan" av Henry Lövbom analyseras utförligare i kapitel 5.

Liksom i kapitlets tidigare diskussioner kring nation och etnicitet, kunde människor genom bilderna och bildtexterna associeras till specifika platser, specifika klädedräkter eller specifika djur och natur. Samer framställs i denna bildsvit som inkluderade inom det svenska territoriet. ${ }^{677}$

Liksom i Telefonkatalogens hembygdsbild från Östersund (bild 3:7) som publicerades 1977 är män i samedräkt, liksom i andra regioner människor i hembygdsdräkter, inkluderade i hembygdsbilderna.

Bild 3:32 visar en skolutflykt till Skansen. ${ }^{678}$ Vi ser elever som står på rad för att få gå in i en samisk tältkåta. Anna-Vara Nylund skriver i Sameliv på Skansen: om natur och kultur, upplevelser och lärande hur samefamiljer periodvis vistades i kåtorna på Skansen, fram till mitten av 1900-talet, som levande installationer. De skötte renarna och sades för övrigt bo som hemma hos sig i syfte att ge besökarna en verklighetstrogen bild av deras förhållanden. ${ }^{679}$ Längst till höger i bilden syns en man i samiska kläder, med karakteristiska färger i blått och rött och en tydlig tofs på mössan. Bakom honom är tältet, och strax till vänster tältöppningen där en pojke just böjer sig för att gå in. Till vänster står en lång kö med nio barn till, och en pojke som ligger på gräsmattan. I mitten avbildas ett stort kalt lövträd, vilket konnoterar att det är vår eller höst. Vi ser även en

\footnotetext{
677 Jfr exempelvis med boken Svenska barn i bild, Hallberg, Mathilda (2017) sid.236ff.

${ }^{678}$ Skansen kan symbolisera ett koncentrat av svenska ethnoscapes, både genom olika djur, byggnader, och typiska klädedräkter från olika delar av Sverige. Vid skapandet av en nationell identitet behövs en känsla av samhörighet, och där blev idén om gemensamma svenska historiska rötter något som Skansen kunde etablera.

${ }^{679}$ Nylund, Anna-Vera (2008) Sameliv på Skansen: om natur och kultur, upplevelser och lärande / Fataburen. 2008, s. 138-157; 290 Eva Silvén Nordiska Museet Stockholm; Upmark 1916: 151.
} 
Vinnande bilder: Teckningstävlingar för barn 1938-2000

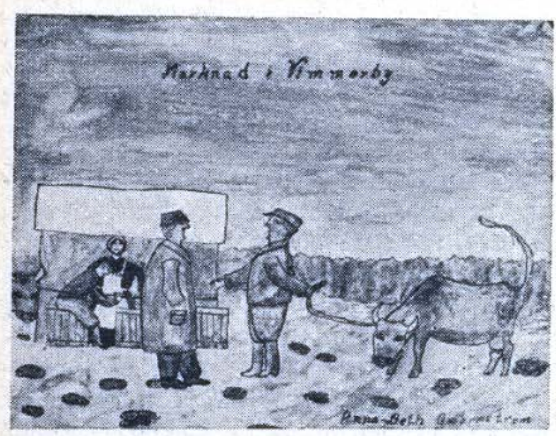

Marknad i Vimmerbys är tecknad av Anna-Beth Qwarnström, 11 år, Vimmerby folkskola.

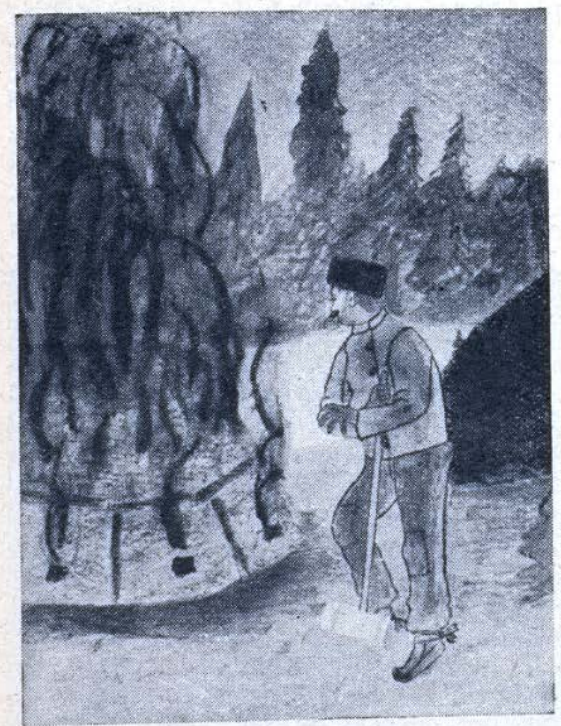

sFar har tänt milan» kallar Henry Lövbom (12 år) denna teckning. Henry går i Segerlunds skola, Norrlảngträsk.
Ti publicerar här ytterligare några av de prisbelönade teckningarna. Tyvärr kan de - som vi tidigare omnämnt - inte återges i färg, vilket givetvis är ett stort minus, men vi hoppas att bilderna ändà ger en uppfattning om teckningarnas höga kvalitet. Vidare har vi klichérat utställningens affisch, som vi för vår del finner mycket trevlig. Eller hur?

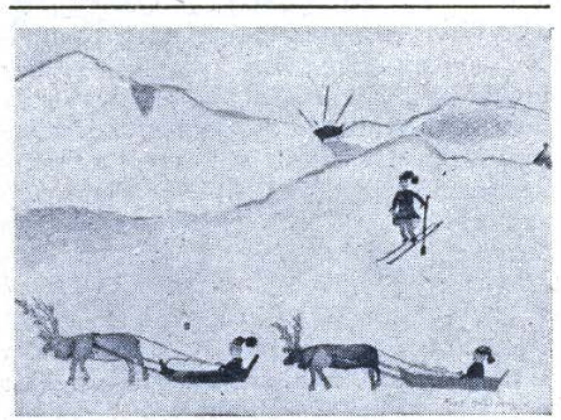

Här en teckning från andra sidan polcirkeln. Lappmotivet är uffört av Kurt Hellberg, 11 år, folkskolan i Abisko.

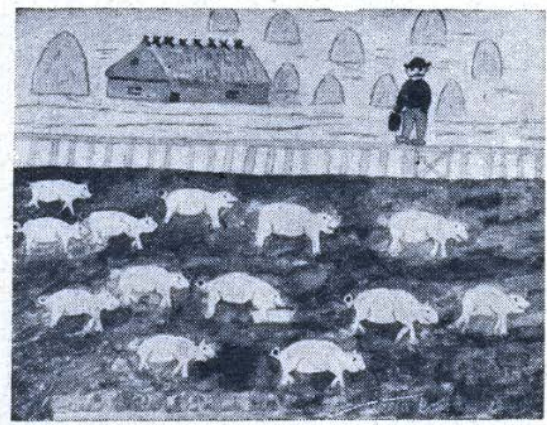

Och sả till slut en typisk skảnebild, tecknnad av en skåning. Det är Gösta Persson, 12 ăr, Slottsvå̉ngsskolan, Hälsingborg, som ritat allá dessa
välfödda nassar och den trygge skảnske odalmannen.

\section{8}

Bild 3:31. Folket i bild 1939 nr 21 sid 28, detalj. 
papperskorg som associerar bilden till en offentlig plats. Genom att barnen står på led och väntar på sin tur, visar bilden även upp en acceptans för skolans restriktioner och disciplin, även under en skolutflykt. Genom att bilden var utvald och utställd på Nationalmuseum bidrog den till att upprätthålla och bevara samhälleliga normer.

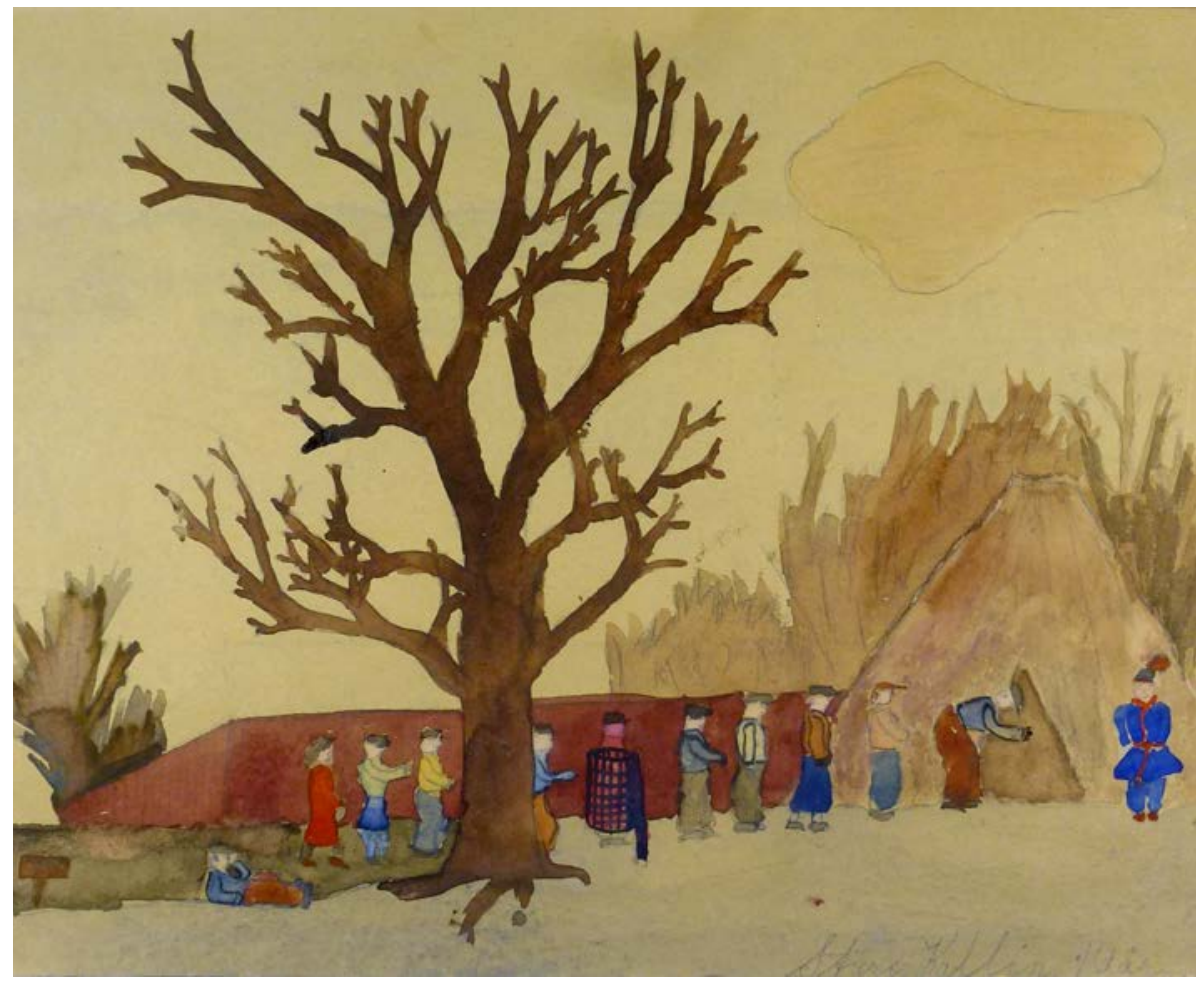

Bild 3:32. Mitt roligaste skolminne, FIB:s tävling 1941.

Barnbilderna har generellt kunnat användas av vuxna för att gömma sig bakom en romantiserande idé om barnets oskyldighet, i detta fall för att normalisera sociala relationer som bygger på politiskt makt. Majoritetssamhällets institutioner, där skolan är en viktig del, förmedlar tydligt i denna bild hur samerna skapas som "de andra".

I följande nummer finns bilder från både landsbygd och stad, upplevelsen av bildsidan som helhet är en betoning av människor i rörelse och arbete. (bild 3:33)

Bilden "En torgdag i Linköping” har bildtexten "Folke Filbyters dekorativa silhuett och folket runtomkring har tecknats av Elvy Lanz, 12år, Folkungskolan (A-skola)." Bilden "Trädklippning vid Odenplan” av Olle Djerf, 14 år, Matteus folkskola (A-skola) " visar en arborist i närbild, i bakgrunden en buss och en staty. Den tredje stadsbilden visar "Bröllop i Mariakyrkan av Ingrid Schulz 12 år St. Jörgens skola, Helsingborg (A-skola); här finns förutom brudparet även 
Vinnande bilder: Teckningstävlingar för barn 1938-2000

Några prisbelönade teckningar ur tävlingen "LIVET I VÅR HEMBYGD"

Vi publicerar hăr nágra av de mánga teckningar, som inkommit i i: FiB ss tock. ningstávling 1939. Tyvärr ầ det omōiligt alt áterge teckningarna $\mathbf{i}$ färg. Samman logt har i ór 150 klasser erhállit 5000 kronor till skolresor i denno táling voi inte mindre ân 650 skolklasser deltogit.
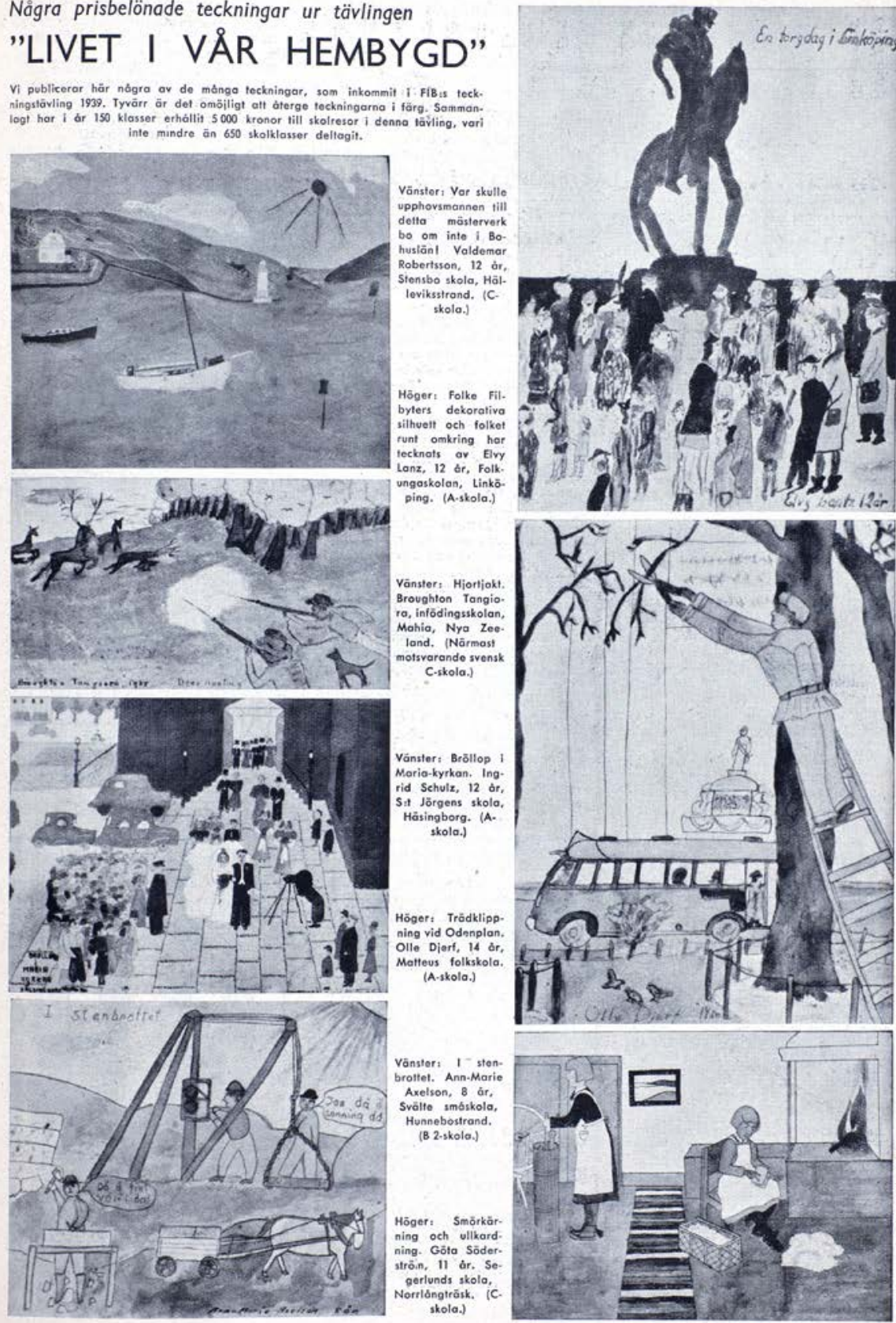

Bild 3:33. Folket i bild 1939 nr23 sid. 29. 
en fotograf, och mycket människor. I två av stadsbilderna rör sig både kvinnor, barn och män. I bilden "I stenbrottet" av Ann-Mari Axelsson, 8 år, Svälte småskola, Hunnebostrand (b2-skola) ser vi män i arbete, med att hugga sten och en häst som drar en vagn. Två av de fyra männen har pratbubblor: "Dä ä fin vär i da" säger mannen till vänster. Ja, dä ä sanning dä" svarar mannen till höger. ${ }^{680}$ Bilden längst ner till höger är en interiörbild med kvinnor/flickor vid en eldstad, med namnet "Smörkärning och ullkardning", tecknad av Göta Söderström 11 år Segerlunds skola, Norrlångersträsk, C-skola.

Av bildtexterna ser vi att det uppfattades som viktigt att lyfta fram vem som målat bilderna, såväl namn, ålder som skola är utskrivet. Att skolformen också var utskriven, om än inom parentes, kan vara för att FIB ville visa att tävlingen haft genomslag inom alla de olika skolformerna, vilket också var ett sätt att vis att man representerade både stad och land, då B- och C-skolorna var vanliga på landsbygden (bild3:33).

Att skildra människor i arbete syns som jag nämnt tidigare även i fotoreportage i FIB, och arbete skildras även i dessa barnteckningar. Det finns endast en mer naturbetonad bild, från Bohuslänskusten, i alla de andra bilderna är människor i förgrunden. Även i bilden av den bohuslänska skärgården syns människor i båtarna, om än väldigt små.

Om förra numret representerades av Skåne i Söder och Abisko i norr, visar dessa bilder både norr och söder men dessutom västkusten och östkusten. Att bilderna visade upp hela landet är tydligt på dessa tidningssidor där både Helsingborg och Abisko är med. Det nationella kunde därigenom skapas genom att visa hur hela Sverige från Norr till Söder och öster till väster var representerat under hela årscykeln. En bild var en vinterbild annars var det vår, höst eller sommarbilder (bild3:33).

Förutom bildrepresentationer från olika delar av Sverige syns även till höger på tidningssidan en bild från nya Zeeland där män med gevär siktar mot hjortar i bakgrunden med bildtexten: "Hjortjakt, Infödingsskolan, Mahia, Nya Zeeland" Att FIB väljer att ha med bilden från Nya Zeeland i tidningen kan tolkas som att de vill visa vilket genomslag tävlingen haft, att den till och med nått ut till missionsskolor på Nya Zeeland. Det kan även vara ett medvetet val att vara internationell, tidningen har flera reportage från olika länder, även om de inhemska fotoreportagen är i majoritet. Bilden visar också i detta sammanhang hur idén om en hembygd ses som universell - Hembygden är något som alla människor anses ha en självklar tillhörighet till. (bild3:33)

I nummer 25 presenteras ytterligare tre bilder; "I timmerskogen" visar en häst som kör ett lass med stockar i skogen, "Vägskälet", visar en bild av en Volvo duett, samt "Hyttkransen", som visar just hyttkransen vid Sandvikens järnverk. Bilen, och kameran i bröllopsbilden från Helsingborg, liksom modern teknik i industrin, påvisar den moderna tekniken, samtidigt som andra bilder visar vardagligare teknik, där hästar fortfarande används i skogen och industrin. ${ }^{681}$

\footnotetext{
${ }^{680}$ FIB nr 231939.

681 FIB nr 251939 sid. 29.
} 
$* * *$

Som jag nämnde i föregående kapitel hade tidningen FIB intentionen att förändra samhället genom att skapa en tidning som inte inriktade sig på att skriva om kungligheter och kändisar, utan istället lyfta fram berättelser från människors vardagsliv. Detta är påtagligt både i tidningens egna fotoreportage från olika arbetsplatser, genom teckningstävlingens tema om hembygd, och genom publiceringen av tävlingsbilderna. Det är människor i hembygden vi ser i bilderna, främst män men även kvinnor och barn i olika aktiviteter.

FIB publicerade ungefär lika många bilder som skildrade stad som landsbygd, även dialekter användes för att skildra olika geografiska platser. Sammantaget av de hembygdsbilder som publiceras i FIB kan vi se att det är bilder som representerar olika geografiska områden i Sverige. Det var väsentligt att införliva regionala olikheter i den nationella bilden. Även de samiska barnen inkluderades till det svenska territoriet, de var svenska men betraktades samtidigt som de andra. I majoriteten av bilderna 1939 avbildas någon form av arbete eller aktivitet. Att arbete och regionala frågor lyfts som del av en nationell diskussion är tydligt även i barnbilderna från Arla/Postens teckningstävling detta vill jag värna om 1976, men i denna tävling var barnens subjektspositioner mera framträdande.

\section{Arla- detta vill jag värna om- barnen som politiska subjekt}

Samma år 1976, som Televerket startade sin tävling för katalogomslagen hade även Arla/Posten en teckningstävling där de fick in ungefär 15. 000 bidrag. Flertalet av Arlas inskickade tävlingsbilder som finns i SBBA:s arkiv är gjorda hemmiljö, några är från fritidshem eller förskola, men tävlingen var inte en skoluppgift, så som Televerkets eller FIB:s tävlingar var. I och med detta förväntades det inte heller att de skulle ta en viss tid, som exempelvis en lektion att göra. Det fanns heller inte några uttalade önskemål kring vilket material som skulle användas, eller att bilderna skulle vara i samma storlek, som i FIB:s och Televerkets tävling. Bilduttrycken är snarast snabba skisser, oftast med text, och att välja teckningar som är tecknade på ett "barnsligt" sätt kan uppfattas som att Arla vill visa att man lyssnar även till (små) barns röster. Bilderna skulle alltså inte $\mathrm{i}$ första hand vara skolade, i bemärkelsen visa på något barnen lärt i skolan, utan istället visa barns genuina röster. Som jag nämnt tidigare var 1970-talet en tid då barnrättsfrågor diskuterades, och barns deltagande i det offentliga samtalet uppmärksammades. Boken "Varför får inte barn bestämma" ska betraktas mot denna bakgrund. Arla/Posten talade inte, som FIB och Televerket, om barnbilden som konst, barns bildkompetenser beskrevs istället som att de genom bilder kommunicerar budskap.

Denna tävling hade heller ingen uttalad jury och inga priser, men bilderna publicerades på mjölkpaketen och 1977 publicerades boken "Varför får inte barn bestämma" med 134 utvalda bilder. Jag ska nu analysera utvalda exempelbilder som har referenser till nations- och hembygdstemat. 
I tävlingen "Detta vill jag värna om" Var uppmaningen från mejerierna och posten att "tala om vad du tycker, saker som du vill göra något åt..." vilket kan vara viktigt att komma ihåg när man ser bilderna, liksom att uppmaningarna i bilderna kan riktas till både barn och vuxna. Att uppmaningen riktades till vuxna är tydligt i denna bild, med texten "SPRID ARBETS-PLATSERNA" textat i kartbild av Sverige centralt i bild (bild 3:34). I förgrunden till vänster svenska flaggan avbildad, till höger om kartbilden återges fyra hus med skorstenar som det ryker ur och husen är sammankopplade genom vägar. Även två lövträd står mellan husen. Sverigekartan är här helt placerad utan koppling till några andra omgivande länder, men betraktarna förstår genom flaggan och att bilden är så vanlig från skolböcker eller exempelvis Tv:s väderprogram, att det är en Sverigebild. Röken ur skorstenarna refererar till att någon bor i husen. Husen är placerade längs med hela landet, och genom texten kan det antingen tolkas som att husen är hem för de som arbetar på olika platser, eller att husen är arbetsplatserna, som ska spridas över landet. Bilden som helhet konnoterar barn som politiska subjekt där deras "röst" uppmanar politiker och näringsliv att skapa arbetstillfällen i alla delar av landet. Under 1940 till 70-talet urbaniserades Sverige alltmer, och många arbetsplatser på landsbygden försvann. Denna bild kan skapa en förhoppning om en politik, som värnar om att det ska finnas kvar arbetsplatser i hela landet. Mejerierna och Arla som valt ut vinnarbilderna kunde också ha intresse av detta, för att skapa bra möjligheter för mjölkbönderna. Genom att välja ut vissa bilder att publiceras i boken, kunde Arla använda barns röster för att framföra sina egna åsikter. ${ }^{682}$ Tävlingsbilderna i Arlas och Postens bok uttryckte även uppmaningar gentemot andra barn vilket jag återkommer till i nästa kapitel. Uppmaningen "sprid arbetsplatserna" hade däremot ett budskap som tydligt riktas mot politiker. År 1976 förväntades bar både ha politiska ståndpunkter och blev uppskattade när de uttryckte sina politiska åsikter.

Tävlingsbilderna 1939 gestaltade ofta olika typer av arbete på olika platser i hembygden. Både 1939 och 1976 framställs arbetet i hembygden eller nationen som essentiella, genom deltagandet i arbetet på "fädrens gård" 1939 eller genom att arbetsplatser finns i hela landet 1976. Om deltagandet i arbetet 1939 framställdes som självklart för alla innebar uppmaningen att "sprida arbetsplatserna" att arbetsplatser fanns för centralt i landet och borde spridas regionalt. Det kunde handla om föräldrars möjlighet till försörjning, eller vara ett argument för ungas möjlighet att bo kvar i olika delar av Sverige. I Arlas tävling uttrycker barnen problem som bör rätts till och politiska förhoppningar om framtiden, där bilderna 1939 snarare är positiva redovisningar av samtiden. I Arla/Postens bok visar flera bilder hur samhället och naturen behöver skyddas mot moderniteten, vilket jag ska visa några exempel på här. ${ }^{633}$ Detta beror naturligtvis på temat "detta vill jag värna om" men det visar även en förskjutning där "hembygden" betraktades som hotad 1976 jämfört med 1939. Även uppmaningarna "Låt små röda stugor vara" av Patrik Alm i Spånga och "Var rädd om milstolparna från förr i tiden"

${ }^{682}$ Söderlind, Ingrid \& Engwall, Kristina (2005).

683 Se även tabell sid. 130. 


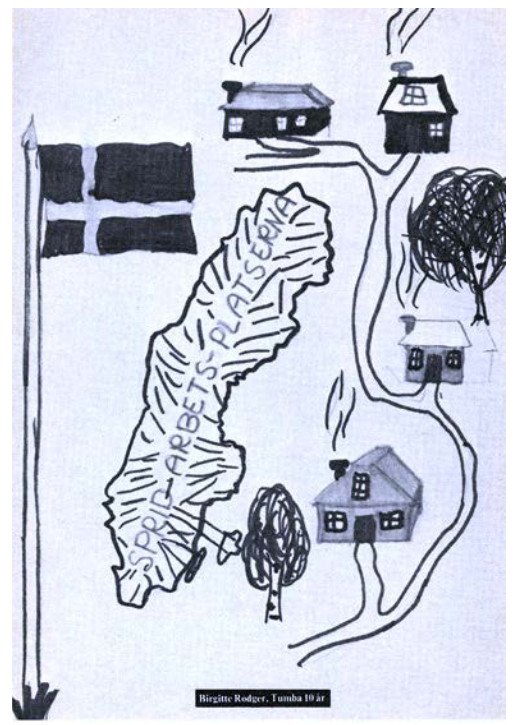

Bild 3:34 Birgitte Rodger i Varför fär inte barn bestämma, (1977).

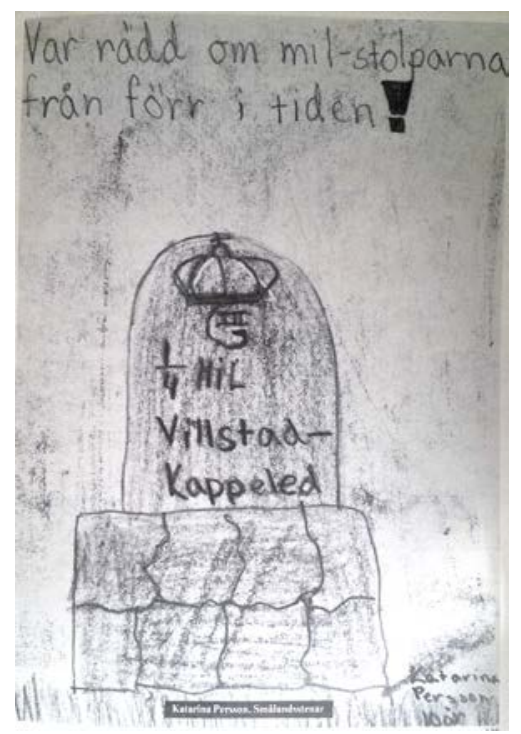

Bild 3:36. Katarina Persson i Varför fär inte barn bestämma (1977).

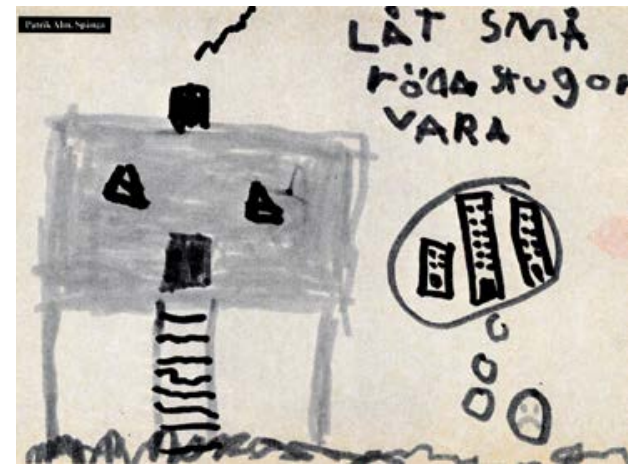

Bild 3:35. Patrik Alm i Varför fär inte barn bestämma (1977).

\section{ASFALTEN VÄXER}

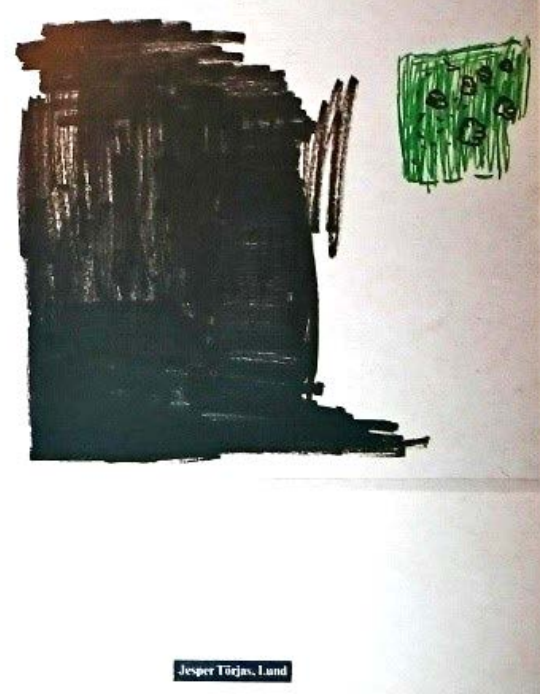

Bild 3:37. Jesper Törjas i Varför fär inte barn bestämma (1977). 
av Katarina Persson från Smålandsstenar, visar att Arla väljer att publicera och uppmärksamma bilder som gestaltar bevarandet av "förr i tiden"(3:35, 3:36). I bilden av den röda stugan (tryckt i svartvitt) har den röda stugan ett närmast mänskligt ansikte, där de trekantsformade fönstren/ögonen ser sorgsna ut, dörren kan liknas vid en ledsen bebismun som skriker (bild 3:35). Bredvid är en ledsen figur, vi ser genom tankebubblan att den tänker på tre höghus.

Bildens konnoterar att den lilla röda stugan riskerar att rivas därför att de tre höghusen ska byggas där istället, där uppmaningen är att låta de små husen finnas kvar. Tankebubblan med höghusen kan symbolisera monster med munnar som kommer för att sluka den lilla röda stugan, den "moderna" utvecklingen borde stoppas och röda stugor räddas. På bilden "Var rädd om milstolparna från förr i tiden" ser vi texten Villstad - Kappeled 1/4 MIL, samt ett Kungligt emblem; Gustav III och en kungakrona ${ }^{64}$ (bild 3:36). Att vara rädd om "förr i tiden" kan förstås som att historiska minnesmärken i hembygden är viktiga för Arla likväl som för barn. Milstolpar användes historiskt för att mäta hur långt man färdats, och därmed hur stor vägavgift som skulle betalas. ${ }^{65}$

I bilden benämnd "Asfalten Växer" av Jesper Törjas 10 år ser vi ett stort svart rektangulärt fält målat med tuschpenna till vänster i bild (bild 3:37). Det svarta är lite ojämnt utspritt i kanterna, det förfaller "växa" åt höger, både vid botten och genom mera spridda streck som närmar sig ett litet grönt fält till höger. Till höger ser vi ett mindre grönt fält också målat med tuschpenna, det är mer kvadratiskt än rektangulärt, men ojämnt i nederkanten. I det gröna fältet syns sex röda blomformer i lite olika storlek. Bilden och texten tillsammans konnoterar att den svarta asfalten växer och hotar att utplåna den lilla gröna plätten med blommor. Moderniteten, staden bilarna och asfalten riskerar att utplåna naturen och blommorna. Till skillnad från FIB:s tävling 1939 där maskiner, teknik och modernitet beskrevs som positivt i bilder av hembygden, var hembygden nu hotad av moderniteten.

Både bilder och text i Arlas bok "Varför får inte barn bestämma" 1977 kunde sägas förebåda den kommande läroplanen 1980, som lyfter fram hur barn genom bildämnet skulle bli: "medvetna om bilden som språk och vänja sig vid att använda bildspråket som ett viktigt kommunikationsmedel vid sidan av att tala, läs och skriva." ${ }^{886}$ Skillnaderna mellan tävlingarna och bildernas uttryck kan också delvis förklaras av att Arlas tävling inte gjordes i skolan, och därför inte behövde anpassas till rådande läroplaner. Sammanfattningsvis visar Arlas tävling hur barn förväntades agera som politiska subjekt, på ett helt annat sätt än i FIB:s

\footnotetext{
684 Villstad och Kappeled ligger i närheten av Smålandstenar. I kapitel 6 återkommer jag till hur visualiserandet av "kungen" deltar i formerandet av olika diskurser, däribland den nationella.

685 2018-02-27 http://www.lansstyrelsen.se/skane/Sv/samhallsplanering-och-kulturmiljo/landskapsvard/kulturmiljoprogram/historia-utveckling/kom-landskap/Pages/Milstolpar.aspx (201803-10).

686 LGR 80 sid. 69.
} 
och Televerkets och tävlingar. Att Arla och Televerkets tävlingar var samtida visar hur skilda barndomsdiskurser kunde verka sida vid sida.

\section{Sammanfattande diskussion}

Utgångspunkten för detta kapitel har varit att undersöka hur Sverige visualiserats och kommenterats genom teckningstävlingarna. Hur etableras olika Sverigediskurser genom tävlingar och tävlingsbilder, och hur visar de förändring eller kontinuitet över tid?

Något som är tydligt i materialet är hur bilden av det Svenska byggs upp som en helhet av de olika hembygdernas delar både på 1940-talet och 1970-talet. Hembygdskunskapsämnet som infördes i 1919 års skolplan, byggde på pedagogiska ideal kring en progressiv och demokratiserande arbetspedagogik. Samtidigt skapade arbetsböcker i hembygdskunskap och geografi, liksom tävlingsbilderna, en visuell retorik som definierade möjliga och önskvärda hembygds- och etnicitetsideal.

Liksom folkskolans arbetsböcker synliggör flera vinnande bilder "ethnoscapes" där historiska minnesmärken och människor som syns i landskapet ges ett specifikt symbolvärde. Genom bilder av olika delar av Sverige upprätthölls idén om ett gemensamt historiskt territorium, med delade myter och historiska berättelser, liksom idén om en delad folkkultur. ${ }^{67}$ Både FIB:s bilder 1939 liksom Televerkets omslagsbilder under sent 1970-tal kan överföra ett nationalromantiskt ideal av landskapsmotiv till nya generationer, samtidigt som de inkluderades i en modern expressionistisk konst genom att de var barnbilder.

Barnbilden betraktades under 1940-talet som förbunden med en ursprunglig folkkonst och barnet och barnbilden kunde på så sätt både sägas både stå i förbindelse med det förflutna och med framtiden. Barns skapande kunde alltså både jämföras med äldre folkkonst, men även ses som förebådande det moderna expressiva måleriet. Att de två bildhäftena Sverige genom konstnärsögon (1911) och Sverige genom barnaögon (1947) har liknande titlar är troligen ingen tillfällighet. Om det svenska skulle lyftas fram genom de etablerade konstnärerna 1911 för att skapa en gemensam nationskänsla från eliten ner till folket, så kunde barnbilderna användas för att visa att barnen, framtidsfolket, nu är nationens hopp. FIB:s tävling är också den som visar hur den nationella diskursen kunde visualiseras i flera skiftande former. Analysen har visat hur Nationalmuseum och FIB som arrangerade tävlingen tillsammans kunde använda bilderna på olika sätt och i olika syften. Nationalmuseum refererade tävlingsbilderna till modernitet och det expressionistiska måleriet. De samtida konstnärerna ville inspireras av barn och barnens bildspråk, och både barnen och konstnärerna kunde berätta om det nya moderna Sverige, som innefattade inte bara landsbygden utan även stad och industri, och ett modernt maskinellt jordbruk. FIB:s hembygdsbilder åskådliggör hur hembygden hör ihop med arbetande människor. Barnkonsten kunde representera idén om barnet som del av den framtida moderna nationen.

${ }^{687}$ Smith, Anthony D. (1999). .sid. 11. 
Hembygden 1939 inkluderar arbete på landsbygden, men även staden, med fabriker, industrier och maskiner.

Både Televerket 1977/78 och FIB 1939 synliggör hur de geografiskt olika hembygdernas bilder är delar som framställs som olika, men ändå kan vara delaktiga i att skapa en gemensam större nation. Detta syntes genom de bilder FIB publicerade i tidningen. Där finns bilder från Skåne i söder till Abisko i norr, liksom både öst och västkust. FIB lyfte vikten av att knyta ihop regionala bilder till en nationell gemenskap. Hembygdsbilden skapade kulturella delskillnader mellan olika svenska platser, men samtidigt inkluderades alla delarna i det gemensamt svenska. Att delta i att teckna hembygden i teckningstävlingar kan ses som en del av ett nationellt identitetsskapande.

Hembygdens förändrade innebörd över tid gestaltas tydligt i tävlingsbilderna. Hembygden i barnens bilder har övergått från att visa samtida bilder under 1940-talet, till att handla om historiskt bevarande och traderande i bilderna från 1970-talet. I Televerkets vinnarbilder 1977-78 har hembygden fått ett nostalgiskt skimmer. Idealbilden av hembygden visar landskapsbilder och historiska hembygdsbilder, främst skildrade genom naturbilder.

Sverige har i alla tre tävlingarna gestaltats genom flaggan som nationell symbol. Främst i FIB:s tävling, där flaggan syns både vid lokala taklagsfester, vid sportevenemang eller vid Nationaldagsfirandet. Kungen symboliserar både gemensam historisk erfarenhet och samtida hyllningar i FIB:s tävlingar Svenskarna $i$ allvarstider- beredskap då och nu, och Svenskt helgfirande. Däremot är kungar helt frånvarande i FIB:s hembygdsbilder. Mest frekvent förkommer kungen i vinnande hembygdsbilder från Televerkets tävlingar 1977/78. Televerkets jury poängterade vikten av att betona kungarnas betydelse i historieskrivningen av det förflutna.

FIB lyfter även fram bilder av demonstrationer på 1:a maj som en svensk högtid. Både bilder av 1a maj, och av hur människor med flaggor hyllar kungen på svenska flaggans dag, blir möjliga som svenska högtidsdiskurser i FIB:s tävling 1944. FIB och Nationalmuseum är delaktiga i att ställa ut och publicera dessa barnbilder som kunde skapa en känsla av nationell gemenskap både mellan stad och landsbygd och över klassgränserna.

Överlag skildrar de vinnande tävlingsbilder som är producerade i skolan (FIB och Televerket) hembygden i idylliska former, både i stads- och landsbygdsbilder, eller i historiska bilder.

I Arlas tävling däremot förändras hembygdsdiskursen från att vara en idyllisk bild av människor eller landskap, till att betraktas som något som är hotat och som behöver värnas och skyddas. Temat för tävlingen "Detta vill jag värna om" ger andra bilder och röster. Vid en jämförelse över tid mellan FIB:s och Arlas tävling på 1970-talets är det tydligt att de sätt som barn förväntades tala genom sina bilder om hembygden förändrats. FIB:s tävlingsbilder avbildar en ideal hembygd, där Arlas tävling avbildar hur gamla hus och skogsområden är hotade av höghus och asfalt. Arla använder, delvis i likhet med Televerket, bilderna för att lyfta historiska värden, men använder en "barnrättighetsdiskurs" där bild och text gemensamt anses kunna ge barn en röst, även om det är en av Arla utvald röst. 
I Arlas och postens tävling 1976 "detta vill jag värna om" vill barn värna om det som då benämns "gamla" traditioner, och symboliseras genom bilder av flaggan, midsommarstången, påskris och julgran. Flaggan som symbol för Sverigekartan i Arlas tävling kan referera till FIB:s bilder av människor i arbete i olika delar av landet, genom uppmaningen "Sprid arbetsplatserna". Arbete definieras som en nationell angelägenhet 1976, och nödvändigt och viktigt för arrangörer och barn att visa upp både 1939 och 1976.

I nästa kapitel kommer jag att diskutera hur barn situerats på specifika platser och vad som betraktats vara barns platser, och förändring över tid i skildrandet av barndomens relationer. 


\section{Kapitel 4. BARNS PLATS}

I det förra kapitlet diskuterade jag hur tävlingsbilderna gestaltade bilden av Sverige. Barnen kunde associeras till det svenska landskapet genom tecken som knöts till Sverige och svenskhet (bild 4:1). Nationalmuseums intendent Ragnar Hoppe beskrev 1947 barnens bilder med detta anslag, där texten positionerar barnens plats och hemhörighet, i albumet Sverige genom barnaögon:

"Livet i vår skola" stimulerade på följande sätt till många roliga och rikt facetterade bilder. Vi hälsa på barnen under lektionerna, vi får vara med om sång, gymnastik och slöjd i gamla hemtrevliga lokaler ute på landet och vi se också här och var prov på mera moderna, funkisbetonade sådana. Allra friskast skildras kanske lekarna under rasterna på skolgården, där fonden ofta blir ett äktsvenskt landskap, slående i sin sanning och omedelbarhet. ${ }^{688}$

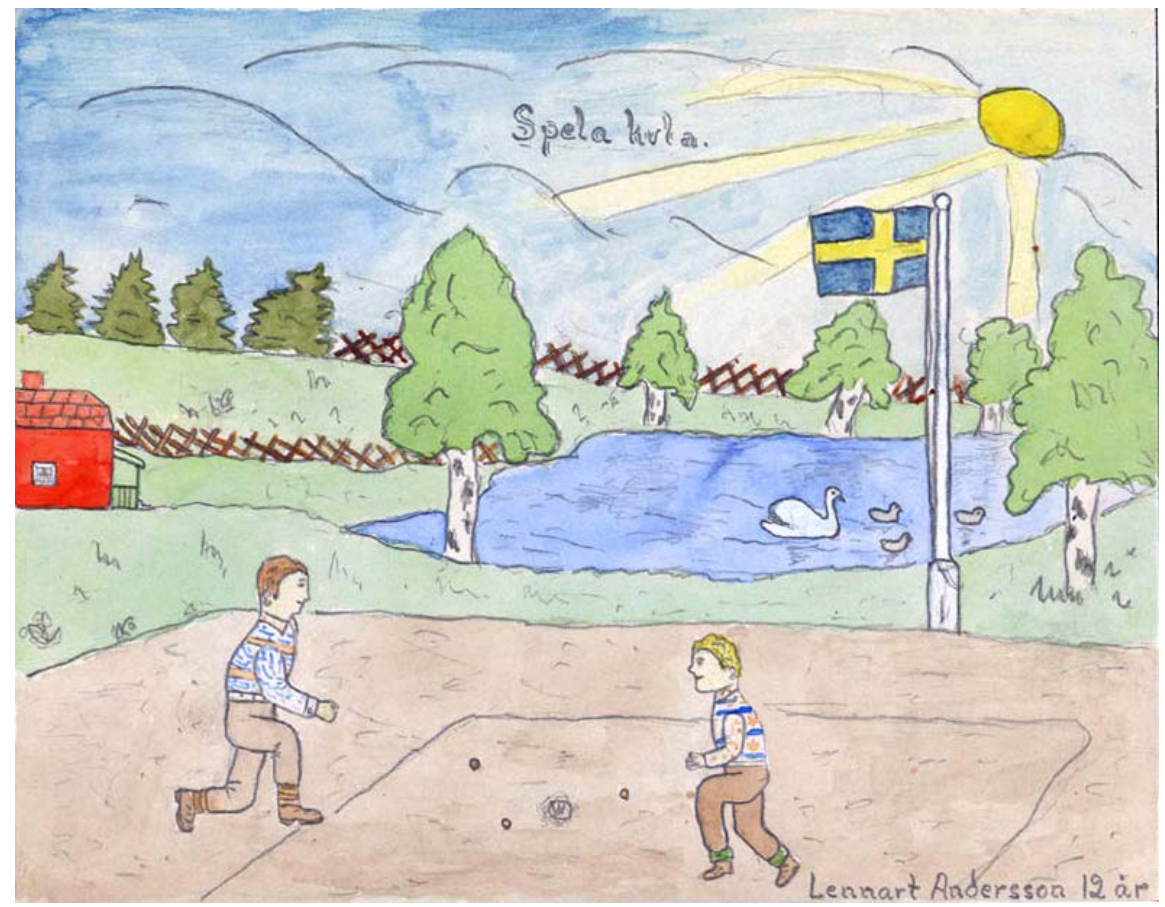

Bild 4:1. Våra lekar, FIB:s tävling 1945.

${ }^{688}$ Jungmarker, Gunnar \& Hoppe, Ragnar (red). (1947). sid. 6. 
Barnen situerades i en svensk kontext genom vad intendenten beskrev som ett "äktsvenskt landskap, slående i sin sanning och omedelbarhet". Det visar också tydligt att skolan och skolgården, uppfattades som etablerade platser för barn. Skolbyggnaden beskrevs som en viktig plats, både den "moderna funkisbetonade" skolan, och den hemtrevliga lantliga, gavs positiva konnotationer. Det gemensamma och "friskaste" enligt Hoppe, för alla barnen var lekarna på skolgården. Det som definierade det svenska barnet, blev dels att de gick i skolan, och dels att de lekte. Tävlingsbilderna beskrevs som "roliga och rikt facetterade" och de skolämnen som specifikt nämns är sång, gymnastik och slöjd. Att dessa ämnen nämns särskilt visar på att de värdesattes, både av barnen som tecknade, och av intendent Hoppe som kommenterade teckningarna. ${ }^{69}$ Genom tävlingsuppdraget Våra lekar 1945 produceras en idealbild av barn som leker. Solen skiner över ett grönskande landskap med två pojkar i förgrunden som spelar kula, de har båda mönstrade slipovers och bruna byxor och skor(se bild 4:1). De är avbildade i profil, lätt knäböjande kanske för att kasta iväg en kula, det ligger tre kulor och en hög av kulor mellan pojkarna. De är på något som föreställer en grusplan, kanske en fotbollsplan, eller del av en skolgård? Pojkarna är omgärdade av det "äktsvenska landskapet" med både björkar, granar och en röd stuga, och en sjö med svanar, en flaggstång med en svensk flagga i toppen. ${ }^{690}$ Naturen skapar både en känsla av ett gemensamt nationsbygge, och är även nära kopplad till idéer om barns hälsa och välbefinnande. ${ }^{691}$

Barns platser har alltså definierats på skiftande sätt. Det här kapitlet handlar om hur barn både tar och ges plats i olika relationer som bilderna beskriver, $\mathrm{i}$ förhållande till andra barn och till vuxna, men det handlar även om var barn är placerade i det fysiska rummet eller i geografin. I någon mening rör det hur barn gestaltar innebörden av att veta sin plats och hur barn kunnat ta plats.

Barndomshistoriker och barndomssociologer har visat hur det inte finns någon universell barndom, att barndomen alltid levs i en speciell tid och på en speciell plats. ${ }^{692}$ Platser som beskrivits som lämpliga eller olämpliga för barn kan således till stor del definiera samhälleliga och kulturella ideal kring den goda barndomen. Föreställningar om var barn kan och bör vara, och vilka platser som ansetts passande för barn har också aktualiserats i tidigare forskning, liksom relationen mellan barn och föräldrar. ${ }^{693}$

${ }^{689}$ En analys av en bild från slöjdämnet återkommer i kapitel 5. Jämfört med tidigare forskning som visar att de estetiska ämnena och bildämnet varit marginaliserade visar citatet hur skilda diskurser om skolan kunnat verka sida vid sida. Jfr Wikberg, Stina (2104) sid. 56.f.

${ }^{690}$ Ehn, Billy, Frykman, Jonas \& Löfgren, Orvar (1993) Försvenskningen av Sverige: det nationellas förvandlingar. Stockholm: Natur och kultur skriver på sid. 95 om hur två träd- furan och björken symboliserar det sant svenska "den skira björkdungen intill den röda stugan eller på en grönskande vitsippsäng".

${ }^{691}$ Halldén, Gunilla (red). (2009) Naturen som symbol för den goda barndomen. Stockholm: Carlsson.

${ }^{692}$ Heywood, Colin (2005) Barndomshistoria. Lund: Studentlitteratur.

${ }^{693}$ Sandin, Bengt \& Halldén, Gunilla (red). (2003) Barnets bästa: en antologi om barndomens innebörder och välfärdens organisering. Eslöv: B. Östlings bokförl. Symposion; Halldén, Gunilla (2007). Barns plats och platser för barn i Den moderna barndomen och barns vardagsliv. s. 81-96. 
Barns skolgång har kunnat tillgodose skilda samhälleliga intressen. Skolan som en plats för barn kunde kombinera förväntningar att alla barn skulle få bildning och kunskap med en förhoppning om att hålla barnen borta från gatorna. Genom att reglera barns plats till skolan och hemmet, kunde samhällsproblem och kriminalitet motverkas. Tidigare forskning har visat hur skolan inte bara är en plats för barn, utan också görs av barn, genom olika praktiker. ${ }^{694} \mathrm{De}$ barn som deltagit i tävlingarna har kunnat visa sitt perspektiv, utifrån de ramar och riktlinjer som gällde för tävlingen, och tävlingarna uppvärderade både barns bildberättelser och teckningsämnet.

Den förändrade synen på barn över tid har under slutet av 1900-talet i Sverige inneburit en betoning av barns individuella och autonoma rättigheter, där staten kunde ge barn skydd mot föräldrar eller institutioner. Barns behov definierades inte längre enbart som specifika, istället ansågs barn ha liknande behov och rättigheter som vuxna. ${ }^{695}$ Det finns följaktligen anledning att vara uppmärksam på om denna förändring ingår i de berättelser som barns skapar med sina bilder.

Hällström har i sin studie av insändare till Kamratposten, visat hur barn uttrycker tillhörigheter till olika platser och relationer som hembygd, familj, kamratgrupper, pojkar eller flickor, som både berikande och inskränkande. ${ }^{696}$

De specifika platser, händelser och relationer som barn gestaltat i de bilder jag har granskat bestäms naturligtvis delvis av vilka teman som tävlingsarrangörerna formulerat och vilka bilder som valts att vinna, men barn har också haft tillfälle att formulera sig i bild tack vare tävlingarna. Tävlingsbilderna synliggör barn som kulturella aktörer, som kan förstås i relation till olika diskurser. Barnens subjektspositioner blir då centrala i analyserna. Frågeställningarna för detta kapitel blir således: På vilka platser och i vilka relationer har barn beskrivits i bild? Hur har barn i bilderna visualiserat vilka positioner som varit tillgängliga för barn att inneha, och vad syns för förändring över tid?

Liksom i föregående kapitel är det FIB:s tävlingsteman som varit utgångspunkt för jämförelser med senare tävlingar, och då främst bilder från 1938 Livet i vår skola, 1941 Mitt roligaste skolminne och 1940 Min fritid.

Från Arlas och Postens bok Varför får inte barn bestämma från 1977 analyserar jag de bilder som refererar till skolan och till relationer mellan barn och mellan barn och vuxna. Dessutom aktualiserar boken förändring i hur barns känslor framställs i bild, och hur barns platser i bilderna 1977 omfattar även andra länder och hela jordklotet. I analysen ingår även omslagsbilden till Telias informationsutskick till skolorna för sin tävling 1993 Den gränslösa världen.

Den semiotiska metoden som jag använder möjliggör en tolkning av hur olika tecken i bilderna definierar barns platser och relationer. Detta innebär en granskning av hur bilderna signalerar normativa föreställningar om den goda barndomens innebörd, och på vilka sätt möjliga subjektspositioneringar för barn förändrats över tid. Även skriven text ur de album som publicerats i anslutning till tävlingarna analyseras.

\footnotetext{
${ }^{694}$ Se tex Halldén, Gunilla (red). (2007).

695 Sandin, Bengt (2012). sid. $128 \mathrm{ff}$.

${ }^{696}$ Hällström, Catharina (2011).sid.55f. Studien sträcker sig mellan 1977-2007.
} 
Det första avsnittet behandlar hur skolan som plats gestaltats. Inledningsvis granskas bildernas berättelse om skolan som institution, som både innebär bilder av stress och instängdhet, men även upplevelser av kunskap och lärande. Därefter analyseras bilder som visar på förändrade diskurser och maktrelationer mellan barn och vuxna. Jag diskuterar också hur bilderna gestaltar en normalisering av barns kroppar i skolan, och hur en förändrad hälsodiskurs kommer till uttryck. Avslutningsvis diskuteras barns egna relationer i skolan och hur bildernas berättelser om dessa förändras över tid.

I det andra avsnittet är det bilden av en förändrad barndom som är i fokus. Barn på 1970-talet ansågs t ex genom exempelvis teckningstävlingar kunna ges utrymme i samhällsdebatten, och i formandet av sin egen uppfostran och sina kamraters. Dessutom diskuteras hur bilderna gestaltar var barn är på sin fritid, och vad de gör, och förändring över tid mellan 1940-tal och 1970-tal.

\section{Skolan}

I de tre tävlingar jag valt att närmare granska har barns bilder av skolan varit föremål för intresse både i FIB teckningstävling 1938 och i Arlas tävling 1976. Det faktum att FIB:s första tävling 1938 hade temat Livet i vår skola, visar att skolan betraktades som en självklar plats för barn. I Arlas och postens bok Varför fär inte barn bestämma, är de bilder som relaterar till skolan placerade först i boken. Även i Televerkets tävling 1984 Handikappad i samhället - lika men ändå olika förekommer bilder i skolmiljöer. ${ }^{697}$ För att vidga kontexten har jag $\mathrm{i}$ detta kapitel även använt mig av Kamratpostens tävling Faror och otrygghet i skolan från 1980. I syfte att diskutera förändring och kontinuitet använder jag Linds analys av elevbilder 1996, från Skolverkets uppdrag "Sveriges elever lyfter skoltaket". ${ }^{698}$

Inledningsvis kommer jag att presentera alla vinnarbilder från 1938 års tävling, för att sätta in de bilder jag valt ut i ett större sammanhang. Därefter kommer jag att diskutera bilderna i förhållande till hur förhandlingsberättelser kring tid och rum framställs i tävlingsbilderna från 1938. I följande avsnitt är bilder som gestaltar skolans normer för barns kroppar i fokus, och därefter hur relationer mellan barn och vuxna skildrats och vilka förändringar som syns över tid. Slutligen diskuteras även förändring över tid i gestaltandet av barns positioner och relationer i förhållande till varandra.

${ }^{697}$ Dessa bilder analyserar jag inte här men de diskuteras i Eriksson Yvonne (2014) ”Handikappad- lika men ändå olika” i Barn tecknar världen att förstå och tolka barns bilder (red). Studentlitteratur.

${ }^{698}$ Lind, Ulla (2010) kap. "Elevers bilder av skolan" sid. 287-347. Även om det är skillnad mellan att teckna för att vara med i en tävling och på uppdrag av Kulturdepartementet för att lyfta fram elevperspektiv på skolan, så är ändå temat eller frågan till barnen liknade mellan FIB:s första teckningstävling med temat Livet i vår skola 1938, och berätta $i$ bild hur det är att vara elev $i$ skolan som var uppdraget 1996. 


\section{Skolan som ordnande av tid och rum}

Det finns 118 bilder i Nationalmuseums samling med temat Livet $i$ vair skola. ${ }^{69}$ 52 visar interiörbilder från skolor, 39 visar exteriörbilder, några visar enbart byggnaden men majoriteten visar både byggnaden och lek eller aktivitet med barn på skolgården. De olika skolämnena visualiseras delvis genom sina specifika platser. Av de olika skolämnena är gymnastik/idrott representerat med 18 bilder, både inomhus och utomhus. Barn i aktivitet i Sy- och träslöjdssalar samt hemkunskap, är representerade med 3-4 bilder från varje ämne, liksom fyra bilder av barn i skolbibliotek. Tre bilder visar inte eleverna utan lärarna, i katedern eller i lärarrummet. Även de teoretiska skolämnena ges delvis olika karaktär, geografi gestaltas med hjälp av hur elever studerar kartbilder i tre bilder. Teckning, matematik och lästimme visar likartade bilder av elever som sitter i bänkar och en lärare eller lärarinna vid eller i katedern. Två utomhusbilder avbildar botaniklektioner. I "Magistern visar bilder" syns barn i en skolsal med läraren bakom en projektor, och diabilder som visas på tavlan. Det finns även fyra bilder av sång, orkester eller teaterföreställningar. Fyra bilder åskådliggör Luciafirandet $\mathrm{i}$ skolan, med Lucia och tärnor uppställda på led. Generellt visas en positiv bild av skolan fram i bilderna. Humor kunde användas för att skildra konflikter, vilket jag återkommer till i kapitlet om relationer mellan lärare och elever.

Men jag vill först återkomma till bilden på omslaget (bild 4:2). Det är en av tre bilder från temat Livet $i$ vår skola 1938, som refererar till en matematiklektion. I bilden porträtteras två nästan identiskt lika flickor, där det som skiljer är mönstret på klänningen. Likheten refererar till att flickorna är i samma skolklass och samma ålder. Även frisyren och den blonda hårfärgen är densamma, liksom den smala midjan. De står båda i samma pose, med högerarmen lyft för att skriva på svarta tavlan, som utgör det största färgfältet i bilden. Till vänster i bild står en orgel. Barnen, tavlan, orgeln, och katedern konnoterar skolsal, vilket också möjliggör föreställningen att det finns en lärare som övervakar det som händer. Siffrorna på tavlan refererar till matematikundervisning, och bildtexten berättar att det handlar om att göra fort och göra rätt. Hur kan man då förstå denna bild? Är flickorna utvalda att skriva på tavlan för att de är extra duktiga? Eller för att läraren vill kontrollera om de gör fel? Utifrån citaten i FIB i början av kapitlet två, där lärare menade att tävlingar väckte elevernas glädje och intresse och gav goda resultat, kan man betrakta bild 4:2 som del av en tävlingsdiskurs i att göra rätt och fort. Den kan beskriva tävling i skolan som något positivt, fartfyllt och roligt. Men bild 4:2 kan även betraktas ur ett annat perspektiv, för att visa hur skolan skapade stress och oro. Frågan: Vem blir först och vem har rätt?” visar att tecknaren förstått att det var att göra snabbt och rätt som belönades i skolsystemet. Betraktaren av bilden kan sedan utifrån egna ideal eller skolerfarenheter tolka bilden som ett uttryck för glädje eller stress i skolarbetet.

De som innesluts i betraktandet är de som kan känna igen bilden från ett elevperspektiv - som samtida skoldagar, och skoldagar man minns. Bilden av

${ }^{699}$ Det gör den till den näst största av samlingarna mellan 1938-1947, endast 1939 Livet i vår hembygd innehåller fler bilder. 
Vinnande bilder: Teckningstävlingar för barn 1938-2000

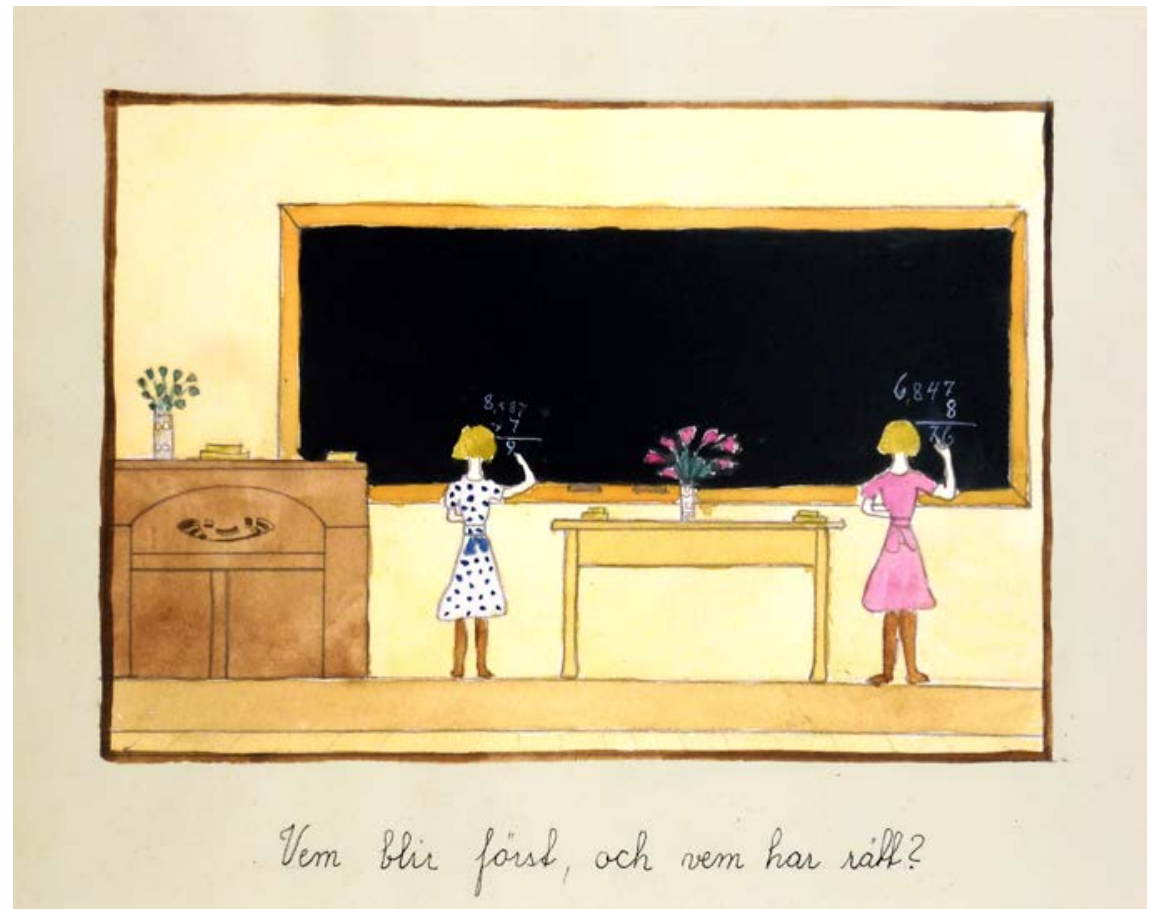

Bild 4:2. Livet i vår skola, FIB:s tävling 1938.

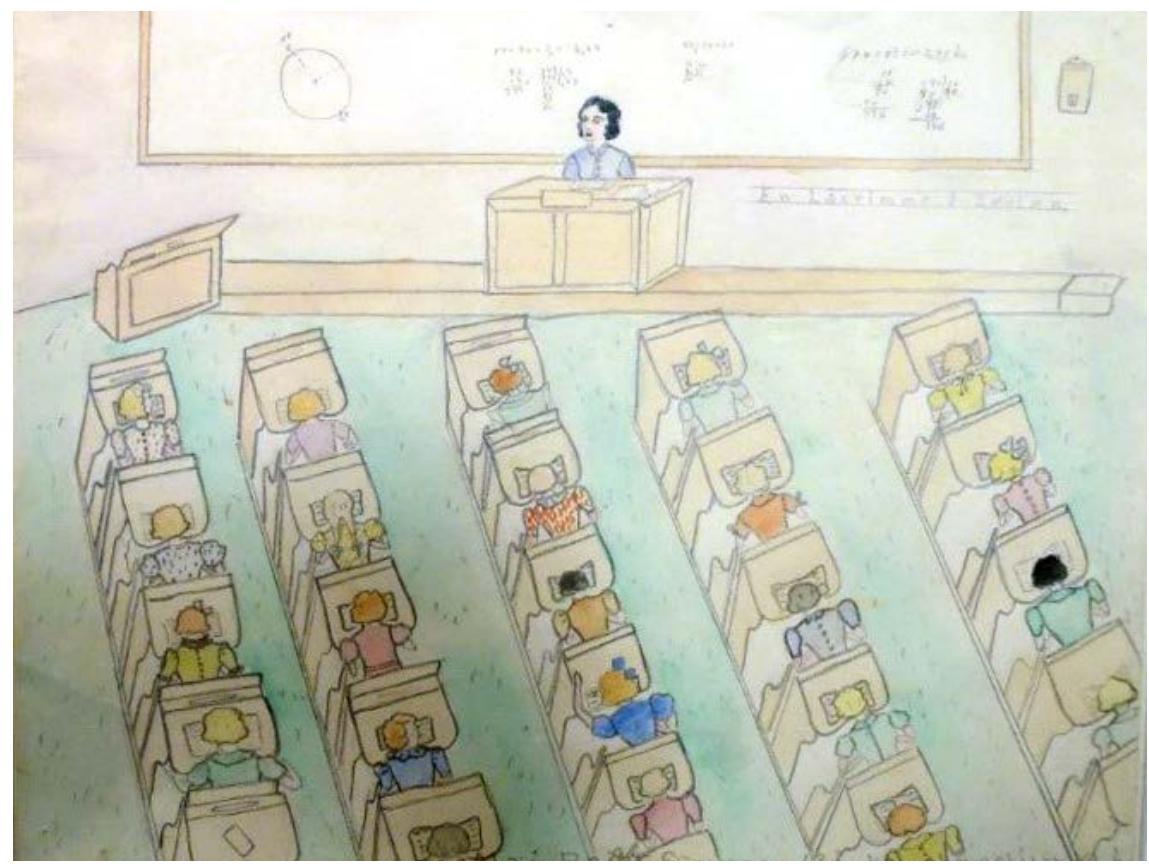

Bild 4:3. Livet i vår skola, FIB:s tävling 1938. 
skolan som en plats där man ska göra rätt och fort fanns i ett kollektivt medvetande 1938. Denna bild kan exemplifiera det Lind i sin studie av elevbilder 1996 definierade som "Skolan som social mening med dialogens och idyllens kronotoper", men även det hon betecknade "Svarta tavlans retorik med underkastelse- och motsats-kronotoper". ${ }^{700} \mathrm{I}$ sin analys av elevbilderna använder Lind Bachtins litterära begrepp kronotop i syfte att diskutera vilka diskurser som synliggörs och hur bilderna konstruerar sina egna rumtider. Dessa kronotoper, visuella teman, är användbara för att visa hur skoldiskursen gestaltades på liknande sätt i tävlingsbilderna 1938 och elevbilderna 1996. ${ }^{701}$ Tid, och stress återfinns i flera av tävlingsbilderna både 1938 och 1996, men också skolan som social mening i att lära sig saker och ha vänner. Lind definierar även hotets, magins och hoppets kronotoper i sin studie av elevbilderna 1996, där skolan bland annat kunde skildras som instängningspraktik med fängelsemetaforer, ensamhet och avskildhet. ${ }^{702}$ Fängelsemetaforen kunde i elevbilderna 1996 visa skolbyggnaden som ett fängelse, med gallerförsedda fönster. ${ }^{703}$ Andra exempel visade skolkare som tvingades till skolan eller en ensam elev i ett klassrum som fått kvarsittning. I 1938 års tävlingsbilder finns däremot inga som explicit visar skolk eller kvarsittning, eller där skolan tydligt associeras till ett fängelse. Men, bilderna är mångtydiga och även om skolan inte avbildas med galler för fönstren kunde skolan gestaltas som en ordnande och kontrollerande miljö (bild 4:3).

I bilden "lästimme i skolan" blir betraktaren en allseende övervakare av barnen, vi ser snett från ovan ryggen av flickorna, och deras prydliga frisyrer och kläder. Från andra hållet sitter lärarinnan rak i ryggen i sin kateder och betraktar, eller övervakar barnen som sitter i räta led. Flickorna positioneras som ett ansiktslöst kollektiv där alla görs lika övervakade av lärarinnans blick.

Skolan som en plats där barn positioneras och ordnas i tiden och rummet är uppenbar både i bilderna från 1938 och 1996. I Bilden "Fem minuter för sent" ser vi en flicka med blå kjol och grå jacka, med böcker under armen, som springer genom stora svarta gallergrindar som ser ut som om de håller på att stängas bakom henne (bild 4:4). Skolgrindarna är höga och kan associera till fängelsegrindar. Flickan har ett oroligt uttryck i ansiktet. Bilden som helhet konnoterar stress och oro. I ytterligare en bild från 1938 ser vi en pojke som springer mot skolan, denna bild saknar namn, men intrycket av bilden är att han är sen, då han är ensam på skolgården. Vi ser även samma fenomen i Kamratpostens tävling faror och otrygghet i skolan, där en av de vinnande bilderna visar en stor röd skolbyggnad där barnet textat: Det känns hemskt att komma försent till skolan när alla barn har gått in..$^{704}$

\footnotetext{
700 (Lind, Ulla) sid. 293. Kronotoper skapas i förhållandet mellan tid och rum, och kan ses som platser där betydelser kan omförhandlas, för att forma meningsfulla berättelser.

701 Bachtin var en rysk litteraturhistoriker (1895-1975) som använde begreppet Kronotop för att visa hur berättande skapas genom förhållandet mellan rum och tid.

${ }^{702}$ Lind, Ulla (2010) sid. $327 \mathrm{ff.}$

${ }^{703}$ Ibid. sid 328.

${ }^{704}$ Kamratposten nr 31980 sid. 11.
} 
Vinnande bilder: Teckningstävlingar för barn 1938-2000

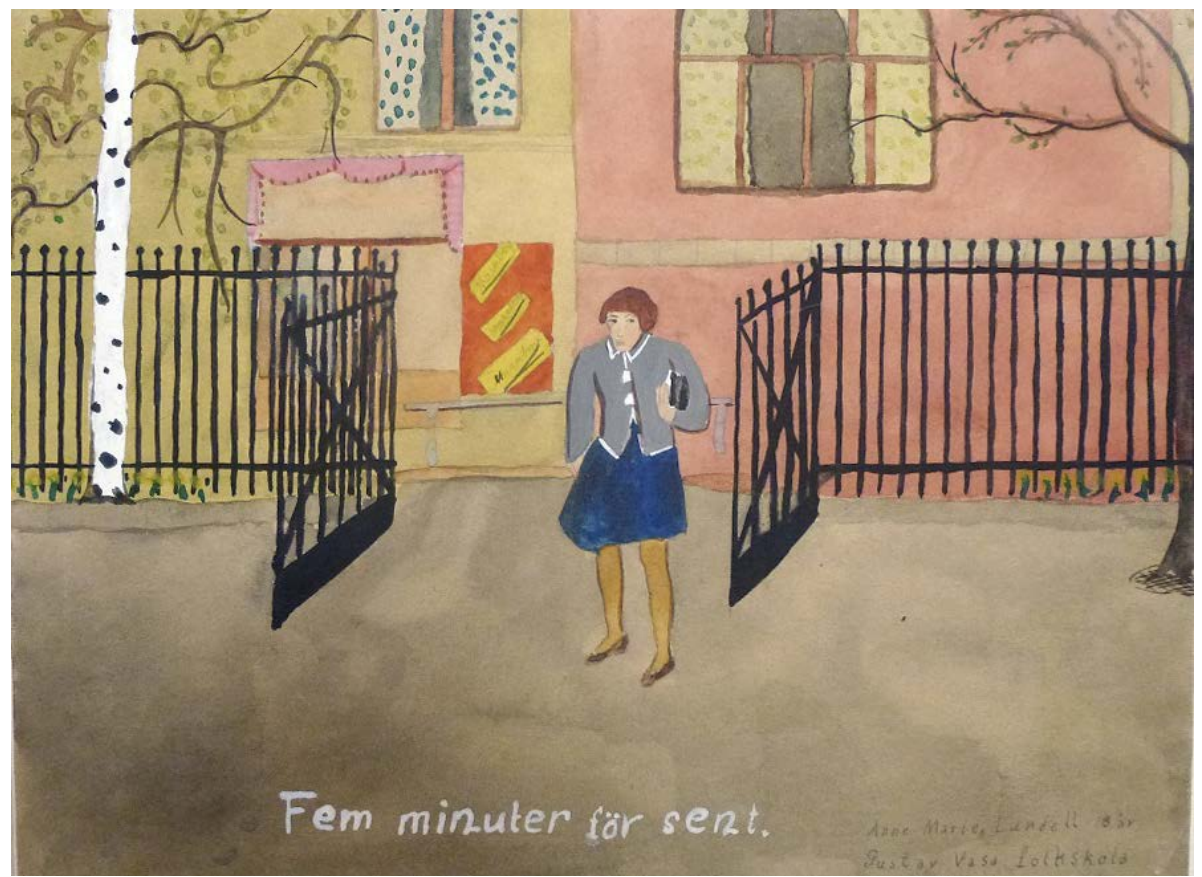

Bild 4:4. Livet i vår skola, FIB:s tävling 1938.

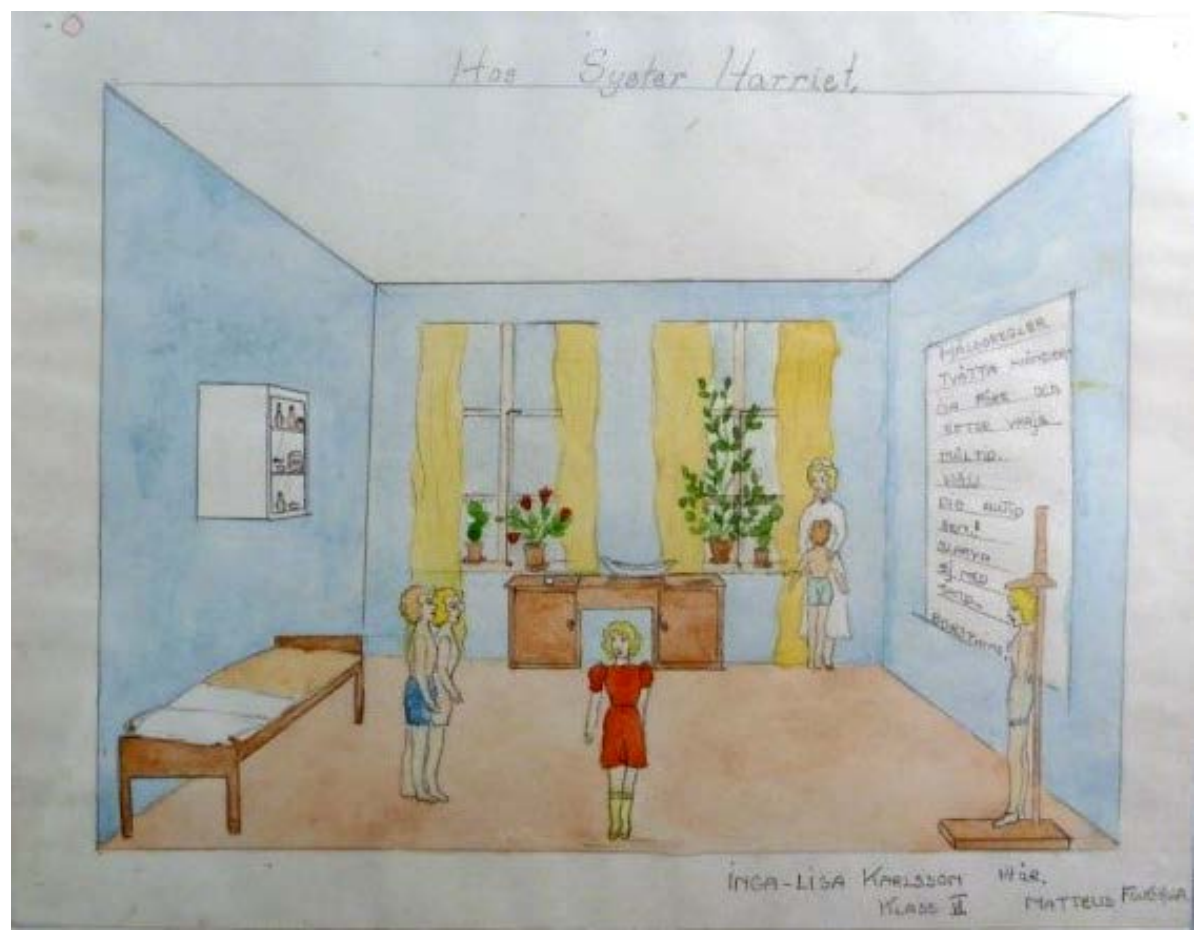

Bild 4:5. Livet i vår skola, FIB:s tävling 1938. 
Gymnastik, bad och bastu, liksom hälsoundersökningar är något som är mer uttryckligt avbildat i Nationalmuseums samling från 1938, än i bilderna från 1996. I FiB tävling visar majoriteten av lektionsbilderna gymnastiklektioner. Hur bilderna beskrivit ordnandet av barns kroppar är temat för nästa avsnitt.

\section{Bilder av skolans normer för barns kroppar}

Under början av 1900-talet blev det alltmer en gemensam nationell angelägenhet i den framväxande välfärdsstaten, att förbättra barns hälsa. ${ }^{705}$ Läkarvetenskapen och undervisningssystemet producerade gemensamt giltig kunskap, som möjliggjorde specifika medborgerliga subjektspositioner för barnen att förhålla sig till. Skolan som institution har haft uppdraget att värdera, reglera och styra barns kroppar. $^{706}$

I elevbilderna från skolan 1938 syns skolans gymnastik- och idrottslektioner i 18 bilder, både inne och ute, sju bilder visar inomhusbad eller läkarundersökningar. Dessa totalt 25 bilder av gymnastik, bad och läkarbesök visar hur barns kroppar ordnas och kontrolleras, och hur detta ordande genom bildernas berättelser kommer till uttryck. ${ }^{707}$ Detta kan exempelvis ske med hjälp av skolläkare, tandläkare eller gymnastikövningar, vilket gestaltats på olika sätt i barnens bilder. Genom skolan nådde man alla barn och kunde upplysa både dem och, genom barnen inte minst föräldrarna, om nya läkarvetenskapliga rön. ${ }^{708}$

Ämnena slöjd och gymnastik poängterades som extra viktiga för att undvika att barnen blev sjuka av för mycket stillasittande. ${ }^{709}$ Ämnenas positiva konnotationer i samtiden kan också vara en förklaring till att det är ett förhållandevis stort antal bilder som porträtterar gymnastik och slöjd som finns bevarade bland de vinnande bilderna 1938. I detta avsnitt kommer jag att granska hur bilderna av skolan visualiserat reglerandet av barns kroppar, och hur bilderna förevisar normer för rätt sätt att sköta sin hygien.

I bilden "Hos syster Harriet" av Inga Lisa Karlsson 14 år klass VI Matteus folkskola, står det på den vita tavlan till höger: HÄLSOREGLER Tvätta händerna före och efter varje måltid. Håll dig alltid ren! Slarva ej med tandborstningen! (bild 4:5). Bilden visar ett rum i tydligt centralperspektiv, med ljusblå väggar. Två fönster på bortre väggen med gula gardiner och fyra olika blommor, står i fönsterbrädet. Till vänster en säng, och ovanför sängen ett skåp med det som kan konnotera medicinburkar då bilden föreställer en skolsköterskemottagning.

Det är fem barn, alla flickor, i rummet hos syster Harriet. Harriet står vänd mot betraktaren av bilden, i bildens högra hörn, hon håller sin hand på en flickas axel. Flickan är vänd med ryggen mot oss.

\footnotetext{
705 Palmblad, Eva (1990). Medicinen som samhällslära. Diss. Göteborg: Univ.

${ }^{706}$ Foucault, Michel (2002). Sexualitetens historia. Bd 1, Viljan att veta. Göteborg: Daidalos. sid $141 \mathrm{ff}$.

707 Detta av totalt 118 bilder i samlingen Livet $i$ vår skola. En gymnastikbild med bara flickor analyseras i kapitlet genus.

708 Hallberg, Matilda, (2017).

709 Palmblad, Eva (1990). sid. 98.
} 
Syster Harriet har en vit rock och en vit mössa med ett märke på. Flickan mitt i bilden har en röd klänning och strumpor, de övriga flickorna har enbart underbyxor på sig. Till höger står en flicka och mäter sin längd, med en mätsticka. Två flickor står i profil till vänster i bild, de ser ut att vänta på sin tur och samtidigt läsa hälsoreglerna noggrant. Alla är ljushåriga med liknade frisyr och kroppsbyggnad. Att flickorna är avbildande i stort sett likadana till utseende storlek, konnoterar en tydlig norm för accepterade utseenden, även om det också kan ha att göra med ett speciellt sätt som tecknaren lärt sig teckna "flicka" på. I enlighet med perspektivreglerna är flickan och sköterskan i bakgrunden mindre än flickorna som är närmare i bild. I de övriga två bilderna med läkare i undersökningsrummet står läkarna mera mitt i rummet, de tar mera plats i bildutrymmet, och deras profession - att undersöka barn, är i fokus. Här är det flickorna som syns mest, framförallt flickan i klänningen, som är den enda av dem som är påklädd.

Bilden refererar också till strikta normer för bedömning, att bli bedömd både av sköterska och läkare, på bilden uppfattar man att den påklädda sköterskan gör en bedömning av den avklädda flickan. Men kanske är det inte enbart sköterskan som bedömer, utan även de jämnåriga kamraterna? Flickorna kan också genom sin likhet och sitt stela sätt att stå, associeras till modedockor där den påklädda flickan kan få en högre status genom att hon har en modern klänning.

De relativt framträdande blommorna i fönstret refererar till en ombonad, "hemliknande" miljö, skrivbordet/katedern framför refererar till skola, och sängen till sjuksäng, vilket gör miljön till en del av skolan, men ändå inte. Sängen visar hur skolsköterskan rum visserligen kan vara ett rum för bedömning, och kunskapsinhämtning om hälsoregler, men även ett rum för omvårdnad och något annat än skolundervisning. Att perspektivteckningen är så tydlig att man ser vissa av hjälplinjerna, visar att både flickan som tecknat bilden, och juryn, ser det som en bra bild, när man visar kunskap om centralperspektiv. Analysen visar att hälsoundersökningar var något som barnen upplevde som en del av deras skolvardag, och det var också något som juryn såg som rimliga bilder att belöna. Juryns motiv kan säkert till del bero på skicklighet att teckna perspektiv och kroppar. Samtidigt visar barnen, och juryn genom urvalet, att skolan inte bara var en plats för att inhämta olika kunskaper och färdigheter i teoretiska ämnen, utan också en plats för normalisering, diagnostisering och att lära sig sköta om kroppen på rätt sätt.

Tre bilder av Livet i vår skola visar bad, en heter: Första gången jag var med och badade bastu av Nils Nilsson 13 år; bilden föreställer 15 barn i ett duschoch badrum, ett barn har en badhandduk runt kroppen och en kvinna, troligen lärarinnan, har badrock. Bildens namn "Första gången" refererar till att detta var en speciell händelse, troligen inte något som man gjorde hemma, eller i så fall inte på samma sätt. Barnen är nakna, tre barn kikar ut från bastun, tre duschar, tre badar i en liten bassäng, några badar i balja och tvättar sig. Den andra bilden heter I vår bastu, och visar en flicka som duschar med badmössa, en flicka sitter bredvid och tvättar fötterna i en balja. Bastun var en del av hur man talade om bad och renlighet i dessa bilder, även om bilderna visar dusch och bad. 
Den tredje bilden av bad heter-Baddagen-Var 14e dag fär vi tvätta oss och bada bastu och duscha (bild 4:6).

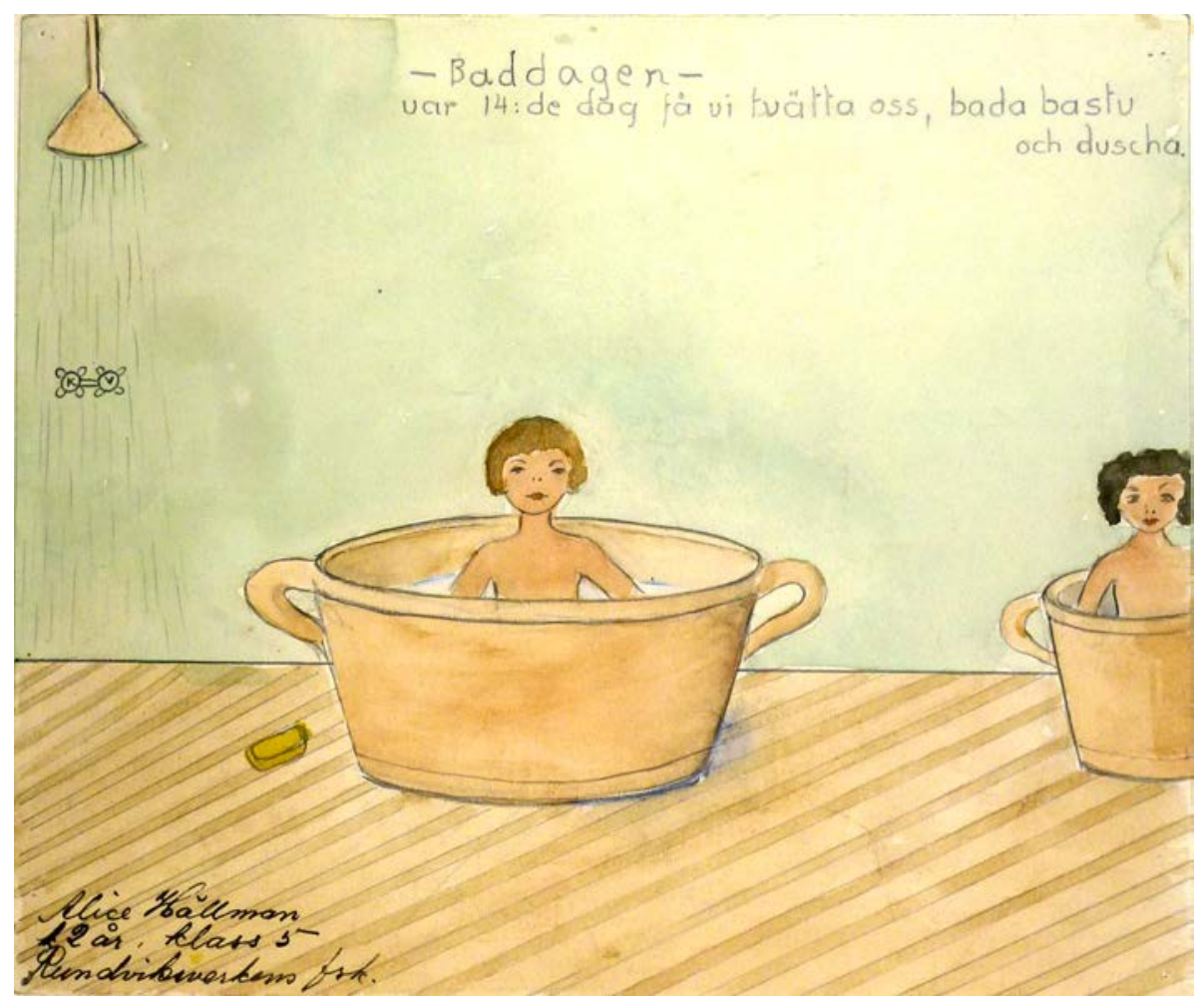

Bild 4:6. Livet i vår skola, FIB:s tävling 1938.

I mitten av bilden ser vi ett barn, en flicka med kort ljusbrunt hår. Hon sitter i en balja, bredvid till höger sitter ytterligare en flicka med brunt lite lockigt hår i en balja. Väggen i bakgrunden är ljust grön, golvet är snett randigt i bruna nyanser, baljorna är i en liknande brun nyans. Baljorna liknar närmast stora soppskålar, med handtag på var sida, där den högra baljan och flickan är betydligt mindre än den i mitten. Till vänster i bild syns en dusch med strilande vatten, och två kranar, på den västra står $\mathrm{K}$ och på den högra står $\mathrm{V}$, som refererar till kallt och varmt vatten. Till höger om baljan ligger också en liten rektangulär gulbrun form, troligen en tvål. Flickorna ser förhållandevis små ut, samtidigt som baljorna de sitter i också upplevs som trånga att få plats i. Skolan var en plats som konnoterade renlighet. I Arlas tävling 1976 Detta vill jag värna om, associeras skolan istället med smutsiga toaletter. Bilden med uppmaningen "Bättre skoltoaletter" bidrog till bilden av skolan som en problemfylld plats, vilket jag återkommer till.

Bilden "baddagen" var en av de bilder som reproducerades i FIB, omnämnd som en "förtjusande teckning" (bild 4:7). Av detta kan vi förstå att fenomenet att bada i balja i skolan var något som förtjänade att visas upp, och som kunde 
Vinnande bilder: Teckningstävlingar för barn 1938-2000

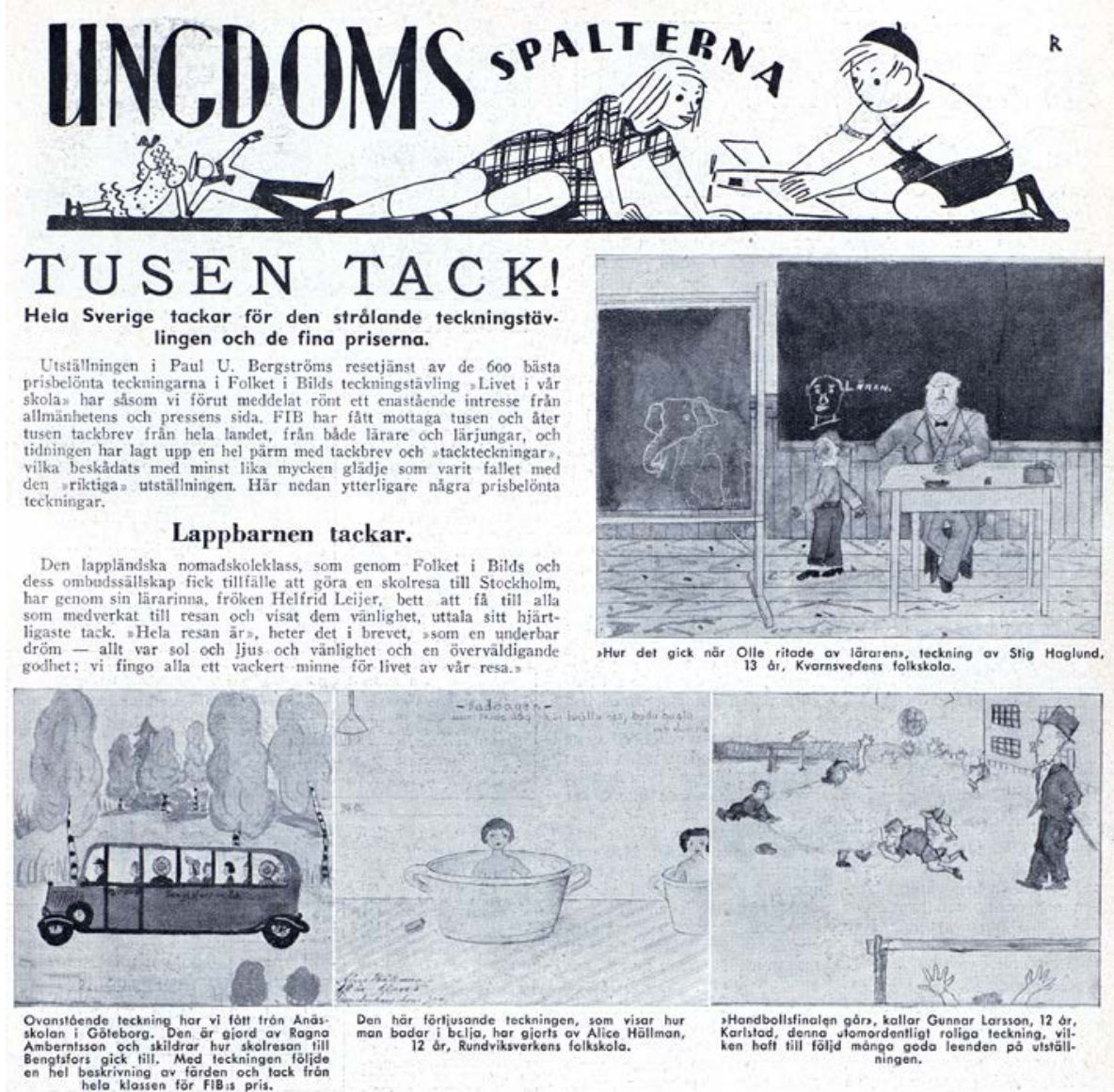

Bild 4:7. Folket i bild 1938 nr 29 sid.27. detalj 
ses som symbol för det nya rena folkhemmet. ${ }^{710}$ Om vi ser till hela bildsidan där bilden är en av fyra bilder som publiceras i Ungdomsspalterna, så visar de hur livet i skolan konnoterar renlighet (bada i balja), att åka buss på skolutflykt och upptäcka. ${ }^{711}$ Många av bilderna från "mitt roligaste skolminne" som blir temat 1941, är just från skolutflykter. Texten Lappbarnen tackar beskriver hur en lärarinna i en samisk nomadskola tackar å barnens vägnar för att FIB:s tävling möjliggjort en skolresa till Stockholm. De två bilderna längst till höger på tidningssidan skildrar livet i klassrummet och på skolgården. Båda bilderna kommenterar relationer mellan lärare och elever (bild 4:7). Hur elever skildrat konfliktsituationer och konfliktfyllda relationer i skolan är i fokus för nästföljande två avsnitt.

\section{Relationer mellan lärare och elever}

Jag kommer i detta delavsnitt att granska skillnad över tid i hur relationer mellan lärare och elever skildrats och beskrivits i tävlingsbilder 1938 och 1980. De bilder jag använt och refererar till är bilder från tävlingen Livet $i$ vår skola publicerade i FIB 1938 samt bilder från Kamratpostens tävling Faror och otrygghet $i$ skolan 1980. Genom att bilderna publicerades och kommenterades i FIB, kan de sägas representera en etablerad skoldiskurs (bild 4:7).

Om vi åter betraktar tidningssidan från FIB:s ungdomsspalter, med bilden "Baddagen", ser vi i bilden högst upp till höger en klassrumsinteriör. Bildens titel lyder "Hur det gick när Olle ritade av läraren" tecknad av Stig Holmlund 13 år i Kvarnsvedens folkskola. Vi ser i bilden hur Olle blir dragen i örat av läraren. Att han står med ryggen vänd mot läraren kan vara ett tecken på att han står i skamvrån. Teckningen av ett ansikte på tavlan och texten "Lären", konnoterar att Olle tecknat av läraren, vilket vi förstår att Olle straffas för. Läraren sitter bakom en kateder, och framför den svarta tavlan där teckningen och texten "lären", syns. Det är oklart om läraren är mest upprörd över att Olle inte kan stava rätt, eller att han tecknat en nidbild av läraren. I förgrunden finns ännu en svart tavla, med en bild av en elefant tecknad med krita. Bilden positionerar läraren som sträng och tillrättavisande och konnoterar en maktutövning som inkluderade fysisk bestraffning. Det är en skolmiljö där det utdelas straff vid icke önskvärda beteenden, som att göra en karikatyr av läraren, och dessutom stava fel. Samtidigt visar bilden, genom att den blev tecknad och även vann, att det ändå är möjligt att göra narr av läraren, både i teckningen på tavlan, och i denna vinnande teckning av teckningen på tavlan.

Som elev 1938 var användandet av satir och humor ett accepterat sätt att förhålla sig till och kanske även ifrågasätta skolans maktstrukturer. Den andra bilden uppskattas av många, får vi veta genom bildtexten: "Handbollsfinalen går” kallar Gunnar Larsson 12 år, Karlstad, denna utomordentligt roliga teckning, vilken haft till följd många goda leenden på utställningen. Vi ser i bilden en

\footnotetext{
710 Palmblad, Eva (1990). Medicinen som sambällslära. Diss. Göteborg: Univ. sid. 41 ff.

711 Lindgren, Anne-Li (1999) Detta tema är framträdande också i Anne-Li Lindgrens studie av Skolradion
} 
man i hög hatt, kostym och käpp, troligen en lärare eller rektor, eftersom han går på en skolgård. han går förbi något som ser ut att vara ett regelrätt slagsmål, men av titeln att döma är en "handbollsfinal." Och vi ser också i förgrunden huvudet av en pojke som står i mål. Om bilden ovan refererade till den stränga läraren, så refererar denna till den passive ointresserade läraren, som bara går förbi ett slagsmål och visslande låtsas som ingenting. Båda dessa lärarroller kunde ifrågasättas genom humor i bild redan under sin samtid. Bilderna ingår i en satir och humorgenre, med Bachtins begrepp, en karnevalisk krontop. ${ }^{72}$ Genom bilden och texten förstår vi att slagsmål och ointresserade lärare kan vara något som av samtiden uppfattas som humoristiskt. Det är ett sätt att förhålla sig till skolvardagen genom att skämta om problem som man kanske inte kunde tala öppet kring. Att teckna karikatyrer eller skämtteckningar görs positivt, framförallt av tidskriften FIB. ${ }^{713}$

Redan den första artikeln i FIB efter den första tävlingen 1938 publiceras en bild av en pojke som blir dragen i örat av en lärare (bild 4:8). Rubriken på tidningssidan är ALLMÄNT JUBEL över teckningstävlingen Livet i vår skola. De två bilder som publiceras är dels en exteriörbild av en skola, och dels en bild av en elev som blir dragen i örat. Med bildtexten i FIB: "Så går det för den som tar flickornas bollar Jo, jo.” är det underförstått att pojken kan anses förtjäna den tillrättavisning han får. Bilderna visar att kroppsliga straff inte sågs som något förvånade eller ovanligt i skolans värld, tvärtom, kan det förstås som så vanligt att det är den bild man väljer att publicera som den allra första bilden från tävlingen. ${ }^{714}$ Det som i en senare kontext skulle komma att betraktas som våldsamt eller bestraffande görs i publiceringen av dessa bilder och hur det skrivs om dem, som något snarast komiskt, eller en del av skolans vardag som accepteras och uppskattas, ett normaliserat sätt att fostra. Bestraffning förefaller inte som ovanligt, eller som något man inte kan tala om, utan att stå i skamvrån, bli dragen i örat eller att hamna i slagsmål var något som förekom i skolmiljön.

Den kritik som finns i tävlingsbilderna mot detta system var utformad som satir, om något kan skrattas åt kan det betyda att det är accepterat, men också att det är något som är under förhandling och förändring. (se även bild 5:1 i slöjdsalen där pojkarna ursäktar att de kommer sent för att de varit i slagsmål)

I Kamratpostens tävling fyrtio år senare ställdes ett hundratal av de vinnande bilderna ut på Kulturhuset i Stockholm. Det är dock viktigt att poängtera att temat 1938 var "Livet i vår skola" och att Kamratposten 1980 frågar efter "Faror och otrygghet i skolan". Uppdraget i sig kan med andra ord visa en förändrad samhällssyn kring vad skolan som plats för barn innebar vid olika tider. Liksom FIB publicerar även Kamratposten några av de utställda bilderna i tidningen. ${ }^{715}$

En av dessa var bilden från klass 5, Ulfshyttans skola i Borlänge, med titeln Varför känner jag mig alltid liten och dum? (bild 4:9). Bilden visar tydligt hur det expressiva och känslosamma och att tala om det som upplevdes som proble-

\footnotetext{
${ }_{712}$ Lind, Ulla (2010) sid. 317.

713 Inte någon av dessa bilder är kvar i Nationalmuseums samling.

${ }^{714}$ Bild från FIB 1938 nr 27 sid. 27.

${ }^{715}$ Kamratposten nr 31980 sid. 10-11.
} 


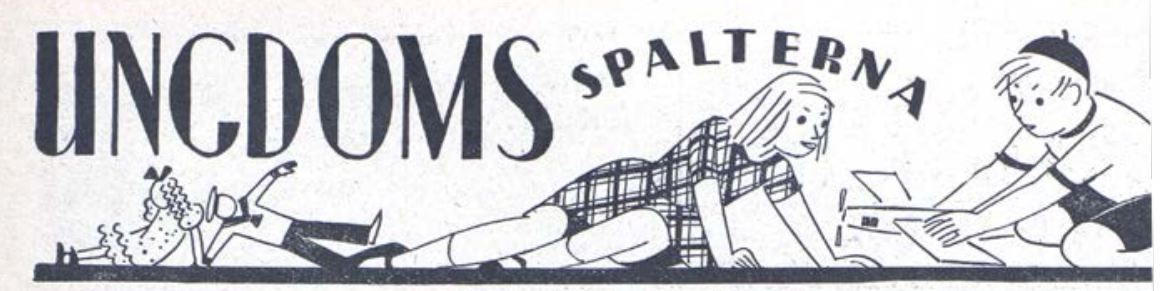

Allmänt jubel

över teckningstävlingen

"LIVET i VÅR SKOLA"

Alla ăr nöjda med Folket i Bilds teckningstâviling, "Livet $i$ vảr skolas, därom vittnar de massor av brev, som varje dag strömmar in. Det âr inte bara pristagarna som talar om hur nöjda de är för sina pris och för at

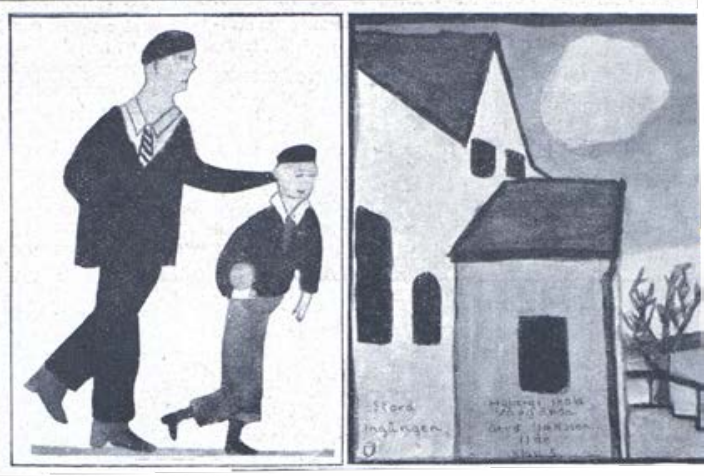

Bild 4:8. Folket $i$ bild 1938 nr 27.sid.27.detalj

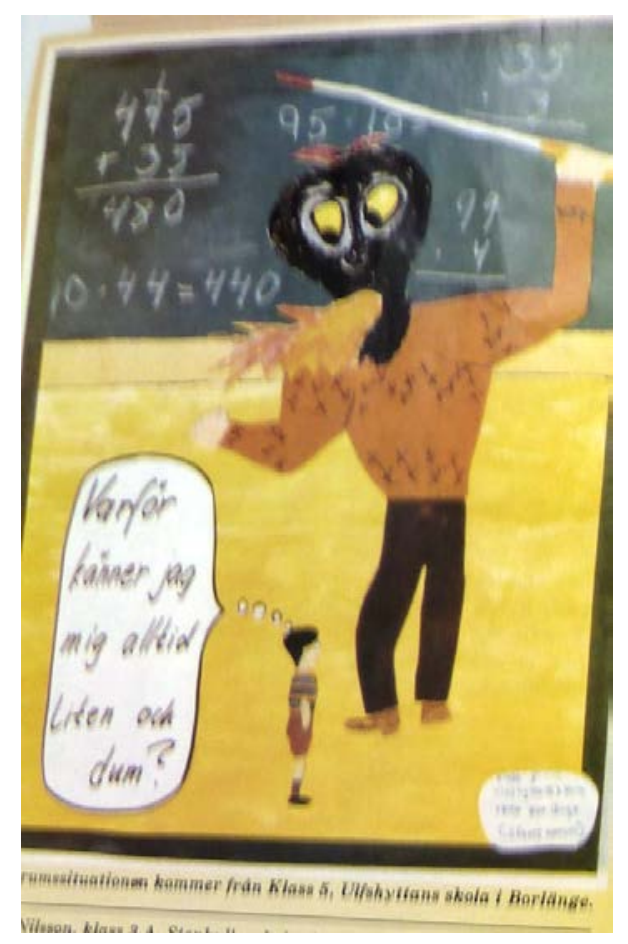

Bild 4:9. Kamratposten 19801980 nr 3 sid.10. 
matiskt i skolan, blivit accepterade normer för barn, jämfört med bilderna från 1938. Både temat i sig, bildtiteln, och bildens uttryck positionerar barnet i en mer utsatt situation än bilderna 1938, trots att fysiska bestraffningar varit förbjudna i lag sedan 1957.

Bildens uttryck är också ett annat än bilderna från 1938, den både expressiv, surrealistisk och drömlik och använder sig samtidigt av formen för tecknad serie, då den visar en liten figur med pratbubblan Varför känner jag mig alltid liten och dum? Det lilla barnet står under det som närmst liknar ett monster eller en drake, med röd eld som sprutar ur munnen och pekpinnen i vänstra handen gör att vi förstår att det är en lärare som är arg/skriker/skäller. Även den svarta tavlan med matematiska tal gör att vi refererar till en skolsal. Barnet är oproportionerligt litet i förhållande till läraren och tavlan, vilket understryker känslan av att vara just "liten", i förhållande till läraren som framstår som både jättelik och skrämmande. Känslan av att vara "dum" kan referera till matematiktalen på tavlan. Bilden konnoterar att "draklärarmonstret" är argt för att eleven inte kan talen på tavlan. I Kamratpostens tävling är således fokus ett helt annat. Skolkontexten har förändrats sedan 1940-talet och vilka bilder som är möjliga och önskvärda bilder från arrangörerna likaså.

Barn- och ungdomstidningen Kamratposten var del av den samtida barnrättighetsdiskursen, som ville lyfta barns egna upplevelser. Genom att barn uppmanas att teckna "otrygghet" visar bilden från 1980 fram lärarauktoritet som något som kan skapa en otrygg skolmiljö, i motsats till 1938 där den auktoritäre läraren beskrevs antingen i humoristiska eller positiva bildberättelser.

\section{Relationer mellan barn}

Inte bara bilderna av relationerna mellan vuxna och barn har förändrats över tid, utan i lika hög grad hur bilderna uttrycker barns relationer med andra barn. Även här syns flera exempel i Kamratpostens tävling. Förutom bilden av läraren som liknar en drake publicerades fyra andra bilder i Kamratposten 1980 från tävlingen faror och otrygghet och dessa porträtterar snarare otrygghet i förhållande till andra barn. ${ }^{716}$ Liksom i bilden av läraren kunde detta visualiseras och kommenteras genom storleksförhållanden, som i bilden "Jag tycker att de stora ska sluta att retas tycker inte du det?". Två stora barn med blå byxor och tröja står mitt $\mathrm{i}$ bilden. Bredvid till höger står ett hälften så stort barn i röd klänning med nedböjt huvud. I bilden Varför måste just jag ha mössa? står också ett litet barn, med en mössa som är lika stor som barnet, på varje sida finns två barn som pekar finger och skrattar, i bakgrunden syns skrattande ansikten. Ytterligare en bild med texten Den som inte har fina kläder blir retad, visar en flicka som är omgiven av två andra flickor med hästsvans, som säger: "Vilka byxor du har "och "Du följer inte med i modet". KP skriver "Vi blev förvånade över att så många är rädda för lärare och betyg, för prov, för att inte kunna svara på frågor och för att komma försent. Många berättar om mobbing, men det hade vi nog

${ }^{716}$ Två bilder visade också skolan som en trygg plats, som gav vänskapsrelationer. 
väntat oss."717 Så att mobbing är ett tema som är diskuterat 1980 blir tydligt, medan istället maktrelationerna mellan lärare och elever inte förväntades vara lika problematisk. ${ }^{718}$

Arlas bok Varför fär inte barn bestämma, visar inga bilder av barns relationer med lärare, men däremot tas mobbing mellan barn upp.

I bilderna "Reta inte de som har glasögon för GLASÖGONORM", "Reta inte barn från andra länder", liksom i bilden" SLUTA MOBBAS", ser vi barn som gråter med stora tårar. Texten syns med tydliga versaler i övre delen av bilden, till höger syns en figur, där det svartbruna fältet konnoterar långt hår vilket tillsammans med ögat med ögonfransar konnoterar flicka (bild 4:10). Flickan är enkelt tecknad men jag tolkar det som att den pekar finger mot en annan flicka till vänster i bild, med långt gult hår, där det mest framträdande i hennes ansikte är stora blå tårar, tre tårar faller ur varje öga, varje tår lika stora som ögat. I bilden; "Reta inte barn från andra länder" av Mikael Persson, Vällingby, 10 år, står en pojke i mitten med lockigt hår och kortbyxor (bild 4:11). Ögonen och munnen är ledsna, pojken gråter med tydliga tårar som trillar ner mot marken. Till höger syns ett barn som pekar och skrattar, till vänster ett barn/pojke med keps, som räcker ut tungan, det ser ut som om han kastar något mot pojken i mitten. I bakgrunden syns två barn som säger "ha ha" och en fyrkantig byggnad som det står "skola" på, vilket refererar till att det utspelar sig på, eller nära, en skolgård. Bilden som helhet konnoterar en mobbingsituation där ett barn blir utsatt av flera andra. I informationen till tävlingen "Detta vill jag värna om" 1976, beskrevs att barnen gärna fick ta upp orättvisor och sådant de vill ändra på. ${ }^{719}$

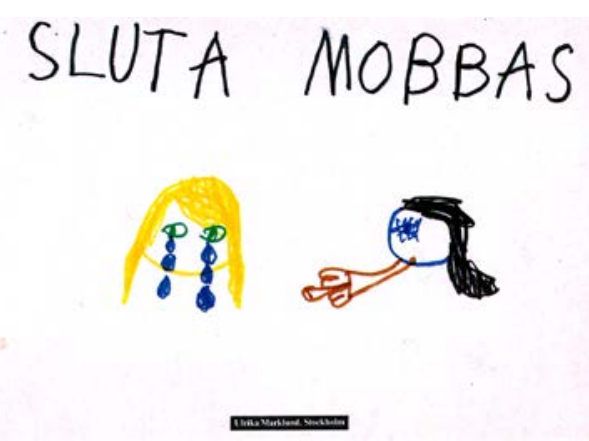

Bild 4:10. Ulrika Marklund i Varför fär inte barn bestämma (1977).

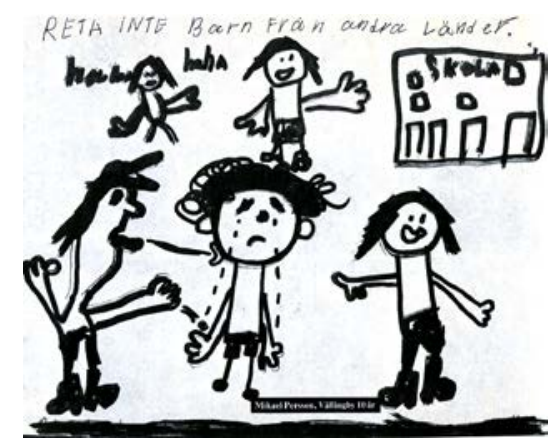

Bild 4:11. Mikael Persson i Varför fär inte barn bestämma (1977).

När barn 1945 gestaltar "våra lekar" i bild är det en positiv bild av gemensam samvaro. Även barn som är i slagsmål framställdes som komiskt, som vi såg i bild 4:6 "Handbollsfinalen går" från FIB 1938. I FIB:s tävling finns även en bild från temat Livet i vår skola 1938, som har namnet Snöbollskrig på Södervärnsskolan

\footnotetext{
717 Kamratposten nr 31980 sid. 10-11.

718 Ibid. sid. 11.

719 Arla Tävlingsbilder 1976 Informationsblad 20001 Å, SBBA
} 
av Tor Hedberg, 10 år. Då juryn väljer dessa bilder för att bli utställda, förstår vi att snöbollskrig är en möjlig och rimlig aktivitet i skolan. Snöbollskrig gestaltas också i en bild från temat våra lekar 1945 av Fredi Windholz, 12 år (bild 4:12). Barnen framställs som aktiva i leken, barnet till vänster i bild ser glad ut, trots att han avbildas som om han just fått en snöboll mitt i ansiktet.

I bilden syns även en pojke som står över en annan pojke med en snöboll i handen, där pojken under verkar försöka skydda ansiktet med händerna. Helhetsintrycket av bilden 1945 är ömsesidig lek och något lustfyllt, då barnen ser glada ut. Ojämlika maktrelationer mellan barn syns, men problematiseras inte i 1938 års tävling. Barn framställs i slagsmål, som i bilden "handbollsfinalen går” (4:7), men på ett humoristiskt sätt. Lärarna har en maktposition av att kunna ingripa ibland men bilderna visar inga tydliga konflikter mellan barn. De maktordningar som finns accepteras som en del av leken.

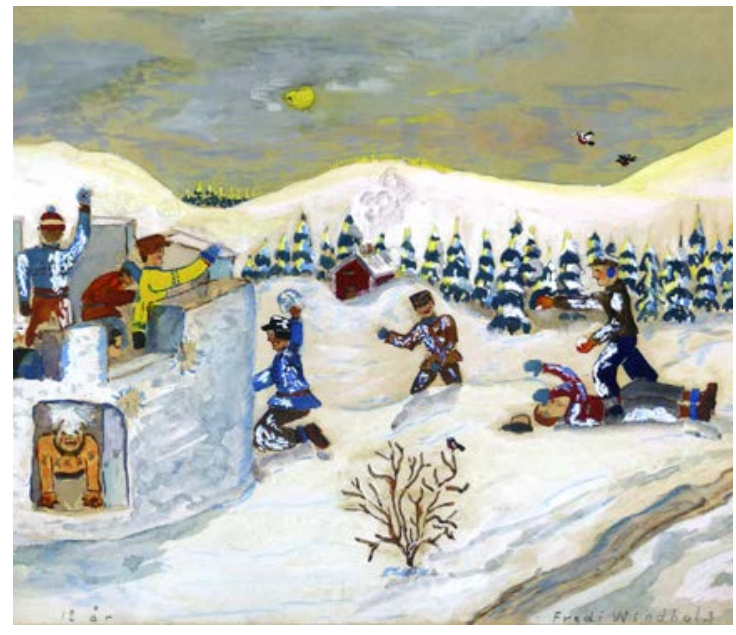

Bild 4:12. Våra lekar, FIB:s tävling 1945.

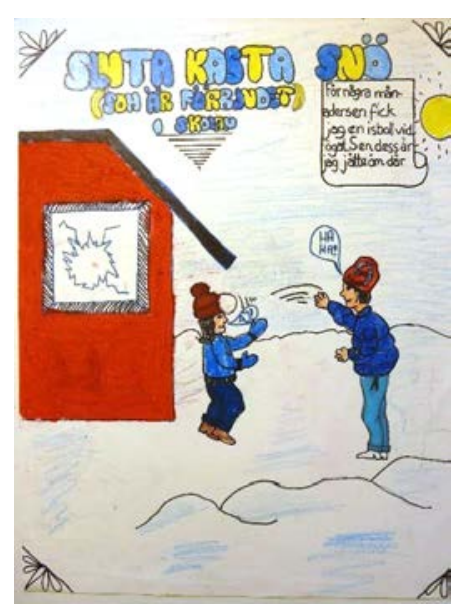

Bild 4:13. Faror och otrygghet i skolan, Kamratpostens tävlingssamling 1980.

Bild 4:13 från KP:s tävling faror och otrygghet $i$ skolan visar hur samma fenomen, snöbollskastning, 1980 inte ses som lek. Diskurser om rädsla och oro, liksom mobbing, både uppmanas och möjliggörs. I bilden syns hur ett barn till höger kastar en snöboll på ett mindre barn till vänster i bild, barnet till höger säger $\mathrm{HA}$, och barnet till vänster $\mathrm{AJ}$. Barnen har liknade kläder, men då barnet till vänster har längre hår, tolkar jag bilden som att det är en pojke som kastar på en flicka. Fönstret med den kraschade rutan i bakgrunden refererar också till problem associerade med snöbollskastning. Bildens text lyder: "Sluta kasta snö (Som är förbjudet i skolan) För några månader sen fick jag en isboll vid ögat sedan dess är jag jätteöm där.” Det som på 40-talet är framställt som en lek, med tuffa och kavata barn, framställs som problematiskt 1980. I Arlas (1977) och Kamratpostens (1980) bilder är det tårar och ledsna barn på skolgården. Att tävlingarna använts som ett sätt att synliggöra och ge röst åt de som tidigare inte synts är tydligt i vissa av tävlingarna under 1970-talet. 
När Televerket 1982 i samarbete med Handikappades riksförbund arrangerade tävlingen "Handikappad i samhället - lika men ändå olika", är förhoppningen också att förändra attityder. ${ }^{720}$ Yvonne Eriksson har analyserat delar av denna samling som finns på SBBA. Eriksson menar att bilderna kunde bidra till ett synliggörande av funktionshindrade, samtidigt som de kunde upprätthålla dikotomiserade föreställningar om "vi och dem". Hon visar exempelvis att begreppet handikappad inte används idag men att vi däremot talar mer om icke synliga funktionshinder, än vad som framkommer i elevbilderna från 1980-talet. ${ }^{721}$ Även i Arla/Postens bok 1977 Varför får inte barn bestämma finns bilder genom vilka barnen kommenterar samhällsfrågor. Exempelvis finns bilder som poängterar hur framkomlighet för rullstolar försvåras av trottoarer, eller vikten av att hjälpa både barn vuxna och gamla som var sjuka eller utsatta i olika situationer. Vid en jämförelse med FIB:s tävling från skolan och hembygden 1938/39, finns där ingen bild av någon som var sjuk eller hindrad att delta i arbete, oavsett om det var av ålder eller sjukdom. ${ }^{722}$

$$
* * *
$$

Bilddiskurser som är konstanta över tid 1938-1996 är både en berättelse om skolan som en positivt konnoterad plats för gemensamt kunskapande, och samtidigt hur skolan kan upplevas som en plats som genererar stress och lydnad, genom förväntningar att göra "rätt och fort". Som vi sett har barn under hela perioden positionerats som skolbarn, både genom tävlingarnas teman och bilderna av skolmiljöer. Dessutom har skolan varit platsen för bildernas produktion i många fall.

Skillnad över tid syns vid en jämförelse mellan FIB tävlingsbilder 1938, och Arlas tävlingsbilder, från boken Varför får inte barn bestämma från 1977. Barns aktivitet i skolan, och lekar på skolgården är positivt skildrade och beskrivna i 1938 års bilder. Bilderna visualiserar hur skolan kontrollerande barns kroppar vilket kan ses som en del i etablerandet av diskurser kring normalitet eller avvikelse. Liksom tidigare forskning som analyserat folkhemsdiskursens bilder av barn under 1940-talet visar analyserna av tävlingsbilderna att vikten av att lära barn bada, basta, duscha och vara rena har poängterats som en del av skolans uppdrag. ${ }^{723}$

Analysen visar också hur bilder av barns relationer i skolan och på fritiden har förändrats mellan 1940-talet och 1970 och 80-talet, och mellan ungdomssidorna i tidningen FIB och barn och ungdomstidningen Kamratposten. Lärare framställdes i bilderna från skolan 1938 som auktoritära, och bestraffande, men på ett delvis positivt sätt, då de bestraffar de som betett sig illa mot andra. Lärarens makt framställdes även humoristiskt 1938. 1977 skildras skolan istället som

\footnotetext{
720 SBBA Televerkets tävlingssamling 1982.

721 Eriksson Yvonne (2014) "Handikappad - lika men ändå olika” I Barn tecknar världen att förstå och tolka barns bilder (red). Studentliteratur. Enbart allergi tas upp som ett icke synligt handikapp.

722 Se avsnittet Bilder av hembygden kapitel tre.

${ }^{723}$ Hallberg, Mathilda (2017) kap. 4.
} 
problematisk, barnen påvisar i bild och text problem med för stora skolor, dåliga skoltoaletter, och mobbing på skolgården. Mobbing som begrepp används i 1970-talets bilder, både av barns själva och av vuxna som kommenterar bilderna, och barns relationer med varandra problematiseras i högre grad än i 1940-talets bilder. 1970-talets bilder visar dessutom barns känslouttryck, vilket visualiseras exempelvis genom tårar. Tävlingsbilderna visar en diskursiv förändring över tid av hur det varit önskvärt och möjligt för barn att beskriva och definiera normer och ideal i skolan och hur relationer i skolan har kunnat återges.

\section{Förändrad bild av barndomens villkor}

Det fanns i FIB:s tävling på 1940-talet ett fokus på det som betraktades som barns egna aktiviteter, eller vad som kan förstås som ett intresse för "barns egna världar". Den romantiserade diskursen om att barn levde i en egen värld som vuxna kunde få kännedom om genom deras bilder, som jag diskuterade i kapitel två under tävlingarnas teman, är inte lika uttalad i senare tävlingar. Exempelvis är tävlingar som "våra lekar" och "min fritid" frånvarande i senare tiders tävlingar. När barns egen aktivitet syns i Arlas eller Televerkets tävling är det ofta för att förmedla en moralisk kod kring hur barn och/eller vuxna uppmanas att bete sig.

I tävlingsbilderna från 1970 och 80 -talet framställs barnen som aktiva samhällsmedborgare, som gör sina röster hörda för att vara med och bestämma. Subjektspositioner både hos barnen och deras föräldrar förändrades som vi skall se. Jag kommer att börja detta avsnitt med att analysera omslaget till Arlas och Postens bok från 1977 (bild 4:14), och hur boken återspeglar diskursiva förändringar genom hur den skildrar barns röst, och relationer mellan barn och vuxna.

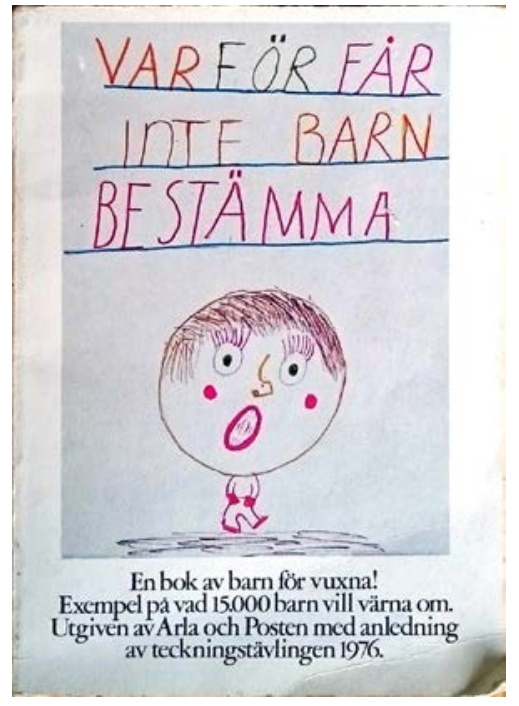

Bild 4:14. Omslag till boken Varför får inte barn bestämma (1977).

\section{Relationer mellan barn och vuxna}

En tydlig förändring mellan FIB:s tävlingar från 1938-46, och Arla/Postens tävling "Detta vill jag värna om" 1976/77 är att det finns en helt annan berättelse om makt och hur makt gestaltas genom bilderna, i och med att barnen 1977 uttalat kan ifrågasätta vuxenmakt i bilderna. Ett urval bilder från tävlingen Detta vill jag värna om publiceras i boken Varför fär inte barn bestämma (bild 4:14).

Omslagsbilden är tecknad med tuschpennor, mestadels i röda nyanser och texten är understruken med blått. Knappt halva bilden består av texten i versaler uppdelad på tre rader: 


\section{VARFÖR FÅR}

INTE BARN

BESTÄMMA

Under texten ser vi en bild av en figur med ett stort huvud, och en liten kropp. Huvudet är cirkulärt i formen och troligen tecknat genom att placera ett runt föremål på pappret. Figuren har röd vidöppen mun, uppspärrade ögon med långa ögonfransar och två röda prickar på kinderna. Håret är brunt och sitter nästan ihop med ögonfransarna. Bildens estetik konnoterar huvudfoting, alltså en teckning gjord av ett ganska litet barn, där huvudet är större/viktigare än kroppen. Den öppna munnen de uppspärrade ögonen och texten konnoterar också att barnet på bilden skriker ut texten ovanför - att barnet vill vara med och bestämma. Med tryckbokstäver står under bilden: "En bok av barn för vuxna! Exempel på vad 15000 barn vill värna om. Utgiven av Arla och Posten med anledning av teckningstävlingen 1976". ${ }^{724}$

I introduktionen till boken skriver Arla/Posten att de visar "ett urval teckningar från olika områden och hoppas att vi någorlunda väl lyckas spegla vad barn i Sverige tycker är angeläget just nu...Med idéer och synpunkter som vi hoppas att ni ska vilja uppmärksamma och diskutera tillsammans. Arla/Posten." 725 På ett uppslag syns en porträttbild i svartvitt av Danny Kaye, en amerikansk skådespelare, men här är han med som företrädare för UNICEF:s barnfond. ”Teckningarna i den här boken talar direkt till oss" är rubriken. Och Kaye fortsätter:

De visar alldeles tydligt att barnen hör och ser och lever med i samma värld som vi ... De funderar över samma problem som vi. Ska vi då inte ge oss tid att lyssna till våra barn - och låta deras åsikter påverka oss? Barnen är det viktigaste vi har. Det är deras framtid vi skapar. Låt oss ta våra barn på allvar! Danny Kaye" 726

Vid bokens tredje och sista introduktionstext visas en bild av en kvinna vid ett skrivbord som vi förstår av bildtexten är barnpsykolog Kerstin Fällström, verksam vid psykologiska institutionen på Göteborgs universitet. Fällström menar i texten att de flesta barn har lättare att kommunicera via bilder än genom ord. Hon menar att barn borde tillåtas vara med och bestämma mer, och att det är väsentligt att tidigt låta barn vara med i diskussioner i familjen.

Att steg för steg låta barnen vara med och bestämma om familjens aktiviteter ökar sammanhållningen, men ger också självständiga och ansvarsmedvetna familjemedlemmar. Så börja tala med era barn medan tid är. Denna bok ger konkreta bevis på att barn från förskoleåldern och upp till tonåren är spännande och utvecklande att umgås med. ${ }^{727}$

\footnotetext{
724 Varför fär inte barn bestämma: en bok av barn för vuxna! .... (1977). Stockholm: Utg.

725 Ibid.sid. 3.

726 Ibid. sid. 5.

727 Ibid. sid. 7.
} 


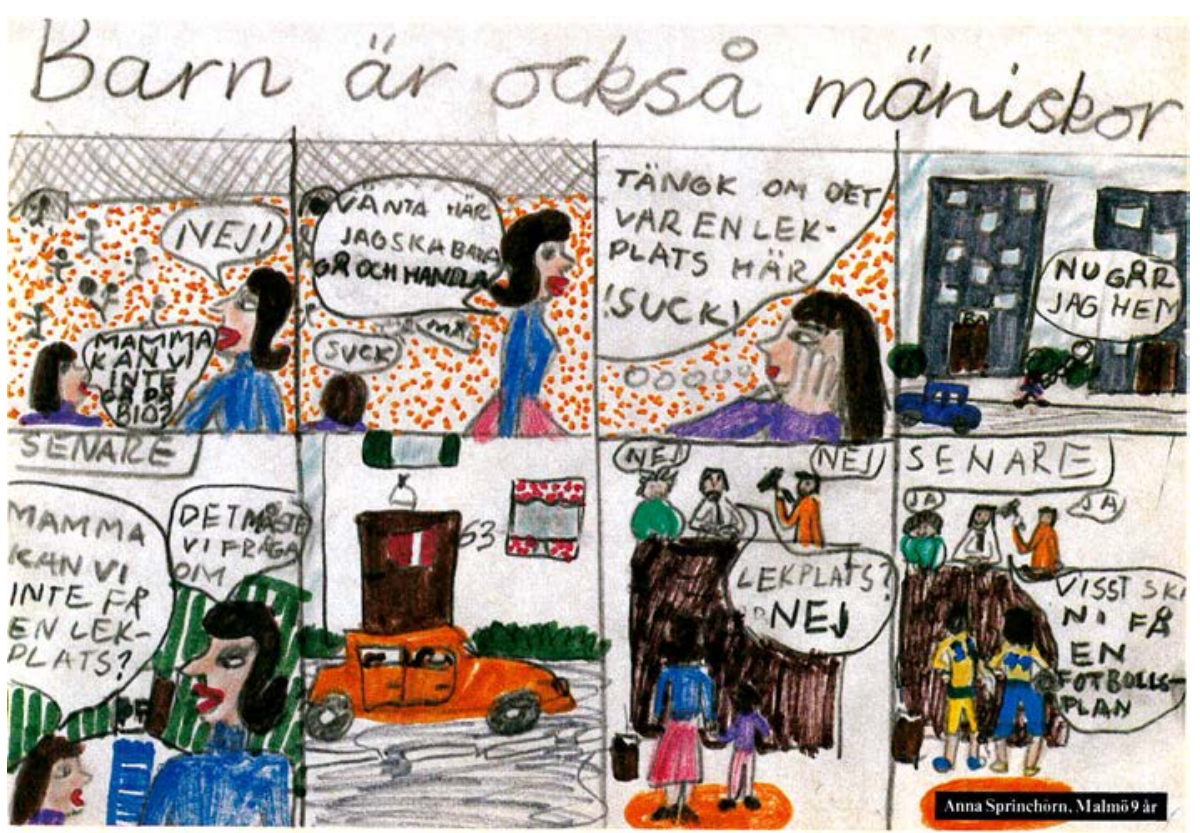

Bild 4.15. Anna Sprinehorn i Varför fär inte barn bestämma (1977).

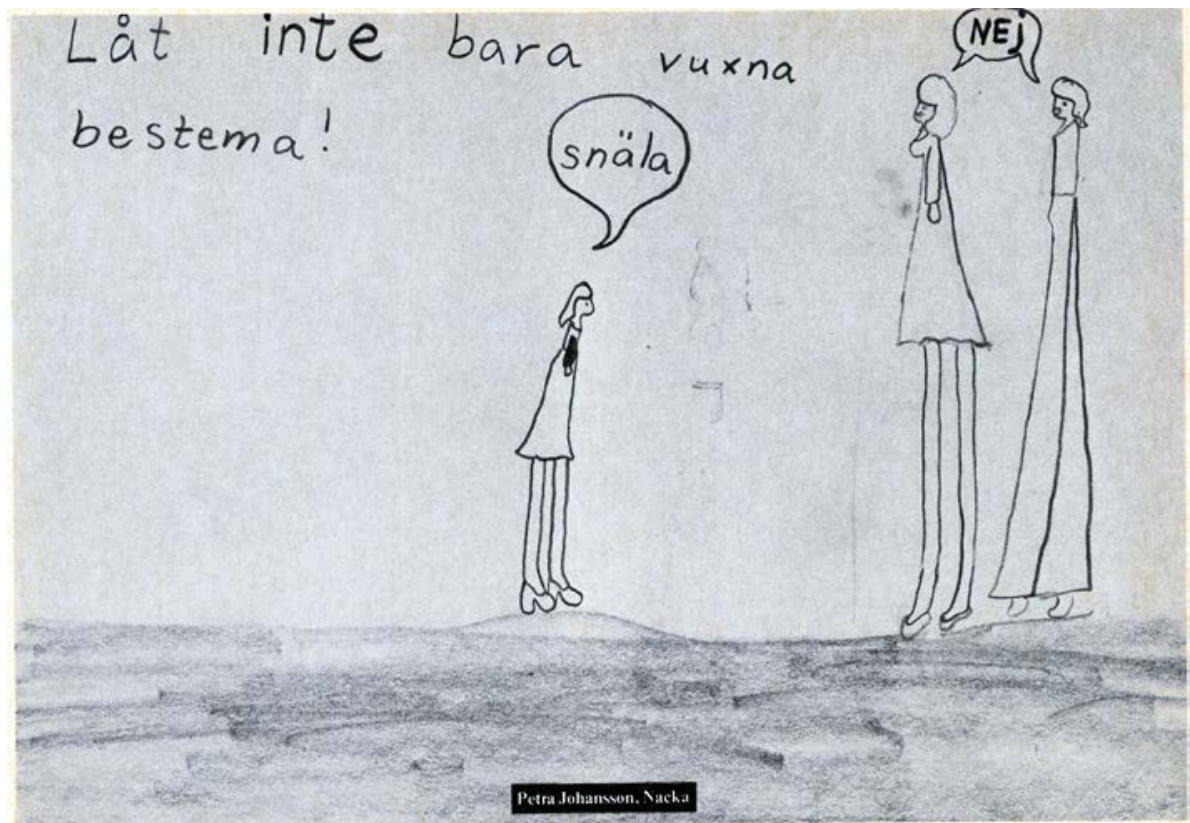

Bild 4:16. Petra Johansson i Varför får inte barn bestämma (1977). 
Boken och dess bilder användes alltså som ett incitament för att förändra vuxnas attityder mot barn, snarare än att som FIB:s eller Televerkets tävlingar visa fram barns konstkompetenser. För att barn skulle bli självständiga och ansvarsmedvetna som vuxna behövde de vara med och bestämma, och genom att lyssna på barnen och studera deras bilder, kunde även de vuxna få erfara en spännande utveckling.

I serien i bild 4:15 "Barn är också mäniskor"(sic). av Anna Sprinehorn i Malmö så drömmer flickan om en lekplats. $\mathrm{F}=$ Flickan $\mathrm{M}=$ Mamman $\mathrm{K}=\mathrm{Kommunen}$

Bild1 F: Mamma kan vi inte gå på bio? M: Nej!

Bild2M: Vänta här ska jag gå och handla. F: Suck. Bakgrund: Mål!

Bild3 F: Tänk om det var en lekplats här. Suck.

Bild4F: Nu går jag hem

Bild5 Bildtext: Senare. F: Mamma kan inte vi få en lekplats? M: Det måste vi fråga om.

Bild7 K: Nej Nej, Lekplats? Nej

Bild8 Bildtext: senare K: Ja, ja Visst ska ni få en fotbollsplan!

Bilden refererar till en serietidning så som den är uppbyggd med rutor och pratbubblor. Serie som form refererar också till barn och ungdom. Seriens innehåll refererar både till en "mor och dotter-relation" liksom till politik och makt. Barnets "röst" i denna bild talar framför allt till vuxenvärlden - dels föräldrar och dels andra vuxna som är med och bestämmer, och bestämmer på ett sätt så att barns önskemål inte lyssnas till. Mamman och flickan sammankopplas också dels genom utseende och dels genom den underordnade position de har i bild sju, där männen med ordförandeklubba sitter på ett podium högt ovanför dem som de måste titta upp till.

De vuxna, männen, beskrivs i serien som människor med värde och rättigheter, men flickan upplever sig inte tagen på allvar. Hon blir först ignorerad och nonchalerad av sin mamma, och sedan blir både hon och mamman ignorerad av männen med makten. Bildens titel refererar till att barn borde tas på allvar som människor, där bildserien ger ett exempel på när barn inte getts lika värde. I denna bild liksom i bild 5:12 (i nästa kapitel) "Jag tycker det är fel att man inte får vara med pojkarna" finns en tydlig önskan om samhällsförändring; eftersom barn är människor, och inte "bara" barn, borde deras åsikt spela roll. En förändring jämfört med 1940-talets tävling, är också det tydliga tilltalet i Arlas tävling genom vilket barn positioneras som "delaktiga i samhället". Barn ombeds nu inte bara berätta om "sin värld", utan även att tala om hur de vill förändra den, och positioneras som därmed som möjliga samhällsförändrare, om de vuxna lyssnar.

I bilden "barn är också människor" berättas hur flickan och hennes mamma går till "de som bestämmer" med ordförandeklubba i handen och frågar efter en lekplats, men blir nekade, fotbollsspelarna däremot får en fotbollsplan. Att leka värderas alltså inte som lika viktigt som att spela fotboll, vilket tecknaren ifrågasätter. Även bilden tecknad av Petra Johansson i Nacka gestaltar maktförhållanden och önskan om förändring är tydligt både i text och bild: Låt inte bara vuxna bestema! står det överst till vänster i bild. Och längst till höger i bild står 
två "vuxna" som refererar till "mamma" med kort klänning och "pappa" med byxor, de står upp och är så långa att de nästan inte får plats i bilden. ${ }^{728}$ Från båda kommer pratbubblan "NEJ". I mitten av bilden står barnet hälften så lång med kort klänning, och i hennes pratbubbla står "snäla"(bild 4:16). Denna bild associerar även till titeln på boken "varför får inte barn bestämma" och liksom med männen från kommunen som säger nej, framstår de vuxnas nej här som en ren maktutövning. Om barnet i "barn är också människor" lierar sig med mamman mot männen i kommunen, upplevs flickan i denna bild ensam och utlämnad till föräldrarnas godtycke. Utan att lyssna till barnet säger de vuxna nej bara för att de kan. Visuellt uppfattas föräldrarna som oerhört stora, med långa ben $\mathrm{i}$ underifrånperspektiv, vilket ytterligare refererar till känslan av att de befinner sig "där uppe" i en upphöjd position, utan vilja eller förmåga att se barnets behov.

Flertalet bilder visar uppmaningar med en trolig vuxen mottagare, som att sluta utrota djur, sluta förstöra miljön eller att vuxna har byggt stora sjukhus och för stora skolor. Samtidigt framställs i andra bilder att barn själva behöver uppfostras för att lära sig ett önskvärt beteende. Exempelvis i bilder som; "Lär er simma", "Visa mer respekt för gamla", "Glöm inte flytvästen", ”Ät inte snask", "Lek inte med elden", "Sluta palla", eller "Köp inte smalare jeans än du själv är" visar både bilder och text tydligt att uppmaningarna riktas från barn till andra barn. Det är alltså inte enbart vuxna som ska lära sig lyssna till barn, barnen har även ett uppdrag av självuppfostran, där Arla väljer vilka av barnens uppmaningar man vill publicera i boken Varför fär inte barn bestämma. Om barn fick bestämma är det alltså viktigt att inte bara vuxna, utan även andra barn lyssnar till och accepterar barnens (Arlas/Postens) uppmaningar och normer. På liknande sätt visar Televerkets tävling 1983 "Så vill vi ha det i trafiken där vi bor" exempelvis problem med att bilar kör för fort, men majoriteten av bilderna visar dessutom barn som använder reflex. Bilderna används alltså för att gestalta ett säkerhetstänkande hos barnen själva. ${ }^{729}$

\section{Platser för vardag och fritid - var kan och bör barn vara}

Att barndomsdisksursen förändras och delvis omdefinieras är också tydligt vid jämförelse över tid i hur lek och fritid framställs mellan 1940-tal och 1970-tal. Förändring över tid i bildernas beskrivning av vilka platser barn kan och bör vara på är i fokus för detta delavsnitt. Jag utgår ifrån bilder i FIB:s tävlingar "Våra lekar", "Min fritid", och "När jag plockade... bär, frukt m.m." samt Arlas/Postens tävling "detta vill jag värna om" 1976 . Om vi jämför bild 4:17 och 4:18 av barn som pallar äpplen, så avbildas i bild 4:17 från 1976 en glad flicka vid ett äppelträd med uppsträckt arm, och en pinne $\mathrm{i}$ armen, som når upp till ett av äpplena i trädet. Genom bildens titel till vänster "Sluta palla" förstår vi budskapet. Även om det kan vara lockande med äpplen, så bör barn sluta att palla äpplen, alltså ta äpplen från äppelträd som tillhör någon annan. I boken Varför får inte barn

${ }^{728}$ Bild från Varför får inte barn bestämma: en bok av barn för vuxna! . (1977). Stockholm: Utg. sid. 46.

729 Bild från Varför får inte barn bestämma: en bok av barn för vuxna! (1977). Stockholm: Utg. Sid. 117. 


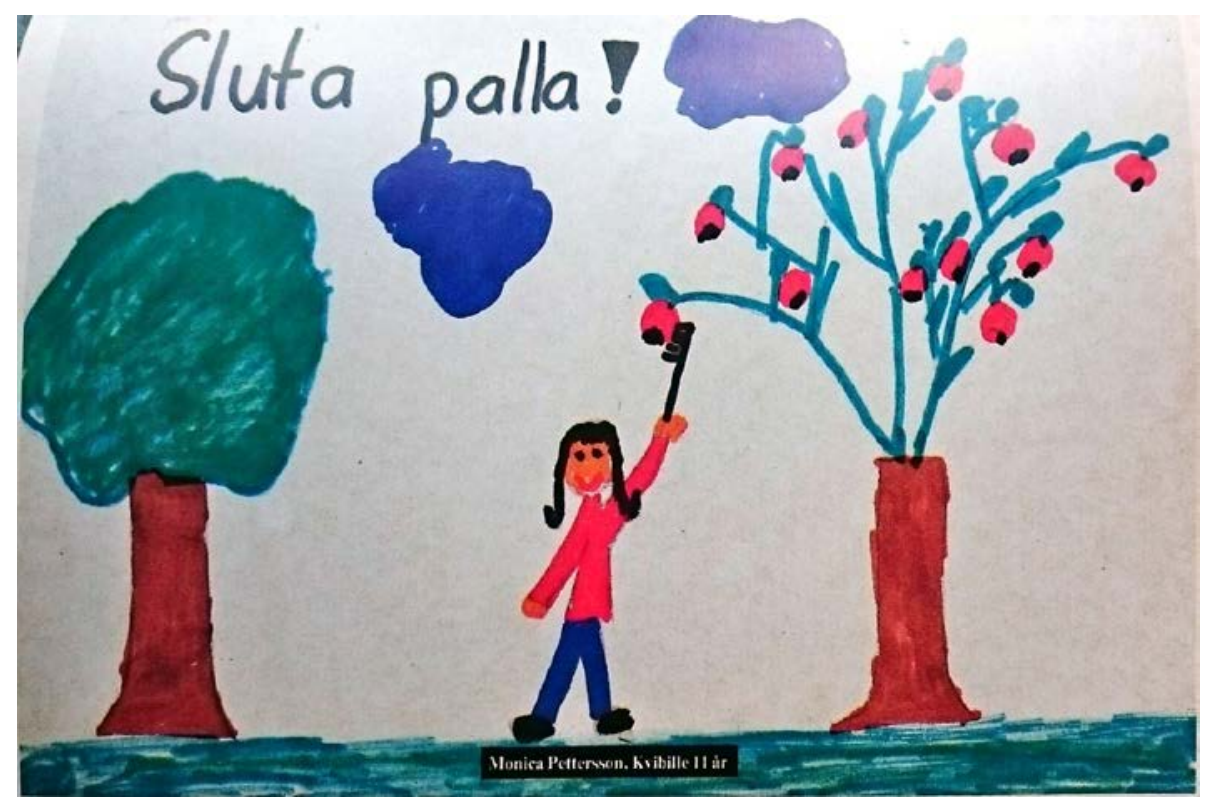

Bild 4:17. Monica Petterson i Varför fär inte barn bestämma (1977).

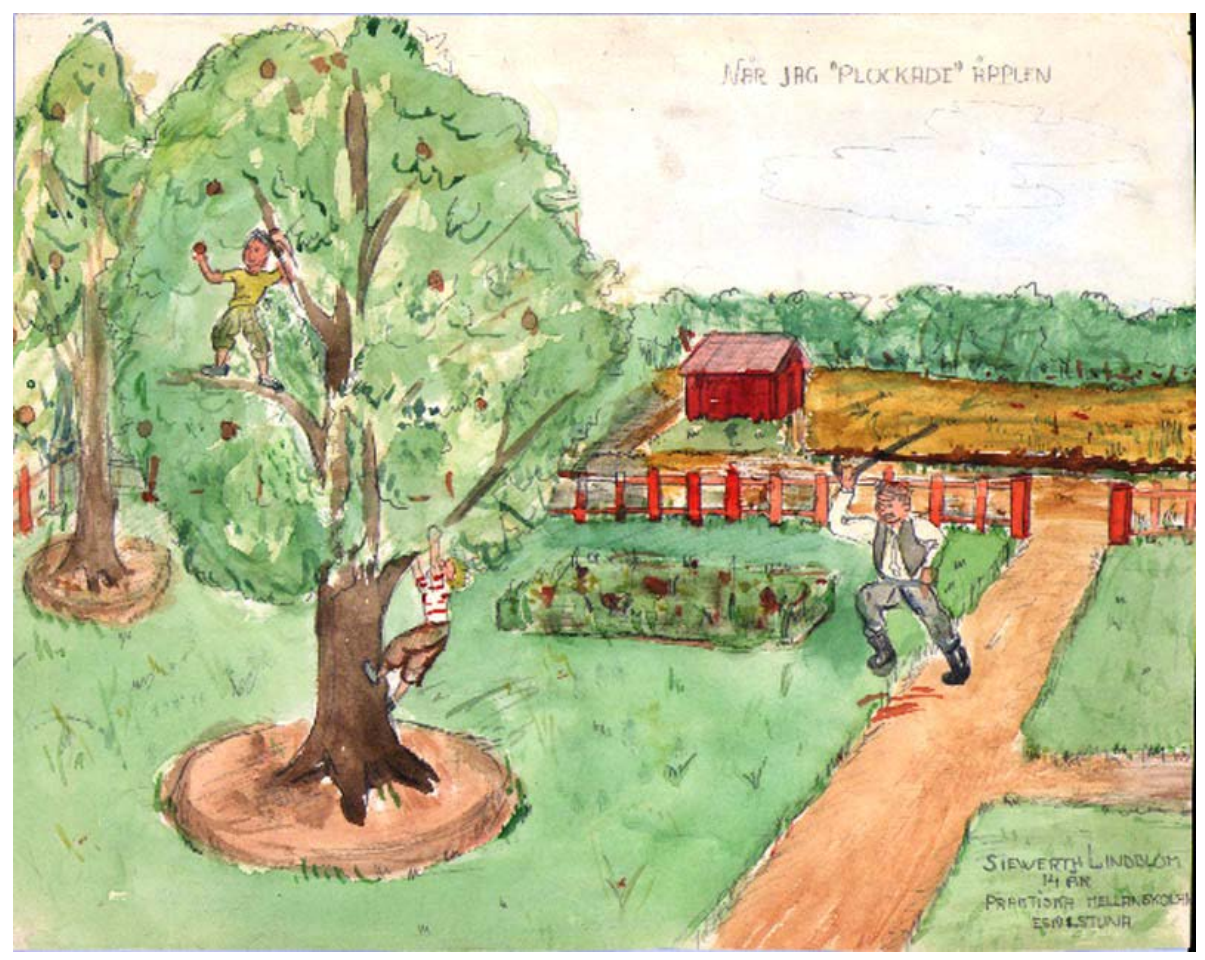

Bild 4: 18. När jag plockade bär, frukt m.m., FIB:s tävling 1946 
bestämma 1977 korrigeras barns beteende inte av vuxna utan av barnen själva. I bild 4:18 från 1946, så är det den vuxne mannen som kommer springande med en käpp i handen mot två barn som sitter i äppleträdet till vänster i bild och jagar barnen i bilden "När jag "plockade” äpplen”. Miljön är en trädgård med fruktträd och trädgårdsland, och vi förstår av mannen med käppen och bildens citattecken "plockade" att barnen inte plockar utan pallar äpplen. Att gestalta barns risktagande och gränsöverskridande kring vad som är tillåtet, som del av en berättelse om vad barndom kan innebära, fungerar 1946.730

Det fokus som finns i FIB :s tävlingar på 1940-talet, med teman som "våra lekar" eller Min fritid" visar på vuxnas intresse och nyfikenhet på barns egna platser för lek som inte syns i tävlingar på 1970-talet. Dels frågar arrangörer inte explicit efter bilder av barns lekar, dels är de när de framställs, delvis lekar som är kontrollerade av vuxenvärlden. ${ }^{731}$ Under 1970-talet definierades fler platser som tydligt olämpliga (eller lämpliga) för barn att vara på.

Bilden "Isjumpning" från temat Våra lekar 1945 avbildas åtta pojkar på eller runt isflak på vattnet, bredvid en brygga (bild 4:19). Vi ser en pojke med (skol) portfölj som är mitt i steget och hoppar mellan två isflak. Bilden konnoterar lek och rörelse. En person har ramlat på ett isflak, vi förstår att det är halt, lite farligt och samtidigt spännande. Det finns ytterligare en bild som gestaltar isjumpning under temat mitt roligaste skolminne. I båda dessa bilder framställs barns och ungdomars lek vid vatten som oproblematisk, det framställs till och med som det roligaste skolminnet. Barn i relation till vatten gestaltas i Arlas tävling av en bild med texten Glöm inte flytvästen!!! då kan det gå illa. Bilden visar en överkorsad pojke som sitter på en brygga och fiskar, och över honom en flytväst i närbild. Till höger i bild har pojken flytväst, och är inte överkorsad (bild 4:20). Korset blir det som i bilden symboliserar fara, och hur man inte bör göra. ${ }^{732}$ Likaså finns en bild av två barn i vattnet med texten: "Lär er simma!". Då 40-talets bilder kunde visa att det var roligt med utmanande lekar som konnoterar oförskräckta, kavata barn är 70-talets bilder av lekar och fritid omgärdade av uppmaningar utifrån ett vuxet säkerhetstänkande, även om uppmaningarna riktas från barn till andra barn. Barnen blir själva bärare av uppförandenormerna.

1944 är temat för FIB:s tävling "Min fritid”, det finns 53 bilder med detta tema i Nationalmuseums samling. Föreställningar om barns arbete och fritid, och betydelsen av att vara barn ser olika ut över tid och i relation till plats. Vad barn betraktade som, och ville visa upp som "sin fritid" 1944 var varierande, och kan ses spegla barnens olika sociala bakgrund. En stor del av bilderna visar barn i olika former av hushållsarbete eller i jord- och skogsbruk. ${ }^{733}$ Söderlind och Engwall skriver i Barndom och arbete att barndom ofta definierats som mot-

\footnotetext{
${ }^{730}$ Vilka beteenden som är önskvärda kan också variera med barnens ålder, men jag har här valt att se tävlingsbilderna som uttryck för arrangörernas barndomsideal.

731 som när flickan i föregående delavsnitt (Bild 4:14) går med sin mamma för att få dem att göra en lekplats.

${ }^{732}$ Lind Ulla (2010) har också diskuterat överkorsningar som kulturellt tecken för negation. Sid. 338.

${ }^{733}$ Baxter, Jane Eva (2005). Även arkeologiska fynd visar att barns arbete långt tillbaka i historien varit väsentligt inom jordbruk.
} 


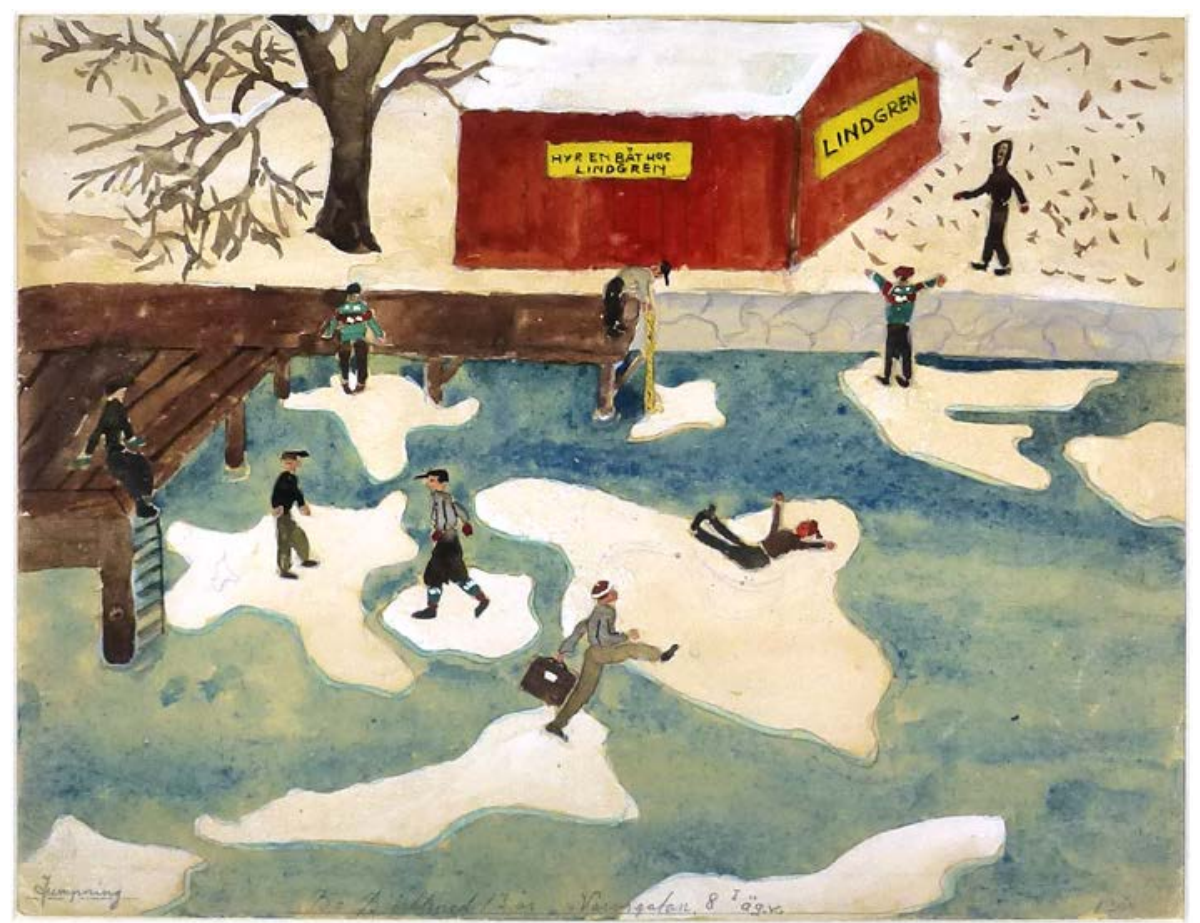

Bild 4:19. Våra lekar, FIB:s tävling 1945

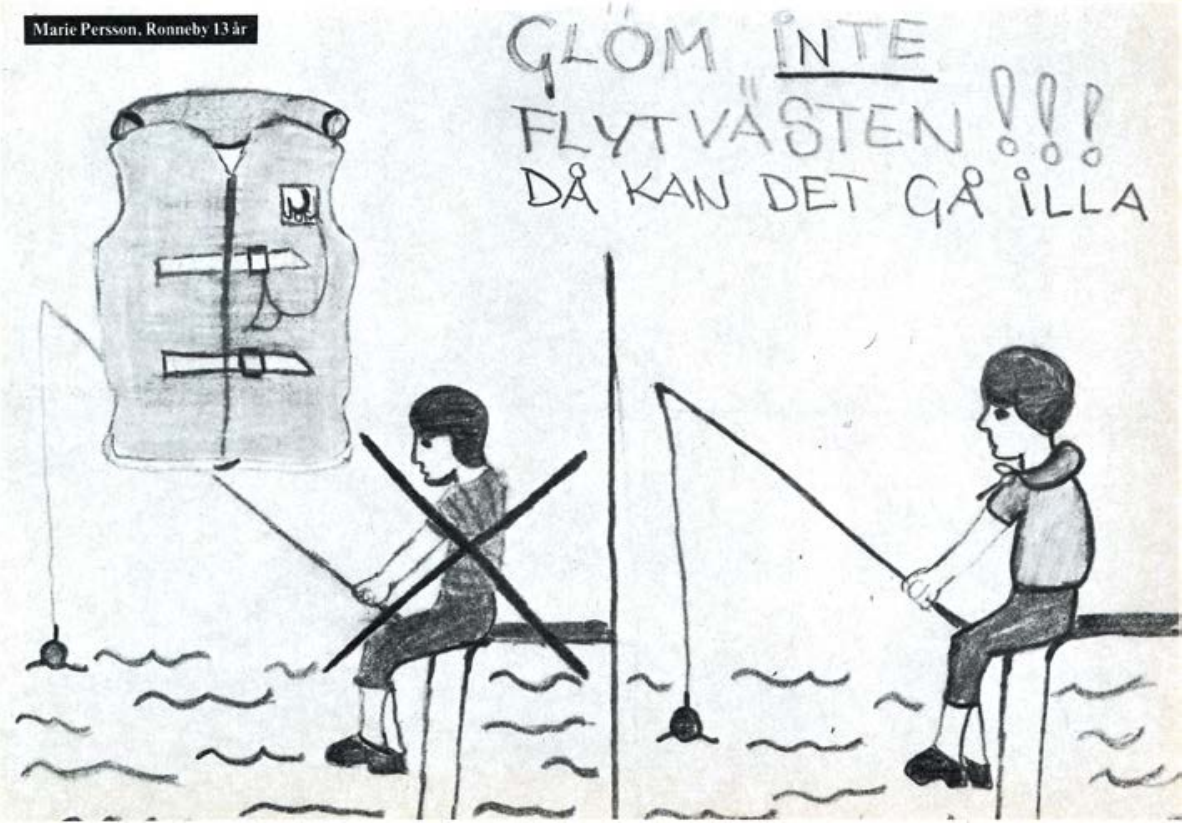

Bild 4:20. Marie Persson i Varför får inte barn bestämma (1977). 
satsen till arbete, men de poängterar också att arbete inom jordbruk och inom hemmet varit positivt värderat och att det dåliga arbetet var betalt industriarbete. ${ }^{734}$ Just barnarbete inom jordbruk var också undantagna från arbetarskyddslagstiftningen 1912 och 1949. "I alla lagar betraktades skolan som det primära i barnens liv och skolgången fick inte åsidosättas på grund av arbete" skriver Mats Sjöberg i Barnförbjudet och barntillåtet - gränser för ungas arbete 1950-2000, men han observerar också att just arbete i jordbruk var ett undantag ända fram till 1980-talet. ${ }^{735}$

I 29 av de 43 bilderna från Nationalmuseums samling 1940 associeras barns fritid till olika former av hemarbete, i 17 bilder hur de på olika sätt arbetar inom jordbruket. De flesta av dessa, sju bilder, visar skötsel av kor, att valla dem, mjölka dem, antingen för hand eller i en bild med mjölkmaskin. ${ }^{736}$ Tre bilder visar arbete i skogen, men det kan också vara att arbeta med höskörd, harva, plocka kottar, baka bröd, diska eller huga ved. Två bilder visar "att gå och handla" och fem bilder visar fiske eller jakt, gestaltat både som fritidsnöje och som ett bidrag till familjens gemensamma arbete. ${ }^{737}$ Andra fritidssysselsättningar är skidåkning och snöbollskastning. Även åka i släde eller kappsegla, bada och campa i tält eller vara med i scouterna och träna livräddning är avbildat.

Bilden ur samlingen Min fritid: "Mjölkning i hagen klockan sex på morgonen" visar en blond flicka till höger I bild med en röd och vitrutig klänning och vitt förkläde, och två spannar i vardera hand (bild 4:21). Bilden kan både referera till hårt arbete, kanske ser flickan lite sorgsen ut? Men den refererar även till en idyll med en soluppgång över en beteshage med kor och hästar som betar. ${ }^{738}$ Så att delta i hushållsarbete framställs i denna vinnarbild som idylliskt, snarare än som utnyttjande av barnarbetskraft eller inskränkande av barns skolgång.

I bild 4:22 också med titeln "Min fritid" ser vi en pojke i förgrunden som står med en yxa höjd bakom huvudet, fångad mitt i arbetet i färd med att kapa grenar från granen han förmodligen nyss fällt. Förutom granen på marken finns ytterligare fyra barrträd/granar i bilden, och tre träd där den runda trädkronan konnoterar lövträd. Vid trädet längst till vänster i bild står ett gevär lutat och bredvid ligger en stor såg. Då bildens titel är "min fritid" konnoterar det att det är den 13 årige pojken som tecknar bilden vi ser i bilden. Bilden framställer genom sin bild och text, att barnet på sin fritid arbetar i skogen, med kunskap i att använda yxa, såg och gevär. Detta har även synts i andra bilder av fritiden, som jag nämnde ovan. Barnen avbildar sig själva som kompetenta, och vuxenlika. Utvalda av FIB och Nationalmuseum blir de även att betrakta som föredöme för andra barn.

\footnotetext{
734 Söderlind, Ingrid \& Engwall, Kristina (red). (2008). Barndom och arbete. 1. uppl. Umeå: Boréa.

${ }^{735}$ Söderlind, Ingrid \& Engwall, Kristina (red). (2008) sid. 37.

${ }^{736}$ I bilden med mjölkmaskin är det en pojke som mjölkar annars är det flickor.

${ }^{737}$ Fiske som fritidssysselsättning syns också i Arlas bild 1977 även om det är användandet av flytvästen som är i fokus för bildens budskap.

${ }^{738}$ Nationalmuseums samling Min fritid 1941 av Greta Mattson 12 år.
} 


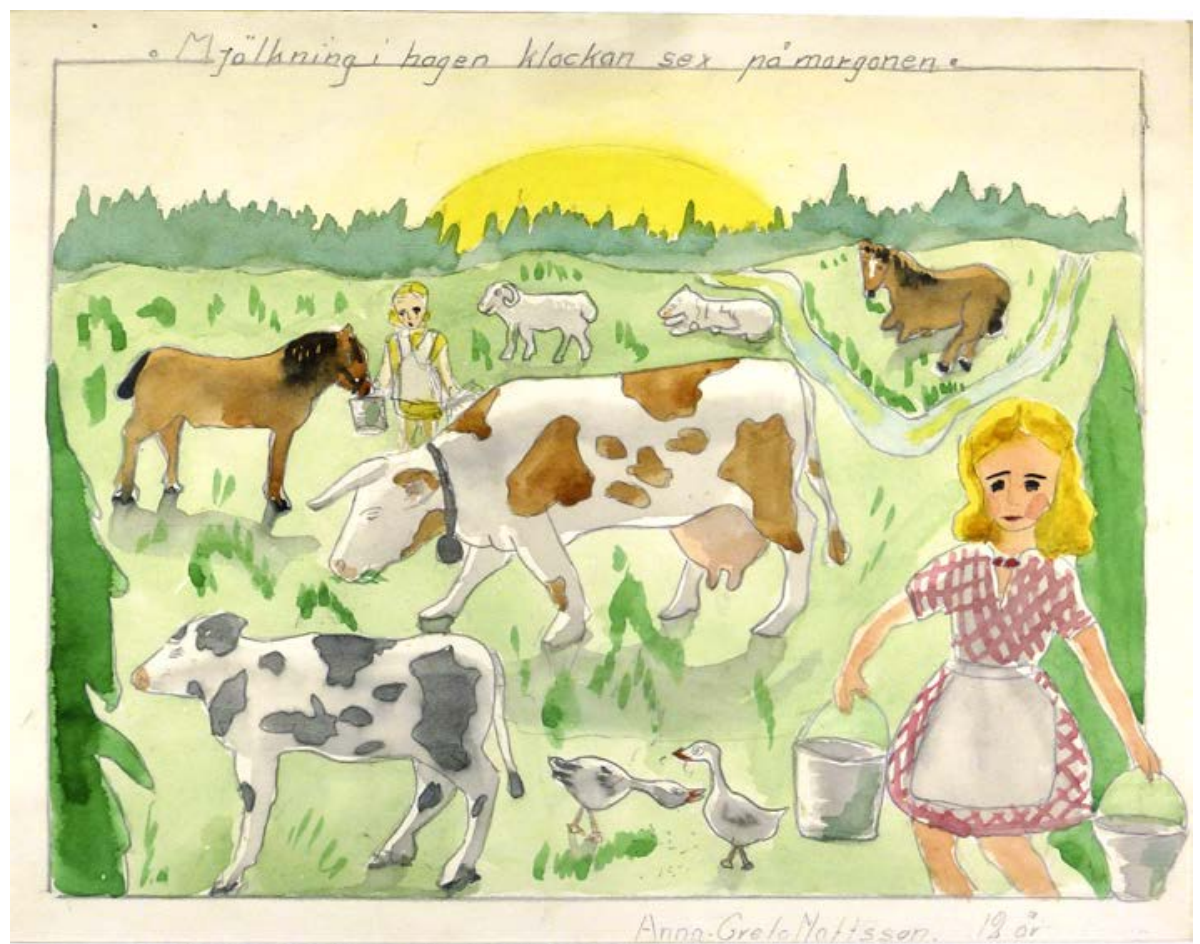

Bild 4:21. Min fritid, FIB:s tävling 1940.

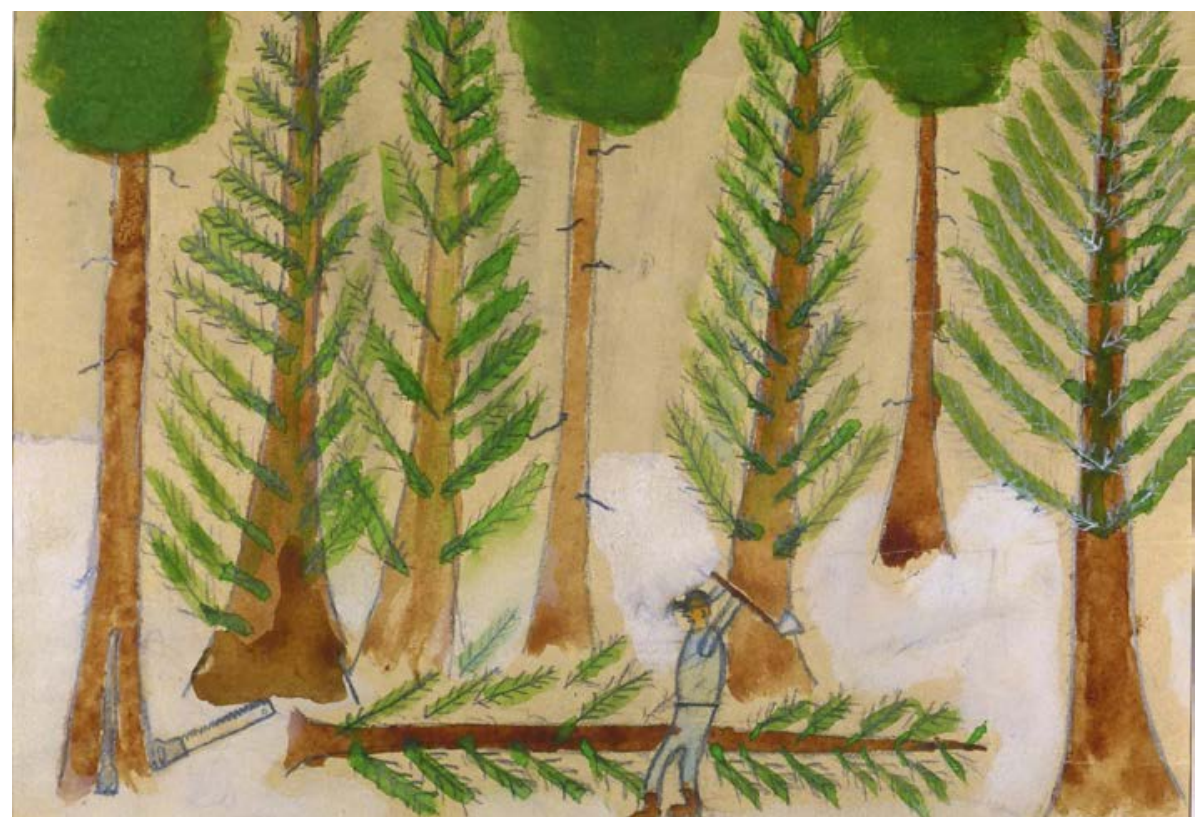

Bild 4:22. Min fritid, FIB:s tävling 1940. 
Det finns även mer medelklassbetonade fritidssysselsättningar, som också är inomhusaktiviteter. Samlingen innehåller tre bilder av barn som spelar piano. Det är två flickor och en pojke. Det förekommer även andra instrument, en bild av en bastuba och en pojke som spelar trumpet. Andra inomhusaktiviteter som avbildats är att sitta i sköna fåtöljer och läsa eller sticka, lyssna på radio eller som i bild 4:23, att måla akvarell.

I bilden av Ulf Ekdahl 14 år, ser vi en pojke centralt placerad i bilden, han sitter vid ett bord och målar med vattenfärger (bild 4:23). Han håller penseln $\mathrm{i}$ handen på det vita pappret framför sig, men blickar samtidigt ut över något snett till höger i bild. Kanske studerar han det han målar av? Till höger om pappret syns en färglåda och till vänster en kopp med vatten. Pojken sitter i ett rum med fyra stora fönster, likt ett burspråk. Till höger i bild syns en stor grön växt som likt en murgröna slingrar sig upp runt det högra fönstret. I de övriga tre fönstren syns ytterligare fyra krukväxter. Utanför fönstren syns ett grönskande sommarlandskap med björkar, granar och ett rött hus med svart tak i bakgrunden.

$$
* * *
$$

Bilderna visar hur "fritid" associerades med tiden som var utanför skolarbetet, och att det då ofta innebar annat arbete än skolarbete, snarare än tid för egna fritidsaktiviteter. En möjlig utgångspunkt för analysen är att se hur bilderna beskriver barns tillgång till vad Bourdieu kallar "kulturellt kapital" och att det kulturella kapitalet, genom skolan och den nya teckningsundervisningen, förväntas nå ut till alla barn. ${ }^{739}$ Medelklassens ideal och livsstil skulle förmedlas till arbetare och bönder. Bilder av barn som spelar instrument, eller målar kunde visa detta. Även de barn som har avbildat sig som arbetande, har i skolan målat likt pojken i bild 4:22 och vunnit i teckningstävlingen. Som jag visade i föregående kapitel hade FIB och teckningslärarförbundet en tydlig intention att lyfta fram att alla kunde delta och att "ingen skulle känns sig underlägsen" även om de gick i Beller C skolor. Lekar eller aktiviteter som ansågs opassande eller farliga, beskrevs i Arlas tävling 1977 av barnen själva som opassande, som att palla äpplen, eller bada utan att kunna simma, eller vara vid vattnet utan flytväst. I tidigare tävlingar kunde barn porträtteras i "sin egen värld" utanför vuxenvärldens normer, även om de tillrättavisades av vuxna.

\section{Platser i rörelse?}

Analysen av bilderna visar också att platser inte är beständiga. I Arlas bok från 1977 Varför fär inte barn bestämma finns en tydlig förändring mot ett globalt engagemang och att barn betraktar hela världen som en gemensam platstillhörighet, vilket visualiseras bland annat med hjälp av jordklotet.

Dessa två bilder är exempel på det (bild 4:24, 4:25). Bilderna av jordklotet i rymden, som togs från rymdfarkosten Apollo 171972 och publicerades i media, har av många människor beskrivits som bilder som förändrade deras

739 Fowler, Bridget (1997). Pierre Bourdieu and cultural theory: critical investigations. London: Sage sid. 49. 


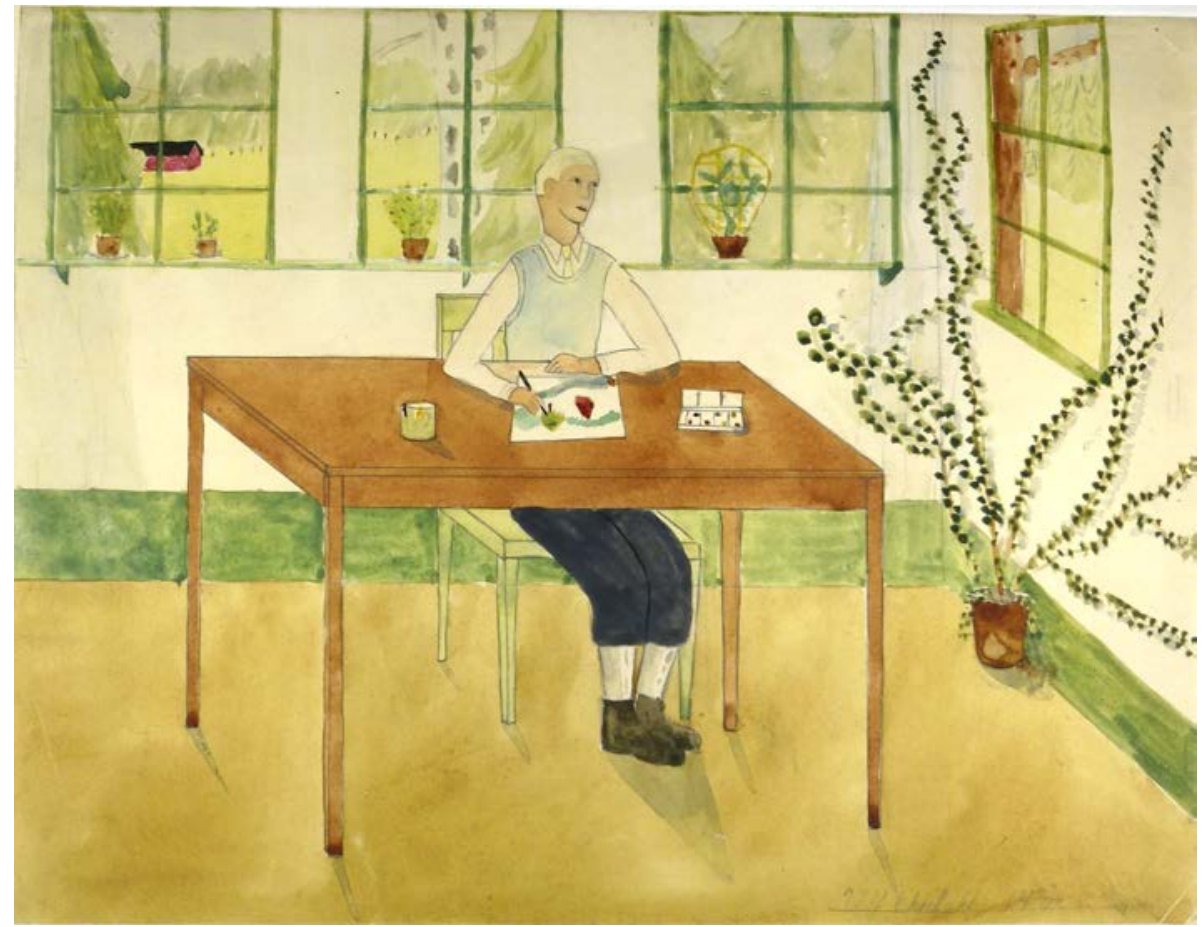

Bild 4.23. Min fritid, FIB:s tävling 1940.

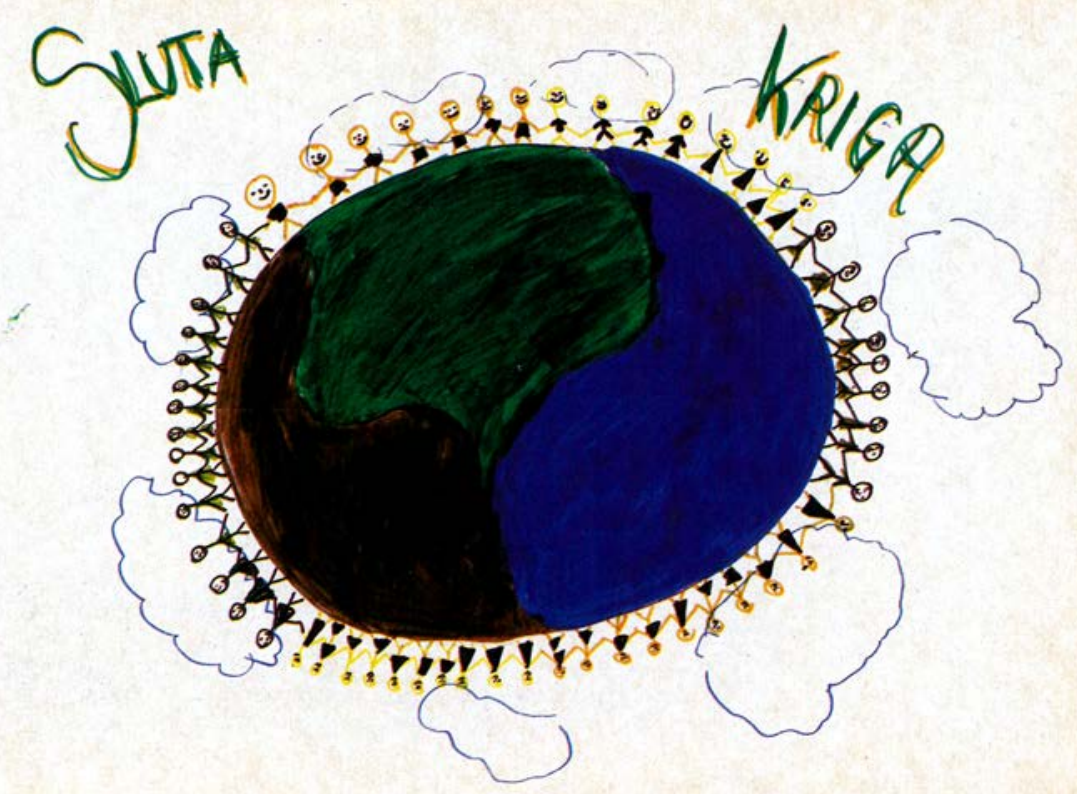

Bild 4:24. Bild publicerad i Varför får inte barn bestämma, (1977). 
Vinnande bilder: Teckningstävlingar för barn 1938-2000

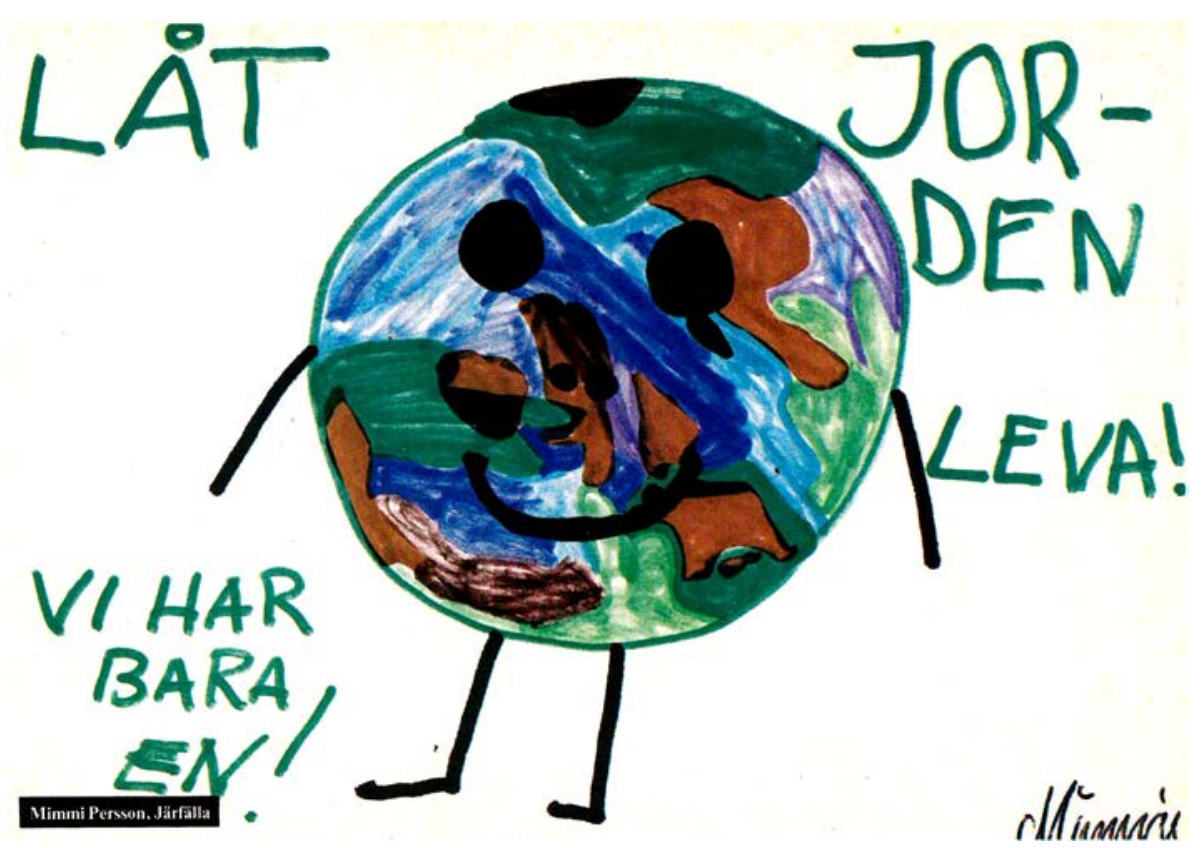

Bild 4:25. Mimmi Persson i Varför får inte barn bestämma (1977).

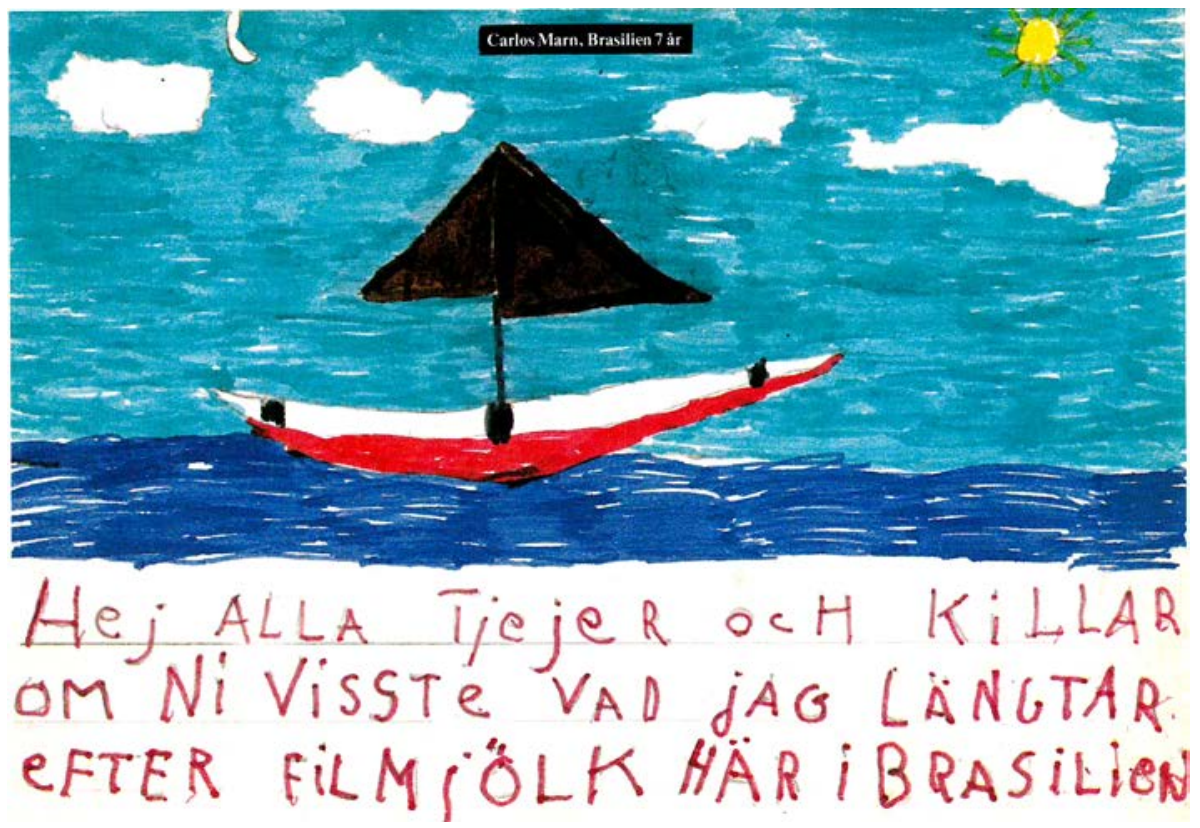

Bild 4:26. Carlos Marn i Varför får inte barn bestämma (1977). 
sätt att se på världen. ${ }^{740}$ Nicholas Mirzoeff menar att bilden visade jorden som en sammanhållen helhet, the blue marble, och inspirerade utopiska tankar om världsparlament och kanske även ett världsspråk. ${ }^{741}$ Bilden av jordklotet som en självklar del av barns vardag syns också i Sparrmans studie om barns visuella kulturer från 2006, där barn på fritidshem diskuterar och färglägger jordklotet utifrån olika länders namn. ${ }^{742}$

I bild 4:24 symboliserar jordklotet ett hem för väldigt många människor människor som håller varandra $i$ hand och uppmaningen i bilden är "Sluta kriga". Att alla människor runt jordklotet hör ihop symboliseras av många små människofigurer som står och håller varandra i hand, runt klotet. Några av figurerna är tecknade med ljus, gulaktig penna, några med mörkare, brunaktig penna, några har tecken för kjol, andra inte. Gestalternas små skillnader konnoterar att det är både flickor/kvinnor och pojkar/män och människor med olika hudfärg som håller varandra i hand runt jordklotet.

Ovanför klotet är textat "Sluta kriga". Om vi jämför med texten "FRED" på bilden av 1a majtåget i kapitel 3, så refererar "sluta kriga" till att det är någon som börjat kriga, och som kan sluta, på ett annat sätt än det mera abstrakta begreppet "Fred". Här finns en mer direkt uppmaning, från barn till vuxna.

På samma sätt kan bild 4:25 förstås innehålla en uppmaning från barn till vuxna. I denna tuschteckning har jordklotet färgerna brunt, grönt och blått i olika fält. men genom att klotet också har ögon, näsa och mun i svart tusch, och armar avbildade som svarta streck, blir jordklotet även en bild av en glad gubbe. Jorden har avtecknats delvis som ett "barn", en huvudfoting med armar och ben. Med texten "Låt jorden leva! Vi har bara en" riktas budskapet som en uppmaning till en tänkt mottagare, i första hand en vuxen. Det finns ett underförstått budskap om att jorden, framställd som ett barn, riskerar att inte överleva, vilket även drabbar jordens barn. I dessa båda bilder tilltalas, främst de som läser svenska, genom att texten är på svenska, men i en större kontext egentligen alla barn och vuxna. ${ }^{743}$

Denna bild av Carlos Marn, Brasilien 7 år, är publicerad i Arlas och Postens bok Varför fär inte barn bestämma 1977. Bilden har titeln "Hej ALLA TjejeR OCH KiLLAR OM Ni VissTe VAD jAG LÄNGTAR eFTER FiLMjöLK HÄR i BrASiLiEN." (bild 4:26)

Genom bildtexten kan bilden ses som medverkande i en reklamdiskurs för Arlas produkter. Bilden är tecknad med tuschpennor och visar en röd och vit segelbåt på mörkblått vatten mot en ljusare blå himmel, några vita moln och en sol uppe i högra hörnet, med texten under bilden. Bilden innehåller ingen bild av filmjölk men vi förstår av kontexten att det är "svensk filmjölk" som längtas efter. En möjlig tolkning är att pojken som gjort bilden är på båten, eller ser båten, när han är i Brasilien. Under vistelsen i Brasilien längtar han efter filmjölk. Att pojken beskriver att han är "i Brasilien” öppnar för en diskursiv förändring

\footnotetext{
${ }^{740}$ Mirzoeff, Nicholas (2015) How to see the world. 1. uppl. London: Pelican sid. 4.

741 Ibid. sid. $4 \mathrm{f}$.

742 Sparrman, Anna (2006).

${ }^{743}$ Denna typ av bilder finns också i internationella samlingar. Se tex Livets träd 1992:052 SBBA.
} 
jämfört med bilder från de tidigare tävlingarna. Bilden visar hur barns platser och subjektspositioner har breddats i jämförelse med 1940-talets tävlingar.

1970-talet var ett betydligt rörligare samhälle, än 1940-talet då få familjer hade möjligheter att resa utomlands, och gränserna var i princip stängda på grund av kriget. ${ }^{744}$ Att förflytta sin plats kan i sig skapa berättelser om en längtan tillbaka till det man lämnat, som filmjölk, eller som i Mobergs beskrivning av hur Kristina som utvandrat från Sverige under 1800-talet i Sista brevet till Sverige längtar efter svenska äpplen. ${ }^{745}$ Här använder Arla barnbilden för att visa hur produkten "filmjölk" är något värt att längta efter.

Det internationella temat är också framträdande i Televerkets sista tävlingar under 1990-talet. Televerket, som 1993 blir ett privat bolag och byter namn till Telia, har i sin tävling 1993 temat "Den gränslösa världen", med följande bildutskick till skolorna (bild 4:27). På bilden syns ett stort hjärta utformat av sönderklippta kartbilder. Länder har formats som ett hjärta omgivet av hav. Texten på framsidan är: "Telias bildtävling1993: Den gränslösa världen" Tävlingen var riktad till årskurs sex och uppgiften var att "uppfinna framtidens resemaskin och beskriva din egen teleresa i en gränslös värld" De vinnande bidragen från varje region ställdes ut på Telemuseum. Här blir barnen delaktiga i att "uppfinna framtiden" och där hjärtat som symbol för kärlek konnoterar att en värld utan gränser innebär kärlek över nationsgränser (och att vi kan nå dit med hjälp av telekommunikation).

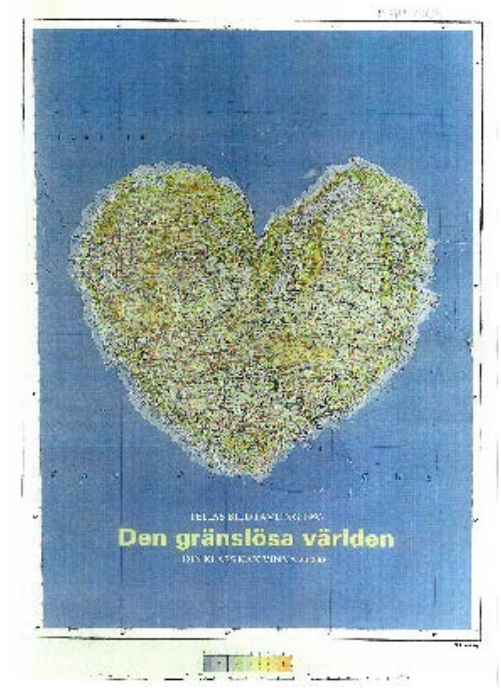

Bild 4:27. Televerkets utskick till skolorna om tävlingen Den gränslösa världen 1993

Hur barns relationer till vuxna visualiserats förändras radikalt i tävlingsbilderna mellan 1940-talet och 1970-tal. Detta syns både i arrangörernas teman till barnen och i barnens bilder. Boktiteln Varför fär inte barn bestämma? från 1977 visar att det handlar om en önskan att förändra normer kring barns deltagande och beslutsfattande.

Jag har visat att lekar och platser som gavs positiva associationer i vinnarbilderna under 1940-talet, exempelvis att hoppa på isflak, kasta snöboll eller palla äpplen, i Arlas och Kamratpostens tävlingar 1977 och 1980 beskrevs som farliga

\footnotetext{
744 Även i Folket i Bilds tävling 1939 vår hembygd finns bilder inskickade från en missionsskola i Nya Zeeland, men då är det den svenska missionären som är rörlig, inte barnen.

745 Moberg, Vilhelm Sista brevet till Sverige ( 1959).
} 
och skadliga. Fritiden på 1970-talet framställdes som mer organiserad, barn associeras till egna platser för barn, som lekplatser eller fotbollsplaner. ${ }^{746}$ Flera av FIB:s vinnande bilder på temat "min fritid" visar bilder där barn deltar i olika former av arbete $\mathrm{i}$ hemmet. Både barnen själva och FIB:s jury vill alltså gärna uppmärksamma barns deltagande i arbete. Bilderna gestaltar kompetenta barn som klarar att tradera föräldragenerationens kunskaper. Att barn arbetar på sin fritid ses som en kompetens snarare än ett problem. Tävlingen betonar alla barns lika villkor utifrån begåvning och inte utifrån klass, eftersom alla har samma möjlighet att vinna teckningstävlingen. ${ }^{747}$

I Arlas och Postens tävlingsbilder syns också en förändring av barns nationella platstillhörigheter, där barn (och vuxna) är mer rörliga både genom turism och migration. Genom bilder av jordklotet kan barnen, och Arla, visa att man värnar om det gemensamma jordklotet och den internationella idén, där jorden är allas (barns) plats, samtidigt som allas nationella identitet visualiseras genom många olika flaggor.

\section{Sammanfattande diskussion}

Tävlingarna visar vad som har beskrivits som bilder av barns egna världar och verkligheter, men även hur tävlingsarrangörerna och barnen kunnat påvisa och uppmärksamma problem för att försöka åstadkomma förändring. Bilderna visas för vuxna för att berätta något om barns värld, alltså för att de vuxna ska förstå barnens perspektiv bättre. I 1938 års bilder framträder ett sakligt realistiskt skildrande av skolmiljön, i jämförelse med senare skolbilder, som mer beskriver skolan genom metaforer och känslor. Samtidigt har bilderna gestaltat skolan som del av en instängningspraktik under hela perioden.

Vad som är möjligt att uttrycka har både förskjutits och omförhandlats över tid. Slagsmål gestaltades i 1940-talsbilderna som en humoristisk del av skolvardagen, medan mobbing och barn med tårar kunde visa en liknande händelse på 1970-talet. Barnen förväntas 1977 använda bildmediet på ett terapeutiskt och självreflekterande sätt. ${ }^{748}$

Bilderna från FIB:s tävling är i första hand "konstbilder". De är noggrant utförda och färglagda, snarast deskriptiva i jämförelse med bilderna från 1970 -80-talet som istället lyfter fram konflikter och lyfter fram barnens egen medvetenhet om känslor och relationer. Olika kunskaper och normer kring vad som betraktades som den goda barnbilden gav barn olika möjligheter att visualisera olika subjektspositioner och gestalta sina erfarenheter. Förändrade barnbildsideal kunde också erbjuda mer jämställda möjligheter för alla barn att kunna delta, utan att behöva vara duktiga på att teckna avbildande.

I Televerkets och Arlas bilder från 1970-talet framträder en mer skyddad, men också mera kontrollerad barndom. Samtidigt som barn skyddas av hjälmar och flytvästar, har de lärt sig kontrollera både sig själva och andra barn. De har

\footnotetext{
${ }^{746}$ Mintz, Steven (2012).

747 Se även tidigare resonemang i kap. 2 om b-och c-skolors deltagande i tävlingen.

748 Jfr tex Wikberg, Stina (2014). Kap. Föreställningar om bild.
} 
också positionerats som individer med ett samhällsansvar, Barnen är inte längre positionerade enbart i det svenska landskapet, utan på det gemensamma jordklotet. ${ }^{749}$ Barnen beskriver sig som kompetenta genom sin arbetsförmåga i skolan och på fritiden i FIB:s tävlingar under 1940-talet. I Arlas tävling 1976 så beskriver de sig som kompetenta genom sin omvårdande och inkluderande förmåga.

${ }^{749}$ Arla/Posten (1977) Varför får inte barn bestämma sid. 51. 


\section{Kapitel 5. \\ BILDER AV FLICKOR OCH POJKAR, KVINNOR OCH MÄN}

Pojkarna äro åtminstone i en något mera mogen ålder utpräglat sakliga, gå direkt på ämnet, medan flickorna gärna brodera ut sina motiv och fördjupa sig i återgivandet av detaljer, i synnerhet allt, som har att göra med kläder, nipper och husgeråd. Redan på långt håll kan man på både ämnesval, komposition, och färgstämning konstatera om det är en liten herre eller dam som varit bildens mästare. ${ }^{750}$

Nationalmuseums intendent Ragnar Hoppe hade som framgår av citatet ovan, en uppfattning om skillnad mellan flickors och pojkars bilder när han beskrev bilderna i boken Sverige genom barnaögon 1947. "Redan på långt håll” kunde man se skillnad mellan pojkars och flickors tecknande i så skilda avseenden som "ämnesval, komposition och färgstämning". ${ }^{751}$

Barnbilderna kunde generellt bedömas enligt en "estetisk måttstock", utifrån förmåga till fantasi och bildsinne, menade Hoppe. ${ }^{752}$ Samtidigt argumenterade han för att barnbilderna visade "att pojkar och flickor reagera på ett sätt, som pekar på fundamentala olikheter i väsen och kynne." 753

I Hoppes beskrivning av tävlingen med temat "Svenskarna i allvarstider beredskap förr och nu" var det tydligt hur pojkarnas tekniska skicklighet framhölls:

Det blev mest pojkarna som tog itu med problemet, och redde sig oftast förvånande bra. Man märker på deras teckningar hur gripna de voro av stundens allvar, inte minst när de skildrade strålkastarljuset över en nattlig stad eller en trupp soldater i hotfull silhuett mot en minspäckad kust. Pojkarna visste mycket väl hur en kanon en tank eller ett bombplan ser ut, svenska pojkar ha ju ofta ingenjörsbegåvning och sakligheten kommer också fram i själva formen. ${ }^{754}$

Teckningsämnet var under slutet av 1800-talet knutet till teknisk ritning, och även om ämnet "ritteknik" flyttades över till den praktiska realskolan under 1930-talet, finns kopplingar mellan yrken som ingenjör och teckningsämnet

\footnotetext{
750 Jungmarker, Gunnar \& Hoppe, Ragnar (red). (1947) sid. 7.

751 Ibid. sid. 7.

752 Ibid. sid. 6.

753 Ibid. sid. 6.

754 Ibid. sid. 7.
} 
kvar. ${ }^{755}$ Liksom Sara Backman Prytz visar hur manlighetsideal bland läroverksungdomar under första världskriget kopplades till ett försvar av fosterlandet, skrivs pojksubjektet på liknande sätt här in i kunskap om kanoner, bombplan och tanks. ${ }^{756}$ Formuleringar som "svenska pojkars ingenjörsbegåvning" konstruerar begåvningen som definierad av nationalitet och kön. Uttalanden som dessa skapade en särhållandets balans och var en del i en genusformering med idéer om dikotomier mellan flickor och pojkar. Genom det sätt som Hoppe väljer att beskriva bilderna på reproducerar han en samhällelig diskursordning som uppvärderade särskiljandet mellan könen ${ }^{757}$

När FIB:s tävling pågick var den svenska skolan segregerad och uppdelad, både vad gällde klass och kön, men framförallt vad gällde möjlighet att efter folkskolan fortsätta till realskola, läroverk eller flickskola. ${ }^{758}$ Flickskolorna var privata och kostade pengar, läroverken var i regel för pojkar. ${ }^{759}$ Som skäl för uppdelningen angavs bland annat utvecklingspsykologiska skillnader mellan flickor och pojkar. ${ }^{760}$ Det speglade också en uppfattning om att utbildning av pojkar, till skillnad från flickor, ansågs vara statens ansvar. ${ }^{761}$ Även då pojkar och flickor undervisades tillsammans i folkskolan, delades de upp i vissa ämnen, vilket jag återkommer till i bildanalyserna.

I vissa utvecklingspsykologiska studier av barnbilder under tidigt 1900-tal uppmärksammas inte skillnad mellan yngre flickors och pojkars utveckling. ${ }^{762} \mathrm{I}$ dessa texter är fokus istället på skillnad mellan barnets olika bildproduktion vid olika åldersstadier, eller skillnader mellan barnbilder från olika kulturer. Anna Maria Roos beskriver dock hur Kirschensteiner (1902) menar att pojkar är mer begåvade i teckning än flickor men att han samtidigt reflekterat över att: "stadsgossarnas öferlägsenhet öfver stadsflickorna delvis kan bero därpå att de har flera tillfällen till växlande företeelser, eftersom de i regel vistas mera utomhus än flickor." 763 Bildämnet har i en senare och nutida kontext istället blivit kvinnligt

\footnotetext{
755 Pettersson, Sten \& Åsén, Gunnar (1989).

756 Backman Prytz, Sara, (2014) Borgerlighetens döttrar och söner: kvinnliga och manliga ideal bland läroverksungdomar, ca. 1880-1930, Acta Universitatis Upsaliensis, Diss. Uppsala, sid. 140.

${ }^{757}$ Hirdman, Yvonne (1988), Genussystemet: teoretiska funderingar kring kvinnors sociala underordning. Uppsala: Maktutredningen sid. 19.

${ }^{758}$ Nordström, Marie (1987), Pojkskola, flickskola, samskola: samundervisningens utveckling i Sverige 1866-1962. Diss. Lund : Univ. sid. 137ff. (Gemensam grundskolans för alla i nio år genomförs 1962)

759 Sandin, Bengt \& Sundkvist, Maria (2014).

${ }^{760}$ Nordström, Marie (1987) sid. 170.

${ }^{761}$ Florin, Christina \& Johansson, Ulla (1993). "Där de härliga lagrarna gro-": kultur, klass och kön i det svenska läroverket 1850-1914. Stockholm: Tiden sid. 90f.

${ }^{762}$ Luquet, Georges Henri (1927/2001); Ricci, Corrado (1906), Kinderkunst: Ber.Ubers.aus dem Ital.von E.Roncali. Leipzig: sid. 36. Ricci menar dock att man delvis kan se skillnad på flickors och pojkars bilder utifrån barnens olika intressen.

${ }^{763}$ Roos, Anna Maria Artikel "Barnet som konstnär” i Ord och Bild (1908) sjuttonde årgången, sjunde häftet sid. 340 .
} 
konnoterat, och flickor uppnår generellt högre betyg än pojkar, vilket har problematiserats i tidigare forskning. ${ }^{764}$

Hur barn tidigt lär sig att positionera sig i rollen som pojke eller flicka, har bland annat diskuterats av genusforskare som Bronwyn Davies, men diskussionen återfinns också i tidigare forskning om barns och ungas bildskapande. ${ }^{765}$ Det finns därför särskilt anledning att uppmärksamma hur skillnad i form och innehåll mellan pojkars och flickors bilder skrevs fram i texterna om tävlingarna på 1940-talet, både vad gäller yngre och äldre barns bilder. ${ }^{766}$

Jag tar avstamp i Yvonne Hirdmans genusteoretiska ramverk som menar att skillnadsskapande mellan könen är del av de maktdiskurser som verkar för att upprätthålla sociala hierarkier mellan män och kvinnor. ${ }^{767}$ Kvinnor har under århundraden exkluderats från det sociala och politiska livet, delvis därför att de ansetts ha en instinktiv fallenhet för omhändertagande och moderskap. Sålunda blev hemmet tillsammans med barnen kvinnans plats, medan mannens plats var i offentligheten. ${ }^{768}$ I problematiseringen av genusstrukturerna har även kvinnors möjlighet att erhålla rättigheter utan att tvingas förhålla sig till patriarkala normer diskuterats. ${ }^{769}$ Simone de Beauvoir anförde redan 1949 argumentet att uppdelning och skillnad mellan könen alltsedan antiken har använts för att skapa en bild av kvinnan som "Det andra könet". ${ }^{770}$ Kön ges betydelse genom vilka positioner som möjliggörs som feminina eller maskulina i ett samhälle, där uppdelningen mellan flickor och pojkar ofta har betraktats som självklara. ${ }^{771}$

Den visuella kulturen spelar en aktiv roll för att upprätthålla och skapa förändring av dessa förhållandevis stabila och trögrörliga genusdiskurser. ${ }^{772} \mathrm{Jag}$ undersöker därför i detta kapitel hur bilderna och talet om bilderna var del av en samhällelig diskursordning. Att studera genusdiskursen innebär att undersöka vilka sociala identiteter och sociala relationer som synliggjordes inom diskursen, bland annat genom tävlingsbilderna, och vilka kunskaper som har setts som giltiga för att upprätthålla eller förändra genusstrukturerna.

\footnotetext{
${ }^{764}$ Se t.ex. Wikberg, Stina (2014). Hellman, Annika (2017). Visuella möjlighetsrum: gymnasieelevers subjektsskapande i bild och medieundervisning. Diss. Göteborg : Göteborgs universitet, 2017.

${ }^{765}$ Davies, Bronwyn (2003). Hur flickor och pojkar gör kön. 1. uppl. Stockholm: Liber sid.26.f; se bl.a. Änggård, Eva (2005).

766 Se även Hirdman, Yvonne (1995). Att lägga livet tillrätta: studier i svensk folkhemspolitik. Stockholm: Carlsson sid. 159-176.

${ }^{767}$ Hirdman, Yvonne (2001). Genus: om det stabilas föränderliga former. 1. uppl. Malmö: Liber.

768 Jordan, Glenn \& Weedon, Chris (1995). Cultural politics: class, gender, race and the postmodern world. Oxford: Blackwell sid. 178f.

${ }^{769}$ Young, Iris Marion (1990). Justice and the politics of difference. Princeton, N.J.: Princeton Univ. Press sid. 173.

${ }^{770}$ Från antiken och framåt har kvinnor beskrivits som fundamentalt annorlunda och med andra förmågor än män, oförmögna att fungera rationellt och exempelvis rösta, men mer lämpad än mannen att ta hand om barn, se t.ex, Beauvoir, Simone de (1949/2002). Det andra könet. Stockholm: Norstedt.

${ }^{771}$ James, Allison \& James, Adrian L. (2008). Key concepts in childhood studies. Los Angeles: SAGE sid. $65 f$.

772 Sturken, Marita \& Cartwright, Lisa (2009); Rose, Gillian (2016).
} 
En utgångspunkt för analysen har varit att studera pojkars och flickors aktivitet, var flickor och kvinnor, pojkar och män syns i bilderna; och vad de gör. På vilka sätt har barn genom tävlingsbilderna visualiserat genusdiskurser och hur kommenterar bilderna tradering och förändring av genusdiskurser över tid?

Vad som betraktats som maskulint respektive feminint, synes delvis stabilt, men visar även förskjutningar och förhandlingar kring vilka subjektspositioner som varit möjliga för flickor och pojkar, både i förhållande till plats och över tid.

De bilder i FIB:s tävling där genus tydligt förhandlades var i tävlingsuppdragen om skola, fritid, lekar, hembygd, och framtid. Dessa teman utgör kapitlets underavsnitt: Genusdiskurser i skolan och på fritiden, Vuxna män och kvinnor representerade $i$ barnens bilder, samt Barn skildrar framtida yrken.

Arlas tävlingsbilder i kapitlet är utvalda utifrån att de också förhåller sig till förväntningar på vad flickor och pojkar, kvinnor och män, kan och bör göra. I avsnitt två analyseras även Televerkets bilder från 1979, Yrke och arbetsliv i vår hembygd. Likaså analyseras Televerkets annons för tävlingen i Lärartidningen 1978. För att visa på bildernas intertextuella referenser använder jag mig av bilder från Sjöholm \& Goes arbetsbok för årskurs 2 i hembygdskunskap, som gavs ut mellan 1916-1951, samt två illustrationer och en annons från tidningen FIB 1941.

Det första avsnittet aktualiserar hur barn avbildat sig själva eller andra barn i skolan, på fritiden och i lekar. I barns bildberättelser om skolan syns både lektioner som är åtskilda mellan flickor och pojkar, och gemensamma aktiviteter. Det synliggör även hur barnen i bilderna beskrev fritid och lek på olika sätt.

Det andra avsnittet behandlar hur vuxna representeras som män och kvinnor i barnens bilder, och diskuterar hur arbetet i hembygden gestaltats som manligt både på 1940-talet och 1970-talet.

I det sista avsnittet undersöks hur barn visualiserade sig själva som blivande vuxna, vilka yrkesroller och könsroller som ansågs eftertraktansvärda både av barnen och av FIB eller Arla.

\section{Genusdiskurser i skolan och på fritiden}

I skolan förväntades ett inordnade i traditionella mönster för att passa in i pojkeller flicknormen. I sin studie av insändare till Kamratposten visar Catharina Hällströms hur barn beskrivit könsroller som hindrande och problematiska. ${ }^{73}$ En flicka beskriver exempelvis att hon i skolan inte kunde vara utåtagerande på samma sätt som betraktades som självklart för pojkar, utan att bli ifrågasatt. ${ }^{774}$ Pojkarna kunde som vi såg redan i förra kapitlet vara avbildade i slagsmål och snöbollskrig.

Tidigare forskning visar hur barn och ungdomar kunnat använda bildskapande praktiker som ett sätt att skapa en identitet eller positionera sig inom

\footnotetext{
${ }^{773}$ Hällström, Catharina (2011).

${ }^{774}$ Ibid. sid. 167.
} 
den egna kamratgruppen. ${ }^{775}$ Majoriteten av tävlingsbilderna är skapade som skoluppgifter, där de bedöms och värderas både av läraren och av andra elever. Förutom att bilderna gestaltar barnets subjektiva vilja att teckna en specifik händelse för att bedömas av en vuxen jury, positionerar bilderna också barnen i gruppen eller klassen. Avbildningarna av Livet i min skola 1938 ska alltså förstås utifrån att de är skapade i förhållande till och anpassade efter både jämnårigas och vuxnas attityder och normer.

FIB:s tävlingsbilder återspeglar hur vissa skolämnen var tydligt uppdelade mellan vad som betraktades som manliga och kvinnliga områden. En tydlig skillnad över tid är att efter grundskolans genomförande på 1960-talet undervisas alla barn i både trä- eller syslöjd, ämnen som tidigare var uppdelat i manlig slöjd och kvinnlig slöjd. I folkskolans läroplan från 1919, var linearritning en del av teckningsämnet. För gossar innebar det projektionsritning, och för flickor "en och annan enkel ritövning i anslutning till slöjdarbetet."776 Teoribildning om genusskapande och särskiljande praktiker pekar på att det är intressant att studera i vilka situationer flickor och pojkar var uppdelade, och när de inte var det. Jag kommer att utifrån denna utgångspunkt undersöka hur bilderna åskådliggör flickaktivitet, pojkaktivitet och gemensam aktivitet i skolan och på fritiden.

Jag kommer i detta avsnitt först att analysera två vinnarbilder från Folket i Bilds tävling: en bild av en träslöjdslektion och en bild av skolkökslektion, samt en illustration från en av FIB:s följetonger. Elevbilderna visar flickors och pojkars olika positioner i skolmiljön, medan FIB:s illustration påvisar bildernas intertextualitet. På så vis kan vi se hur bilderna inte enbart refererar till samtida skolböcker, vilket jag diskuterade tidigare, utan även till bilder i samtida populärkultur.

I tävlingsbilderna från träslöjdssalar 1938 syns följaktligen enbart pojkar, och manliga lärare. Erik Sigurdsson beskriver slöjdlärarutbildningen, grundad av Otto Salomon på Nääs slöjdseminarium, som en under 1940-talet manlig utbildning. ${ }^{777}$ Han menar vidare att kön fortfarande i början av 2000-talet är en konfliktyta i slöjdämnet, trots att det inte är uppdelat längre:

Behovet av att särskilja manligt och kvinnligt ses här som grund för slöjdens praktiska och estetiska aspekter. Konkret innebär detta att trä- och metallslöjdens praktiska och estetiska kunskapsinnehåll är en konsekvens av föreställningar om maskulinitet, men det stannar inte bara vid föreställningar och

775 Göthlund, Anette (1997) Bilder av tonårsflickor: om estetik och identitetsarbete. Diss. Linköping: Univ.; Lind, Ulla (2010); Wikberg, Stina (2014); Hellman, Annika (2017).

776 Undervisningsplan för rikets folkskolor den 31 oktober 1919.. (1920). Stockholm: Norstedt sid. 114-115. (Slöjdarbete var syslöjd för flickor, projektionsritning är en form av teknisk ritning, där föremål tecknas från olika håll).

777 Otto Salomon startade upp slöjdutbildningen och propagerade för behovet av praktiska kunskaper i skolan, han skrev bland annat Om slöjden såsom uppfostringsmedel (1884) Stockholm: Samson \& Wallin. 
språk. Trä- och metallslöjdsalen är i sig själv ett resultat av dessa föreställningar. ${ }^{778}$

Bild 5:1 visar en träslöjdssal. Detta tydliggörs bland annat genom benämnandet av de verktyg och saker som används i en slöjdsal. I bakre delen av rummet hänger verktyg med tydligt skriven text över; stämjärn, prylar, hyvlar, filar, borrar knivar, och metermått, och de respektive verktygen hänger prydligt i ordning därunder.

I Nationalmuseums samling från FIB:s tävling 1938, finns fyra interiörbilder från träslöjdssalar. Bilderna är ganska lika varandra med de karakteristiska slöjdbänkarna och slöjdverktyg på bänkarna och längs väggarna. Endast i en av bilderna syns något föremål som framstår som tillverkat i slöjden, en gunghäst, placerad på en slöjdbänk.

I bild 5:1 finns även en dialog mellan lärare och elever. Vi ser en skolsal i lätt fågelperspektiv, snett uppifrån. I salen finns sju bänkar, eller del av bänkar, som vi kan tolka som träslöjdsbänkar, genom den utformning de har samt de verktyg som avbildas på bänkarna: hyvel, skruvstycke och såg. Vid en bänk står en pojke och hyvlar, en annan pojke sitter på bänken. Vid en bänk till höger står en pojke och sågar. En bänk i förgrunden är lite högre och med plan skiva. Denna konnoterar en kateder också för att det är den som läraren står och lutar sig emot. Läraren är klädd i svart och syns bakifrån, i bildens förgrund, närmast oss. Han lutar sig fram med handen på katedern och vi känner igen hans position som lärare både genom hans storlek och genom tilltalet "Vad har ni gjort eftersom ni kommer sent?”. På andra sidan katedern står två pojkar, med händerna i byxfickorna. De är klädda i gula tröjor och bruna knäbyxor, svarta skor och svart kort hår som står upp. Den ena är lite längre än den andra, de säger unisont, i samma pratbubbla "Vi har slagits", där användandet av "vi" visar att det är ett gemensamt uttalande.

Dialogen mellan pojkarna och läraren kan sägas visa fram en typisk subjektsposition för en pojke. Om vi betraktar detta tillsammans med bilden av slagsmålet/handbollsmatchen framställd som något närmast komiskt eller satiriskt $\mathrm{i}$ bild 4:6, så är det tydligt att slagsmål hör ihop med pojkars aktivitet på ett sätt som inte ifrågasätts. Det ses snarare som något som kan råka hända på rasten och kan användas som förevändning för att komma försent.

Om vi fortsätter med tolkningen av bilden, så refererar både slöjdsalen som plats och slagsmålet som företeelse till pojkars verksamhet. Både att använda verktyg, och att slåss var en manlighetsnorm som befästs i flera av tävlingsbilderna.

Bilden refererar även till en skoldiskurs, och relation mellan lärare och elever. Dels är temat 1938 Livet i vår skola, och vi ser "skola" i skolsal, bänkar och även i en tydlig maktordning där läraren står central i bilden som en mörk och stor gestalt med rätt att ifrågasätta eleverna. Pojkarnas sätt att svara och att stå med händerna i byxfickorna kan ses som ett ifrågasättande av lärarens auktoritet och

778 Sigurdson, Erik (2014). Det sitter i väggarna: en studie av trä- och metallslöjdsalens materialitet, maskulinitet och förkroppsliganden. Diss. Umeå: Umeå universitet, 2014 sid. 29. 


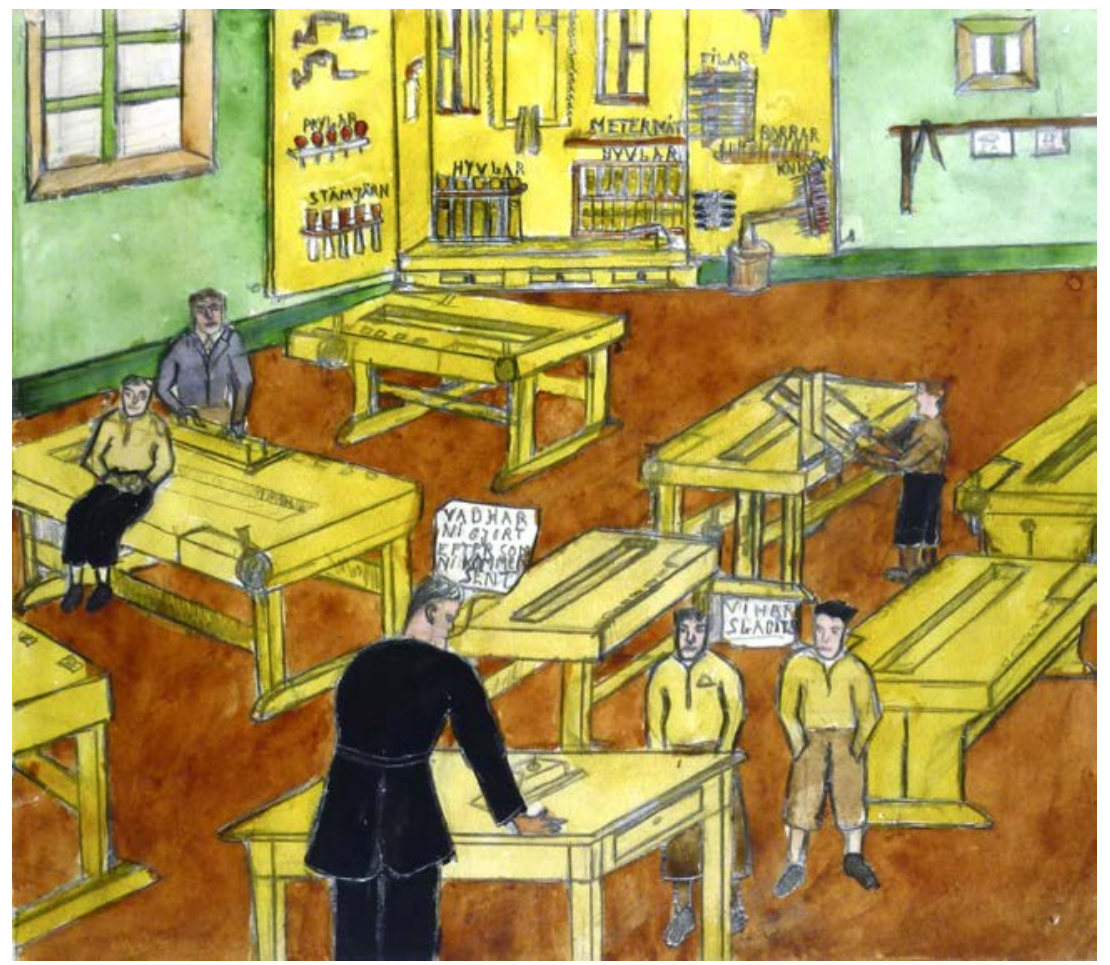

Bild 5:1. Livet i vår skola, FIB:s tävling 1938.

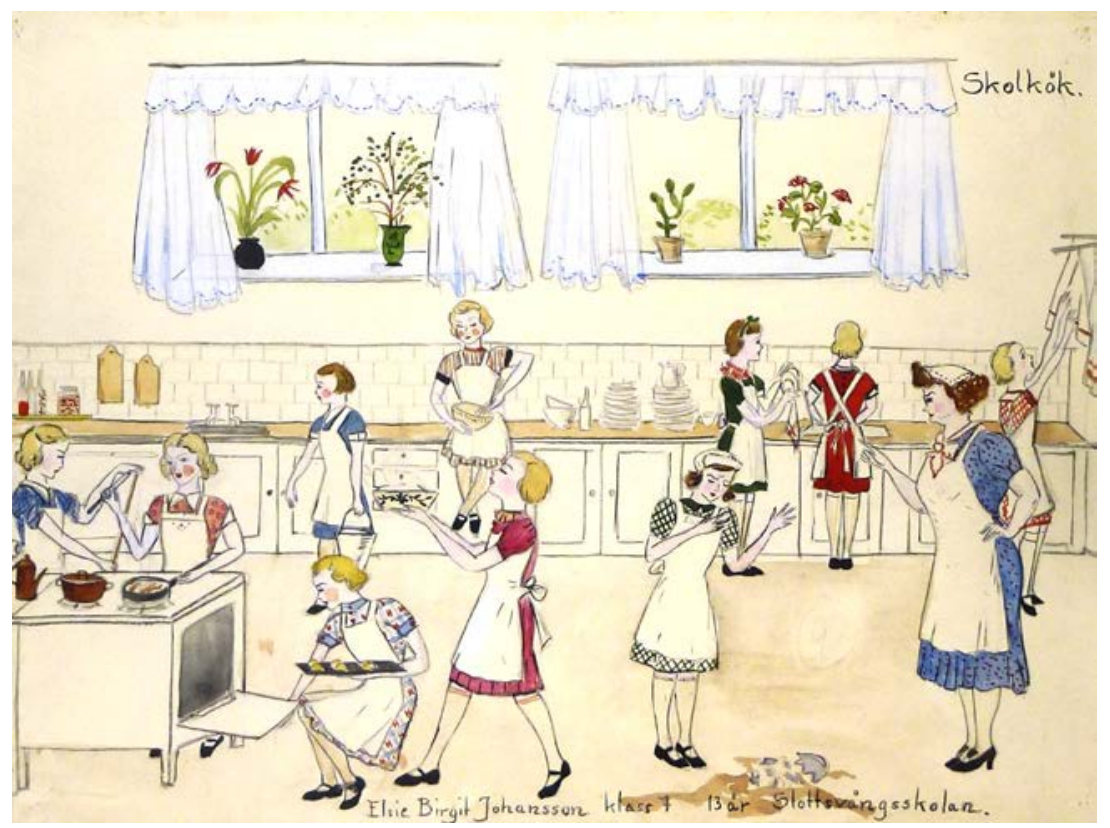

Bild 5:2. Livet i vår skola, FIB:s tävling 1938. 
skolans normer, på ett sätt som uppenbarligen ändå uppskattades av juryn. Bilden relaterar till andra samtida bilder, exempelvis skolplanscher eller detaljrika arbetsböcker som jag visade exempel på i kapitel tre. Användandet av text och pratbubblor hänvisar även till samtida skämtteckningar i veckopressen, bland annat i FIB, exempelvis Storm-P. eller Rit-Ola. ${ }^{779}$ Bildens formella funktion är att den är utvald som vinnarbild bland andra barnbilder i en teckningstävling, med tydliga referenser till barnbild som konstbild. ${ }^{780}$

De som i första hand blir interpellerade av bilden är andra pojkar: Att pojkarna svarar läraren "vi har slagits" kan vara ett sätt att inordna sig i en idé om vad pojkar gör - som en mera godtagbar ursäkt än många andra ursäkter. Bilden skapar också en inneslutning kring det manliga både genom material och uppförande. De manliga subjekt som är synliga är läraren, pojkar som håller på med verktyg, och pojkar som slåss (har slagits), samt en pojke som sitter på bänken och iakttar. Men även FIB-läsare och utställningsbesökare är tilltalade. Bilden blir en del i en gemensam historia kring "livet i skolan" som en plats där genus görs.

Förutom flickslöjden var även skolköket en kvinnligt könad arena, fram till 1955. Det finns fyra bilder från flickslöjd i Nationalmuseums samling, och tre från skolkök. "Huslig ekonomi” var ett ämne som infördes för flickor både i flickskolan och folkskolan, och skrevs in i folkskolestadgan från slutet av 1800-talet. Ursprungligen fanns två inriktningar, en för folkskolan och en för flickskolan. ${ }^{781}$ Folkskolans inriktade sig mot arbete i hemmet, medan flickskolans var mera yrkesbetonad, vilket också medförde att skolväsendet tydligt höll isär arbetarklasskvinnor och borgerliga kvinnor.

Behovet av undervisning i folkskolan växte i takt med industrialiseringen när traderingen över generationer av mäns och kvinnors arbete på landsbygden inte längre var giltig för stora grupper. ${ }^{782} \mathrm{I}$ folkskolan, som alltså var gemensam för flickor och pojkar, låg ämnet huslig ekonomi först utanför den egentliga undervisningen. ${ }^{783}$ En likhetsdiskurs kring det kvinnliga framträder genom att det handlade om hushållet, en plats där alla kvinnor förväntades befinna sig. Däremot syns en skillnadsdiskurs avseende vilken typ av arbete som skulle utföras, beroende på klasstillhörighet. men på skillnad i vilken typ av arbete som kunde utföras, beroende på klass. Arbetarklasskvinnor under tidigt 1900-tal skulle lära sig laga billig och näringsrik mat, undervisas i hygien och renlighet, skapa trivsel i hemmet för att på så sätt hålla mannen borta från alkohol och krogbesök. ${ }^{784}$ Borgarkvinnor undervisades inte i något tyngre hushållsarbete, men behövde bland annat lära sig att administrera tjänstefolk. Det främsta målet i flickskolan

\footnotetext{
779 Se t.ex.: Storm Petersen, Robert (1960) Respekt för rätten: med Storm P inför domstolen : muntra teckningar. Stockholm: Folket i bild.

780 Sverige genom barnaögon: Katalog. [Ny tr.] (1945) Stockholm: Förb. Vandringsutställning / Riksförbundet för bildande konst, 99-0522549-8; 36 sid. 9.

781 Petersson, Monica (2007) Att genuszappa på säker eller minerad mark: hem- och konsumentkunskap ur ett könsperspektiv. Diss. Göteborg: Göteborgs universitet, 2007.

${ }^{782}$ Ibid. sid. $40 \mathrm{f}$.

783 Ibid. sid. 39.

784 Ibid. sid. 42.
} 
var att fostra flickor till lämpliga fruar, genom kunskap om de specifikt kvinnliga dygderna. "Häri ingick även huslighet vilket innebar en estetisk dygd för att kunna sprida trevnad och ha en god hälsa". ${ }^{785}$ Från mitten av 1950-talet undervisas både flickor och pojkar och ämnet byter namn till "Hemkunskap och hushållsgöromål”.

Det finns i samlingen tre bilder som visar arbetet i skolkök. Det är flickor som tecknar "flickaktiviteter" och pojkar som tecknar "pojkaktiviteter" i bilderna av livet i skolan. ${ }^{786}$

Bild 5:2 visar en skolkökssal. Bänkar, spis och gardiner är skinande vita, i fönstren står vackra blommor i olika färger. I bilden syns tio flickor, alla har klänning som slutar vid knät och alla har vita förkläden. En vuxen kvinna stå i profil till höger i bild, även hon har förkläde och kjol. I denna ögonblicksbild syns flera simultana händelser; en flicka sätter in bröd i ugnen, en flicka steker något i en stekpanna, en vispar, en bär ut slaskhinken, en diskar, en torkar disk. Bilden uppvisar ljus, rymd, renlighet, fart, arbete och rörelse. Som Eva Palmblad redogör för förväntades flickorna genom övning lära sig sunda hygieniska vanor. ${ }^{787}$ Att flickorna deltar i både matlagning, disk och att bära ut slaskhinken refererar till att detta är en bild från en folkskola, och inte en flickskola. Vilka subjektspositioner och maktrelationer kan vi notera i bilden?

Det kanske mest iögonfallande i bilden är flickan som tappat något som gått sönder i golvet, och som blir uppläxad av sin lärarinna. Liksom i bild 5:1 är den vuxna personen ifrågasättande och här mera tydligt arg än i den förra bilden (vi ser hennes ansiktsuttryck och den höjda armen, där slöjdläraren var avbildad bakifrån) I denna bild finns inga pratbubblor, men väl så uttrycksfulla ansikten. Att flickan och lärarinnan ska framstå som bekymrade eller arga, förstår vi av deras ansiktsuttryck. Den arga lärarinnan markeras tydligt; handen i sidan och höttande pekfinger, liksom rynkade ögonbryn. Även flickan har rynkade ögonbryn, kanske för att visa att hon är oskyldigt anklagad, eller bara arg. Hennes händer är fortfarande uppe i luften så vi förstår att hon just tappat det som ligger trasigt på golvet. Samtidigt ser flickan och kvinnan ganska lika ut med vit hätta, vitt förkläde och lite lockigt hår, som att den mindre lätt kan komma att bli en kopia av den större, om några år.

Andra subjektspositioner är tillexempel "den duktiga flickan" med näsan i vädret och sitt fina bakverk i händerna. Hon går framåt obekymrad om risken att krocka med flickan framför. I det individuella visas samtidigt ett nödvändigt samarbete mellan flickorna för att skolköksarbetet ska fungera. Bilden som helhet konnoterar livfullhet och rörelse, en glädje i hushållsarbetet även om det kan hända små missöden ibland.

\footnotetext{
785 Petersson, Monica (2007), sid. 42.

786 Vissa bilder på temat Livet i vår skola visar skolsalar där det är enbart flickor, däremot finns inga skolsalsbilder på enbart pojkar förutom i de ämnen där de är uppdelade, dvs slöjd och idrott. Detta kan bero på att det var främst flickskolor och folkskolor som deltog i tävlingen.

787 Palmblad, Eva (1990). Medicinen som sambällslära. Diss. Göteborg : Univ. sid. $100 \mathrm{f}$.
} 
Bilden refererar intertextuellt till tidens mode vad gäller hår och kläder (se även bild 5:22 av klänningsmodell från FIB) liksom till olika samtida illustrerade veckotidningsnoveller i FIB (bild 5:3).

De som främst interpelleras av bilden är andra flickor som kan tänkas känna igen sig i de situationer som visas.

Bilderna av sådana skolpraktiker, goss-slöjden och skolköket, visar hur ämnen kodats som maskulina eller feminina, samtidigt som de upprätthöll skillnader mellan könen. Genom bilder som dessa synliggörs vad flickor och pojkar gör, men

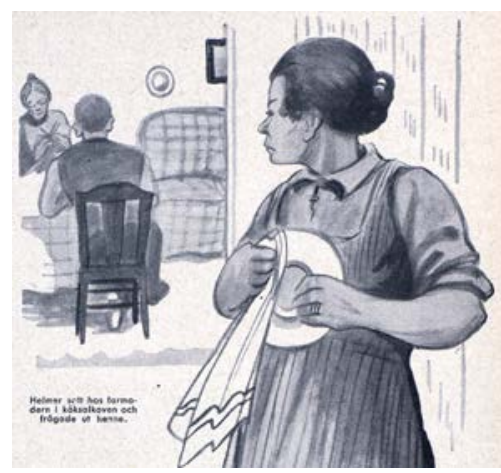

Bild 5:3. Illustration till novellen Jordbunden, Folket i bild 1939 nr 2 sid.14. också vad de inte gör. Flickorna hör inte hemma i träslöjdssalen och pojkarna hör inte hemma i köket. Bilderna gestaltar även konflikten mellan elever som inte gjort som de ska, och en vuxen, i de här fallen lärare, som reagerar på detta. Flickors och pojkars vardag liknande på detta sätt varandra, genom att skolan skapade maktrelationen lärare-elev som barn och vuxna hade att förhålla sig till.

Jag har också undersökt de områden i "Livet i vår skola" där pojkar och flickor syns gemensamt, där det finns exempel från gymnastiklektioner, som här i simundervisningen, i bilden "på skidutflykt" eller under bollsspelande.

I bild 5:4 har Gudrun Thunelius avbildat "Vår klass lär sig simma. Det tycker vi alla är så roligt" Om de tidigare två bilderna visade fram någon form av konfliktsituation, så talar denna bild istället om enighet och glädje: både genom en formulering som "tycker vi alla är så roligt" och sitt motiv.

I förgrunden syns ett vattendrag eller sjö, en brygga, fjorton barn och en lärarinna. I bakgrunden syns en åker och några gröna buskar, och en ljust blå himmel där bildens titel är textad. Att det är en fröken vet vi också för att "vår fröken" är textat ovanför hennes huvud. Hon utmärker sig även genom sin badmössa, och att hon håller i och instruerar ett barn som är i vattnet. Barnen har badkläder i gult, grönt eller rött, de har gult eller brunt hår och liknande frisyrer. Barnen framställs här snarast som ett gemensamt "vi" och det är mer tydlig färgskillnad på badkläder, än att några har badbyxor och några har baddräkt.

Utifrån denna uppdelning i badbyxor och baddräkt är det sju pojkar och sju flickor. En pojke dyker precis från bryggan, två sitter på bryggan, Fyra flickor, liksom två pojkar, gör gemensamma aktiviteter i vattnet och de andra simmar i vattnet, eller flyter. Det finns ett tilltal här som riktar sig både till en vuxen jury, fröken som lär ut simning, och andra barn, för att berätta om vad som är roligt i skolan. De som tydligt innesluts och inkluderas är "klassen" vilket inbegriper både flickor och pojkar, och till viss del även fröken. Bilden refererar till sommar, bad, lek och lärande. Händelsen beskrivs av barnet som en bild av en bekymmersfri barndom, där "vi alla" i klassen tycker att det är "så roligt" att lära sig simma. 


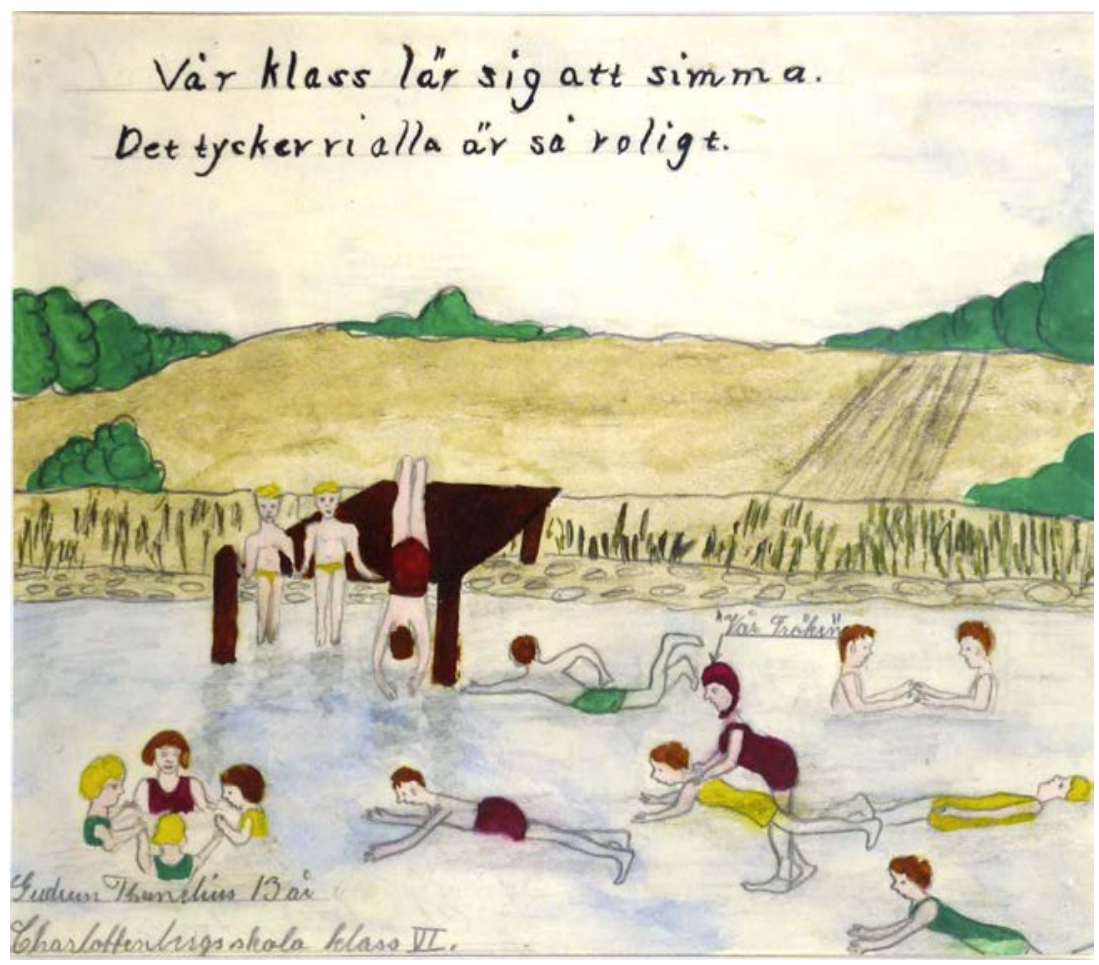

Bild 5:4. Livet i vår skola, FIB:s tävling 1938.

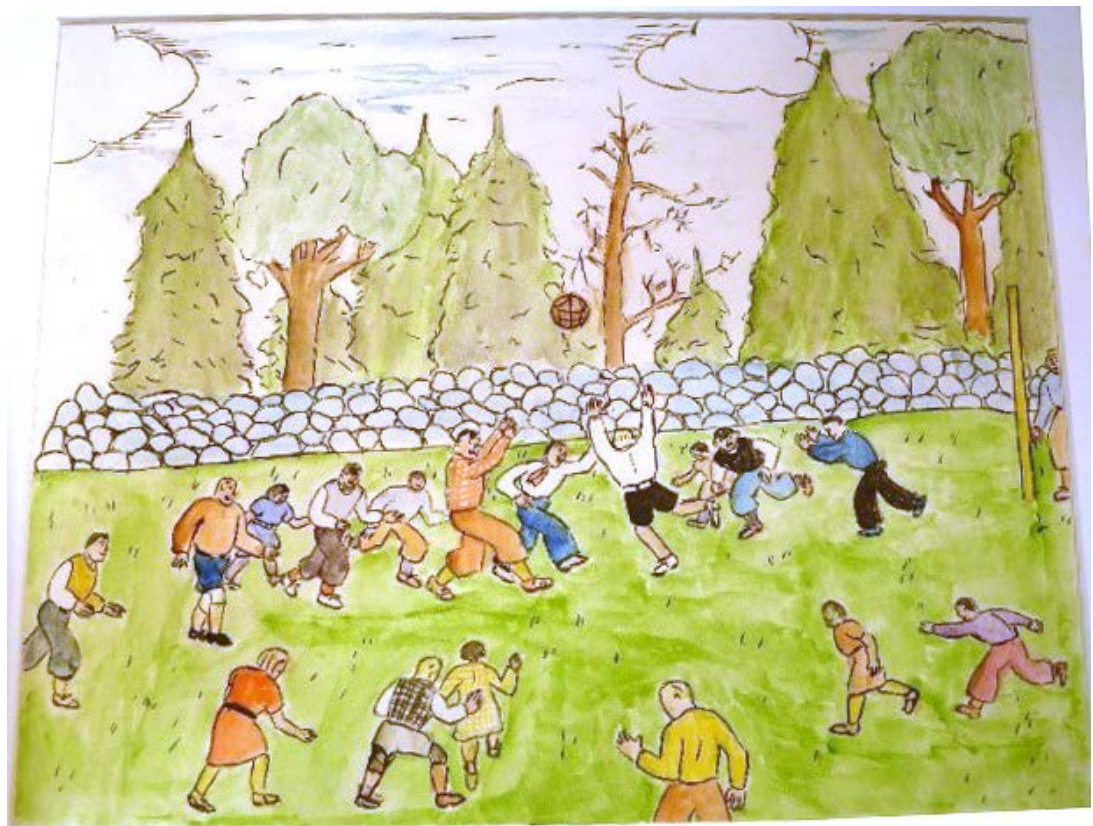

Bild 5:5. Mitt roligaste skolminne, FIB:s tävling 1941. 
Bild 5:4 är från temat "Livet i vår skola", och bild 5:5 är från temat "Mitt roligaste skolminne" vilket betyder att bild 5:5 kan vara både bollspel inom idrottsämnets ram, eller ett minne från en rolig händelse på rasten. Det är tydligt att det är flest pojkar (12), men ändå fem flickor som är med i spelets ytterkanter. Det är alltså inte en helt manlig arena. Sara Backman Prytz, som undersökt kvinnliga och manliga ideal bland läroverksungdomar, beskriver hur Uppsala flickskolas tidning 1915 skriver att det "numera ej är opassande för en kvinna att deltaga i sportslifvet..." 788 En generation senare har, som tävlingsbilderna visar, flickors och pojkars gemensamma deltagande i sportaktiviteter blivit än mer accepterat, även om idrottslektioner ibland fortsatt vara uppdelade mellan flickor och pojkar.

Även i bild 5:6 "På skidutflykt" av Doris Carlsson 11 år, ser vi hur flickor och pojkar gemensamt deltar i en skidutflykt, det är snarast likhet mellan barnen som betonas även om några har kjol.

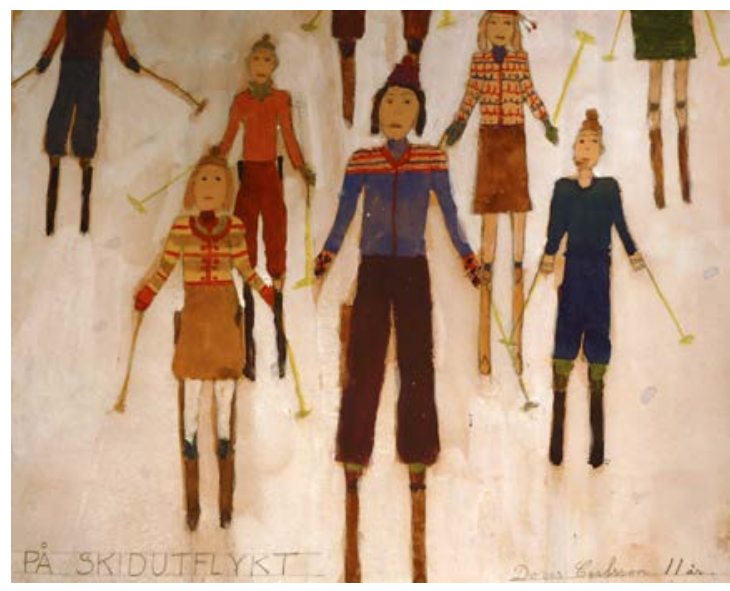

Bild 5:6. Livet i vår skola, FIB:s tävling 1938.

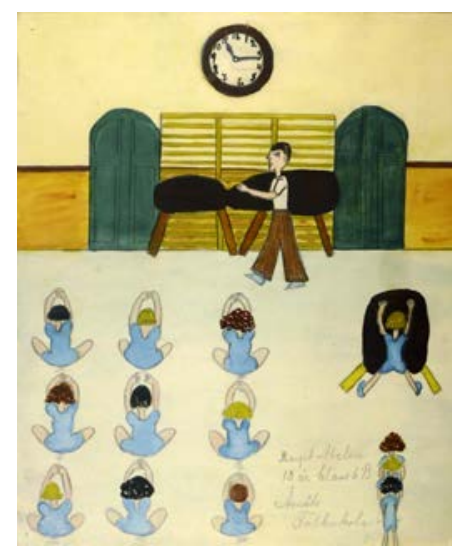

Bild 5:7. Livet i vår skola, FIB:s tävling 1938.

Att både flickor och pojkar deltar i samma aktiviteter ger också samma handlingsutrymme, samma rätt, och samma skyldighet, till kroppslig rörelse och aktivitet. Att målsättnignen med idrottsutövande i skolan kunde se olika ut för folkskolan och för läroverken, har diskuterats av Pia Lundquist Wannberg. Läroverken betonade vikten av att eleverna genom idrotten skulle åstadkomma en stark självdisciplin, vilket ansågs behövas för att kunna nå höga samhällspositioner, och skapa en bild av sig själva som elit. För arbetarklassen kunde idrotten därmot ses som ett sätt att få kroppslig övning och lära sig samarbesförmåga. ${ }^{789}$

\footnotetext{
${ }^{788}$ Backman Prytz, Sara, Borgerlighetens döttrar och söner: kvinnliga och manliga ideal bland läroverksungdomar, ca. 1880-1930, Acta Universitatis Upsaliensis, Diss. Uppsala : Uppsala universitet, 2014, Uppsala, 2014 sid. 140.

${ }^{789}$ Lundquist Wanneberg, Pia (2004), sid.164.
} 
Det finns även fyra bilder från gymnastiklektioner där det enbart förekommer flickor, som till exempel i bild 5:7 av Margit Abelin 13 år klass 6b i Åmåls folkskola. I förgrunden sitter nio flickor med ryggen mot betraktaren på golvet med benen i kors, de har armarna uppsträckta över huvudet. Till höger i bild står tre flickor i rad efter varandra, en flicka försöker hoppa över en plint.

Alla flickor har likadana blå kläder, kortbyxor och tröja. ${ }^{790}$ Likheten i klädsel och position, samt ytterligare plintar och ribbstolar i bakgrunden konnoterar gymnastiksal och gymnastiklektion. Det som skiljer flickorna åt är lite olika frisyrer och hårfärg. Framför flickorna står en manlig lärare med bruna byxor och vit tröja i profil, han går mot vänster i bild och har vänster arm höjd, Bakom läraren ser vi två plintar samt två gröna dörrar, tre ribbstolar och en klocka. Bildens ordnade form är del i att skapa en känsla av kontroll och ordning. Klockan är i denna bild väldigt stor i förhållande till rummet, vilket konnoterar att tiden är viktig. Skolklockor återkommer även i flera andra tävlingsbilder på temat Livet $i$ vår skola. Genom att synliggöra reglering av tiden och rummet, är skolklockan en tydlig symbol för skolans disciplinering och kontroll. ${ }^{791}$ Flickornas likadana blå kläder konnoterar skoluniform, likheten i att vara "skolflicka" betonas av de likadana kläderna. Att de dessutom utför samma rörelse ger intryck av kontroll och kollektiv, att vara del i en opersonlig massa. Vi ser också flickorna bakifrån, de är inga tydliga subjekt. Även formen med de nio flickorna liksom "staplade" på varandra utan perspektivverkan bidrar till detta.

De som specifikt innesluts genom bildens tilltal är andra flickor som kan känna igen sig i hur deras kroppar förväntas formas. Iris Marion Young hävdar att kvinnor lär sig att betrakta sig själva, och sina kroppar som objekt snarare än subjekt, som där flickorna till vänster i bilden sitter i exakt samma pose, övervakade av läraren. Flickornas kroppar är nästan likadana, alla gör samma rörelse. Young diskuterar även vilka möjligheter som skapas för kroppslig feminin existens där det finns en feminin tvekan kring kroppens möjlighet, en idé om att "jag kan inte". ${ }^{792}$ Detta kan gestaltas av flickan till höger som ska hoppa över en plint, kanske är hon mitt i språnget, eller har hon fastnat på plinten? (Bild 5:7) Plinten är tecknad som oerhört stor i förhållande till flickan, och svår att komma över.

Samtidigt som bild 5:7 är en av de fyra bilder som visar enbart flickor på gymnastiklektioner, visar bild 5:4 och 5:5 och 5:6 att aktiviteter som simning, skidutflykt, och bollspel kunde erbjuda en likvärdig subjektsposition för flickor och pojkar. Det går att se "skillnad" genom kläder, men det är samma aktivitet där både flickor och pojkar använder sina kroppar på liknande sätt. Även vid lekar på skolgården, som exempelvis i bilden "slå den tredje" är det både pojkar och flickor med, då under temat Vara lekar 1945.

I bild 5:8 från Livet i vår skola ser vi en skolgård med både pojkar och flickor, men de gör olika saker. Flickor kastar boll, och hoppar rep, och pojkar sparkar boll eller slåss. Den som är avbildad som "vuxen" med grå kostym och hatt, är

\footnotetext{
790 I alla bilder av flickgymnastik har flickorna just blå kläder.

791 Lind, Ulla (2010) sid. 348.

792 Young, Iris Marion (2005). On female body experience: "Throwing like a girl" and other essays. New York: Oxford University Press sid. $36 \mathrm{f}$.
} 
troligen just på väg att avbryta slagsmålet, som flera barn har samlats omkring. Liksom i tidigare bild 4:8 "Så går det för den som tar flickorans bollar" avbildas den manlige läraren som garant för att ordningen upprätthålls.

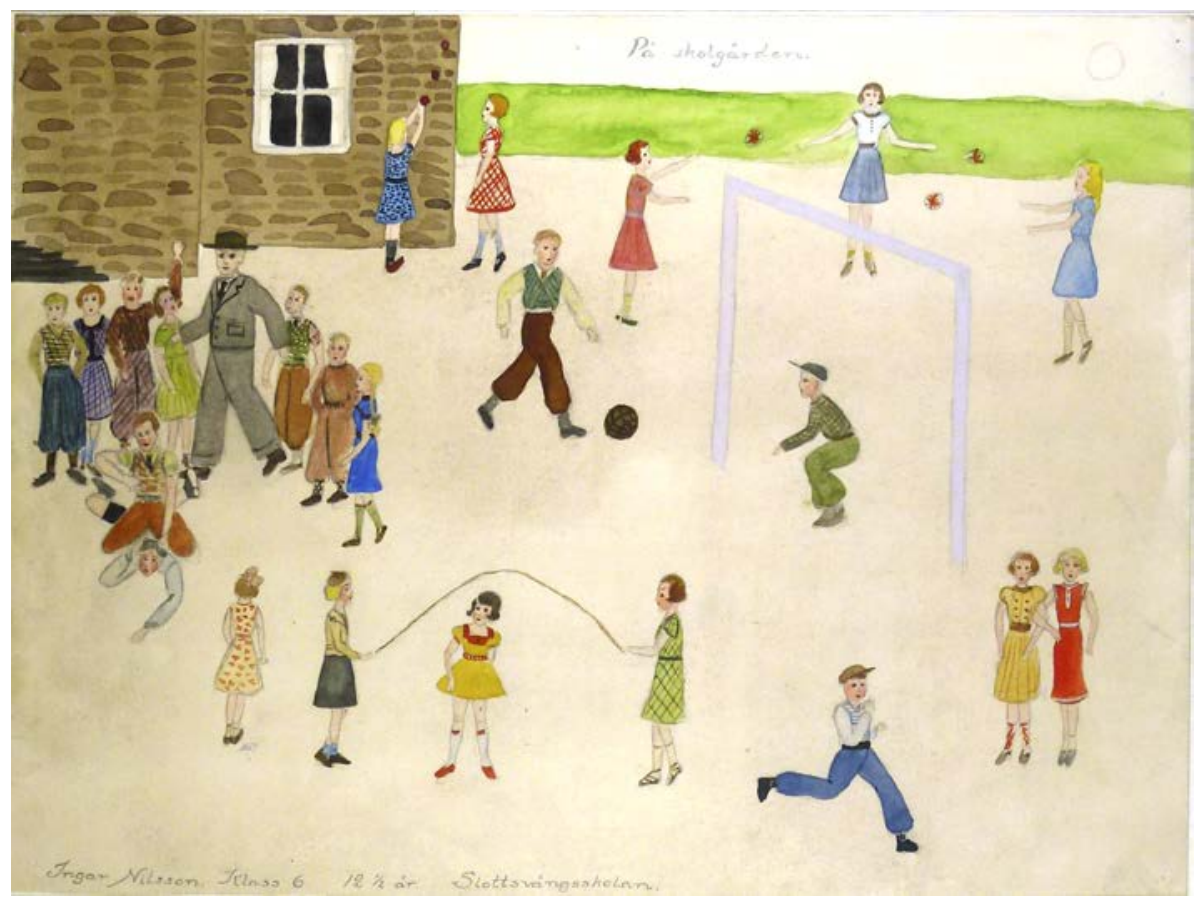

Bild 5:8. Våra lekar, FIB:s tävling 1945.

Som vi har sett skildrades livet i skolan i tävlingsbilderna år 1938 både genom uppdelade och gemensamma aktiviteter för flickor och pojkar. Även om folkskolan innebar en gemensam mötesplats och erbjöd en gemensam elevposition i förhållande till lärare, gestaltades pojkars och flickors handlingsutrymme oftast som åtskilt och uppdelat. Det fanns också andra sammanhang där spel och lek var tydligt uppdelade. Bilderna visar till exempel enbart pojkar som spelar bandy, ägnar sig åt "isjumpning" eller flyger med modellflygplan. Fyra bilder från "våra lekar" visar flickor med dockor och dockvagnar. En av dessa finns också publicerad i boken Sverige genom barnaögon. Nästa avsnitt diskuterar bilderna från temat våra lekar samt hur flickors och pojkars handlingsutrymme kan upprätthållas eller förändras i förhållande till hur saker genuskodats.

\section{Barns lekar och saker}

I föregående kapitel såg vi hur specifika ting har kodats som manliga eller kvinnliga. Yxan och sågen användes av pojkar och män i bilderna, och mjölkspannen av kvinnor och flickor. Både vuxna och barn definieras av relationer till den materiella kulturen. De ting som vi associerar med barn är oftast inte något som barnen 
själva skapat utan är skapat av vuxna för barn. Barndomens artefakter är därför speciellt problematiska om vi förväntar oss att de ska säga något om barn. De säger snarare något om vuxnas föreställningar om vad barn bör förknippas med och vad barn bör göra. Jane Eva Baxter menar att barnlitteratur och det som betraktas som barnkultur i första hand visar hur den samtida kulturen vill att barn ska se sig själva. ${ }^{793}$ Vuxnas barndomsideal kring barns lekar och saker avspeglar sig också i vilka bilder som väljs ut i de tävlingar jag studerar.

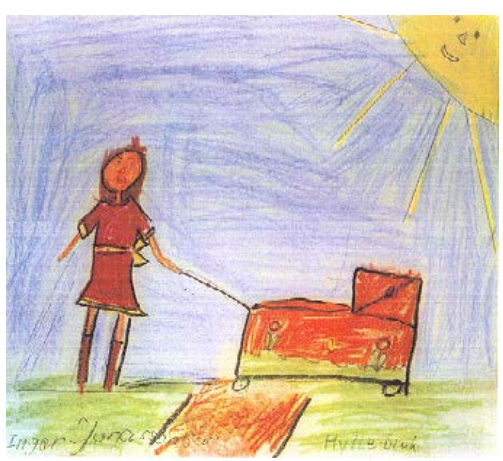

Bild 5:9. Våra lekar, FIB:s tävling 1945.

Jag kommer i det följande att granska de 42 bilderna från Nationalmuseums samling Våra lekar 1945. Två av dessa publicerades i albumet Sverige genom barnaögon. ${ }^{794}$ Den ena var "korgboll", en bild av pojkar uppdelade i två olika lag med röda och blå färger på tröjorna, som spelar korgboll på en gräsplan en solig dag. Den andra hade titeln "Jag leker med min docka", bild 5:9, och var tecknad av Inger Jonasson, 8 år, som också var den yngsta vinnaren som publicerades i albumet.

Bilden är mer naivistiskt tecknad än de övriga i albumet, med en trekantig sol i högra hörnet, och motivet tecknat med enkla linjer ifyllda med krita, inte med vattenfärg. Vi ser en flicka i röd klänning och med röd rosett i det bruna håret. Hon håller i en röd barnvagn till höger i bild. Flickan är vänd mot oss. I förgrunden finns grönt gräs och en brun stig eller grusgång. Av solen och gräset förstår vi att flickan och barnvagnen är utomhus. Dockan syns inte i bild, även om den nämns i bildens titel. Vi förstår att dockan ligger i den röda barnvagnen. Bildens naiva formspråk och flickans ålder konnoterar att redan små flickor leker mor och barn. Den reproducerade och omvårdande diskursen framstår därmed som biologisk snarare än kulturell. Det finns i Nationalmuseums samling Våra Lekar ytterligare fyra bilder där flickor avbildas med docka och eller dockvagn, alla tecknade av flickor. ${ }^{795}$

Om dockorna används för att definiera flickor och femininitet, finns egentligen ingen tydlig motsvarighet för någon leksak som pojkar förväntas leka med i bilderna. Bollar som artefakter är viktiga leksaker - både flickor och pojkar använder bollar i bilderna men där pojkarna utövar bollsport, kastar flickorna bollar till varandra två eller tre stycken, eller mot en vägg (bild 5:8). Förutom dockor, är bollar och spelkulor de vanligaste leksakerna i bilderna. ${ }^{796}$ Pojkars lek

\footnotetext{
${ }^{793}$ Baxter, Jane Eva (2005). The archaeology of childhood: children, gender, and material culture. Walnut Creek, CA: AltaMira Press sid. 91.

794 Även omslagsbilden (bild 3:24) var från temat våra lekar.

795 NM Våra lekar 1945 av Inger Jonasson 8 år, även publicerad i Sverige genom barnaögon Jungmarker, Gunnar \& Hoppe, Ragnar (red). (1947) Jag lekte med min docka, bild nr. 8.

${ }^{796}$ Detta bekräftas också av arkeologisk och museal forskning, där det som kategoriserats som barns artefakter är just dockor och bollar.
} 
är representerad i dubbelt så många bilder som flickors lek. Leken är tydligast maskulint kodad vid bilderna av tävlingssport, ofta med bilder av äldre pojkar, exempelvis som spelar fotboll, bandy eller handboll. ${ }^{797}$

Många av bilderna i samlingen Vara lekar visar alltså lek i from av sport, vilket synliggör hur även idrott och tävling betraktades som barns lek 1945.798 Tio bilder är vinterbilder, av dessa är två skidtävlingar där en eller flera skidlöpare är på väg in i målet, där svenska flaggor vajar, och människor hejar på vid målgången.

Intendent Hoppe skriver i Sverige genom barnaögon:

Att den svenska ungdomen numera med liv och lust går upp i intresset för idrott och sport framgår av de teckningar, som resulterade av denna tävling ("våra lekar" min anm). [...]

"Camping, fotboll, bandy och skidlöpning ha funnit högst sakkunniga skildrare, och liksom under tidigare generationer tycks pojkarna alltjämt med lika stor iver ägna sig åt att leka sjörövare, indianer och vita, för att nu inte tala om att isjumpning och snöbollskastning trots den nya tiden äro högst populära. Flickornas fantasi sysslar däremot helst med ämnen som Far och Mor, klädtvätt och Handelsbod och sjukhus.”799

I tilltalet "den svenska ungdomen" kan man tänka sig att både flickor och pojkar, är "sakkunniga skildrare" av idrott och sportaktiviteter. Det syns också i tidigare bildexempel (se bild 5:4,5;5,5:8). Hoppe poängterar "och liksom under tidigare generationer" är det skillnad mellan vad flickor och pojkar leker, men betoningen på att det är likt hur det tidigare varit, kan både tolkas som att det skulle kunna förändras över generationer, eller att det är något som förväntas fortgå även $i$ generationer framåt, så som det alltid varit. Att diskurser håller på att förändras kan anas "för att nu inte tala om att isjumpning och snöbollskastning trots den nya tiden äro högst populära.” (min kursiv)

Det är alltså populärt bland pojkar att avbilda, och troligen även delta i, snöbollskastning och isjumpning trots den nya tiden. Det är oklart vad som definierar "den nya tiden", men troligen ser Hoppe barnbilderna som ett bevis på traditionens makt. 800

I FiB:s tävling 1945 kunde leken betraktas som lik vuxna mäns idrottsaktivitet, med sportaktiviteter som bandy, fotboll eller tävlingar i längdskidor eller skidhoppning (bild 5:10). ${ }^{801}$ Att dessa lekar i vissa fall är organiserade, troligen av vuxna, definieras förutom av målgång med svenska flaggor även med titlar som "När vi spelade bandy mot läroverket" eller "fotbollslag i vår skola".

797 Här kan man också fundera över om "våra" lekar i vissa fall ses som "svensk tävlingslek" snarare än som "våra" i bemärkelsen "barns egna lekar".

798 jfr Caillois, Roger (1961/2001) som definierar "Play" som en gemensam beteckning för tävlingar, lekar, teater och lotterier. sid. 13ff.

799 Jungmarker, Gunnar \& Hoppe, Ragnar (red). (1947). Sverige genom barnaögon: Folket i bilds teckningstäuling för skolungdom. Stockholm: Nationalmuseum sid. 7.

800 Se t.ex. bild 4:12, 4:18.

${ }^{801}$ Se t.ex. bild 3.15. 
Även i tävlingsbilderna från 1945 framstår organiserad lek och tävling som en tydlig del av ungdomars, framförallt pojkars, vardag. I bild 5:10 "När vi spelade bandy mot läroverket" ser vi sex pojkar med röda tröjor och sex med gula. Tröjornas olika färger konnoterar att det är två olika lag. Pojkarna har klubbor i händerna, i mitten av planen står en man klädd i svart som vi tolkar som domare. Planen är tydligt uppritad, och det finns två mål. I bakgrunden syns höga träd, en stor byggnad som kan vara en läktare med åskådare. Begreppet "vi” innebär här folkskolans elever, då teckningen är signerad Stig Wallin, 13 år, Strängnäs folkskola. Eftersom det är två skolor som tävlar mot varandra är det troligt att det inte är på fritiden, utan inom skolans ram som bandymatchen äger rum.

Det finns även bilder av lekar som tydligare associerar till barndomen som en fantasifull och bekymmerslös tid, där barnen leker i kojor och träd, vid vatten och på land. Gauffins uttalande, om "barnen som är omedvetna som skogens blomster" i tidigare kapitel, är del av samtida diskurser om barndomen som en värld av oskuldsfullhet, glädje och fantasifull frihet, viket också kunde skapa förväntningar på barn att framställa sig själva i bild som glada och obekymrade. I bilderna från temat Våra lekar, syns inte några konflikter utan enbart en samstämmig gemenskap, även i de fall bilderna visade tävlingsmoment.

Tre bilder visar "när vi lekte indianer och vita", tre visar pirater: landpirater, pirater stiger i land i viken, och pirater i gravarna. Artefakterna i teckningarna av när barn leker pirater är svärd och gevär eller fjäderskrudar och yxor när de leker indianer och vita. Av alla totalt 48 bilder är alla utom åtta utomhus. Bilderna inomhus avbildar lek med docka, blindbock, eller viskleken "Köra sladder genom byn". I de två bilderna som visar blindbock, avbildar en både flickor och pojkar, en bara flickor. Inomhuslekar associerades således främst till det feminina, och pojklekar främst till utomhusaktivitet. En av vinnarbilderna 1945 visar pojkar som flyger modellflygplan, FIB organiserade också modellflygstävlingar under denna period, vilket kan vara en anledning till flygplanet i den vinjett man använder för Ungdomsspalterna 1939 (bild 5:11).

Vi ser i bilden hur både flickan och pojken tydligt visar intresse för den moderna flygmaskinen, både flick- och pojkdockan är däremot slängda i ett hörn. Bilden visar att både pojken och flickan också leker tillsammans, även om pojken är den som håller i flygplanet.

Samtidigt som barnbilderna innehållande flickor med dockor och dockvagnar visas uppskattning av FIB:s jury, så visar vinjetten att barn och ungdomar gemensamt kan och bör intressera sig för samma saker. Vinjetten kan också spegla FIB:s förhoppning om samhällsförändring. Det är tydligt hur det som uppskattas är att flickor intresserar sig för pojkars saker, som flygplanet, men inte tvärtom.

Hur har då barns bilder av flickor och pojkars lek förändrats över tid, och vad lyfter en jury av vuxna fram för vinnarbilder fyrtio år senare?

Temat för FIB:s tävling var deskriptivt, exempelvis "Livet i vår skola", "Roligaste skolminne" eller "Våra lekar", medan det i Arlas tävling är formulerat som en uppmaning: "Detta vill jag värna om!" 


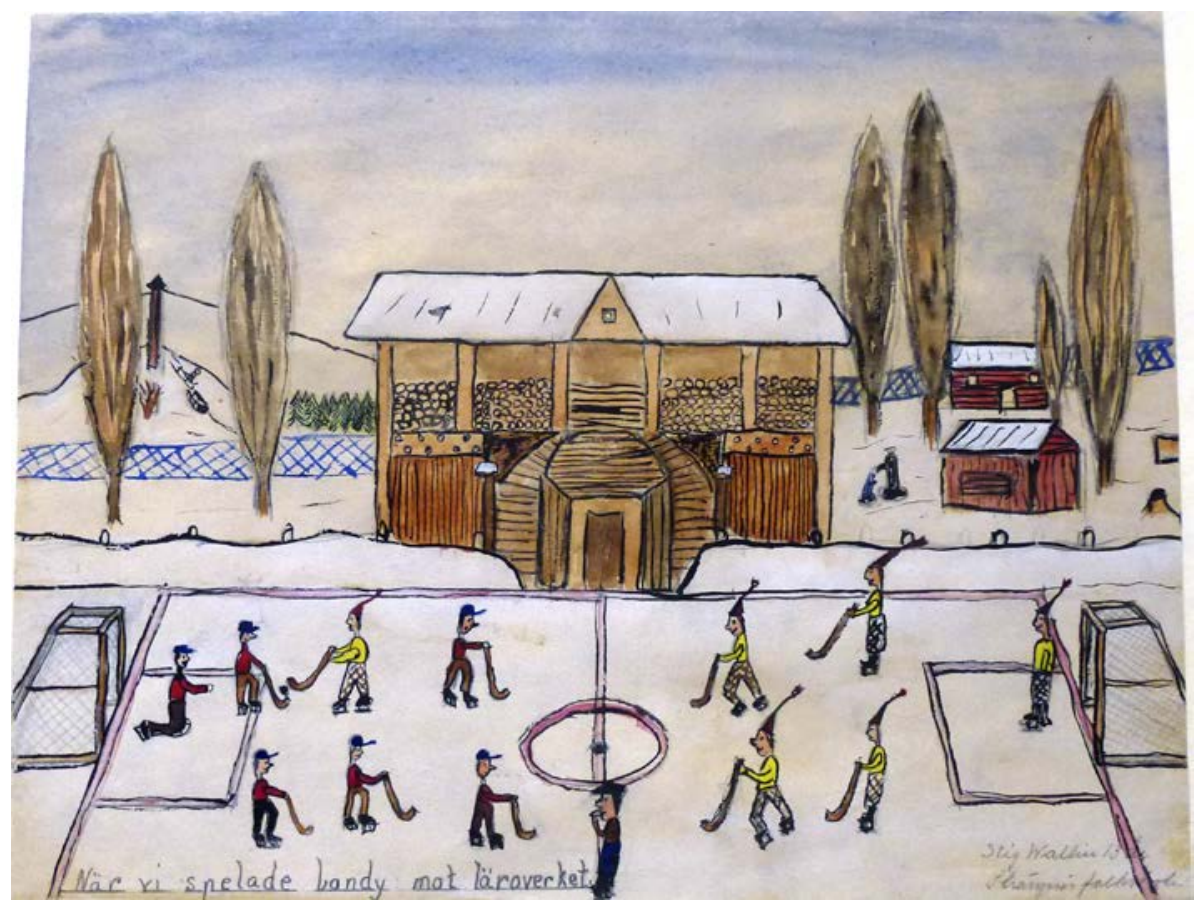

Bild 5:10. Våra lekar, FIB:s tävling 1945

Jag tycker att det ä fel att man inte far vara med pojkarna.

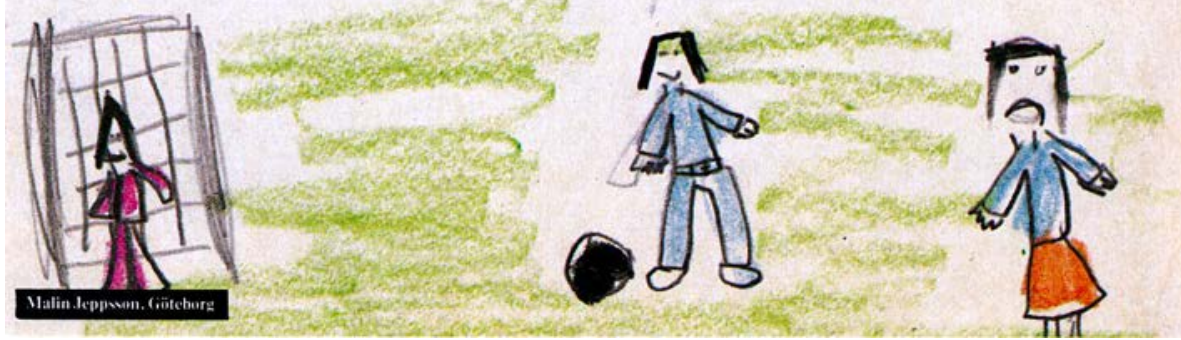

Bild 5:12. Malin Jeppson i Varför får inte barn bestämma (1977). 


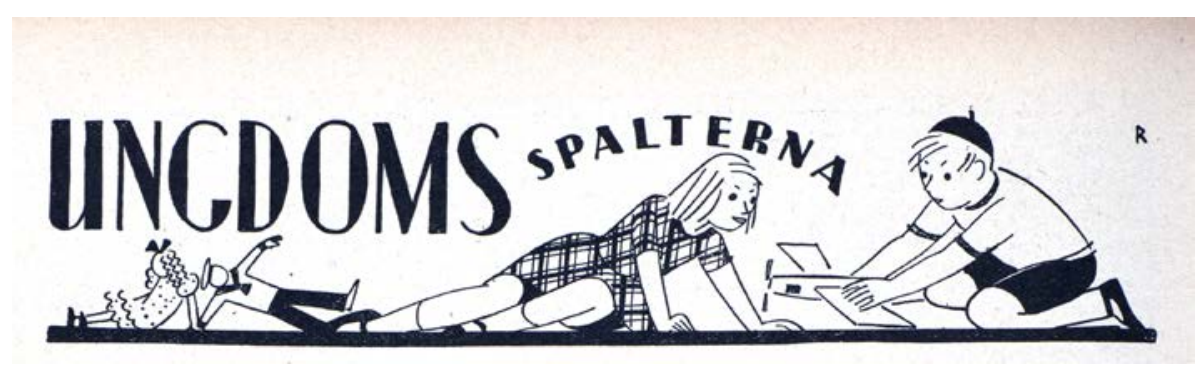

Bild 5:11. Folket $i$ bild, vinjett ungdomssidorna 1939.

Uppropet "detta vill jag värna om" ger en annan ingång än 40-talsbilderna, och denna bild visar ett tydligt budskap om önskad förändring (bild 5:12).

Fortfarande ser vi i hur fotbollens idé som en pojksport, lever kvar $1977 .{ }^{802}$ Malin Jeppson i Göteborg gestaltar en tydligt arg eller ledsen figur och skriver på övre halvan av den horisontella bilden "Jag tycker att det är fel att man inte får vara med pojkarna". I förgrunden syns en flicka med röd kjol och blå tröja, och väldigt ledsen min, med armarna utsträckta. Bakom snett till vänster, står en pojke med byxor och glad min och bredvid sig har han en boll, till vänster i bild står en figur med rosa kläder i ett fotbollsmål. I bakgrunden lyser en rund gul sol. Bilden konnoterar sommar och lek, men visar också vilka som inte får vara med och leka.

Det blir tydligt för betraktaren av bilden att flickan i förgrunden inte får vara med pojkarna när de spelar fotboll, "att man" inte får vara med pojkarna, kan här tolkas som synonymt med "att man som tjej" inte får vara med pojkarna. Det är pojken i bilden som har bollen bredvid sig och därmed makten. Detta påpekas som "fel" och det finns ett tydligt ifrågasättande av rådande normer i bilden och texten. Bildens expressiva funktion är återigen en önskan om förändring. De som interpelleras är andra barn, både pojkar och andra flickor som också vill spela fotboll. Men kanske riktas tilltalet framförallt till vuxna. Genom undertiteln på boken "en bok av barn för vuxna" positioneras vuxna som de som skulle kunna göra något åt problemet.

Steven Mintz har visat hur barndomskulturen inom den amerikanska medelklassen var en till stora delar könssegregerad barndom under 1940 -50-talet. Det inträder dock en förändring under 1970-talet, med mera gemensamma aktiviteter och lekar mellan flickor och pojkar på fritiden. ${ }^{803}$ På liknande sätt aktualiserar bilden "Jag tycker att det är fel att man inte får vara med pojkarna" en attitydförändring som speglar viljan att åstadkomma gemensamma arenor för barns lek på 1970-talet.

8021973 spelades den första damlandskampen i fotboll, vilket ger en bild av hur flickor tagit sin in på en tidigare manlig arena se t.ex. Bengtsson, Claes G. \& Glanell, Tomas (1998). 25 ar med svensk damfotboll: 1973-1998. Solna: Svenska fotbollförb.

${ }^{803}$ Mintz, Steven The changing Face of Childrens culture in Fass, Paula S \& Grossberg, Michael (red). (2012). Reinventing childhood after World War II. Philadelphia: University of Pennsylvania Press. 
$* * *$

Bilderna från tävlingen Livet i vår skola 1938 visar hur uppdelning och särskiljande i specifika skolämnen framställs som något självklart som inte ifrågasätts. Genom att barnen delades upp återskapades också normer om det maskulina och feminina. Detta visualiserades förutom genom lektioner i särskilda salar, även genom rasternas uppdelade aktiviteter.

Vissa saker framträder som tydligt könade i bilderna, som exempelvis såg och yxa och sådant som associeras med träslöjdens material, eller kokkärl och spis som hörde ihop med ämnet huslig ekonomi.

Tävlingsbilderna från 1945 av Våra lekar visar att den vanligaste leksaken var dockan. Genom att leken med dockan väljs för publicering i Sverige genom barnaögon kan idén om den omvårdande kvinnligheten som universell reproduceras. Lekarna som skildrades i bilderna var oftast uppdelade mellan flickor och pojkar, flickorna lekte med dockor och pojkarna deltog i olika sporter. Det var också pojkar som hade snöbollskrig eller lekte pirater. Flickor och pojkar syns tillsammans i några få bilder av våra lekar, som blindbock och maskerad. I barndomens "lekar" framställs barndomen såväl som en oskuldsfull tid för att leka kurragömma, indianer och vita eller pirat, men även leken som konkurrens och tävlan och del av ett nationsskapande.

Skolan upprätthöll på många sätt skillnaden mellan flickors och pojkars områden. Men bilderna visar också hur skolan gav möjlighet till gemensamma aktiviteter, tydligast vid sportaktiviteter, som skidåkning, simning eller fotboll. Även om fler gymnastik- och idrottsbilder visar flickor eller pojkar uppdelade, kunde skolan också skapa utrymme för förändrade genusdiskurser och därmed fler subjektspositioner möjliggöras.

Bilden "Jag tycker att det är fel att man inte får vara med pojkarna" från Arlas bok Varför får inte barn bestämma från 1977, framställde flickors önskan att delta på tidigare manliga arenor, och ifrågasätter kvardröjande genusstrukturer.

Vi ska nu gå vidare och studera hur vuxnas positioner och platser i tävlingsbilderna deltar i att reproducera genusordningen, i tävlingsbilderna från FIB Livet i vår hembygd 1939 och Televerkets vinnarbilder från temat Yrke och arbetsliv i vår hembygd 1979.

\section{Vuxna män och kvinnor representerade i barnens bilder}

I detta avsnitt diskuteras hur män och kvinnor representerades och hur genus förhandlades i barnens bilder 1939 och 1979. Två tävlingar är i fokus i detta avsnitt; dels FIB:s tävling med tema: Livet $i$ vår hembygd 1939 och dels Televerkets tävling med tema: Yrke och arbetsliv $i$ vår hembygd 1979. Tematiken var alltså något olika mellan "Livet i vår hembygd" 1939 och "Yrke och arbetsliv i vår hembygd" 1979. Men även bilderna 1939 berörde ofta just yrke och arbetsliv i hembygden. ${ }^{804}$ Bilderna ska förstås i relation till samhällets förändring, där 1940-talets politiska diskussion betonade kvinnans roll i familjen och som

${ }^{804}$ Något som även diskuteras i kapitel tre. 
mor. ${ }^{805}$ Under slutet av 1970-talet var kontexten en annan. Inte bara barns röster och deltagande debatterades, även genusstrukturer ifrågasattes och både kvinnoroller och mansroller var under förhandling och förändring. ${ }^{806}$ Denna kontext visar hur tävlingen 1979 kunde användas som en del av en samtidsdiskussion för att ifrågasätta kritiken mot traditionella könsroller.

"Hembygdsdiskursen" representeras i dessa bilder till stor del av män, och ofta av män i arbete. ${ }^{807}$ Tydligast är det i Telefonkatalogens tema "Yrke och arbetsliv i vår hembygd", vilket jag också kommer att sätta i relation till de läroplansmål som fanns 1979 kring skolämnet hembygdskunskap.

Bild 5:13 visar Televerkets annons för tävlingen 1979 som man publicerar i Lärartidningen riktad till klasslärare i Årskurs 3. På bilden syns en kvinna och fem män, utifrån deras klädsel och symboliska attribut kodade som fiskare, bagare, sjuksköterska, präst, bonde och stins. ${ }^{808}$ Denna annons lyfter även fram saker eller artefakter som hör till de olika yrkena, som spaden, kringlan, termometern eller fisken. Televerket etablerar genom bilden både vilka yrkesroller och vilket könsroller de ser som lämpliga exempelbilder. Tävlingsbilderna med uppdraget Yrke och arbetsliv i vår hembygd 1979 var också tydligt manligt kodade då 28 av 34 bilder visar män som arbetar, medan endast tre visar kvinnor i arbete. ${ }^{809}$ Bilderna kunde delta i att bekräfta uppdelningar mellan vad män och kvinnor gör, liksom vilka möjliga framtida yrkespositioner som etableras för pojkar och flickor. ${ }^{810}$

Vissa arbeten hade tydligt historiska konnotationer, exempelvis hade en av de bilder där kvinnor arbetar med titeln "mjölkning för hand" på Växjödelens telefonkatalog 1979, där en kvinna med långt ljust hår sitter i en hage och mjölkar en ko, med ett brunt staket runt hagen och en stor sol på himlen. Men det finns också många bilder som är samtida både 1939 och 1979, som exempelvis järnverksarbetare, fiskare eller skogshuggare. Hembygdsbilderna i

\footnotetext{
${ }^{805}$ Hallberg, Mathilda (2017).

${ }^{806}$ Klinth, Roger (2002). Göra pappa med barn: den svenska pappapolitiken 1960-95. Diss. Linköping: Univ., 2002.

807 Även Televerkets tävlingar 1977-78 syns fler män än kvinnor i bilderna, främst kungar.

${ }^{808}$ Kopia av Annons införd i Lärartidningen 1978-02-20, Televerket telemedia Omslag till rikstelefonkataloger 1979-80 F2A:4. Riksarkivet

${ }^{809}$ Några visar t.ex timmer som flottas eller fiskebåtar vilket konnoterar manligt arbete även om det inte finns någon människa på bilden. Jag återkommer till detta längre fram.

810 http://www.scb.se/statistik/_publikationer/le0201_2012a01_br_x10br1201.pdf 1979 är det ca $40 \%$ kvinnor som yrkesarbetar heltid och ytterligare $25 \%$ som yrkesarbetar fyra-sex timmar per dag.(2018-03-07)
} 
boken Sverige genom barnaögon visar män i arbete vid ett järnverk, en byggarbetsplats och med skördetröska, liknande bildberättelser kommer även igen i 1979 års bilder. ${ }^{811}$

Sammantaget av de 126 bilder som finns av "Livet i vår hembygd" i Nationalmuseums samling, så visar bilderna ofta upp olika typer av arbete, och då är det nästan uteslutande män som utför arbete på bild. Att plöja, både med traktor och häst, att arbeta i gruvan, arbeta i skogen, på bygget, vid smältverk, eller att tända milan, är någonting som män gör. Av de bilder som valdes ut och publicerades i FIB 1939 (bild 3:31, 3:33) syns män i arbete i bilderna av stenhuggare, arborist som klipper träd, jägare som siktar på hjortar, bonde med sina grisar, och "far har tänt milan", som jag strax återkommer till. Bilderna visade också specifika händelser där både män och kvinnor deltog, som bröllop, marknad eller en torgdag. Enbart kvinnor syntes i bilden "smörkärning och ullkardning", med två flickor eller kvinnor som båda har förkläden. De arbetar inomhus med de redskap som behövs för att kärna smör och karda ull, i bakgrunden syns en öppen spis.

Även bilden "Far har tänt milan" trycktes i FIB (bild 5:14). Bilden är målad av Henry Lövbom 12 år, och förutom att den är tryckt i tidningen FIB är den med i albumet Sverige genom barnögon, i svartvit reproduktion.

${ }^{811}$ Jungmarker, Gunnar \& Hoppe, Ragnar (red). (1947), se bild 3:26, 3:27, 3:30. 


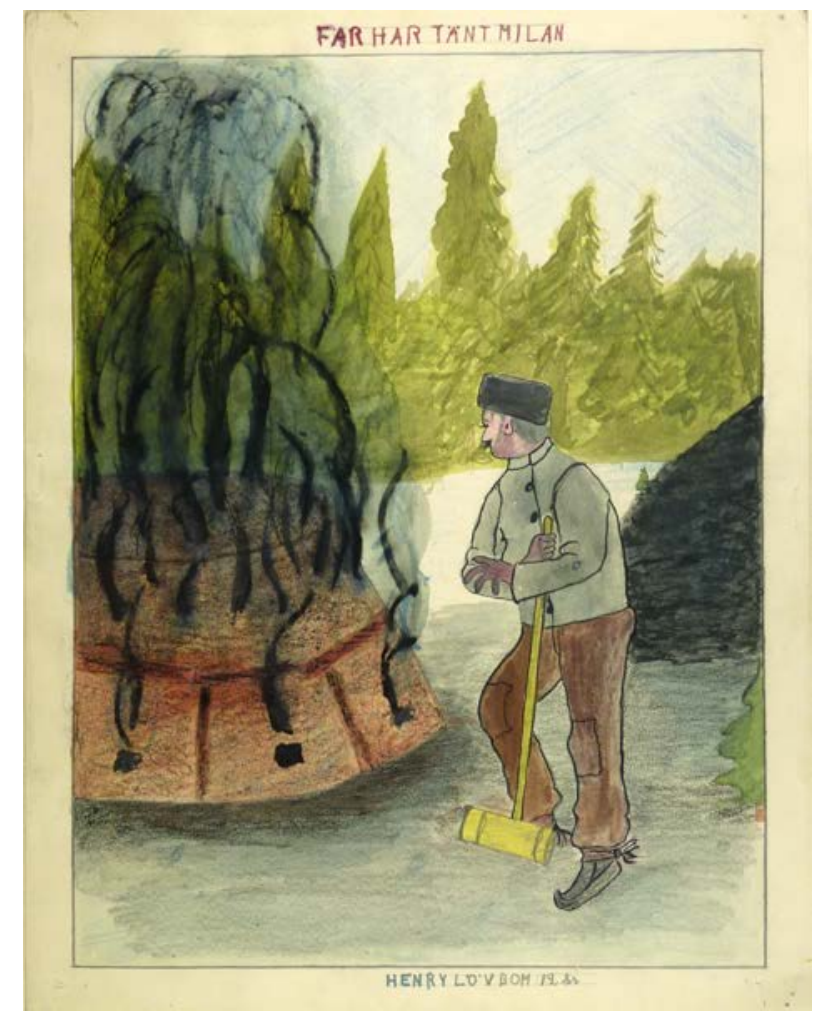

Bild 5:14. Livet i vår hembygd, FIB tävling 1939.

I bildens förgrund ser vi en man som står halvt bortvänd från oss, han lutar sig på en klubba och tittar på "milan", som han just tänt, enligt bildens namn. Ur den konformade, tegelfärgade milan till vänster kommer svart rök ur svarta hål runt om. "Far" har pälsmössa, byxor med lappar på knäna, och näbbstövlar, som refererar till Norrland. I bakgrunden syns lite ljusblå himmel och en tät mörkgrön granskog. Till höger ligger ett mörkt fält, som skulle kunna vara kol. Milan refererar också till tillverkning av kol för gruvdrift. "Far" associeras till att det är tecknarens pappa som vi ser på bild, men de som vaktade vid kolmilorna refererar också till "den ensamme mannen", kolaren, som bodde i skogen i en kolarkoja för att vakta milan. Bilden ger intrycket av en stark, ensam man som kan bemästra och använda naturen. Han har huvudet vänt bort från oss, mot milan, uppmärksamheten riktas mot arbetet och inte mot betraktaren. Av mannens lappade byxor förstår vi att det är en man i ganska enkla omständigheter. I den socialistiska tidningen FIB fanns det också ofta bildreportage från olika arbetsplatser runt om i Sverige. Att lyfta fram det arbetande folket var något som låg $\mathrm{i}$ tidningen FIB:s intresse. Berättelsen om bondens kamp mot naturen och vikten av att visa upp allmogens kultur- produktionslandskap är något som synliggjorts bland annat av Orvar Löfgren och Jonas Frykman. De diskuterar hur diskursen om svensken som ett naturälskande folk, kan sättas i relation till Sveriges relativt 
sena industrialisering. ${ }^{812}$ Detta kan bekräftas av tävlingsbilder likt denna, som visar hur män arbetar i kulturlandskapet. De återkommande bilderna av mannen $i$ hembygden, skapar en bild av hembygden som sammanhörande med mannen. I barnens 117 teckningar av hembygden 1939, visar en övervägande majoritet bilder av bara män, endast tre bilder visar bara kvinnor och 10 bilder avbildar både vuxna och barn. Mannen och mannens arbete blir det som tydligast definierar hembygden. På liknande sätt har Ingegerd Rydin visar hur SVTs innehållsanalys från början av 1980-talet visade att män synliggjordes betydligt mer än kvinnorna i SVTs barnprogram, och hur barnprogrammen skildrade en gammaldags idyll av trygghet och harmoni. ${ }^{813}$

Att det var åtskilda arbetsmoment som utfördes av kvinnor eller män är tydligt i bilderna på samma sätt som man kan se i samtida skolböcker, kvinnor kärnar smör, mjölkar och väver, och män plöjer och arbetar i skogen. ${ }^{814}$

Det fåtal bilder där kvinnor syns i bilderna 1939 är vid aktiviteter som mjölkning, smörkärning, potatisplockning, och ullkardning. I en bild är det en kvinna som avbildas i seriell produktion, troligen betalt arbete "I nästan varenda stuga här stickar vi tröjor till sticke-ställen i Borås" av Allan Karlsson 8 år. I Bilden står en person, troligen ett barn, med blå byxor och röd tröja, som avbildas bakifrån framför en stickmaskin. Till höger sitter en kvinna med kjol vid en symaskin. Samlingen innehåller även två bilder av "slåtter", där män och kvinnor arbetar tillsammans, i båda är det mannen som slår med lie och kvinnan som krattar. Fördelningen av arbetsuppgifter är alltså ofta tydlig i bilderna av hembygden.

Bilden från Sjöholm och Goes lärobok i hembygdskunskap, med teckningsanvisningar, visar att kvinnor associeras till att sköta korna och hur de tar hand om och separerar mjölken (bild 5:15). Både lärobokens och barnens bilder visar inte självklart hur arbetsfördelningen såg ut, de deltar däremot i att konstruera föreställningar och ideal om hur det borde se ut.

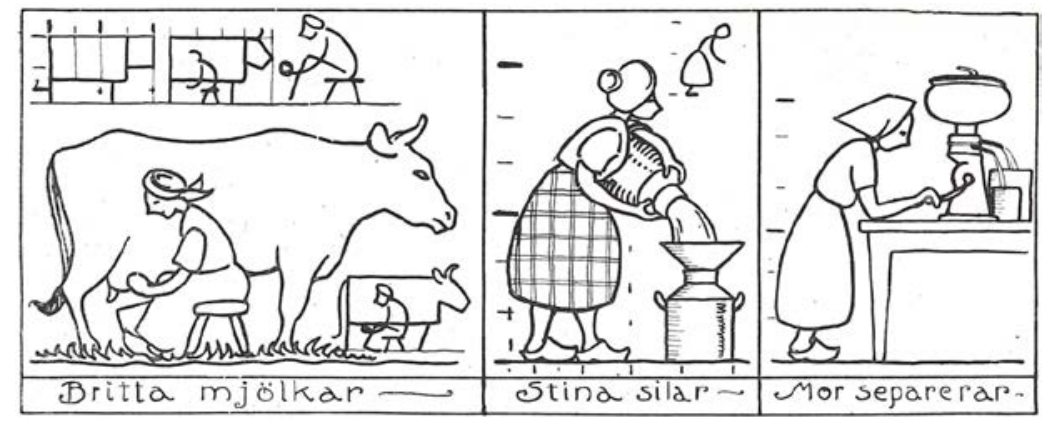

Bild 5:15. Sjöholm Goes Handledning vid arbetsövningar i Hemkunskap tredje skolåret sid.134.

812 Frykman, Jonas \& Löfgren, Orvar (1979). Den kultiverade människan. 1. uppl. Lund: LiberLäromedel sid. 46. Detta resonemang återkommer även i nationskapitlet.

${ }^{813}$ Rydin, Ingegerd (2000). Barnens röster: program för barn i Sveriges radio och television 19251999. Stockholm: Stift. Etermedierna i Sverige sid. 334.

${ }^{814}$ Sjöholm, L. Gottfrid (1923). Handledning vid undervisningen i hembygdskunskap. 3, Tredje skolåret. 2. uppl. Stockholm: Sv. bokförl. (Norstedt) sid. 134. 
När enbart flickor och kvinnor syns i arbete i utomhusbilder på landsbygden 1939 är det med djur, kor eller hästar. I bild 5:16 ser vi tre kor i en hage, en ko i bakgrunden är bunden vid ett träd. Kvinnan i prickig klänning, som syns i mitten av bilden kan vara på väg för att mjölka den. Längst ner till höger i bild står en flicka i rödrutig kjol och röd mössa, hon håller gräs i handen, som kan vara tänkt att ge till den brunvita kon som står centralt i bilden. I bakgrunden finns björkar och granar och ett rött hus med svart tak. Bilden har inget namn, men konnoterar kvinnoarbete, likt läroboksbilden ovan. I mitten av bilden syns ett stort kärl, liknande det som visades i bild 5:15 av "mor silar". En ytterligare bild heter "När mor har mjölkat korna ute". Även den konnoterar hembygdsromantik med ett grönskande sommarlandskap och refererar likt skolboken bild 5:14 att mjölkning av kor var flickors arbete. Däremot finns från samlingen min fritid, en bild av en pojke med korna i ladugården, men det är också den enda bilden som visar en mjölkmaskin. ${ }^{815}$ Tekniken kunde göra det som tidigare betraktades som kvinnoarbete åtråvärt även för pojkar och män.

I bilderna 5:16 och 5:17 visualiseras hur mäns och kvinnors arbete överförs över generationer, som när den lilla flickan följer med en vuxen kvinna för att mjölka, eller när "Pappa och Olle hugga timmer", i bild 5:17 av Stig Karlsson 10 år.

I bildens förgrund ligger ett träd på marken uppdelat i bitar, vid ett annat träd till höger i bild står en man, troligen barnets far och sågar i trädet, bredvid ligger en yxa. Till vänster i bild ser vi ytterligare fyra träd, och i mitten av bilden ett mindre träd som ligger ner, vid trädet står en figur med en yxa i ena handen, troligen "Olle", om Olle är bror till tecknaren. Genom att personen i förgrunden gör det mera farliga arbetet med att fälla trädet och använda en tung såg, konnoteras han snarast som barnets far.

Yxan är ett viktigt verktyg för det finns tre stycken i bild, en som "Olle" håller och två som ligger på marken. Att de hugger "timmer" talar om att det är stora träd, som kan göras plank och brädor av för att bygga hus. Vi se också att figuren till höger är liten i förhållande till trädet. Bilden konnoterar skogsbruk och skogsarbete.

Genom titeln är det "Pappa och Olle" som tilltalas, där "Olle" kan vara en bror, eller en annan man. De som inkluderas i denna, liksom i många andra hembygdsbilder är just "män som arbetar". Bilderna kan även referera till nationalromantiskt landskaps- och landsbygdsmåleri.

Därigenom kunde bilderna tilltala Nationalmuseums juryledamot, då barnbilden ansågs kunna referera både till det historiska och det moderna. Juryledamöterna från FIB, kunde ha intresse av att lyfta fram bildernas samband med en samtida arbetarrörelse som i hög grad ville poängtera vikten av att synliggöra bönders och arbetares vardag. Fördelningen av arbetsuppgifter är alltså ofta tydlig i bilderna av hembygden. Dikotomi och åtskillnad mellan det manliga och

${ }^{815}$ Från temat Min fritid 1940 i Nationalmuseums samling finns en bild som visar en pojke/man som mjölkar med mjölkmaskin. 


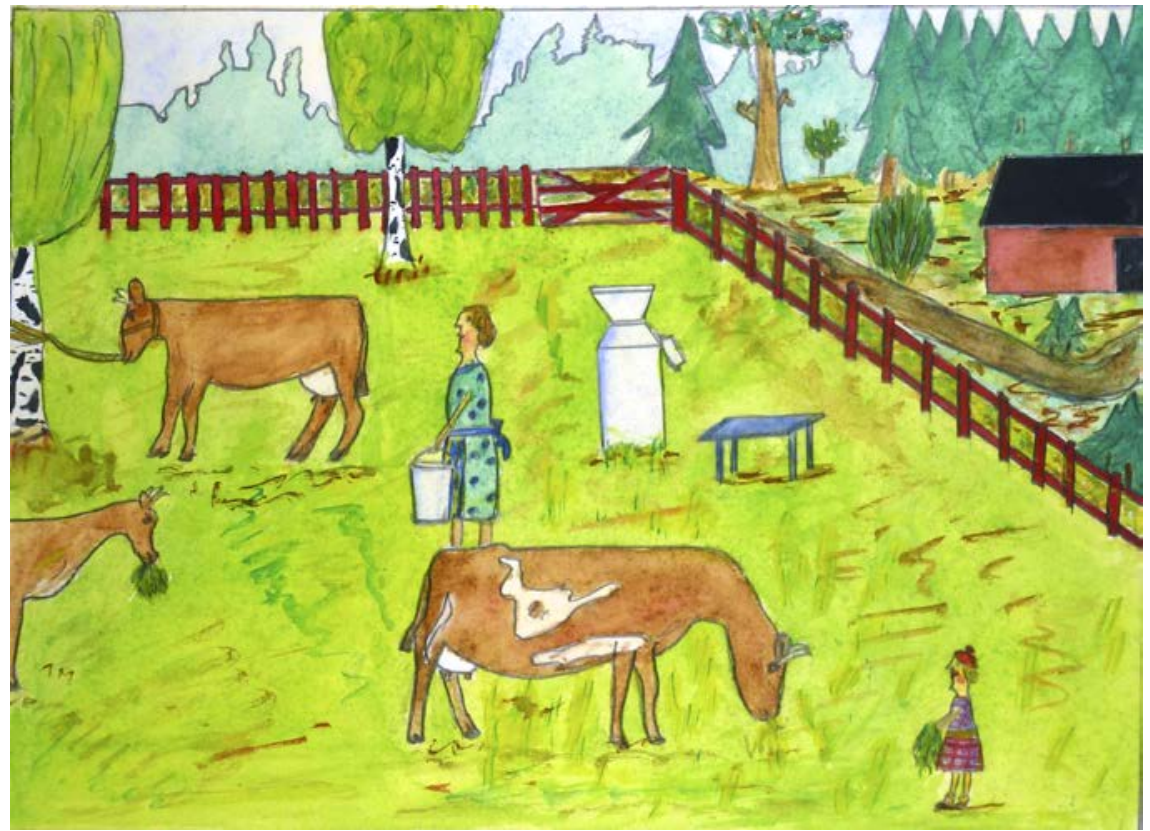

Bild 5:16. Livet i min hembygd, FIB:s tävling 1939.

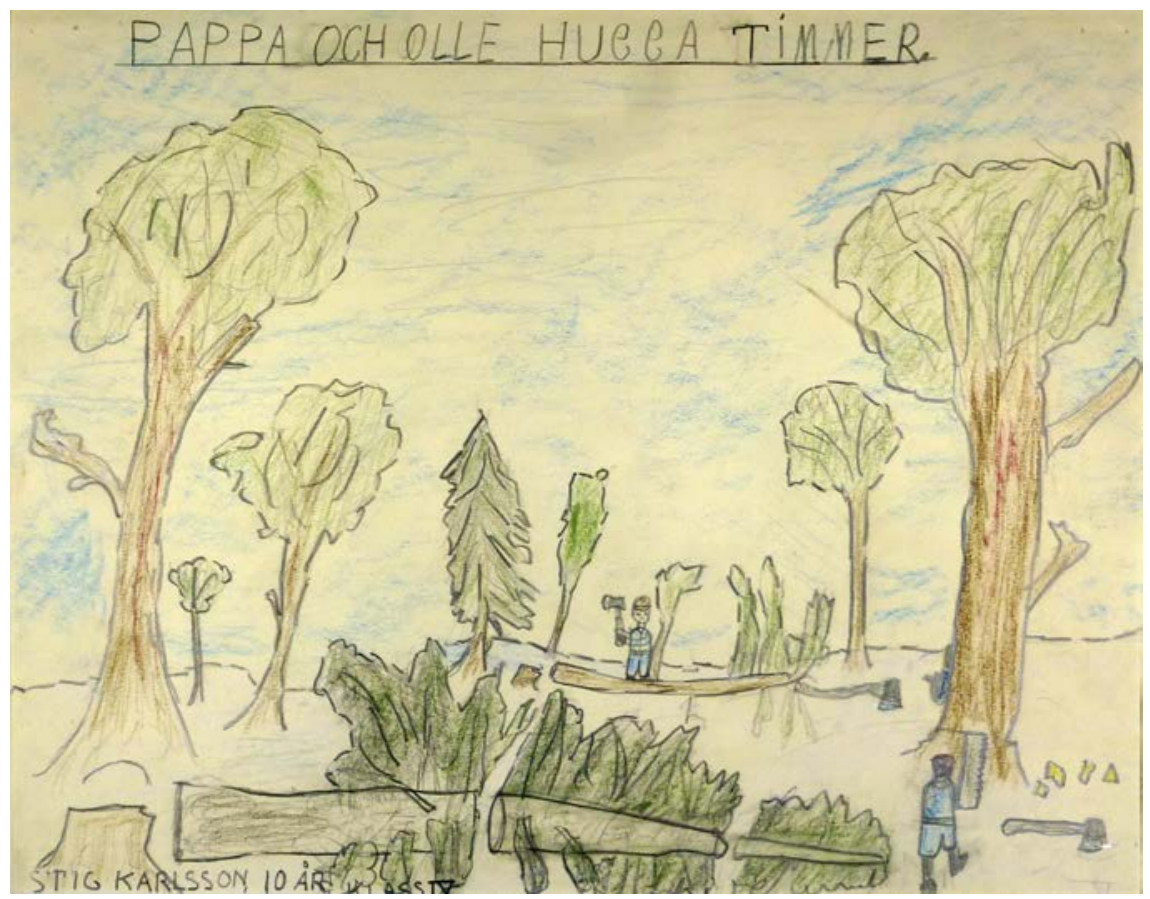

Bild 5:17. Livet i min hembygd, FIB:s tävling 1939. 
kvinnliga upprätthålls tydligt i FIB:s tävling, och som vi ska se, fortfarande 1979 i Televerkets tävlingsbilder.

1979 när barn ska teckna "yrke och arbetsliv i vår hembygd" är det som sagt flest män och oftast mansyrken definierade genom teknik och maskiner (bild $5: 18) .{ }^{816}$

I LGR 69, som använts i skolorna i tio år när tävlingen "yrke och arbetsliv i vår hembygd" är aktuell, står i anvisningar och kommentarer kring "Lärostoff" till ämnet hemkunskap: "Ett angeläget syfte i undervisningen bör vara att ge en nyanserad bild verkligheten och att motverka traditionella föreställningar om könsroller. Man bör utgå från att pojkar och flickor kan ha samma intressen och samma beteendemönster". ${ }^{817}$ Av att man i denna texter formulerar "bör" och inte "skall" kan man förstå att detta ämne inte är helt okontroversiellt.

...Redan på detta stadium bör undervisningen söka klargöra,
att män och kvinnor kan utföra samma arbetsuppgifter både
i hemmet och på arbetsmarknaden, ge konkreta exempel på
avvikelser från det traditionella könsrollsmönstret och stimu-
lera eleverna att ifrågasätta den arbetsfördelning efter kön som
de möter i samhället.

Utifrån läroplanstexten anmodan att ifrågasätta samhällets arbetsfördelning efter kön, kunde vinnarbilderna som ska gestalta yrke och arbetsliv i vår hembygd sett annorlunda ut. Tävlingsbilderna bekräftar istället traditionella och tydligt maskulina arbeten. Av de 34 vinnarbilderna till 1979 års telefonkataloger är det bara tre där kvinnor är representerade; Heby och Sala som har sjuksköterskor, Växjö som har en flicka som mjölkar kor, samt Jönköping som har både män och kvinnor på en marknad.

Man hade naturligtvis kunnat fråga sig om de hade kunnat välja andra bilder. Då jag granskat de bilder som skickats in från Malmödelens katalog har jag noterat att det fanns bilder av kvinnor i arbete som juryn hade kunnat välja ${ }^{819}$ Vid genomgång av det totala materialet av 1074 bilder från Malmödelens inkomna förslag till katalogomslag, visar det att knappt 200 bilder gestaltade kvinnor som arbetar. Den manliga normen är således genomgående även bland de bilder som kommit in till juryn. Av de knappt 200 bilder där kvinnor representerades som deltagande $\mathrm{i}$ arbetslivet fanns dels bilder av kvinnor i mera traditionella kvinnoyrken, som sjuksköterska, lärarinna, servitris eller frisör. Eller mindre könskodade som bagare, kock, bonde, skådespelerska eller konstnär. Samlingen innehåller även bilder som tydligt avviker från det traditionella könsrollsmönstret" som exempelvis militär, polis, eller präst. ${ }^{820}$ Juryn hade alltså kunnat aktivt välja bilder som följde läroplanens intentioner. Bild 5:19 och 5:20 visar två av de

\footnotetext{
81620 av 34 bilder är av landsbygd, De övriga är gruva, fabrik, svets, sl-vakt, bagare, orkester, och sjuksköterskor.

${ }^{817}$ Läroplan för grundskolan 1969 sid. 179.

818 Ibid. sid. 179.

819 Fem bilder från varje klass i årskurs tre i katalogområdet.

${ }^{820}$ Bilder ur SBBA samling 2003:009.
} 
Vinnande bilder: Teckningstävlingar för barn 1938-2000
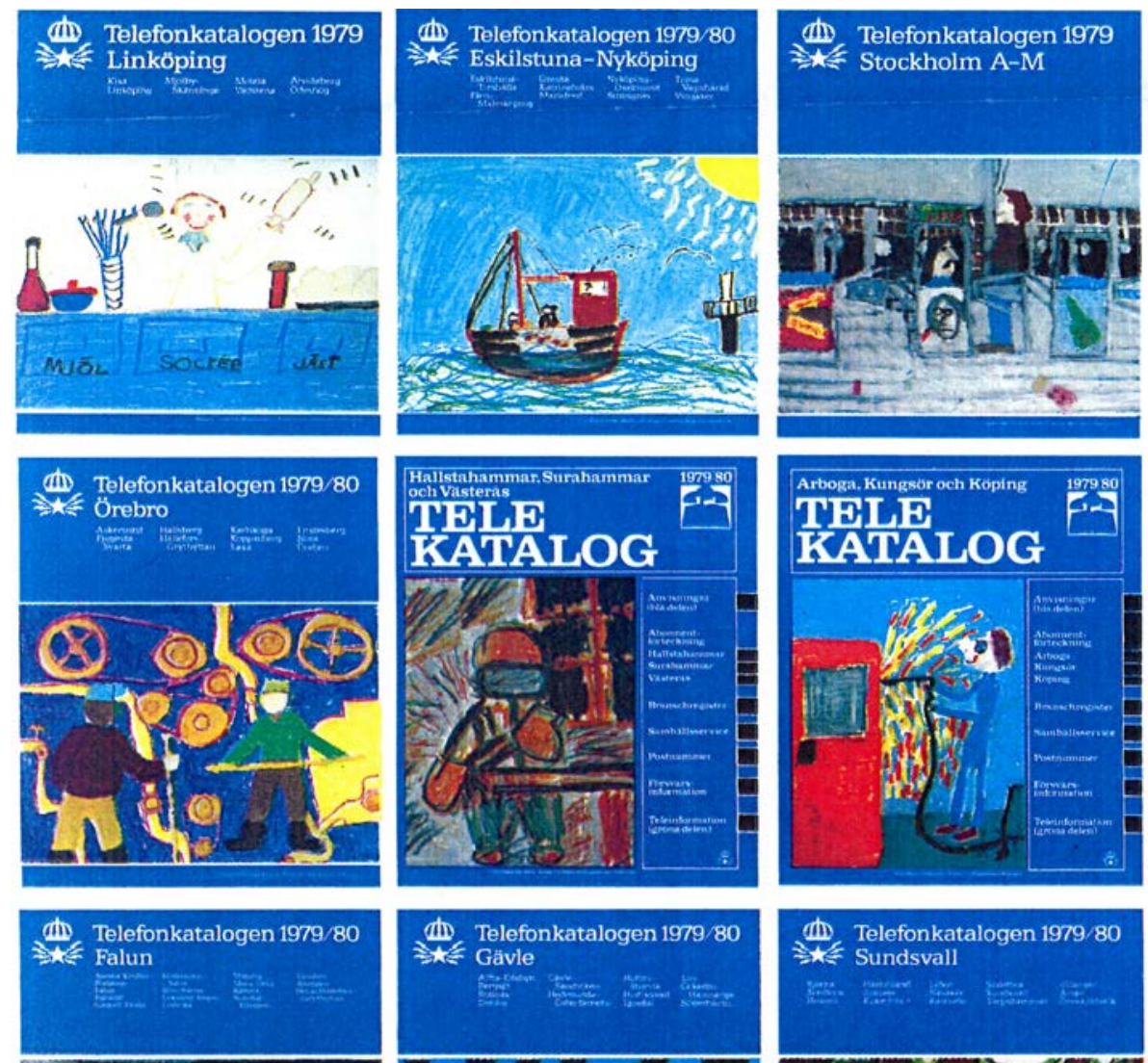
$\Rightarrow k$ Sundsvall
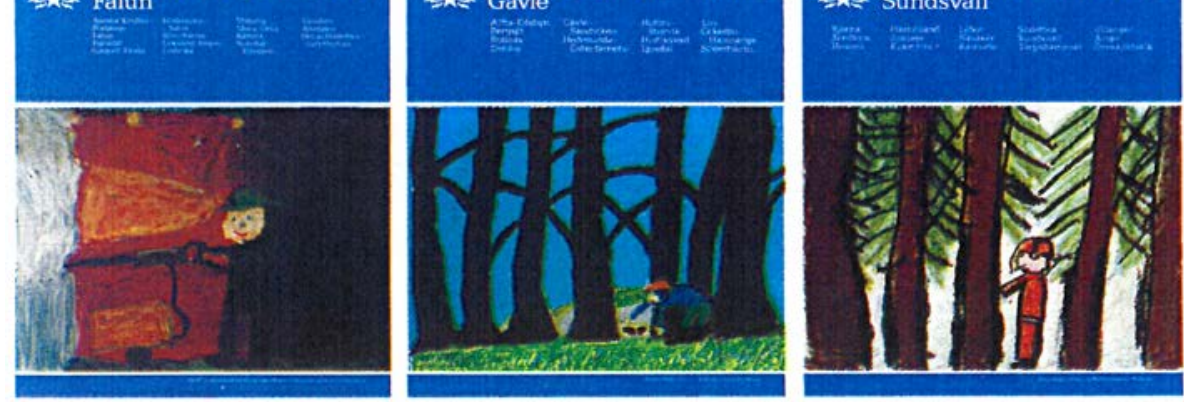

Bild 5:18. Yrke och arbetsliv i vår hembygd, Vinnarbilder Televerkets tävling 1979, detalj. 
1074 bilder som skickades in till Televerket av elever från Malmöområdet 1979 med temat "yrke och arbetsliv i vår hembygd", men inte vann.

Bilderna gjordes inom ramen för ämnet hembygdskunskap, där vi sett ovan vilka riktlinjer som fanns. Däremot var lärarna som undervisande i årskurs tre $\mathrm{i}$ hemkunskap inte representerade i juryn, där satt för varje telefonkatalogområde två bildlärare eller fortbildningskonsulenter och en representant från Televerket. Som vi såg i kapitel två var det tydligt i tävlingsbestämmelserna att bilderna inte fick innehålla omotiverad reklam eller politiska budskap, men det fanns däremot inga anvisningar om att man borde följa läroplanen.

Bild 5:19 visar en kvinna med en kyrkobyggnad i bakgrunden; kvinnans svarta klädsel med vita band i halsen refererar till prästyrket. Det blonda långa håret och de långa ögonfransarna konnoterar kvinna. Kvinnan blickar upp mot himlen, händerna är knäppta runt ett rött föremål som i kontexten konnoterar till bibel eller psalmbok. I båda bilderna är det blå himmel. I bild 5:20 ser vi till vänster en person med blå jeans, röd tröja och brunt rakt hår ner över axlarna. Personen står på en stege och plockar äpplen från ett träd. Till höger står ytterligare två träd med äpplen, vilket refererar till att det är en äppelodling och ett arbete att plocka äpplen. Personen konnoteras snarast som flicka/kvinna, men kläderna och håret refererar till ett unisexmode under 1970-talet som kan konnotera både kvinna, man och barn/ungdom, jämfört med 1939 års bilder där flickor och kvinnor alltid framställdes med kjol eller klänning.

På Televerkets bilder är det ibland svårt att svårt att definiera kön, exempelvis i yrken som har uniform, som polis eller militär. Eftersom bilderna är gjorda med tjocka kritor, kan stilen att måla göra bilderna könsneutrala. I några av de vinnande bilderna från föregående uppslag är det på grund av yrkets art, som svetsare, skogshuggare eller grävmaskinist så att vi kodar yrket som del av en manlig yrkesdiskurs, även om det inte syns andra attribut för manlighet. ${ }^{821}$

I Arla/Postens Varför får inte barn bestämma finns också fler vuxna män (8) än kvinnor (4), men till skillnad från FIB 1939 och Televerket 1979, finns fler bilder av barn än av vuxna. Att barn 1976 bjudits in av Arla/Posten att delta i samhällsdiskussionen och uttrycka sina åsikter, innebar ett problematiserande av mansrollen. Även om bildtexterna inte påtalar mannen, är det män som avbildats och som behöver ändra sitt beteende. Det kan handla om att sluta slå ihjäl sälar, skjuta elefanter, eller män som behöver hjälp för att de är alkoholister. Männen är i Arlas tävlingsbilder är alltså oftast negativt konnoterade. En manlig yrkeskategori finns det dock som är värd att värna; det är en bild av en man med skägg, pipa i munnen och sydväst med titeln "Jag vill värna om det svenska fisket" ${ }^{822}$ Även om yrket fiskare är något man vill "värna om" så är mansrollen och mäns makt ifrågasatt i boken Varför får inte barn bestämma 1977, där FIB:s och Televerkets bilder snarare deltar $\mathrm{i}$ återskapandet av rådande genusordningar.

$$
* * *
$$

\footnotetext{
${ }^{821}$ I kapitlet om barns platser och relationer, återkommer hur synen på både barns, kvinnors och mäns arbete förändrats över tid.

822 Varför fär inte barn bestämma: en bok av barn för vuxna! (1977) Stockholm: Utg.sid. 126.
} 


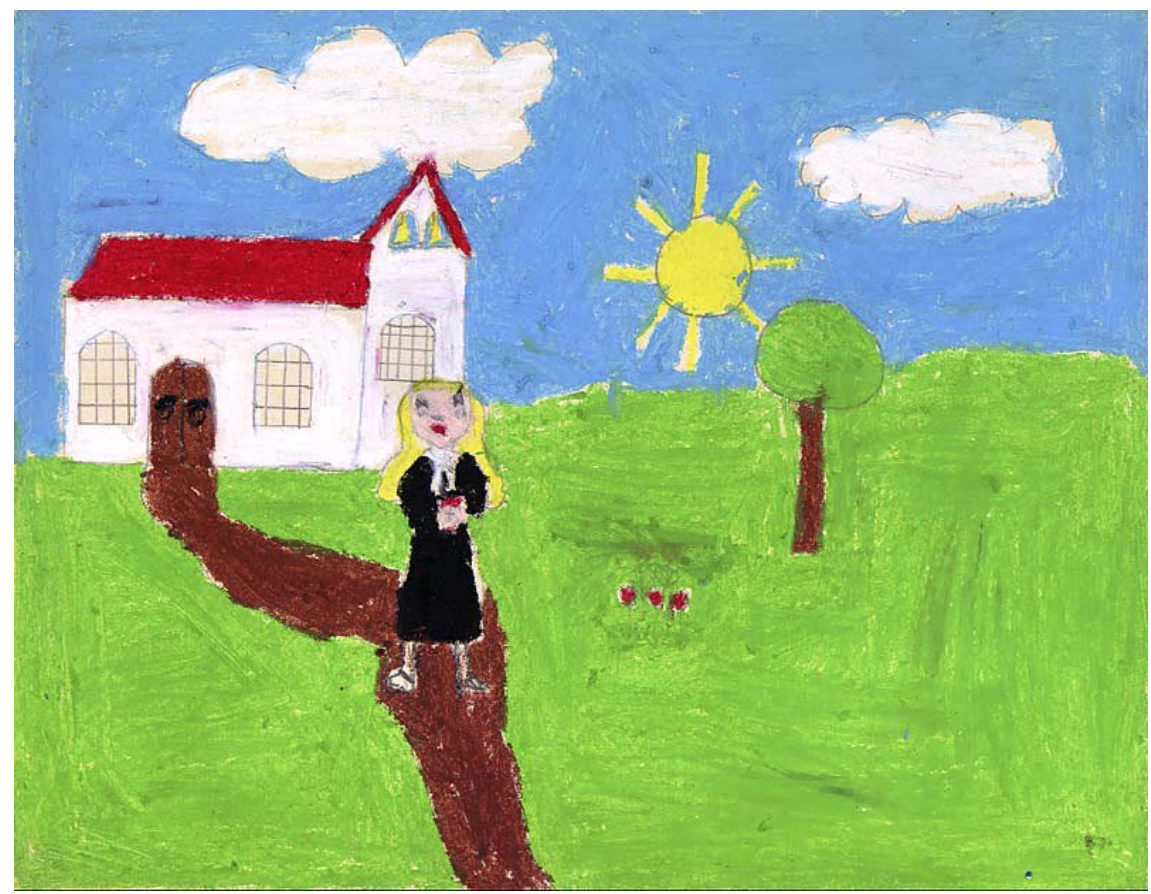

Bild 5:19. Yrke och arbetsliv i vår hembygd, Bidrag till Televerkets tävling 1979

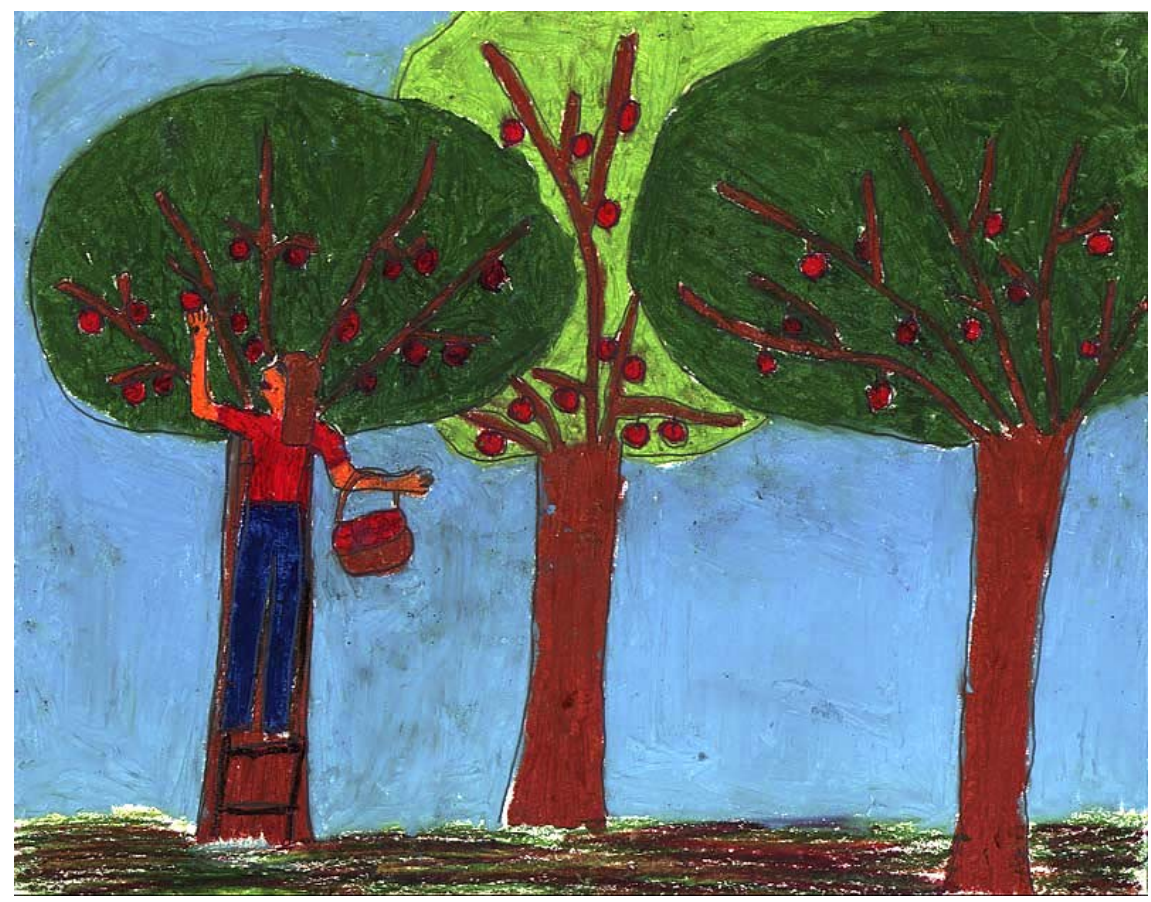

Bild 5:20. Yrke och arbetsliv i vår hembygd, Bidrag till Televerkets tävling 1979. 
Män förekommer i betydligt högre utsträckning än kvinnor i bilderna både från 1939 och 1979. Det finns alltså en tydlig kontinuitet över tid i att bilder av hembygden i stor utsträckning associerats med manlig aktivitet. I bilderna från 1939 visualiseras även hur genusspecifika arbeten traderas från en generation till en annan, både i skolböcker och i barnens bilder.

Diskursen i Televerkets vinnarbilder av yrke och arbetsliv i hembygden 1979 reproducerar normen, att mannen och det manliga arbetet i "Hembygden" är det som ges plats och utrymme, vilket innebär att kvinnor och kvinnors arbete till stor del osynliggörs. Min granskning visar att det fanns andra bilder tillgängliga som juryn hade kunnat välja som vinnarbilder och därmed följa läroplanens tankar om att skolans undervisning borde ifrågasätta den arbetsfördelning efter kön som finns i samhället. Men istället blir bilden av mannen liktydig med bilden av "arbete".

Bilden av mannen/fadern har alltså positiva konnotationer som en aktiv yrkesman i Televerkets tävling från 1970 -talet och i FIB:s tävlingar från 1940-talet, men mansrollen är mindre positivt konnoterad i Arlas tävling. Det som gestaltades som manligt eller maskulint gavs genom Arlas och Televerkets tävlingsbilder delvis olika innebörder, även då de är producerade under samma tid.

\section{Barn skildrar framtida yrken}

Förutom att uppdra åt barn att skildra samtida liv i skolan, på fritiden och i hembygden, har olika arrangörer också frågat efter bilder av barnens tankar kring framtiden. Framtidstemat diskuterade jag delvis i kapitel två under avsnittet om tävlingarnas teman. Där arrangörer under den senare perioden kunde fråga efter barns rädslor inför framtiden, var uppdraget I FIB:s tävling 1942 "Vad jag vill bli när jag blir stor", ett tävlingstema som snarare representerar framtidstro och förändring. Uppdraget kan enbart ges till barn och ungdomar och genom att ställa denna fråga impliceras att det finns möjlighet att göra annat än att gå i sina föräldrars fotspår: Tema kan visa på vuxnas intresse för att barn "ska bli något". De är symboler för de framtida medborgarna, och bilder av vad de unga vill efterfrågas och ställs ut. Hur avbildar då flickor och pojkar sig själva i framtida yrkesroller, och vad kan juryns urval och kommentarer av bilderna berätta om vuxenvärldens förväntningar?

Det är de tävlingsbilder som publicerades 1942 i FIB:s som analyseras i detta avsnitt. Bilderna kommer också att sättas i relation till samtida annonsbilder i FIB, samt till en bild från Arla/Postens bok från 1977.

I FIB nr17 1942 uppmanar Karin Lundström, teckningslärarinna vid Stockholms folkskolor och medlem i juryn för 1942 års teckningstävling, fler att skicka in bidrag till årets tävling där temat varit "vad jag vill bli när jag blir stor”. På följande sätt beskriver hon för läsarna de hittills inkomna tävlingsbidragen:

Det tycks som om pojkarnas fantasi mest går i olika maskinella riktningar, och det är ju ganska förklarligt, - men till flickorna har det faktiskt ibland behövts det lilla påpekandet att det finns 
andra yrken än barnsköterska och butiksbiträde, som är roliga både att bli och illustrera! $!^{823}$

Denna progressiva lärarinna uppmanar flickorna att tänka bredare kring framtida yrke och ifrågasätter de genusstrukturer hon menar syns i bilderna. Men citatet visar även en föreställning om att när pojkarna väljer "maskinella riktningar" är det "förklarligt" och de behöver inga påpekanden om att det finns andra yrken. Diskursen 1942 kring flickors framtida yrke är under förändring men pojkars fantasier om maskinella yrken beskrivs av lärarinnan som självklar och ifrågasätts inte.

Jag kommer i detta avsnitt först att diskutera de två bilderna som väljs ut när man första gången presenterar vinnarbilderna från årets tävling i FIB nummer 22, det är dels bilden "Jag vill bli mamma till åtta barn" och dels bilden "Civilingenjör". ${ }^{824}$ Därefter analyseras en av bilderna från Arlas bok Varför fär inte barn bestämma 1977, som anknyter till den tidigare bilden "Jag vill bli mamma till åtta barn" och där barns röster kunnat användas för att uppmana kvinnor att vilja vara hemmafruar. Därefter granskas de nio vinnande bilderna publicerade i nästföljande nummer av FIB 1942 (nr 23), och bland annat hur bilderna visar liknande arbetsområden gestaltade som avlönat arbete för män och oavlönat för kvinnor. ${ }^{825}$ För att visa intertextuella referenser i en bredare kontext har jag även valt att ta med en reklambild för damkläder, även den publicerad i FIB, och en utbildningsannons från "NKI" publicerad i FIB 1943. 826

FIB har arrangerat återkommande tävlingar sedan 1938, och 1942 är andra gången bilderna ställs ut på Nationalmuseum (bild 5:21). Rubriken på tidningssidan är Årets teckningstävling en glänsande framgång! Jag analyserar hela tidningssidan, det vill säga både text och bild och de olika betydelseelementen på sidan utgörs av tecken.

I rubriken slås fast att årets teckningstävling var en framgång, och i texten till vänster ser vi att det var över 800 klasser som deltog, där antalet klasser troligen var en del i det som bedöms som framgångsrikt, då det var fler än tidigare år. Texten deltar i att skapa skillnad mellan flickor och pojkar när FIB beskriver att: "Pojkarna ska bli..." medan däremot "... bland flickorna kretsar fantasien mest kring..." vilket skapar en bild av hur pojkar självklart ÄR ett yrke, där flickor snarare har fantasier om framtiden. Hirdman menar att grundtanken i folkhemmet vilade på ett genuskontrakt där staten stöttade idealbilden av en

823 FIB 1942 nr 17 sid. 38.

8241942 delades ut $5000 \mathrm{kr}$ i pris, fördelat på tjugofem 50 kronor pris och hundra 25 kronors pris. Flera andra fick diplom. C:a 4000 bilder skickades in 1942. Indelningarna av bilderna gjordes utifrån ålder, Grupp 1 var över tolv år och gick i A-skola (stadsskola), grupp 2 A-skola upp till tolv år, och grupp 3 var B- eller C-skola utan åldersindelning. I FIB nr 131939 står att "De bästa teckningarna kommer i folket i bild under sommaren”, och tidningen fortsätter sedan varje år att publicerabilder ett antal vinnande bilder.

825 Hirdman, Yvonne (1988) sid. 15.

826 NKI-skolan, Nordiska korrespondensinstitutet, grundades i början av 1900-talet och där kunde man från 1940 läsa in bland annat ingenjörsexamen per korrespondens. 


\title{
ARETS TECKNINGST ÄVLING en glänsande framgång!
}

NÄRA 800 SKOLKLASSER

ōver hela Sveriges land har sănt in bidrag till Folket i Bilds årligen áterkommande stora teckningstävling för skolungdom, $\times$ Vad jag shall bli när jag blir storn har stâtt som tema for denna vấ femte tavling, och detta har vackt lantasien hos vara unga konstnarer pai ett fallikotnligt stralande satt. Nara nog alla tankbara yrken ar representerade med en largglàjje och idérikedom som ar rent forblufiande. Pojkarna skall bli dykare, brandsoldater, forskningsresande, officerare, lantbrukare $a$. * v. och bland flickorna kretsar tantasien mest kring sildana yrken som danirissorskor, barnskôterskor, veterinărer, artister m. m.

Allt som allt har det kommit in flera tusen bidrag, och taivlingsjeryn àr nu $i$ full fart med sitt svâra och kravande varv, prisbedomningen. Emellertid iramskrider det digra arbetet i snabb takt, och i de tva nastkommande numiren av Forket i Bild. alltsi i $\mathrm{nr} 23$ och 24 kommer pristagarna att publiceras.
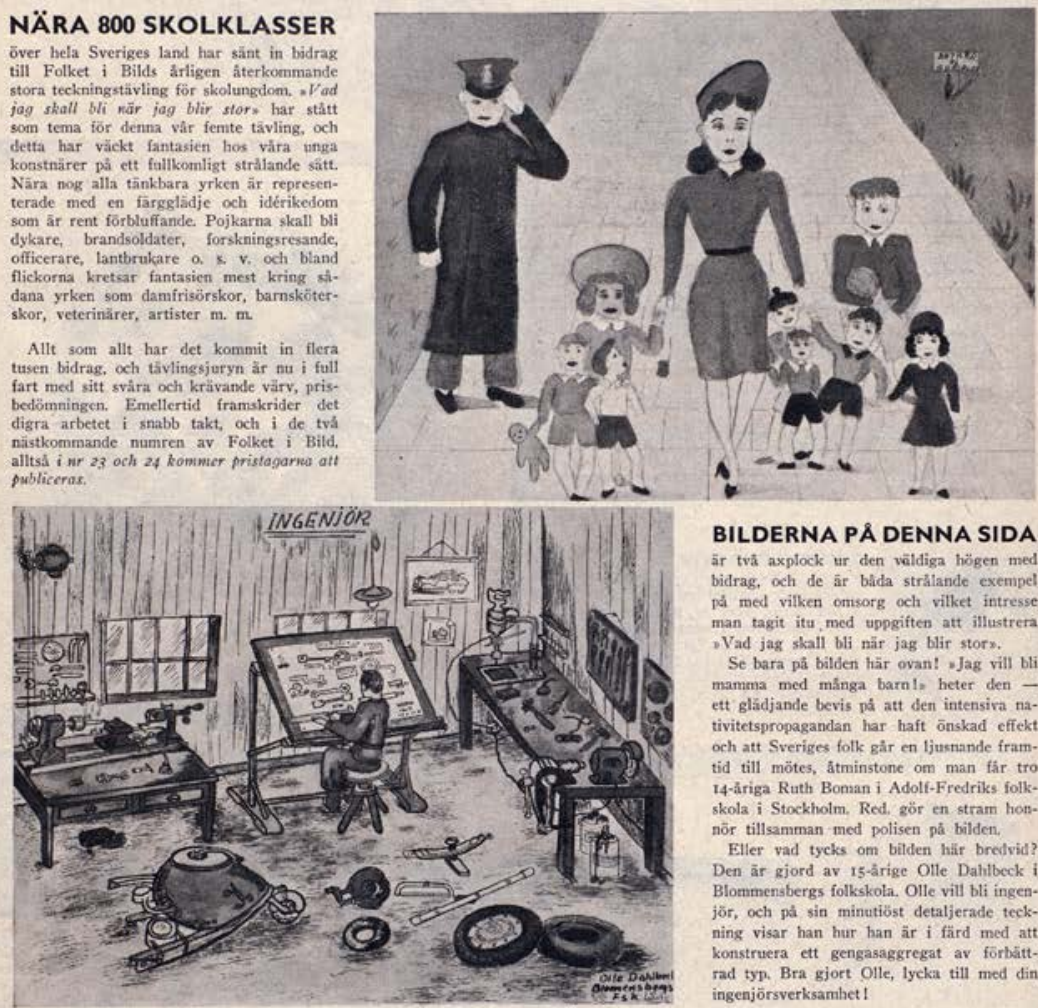

BILDERNA PÅ DENNA SIDA àr tvấ axplock ur den waildiga högen med bidrag, och de âr bâda stralande exempel pá med vilken omsorg och vilket intresse man tagit itu med upggiften att illustrera ,Vad jag skall bli när jag blir stors. Se bara pâ bälđen hăr ovan! \& Jag vill bi mamma med mánga barnl, heter den ett gladjande bevis páa att den intensira nativitetspropagandan har haft ônskad effekt och att Sveriges folk găr en ljusnande framtid till mötes, âtminstone om man fär tro 14-ẩrige Ruth Boman i Adolf-Fredriks folkskola i Stockholm. Red, gör en stram honnồr tillsamman med polisen pẩ bilden. Eller vad tycks om bilden hil bredvid? Den är gjord av 15 -ärige Olle Dahlbeck Blommensbergs folkskola. Olle vill bli ingenjör, och pá sin minutiöst detaljerade teckning visar han hur han är $\mathrm{i}$ färd med att konstruera ett gengasaggregat av forbaittrad typ. Bra gjort Olle, lycka till med din ingenjörsverksamhet!

\section{Utställning på Nationalmuseum}

\begin{abstract}
I likhet med föregtende, âr kommer en varar, kan om anmälan göres till museet er-
del av de 600 prishelönade bilderna att ut- hallla sakkunnig ledning av en av museets

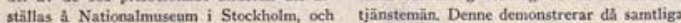
vi har all anledning förmoda att denna ut- museets samlingar. stâlning skall

Fredagen den 20 maj öppnas utstâllningen fầ plats fồ en del prisbilder frản tidigare av ôverintendenten Axel Gauffin. Hur lảnge tâvlingar. Alla skolklasser, som besöker Na- utstilliningen sedan kommer att păgà ầ ânn tionalmuseum under den tid utställningen inte bestàmt. Vi kan dock säga sà mycket

som att det blir en bra tid framát, och vi vill âven hãr passa pấ och be alla som ôver huvud taget har mōjlighet att gå dit att gōra det; det finns verkligen mânga bảde intressanta och reande teckningar att titta ns. $\mathrm{Vi}$ santa ochi roande te blir det nate utfortligt foto-reportage frán utstallningens öppnande $i$ nảgot kommande nummer av FIB.
\end{abstract}

Bild 5:21. Folket i bild 1942 nr.22 sid. 23. 
arbetande man och en hemmafru. ${ }^{827}$ FIB deltog i att förmedla denna folkhemsdiskurs, bland annat genom bildurval och textkommentarer, där barnbilderna kunde användas för att reproducera idéer inte bara om kvinnor och män, utan även om att det är att vara mor som flickor drömmer om eller att yrkesarbeta som pojkar drömmer om.

I det nedre textpartiet får vi veta att bilderna ska ställas ut på Nationalmuseum, och att det var fler än 600 bidrag som fick pris. Det är intressant att tidningen bland dessa 600 väljer ut just dessa två bilder som får representera tävlingen.

Även om bilderna är mest framträdande på tidningssidan, har även texten betydelse för budskapet. Så här lyder texten under den översta bilden:

\begin{abstract}
BILDERNA PÅ DENNA SIDA är två axplock ur den väldiga högen med bidrag, och de är båda strålande exempel på med vilken omsorg och vilket intresse man tagit itu med uppgiften att illustrera "Vad jag skall bli när jag blir stor". Se bara på bilden här ovan! Jag vill bli mamma med många barn! heter den. Ett glädjande bevis på att den intensiva nativitets propagandan har haft önskad effekt, och att Sveriges folk går en ljusnande framtid till mötes, åtminstone om man får tro 14-åriga Ruth Boman i Adolf Fredriks folkskola i Stockholm. Red. Gör en stram honnör tillsammans med polisen här på bilden.
\end{abstract}

Eller vad tycks om bilden här bredvid? Den är gjord av 15årige Olle Dahlbeck i Blommensbergs folkskola. Olle vill bli ingenjör, och på sin minutiöst detaljerade teckning visar han hur han är i färd med att konstruera ett gengasaggregat av förbättrad typ. Bra gjort Olle, lycka till med din ingenjörsverksamhet. ${ }^{828}$

Den övre bilden beskrivs med titeln: "Jag vill bli mamma med många barn" texten talar även om för oss vem som gjort bilden och texten fyller funktionen att förstärka och omtala flickans önskade framtid som positiv. Bildtexten $\mathrm{i}$ tidningen ger också andra referenser, då man skriver om att Sveriges folk härigenom går en ljusnande framtid till mötes, eftersom denna unga flicka har lyssnat till samtidens "intensiva nativitetspropaganda". ${ }^{829}$ Redaktionen uppmuntrar och uttrycker sitt gillande genom att "göra en stram honnör tillsammans med polisen på bilden." Flickors framtid som mor, gärna till åtta barn, är till glädje inte bara för henne själv, utan för hela "Sveriges folk". Genom sina åtta barn, får kvinnan på bilden en plats i strålkastarljuset. Bilden inkluderar dem som betraktar moderskapet som flickors självklara framtidsdröm. Redaktionen skriver också in sig själva i en manlighetsnorm genom att göra gemensam sak med polisen på bilden.

${ }^{827}$ Hirdman, Yvonne (2001). Genus: om det stabilas föränderliga former. 1. uppl. Malmö: Liber sid. 149.

${ }^{828}$ Folket i Bild 1942, nr 22, sid 23.

829 http://www.ne.se/uppslagsverk/encyklopedi/lång/befolkningsutredningen (2018-03-07) Befolkningsutredningen, en 1941-46 verksam kommitté med uppdrag att fullfölja de frågor som behandlats av den tidigare Befolkningskommissionen (1935-38). Ordförande var Tage Erlander. Till utredningen var en särskild kvinnodelegation knuten. Den tillsattes på grund av nativitetsminskningen under de första beredskapsåren. Se även Hallberg, Mathilda (2017). 
På den beskrivande, denotativa analysnivån av bilden ser vi en kvinna centralt placerad i bilden. Av bildtexten förstår vi att det är en mor, och det konnoterar även de åtta barn hon har omkring sig. De står på en upplyst väg och snett bakom till vänster står en man i skärmmössa och lång rock, som vi genom texten förstår är en polis, och som gör honnör. Kvinnan har välfriserat hår, hatt, snäv dräkt, skor med höga klackar och hon håller ett barn i varje hand. De åtta barnen är alla grupperade runt kvinnan, lite olika stora, men tecknade som små vuxna. Alla i bilden tittar på betraktaren, utom ett barn längst fram, som tittar upp mot den vuxna kvinnan. Även barnen är klädda i fina kläder, den största flickan har en liknande hatt som sin mamma.

På den konnotativa analysnivån kan man se hur kopplingen mellan att vara en snygg kvinna, som beundras av män i uniform, görs gemensam med att vara mor till åtta barn. Att ha många barn görs synonymt med framgång och skönhet, och att få beundran och uppskattning.

Bilden kräver även en kontextuell tolkning för att vi bättre ska förstå sammanhanget i vilket den publiceras. Även om textens teman handlar om framtiden, har den tydliga samtida referenser. Det kan exempelvis handla om samtida veckotidningsbilder, som visar bilder av kvinnor med liknande frisyr/kläder (bild 5:22). Det är alltså inte enbart läroboksbilder utan även andra bilder i barns vardag som tolkas och

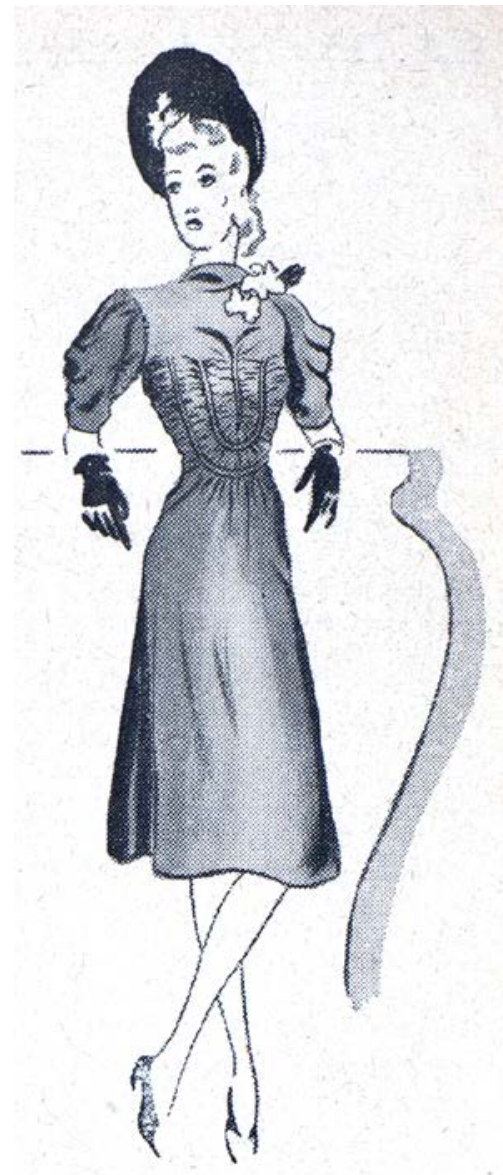

Den enklare klänningen piffas upp med isättning eller ärmslag och krage. Sidenbitar av alla slag är utmärkta till att sy sådana av.

Bild 5:22. Folket $i$ bild 1942 nr 17 sid. 26. omtolkas av barnen. ${ }^{830}$

På den denotativa nivån av den undre bilden ser vi en överblicksbild i fågelperspektiv över en verkstad. (5:21) I mitten av rummet sitter en man vid ett ritbord snett vänd bort ifrån betraktarna. Bredvid ritbordet finns ett fönster. På golvet och på väggarna och på en diskbänk till höger, finns olika typer av verktyg, däck och apparater. Bilden är tecknad med många detaljer. De ljusaste fälten är fönstret, en tavla på väggen av en bil, och själva ritbordet som mannen sitter

${ }^{830}$ Sparrman, Anna (2006). 
vid. I mitten högst upp i bilden står ordet "Ingenjör". Vi får veta av texten, citerad ovan, att Olle som tecknat bilden vill bli ingenjör när han blir stor och att han på bilden håller på att konstruera ett gengasaggregat av förbättrad typ. Ritningarna på bordet refererar till konstruktion/arkitektur. Texten "ingenjör" uppe till vänster i bild, olika verktyg och däck på golvet och bänken till höger, samt bilden av bilen på väggen refererar till "manlighet". Genom att omge mannen på bilden med de olika föremålen, skapas det också en relation mellan föremålen och mannen, som att de "hör ihop", liksom kvinnan och barnen i bilden ovanför. Den manlighetsdiskurs som görs gällande är att pojkar/män gillar och är bra på att meka med prylar, att uppfinna saker och förbättra drivmedel för bilar. ${ }^{831}$ Att detta är något tidningen också uppskattar förstår man av att de önskar Olle "Lycka till!"

I vårt bildspråkliga system vet vi vilka tecken som kan användas för att skapa en "kvinna" och kommunicera hur en kvinna ser ut: /hår/kjol/skor etc., sedan kan vi använda språket på olika sätt för att gestalta "kvinnan." ${ }^{832}$ Intressant i bilduppslaget från teckningstävlingen är också att kvinnan gestaltas framifrån, där hennes utseende är av vikt, medan mannen gestaltas sittandes bakifrån. Hans yttre är inte betydelsefullt, han skapar sin yrkesidentitet snarare av de ting han omger sig med. De myter som görs tydliga är framförallt via diskurser kring vad som anses vara manligt eller kvinnligt och vad som därigenom ses som möjliga och föredömliga framtidsdrömmar för barn.

Genom att dessa bilder är gjorda av ungdomar och publicerade på tidningens ungdomssidor kan de sägas tala primärt till andra ungdomar. Bilderna är utvalda både av lärare i klassen och sedan av en jury, men skrivs ändå fram här av redaktionen som uttryck för"barns/ungas "egna" röster.

Även i Arlas publicering av boken Varför får inte barn bestämma 1977, är det tydligt att man vill nå ut med barns röst. Jämfört med tävlingsbilderna från 1940-talet kan bilderna i boken generellt sägas ha ett mera "barnsligt" tilltal, med ett genomgående naivt bildspråk i bild och text. I bilden av Anne Marie Salomonsen i Halmstad med bildtexten "Jag önskar att alla barn hade sin mamma hemma när de kommer hem från skolan.” är figurerna tecknade som streckgubbar, med kläder på, i en serietidningsgenre (bild 5:23). Mamman har

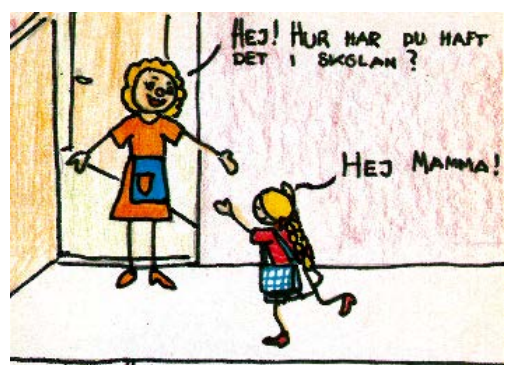
JAG ONSKAR ATT ALLA BARN HADE SIN MAMMA HEMMA NĂR DE KOMMER HEM

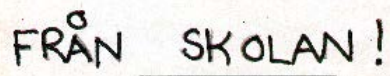

Bild 5.23. Anne-Marie Salomonsson i Varför får inte barn bestämma (1977). en orange klänning och ett blått förkläde,

\footnotetext{
${ }^{831}$ Vi konnoterar också idag gengas som något som hör ihop med bensinbristen under andra världskriget.

832 Saussure, Ferdinand de (1986). Course in general linguistics. Chicago: Open Court.
} 
flickan en röd klänning och en blå och vitrutig väska. Båda har gult hår, flickan i fläta och mamman ner till axlarna. Flickan springer mot sin mamma med ena benet lyft, och mamman står mad armarna utsträckta som om de i nästa scen ska krama om varandra. Flickan säger: "Hej mamma!”. Det som vi förstår är mamman ler stort och säger: "Hej! Hur har du haft det i skolan?". Det är ett varmt, rött ljus i hela bilden, som kommer både från figurernas hår och klädsel, och från en orange/rosa bakgrund. Bakom mamman står en dörr på glänt, mot det vi uppfattar som en lägenhet. Att posten och Arla väljer att ta med just denna bild bland de 130 av 15000 de uppger att de fått in, för att tryckas i boken kan ses som en tydlig politisk markering där det precis som i 40-talets bilder understryks att kvinnans främsta uppgift bör vara i hemmet och med barnen. Att det är en hemmafru snarare än en mamma som eventuellt har ett arbete som kan skötas hemifrån, understryks också av förklädet, som konnoterar köksarbete. ${ }^{833}$ Skolan och hemmet blir här också tydliga som de platser barn bör vistas på, genom texten "ha mamma hemma när de kommer hem från skolan". På en sociohistorisk nivå kan Arlas val av denna bild ses som ett politiskt inlägg för vårdnadsbidrag. Centerpartiet skrev i sitt partiprogram tre år senare:

För att småbarnsföräldrar själva skall kunna välja hur de vill fördela sin tid mellan förvärvsarbete och arbete i hemmet med barnens omvårdnad skall vårdnadsersättningen byggas ut. Den som av olika skäl väljer att själv vårda sina barn gör en för samhället värdefull arbetsinsats och bör få ekonomisk ersättning för sitt arbete. ${ }^{834}$

Ett samband mellan Arlas tävling och Centerpartiet, det gamla Bondeförbundet, är att Arla och bönderna kunde ha gemensamma ekonomiska intressen i mjölkproduktion, eftersom Arla är en kooperation av mjölkproducenter. Jonas Hinnfors har visat hur Centerpartiets argumenterade för vårdnadsersättning som politiskt medel för att främja den traditionella enförsörjarfamiljen. ${ }^{835}$ Det fanns också under 1960 och -70-talet en konservativ organisation Familjekampanjen - för barnets bästa som 1970 lämnade in 60000 namnunderskrifter till statsminister Olof Palme där de var kritiska mot den socialdemokratiska familjeoch jämställdhetspolitiken. ${ }^{836}$ Skillnaden mot flickan 1942 som vill bli mamma till åtta barn, är att det i bild 5:23 är barnet/flickan som önskar att alla mammor var hemma. Flickan vill ha mamman hemma, men att hon sedan själv skulle vilja bli lik sin mamma är inte något som görs självklart. Texten kan tolkas som att många barn är lämnade ensamma, de har inte någon mamma hemma och är

\footnotetext{
833 Förkläde syns även i tidigare bild av skolkök.

834 https://snd.gu.se/sv/vivill/party/c/program/1981

835 Hinnfors, Jonas (1992). Familjepolitik: sambällsförändringar och partistrategier 1960-1990. Diss. Göteborg : Univ. sid. 206.

${ }^{836}$ https://familjekampanjen.wordpress.com/about/
} 
därför inte inneslutna i den värme och gemenskap som bilden förmedlar. ${ }^{837} \mathrm{Då}$ tävlingens uppdrag var "Detta vill jag värna om", och andra bilder i boken ger exempel som utrotningshotade fåglar, valar eller isbjörnar, kan även mammor som är hemma ses som en utrotningshotad art, värd att värna om. Arla förmedlar genom bilden ett tydligt budskap: Barn vill värna om hemmafruar, och om barn får bestämma ska mammor vara hemma.

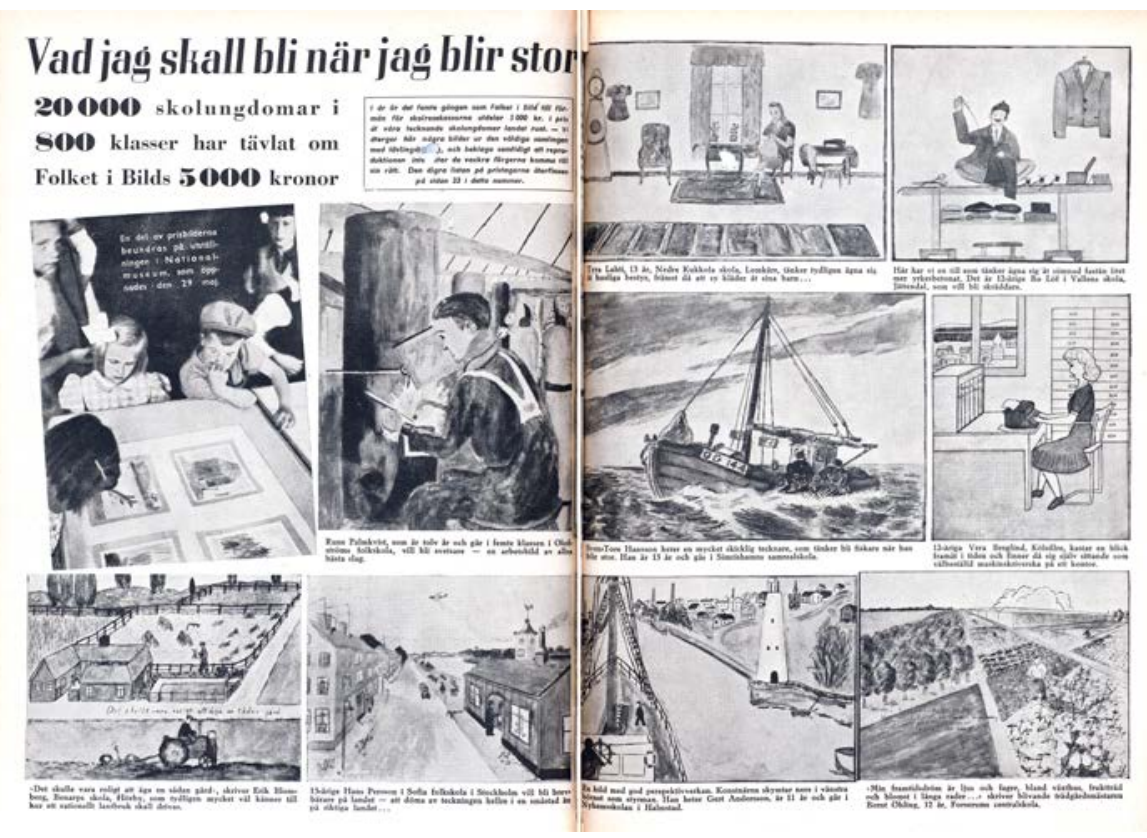

Bild 5:24. Folket i bild $1942 \mathrm{nr} 23$ sid.24-25.

I FIB nr 231942 publiceras ytterligare nio bilder med temat Vad jag vill bli när jag blir stor (bild 5:24). Sju bilder visar fram pojkars framtidsdrömmar, två visar flickors. Enbart denna fördelning åskådliggör hur pojkar förväntas ha ett yrke i betydligt högra grad än flickor. Bilduppslaget visar tydligt hur kvinnor och män utförde samma sorts arbete, men då det för kvinnor beskrevs som hemarbete "husliga bestyr, ... att sy kläder åt sina barn" var det för män betalt arbete. Där kvinnan "syr kläder åt sina barn" syr skräddaren "lite mera yrkesbetonat" i de två bilderna överst till höger. Det finns en yrkesarbetande kvinna; som tänker sig en framtid som välbeställd maskinskriverska. Att kvinnan beskrivs som just "välbeställd" kan uppfattas som att hon tjänar bra med pengar, och därigenom

837 Se tex Lundqvist, Åsa (2011). Family policy paradoxes: gender equality and labour market regulation in Sweden, 1930-2010. Bristol: Policy sid. 75; utifrån SOU rapport 1975:"While the fixed roles of women and men were increasingly under pressure, at least because of the growing number of women participating in the labour market, the sanctity of motherhood nevertheless remained a starting point for the everyday life of women and men, and for social reform." 
kan vara självförsörjande, snarare än att hon yrkesarbetar vid sidan om arbete som maka och mor. De övriga yrkena visar män, och är trädgårdsmästare, styrman, brevbärare, lantbrukare, svetsare och fiskare. Det är företrädesvis arbetaryrken, och som också till viss del visar fram betydelsen av olika geografisk hemvist för utövandet av yrkena, något jag även diskuterade $\mathrm{i}$ kapitel tre.

Bilderna refererar som sagt även till andra bilder. Med hjälp av texten som är tyckt på bilden av barnen som betraktar bilderna, associeras bilderna till "Utställning på Nationalmuseum" och därigenom till en konstdiskurs, med exempelvis samtida arbetarmålare som exempelvis Sven Eriksson eller Albin Amelin. (se bild 3:25)

Den formella funktionen hos alla dessa bilder är att de kodas som just barnbilder. Vad detta "gör" med bilderna varierar del-

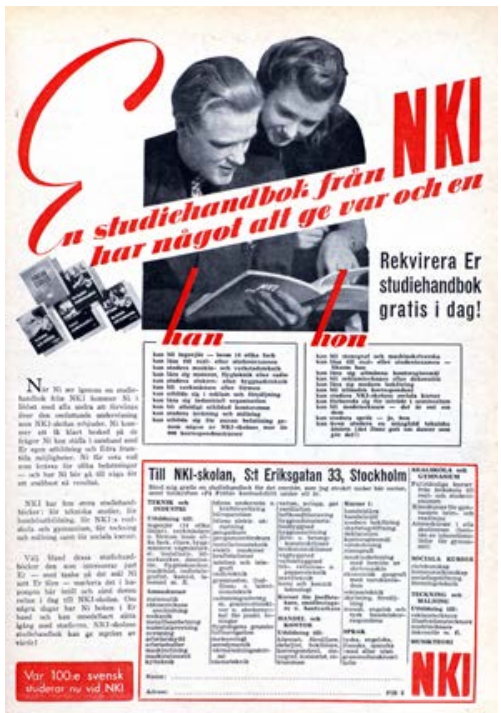

Bild 5:25. Annons i Folket i bild $1943 \mathrm{nr}$ 5 sid. 3. vis under olika tider, beroende på vad man har för förväntningar på barn, och på barns bildskapande. Barnen skrivs av både FIB och Nationalmuseum fram som "unga konstnärer" vilket signalerar en förhoppning om framtida konstnärer.

För att studera bildernas intertextualitet, har jag även granskat en samtida utbildningsannons som relaterar till framtida yrkesmöjligheter för flickor och pojkar.

Tävlingsbilderna på temat vad jag vill bli när jag blir stor kan således sägas bevara och förstärka rådande könsmaktsnormer och visa fram ungdomarnas önskan att anpassa sig efter de genusstrukturer som efterfrågas i samhället. Samtidigt syns i FIB:s annonser hur olika studier och utbildningar skapar nya möjligheter för den nya generationen. Det visar ett samhälle där både kvinnor och män efterfrågas på arbetsmarknaden, och där möjlighet gavs till allt fler även från lägre socialgrupper att studera. ${ }^{838}$

NKI har flera annonser i FIB under dessa år, främst för att utbilda till ingenjörer, och oftast riktade till män. Men i annonsen (bild 5:26) kan man också se att det skapas utrymme för flera olika yrkesval även för kvinnor, även om "han" och "hon" fortfarande är strikt uppdelade. ${ }^{839}$ Denna uppdelning i sig själv är ett synliggörande av skillnad, och det som står överst under "HAN" är ingenjörsexamen med 14 olika inriktningar, det som står överst under "HON" är "stenograf och maskinskriverska". Men, längst ned under "hon" står det även: "kan även studera en mängd tekniska yrken; det finns mängder av damer som gör det".

${ }^{838}$ Sandin, Bengt \& Sundkvist, Maria (2014) sid.139f.

839 NKI-skolan, Nordiska korrespondensinstitutet, grundades i början av 1900-talet och där kunder man från 1940 läsa in bland annat ingenjörsexamen per korrespondens. Det slogs 1965 samman med Hermods. 
Likaså skrivs real- och studentexamen fram som positiva framtidsmöjligheter för både Han och Hon. Genom att studera både bildernas och tävlingens kontextuella och sociohistoriska nivå har jag visat hur barnens bilder i samtal med andra bilder är med och formar diskurser kring barn, flickor och pojkar och kvinnor och män.

$$
* * *
$$

I en sammanfattande analys är det tydligt att tävlingsbilderna visar hur män och kvinnor inordnats i ett genussystem, med tydliga roller och uppdelningar. Bilderna har visat vilka förväntningar som fanns och vad som uppskattades som framtida arbeten för flickor och pojkar. Uppmaningen till kvinnor både politiskt och socialt var under 1940-talet i stor utsträckning att drömma om att vara hemma och ta hand om barn och för män var det önskvärt att de utbildade sig för att kunna försörja familjen. 1930-talets befolkningskommission hade varnat för att det föddes alltför få barn. Att även unga flickor lyssnade till nativitetspropagandan omtalades i uppskattades ordalag i FIB 1942. ${ }^{840}$ Det fanns också under folkhemmets uppbyggnad behov av att skapa människor med mer kvalificerad utbildning, vilket bilden av "ingenjören", men även den "välbeställda maskinskriverskan" och annonsen för utbildning per korrespondens för både kvinnor och män kan ge en bild av. ${ }^{841}$

\section{Sammanfattande diskussion}

Hur har då genus diskuteras och reproduceras i bilderna, och i texter om bilderna? Genom att i förordet i Sverige genom barnaögon beskriva pojkar och flickor och deras bildskapande som fundamentalt olika, kan Nationalmuseum och FIB använda bilderna för att befästa samtida genusdiskurser. Läsarna av boken uppfattade troligen skillnader i bilderna, efter att ha läst texten i förordet. Hoppe menade att bilderna visade tydliga skillnader mellan flickors och pojkars bilder vad gäller exempelvis komposition och färgstämning, men om vi betraktar bilderna från FIB:s tävling och tävlingarna från 1970-talet, är skillnaderna över tid tydligare än skillnader i bilduttryck mellan flickor och pojkar. Även om FIB:s tävling utfördes av barn i olika ålder, var de generellt mer detaljerade och realistiskt tecknade än tävlingsbilderna på 1970-talet.

FIB:s tävlingsbilder uppvisar snarast en generell likhet genom att de reproducerar dåtida bildideal, vid jämförelse med tävlingsbilderna från 1970 -80-talet, som speglar de olika tidernas syn på vad som är en bra barnbild. ${ }^{842}$ Då tävlings-

${ }^{840}$ Myrdal, Alva \& Myrdal, Gunnar (1934) Kris i befolkningsfragan. Stockholm: Bonnier bl.a. sid. 192 där makarna Myrdal argumenterar för ett ekonomiskt bidrag till barnrika familjer för att se till barnens och samhällets intressen.

${ }^{841}$ Dahlstedt, Magnus \& Olson, Maria (2013) Utbildning, demokrati, medborgarskap. 1. uppl. Malmö: Gleerup sid. 43.

${ }^{842}$ En del av dessa bildideal innebär just sakligt återgivande av detaljer Jag har inte sett alla vinnarbilder, enbart de som är sparade i Nationalmuseums samling. Hoppe satt i juryn för tävlingen, och i och med det såg han även alla de bilder som inte vann, men det är ändå i första hand de vinnande bilderna han uttalar sig om i albumet. 
bilderna var ett urval av det som juryn betraktat som de "bästa" bilderna är bilderna del av den kulturella kanon som definierar en bra barnbild i sin tid.

Bilderna avspeglar också hur flickor och pojkar under tiden för FIB:s tävling 1938-1947 ofta hänvisades till olika aktiviteter, bland annat i skolan. Det sätt som Nationalmuseums intendent Hoppe beskriver flickors intresse knutet till hemmets "nipper och husgeråd", där pojkar är "sakliga" definierar samhälleliga normer som även gestaltades genom hur skolan som institution var organiserad och förhöll sig till föreställningar om manligt och kvinnligt.

Barnens bilder under de studerade perioderna 1938-1942 och 1977-1979, gestaltar i flertalet fall att det är tydliga skillnader mellan vad flickor och pojkar och män och kvinnor gör. Bilderna kunde bekräfta denna skillnad som sann, vilket understryks genom bildurval och kommentarer. Skolan och tävlingarna har delvis deltagit i att återskapa och producera maktordningar genom normerande och särhållande mekanismer.

Pojksubjektet hör ihop med träslöjden och dess materialitet, liksom flicksubjektet hör ihop med köket, kökets saker, förkläde, renhet och matlagning.

Problemsituationer kunde synliggöras i bilderna av skolan 1938, som då pojkarna slagits eller flickan tappar ett kärl, en specifik händelse som visar hur barnet som elev också positioneras som subjekt i förhållande till läraren. I dessa sammanhang kunde att vara elev i relation till en lärare, vara det primära motivet i bilderna, oavsett om bilderna visade pojkgrupper eller flickgrupper, samtidigt som reaktionen på tillsägelser från lärare också kan ses som genuskodade.

Genusdiskurser möjliggjorde specifika identiteter som var olika för flickor och pojkar, och upprätthölls genom en gemensam samhällelig ideologi. Åtskillnaden upprätthölls genom skilda aktiviteter och upplevelser där bilderna från 1938 visar skolan som en plats som bidrar till att upprätthålla skillnad mellan kön, förutom i viss idrottsutövning, där flickors och pojkars handlingsutrymme delas.

Det är tydligt i FIB:s tävling 1938-1942 att barn generellt visas fram som aktiva, ofta i rörelse. Detta kan också sätts i relation till en samtida diskussion angående att stillasittandet som skolan innebar ansågs skapa hälsoproblem. ${ }^{843}$ När pojkar och flickor syns i bilderna i gemensamma aktiviteter i temat Livet i vår skola visas skidåkning, simning och bollsport. I bilder från raster på skolgården gör däremot flickor och pojkar olika saker.

I analysen av tävlingsbilderna och texter om bilderna framstår genusdiskurser som både permanenta och kontingenta. Den yrkesarbetande mannen som norm är permanent över tid i bilderna. Genom bilder av män i arbete kunde arbetare och bönder uppvärderas, i förhållande till medel- och överklass. Både av Nationalmuseum och FIB uppskattades 1939 bilden av den manlige arbetaren, liksom av Televerket 1979.

Bilden av män som arbetar är fortfarande aktuell vid publiceringen av bilderna på telefonkatalogens omslag efter Televerkets tävling Yrke och arbetsliv i vår hembygd 1979. Televerket hade, som jag visade, kunnat välja andra bilder. Tele-

${ }^{843}$ Palmblad, Eva (2005). 
verkets teckningstävling befäster tidigare generationers könsroller i sin beskrivning av yrke och arbetsliv, närmast i protest mot läroplanstexterna i LGR-69.

På liknande sätt menar Ingegerd Rydin att trots att SVTs försökte motverka traditionella könsrollsmönster när man producerade barnprogram, kunde de ansvariga för barnprogrammen, ändå omedvetet ha kvar ideal och värderingar från sin egen barndom, vilket gjorde att könsrollsstrukturer endast långsamt förändras. ${ }^{844}$

FIB:s tävling är både mest omfattande i antal teman och antal bilder, vilket också ger en flerstämmig bild av var flickor, pojkar, män och kvinnor syns. FIB:s tävling har 1942 temat Vad jag vill bli när jag blir stor, men liknande tema finns inte i Televerkets eller Arla/Postens tävlingar på 1970-talet.

De barnbilder som valdes ut för publicering i FIB på temat Vad jag vill bli när jag blir stor, befäster i stor utsträckning samhälleliga gensnormer.

De traditionella genusmönster som framträder i tävlingsbilderna, emotsägs delvis i andra artiklar och annonser i FIB, kring att det exempelvis "finns gott om damer som studerar tekniska yrken" i NKI- annonsen 1943, eller teckningslärarinnan som i FIB 1942 efterlyser att flickor själva utvidgar sin repertoar av framtidsutsikter. Detta visar hur genusdiskurser var under förhandling men att barnbilderna i detta sammanhang till stor del användes för att befästa rådande normer.

Om vi ser bildernas utveckling över tid är Arlas tävling intressant eftersom den lyfter fram både idéer om förändring av rådande genusmönster, och idéer om kontinuitet. Bilden "Jag tycker att det är fel att man inte får vara med pojkarna" från Arlas bok Varför får inte barn bestämma från 1977, påtalar ett behov av förändring. Bilden aktualiserar en attitydförändring där det betraktades som fel att inte flickor och pojkar skulle kunna leka eller spela boll tillsammans. Rådande genusstrukturer och normer ifrågasätts, genom påpekandet att det är fel att inte flickor inkluderas i spelet. Kontinuitet gestaltas i bilden "jag önskar att alla barn hade sin mamma hemma när de kommer hem från skolan"

Mödrar och döttrar syns tillsammans i bilderna i Arlas tävling, både i bilden av att ha mamma hemma $(5: 23)$, men också i bild av flickan som går med sin mamma för att få en lekplats, (4:15) Mannen framställs däremot i Arlas tävling som någon som behöver hjälp, som alkoholisten, eller någon som förstör för djur och natur, eller som en maktfullkomlig kommunalpolitiker. Bilderna lyfter en kritik mot patriarkala strukturer där vuxna män är en del av de problem som bör förändras om barn får bestämma.

${ }^{844}$ Rydin, Ingegerd (2000) Barnens röster: program för barn i Sveriges radio och television 1925 1999. Stockholm: Stift. Etermedierna i Sverige sid. 334. 
Kapitel 6.

\section{VINNANDE BILDER - TECKNINGSTÄVLINGAR SOM ARENA FÖR EN FÖRHANDLING AV BARNDOMENS INNEBÖRDER}

I den här avhandlingen har jag uppmärksammat ett fenomen, teckningstävlingar för barn, som inte tidigare varit föremål för vetenskaplig granskning. Barn har engagerats i tävlingar i såväl skolan som hemmen och på initiativ av en rad skilda aktörer. Avhandlingens övergripande syfte har varit att studera barnteckningstävlingarna som ett historiskt och föränderligt fenomen. Analysen av tävlingarna har problematiserat vad tävlingsarrangörerna velat uppnå med att organisera teckningstävlingar och analysen av tävlingsbilderna har undersökt hur barn har kunnat och velat gestalta olika uppdrag under olika tid. Samtidigt som teckningstävlingar förekom under hela perioden 1938-2000 så blev tävlingsformen och tävlandets innebörder efterhand alltmer omdebatterat. Tävlingarna och bilderna har därmed legat till grund för en diskussion om synen på barn och barndom. Den övergripande frågeställningen rör hur tävlingarna uttrycker samhällets skilda synsätt på barn och barndom under den undersökta perioden, och hur barns olika subjektspositioner kommit till uttryck i bilderna.

Avhandlingen har således haft två fokus. Det första har varit kontexten kring bilderna; tävlingarnas organisation, vilka aktörer som var drivande, var bilderna producerats och visats, liksom vilka argument som angavs för teckningstävlingarna. Mitt andra fokus har varit bildernas innehåll. Bildernas innehåll och utförande berättar om på vilka sätt barn har varit med och gestaltat sin samtid, både vad gäller form och innehåll.

De tävlingar och bilder jag granskat sträcker sig över en period på över sextio år. Studiens material utgörs av de tävlingssamlingar som finns i SBBA:s arkiv 1938-2000, och de tävlingar som förekommer i teckningslärarförbundets tidskrift 1938-2000.

Jag har närmare analyserat tre tävlingar under två tidsperioder, Folket i Bilds tävlingar mellan 1938-1946, Televerkets tävlingar 1977-78 och Arla/Postens tävling 1976. Folket i Bilds tävling arrangerades i samarbete med Teckningslärarnas riksförbund, och från 1941 även med Nationalmuseum som medarrangör. De tävlingar jag analyserat från1970-talet arrangerades av Televerket och Arla/ Posten. Televerket har tävlingar för telefonkatalogomslag 1977-1984, där jag analyserat tävlingarna 1977/78. Av dessa tre tävlingar var FIB och Televerket utformade som skoltävlingar, med prispengar till klassresor. Arla/postens tävling däremot riktade sig mot barn i hemmet. 
I avsnittet om skolan i kapitel fyra Barns plats, har även bilder från Kamratpostens tävling "Faror och otrygghet i skolan" 1980 använts som jämförelsematerial. För att sätta in bilderna i en kontext har jag använt intertextuella referenser från exempelvis samtida konstbilder eller läroboksbilder.

I analysen av materialet har jag använt mig av både kritisk diskursanalys och semiotisk analys. Jag har granskat vilka aktörer som arrangerat teckningstävlingar, vad de angett för syften och även vilka olika teman barnen ombads teckna, samt hur detta förändras över tid och i olika kontexter. Även arrangörernas argumentation för vilka som är vinnande bilder diskuteras och analyseras. Den semiotiska analysen har jag använt för att tolka bildernas tecken och symboler, och därigenom visat hur bilderna har varit delaktiga i skapandet av olika diskurser. Jag har granskat hur olika och föränderliga ideal om barn och barndom producerats genom tävlingarna som diskursiv praktik, och hur tävlingarna och bilderna därigenom deltagit $\mathrm{i}$ att forma eller förändra vad som betraktats som sant under en specifik tid.

Avhandlingen har granskat hur tävlingarna och bilderna ger uttryck för arrangörernas skilda föreställningar om barn och barndom och hur de kan relatera till olika kontexter i samtiden. Den förändrade konstscenen och det expressiva och moderna måleriet skapade under 1900-talets början ett intresse för barnkonst. Barns bildskapande kunde representera det okonstlade och naiva som modernismen sökte. Barnbilder kunde användas för att ge Nationalmuseum uppmärksamhet, och samtidigt gav utställningarna och publiceringen av bilderna möjlighet att lyfta fram barnen och öka barns deltagande i samhälls- och kulturlivet.

I detta slutkapitel vill jag diskutera hur tävlandet på 1940-talet framställs som något positivt för barnen och hur lärarna med tävlingens hjälp ville modernisera teckningsundervisningen. Samtidigt med detta framträder nya moderna bildpedagogiska ideal som var kritiska till tävlingen som form. I detta finns en intressant ambivalens.

Jag vill också återvända till tävlingsarrangörerna och närmare granska dessa aktörer och hur de har använt barnbilderna för olika syften. Tävlingarna gav också möjligheter för arrangörer att lyfta fram sig själva som intresserade av och engagerade i barn. Genom analys av bilderna, och av bild och text i samverkan, har jag visat på förändring över tid av hur barn kunnat och förväntats framställa och svara mot de uppdrag de gavs av arrangörerna. Ett återkommande tema för tävlingarna har varit hembygden. Analysen av FIB:s bilder från 1939 och Televerkets bilder från 977/78, visar hur innebörden av Sverige och hembygden konstruerats och förhandlats på skilda sätt. Avslutningsvis återkommer jag även till hur tävlingsbilderna visat att barns subjektspositioner förändrats över tid: i bilder av skolan, fritiden, i relationer med vuxna, samt i relationer mellan flickor och pojkar. 


\section{Teckningstävlingar för barn - bra eller dåligt?}

Analysen av barnteckningstävlingarna har visat ett komplext och ambivalent förhållande till relationen mellan barns skapande och barns tävlande. Den moderna konstens idé om barns kompetenser som konstnärer var en del i att möjliggöra studiens första teckningstävling 1938. Tävlingen arrangerades av tidningen Folket $i$ Bild och Teckningslärarnas riksförbund och från 1941 även av Nationalmuseum.

I den framväxande välfärdsstaten var det väsentligt både att skapa jämlika förutsättningar för barn i hela landet och att mobilisera barns kompetenser. Detta kunde tävlingarna bidra med. Folkrörelsetidningen FIB ville göra en tidning för folket, det fanns också en satsning på barn och unga genom tidningens Ungdomssidor, där teckningstävlingen presenterades. Barnen anmodades att ta med tidningen till skolan och göra lärarna intresserade av tävlingen. Att tävla i teckning framställdes i tidningen som roande och lustfyllt, och både barnen och folkskollärarna kunde genom tävlingen omfattas av en ny och friare undervisning. Tävlandet i skolan betraktades som positivt och lekfullt, där det som bedömdes var barnens förmåga att prestera inom olika ämnen, oavsett socioekonomisk bakgrund.

Teckningstävlingen lyftes fram för att påvisa att svenska skolbarn kunde teckna. Nationalmuseum, som hade tradition av tävlingar även för vuxna, intresserade sig för tävlingen. Både då man menade att barnkonstbilden hade ett eget konstnärligt värde, och även som inspiration för konstnärer.

Nationalmuseum ordnade i samarbete med Riksförbundet för bildande konst en vandringsutställning 1946 med ett urval av tävlingsbilderna, som visades i tjugo svenska städer. Tävlingen kunde också introducera barn till att uppskatta konstnärliga värden och vad som ansågs vara god smak, där uppskattning av barnbilden var en del av den goda smaken.

Analysen visar också hur skolans och lärarnas förhållande till barn och tävlande förändrats över tid. Under den tidiga perioden var tävlingen ett medel för att barn genom tävlingarna skulle få möjlighet att teckna utifrån sin fantasi, vilket var en del av den nya moderna pedagogiken. Ett par decennier senare uppfattades teckningstävlingar i skolan som djupt problematiska. Inom den pedagogiska diskursen från 1950-talet och framåt kom tävlan alltmer att framställas som samarbetets motsats, vilket ansågs vara i motsättning till de kvalitéer som skolan skulle uppmuntra. Dessutom borde barnbilderna, som uttryck för barnens inre värld, inte bedömas och värderas. Värdering och bedömning kunde motverka barns vilja att utrycka sig i bilder, och det fria skapandet ansågs viktigt för barns harmoniska utveckling.

1970-talet var en tid där barn- och barnrättsfrågor förekom flitigt i samhällsdebatten. Olika aktörer talade då både för och emot teckningstävlingar. I ett växande medieutbud skapades också nya arenor för spridning och distribution av barnbilder. Televerkets tävling för omslagen till telefonkatalogerna lyfte 1976 fram barnbilden som barnkonst, där bilderna genom sin "obestridliga charm" skulle förändra Televerkets stela image. Barnbilderna gav mediepublicitet och 
kunde visa fram Televerket som progressivt och nyskapande. Samtidigt hade tävlingar där barnbilder refererade till konstbilder blivit mer problematiska än på 1940-talet, inte bara på grund av skolans förändrade inställning. Att lyfta barns kulturella kompetenser är en sak, men att låta barn tävla uppfattades som problematiskt. Även om lokalmedia gav positiv press med reportage om de vinnande skolklasserna och tävlingsbilderna, skapade Konstnärernas riksförbund negativ mediepublicitet genom att gå ut med att de uppfattade bilderna som ett hot och att barnbilderna inkräktade på deras möjlighet till försörjning. KRO menade dessutom att barnen utnyttjades som billig arbetskraft, och att tävlingarna positionerade barnen som deltagare i ett kapitalistiskt system där de gjorde reklam för specifika företag och vann prispengar. Samtidigt fortsätter Televerkets tävlingar för telefonkatalogomslag till 1984. Under slutet av perioden får teckningstävlingar alltmer karaktären av att skapa opinion eller förändra attityder, snarare än att skapa naivistiska konstbilder. Genom att granska vilka företag, organisationer och institutioner som arrangerat teckningstävlingar, har jag visat vilka aktörer som velat använda sig av barnbildens kulturella uttryck för att samtidigt föra fram sina egna samhälleliga intressen.

\section{Vad har tävlingarna använts till}

Trots att teckningstävlingar som jag visat varit ett omtvistat fenomen lever de ändå kvar. Genom tävlingarna nådde man ut till många barn, speciellt genom skolan. I vilka syften bilderna används har naturligtvis förändrats över tid, även om barnkonstdiskursen funnits med under hela perioden, om än initierad av olika arrangörer. Vissa arrangörer är framträdande under den tidigare perioden1938-1970, andra under den senare perioden, 1970-2000. De vinster som delades ut var under hela perioden oftast pengar som gavs till hela klassen, som bidrag till skolresor. Bidragen till skolresor kunde möjliggöra ökat skolresande för fler barn. Genom att den personliga prestationen var för klassen gemensamt, kunde tävlandet accepteras i skolan.

Föreställningar om barn och barndom formulerades på skilda sätt av skilda arrangörer, och visar på motstridiga barndomsdiskurser både över tid och i samtida tävlingar. Under 1930 -40-talet fanns ett intresse för barns villkor och uppväxt som kan sägas spegla välfärdsstatens framväxt och uppbyggnad, vilket även belysts i tidigare barndomshistorisk forskning. Jag har här visat hur tävlingarna kunnat delta i att förhandla flera skiftande samhällsintressen; folkrörelsernas intressen, finkulturens intressen, kommersiella intressen eller pedagogiska intressen. Folkrörelsetidningen FIB:s tävling speglar detta bredare samhälleliga engagemang för barn. FIB, som propagerade för arbetarklassens bildning, kunde förenas med teckningslärarna i en önskan att engagera barn och unga i det moderna folkhemsbygget, där en förnyad bildundervisning ingick, genom arrangerande av tävlingen med temat Livet $i$ vår skola 1938. Tävlingen under 1940-talet kan ses som del av folkrörelsernas samtida ambition att utjämna klassklyftor. Denna ambition syns även i tävlingens organisation, där tidningen skänkte vattenfärg- 
slådor till landsortsskolor, och även påpekade hur landsortsskolorna klarade sig bra i konkurrensen.

FIB:s tävling arrangerades från 1941 gemensamt av FIB, Nationalmuseum och Teckningslärarnas riksförbund. Nationalmuseum kunde genom att visa upp bilderna på museum och bjuda in skolklasser intressera den unga generationen för konst och för museet. Dessutom såg man barnens konstnärliga uttryck som intressanta för en samtida publik. Tävlingsbilderna kunde alltså användas både för att få en ny generation att komma till museet och för att skapa intresse hos en vuxen publik.

Även Teckningslärarnas riksförbund var engagerade i flera tävlingar under perioden 1938-1970. Lärarna kunde höja yrkets status genom att som specialister på barnbilder delta i tävlingarnas juryarbete. En förändrad teckningsundervervisning - teckning för alla - var ett uttalat mål för förbundet. Detta kan ses i ljuset av 1940-talets samhällsutveckling där man går från ett parallellskolesystem mot en enhetsskola, där frågan om en gemensam och likvärdig skola för alla barn var omdebatterad.

Ett uttalat syfte med FIB:s tävling var också att teckningslärarna önskade åstadkomma ett friare tecknande där barnen använde sin fantasi. Men att teckna fritt handlade vid denna tid främst om att inte teckna av förlagor, och att "fritt" kunna teckna sina vardagliga omgivningar. Analyserna visar tydligt att både juryn, lärarna och eleverna ansåg att det till största del var naturalistiska avbildningar som efterfrågades. Trots att barnbilderna användes som inspiration för det expressiva surrealistiska moderna måleriet, är de vinnande barnbilderna ofta en uppvisning i perspektivlära. De mer expressiva känslouttrycken syns inte i tävlingsbilder förrän under 1970-talet.

Teckningslärarnas riksförbund annonserar och samordnar även under efterkrigstiden och kalla kriget under 1950 -60-talet internationella tävlingar, som syftade till ett ökat internationellt och kulturellt utbyte. Även om tävlingarnas intention var att främja fredligt internationellt utbyte, befästs den nationella diskursen genom uppdraget att teckna "mitt land".

På liknande sätt använde EG och EU tävlingsformen under 1950-1980-talet, med syftet att skapa gemenskap mellan olika länder, men samtidigt konstrueras nationen genom specifika och traditionella visuella symboler. Tävlingsbilderna har också använts i syfte att främja turism, exempelvis av Svenska turistföreningen.

Under den senare perioden 1971-2000 syns inte Teckningslärarförbundet alls som medarrangör i tävlingar. Tävlingspraktiken fortsätter däremot i skolan även under den senare perioden, bland annat i tävlingar arrangerade av Televerket efter samråd med Skolöverstyrelsen. Liksom 1940-talet var slutet av 1970-talet en tid av strukturomvandling där barns deltagande och barns röster i samhället debatterades. Då den socialdemokratiska hegemonin bröts genom maktskiftet 1976 där centerpartisten Torbjörn Fälldin blev stadsminister, var miljörörelsen stark. Ett skäl till Centerpartiers framgångar i valet var motståndet mot kärnkraften, en fråga som kulminerande i kärnkraftsomröstningen 1980. I ljuset av denna förändrade omvärld ska också Arla/Postens tävling förstås, en tävling som 
framförallt lyfter miljöfrågor och barns deltagande. Som tidigare barndomshistorisk forskning visat fanns under 1970-talet en samhällelig intention att stärka barns inflytande över politiska beslut. Dessa intentioner avspeglas även i tävlingarna.

Genom att arrangera teckningstävlingar kunde olika grupper nå ut med sitt budskap, inte bara till barn utan ofta också genom att använda sig av "barns röster” i en samhällsdebatt. På liknande sätt kunde bilderna användas för att förändra attityder i en viss fråga. Ett exempel är Världsnaturfonden, som genom internationella teckningstävlingar under1970-1980-talet ville uppmärksamma utrotningshotade djur och växter. Med hjälp av barnens bilder kunde man understryka barns koppling till naturen och hur arrangörens engagemang berör inte bara dagens utan även framtidens barn.

Undersökningen har också visat att även om arrangörernas uttalade syfte var att lyfta barns röst och barns rättigheter, kunde barnbilderna samtidigt användas för att göra reklam för det egna företaget eller organisationen. I mejeriproducenten Arlas tävling 1976 med temat "Detta vill jag värna om" synliggörs detta genom att Arlas produkter finns i ett par av de publicerade bilderna. Samtidigt är denna tävling ett exempel på barndomens förändrade innebörder där både barnbildens uttryck och barns delaktighet omförhandlas. Arla/Postens tävling poängterar att det är budskapet som är viktigast, inte hur det är utfört. Dessa bilder är också enkelt tecknade tuschteckningar ofta med text, som likt en reklambild explicit uttalar vad bilden vill förmedla. Arla menade att de tävlingsbilder som publicerades på mjölkkartongerna var tänkta att ge barnen massmedialt utrymme att uttrycka sina känslor. I Arlas/Postens bok Varför får inte barn bestämma beskrivs barnbilden som ett språk, som är lätt för barn att uttrycka sig på. Man menar att bilderna kan används som en form av samtal, vilket ligger i linje med hur bildämnet presenteras i den nya läroplanen 1980 .

Om tävlingen för telefonkatalogernas omslag kunde ingå i barnkonstdiskursen, där Televerket önskade förnya sin image genom barnbilder, så användes tävlingen "Stoppa Sabbet" 1980-1990 för andra syften. Televerket menade att sabotage av telefonkiosker var ett ungdomsproblem som man hoppades kunna lösa genom att upplysa och influera ungdomar i skolan. Det främsta syftet med tävlingen var inte tävlingsbilderna, även om de hade "stoppa sabbet" som tema och trycktes som affischer. Huvudsyftet var att genom tävlingen påverka och förändra barns och ungas beteenden, bland annat genom diskussionsmaterial som skickades ut till skolorna. Genom äldre samtida ungdomsförebilder, och tidigare "värstingar", hoppades man etablera en skötsam ungdomsdiskurs som eleverna skulle inspireras av. Genom att rikta tävlingen till 12-åringar tänkte man sig förebygga tonårsproblem.

Barn gavs under denna tid samtidigt tillträde till det som tidigare varit vuxnas arenor, exempelvis som programledare i SVT:s barnprogram. På likande sätt medverkade barn i tävlingarna på 1980-talet i juryarbetet, vilket också kan ses i relation till nya diskurser där barn förväntades bedöma och utvärdera sitt eget arbete $\mathrm{i}$ allt högre grad. 
När tävlingsbilderna visades på museum på 1940-talet nådde bilderna en begränsad publik. Nya möjligheter för tryck i färg gjorde att Telefonkataloger och mjölkpaket spreds till i stort sett alla svenska invånare. Barnbilderna blev del av andra populärkulturella bilder som var synliga i människors vardag. Om tävlingsbilderna var del av konstdiskursen under den tidigare perioden ingår tävlingsbilderna snarare i en reklam- och marknadsdiskurs under den senare perioden. Även Konsumentverket arrangerade tävlingar under den senare perioden, och var en av de arrangörer som hade ett tydligt framtidstema, när de frågar om hur barn tänker sig framtidens konsumtion.

Under både den tidigare och senare perioden har psykologer fått uttala sig om bilderna, men på skilda sätt. År 1945 beskrevs tävlingsbilderna i förordet till katalogen för Folket $i$ Bilds vandringsutställning. Barnbildsdiskursen utgick då från barns utvecklingsstadier och barnbilders ursprunglighet. I förordet till boken Varför får inte barn bestämma utgiven av Arla/Posten 1977, beskrevs bilden däremot som medel för kommunikation: barnen talar genom bilder och bör bli lyssnade på. Relationen mellan barnkonst och samtida eller historisk konst, lyfts inte fram under den senare perioden, vilket alltså skedde under 1940-talet.

Jag ska nu diskutera vilka diskurser om barn och barndom som kommer till uttryck i tävlingsbilderna, dels under den tidigare perioden och dels under den senare perioden, men också vad som varit genomgående under hela undersökningsperioden.

\section{Förändring och kontinuitet}

En utgångspunkt för analysen av tävlingsbilderna har varit att undersöka hur bilderna beskriver vad vuxna haft för förväntningar på barnens bilder genom tävlingarnas teman - men också hur barn har svarat mot dessa förväntningar.

I relation till tidigare forskning som lyft fram hur barnbilder används för att tolka barns berättelser och utveckling, försöker denna studie snarare lyfta fram hur tävlingsbilderna kan förstås i relation till sin samhälleliga kontext. Detta innefattar bland annat hur bilderna refererat intertextuellt till andra samtida bilder, exempelvis konst- eller läroboksbilder. Genom att vara utvalda, exponerade och publicerade som "vinnande bilder" under sin tid, visar bilderna och deras kontexter hur föreställningar om barn och barns skapande förändrats över tid. Tävlingsbilderna har beskrivits av arrangörerna som bilder av barns egna världar och verkligheter, samtidigt som de uppdrag arrangörernas gav barnen belyste vad man ansåg borde reproduceras eller förändras genom tävlingarna. Då barnen haft likartade uppdrag under den tidigare och senare perioden, visar analysen av bilderna hur deras innehåll förändrats över tid, vilket också visar hur barndomens innebörder förhandlats genom tävlingarnas diskursiva praktiker.

Barn har under hela perioden förväntats skildra bilder av hembygden, framför allt i anslutning till skolans hembygdskunskapsämne. På vilka sätt hembygden har beskrivits och gestaltats har däremot förändrats över tid.

Under 1940-talet beskrevs bilderna av Nationalmuseum som associerade till en gemensam historisk folkkulturdiskurs. På samma gång användes bilderna som 
representanter för det "det moderna" med referenser till en samtida konstscen med motiv från både arbete och industri. Att lyfta fram barns skapande kunde ingå i denna nya moderna identitet, vilket förstärks genom att barnbilderna ställs ut på Nationalmuseum. Bilderna av arbete i landskapet och i fabrikerna gör att olika yrkesgrupper visas fram och alla är delar i det gemensamma "svenska". Barn och vuxna arbetar ofta gemensamt i bilderna vilket visar hur arbete traderas över generationer.

Hembygdsbilderna från den senare perioden i Televerkets tävling 1977-78 framställer hembygden som ett historiskt fenomen, med kungar, minnesmärken eller landskap. Idealbilden av hembygden visar då landskapsbilder och historiska hembygdsbilder, främst skildrade genom naturbilder. Både Televerket och FIB:s tävlingar synliggör hur de olika hembygdernas bilder framställs som olika, men tillsammans delaktiga i att skapa en nationell enhet. Naturbilden har varit en viktig del av hembygdsbilderna. Hur landskap och naturbilder associerats med historiska personer eller specifika grupper, etablerar en förställning om det jag har beskrivit som specifikt svenska etnoscapes, som del av barns gemensamma visuella erfarenheter. Genom att återberätta och återskapa historiska minnesbilder och naturbilder, positioneras barnen i ett gemensamt nationellt förflutet, en gemensam nationell natur och tillhörighet till det som benämns ett gemensamt fosterland.

Temat Svenskt helgfirande från 1944 visade också hur firandet av svenska helger kunde vara så skiftande som att demonstrera på 1:a maj, hylla idrottsmän vid skidtävlingar, gå i julottan eller hylla kungen på svenska flaggans dag. Olika samhällsgrupper och både stad och landsbygd framställdes som delaktiga i den nationella gemenskapen. Genom bilder av män i arbete kunde arbetare och bönder uppvärderas, i förhållande till medel- och överklass.

Om bilderna under 1940-talet skildrade en framväxande arbetarrörelse och nationell enighet över klassgränser, så har bilderna under samma tid använts för att befästa och etablera skillnader mellan flickor och pojkar. I textkommentarer till bilderna i boken Sverige genom barnögon 1947 beskrivs flickors och pojkars fundamentalt olika kynne, och hur det syns exempelvis i bildernas komposition och färgstämning. Detta trots att vinnarbilderna under den tidigare perioden snarare är lika varandra, genom att vara utvalda vinnarbilder, av elever skolade i liknande bildpraktik. Däremot skildrar bildernas innehåll, från exempelvis skola eller fritid, i vilka situationer flickor och pojkar syns tillsammans eller uppdelade. I bilder från raster på skolgården syns både flickor och pojkar, men de gör oftast olika saker. Skillnadsskapandet mellan flickor och pojkar upprätthölls under 1940-talet även genom uppdelning i vissa skolämnen, vilket syns i bilderna. Samtidigt visar andra skolbilder gemensam lek och aktivitet och hur flickor och pojkar inkluderades i en gemensam barndom, framförallt i idrottsaktiviteter som organiserades av skolan. Skolan fungerade alltså både som åtskiljande och gemenskapande praktik. Genom de bilder FIB väljer att publicera på temat "vad jag vill bli när jag blir stor" används barnens bilder för att etablera och befästa genusdiskurser med mannen som yrkesarbetande och kvinnan som mor. Genom textkommentarer och genom urval av bilder, kunde genusstrukturer befästas, 
både på 1940-och 1970-talet, och definiera vad som är kvinnors eller flickors platser och vad som är mäns och pojkars. 1970-talet är en tid då jämställdhet diskuteras, och både kvinnors och mäns roller är under förhandling. Att barns bästa kunnat användas som argument mot kvinnors yrkesarbete görs tydligt $\mathrm{i}$ Arlas och postens tävlingsbild från 1977 "Jag önskar att alla barn hade mamma hemma när de kom hem från skolan.” Över båda perioderna, både i FIB och Televerket avbildas framförallt män och mäns arbete i hembygden. Trots nya läroplaner är manligt arbete normen i Televerkets tävling 1979, vilket visar genusstrukturers långsamma förändring. En förändring över tid är att Arlas och postens tävling också visar bilder av en problemfylld mansroll, där mannen är alkoholiserad, förstör naturen och skjuter djuren.

Bilder av hembygden och naturen som något som behöver värnas och skyddas mot modernitet och asfalt framträder under den senare perioden. Jag har visat hur flera tävlingar från 1970-80-talet fram lyfter budskap i text och bild om en önskad återgång till gamla värden, där det moderna betraktades som ett hot. Bilder visar exempelvis det moderna samhällets miljöproblem, men även förhoppningar om att en återgång till en mer oförstörd värld var möjlig. Detta står i stark kontrast till den positiva bild av modernitet som syns i 1940-talets bilder.

Under den senare perioden blir barn i bland annat i Arla/Postens tävling uppmanade att uttrycka känslor kring faror och oro. Bilderna visar också fler tårar, och mer känslouttryck än bilderna under den tidigare perioden. Situationer som i senare periodens bilder skildrades som konflikter visades i FIB:s tävling som del av en lek eller i en humoristisk genre. Slagsmål gestaltades i 1940-talsbilderna som en humoristisk del av skolvardagen, där bilder av 1970-talets skolgård visade mobbing och barn med tårar. Barnen förväntas 1977 snarare använda bildmediet på ett terapeutiskt självreflekterande sätt. Vad som har varit möjligt att uttrycka angående barndomens innebörder har alltså både förskjutits och förändrats över tid.

Det är också tydligt i den tidigare perioden att barn framställs som hälsosamma, aktiva och ofta i rörelse i bilderna. När pojkar och flickor syns i bilderna i gemensamma aktiviteter i temat "livet i vår skola" visas skidåkning, simning och bollsport. Under denna period skildras skolmiljön mer sakligt och detaljerat, än i senare skolbilder, som mer beskriver skolan genom metaforer och känslor. Detta kan förstås i relation till innebörden av det "fria skapandets" bildpedagogiska diskurs som även FIBs tävlingar ville initiera men som först under 1970-talet syns i den pedagogiska praktiken. Bilduttrycken i Arlas/Postens tävling är enkla och oskolade jämfört med tävlingsbilderna från fyrtiotalet. Tävlingsbilder visar under den senare perioden skolan som en problemplats. Skolorna är för stora, det behövs bättre skoltoaletter, barn blir mobbade och lärare framställs som elaka monster. Samtidigt framställs barn under den senare perioden som mer skyddade, exempelvis av hjälmar och flytvästar, och de visar hur har lärt sig att kontrollera både sig själva, andra barn och vuxna, genom att förevisa önskvärda beteenden i bilderna. Barnen framställs i bilderna under 1940-talet som kompetenta genom sin arbetsförmåga i skolan och på fritiden, i Arlas tävling 1976 
framstår de snarare som kompetenta genom sin omvårdande och inkluderande förmåga.

Under den senare periodens förändrade massmediala landskap, är bland annat fotot av jordklotet en etablerad bild. Barnen framställer sig nu inte längre som positionerade enbart i det svenska landskapet, utan på det gemensamma jordklotet. Under den senare perioden symboliserar jordklotet i vissa bilder ett gemensamt hem och ansvar för alla människor, samtidigt blir jordgloben omringad av olika staters flaggor en symbol för en värld av nationer. I senare tävlingar gestaltades också en framtid i rymden i barnens bilder.

$* * *$

Jag har visat att det under hela perioden funnits en ambition från olika arrangörer att genom teckningstävlingar både vilja använda sig av och lyssna till barns röster. Olika aktörer har genom tävlingen som medium kunnat etablera kunskap om företaget eller organisationen hos barnen, för att skapa framtida konsumenter. Samtidigt har bilderna använts i syfte att belysa och förstå barns perspektiv bättre. Att det är genom barnen framtiden skapas, och att de därför behöver upplysas, påverkas, eller bli lyssnade till, är ett underförstått syfte i tävlingarna.

Tävlingarna uppvisar både kontinuitet och förändring av barndomens innebörder. Kontinuitet genom att barnbilder under hela perioden efterfrågats och barn betraktats som kompetenta konst- och åsiktsskapare. Förändring genom de olika bardomsdiskurser tävlingarna och bildernas innehåll och uttryck representerar.

1940-talets framtidsoptimistiska bildbudskap av ett gemensamt statsbygge, där barn både lekte, gick i skolan och deltog i arbete med vuxna, förbyttes under 1970-talet i barndomsbilder av problem och hot, där skolorna är för stora, barn är mobbade, naturen besprutad och asfalten växer. 1970-talets barn hade en problematisk framtid att vänta där det i bilderna inte heller syns några vuxna förebilder. Tävlingarna kan samtidigt ses som del av en barndomsdiskurs under 1970-talet där det var angeläget att lyssna till barns åsikter. Tävlingsbilderna visar hur barn gavs ansvaret att uppfostra både andra barn och vuxna. Barnen gavs en röst, men samtidigt beskrev bilderna, i motsats till 1940-talets bilder, en komplex och hotfull framtid. 


\section{SUMMARY}

\section{Winning Pictures - Art Competitions as an Arena for the Negotiation of Meanings of Childhood}

This dissertation calls attention to a phenomenon not earlier the subject for scholarly analysis, art competitions for children. A number of different actors have taken the initiative and involved children in competitions at school as well as at home. The overall purpose of this dissertation has been to study children's art competitions as a changing historical phenomenon. The analysis of children's art competitions has problematized the goals of the competition organizers, and what themes children were asked to draw, as well as analyzing how the children have chosen to portray various topics during different periods of time. Art competitions took place throughout the entire period from 1938 to 2000, but the format and the implications of contests became increasingly matters for debate. The competitions and the pictures have thus provided the foundation for a discussion on how children and childhood were constructed. The overriding questions concern how the competitions express society's different views on children and childhood during the period studied, and how the children's varying subject positions were expressed in the pictures.

The dissertation thus has two foci. The first is the context within which the pictures are found: the organization of the competitions, the actors behind the events, the location where the pictures were produced and shown, and the arguments that were made for the art competitions. The second focus is on the content of the pictures. The content and execution of the pictures tell about the ways in which the children have been involved and how they portray their contemporary world. The competitions and pictures that have been studied here stretch over a period of more than 60 years. The material is comprised of collections of competitions that are found in Svenskt barnbildsarkiv (Swedish archives for children's pictures - SBBA), 1938-2000, and the competitions in the journal of the Teckningslärarnas Riksförbund (National association of art teachers), 1938-2000.

Three competitions have been studied during two time periods: the contests in the magazine Folket $i$ Bild (People in pictures) between 1938 and 1946 and the competition sponsored by Arla (the farmer owned dairy) and Posten (the post office) in 1976. The Folket $i$ Bild competition was sponsored in cooperation with the Teckningslärarnas Riksförbund and from 1941 also by the Nationalmuseum (The National Museum). The competitions from the 1970's that have been analyzed were arranged by Televerket (the telephone company) and Arla/Posten. Televerket held contests for the telephone catalogue cover 1977-1984. The contests $1977 / 78$ have been analyzed here. Of these three competitions those sponsored by Folket $i$ Bild and Televerket were designed as school competitions with prize 
money for class trips. On the other hand, the Arla/Posten contests were directed towards children in the home.

In the section dealing with the school, pictures from the contest in Kamratposten (a magazine for children) entitled "Dangers and lack of security in school" (1980) were used for purposes of comparison. Intertextual references from, for example, contemporary art or pictures from schoolbooks have been used to place the pictures in a context.

Critical discourse analysis and semiotic analysis have been used in dealing with this material. The actors who arranged the art competitions, their declared purpose and even the themes that the children were asked to draw have been studied, as well as how these changed over time and had varying contexts. The argumentation for the winning pictures is discussed and analyzed. The semiotic analysis has been used for interpreting signs and symbols and has thus shown how the pictures have participated in the creation of various discourses. The changing ideals of children and childhood that have been produced within the competitions have been studied as discursive practice, as well as how the contests and pictures have thus been a part of forming and modifying what has been regarded as true during a particular time period.

The dissertation has analyzed how the contests and the pictures express the different conceptions of children and childhood that the arrangers had, and how they could be related to various contemporary contexts. The changes that had taken place on the art scene and in expressive and modern art in the beginning of the 20th century created interest in children's art. The creation of pictures by children could represent the simplicity and naivety that modernism sought. Children's pictures could be used to call attention to The National Museum and at the same time through the exhibition and publication of pictures make it possible to bring children to the fore and to increase children's participation in social and cultural life. The analysis shows how the competitions in the 1940's were depicted as fun for the children and how their teachers wanted to modernize art education with the help of the contests. At the same time the new modern pedagogical ideal that teachers wanted to achieve through the art competitions was itself critical to art competitions as a method.

The second chapter studies the actors who arranged the contests. It also shows how children's pictures could be used for a specific purpose. The competitions provided opportunities for the arrangers to present an image of themselves as interested and involved in children. The last section discusses the pictures per $s e$. Through the analysis of the pictures and the accompanying texts it has been possible to show changes over time in how children have been expected and able to carry out the task they were given by the arrangers. A recurring theme for the contests was the local area (hembygden). An analysis of competition pictures from Folket $i$ Bild from 1939 and the 1977/78 pictures from Televerket shows how the meaning of Sweden and of the local area was constructed and dealt with in different ways. There is a discussion of how the childrens subject positions changed over time in pictures of school, leisure time, and relationships to adults and to girls and boys. 


\section{Children's Art Competitions - Good or Bad?}

The analysis of the children's art competitions has shown a complex and ambivalent situation in the relationship between children's creativity and children's competition. The ideas found in modern art about children's competence as artists were part of what made possible the first art competition in 1938. The contests were arranged by the magazine Folket $i$ Bild and the Teckningslärarnas Riksförbund, and from 1941 onwards also by The National Museum.

In the emerging welfare state it was important to create equal conditions for children in the entire country and to mobilize the competence of children. Competitions could contribute to this. The magazine of the popular movements Folk $i$ Bild wanted to create a weekly magazine for the people, and there were special pages devoted to children and youths (Ungdomssidor), where the art contest was presented. Children were encouraged to take the magazine to school to get the teachers interested in the contests. To compete in art was presented in the magazine as joyful and fun. By means of the contest both children and elementary school teachers could be included in a newer or freer kind of education. In school the competition was regarded as positive and playful, whereby children's ability to achieve in different subjects was evaluated, regardless of their socio-economic background.

The art competition was presented as a measure of how "Swedish school children can draw." The National Museum, which had a tradition of contests, even for adults, became interested in the competition both because it was maintained that children's artwork had a value as art and as an inspiration for artists.

In cooperation with Riksförbundet för bildande konst (The national association for educational art) The National Museum organized a wandering exhibition that showed a selection of the pictures and visited twenty Swedish cities in 1946. The competition was also supposed to introduce children to an appreciation of the world of art and what was regarded as good taste.

The analysis shows how the relationship of schools and teachers to children and competitions changed over time. During the early period the contests were a means for children to have the opportunity to use their own fantasy in art. The competitions were a part of modern educational methods. A couple of decades later art competitions in the schools were considered problematical. Within the pedagogical discourse from the 1950's onward, competition was increasingly portrayed as the opposite of cooperation and contrary to the qualities that the school should encourage. Furthermore, children's pictures, which expressed their inner values, should not be judged and evaluated. Judging and evaluating could counteract the child's desire to express her/himself in pictures, and free creation was regarded as important for the child's harmonic development.

\section{Using Children's Competition Contributions}

Although the art competitions shown here were controversial, they existed throughout the period studied. The competitions made it possible to reach many children, particularly through schools. The way in which the pictures have been used has partly varied over time, although the children's art discussion has exist- 
ed throughout, albeit with different arrangers. Certain arrangers stick out during the earlier part of the period (1938-1970), while others are prominent in the later part (1970-2000). The prizes that were awarded during the entire period were most often money which was given to the entire class as a contribution to school trips. The contributions to school trips made possible an increase in excursions for more children. Because the achievement through personal production was for the entire class, competition in school could be accepted.

Attitudes towards children and childhood were formulated in various ways by different arrangers, which demonstrate the contradictory discourses on childhood both over time and in contemporary competitions. During the 1930's and 1940's there was interest in children's conditions and growing up which can be said to mirror the growth and construction of the welfare state. This has also been illustrated in earlier historical research on childhood. It has been shown here how the competitions were part in the negotiation of several varying social interests: the popular movements, "fine" culture, commercialism and pedagogical interests. The contest of the popular movement's magazine Folket $i$ Bild mirrors a wider, social interest in children. Folket $i$ Bild, which promoted the education of the working class, could unite with the art teachers in a desire to involve children and youths in the construction of the welfare state. There a new kind of art instruction was included, which was arranged by the contest with the theme "Livet i vår Skola" (life in our school) in 1938. The competition during the 1940 's can be regarded as part of the popular movements' contemporary ambition to obliterate classes. Its ambitions were evident even in the organization of the competition, where the magazine gave boxes of water colors to rural schools and also pointed out how well the rural schools did in the competition.

The Folket $i$ Bild contest was arranged from 1941 in cooperation with The National Museum and Teckningslärarnas Riksförbund (the national association of art teachers). By exhibiting pictures at the museum and inviting school classes to The National Museum, they could interest the younger generation in art. Furthermore, the museum regarded children's artistic expression as interesting for a contemporary public. The competition pictures could thus be used both for attracting a new generation to the museum and for shaping interest among an adult public.

Teckningslärarnas Riksförbund was also involved in several contests during the earlier period, 1938-1970. The teachers could increase the status of the profession by participating in the juries of the contests as specialists in children's art. Changes in art instruction - art for all - was a specific goal of the association. This can be seen in light of the social development of the 1940's from a parallel school system to a unified school, where the common and equal school for all children was a debated question.

A pronounced goal of the contest in Folket $i$ Bild was also shared with the art teachers, that is, achieving freer art in which children would use their own fantasy. But to draw freely at that time meant, above all, not copying a picture, but rather "freely" interpreting everyday surroundings. The analysis shows clearly that the jury, the teachers and the pupils for the most part regarded naturalistic 
replications as what was asked for. In spite of the fact that children's pictures were used as inspiration for the expressionistic surrealistic modern painting, the winning children's pictures were often an exhibition of knowledge of perspective. The more expressive manifestations of emotions are not seen in the competition pictures until the 1970's. The different picture discourses also mirror how competition later became more problematic when art with a correct perspective was no longer requested.

Teckningslärarnas riksförbund also announced and coordinated international competitions during the post-World War II era and the Cold War that had as their goals increased international and cultural exchange. Even though the intention of the competitions was to promote peaceful international exchange, the national discourse was strengthened by the assignment to draw "my own country."

In a similar manner the European Economic Community and the European Union have used competitions with the goal of creating a sense of community among various countries, but especially constructing the nation by means of specific and traditional visual symbols. During the later period (1971-2000) competition pictures were also used to promote tourism.

In this later period the art teacher union has not been seen at all as co-arranger of contests. The practice of having contests in the schools continued, even in this period, including competitions arranged by Televerket or in cooperation with Skolöverstyrelsen (the government agency responsible for all schools until 1991). As was the case in the 1940's, the 1970's was an era of structural change where even children's participation and voices in society have been debated. It was then that the Social Democratic hegemony came to an end with the shift in power in 1976 when the Center Party member Thorbjörn Fälldin became Prime Minister. The environmental movement was strong, and one of the reasons for the success of the Center Party was its opposition to nuclear energy, a question that culminated in the referendum on nuclear energy in 1980. The Arla/Posten contests must be understood in the light of the changing world around them. Above all, the contest emphasized environmental questions and children's participation.

The investigation has also shown that even if the expressed goal of the arrangers was to emphasize children's voices and children's rights, children's pictures could at the same time be used as advertising for one's own company or organization. The 1976 contest sponsored by the producer of dairy products, Arla, had the theme "This is something I would like to protect," which was visualized by the presence of Arla's products in a couple of the published pictures. The competition is an example of the modified content of childhood where both the expression of the children's pictures and the participation of children are negotiated. The competition sponsored by Arla/Posten points out that the message is most important, not the execution of the picture. These pictures are simple ink drawings, often with texts, which express what the picture wants to communicate, as do advertisements. Arla intended for the competition pictures to be published on milk cartons which was considered a way of giving children space in the mass media to express their feelings. In the Arla/Posten book Varför 
får inte barn bestämma? (Why aren't children allowed to decide?) the children's pictures are described as a language with which it is easy for children to express themselves. It was also seen as a kind of conversation, which is in line with how pictures were presented as a subject area in the new 1980 national educational plan.

If the competition for the telephone catalogue covers could be considered a part of the children's art discourse, whereby Televerket wished to renew their image using children's pictures, then the contest Stoppa Sabbet (Stop the sabotage) 1980-1990 had another intention. Televerket regarded sabotage of telephone booths as a youth problem that they hoped could be solved by informing and influencing youths in school. The primary goal of the contest was not the submitted contributions, even if these had Stoppa Sabbet as a theme and were printed as posters. The main goal of the contest was to influence and modify the behavior of children and youths, among other things, by means of the discussion material that was distributed to the schools. Through older contemporary youth examples and former $v$ ärstingar (delinquents) the hope was to establish a discourse of conscientious youths that would inspire the pupils. By directing the competition to 12 -year-olds, the hope was to prevent teenage problems.

In the competitions in the 1980's pupils also participated in the work of the juries, which can be seen in relation to the new discourses within which children were expected to judge and evaluate their own work to a greater extent.

Using pictures to change attitudes in a certain question was used during the same period by the World Wide Fund for Nature, which by means of international art competitions during the 1970's and 1980's wanted to bring attention to threatened animals and plants. The connotation of the children's pictures could also underline the connection between nature and the involvement of the arrangers that would affect not just today's but also future children.

By sponsoring art contests various groups could reach out with their message by using "children's voices," not just to children but also to society's debates as well. Through the contests the sponsors have been able to draw attention to various social questions with the intention of bringing about changes, for example, in environmental questions or children's rights. At the same time by means of the competitions the sponsors could establish knowledge among children about the company or organization in order to cultivate future customers, something that Televerket expressed. Other arrangers argued during the entire period that the pictures were used for spreading information and better understanding of the perspective of the child. It was an implicit goal of the competitions that the future could be created through children and that they therefore needed to be informed or influenced.

When the competition pictures were exhibited in the museum in the 1940's they did not reach many. New possibilities to print in color meant that the telephone catalogues and milk cartons were distributed to nearly all Swedish residences. The children's pictures became part of other examples of pictures in popular culture that were visible in people's everyday life. If the competition pictures were part of an art discourse in the earlier period, in the later period they were 
rather part of an advertising and marketing discourse. Even the Konsumentverket (The Swedish Consumer Agency) was an arranger of contests during the later period and is one that clearly had the future as a theme, when they asked about children's thoughts concerning future consumption.

During both the earlier and later periods psychologists have described the pictures, but in different ways. In 1945 the competition pictures were characterized in the foreword to the catalogue for Folket $i$ Bild's wandering exhibition. The discourse concerning children's pictures had as its departure point the developmental stages of the child, but in 1977 in the foreword to the book Varför far inte barn bestämma? that was published by Arla and Posten the pictures were described as a means of communication, as the way that children talked through pictures. How they should be listened to was also included. The relationship between children's art and the contemporary art or historical art, were not emphasized during the later period as it had been in the 1940's.

The discourses about children and childhood that were expressed in the competition pictures are discussed, both in the earlier and later periods, but there were also themes that were present throughout the entire period.

\section{Continuity and Change}

One departure point for the analysis of the competition pictures has been to study how the pictures describe the expectations of adults regarding the children's pictures in relation to the competitions' themes - but also how the children lived up to these expectations.

Although earlier research has emphasized how children's pictures have been used to interpret children's stories and development, this study attempts rather to comprehend how the competition pictures can be understood in relation to their societal context. For example, how do the pictures refer intertextually to other contemporary pictures such as art and illustrations in textbooks? By being chosen, exposed and published as "winning pictures" of their period, the pictures and their contexts show how conceptualizations of children and children's creativity changed over time. The competition pictures have been described by the arrangers as depictions of the child's own world and realities, while the sponsors of the contests provided information about what they thought should be reproduced or changed by means of the competitions. Where children have had similar assignments during the earlier and later periods, the analysis of the pictures shows that their content changed over time, which means that the content of childhood was negotiated through the competitions' discursive practices.

During the entire period children have been expected to produce pictures of their local region in relation to studies of the local district as a school subject. The way in which the immediate area was described and portrayed has varied over time. A clear difference is that during the earlier period in the Folket $i$ Bild competitions, the pictures show the contemporary situation by means of pictures of the city, factories and the countryside, and both the children's and the parents' have places in their district. 
The 1944 theme Svenskt helgfirande (celebrating Swedish holidays) also showed how celebration of the Swedish holidays could be as varied as political demonstrations on May 1, the honoring of Swedish athletes at skiing races, attending the Christmas church service or cheering for the King on Swedish Flag Day. Various social groups and both the city and the countryside were presented as participating in the national community. By means of pictures of men at work, laborers and farmers could gain higher esteem in relation to the middle and upper classes.

During the 1940's the pictures were described by The National Museum as being associated with a common folk historical discourse. The pictures were at the same time used as representatives of "The Modern" with references to a contemporary art scene with motifs from both labor and industry. The emphasis on the creativity of children as part of the new modern identity was strengthened by the fact that the children's pictures were exhibited at The National Museum. The pictures of work in the landscape and in the factories meant that different occupational groups were shown and all were represented as being part of something "Swedish." Children and adults often work in the pictures which show how skills are passed on through the generations.

The pictures from the local area from the later period depict the local region as an historical phenomenon, with kings, monuments and/or the countryside. The ideal picture of the local district consists of pictures of the countryside and historical local pictures shown primarily by means of depictions of nature. The contests of both Televerket and Folket $i$ Bild made visible how the different localities are presented as divergent, but, as part of a whole, part of a national unit. The representations of nature have been an important part of capturing the local region. How the landscape and nature are associated with historical persons or specific groups establishes an idea of what I have described as specific Swedish ethnoscapes, as part of the children's common visual experiences. By means of retelling and recreating historical memories and pictures of nature, the children are placed within a common national past, a common national nature and what is called a common native country.

If the pictures of the 1940's depicted a growing labor movement and national unity over class boundaries, the pictures had also been used to establish and consolidate the differences between girls and boys. In the comments in the texts that accompany the pictures in the book Sverige genom barnögon (Sweden through the Eyes of Children, 1947) girls and boys are described as having fundamentally different characters, temperaments that are manifested in, for example, composition and color combinations. This was maintained in spite of the fact that the winning pictures during this period were rather similar to one another because all winning pictures selected were executed by pupils taught in a similar manner. But, the contents of the pictures also show school and recreation when girls and boys are seen together or separated. In the pictures from recesses in the school yard the boys and girls are in the same yard, but they are usually doing different things. The creation of the differences between girls and boys was maintained throughout the 1940's even in the differentiation in various school subjects that 
are seen in the pictures. At the same time other school pictures show games and activities and how the girls and boys were included in a common childhood, particularly in sports organized by the school. Thus, the school worked both by differentiating but also by creating a community were boys and girls participated equally. By means of the pictures that Folket $i$ Bild chose to publish on the theme "Vad jag vill bli när jag blir stor," (What I want to be when I grow up.) children's pictures were used to establish and consolidate the gender discourse with men as breadwinners and women as mothers. Through the comments in the picture texts and the choice of pictures, the gender structures could be fortified both in the 1940's and the 1970's, and they defined what comprised women's and girl's roles and what belonged to the men and boys. The 1970's was a time when equality was discussed, and both men's and women's roles were being negotiated. The fact that the concept of the "child's best interests" could be used as an argument against women's occupational work is made clear in the Arla/posten art competitions from 1977, "Jag önskar att alla barn hade mamma hemma när de kom hem frä skolan." (I wish all children had mama at home when they come home from school.) During both periods in the Folket I bild and Televerket contests it was above all men and men's work in the local district that was depicted. In spite of that and a new curriculum, male work was the norm in Televerket's 1979 contest, which illustrates the slow change in the gender structure. One change over time is seen in the contests sponsored by Arla and Posten where a problematical male role was portrayed: the man is an alcoholic, destroys nature and shoots animals.

Pictures of the local district and nature as something to be protected and safeguarded against modernity and asphalt appear during the later period. Earlier research has argued that modernism's praise of imagination and creativity, caused the generation of youths after 1968 to have a need to cling to conventions and symbols of security. It has been shown that several of the contests from the 1970's and the 1980's carried a message of text and pictures with a return to older values, where things modern were regarded as a threat, but also the hope that a return to a more unspoiled world was possible, which was in sharp contrast to the positive concept of modernity that is seen in the pictures of the 1940's.

During the later period the children in, for example, Arla/posten's contest were encouraged to express their feelings of danger and anxiety. The pictures show more tears and more expressions of emotions than the pictures in the earlier period. Situations that were portrayed in the later period as conflicts were shown in Folket $i$ bild's competition as part of a game or as fun. Fistfights were represented in the 1940's pictures as a humorous part of the school day, whereas pictures of the 1970's schoolyard showed mobbing and children crying. The children in 1977 were expected to use the medium of the picture as a kind of therapeutic contemplation. The content of childhood that has been permissible to express has thus shifted and changed over time.

It is also clear in the earlier period that children were presented as healthy, active and often in motion. When the boys and the girls are shown in the pictures in common activities in the theme "livet i vår skola" (life in our school), skiing, 
swimming and ball sports are shown. During this period the school environment is shown more factually and in more detail than in later school pictures, which describe the school by means of metaphors and emotions. This can be understood in relation to the discourse derived from the "free creativity" pedagogy of pictures that the Folket $i$ Bild contest initiated but which first came into pedagogical practice in the 1970's. The pictorial expressions in the competitions from Arla and posten are simple and unschooled in contrast with contributions to the contests from the 1940's. The competition pictures during the later period show the school as a place with problems. The schools are too big, better school toilets are needed, children are bullied, and teachers are portrayed as spiteful monsters. At the same time during the later period children were depicted as being more protected, for example, by helmets and safety jackets, and they show how they have learned to control both themselves and other children and adults by showing desired behavior in pictures. The children are shown in the pictures from the 1940 's to be competent by reason of their ability to work in school and during their free time. Here, as in Arla's 1976 contest, they appear as competent because of their capacity to provide care and include others.

During the later period the landscape of the mass media changed and the photo of the earth became an established picture. Children no longer portrayed themselves as only being part of the Swedish landscape; now they were part of the entire globe. During the later period in certain pictures the earth symbolizes a common home and the responsibility for all people, but the globe was also surrounded by the flags of different countries as symbols of a world of nations. In later contests the future in space was also included in the children's pictures.

This dissertation shows that during the entire period there has been an ambition from various sponsors to want both to use and listen to children's voices by means of the art competitions. The contests show both continuity and change in the contents of what constitutes childhood. Continuity is seen in that children's pictures were in demand during the entire time, and children were regarded as competent creators of art and opinions. The pictures contain changes through the various discourses of childhood that the contests and the pictures include and represent. The optimistic message for the future from the 1940's depicted the construction of the welfare state, where children played, went to school, and participated in the work of the adults; during the 1970's it was transformed into pictures of problems and threats, where the schools were too small, children were bullied, nature was sprayed with poisons and asphalt grew. The children of the 1970's could expect a problematic future, where the pictures do not show any adult models. At the same time competitions can be seen as part of the discourse of childhood during the 1970's where it was important to listen to the views of children. The competition pictures show that children were given the responsibility of fostering both other children and adults. Children were given a voice, but at the same time in contrast to those of the 1940's the pictures foresaw a complex and menacing future.

Translated by Marie Clark Nelson 


\section{BILDER, TABELLER \& DIAGRAM}

\section{KAPITEL 1}

Bild 1:1 Folket i bild nr 111940 sid. 29 detalj. Reproduktion: Lina Löfström Baker, Kungliga biblioteket.

\section{KAPITEL 2}

Bild 2:1 Folket i bild nr 211939 sid. 28 detalj. Reproduktion: Lina Löfström Baker, Kungliga biblioteket.

Bild 2:2 från Folket $i$ bild 1941 nr 16 sid. 29 detalj. Reproduktion: Lina Löfström Baker, Kungliga biblioteket.

Bild 2:3 Livet i vår skola FIB:s tävling 1938. Vem blir först och vem har rätt, Britt Pettersson NMH/1939.

Bild 2:4 Exempel på adressetikett använd vid Televerkets tävling 1977.

Televerkets tävlingsbilder, En händelse i vår hembygd, Stockholm, SBBA.

Bild 2:5 Folket i bild 1940 nr 9 sid. 29. Reproduktion: Lina Löfström Baker, Kungliga biblioteket.

Bild 2:6 Europeiska skoldagen Måla något typiskt svenskt, arrangerad av Europarådet, EG, och Europeiska kulturstiftelsen 1959. Europeiska skoldagen 1959, 2005:019 SBBA.

Bild 2:7 I Nils Holgersons spår, arrangerad av Hemmets Journal, Sas/Linjeflyg och Sunne hembygdsförening 1989. Nils Holgerssons underbara resa, 1989:040 1987-89, SBBA.

Bild 2: 8 Sverige är fantastiskt, arrangerad av Sveriges turistråd och STF 1978. 1993:017, SBBA.

Bild 2:9 Rita Konsumtomten, arrangerad av Konsum Sörmland 1988. 1988:010, SBBA.

Bild 2:10 Eskilstunakuriren 24 dec.1999 sid.12-13. Framtidens jul 1999, 2000:002 SBBA

Bild 2:11 Vad jag vill bli när jag blir stor, FIB:s tävling 1942. Folket i bilds tävling Sörmland,1990:017, SBBA.

Bild 2:12 Lutherhjälpen nr 11971 sid. 5. Lutherhjälpens tävlingar 1971-1986, 2007:012, SBBA.

Bild 2: 13 Mikael Hansson, i Varför fär inte barn bestämma (1977).

Bild 2:14 Trafiken och miljön, arrangerad av Länstrafikens 1989. 1990:002, SBBA.

Bild 2:15 Del av Televerkets informationsfolder om tävlingen Stoppa sabbet 1989. Televerket tävlingsbilder, informationsmaterial, Stoppas sabbet, SBBA.

Bild 2:16 Folket $i$ bild 1944 nr. 9 sid.33. detalj. Reproduktion: Lina Löfström Baker, Kungliga biblioteket.

Bild 2:17 Gotlands Allehanda, 197919 maj. Pressklipp, Televerket Telemedia arkiv 1980, Riksarkivet.

Bild 2:18 Brevmärken WWF, 1975, WWF teckningstävling, 1990:032, SBBA. 
Bild 2:19 Mjölkpaket Arla/Postens tävling, 1976. Arla foods arkiv, Centrum för näringslivshistoria.

\section{KAPITEL 3}

Bild 3:1 Sjöholm, L. Gottfrid \& Goës, Axel (1943) Arbetsöuningar (tysta övningar) $i$ geografi sid. 19.

Bild 3:2 Livet i vår hembygd, FIB:s tävling 1939. Ingegerd Möller, $\mathrm{NMH}$ 292/1939.

Bild 3:3 Sjöholm, L. Gottfrid \& Goës, Axel (1920) Handledning vid undervisningen i hembygdskunskap. 2, Andra skolåret Färgplansch 16.

Bild 3:4 Livet i vår hembygd, FIB:s tävling1939. Margit Rosvall 301/1939.

Bild 3:5 Televerkets informationsfolder för tävlingen En händelse i vår hembygd 1976. Televerkets tävlingssamling 1977, informationsmaterial SBBA.

Bild 3:6 En händelse i vår hembygd, Telefonkatalogen Falun 1977/78. Kungliga biblioteket.

Bild 3:7 En händelse i vår hembygd, Telefonkatalogen Östersund 1977/78. Kungliga Biblioteket.

Bild 3:8 En händelse i vår hembygd, Telefonkatalogen Ystad 1977/78. Kungliga biblioteket.

Bild 3:9 En händelse i vår hembygd, Telefonkatalogen Göteborg 1977. Kungliga biblioteket.

Bild 3:10 En händelse i vår hembygd, Televerkets tävling 1976. Televerkets tävlingssamling 1977, Stockholm, Peter Norbergh, 2008:001:2928, SBBA.

Bild 3:11 Svenskt helgfirande, FIB:s tävling 1944 i Sverige genom barnaögon 1947.

Bild 3:12 Mitt roligaste skolminne, FIB:s tävling 1941. Esther Sandström, Svenska flaggans dag den 6 juni, NMH 282/1942.

Bild 3:13 Dan Andersson 11 år Göteborg, i Varför får inte barn bestämma (1977).

Bild 3:14 Svenskt helgfirande, FIB:s tävling 1944. Taklagsfest, Börje Ivergård, NMH 252/1944.

Bild 3:15 Våra lekar, FIB:s tävling 1945. Elmar Larsson, NMH 91/1945.

Bild 3:16 Svenskt helgfirande, FIB:s tävling 1944. Sten Gustavsson, 1:a maj NMH 214/1944.

Bild 3:17 Detta vill jag värna om, Arla/postens tävling 1976. Juha Kuru, Arlatävlingsbilder, 1991:016:0418.

Bild 3:18 Svenskarna i allvarstider-beredskap då och nu, 1944, i Sverige genom barnaögon (1947).

Bild 3:19 En händelse i vår hembygd, Telefonkatalogen Karlskrona 1977. Kungliga biblioteket.

Bild 3:20 En historisk händelse i vår hembygd, Telefonkatalogen Göteborg 1978. Kungliga biblioteket.

Bild 3:21 Svenskt helgfirande, FIB:s tävling 1944. Hur Gustav II Adolf firas i Göteborg, Mona-Lisa Nodvall, NMH 249/1944.

Bild 3:22 Mitt roligaste skolminne, FIB:s tävling 1941. Karl II på museum, Maj-Britt Jonsson, NMH 266/1942. 
Bild 323 En historisk händelse i vår hembygd, Televerket 1978. Kungliga biblioteket.

Bild 3:24 Omslag till katalogen Sverige genom barnaögon (1947).

Bild 3:25 Albin Amelin (1902-1975) Norrbottens järnverk.

http://www.sinklar.se/index.php?album=Albin-Amelin\&image=IMG_1785.jpg.

Bild 3:26 Livet i vår hembygd, FIB:s tävling 1939, i Sverige genom barnä̈gon (1947).

Bild 3:27 Livet i vår hembygd, FIB:s tävling 1939, i Sverige genom barnaögon (1947).

Bild 3:28 Einar Jolin (1890-1976) Skridskobanan vid Stallmästargården

1919. https://www.bukowskis.com/auctions/553/73-einar-jolin-skridskobanan-vid-stallmastaregarden.

Bild 3:29 Livet i vår hembygd, FIB:s tävling 1939, i Sverige genom barnaögon (1947).

Bild 3:30 Livet i vår hembygd, FIB:s tävling 1939, i Sverige genom barnaögon (1947).

Bild 3: 31 Folket $i$ bild 1939 nr 21 sid 28, detalj. Reproduktion: Lina Löfström Baker, Kungliga biblioteket.

Bild 3: 32 Mitt roligaste skolminne, FIB:s tävling 1941. Sten Kallin, NMH 238/1942

Bild 3:33 FIB 1939 nr 23 sid. 29. Reproduktion: Lina Löfström Baker, Kungliga biblioteket.

Bild 3:34 Birgitte Rodger i Varför får inte barn bestämma, (1977).

Bild 3: 35 Patrik Alm i Varför fär inte barn bestämma (1977).

Bild 3:36 Katarina Persson i Varför fàr inte barn bestämma (1977).

Bild 3:37 Jesper Törjas i Varför får inte barn bestämma (1977).

\section{KAPITEL 4}

Bild 4:1 Våra lekar, FIB:s tävling 1945. Folket i bilds tävling 1990:007 SBBA.

Bild 4:2 Livet i vår skola, FIB:s tävling 1938. Vem blir först och vem har rätt?

Britt Pettersson, Örkelljunga folkskola NMH 289/1939.

Bild 4:3 Livet i vår skola, FIB:s tävling 1938. En lästimme i skolan, Maj-Britt Svensson, NMH 192/1939.

Bild 4:4 Livet i vår skola, FIB:s tävling 1938. Fem minuter för sent, Anne Marie Lundell, Gustav Vasa folkskola NMH 257/1939.

Bild 4:5 Livet i vår skola, FIB:s tävling 1938. Hos syster Harriet, Anna-Lisa Karlsson, Matteus Folkskola NMH 289/1939.

Bild 4:6 Livet i vår skola, FIB:s tävling 1938. Baddagen - var 14e dag får vi tvätta oss och bada bastu, Alice Källman, NMH 286/1939.

Bild 4:7 Folket i bild 1938 nr 29 sid.27. detalj Reproduktion: Lina Löfström Baker, Kungliga biblioteket.

Bild 4:8 Folket $i$ bild 1938 nr 27.sid.27.detalj Reproduktion: Lina Löfström Baker, Kungliga biblioteket.

Bild 4:9 Kamratposten (1980) nr 3 sid.10. Kamratpostens tävlingssamling, 2014:006, SBBA.

Bild 4:10 Ulrika Marklund i Varför fär inte barn bestämma (1977).

Bild 4:11 Mikael Persson i Varför fär inte barn bestämma (1977). 
Bild 4:12 Våra lekar, FIB:s tävling 1945. Freddie Winholz NMH 93/1945.

Bild 4: 13 Faror och otrygghet i skolan, Kamratpostens tävlingssamling 1980. 2014:006, SBBA.

Bild 4: 14 Omslag till boken Varför fär inte barn bestämma (1977).

Bild 4.15 Anna Sprinehorn i Varför får inte barn bestämma (1977).

Bild 4:16 Petra Johansson i Varför fär inte barn bestämma (1977).

Bild 4:17 Monica Petterson i Varför fär inte barn bestämma (1977).

Bild 4: 18 När jag plockade bär, frukt m.m., FIB:s tävling 1946. Folket i bilds tävling Sörmland 1990:017, SBBA.

Bild 4:19 Våra lekar, FIB:s tävling 1945, Isjumping, Bo Björklind, NMH 94/1945.

Bild 4:20 Marie Persson i Varför får inte barn bestämma (1977).

Bild 4:21 Min fritid, FIB:s tävling 1940. Mjölkning i hagen klockan sex på morgonen, Anna Greta Mattson, NMH112/1940.

Bild 4:22 Min fritid, FIB:s tävling 1940. Ingemar Sjögren, NMH 120/1940.

Bild 4.23 Min fritid, FIB:s tävling 1940. Ulf Ekendahl, NMH 100/1940.

Bild 4:24 Bild publicerad i Varför får inte barn bestämma, (1977).

Bild 4:25 Mimmi Persson i Varför fär inte barn bestämma (1977).

Bild 4:26 Carlos Marn i Varför fär inte barn bestämma (1977).

Bild 4:27 Televerkets utskick till skolorna om tävlingen Den gränslösa världen 1993. Televerkets tävlingsbilder SBBA.

\section{KAPITEL 5}

Bild 5:1 Livet i vår skola, FIB:s tävling 1938. Vi har slagits, NMH 217/1939.

Bild 5: 2 Livet i vår skola, FIB:s tävling 1938. Skolkök, Elsie Birgit Johansson, NMH 213/1939.

Bild 5:3 Illustration till novellen Jordbunden, Folket $i$ bild 1939 nr 2 sid.14.

Reproduktion: Lina Löfström Baker, Kungliga biblioteket.

Bild 5:4 Livet i vår skola, FIB:s tävling 1938. Vår klass lär sig simma och det tycker alla är så roligt. Gudrun Kummelin, NMH 284/1939.

Bild 5:5 Mitt roligaste skolminne, FIB:s tävling 1941. Bertil Johansson, NMH 228-292/1942.

Bild 5:6 Livet i vår skola, FIB:s tävling 1938. På skidutflykt, Elsa Carlsson, NMH 203/1939.

Bild 5:7 Livet i vår skola, FIBs tävling 1938, Margit Abelin, NMH 281-1939.

Bild 5:8 Livet i vår skola, FIB:s tävling 1938. På skolgården, Ingar Nilsson, NMH 261/1939.

Bild 5:9 Våra lekar, FIB:s tävling 1945 i Sverige genom barnaögon (1947).

Bild 5:10 Folket $i$ bild, vinjett ungdomssidorna 1939. Reproduktion: Lina Löfström Baker, Kungliga biblioteket.

Bild 5:11 Våra lekar, FIB:s tävling 1945. När vi spelade bandy mot läroverket, Stig Wallin, NMH 90/1945.

Bild 5:12 Malin Jeppson i Varför får inte barn bestämma (1977).

Bild 5:13 Kopia av annons införd i Lärartidningen 1978-02-20, Televerket

Telemedia Omslag till rikstelefonkataloger, Riksarkivet.

Bild 5:14 Livet i vår hembygd, FIB tävling 1939. Far har tänt milan, Henry Lövbom, NMH 340/1939. 
Bild 5:15 Sjöholm Goes (1923). Handledning vid arbetsövningar i Hemkunskap tredje skolaret, sid.134.

Bild 5:16 Livet i min hembygd, FIB:s tävling 1939. Mjölka i hagen, Viola Rundlöv, NMH, 313/1939.

Bild 5:17 Livet i min hembygd, FIB:s tävling 1939. Pappa och Olle hugga timmer, NMH 331/1939.

Bild 5:18 Yrke och arbetsliv i vår hembygd, Vinnarbilder Televerkets tävling 1979, Televerkets tävlingsbilder, Informationsmaterial Televerket, SBBA.

Bild 5:19 Yrke och arbetsliv i vår hembygd, Bidrag till Televerkets tävling 1979, Malmö, bild 0151, SBBA.

Bild 5: 20 Yrke och arbetsliv i vår hembygd, Bidrag till Televerkets tävling 1979, Malmö, Bild 0517, SBBA.

Bild 5: 21 Folket $i$ bild 1942 nr.22 sid. 23. Reproduktion: Lina Löfström Baker, Kungliga biblioteket.

Bild 5:22 Folket $i$ bild 1942 nr 17 sid. 26. Reproduktion: Lina Löfström Baker, Kungliga biblioteket.

Bild 5.23 Anne-Marie Salomonsson i Varför fär inte barn bestämma (1977).

Bild 5:24 Folket $i$ bild 1942 nr 23 sid.24-25. Reproduktion: Lina Löfström Baker, Kungliga biblioteket.

Bild 5:25 Annons i Folket i bild 1943 nr 5 sid. 3. Reproduktion: Lina Löfström Baker, Kungliga biblioteket.

NMH Nationalmuseum handtecknings- och gravyravdelning.

\section{TABELLER \& DIAGRAM}

Tabell 1. De tävlingar som varit föremål för näranalys och deras teman.

Tabell 2. Arrangörer av teckningstävlingar i SBBA respektive Teckningslärarförbundets tidskrift.

Tabell 3. Namn, årtal och tema på bilderna i boken Sverige genom barnaögon

Diagram 1. Antalet tävlingar i SBBA:s arkivsamling och i teckningslärarförbundets tidskrift mellan 1935-2000 fördelat på femårsperioder. 



\section{LITTERATUR \& KÄLLMATERIAL}

\section{LITTERATUR:}

Andersson, Flood, Königsson (1990) "Bevara, Registrera, Upplev" Handbok $i$ hanteringen av barnteckningar vid Svenskt barnbildarkiv; Svenskt barnbildsarkiv, Eskilstuna.

Andersson, Torbjörn (2002). Kung fotboll: den svenska fotbollens kulturhistoria fran 1800-talets slut till 1950. Diss. Lund: Univ.

Ariès, Philippe (1982), Barndomens historia. Stockholm: Gidlund Aronsson, K. (1997). Barns världar - barns bilder. Stockholm: Natur och kultur.

Aronsson, Karin (1997). Barns världar - barns bilder. Stockholm: Natur och kultur.

Aronsson, Karin "Barnbilder som försvann” i Lind, Judith (red.) (2009), Historien, barnen och barndomarna: vad är problemet?: en vänbok till Bengt Sandin. [Linköping: Linköpings universitet].

Backman Prytz, Sara, (2014), Borgerlighetens döttrar och söner: kvinnliga och manliga ideal bland läroverksungdomar, ca. 1880-1930, Acta Universitatis Upsaliensis, Diss. Uppsala.

Banér, Anne (1994). Bilden av barnet: från antiken till 1900. Stockholm: Bergh.

Barker, Chris (2012), Cultural studies: theory and practice. 4. ed. London: SAGE.

Barthes, Roland (2016), Bildens retorik. Stockholm: b Faethon.

Barthes, Roland (2007), Mytologier. Lund: Arkiv Mytologier. Lund.

Baxter, Jane Eva (2005), The archaeology of childhood: children, gender, and material culture. Walnut Creek, CA: AltaMira Press.

Beauvoir, Simone de (1949/2002). Det andra könet. Stockholm: Norstedt.

Bendroth Karlsson, Marie (1996). Bildprojekt i förskola och skola: estetisk verksambet och pedagogiska dilemman. Diss. Linköping: Univ.

Bengtsson, Claes G. \& Glanell, Tomas (1998). 25 àr med svensk damfotboll: 1973-1998. Solna: Svenska fotbollförb.

Beskow, Elsa (1937). Tomtebobarnen: bilderbok [5. uppl.] Stockholm: Åhlén \& Åkerlund.

Billig, Michael (1995), Banal nationalism. London: Sage.

Bourdieu, Pierre (1996). The rules of art: genesis and structure of the literary field. Cambridge: Polity press.

Breitholtz, Nils (1962). Barnens bildvärld: idéer och motiv. Stockholm: Svensk läraretidnings förlag.

Broady, Donald (2007). Den dolda läroplanen. Göteborg: Krut.

Caillois, Roger (2001). Man, play and games. Urbana, Ill.: University of Illinois Press.

Carabine, Jean "Unmarried Motherhood 1830-1990: A genealogical Analysis" in Wetherell, Margaret, Taylor, Stephanie \& Yates, Simeon J. Eds. (2001) Discourse as Data. A Guide for Analysis London: Sage.

Cardell, David "Barnidrottens spridning, kulturindustrin och kulturstudiernas möjligheter” I Tolvhed, Helena \& Cardell, David (red.) (2011), Kulturstud- 
ier, kropp och idrott: perspektiv på fenomen i gränslandet mellan natur och kultur. Malmö: idrottsforum.org.

Dahlstedt, Magnus \& Olson, Maria (2013) Utbildning, demokrati, medborgarskap. 1. uppl. Malmö: Gleerup

Davies, Bronwyn (2003). Hur flickor och pojkar gör kön. 1. uppl. Stockholm: Liber.

Dewey, John (1999), Demokrati och utbildning. Göteborg: Daidalos (democracy and education 1916).

Edwards, Folke (2000) Från modernism till postmodernism: svensk konst 1900-2000. Lund: Signum.

Ehn, Billy, Frykman, Jonas \& Löfgren, Orvar (1993), Försvenskningen av Sverige: det nationellas förvandlingar. Stockholm: Natur och kultur.

Eriksson, Yvonne \& Göthlund, Anette (2012), Möten med bilder: att tolka visuella uttryck. 2., [rev.] uppl. Lund: Studentlitteratur.

Eriksson, Yvonne (red.) (2014), Barn tecknar världen: att förstå och tolka barns bilder. 1. uppl. Lund: Studentlitteratur.

Eriksson Yvonne (2014) "Handikappad - lika men ändå olika" I Barn tecknar världen att förstå och tolka barns bilder (red.) Studentlitteratur.

Fairclough, Norman (1995/2010), Media discourse. Bloomsbury academic.

Fairclough, Norman (2003). Analysing discourse: textual analysis for social research. New York: Routledge.

Fairclough, Norman (1992). Discourse and social change. Cambridge: Polity.

Faith-Ell, Zacha \& Faith-Ell, Siri (1955-1963), Färg och form. Stockholm: Ehlin.

Florin, Christina \& Johansson, Ulla (1993). ”Där de härliga lagrarna gro": kultur, klass och kön i det svenska läroverket 1850-1914. Stockholm: Tiden.

Fornäs, Johan (2012), Kultur. 1. uppl. Malmö: Liber.

Forsberg Warringer, Gunnel \& Nyström, Jenny (1999). God jul med Jenny Nyström. [Ny utg.] Stockholm: Forum.

Foucault, Michel (2002), Sexualitetens historia. Bd 1, Viljan att veta. Göteborg: Daidalos.

Fowler, Bridget (1997). Pierre Bourdieu and cultural theory: critical investigations. London: Sage.

Frost, U. (1988), Förlagor och teckningsläror. Ett bidrag till den svenska tecknings-undervisningens historia särskilt avseende 1800-talet. Akademitryck AB, Edsbruk och Täby.

Frykman, Jonas \& Löfgren, Orvar (1979), Den kultiverade människan. 1. uppl. Lund: Liber Läromedel.

Fröbel, Friedrich (1826/1995), Människans fostran. Lund: Studentlitteratur.

Fröberg, Per (red.) (1979), Oegennyttans politik. Stockholm: Frivilligorganisationernas informationscentral i samarbete med SIDA, Lutherhjälpen, Sv. missionsrådet.

Gellner, Ernest (1999), Nationalism. Nora: Nya Doxa.

Gullberg, Eva (2004). Det välnärda barnet: föreställningar och politik $i$ skolmåltidens historia. Diss. Linköping: Univ., 2004. 
Göthlund, Anette (1997) Bilder av tonårsflickor: om estetik och identitetsarbete. Diss. Linköping: Univ.

Hallberg, Mathilda (2017). Barn till beskådan: familj, välfärdsstat och nation i fototävlingar och fotoböcker 1930-1944. Diss. Linköping: Linköpings universitet.

Hallberg, Mathilda, Sandin, Bengt; Pictured "Political Projects - the children in the welfare Story", opublicerat manuscript (2017).

Halldén, Gunilla (red.) (2007), Den moderna barndomen och barns vardagsliv. Stockholm: Carlsson.

Halldén, Gunilla, "Barnperspektiv som ideologiskt eller metodologiskt begrepp” I Pedagogisk Forskning i Sverige 2003 årg. 8 nr 1-2 sid. 12-23.

Halldén, Gunilla (red). (2009) Naturen som symbol för den goda barndomen. Stockholm: Carlsson.

Halldén, Gunilla (2011). Barndomens skogar: om barn i natur och barns natur. Stockholm: Carlsson.

Hammarberg, Elis "Synpunkter på barns utveckling och teckningsundervisning” i Falck, Kurt \& Orrgård, Stellan (red.) (1954). Folkskolans metodik: en handbok. Stockholm: Sv. bokf./Bonnier.

Hansson, Hasse "När varje lärare kunde teckna" I Lind, Ulla, Hasselberg, Kersti \& Kühlhorn, I Tidsbilder, Perspektiv på skola och bildskapande under 150 ar. Utbildningsradion och Skolverket.

Hedling, Erik \& Jönsson, Mats (red.) (2008), Välfärdsbilder: svensk film utanför biografen. Stockholm: Statens ljud- och bildarkiv.

Heikkilä, Mia "Genusperspektiv på teckningar av favoritleksaker" "i Eriksson, Yvonne (red.) (2014). Barn tecknar världen: att förstå och tolka barns bilder. (red.) Studentlitteratur.

Hellman, Annika (2017). Visuella möjlighetsrum: gymnasieelevers subjektsskapande $i$ bild och medieundervisning.

Hendrick, Harry (2003), Child welfare: historical dimensions, contemporary debates. Bristol: Policy.

Hendrick, Harry (1997) Children, childhood and English society, 1880-1990. Cambridge: Cambridge Univ. Press.

Hertting, Krister (2007). Den sköra föreningen mellan tävling och medmänsklighet: om ledarskap och lärprocesser $i$ barnfotbollen. Diss. Luleå: Luleå tekniska universitet.

Heywood, Colin (2005) Barndomshistoria. Lund: Studentlitteratur.

Higonnet, Anne (1998), Pictures of innocence: the history and crisis of ideal childhood. London: Thames \& Hudson.

Hinnfors, Jonas (1992). Familjepolitik: samhällsförändringar och partistrategier 1960-1990. Diss. Göteborg : Univ.

Hirdman, Yvonne (1988), Genussystemet: teoretiska funderingar kring kvinnors sociala underordning. Uppsala: Maktutredningen.

Hirdman, Yvonne (2001), Genus: om det stabilas föränderliga former. 1. uppl. Malmö: Liber.

Hirdman, Yvonne (1995). Att lägga livet tillrätta: studier $i$ svensk folkhemspolitik. Stockholm: Carlsson. 
Hobsbawm, E. J. (1992), Nations and nationalism since 1780: programme, myth, reality. 2. ed. Cambridge: Cambridge Univ. Press.

Hobsbawm, E. J. \& Ranger, T. O. (red). (1992). The invention of tradition. Canto ed. Cambridge: Cambridge University Press.

Hällström, Catharina (2011), Insändare i Kamratposten: uttryck för villkor $i$ barns kulturella sammanhang. Diss. Stockholm: Stockholms universitet, 2011.

Hörnfeldt, Helena (2009). Prima barn, helt u.a.: normalisering och utvecklingstänkande i svensk barnhälsovård 1923-2007. Diss. Stockholm: Stockholms universitet, 2009.

Illeris, Helene (2002), Billede, poedagogik og magt: postmoderne optikker $i$ det billedpoedagogiske felt. 1. uppl. Frederiksberg: Samfundslitteratur.

James, Allison, Jenks, Chris \& Prout, Alan (1998), Theorizing childhood. Cambridge: Polity Press.

James, Allison \& James, Adrian L. (2008). Key concepts in childhood studies. Los Angeles: SAGE.

Johansson, Ulla (2008). Normalitet, kön och klass - liv och lärande $i$ svenska läroverk 1927-1960. Enskede: TPB.

Jonsson, Olof G. (2006). Skolplanschen: argument $i$ spänning mellan bild och text, perspektiv och kontext. Licentiatavhandling Uppsala: Uppsala universitet, 2006 sid. 56.

Jordan, Glenn \& Weedon, Chris (1995). Cultural politics: class, gender, race and the postmodern world. Oxford: Blackwell.

Jönsson, Mats "visuell fostran: Barnens dag i Sverige under andra världskriget” i Hedling, Erik \& Jönsson, Mats (red). (2008). Välfärdsbilder: svensk film utanför biografen. Stockholm: Statens ljud- och bildarkiv.

Kandinsky, Marc, Frans (1912/2016) Der Blaue Reiter München Piper \& co. Verlag.

Kellogg, Rhoda (1970), Analyzing children's art. Palo Alto, Calif.: Mayfield Pub.

Kerbs, Diethart \& Siepmann, Eckhard (red.) (1976). Kind und Kunst: eine Ausstellung zur Geschichte des Zeichen- und Kunstunterrichts. 2. verb. Aufl. Berlin: BDK.

Ketelaar, Eric (2001), “Tacit Narratives - The meanings of Archives” Archival Science 1, sid. 31-41.

Klee, Paul Pedagogical sketchbook (1953). Introduction by Sibyl Maholy-Nago sid. 7.

Klinth, Roger (2002). Göra pappa med barn: den svenska pappapolitiken 1960-95. Diss. Linköping: Univ., 2002.

Key, Ellen (1900/1996), Barnets århundrade. [Nyutg.] Stockholm: Informationsförl.

Köhler, Rolf \& Pedersen, Kristian (1978). Børns billedproduktion i en billedkultur. Bredsten: Ulrika.

Landahl, Joakim "Aesthetic Modernisation and International Comparisons: Learning About Drawing Instruction at the Paris Exposition Universelle of 1900 " in History of Education (forthcoming). 
Larsson, Arne (1956). Det fria skapandet: en bok om teckningsundervisning. Stockholm: Almqvist \& Wiksell/Geber.

Lasko, Peter (2003). The expressionist roots of modernism. Manchester: Manchester University Press.

Laurin, Carl G. (1911), Sverige genom konstnärsögon. Stockholm: Norstedts.

Lee, Nick (2001). Childhood and society: growing up in an age of uncertainty. Maidenhead: Open University.

Lind, Judith (2000). Det sinnesslöa skolbarnet: undervisning, tvång och medborgarskap 1925-1954. Diss. Linköping: Univ.

Lind, Ulla; Hasselberg, Kerstin "Kan min mammas bilder finnas här?” Arkiv B- bilder som kunskapskälla Rapport KU-projekt 2006-12-04 Konstfack, institutionen för bildpedagogik.

Lind, Ulla, Hasselberg, Kersti \& Kühlhorn, Britt-Marie (red.) (1992). (red.) (1992) Tidsbilder, Perspektiv på skola och bildskapande under 150 år. Utbildningsradion och Skolverket.

Lind Ulla (2010), Blickens ordning: Bildspråk och estetiska lärprocesser som kulturform och kunskapsform. Stockholm: Institutionen för didaktik och pedagogiskt arbete, Stockholms universitet.

Lindberg, Anna Lena (1991), Konstpedagogikens dilemma: historiska rötter och moderna strategier. [Ny utg.] Lund: Studentlitteratur.

Linde, Göran, Det ska ni veta! En introduktion till läroplansteori, 3:dje uppl., Lund: Studentlitteratur 2000, 2012.

Lindgren, Simon (2009), Populärkultur: teorier, metoder och analyser. 2., [rev.] uppl. Stockholm: Liber.

Lindgren, Anne-Li (1999), "Att ha barn med är en god sak": barn, medier och medborgarskap under 1930-talet. Diss. Linköping : Univ., 2000.

Lindgren, Anne-Li och Halldén, Gunilla, Individuella rättigheter; autonomi och beroende. Olika synsätt på barn i relation till FN: s barnkonvention, 2001, Utbildning och Demokrati, (2).

Lindstrand, Fredrik \& Selander, Staffan (red.) (2009), Estetiska lärprocesser: upplevelser, praktiker och kunskapsformer. 1. uppl. Lund: Studentlitteratur.

Lindström, Sylvia, Berefelt, Gunnar \& Wik-Thorsell, Anna Lena (1978). Livets träd: världen genom barnets ögon. Stockholm: Rabén \& Sjögren.

Lissner, Jørgen (1977), The politics of altruism: a study of the political behaviour of voluntary development agencies. Geneva.

Literat, I (2013). Participatory Innovation: The Culture of Contests in Popular Science Monthly, 1918-1938. Journalism \& Mass Communication Quarterly, 90(4).

Lowenfeld, Viktor (1957), Alla barn kan måla. Stockholm: Rabén \& Sjögren.

Lowenfeld, Viktor, (1947), Creative and mental growth: a textbook on art education, Macmillan, New York.

Lowenfeld, Viktor (1954). Your child and his art: a guide for parents. New York: Macmillan

Lundahl, Christian and Lawn, Martin, 'The Swedish Schoolhouse: a Case study in Transnational influences in Education at the 1870s World's fairs', Paedagogica historica, 51 (2014), 319-334. 
Lundgren, Ulf P. (1989), Att organisera omvärlden: en introduktion till läroplansteori. 2. [dvs 4.] uppl. Stockholm: Utbildningsförl.

Lundström, Gunilla, Rydén, Per \& Sandlund, Elisabeth (red.) (2001). Den svenska pressens historia. 3, Det moderna Sveriges spegel (1897-1945). Stockholm: Ekerlid.

Lundqvist, Åsa (2011). Family policy paradoxes: gender equality and labour market regulation in Sweden, 1930-2010. Bristol: Policy

Lundquist Wanneberg, Pia (2004). Kroppens medborgarfostran: kropp, klass och genus $i$ skolans fysiska fostran 1919-1962. Diss. Stockholm.

Luquet, Georges Henri (1927/2001) Children's drawings: (le dessin enfantin). London: Free Association Books.

Machón, Antonio (2013). Children's drawings: the genesis and nature of graphic representation : a developmental study. Madrid, Spain: Fíbulas Publishers.

Martola, Ulla, "Barns bilder - bevarade och tillgängliga" I Eriksson, Yvonne (red). (2014) Barn tolkar världen att förstå och tolka barns bilder.

Mintz, Steven (2012). The changing Face of Childrens culture in Fass, Paula S \& Grossberg,

Michael (red.) I Reinventing childhood after World War II. Philadelphia: University of Pennsylvania Press.

Martola, Ulla (red.) (2008). Folk och färd: Svenskt barnbildarkiv: 30 àr jubileumsutställning. Eskilstuna: Svenskt barnbildarkiv i Eskilstuna.

Mirzoeff, Nicholas (red.) (1998). The visual culture reader. London: Routledge.

Mirzoeff, Nicholas (2015). How to see the world. 1. uppl. London: Pelican.

Mirzoeff, Nicholas (1999). An introduction to visual culture. London: Routledge.

Myrdal, Alva \& Myrdal, Gunnar (1934). Kris i befolkningsfrågan. Stockholm: Bonniers.

Nordenfalk, Katarina (1996). Barns bilder och solen lyste blå. Stockholm: Bergh i samarbete med Moderna museet och Riksutställningar.

Nilsson, Jakob \& Wallenstein, Sven-Olov (red.) (2013). Foucault, biopolitics, and governmentality. Huddinge: Södertörns högskola.

Nordström, Gert Z. \& Romilson, Christer (1970). Bilden, skolan och sambället. Orig. utg. Stockholm: Aldus/Bonnier.

Nordström, Gert Z. \& Romilson, Christer (1973). Bilden, skolan och sambället. 2., utök. uppl. Stockholm: Aldus/Bonnier.

Nordström, Marie (1987), Pojkskola, flickskola, samskola: samundervisningens utveckling i Sverige 1866-1962. Diss. Lund : Univ.

Nylund, Anna-Vera (2008) Sameliv på Skansen: om natur och kultur, upplevelser och lärande / Fataburen. 2008, sid. 138-157; 290 Eva Silvén Nordiska Museet Stockholm; Upmark 1916: 151.

Palmblad, Eva (2005) Medicin som sambällslära Stockholm: Norstedts akademiska förlag.

Petersson, Monica (2007). Att genuszappa på säker eller minerad mark: hemoch konsumentkunskap ur ett könsperspektiv. Diss. Göteborg: Göteborgs universitet, 2007. 
Pestalozzi, Johann Heinrich (1801/1896). Huru Gertrud undervisar sina barn: ett försök att gifva mödrarna ledning att själfva undervisa sina barn. Göteborg: Wettergren \& Kerber.

Pettersson, Sten \& Åsén, Gunnar (1989). Bildundervisningen och det pedagogiska rummet: traditioner, föreställningar och undervisningsprocess inom skolämnet teckning/bild i grundskolan. Diss. av båda förf. Stockholm : Univ.

Pettersson, Åsa (2013). TV for children: how Swedish public service television imagines a child audience. Diss. Linköping : Linköpings universitet.

Piaget, Jean (1929). The childs concenption of the world. 3. uppl. Stockholm: Norstedts.

Read, Herbert (1943). Education through art. London: Faber and Faber.

Read, Herbert (1956). Uppfostran genom konsten. Stockholm: Natur och Kultur.

Ricci, Corrado (1887/1906). Lárte dei Bambini Översatt:Kinderkunst: Ber. Ubers.aus dem Ital.von E.Roncali. Leipzig:

Rose, Gillian (2007). Visual methodologies: an introduction to the interpretation of visual materials. 2. ed. London: Sage.

Rose, Gillian (2016). Visual methodologies: an introduction to researching with visual materials. 4th edition London: Sage.

Rothe, Richard (1937). Den fria barnteckningen. Stockholm: Sveriges lärarförbund.

Rousseau, Jean-Jacques (1762) (1977-1978) Emile eller Om uppfostran. D. 1. Göteborg: Stegeland.

Rydin, Ingegerd (2000). Barnens röster: program för barn i Sveriges radio och television 1925-1999. Stockholm: Stift. Etermedierna i Sverige.

Salomon, Otto (1904). Johan Henrik Pestalozzi: ett blad ur människokärlekens bistoria. Stockholm: Folkskolans vän.

Sandblad, Henrik (1985). Olympia och Valhalla: idéhistoriska aspekter av den moderna idrottsrörelsens framväxt = Sport and ideas: aspects of the rise of the modern sport movement. Grillby: Lärdomshistoriska samf.

Sandin, Bengt (1995). "The Century of the Child": on the changed meaning of childhood in the twentieth century. Linköping: Univ.

Sandin, Bengt "Education" in Heywood, Colin (red). (2010). A cultural history of childhood and family in the age of empire, Berg, Oxford.

Sandin, Bengt (2012). Children and the swedish welfare state: from different to similar I Fass, Paula S \& Grossberg, Michael (red.) Reinventing childhood after World War II.

Sandin, Bengt \& Sundkvist, Maria (2014). Barn, barndom och sambälle: svensk utbildningshistoria. 1. uppl. Malmö: Gleerup.

Sandin, Bengt "Swedish childhoods from the Era of Great Power to the Welfare State" I Ogata, Amy Fumiko \& Weber, Susan (red.) (2014). Swedish wooden toys. New Haven: Yale University Press.

Sandin, Bengt, Aronsson, Karin “The sun match boy” (1996) I Hwang, Philip, Lamb, Michael E. \& Sigel, Irving E. (red.), Images of childhood, Lawrence Erlbaum Associates, Mahwah, NJ. 
Sandin, Bengt \& Halldén, Gunilla (red.) (2003). Barnets bästa: en antologi om barndomens innebörder och välfärdens organisering. Eslöv: B. Östlings bokförl. Symposion.

Sandin, Bengt (2003). Skolan, barnen och samhället i ett historiskt perspektiv I Staffan Selander (red) Kobran, nallen och majien: tradition och förnyelse $i$ svensk skola och skolforskning. Myndigheten för skolutveckling, Stockholm.

Saussure, Ferdinand de (1986). Course in general linguistics. Chicago: Open Court.

Sehlin, Halvar (red.) (1985). Svenska turistföreningens årsskrift. 1986, Svenska turistföreningen 100 år. Stockholm: Fören.

Sievert-Staudte, Adelheid, Kind und Kunst In: Schreiner-Maierhofer, Marie (Ed..): Kinder kennen/ können Kunst (1998) Johannes Hey verlag: Wien.

Sigurdson, Erik (2014). Det sitter i väggarna: en studie av trä- och metallslöjdsalens materialitet, maskulinitet och förkroppsliganden. Diss. Umeå : Umeå universitet, 2014.

Sjöberg, Johanna (2013), I marknadens öga: barn och visuell konsumtion, 1. uppl., Tema barn, Institutionen för Tema, Linköpings universitet, Diss.

Sjöholm, L. Gottfrid \& Goës, A. (1927-1928). Arbetsövningar (tysta övningar) i geografi.. Arlöv ...: Skriv- och ritboks a.-b.

Sjöholm, L. Gottfrid (1946). Handledning vid undervisningen i hembygdskunskap. 2, Andra skolåret. Stockholm: Sv. bokförl. (Norstedts).

Sjöholm, L. Gottfrid (1923). Handledning vid undervisningen i hembygdskunskap. 3, Tredje skolàret. 2. uppl. Stockholm: Sv. bokförl. (Norstedt)

Sjöholm, L. Gottfrid (1919). Handledning vid undervisningen i hembygdskunskap. 1, Första skolåret. 3. uppl. Stockholm: Sv. bokförl. (Norstedt)

Sjöholm, L. Gottfrid, (1920) Handledning vid undervisningen i hembygdskunskap. 1, Andra skolåret, Sv. bokförl. (Norstedt), Stockholm.

Sköld, J., Söderlind, I., (2018), Agentic Subjects and Objects of Political Propaganda: Swedish Media Representations of Children in the Mobilization For Supporting Finland During World War II, I Journal of the History of Childhood and Youth.

Smith, Anthony D. (1999). Myths and memories of the nation. Oxford: Oxford University Press.

SOU 2006:45, Tänk framåt, men gör nu: Så stärker vi barnkulturen.

Sparrman, Anna (2006). Barns visuella kulturer: skolplanscher och idolbilder. Lund: Studentlitteratur.

Sparrman, Anna "Barn tecknar nakenhet- och sexualitet?" I Eriksson, Yvonne (red). (2014) Barn tolkar världen att förstå och tolka barns bilder. Studentlitteratur.

Stephens, Sharon (1995). Introduction: Children and the politics of culture in "late capitalism", In Sharon Stephens (ed.), Children and the politics of culture. Princeton, N.J.: Princeton Univ. Press.

Storm Petersen, Robert (1960) Respekt för rätten: med Storm P inför domstolen: muntra teckningar. Stockholm: Folket i bild.w

Stråth, Bo (2005). Union och demokrati: de förenade rikena Sverige och Norge 1814-1905. Nora: Nya Doxa. 
Stuhlmann, A. (1878). Lärobok i frihandsteckning. 2. Stockholm: Beijer.

Sturken, Marita \& Cartwright, Lisa (2009). Practices of looking: an introduction to visual culture. 2. ed. New York: Oxford University Press.

Söderlind, Ingrid \& Engwall, Kristina (2005). "Var kommer barnen in?: barn i politik, vetenskap och dagspress". Stockholm: Institutet för framtidsstudier.

Söderlind, Ingrid \& Engwall, Kristina (red.) (2008). Barndom och arbete. 1. uppl. Umeå: Boréa.

Tingsten, Herbert, Gud och fosterlandet: studier $i$ hundra års skolpropaganda, Norstedts, Stockholm, 1969.

Tolvhed, Helena (2008). Nationen på spel: kropp, kön och svenskhet i populärpressens representationer av olympiska spel 1948-1972. Umeå: h:ström - Text \& kultur.

Van Leeuwen, Theo \& Jewitt, Carey (red.) (2001). Handbook of visual analysis. London: SAGE.

Viola, Wilhelm (1936). Child art and Franz Cizek. Vienna: Austrian Junior Red Cross.

Werner, Jeff \& Björk, Tomas (2014). Blond och blåögd: vithet, svenskhet och visuell kultur = Blond and blue-eyed: whiteness, Swedishness, and visual culture. Göteborg: Göteborgs konstmuseum.

Wikberg, Stina (2014). Bland självporträtt och parafraser: om kön och skolans bildundervisning. Diss. Umeå.

Winther Jørgensen, Marianne \& Phillips, Louise (2000). Diskursanalys som teori och metod. Lund: Studentlitteratur.

Winther Jørgensen, Marianne \& Phillips, Louise (2002) Discourse analysis as theory and method. London: Sage.

Zelizer, Viviana A. Rotman (1994). Pricing the priceless child: the changing social value of children. Princeton, N.J.: Princeton University Press.

Ziehe, Thomas (1993). Kulturanalyser: ungdom, utbildning, modernitet: essäer. 3. uppl. Stockholm: B. Östlings bokförl. Symposion.

Zilversmit, Arthur, John Dewey, I Encyclopedia of Children and Childhood: In History and Society. . Ed. Paula S. Fass.Vol.1. New York: Macmillan Reference USA, 2004.

Young, Iris Marion (2005). On female body experience: "Throwing like a girl" and other essays. New York: Oxford University Press.

Young, Iris Marion (1990). Justice and the politics of difference. Princeton, N.J.: Princeton Univ. Press.

Änggård, Eva (2005). Bildskapande: en del av förskolebarns kamratkulturer. Diss. Linköping: Linköpings universitet.

Öhman-Gullberg, Lisa (2008). Laddade bilder: representation och meningsskapande i unga tjejers filmberättande. Diss. Stockholm: Stockholms universitet.

Öhman, Ivar (red.) (1984). Folket $i$ bild: tidningen som var en folkrörelse. D. 1, 1934-1949. Stockholm: Tiden. 


\section{TRYCKTA KÄLLOR:}

Ord och Bild (1908) sjuttonde årgången, sjunde häftet

DN 1916-05-28

DN 1916-08-09

DN 1917-06-09

DN 1918-02-17

Idun 1923 nr 38

Idun 1923 nr 37

FIB 1938-1946

Aftonbladet 1976-07-04.

Expressen 1977-07-31

DN 27 juli 1977

Undervisningsplan för rikets folkskolor den 31 oktober 1919. (1920). Stockholm: Norstedts.

Timplaner och huvudmoment vid försöksverksambet med nioårig enhetsskola: fastställda av Kungl. Skolöverstyrelsen för läsåren 1955/1958. (1955) Sverige. Skolöverstyrelsen.

Läroplan för grundskolan: Lgr 69. (1969-1978). Sverige. Skolöverstyrelsen. Stockholm:

Utbildningsförl.

Läroplan för grundskolan: Lgr 80. (1980-1986). Sverige. Skolöverstyrelsen. Stockholm: Liber Läromedel/Utbildningsförl.

Sverige genom barnaögon: Katalog. (1945). Stockholm: Riksförbundet för bildande konst Folket i Bild vandringsutställning 36.

Jungmarker, Gunnar \& Hoppe, Ragnar (red). (1947). Sverige genom barnaögon: Folket $i$ bilds teckningstäuling för skolungdom. Stockholm: Nationalmuseum

Varför får inte barn bestämma: en bok av barn för vuxna! .... (1977). Stockholm: Utg.

Teckningslärförbundets tidskrift: Tidning för Sveriges teckningslärare 19311938, Teckning 1939-1979, Bild i Skolan 1979-2000.

Barns framtidssyn: [en analys av mellanstadiebarns bidrag till tävlingen "Konsument 2000”]. (1985). Vällingby: Konsumentverket.

Kerschensteiner, Georg (1905). Die Entwickelung der zeichnerischen Begabung: neue Ergebnisse auf Grund neuer Untersuchungen. München: Carl Gerber.

Konstperspektiv $1985 ; 2$.

Levinstein, Siegfried (1905). Kinderzeichnungen bis zum 14. Lebensjahr.: Mit Parallelen aus der Urgeschichte, Kulturgeschichte und Völkerkunde. Mit einem Anhang von Karl Lamprecht.. Leipzig.

Prop 1974:28 Kungl. Majts proposition angående den statliga kulturpolitiken; given den 8 mars 1974.

Roos, Anna Maria (1981). Gustav Vasas äventyr i Dalarne. [Ny utg.] Stockholm: Bonniers juniorförl.

Tim- och kursplaner för sjuårig folkskola (klasserna 1-6 i folkskola med flera än sju årsklasser): fastställda av Kungl. Maj:t den 4 juni 1954. 2. uppl. (1954). Lund: H. Ohlsson. 


\section{OTRYCKTA KÄLLOR:}

Centrum för näringslivshistoria: I Arla Foods AB (Stockholm)s arkiv B3b:2, 3, B3c:2, 3, B4 a; 27, F1 3;7 K1 db;6.

Svenskt barnbild arkiv (SBBA); Tävlingssamlingar (se bilaga 1)

Riksarkivet Televerket Telemedia; Omslag till rikstelefonkatalog F2A:110 1977-81, Nationalmuseums samling, Teckning och grafikavdelningen; Barnteckningar: "Gåva av veckotidningen Folket i bild, Sthlm, i samband med den utställning i Nationalmuseum, som ordnats efter pristävling"1938-1947.

\section{INTERNETKÄLLOR:}

Albin Amelin, http://www.lexikonettamanda.se/show.php?aid=20505 (201803-06)

Barnkonventionen,artikel två, https://www.raddabarnen.se/omoss/barnkonventionen/barnkonventionen-lang-version/\#Art 2 (2018-03-10)

Befolkningsutredningen, NE, http://www.ne.se/uppslagsverk/encyklopedi/lång/ befolkningsutredningen (2018-03-07)

Då konsten blev olympisk, http://www.idrottsforskning.se/da-konsten-blevolympisk-os-1912-fick-aven-kulturen-medalj/ (2018-03-06)

Familjekampanjen, https:/familjekampanjen.wordpress.com/about/ (2017-0607)

Gustav II Adolfsstatyn i Göteborg, Wikipedia https://sv.wikipedia.org/wiki/ Gustav_II_Adolfs_staty,_G\%C3\%B6teborg (2018-03-06)

Gustav Adolfsdagen: http://spanaren.se/2015/05/15/inga-fler-hogtidstal-av-anneli-hulthen-pa-gustaf-adolfsdagen (2016-08-05).

Håkan Jönsson: http://fof.se/tidning/2006/3/den-svenska-mjolkpropagandan

Karl den tolftes likfärd, http://www.nationalmuseum.se/sv/Om-samlingarna1/ Hojdpunkter-maleri/Karl-XIIs-likfard/ (2018-03-06)

Kultur och fritid Huddinge: http://kulturfritid.huddinge.se/sv/IBKM/Om-oss/ (2017-06-07)

Livets träd, http://www.livetstrad.se/index.html (2017-06-15)

Milstolpar, Länsstyrelsen Skåne, http://www.lansstyrelsen.se/skane/Sv/samhallsplanering-och-kulturmiljo/landskapsvard/kulturmiljoprogram/historia-utveckling/kom-landskap/Pages/Milstolpar.aspx (2018-03-07)

Mjölkpropagandan, förening: http://fof.se/tidning/2006/3/den-svenska-mjolkpropagandan (2018-03-07)

Österjön fredens hav, Ne.se, https:/www.ne.se/uppslagsverk/encyklopedi/l\%C3\%A5ng/fredens-hav (2018-03-09)

Patrik Steorn 2012, http://www.idrottsforskning.se/da-konsten-blev-olympiskos-1912-fick-aven-kulturen-medalj/ (2017-06-15)

Revolternas decennium, http://www.aftonbladet.se/kultur/konst/article18588483.ab (2018-03-06)

SBBA, Svenskt Barnbildsarkiv: http://www.eskilstuna.se/sv/Uppleva-och-gora/ Museer-2/Eskilstuna-konstmuseum/Svenskt-Barnbildarkiv (2017-06-15)

Andel kvinnor som yrkesarbetar över tid, SCB, http://www.scb.se/statistik/_ publikationer/le0201_2012a01_br_x10br1201.pdf (2018-03-07) 
Urbanisering över tid, SCB, http://www.scb.se/sv_/Hitta-statistik/Artiklar/Urbanisering--fran-land-till-stad/2016-06-10 (hämtat 2018-03-06)

Svenska flaggans dag, http:/www.nordiskamuseet.se/aretsdagar/sveriges-nationaldag (2018-03-06) 


\section{BILAGA 1}

Tabell över arrangörer i kronologisk ordning med Tävlingssamlingar från Svenskt Barnbildarkiv

\begin{tabular}{|c|c|c|}
\hline Arrangör & År & Tävlingssamling \\
\hline $\begin{array}{l}\text { FIB } \\
\text { Nationalmuseum } \\
\text { Teckningslärarförbundet }\end{array}$ & $1938-1946$ & $\begin{array}{l}1938 \text { Livet i vår skola } \\
1939 \text { Livet i vår hembygd } \\
1940 \text { Min fritid } \\
1941 \text { Mitt roligaste skolminne } \\
1942 \text { Vad jag skall bli när jag blir stor } \\
1943 \text { Svenskarna i allvarstider - beredskap } \\
\text { förr och nu } \\
\text { 1944 Svenskt helgfirande } \\
\text { 1945 Våra lekar } \\
1946 \text { När jag plockade...bär, frukt mm. }\end{array}$ \\
\hline Jämtlands länsmuseum & 1949 & Konstens vecka \\
\hline FIB & 1954 & "Vi spelar teater" \\
\hline $\begin{array}{l}\text { Europarådet, EG, och Europeiska kultur- } \\
\text { stiftelsen. }\end{array}$ & $\begin{array}{l}\text { 1959+1966 } \\
\text { (Sverige) }\end{array}$ & $\begin{array}{l}\text { 1959: ålder 12-14 år: Rita eller måla nå- } \\
\text { got, som du tycker är typiskt svenskt. }\end{array}$ \\
\hline $\mathrm{DN}$ & 1955 & Min roligaste jul \\
\hline Stockholmstidningen & 1960 & Historia med färg \\
\hline KF (konsum) & 1961 & Min önskejulklapp \\
\hline Sörmlandsungdomens arbetstävling & 1961 & Tackbok till Länsarbetsdirektör Nils Böös \\
\hline DN/Kamratposten & 1968 & Jul på landet \\
\hline Lutherhjälpen & 1971,1986 & Dela med dig - "share" \\
\hline Posten/Mejerierna & 1976 & Det här vill jag värna om \\
\hline $\begin{array}{l}\text { Televerket } \\
\text { Omslag till telefonkataloger } \\
\text { Arrsurs } 3\end{array}$ & $1977-1985$ & $\begin{array}{l}\text { 1977-81 Hembygdstema } \\
\text { 1982Handikappad i samhället - Lika men } \\
\text { ändå olika } \\
\text { 1983Så vill vi ha det i trafiken där vi bor } \\
\text { 1984 Så blir idrotten i skolan roligare } \\
\text { 1985 En sevärdhet i vår hembygd } \\
\end{array}$ \\
\hline $\mathrm{DN}$ & 1977 & Liv i rymden \\
\hline Sveriges turistråd & $1978 / 79$ & Sverige är fantastiskt \\
\hline SVT & 1978 & Idolen \\
\hline Eskilstunakuriren & 1978 & Julteckningar/Julkort \\
\hline $\mathrm{DN}$ & 1978 & Min Stenmark \\
\hline $\begin{array}{l}\text { Televerket } \\
\text { Årskurs } 6 \\
\end{array}$ & $1980-1990$ & $\begin{array}{l}\text { "Stoppa sabbet" om att inte förstöra tele- } \\
\text { fonkiosker }\end{array}$ \\
\hline Kamratposten & 1979 & $\begin{array}{l}\text { Affischtävling - faror och otrygghet i sko- } \\
\text { lan }\end{array}$ \\
\hline Kamratposten & 1982 & Rita en hatt \\
\hline Kamratposten & 1982 & Rita en serie \\
\hline Kamratposten & 1982 & Collage/Jul-vinterbilder \\
\hline Kamratposten & $1983 / 84$ & Rita natten \\
\hline
\end{tabular}




\begin{tabular}{|c|c|c|}
\hline Arrangör & År & Tävlingssamling \\
\hline Kamratposten & 1984 & Gör ett självporträtt \\
\hline Kamratposten & 1983 & Gör en tidning \\
\hline Kamratposten & 1984 & Skolgårdstävlingen \\
\hline Televerket & 1984 & Sevärdheter i Sörmland \\
\hline $\begin{array}{l}\text { Europarådet, EU, och Europeiska kultur- } \\
\text { stiftelsen }\end{array}$ & $1986-1987$ & $\begin{array}{l}\text { Europeiska miljövärnsåret; Rita ett eller } \\
\text { flera vilda djur som finns i Europa och } \\
\text { som hotas av utrotning }\end{array}$ \\
\hline $\begin{array}{l}\text { WWF Världsnaturfonden } \\
\text { Ica Kuriren }\end{array}$ & $1985 / 86$ & \begin{tabular}{|l|} 
"Vårt gröna arv" \\
(7 samlingar)
\end{tabular} \\
\hline Uppsalahem AB & 1986 & Framtidens boende - år3 \\
\hline Arla & $1986 / 87$ & Rita en "mellankossa" \\
\hline Fritids, Södermalm & 1985 & Söder år 2001 \\
\hline Konsum Sörmland & 1988 & Konsumtomten \\
\hline Bokförlaget Natur\&Kultur & 1988 & Skattkammartävling \\
\hline Tekniska verken & 1988 & Var rädd om Eskilstuna \\
\hline $\begin{array}{l}\text { Länstrafik,Skaraborg, Dalarna länstrafiken } \\
\mathrm{AB}\end{array}$ & 1989 & \begin{tabular}{|l|} 
Trafiken och miljön \\
"Var bussig mot miljön" \\
Finns lärarhandledning
\end{tabular} \\
\hline $\begin{array}{l}\text { Sunne Hembygdsförening, Tidningen VI } \\
\text { Sas/Linjeflyg }\end{array}$ & 1989 & $\begin{array}{l}\text { Nils Holgerssons underbara resa } \\
\text { Finns infoblad }\end{array}$ \\
\hline SVD & $1989 / 90$ & $\begin{array}{l}\text { Barnens favoritmotiv } \\
\text { Finns tidningsartiklar }\end{array}$ \\
\hline Barnkulturcentrum & 1990 & Någon som arbetar i Eskilstuna kommun \\
\hline $\begin{array}{l}\text { Utbildningsbyrån/ } \\
\text { Konsumentverket }\end{array}$ & 1990 & $\begin{array}{l}\text { Motbilder till reklamen } \\
\text { (finns tidningsurklipp) }\end{array}$ \\
\hline Rädda barnen & 1990-tal & Alla barn är lika värda \\
\hline Rädda barnen & 1990-tal & Konfliktlösning \\
\hline Rädda barnen & 1990-tal & Barnkonventionen \\
\hline Eskilstuna arbetarekommun & 1993 & Fritiden förr och nu \\
\hline Televerket & 1993 & Den gränslösa världen \\
\hline Telia & 1994 & Tittofonresan \\
\hline Telia & 1995 & Miljö i skolan \\
\hline Eskilstuna konstförening & 1994 & Hästen \\
\hline Ja-centrum Eskilstuna & 1994 & \begin{tabular}{|l|} 
Eu-bilder \\
\end{tabular} \\
\hline $\begin{array}{l}\text { Utbildningsradion } \\
\text { Sveriges Hembygdsförbund }\end{array}$ & 1996 & $\begin{array}{l}\text { Nils Holgerssons underbara resa genom } \\
\text { Sverige }\end{array}$ \\
\hline Idrottsutbildarna (SISU) & 1996 & Min idrott \\
\hline $\begin{array}{l}\text { Barn och Ungdomskulturgruppen Uppsala } \\
\text { kommun }\end{array}$ & 1996 & $\begin{array}{l}\text { Barnets rättigheter FNs Barnkonvention } \\
\text { Paragraf } 2\end{array}$ \\
\hline Rädda barnen & 1999 & Framtiden, mitt liv på 2000talet \\
\hline Sbba, Sörmlands museum & 1999 & Framtidstro, när jag blir stor \\
\hline Nationalmuseum & 1999 & Barns självporträtt \\
\hline Eskilstunakuriren & 2000 & Framtidens jul \\
\hline Arla & 2000 & Det bästa jag vet \\
\hline Rädda Barnen & 2000 & Trygghet är att...Jag känner mig trygg.. \\
\hline
\end{tabular}


